Faculdade de Arquitetura e Urbanismo Universidade de São Paulo

Dissertação de mestrado

\title{
A OBRA DE ABELARDO DE SOUZA
}

Arq. Regina Adorno Constantino

Or. Prof.Dr.Lúcio Gomes Machado

Ago/2004 
Faculdade de Arquitetura e Urbanismo da Universidade de São Paulo

Dissertação de Mestrado

A obra de Abelardo de Souza

Arq. Regina Adorno Constantino Or. Prof. Dr. Lúcio Gomes Machado

Agosto de 2004 
Aos Fábios e Carolina 
Agradeço pelo apoio e amizade:

A meu orientador Lúcio Gomes Machado

Miranda Magnolli

Ma Esther de Souza

Renina Katz

Antonio

Carlos

Alves

de

Carvalho

Amigos da Nave

Juliana Mammana

Carmen Silvia

Rosilene

Biblioteca da FAU/USP

CNPQ 


\section{Resumo}

Abelardo Riedy de Souza, arquiteto formado pela E.N.B.A, no Rio de Janeiro em 1932, pertence à geração que transformou os rumos da moderna arquitetura brasileira.

Sua vinda à São Paulo na década de 1940, coincide com a acentuação do crescimento da cidade e sua contribuição somada a de outros pioneiros ajudou a provinciana capital paulistana a ingressar no âmbito do modelo moderno e da metropolização.

Apresentar uma seleção de projetos, mais ou menos conhecidos, inseridos nos eventos que marcaram cada período e o percurso do arquiteto, de forma a constituir uma coleção representativa de sua obra é o que se pretende no presente trabalho.

\section{Abstract}

Abelardo Riedy de Souza, architect graduated by E.N.B.A., at Rio de Janeiro in 1932, was part of the generation that changed the directions of the modern Brazilian architecture.

His arrival to São Paulo on 1940, matches with the city growth emphasis and his contribution, added to the other pioneers, helped the provincial capital of São Paulo to enter in the extent of the modern and metropolitan model.

The present work objectives to present a selection of projects, more or less known, inserted in the events that recorded each period and the architects's path, in order to stablish a representable collection of his work. 


\section{Sumário}

\section{Introdução}

1. Rio de Janeiro - os anos de E.N.B.A.

A experiência da ENBA

Visita de FLW

Casa da Rua Toneleros

A visita de Le Corbusier

Salão Tropical

Revista Base

Universidade do Distrito Federal

Edgar Vianna e Rafael Galvão

Os primeiros projetos

Ed. Cananéia - 1938

2. Vinda à São Paulo

A arquitetura paulista

Os primeiros anos em São Paulo

A verticalização em São Paulo

BHLB

Incorporações e o BNI

Edifício Nações Unidas

A maturidade do moderno

Revistas especializadas

As Bienais de Arquitetura

3. Grandes Estruturas

Elemento diferencial da arquitetura moderna Brasileira: o concreto

Brasilia e Ronchamps

Plano de ação Carvalho Pinto

Hélio Duarte e o convênio escolar 
Artigas, escola paulista e

brutalismo paulista $\quad 89$

Projetos com Miranda Magnoli 91

O Mercado de Pirituba 93

\section{Projetos residenciais}

Fugindo dos Padrões 97

As primeiras casas e a linguagem carioca 98

O PCB e a crise de projetos $\quad 102$

O Clubinho 105

5. Fichas:

\subsection{Edifícios}

1. Edifício Conceição 111

2. Edifíco Hecilda 114

3. Edifício Pedra Azul 117

4. Sede ABI em Salvador $\quad 120$

5. Edifícios do Largo Ana Rosa 125

6. Dois edifícios em Santos 129

7. Plano Diretor para Conj.

Residencial de Perdizes: 131

Ed . Ministro Godói e Franco da Rocha 133

8. Ed. Nações Unidas 137

9. Ed. Três Marias 142

$\begin{array}{ll}10 . \text { Ed. Bienal } & 147\end{array}$

11. Hotel e apartamentos em Goiás $\quad 150$

12. Tropical palace SP 151

\subsection{Projetos Institucionais}

13. Cobertura de piscina -

Clube Atlético Ourinhense

14. Estúdios Tupã Filmes

15. Igreja na Rod. Pres. Dutra 158 
16. Cruzeiro Futebol Clube $\quad 160$

17. Mercado do Brás 162

18. Teatro Thalia 166

19. Escola em Pres. Venceslau 169

20. Capela em Pres. Venceslau 171

21. Estação Rodoviária Pres. Venceslau 173

22. Paço Municipal Prefeitura de Valinhos 176

23. Clube de Campo de Piracicaba 179

24. Aproveitamento Foz do Chopim 183

25. Mercado de Pirituba 184

\subsection{Residências}

26. Residência Oswaldo Young 189

27. Residência do Arquiteto 192

28. Casa de Campo 195

29. Residência Zoroastro Leme 197

30. Residência Waldomiro Delboni 199

31. Residência Aldo Bove/Carmen Arruda 201

32. Residência Chaim Goldenstein 204

33. Residência Francisco Mosetic 208

34. Residência Bernardo Blay 210

35. Residência José Ribeiro Sobrinho 211

36. Residência em São Paulo 215

37. Residência Ma Ricardina M. Gonçalves 218

38. Residência João de Scantimburgo 221

6. Conclusão 229

$\begin{array}{ll}\text { 7. Bibliografia } & 237\end{array}$

8. Anexos 249 
Introdução 


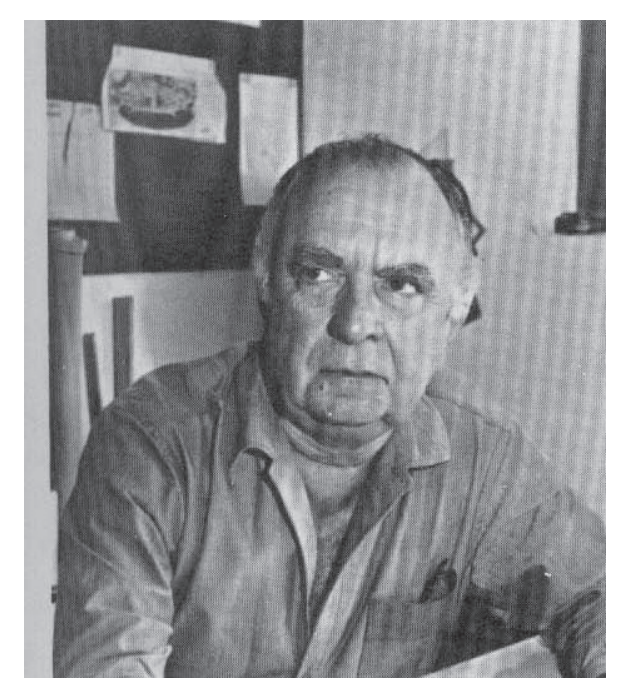

\section{Introdução}

O primeiro contato que tive com o trabalho de Abelardo de Souza foi em 1992, quando estive no edifício Três Marias. As linhas precisas do Hall com seu travertino romano forrando piso e paredes, as luminárias contínuas com até 7 metros de comprimento num desenho decidido, o apartamento com amplas janelas, estruturas recuadas, soluções de ventilação pelo uso de venezianas fixas de madeira que compunham a fachada. A fachada em cores e materiais numa transição equilibrada, os recuos e as sombras... Tudo no espaço era agradável, a composição rica e ao mesmo tempo serena. Foi tão grande a impressão que acabei aí vivendo por mais de 10 anos.

Pouco tempo depois conversando com o Prof. Paulo Bruna da possibilidade de desenvolver uma pesquisa, comentei sobre a curiosidade que o trabalho de Abelardo de Souza me despertara. O que ouvi a seguir foi uma aula sobre como alguns nomes ficaram relegados a um segundo plano e de como deveríamos rever alguns percursos na arquitetura brasileira para procurar novos caminhos. 
Visitei mais algumas obras, percebia a qualidade do discurso e já estava totalmente envolvida com o trabalho.

Mas os encontros emocionados continuaram. A professora Miranda, aluna, amiga e sócia de Abelardo, falou da riqueza de seu trabalho e de sua pessoa; a família de Abelardo me abriu seus arquivos.

O ex-aluno Antonio Carlos Alves de Carvalho empresta seu depoimento:

"Preciso Ihe relatar a ansiedade da 1 a turma no aguardo da aula. Ficávamos no portão da Maranhão 88 aguardando Abelardo dobrar a esquina da Piauí com Maranhão e nos dirigíamos então em grupo ao seu encontro - 8 ou 10 jovens ansiosos de não perder um minuto da sua presença. Levavamos 10, 15 minutos - depois de passar pelo "café da Célia" para chegar a sala, parando no patamar sempre com notícias, com livros..."

Em 2001 o professor Lúcio Gomes Machado assumiu minha orientação e já então como aluna da USP, iniciei oficialmente minha pesquisa.

Como reforço no interesse do estudo, veio de encontro a boa disposição da família do arquiteto que gentilmente cedeu seu arquivo particular e, a descoberta de um tesouro na biblioteca da FAU/USP: 300 projetos distribuídos em 600 tubos com toda obra de Abelardo de Souza, provenientes de doação realizada em 1981 e inexplorados até então.

Era o próprio Abelardo conspirando a meu favor.

A necessidade da pesquisa passou então de um envolvimento pessoal, a uma missão de preencher a lacuna existente a respeito de sua obra.

Abelardo de Souza possui uma extensa obra, divulgada em diversas publicações e eventualmente retomada ou citada em livros, textos sobre arquitetura moderna brasileira, teses e dissertações, principalmente quando se fala de edifícios da década de 50 . Os edifícios de Souza para o período 
' FERRAZ, Geraldo, Novos Valores da Arquitetura Brasileira: Abelardo Riedy de Souza,(1957) revista Habitat, no 39, pp.2-21

SOUZA, Abelardo Riedy de

(1978) Arquitetura no Brasil: depoimentos. Diadorim/EDUSP, São Paulo.

${ }^{3}$ SANTOS, Lena Coelho (1985). Arquitetura Paulista em torno de 1930-40. Orientador Eduardo Corona. Nível Mestrado. FAU/USP. São Paulo. ilustram a reinterpretação do modo de vida brasileiro, associada a novos procedimentos técnicos e ao modelo de urbanização proposto pelo urbanismo moderno, do ponto de vista dos empreendimentos particulares.

Entretanto, como é citado na dissertação de Helio Herbst sobre as primeiras bienais de arquitetura, Abelardo encontra-se entre os "nomes quase sempres relegados a um segundo plano".

Ao propor relacionar o legado de Souza, fornecendo um enfoque geral sobre o conjunto da obra e uma visão analítica de alguns projetos, o que se oferece é uma tentativa de fornecer subsídios para novos estudos dentro da arquitetura brasileira com dados que ajudem a preencher lacunas da historiografia conhecida.

\section{Critérios e Seleção}

Não existe nenhum estudo anterior sobre a obra deste arquiteto, o único material exclusivo sobre seu trabalho resumia-se ao artigo de Geraldo Ferraz, publicado em Habitat ${ }^{1}$ e que serviu como orientador para algumas escolhas da pesquisa. Foi também este artigo que somado aos relatos do arquiteto em seu livro "Depoimentos" a Lena Coelho Santos ${ }^{3}$, além de cartas e documentos obtidos que tornou possível montar um painel biográfico sobre Abelardo de Souza.

Desta forma, a pesquisa possuia dois elementos a destrinchar: o primeiro era inserir a obra de Abelardo dentro do contexto histórico e de arquitetura no momento de sua ocorrência, buscando paradigmas e o segundo selecionar um conjunto capaz de exemplificar seu percurso. 


\section{Pesquisa Histórica}

A pesquisa histórica procura localizar a obra de Abelardo de Souza em confronto com o pensamento arquitetônico nacional dentro dos períodos determinados. Trabalhando com fatos e fenômenos históricos a partir dos processos de construção da realidade. Foram utilizados bibliografia específica, entrevistas e pesquisa em periódicos.

Foram de extrema importância, no sentido de cobrir as falhas na bibliografia disponível, os depoimentos de Miranda Magnoli e Renina Katz, respectivamente sócia de Abelardo e sua assistente na FAU, ambas grandes amigas dele.

O arquivo de recortes, gentilmente cedido pela família, reúne artigos e críticas dispersos em diversos jornais e revistas, relacionados ao arquiteto e sua obra. Memória de alguns dados por vezes não presentes nas revistas especializadas, este arquivo, como foi organizado pelo próprio Abelardo, representa um indício do percurso que ele gostaria de ver retratado.

\section{Seleção de projetos}

O recorte de projetos baseou-se nos critérios utillizados por Rosales ${ }^{4}$, selecionando as obras que preenchessem os seguintes critérios:

- Publicações em livros ou revistas especializadas

- Citações, comentários ou análise em dissertações ou teses

- Inovações técnicas

- Inovações programáticas

- Reflexão cultural ou estética

- Premiações em exposições

- Diversidade de abordagem sobre determinada tipologia

${ }^{4}$ ROSALES, Mario Arturo Figueroa (2002) Habitação coletiva em São Paulo 1928>1972.

Orientador: Prof. Dr.Paulo J.V.

Bruna. Nível: Doutorado. FAU/USP, São Paulo. 
A indisponibilidade de material - plantas no caso de projeto ou não localização de obras - acabou se tornando ítem excludente.

Foi dada preferência para obras de autoria exclusiva de Abelardo de Souza, desta forma os projetos com Zenon Lotufo e Hélio Duarte e com a arquiteta Miranda Magnoli só entraram na medida em apresentavam relevância para compreensão de outras obras do arquiteto.

A obtenção de fichas de projetos foi resultante da sistematização dos dados através de procedimentos de arquivamento, catalogação e digitalização de todo material obtido e visa a análise da obra a partir de parâmetros obtidos em torno das discussões da arquitetura moderna brasileira.

Foi realizado levantamento do acervo e colhido material iconográfico através de fotografia e scaner digital.

Os projetos publicados também foram levantados e digitalizados. Os projetos à partir da década de 50 foram obtidos através do Índice de Arquitetura Brasileira, os da década de 40 por pesquisa nas publicações.

O trabalho de coleta de material, mostrou-se imprescindível, uma vez que grande parte dos projetos citados, em se tratando de obras de caráter privado, encontra-se demolido ou descaracterizado em sua forma original.

No levantamento do acervo de Abelardo de Souza na FAU e de publicações foram registradas 302 obras; sendo que 60 projetos foram publicados; 9 participaram de exposições e concursos; e 87 constavam no currículo do arquiteto.

Foram montadas, para a pesquisa, 38 fichas individuais de projetos, agrupados por categorias: edifícios, grandes estruturas e residências. Em um anexo após a conclusão foi disposto o índice geral de projetos com as informações disponíveis sobre datas e localização. 
Rio de Janeiro - Os anos de E.N.B.A.

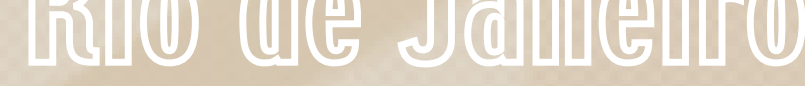




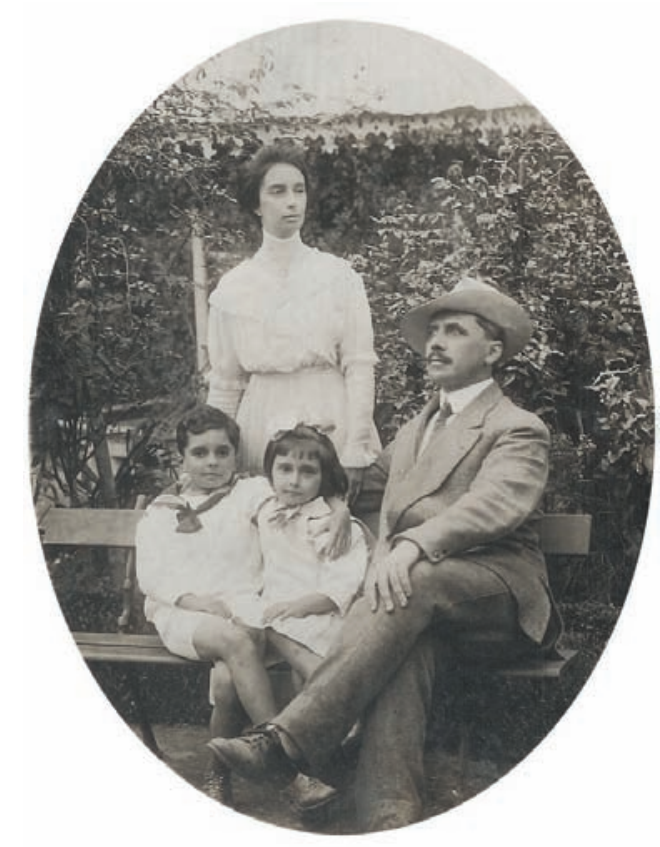

Foto de família. 1916.

${ }^{1}$ Depoimento de Abelardo de Souza in SANTOS, Lena Coelho (1985) Arquitetura Paulista em torno de 1930-40. Orientador: Eduardo Corona. Nível: mestrado FAU/USP São Paulo.
Abelardo Riedy de Souza nasceu no Rio de Janeiro em 15 de julho de 1908, filho de Absalão F. de Souza e Esther Riedy. Seu pai de ascendência portuguesa e origem simples, trabalhava com Hipotecas para a Caixa Econômica Federal e sua mãe era uma delicada mulher que vinha de uma abastada família belga e Abelardo a perdeu prematuramente quando tinha dezessete anos.

Passou a infância na Rua Marques de Abrantes 117 no bairro do Flamengo, tendo realizado o curso primário no Lycée Français e completado seus estudos na Escola José de Alencar e Colégio Pedro II.

Não se conhece em seu ambiente familiar nenhum fator que determinasse seu estudo voltado para as artes. Resta a história relatada pelo próprio Abelardo, que quando questionado sobre o que o levou a estudar arquitetura, respondia que havia sido por acaso, pois seu desejo era ingressar na aeronáutica e havia se preparado para a Escola Militar. Porém, diante da objeção do pai que considerava perigosa tal atividade, ele se viu forçado a se optar por outra profissão. Em depoimento colhido por Lena Coelho Santos ${ }^{1}$ em 1985, ele justifica através de um episódio bizarro sua escolha pela arquitetura:

"Para começar, eu não queria ser Arquiteto. Eu, quando saí do Colégio Pedro II, do ginásio (...) queria entrar para a Escola de Aviação, como todo moleque tem mania de ser aviador, né? Então me preparei todo para ser, para entrar para a Escola Militar, fazer Aviação. Meu pai não deixou, porque subia um avião, caiam dois, subia um, caiam dois. Então eu disse: o primeiro bonde, a primeira Escola que eu encontrar aberta, Superior, eu entro. Por sorte minha, eu tomei um bonde em Botafogo. Em vez de ir pelo Catete - o bonde era um bonde do Leblon - foi pelo Flamengo. 
Então, se eu passasse pelo Catete, ia dar na Escola de Direito, o que seria uma desgraça. Então eu cheguei na Escola de Belas Artes e perguntei: o que se ensina aqui? E me disseram: "ensina pintura, escultura, gravura, arquitetura".

\section{- Quantos anos são"}

- "Seis anos"

- Tá bom! Então me matriculei. Sou Arquiteto por causa do Bonde que passou pelo Flamengo!"

Em um artigo para jornal de $1966^{2}$, ele ele já havia contado o "caso" do bonde, porém em sua declaração final ele afirmava: "Arquitetura era o meu destino mesmo" e voltando ao tom humorístico termina: "Se eu estivesse na aviação, provavelmente a estas horas estaria cassado".

Era o ano de 1926, quando ingressou na Belas Artes e ocorriam profundas transformações sociais econômicas e políticas em diversos setores da sociedade brasileira. Se de início realmente não havia nenhuma predisposição em Abelardo de Souza para Arquitetura, certamente ele não passaria ileso pelos eventos que estavam por ocorrer no interior da Escola Nacional de Belas Artes. Em 1930 dentro da ENBA ele encontrava-se no olho do furacão na discussão sobre os rumos da arquitetura brasileira na gênese do movimento moderno.

\section{A experiência da E.N.B.A.}

Na Escola Nacional de Belas Artes se fazia a formação das quatro artes: pintura, arquitetura, escultura e gravura. Durante os três primeiros anos as aulas eram em comum, o ensino de arquitetura se fazia à partir do $3^{\circ}$ ano, como uma de suas especializações - as outras eram gravura

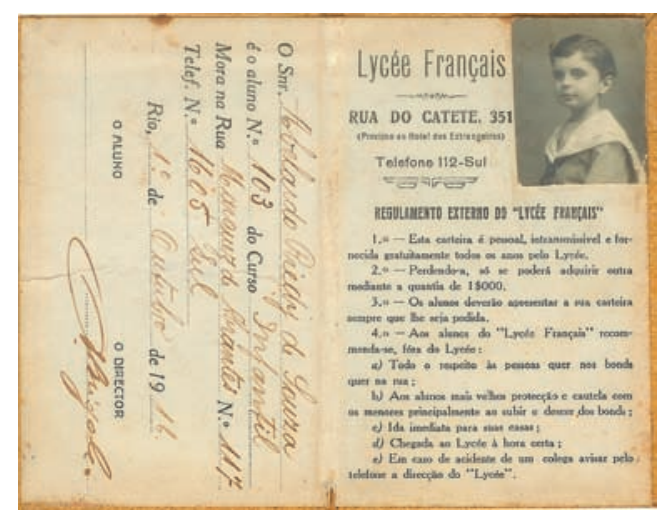

O menino Abelardo 
3 SOUZA, Abelardo Riedy de (1978) Arquitetura no Brasil: depoimentos. Diadorim/EDUSP, São Paulo.P.14 ${ }^{4}$ CAVALCANTI, Lauro

(2001)organizador. Quando o Brasil era moderno: artes plásticas no Rio de Janeiro 1905-1960. Rio de Janeiro, Aeroplano. P.22

Aeroplano. P.22 (1981) Arquitetura

${ }^{5}$ BRUAND, Yves (1981) Arau
contemporânea no Brasil

Editora Perspectiva S.A., São Paulo. 3a ed ição, 1997. p.71

${ }^{6}$ FROTA, Lélia Coelho.Alcides da Rocha Miranda caminho de um arquiteto. Rio de Janeiro: Editora UFRJ, 1993.232p; il e medalhística. Para arquitetura havia necessidade de matrícula e exame, porque esta cadeira exigia conhecimentos teóricos.

Na introdução de Arquitetura no Brasil: Depoimentos, Abelardo de Souza ressalta a importância desses primeiros anos: "Era um bom ambiente para o estudo das artes. Criava o convívio direto entre os alunos e a arte, convívio indispensável à sua cultura e formação artística, indispensável para os arquitetos" e sobre o ensino em 1978 ele complementa "Este convívio pouco existente hoje em dia nas nossas escolas de arquitetura, está fazendo falta. "13

Lauro Cavalcanti ${ }^{4}$ quando comenta o ensino de arquitetura na Belas Artes acredita que a ligação travada entre as artes e arquitetura era tão estreita que poder-se-ia traçar um paralelo entre as transformações da própria cidade com as pequenas revoluções rumo ao estilo moderno nas artes plásticas, visto que "Artistas e arquitetos frequentavam o mesmo universo, tinham a mesma formação básica inicial e pensavam os dois domínios de modo muito mais integrado que a historiografia estuda."

A Escola Nacional de Belas artes foi instituida no governo republicano, como continuidade da Real, depois Imperial Academia de Belas Artes, criada pela missão Francesa de 1816.

Seus padrões academicistas sofrerão os primeiros abalos durante os anos 20 pelos movimentos modernistas em São Paulo e no Rio de Janeiro. De acordo com Bruand5, até 1930 a Capital Federal não contava com adeptos da "arquitetura moderna" e no interior da Belas Artes, sob a direção de José Mariano Filho, dominava o modismo do Neocolonial. Será nos anos 30, que ocorrerão "duas extraordinárias experiências, que marcarão época na história da educação e da cultura no Brasil"6 e Abelardo de Souza estará presente em ambas. A primeira foi a reforma que Lúcio Costa introduziu na Escola Nacional de Belas Artes, quando a dirigiu em 
31. A segunda a criação da Universidade do Distrito Federal em 1935, sob a orientação de Anísio Teixeira.

Quando Abelardo de Souza estava nos primeiros anos da ENBA, já havia um decompasso entre o que os alunos ansiavam aprender e seus mestres insistiam em ensinar. Apesar de seguirem a orientação dentro dos moldes tradicionais, os estudantes através de colegas mais informados como Carlos Leão, Luiz Nunes e Affonso Reidy, familiarizavam-se com o que estava sendo feito no exterior.

"Víamos, pelas poucas revistas de arquitetura que esses colegas traziam, que existia um franco-suíço chamado Charles Edouard Jeanneret, mais conhecido por Le Corbusier, que abria os olhos do mundo, através da sua arquitetura, para uma nova maneira de viver; que na Bauhaus se ensinava a verdadeira arquitetura; que em São Paulo, já por volta de 1925, um jovem arquiteto russo, Gregori Warchavchik lançava um manifesto "Acerca da Arquitetura Moderna", que causou grande polêmica entre o grupo mais reacionário e a turma mais evoluída, componentes da Semana de Arte de 22. Na Europa e nos Estados Unidos se falava em arquitetura em termos de concreto armado ou estrutura metálica, enquanto nós ainda pensávamos em paredes de tijolo ou de taipa."

No ano de 1930 estourou a Revolução que levou Getúlio Vargas ao poder. O novo governo, ainda que caracterizado pelo autoritarismo e populismo iniciou um processo de modernização acarretando numa industrialização e urbanização aceleradas induzidas pelo Estado. O próprio Estado procurava se reestruturar para enfrentar os desafios da transformação. Esta nova conjuntura terá forte impacto nas demandas colocadas aos arquitetos.

Uma das ações do novo governo foi a criação do Ministério da Educação. Seu titular, o jurista Francisco Campos, escolhe como chefe de

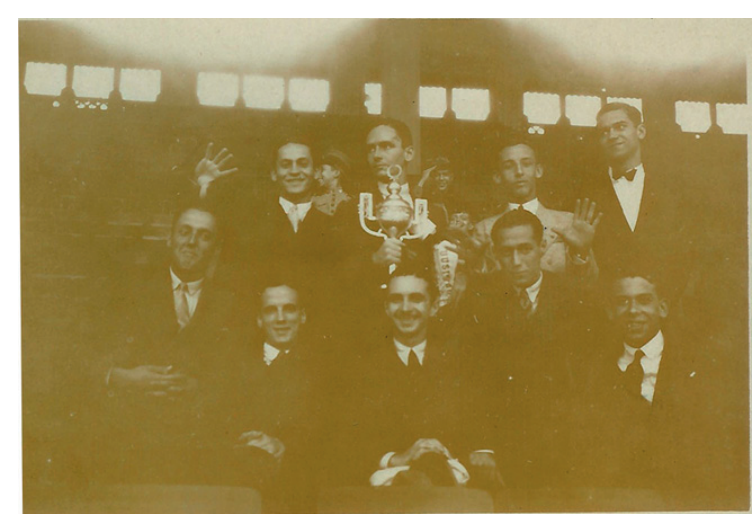

Abelardo entre os colegas da E.N.B.A., no centro em baixo. 1929

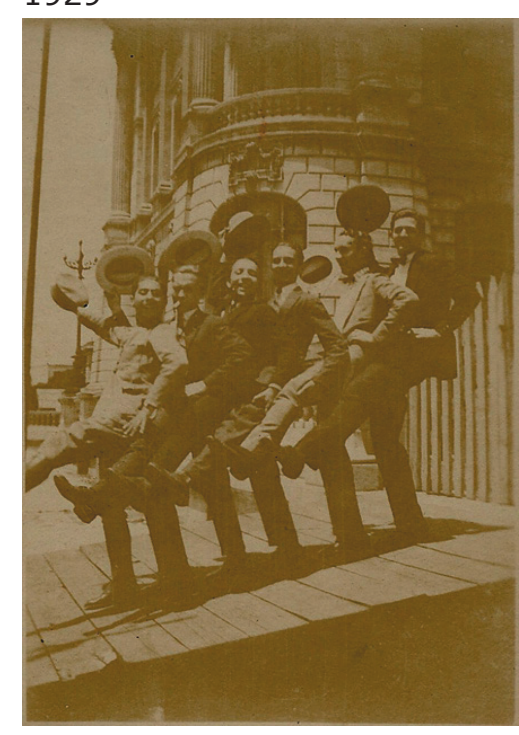

7 SOUZA, Abelardo Riedy de (1978) Arquitetura no Brasil: depoimentos. Diadorim/EDUSP, São Paulo. 
8 FROTA, Lélia Coelho.Alcides da Rocha Miranda caminho de um arquiteto. Rio de Janeiro: Editora UFRJ, 1993.232p; il

${ }^{9}$ A lista de professores das áreas artísticas foi obtida em FROTA, Lélia Coelho.

Alcides da Rocha Miranda caminho de um arquiteto. Rio de Janeiro: Editora

UFRJ, 1993.232p; il. e os professores das áreas técnicas foram obtidos em SOUSA, Abelardo Riedy de (1978) Arquitetura no Brasil: depoimentos. Diadorim/EDUSP, São Paulo. gabinete Rodrigo Mello Franco de Andrade, "intelectual ativo e de espírito aberto"s, que por indicação de Manuel Bandeira, propõe o nome de Lúcio Costa para efetivar a renovação de ensino na Belas Artes. Em dezembro de 1930 Costa, então com 29 anos, é nomeado diretor da Escola e chama para o corpo docente um grupo escolhido de professores brasileiros e estrangeiros.

Alexandre Buddeus, jovem arquiteto belga, com projetos na Europa e Brasil e Gregori Warchavchik ficam com as cadeiras de arquitetura

Warchavchik, um arquiteto russo radicado em São Paulo foi pioneiro da arquitetura moderna no Brasil e havia sido nomeado por Le Corbusier, em sua passagem pelo Brasil em 1929, como representante do CIAM na América do Sul. Costa o conhecera em São Paulo por intermédio de Mário de Andrade.

Nas cadeiras de plástica, Celso Antonio, que estudara com Bourdelle em Paris, fica com a de escultura e o alemão Leo Putz, que vinha de Neue Sezessino de Munique, com a de Pintura.

Para as áreas técnicas: Emilio Baumgarten, "grande inovador do processo do cálculo estrutural no Brasil"; Felipe dos Santos Reis, catedrático da cadeira de Resistência dos Materiais, da Politécnica; Mello e Souza, para cadeira de cálculo integral; Edson Passos, da Politécnica, para cadeira de Materiais de Construção. ${ }^{9}$

Affonso Eduardo Reidy, recém saído das salas da própria ENBA, junta-se ao grupo como assistente de Gregori Warchavchik.

A nomeação de Costa não encontra de início oposição dos tradicionalistas, visto que ele era adepto do "neocolonial". Porém, logo após seu ingresso no cargo, Lúcio deixa claras suas intenções: a introdução de idéias racionalistas e funcionalistas e, através um conhecido processo de renovação do ensino, instaura cursos com um claro espírito de modernidade 
ao lado dos tradicionais de caráter academicista.

A reação acadêmica na ENBA não se fez esperar, José Mariano Filho aproveita-se de uma brecha legal, resultante de uma das ações de Costa, que foi a da integração da Escola de Belas Artes à Universidade e obtém sua demissão automática, pois o estatuto universitário previa que o diretor de uma faculdade devia ser um professor titular.

Costa deixa o cargo no dia 10 de setembro de 1931 juntamente com Warchavchik. Reidy permaneceu como docente até 1933, na Cadeira de Pequenas Composições. No mês seguinte, tem lugar o extraordinário salão de 31 , organizado por Costa, reunindo os principais representantes da vanguarda artística do país, incluindo alguns jovens arquitetos.

A agitação e insatisfação dos alunos no interior da Escola acarretou numa greve geral, liderada por Luís Nunes, que já havia liderado a greve pela remoção de José Mariano Filho da direção e pela mudança de ensino, quando permaneceram sentados três meses à porta da Escola, noite e dia, se revezando em três alunos para cada aula, o mínimo obrigatório para que os professores fossem obrigados a comparecer em sala ${ }^{10}$.

Durante o período que dirigiu a escola, Costa cumpriu não só o objetivo de renovar seu ensino na Escola, como "o de operar uma mudança irreversível nas mentalidades"11. Através da imprensa o jovem arquiteto recebe a solidariedade de Rodrigo de Mello Franco e de Manuel Bandeira. Frota relata a posição de Bandeira, afirmando que Lúcio Costa deixava " um ponto luminoso na história daquela casa"12, reformando "em bases decentes o ensino da arquitetura e dando o exemplo de uma verdadeira exposição de artes plásticas".

Para Abelardo de Souza as mudanças no programa de ensino durante o período em que Costa e Warchavchik atuaram na ENBA foram fundamentais não só no ânimo dos alunos como na confiança que adquiriram para criar
10 SOUZA, Abelardo Riedy de (1978) Arquitetura no Brasil: depoimentos. Diadorim/EDUSP, São Paulo.

11 FROTA, Lélia Coelho.Alcides da Rocha Miranda caminho de um arquiteto. Rio de Janeiro: Editora UFRJ, 1993.232p; il.

12 Bandeira, Manuel. O Salão dos

tenentes. Diário Nacional, São Paulo, 5/9/31 in FROTA, Lélia Coelho.Alcides da Rocha Miranda caminho de um arquiteto. Rio de Janeiro: Editora UFRJ, 1993.232p; 
13 SOUZA, Abelardo Riedy de (1978) Arquitetura no Brasil: depoimentos. Diadorim/EDUSP, São Paulo. P.27 14 entrevista em 23/8/1984Vieira, Lucia Gouveia. Salão de 1931. Rio de Janeiro: MEC/Secretaria de Cultura/Funarte,

1984 p.71-73 in FROTA, Lélia Coelho. 1984 p.71-73 in FROTA, Lélia Coelho.
Alcides da Rocha Miranda caminho de um arquiteto. Rio de Janeiro: Editora UFRJ, 1993.232p; il.

novos modelos com bases funcionalistas e racionalistas:

"Passamos de uma longa fase de cópias de modelos e fórmulas arquitetônicas, para a criação.

O Vignola foi solenemente queimado e suas cinzas espalhadas pelas praias do Rio.

(...)os novos professores lecionavam apenas nos três primeiros anos, nós seus alunos, com grande entusiasmo, passamos a estudar temas mais práticos como "casa mínima", postos de gasolina, grupos escolares, equipamentos de cozinhas e banheiros. Esses temas eram estudados em todos os seus mínimos detalhes, observando seu funcionamento com muito cuidado. E esta já era uma coisa que até então nós desconhecíamos: a função das coisas que éramos chamados a projetar.

Era a função de cada cômodo; era a utilidade de uma cozinha, observando seu funcionamento e disposição de seu equipamento; era a interligação desses cômodos, mais os quartos e salas, que davam a funcionalidade da planta. Tínhamos uma planta livre, sem os cânones e a simetria até então obrigatórios.

Podíamos criar uma fachada, uma cobertura e uma estrutura."13

Diz Alcides da Rocha Miranda, contemporâneo de Abelardo de Souza, em depoimento a Cristina Burlamaqui ${ }^{14}$ que estava desanimado com o ecletismo vigente na ENBA, quando Lúcio Costa foi nomeado diretor. Sobre o curso de Warchavchik:

"As aulas dele eram de crítica. Imediatamente ele nos fez abandonar o ecletismo. Dava temas e depois fazia críticas de como nós tínhamos interpretado o tema; essas críticas/desenhos eram muito boas."

Bruand credita os primeiros passos em direção à uma arquitetura moderna brasileira a uma influência decisiva de Le Corbusier a partir de 1936, mas também não ignora o exemplo dado por Warchavchik: 
"Com efeito é provável que o talento dos arquitetos cariocas tivesse de qualquer forma se manifestado e que mais cedo ou mais tarde, a influência de Le Corbusier assumisse papel decisivo, mas o exemplo dado por Warchavchik não pode ser ignorado. (...) permanece o fato de que ele guiou os primeiros passos dos pioneiros cariocas, que por um breve instante, foram seus discípulos ou seus associados. "15

Neste ambiente de inovação e discussão se forma uma das primeiras gerações de arquitetos modernos como: Oscar Niemeyer, Carlos Leão, Luis Nunes, Jorge Moreira , Alcides da Rocha Miranda, Abelardo de Souza e tantos outros que, abrindo caminho, iriam dar um grande impulso à arquitetura que nascia.

\section{Visita de F.L.W.}

No meio do confronto entre tradicionalistas e modernos é que chega ao país o arquiteto americano Frank Loyd Wright.

Ele viera ao Rio convidado a fazer parte de um júri em um concurso para um Farol em honra a Cristóvão Colombo, a ser construído em São Domingos na República Dominicana

O concurso teve sua primeira etapa realizada em Madri, em 1929, onde haviam sido pré classificados dez trabalhos escolhidos entre quatrocentos e cinquenta e cinco projetos participantes.

Além de Wright Integram o júri Albert Kelsey (delegado da União Pan-Americana), Horacio Acosta y Lara (representante da América Latina), Wright (América do Norte) e Eliel Saarinen (Europa). Também os brasileiros Nestor E. Figueiredo (presidente do Instituto Central de Arquitetos), Adolfo
15 BRUAND, Yves (1981) Arquitetura contemporânea no Brasil

Editora Perspectiva S.A., São Paulo.

3a edição, 1997. p.74

Projeto de Flávio de Carvalho para o concurso do Farol de Colombo

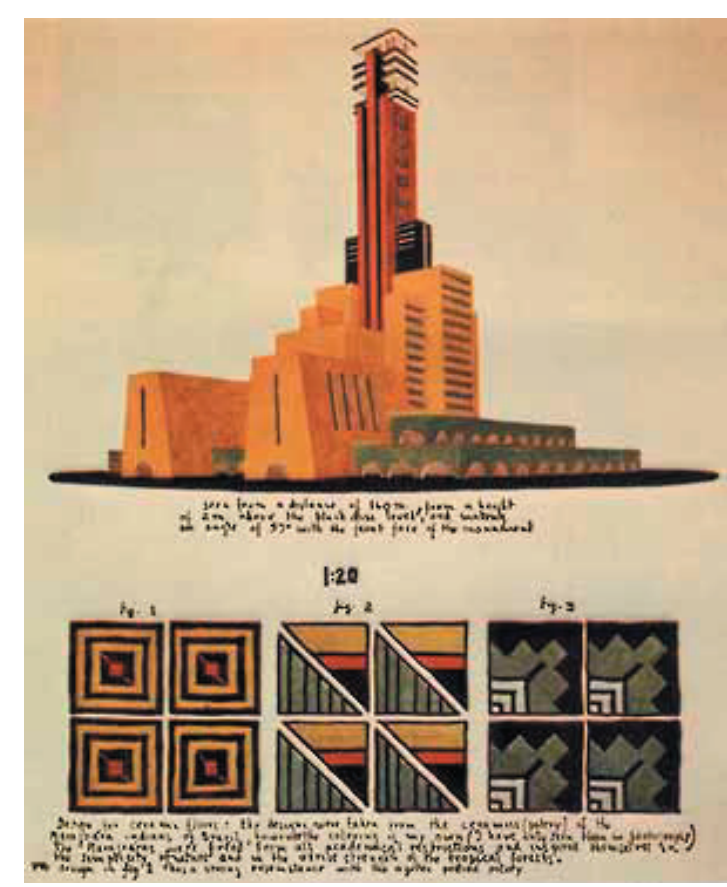




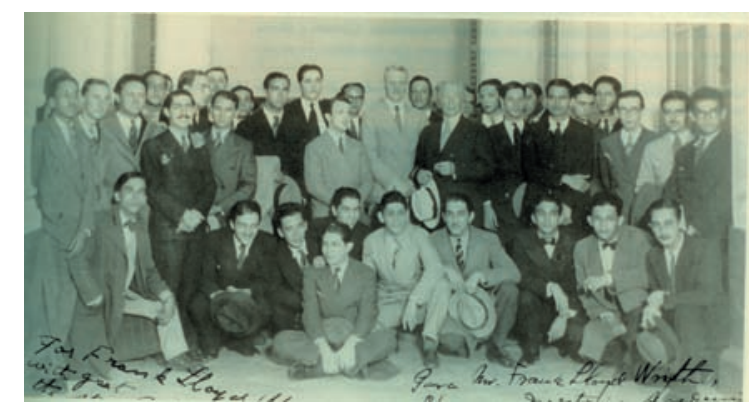

F.L.W. entre os alunos da E.N.B.A.

Morales de Los Rios, José Cortez, Cypriano Lopes, Edgard Vianna, Leonidas Vargas Dantas e Archimedes Memória, diretor da ENBA que substitui Lucio Costa e avesso aos "modernos". ${ }^{16}$

O vencedor do concurso é um projeto da Inglaterra de J.L. Gleave.

Entre os finalistas não há projetos brasileiros. Flavio de Carvalho que havia enviado uma ousada proposta não ultrapassa a primeira etapa do concurso.

Wright é procurado pelos alunos da ENBA e se posiciona em favor dos jovens arquitetos brasileiros. Saarinen o aconselhara ser mais precavido, mas Wright se entusiasmou e foi em frente, falando aos estudantes numa série conferências na ENBA em greve, tendo Herbert Moses como tradutor.

No dia 13 de outubro, a convite do Diretório Acadêmico, Wright fala aos estudantes sobre os novos rumos da arquitetura moderna.

"O espírito que produziu as melhores formas é o mesmo que produz as formas de hoje; somente as formas de vida mudam, porque as condições de vida mudam (...). Nós não podemos repetir sempre as formas antigas, por qualquer processo que seja. Assim sendo, o resultado é a rebelião"17

No dia 21 de outubro, Wright faz outra conferência nos salões da ENBA, novamente apoiando a greve e retomando o ataque aos estilo tradicionais. Ressalta que a arquitetura deve refletir o povo e o clima: e Artigas duas viagens

Ateliê editorial, São Paulo.

17 O Correio da Manhã (1931), 14

de outubro, In IRIGOYEN, Adriana

(2002), Wright e Artigas duas

Ateliê editorial, São Paulo. P.28

"No Brasil, onde o povo é sentimental, as edificações devem ter muita sombra, grandes aberturas e amplos espaços internos(...)A fachada, no clima do Rio, deve possuir três dimensões, dominando em sua composição a linha horizontal"

Ao finalizar sua segunda conferência: 
"Não devemos transplantar uma arquitetura estranha e, sim, criar uma arquitetura orgânica do solo para a luz. Isso é arquitetura moderna" 18

O arquiteto americano se encontrava com os moços, falava a seu favor nos jornais e em todas as recepções que comparecia. Chegou mesmo e escrever artigos no Correio da Manhã e em O Globo ${ }^{19}$ criticando o ensino acadêmico das chamadas Belas Artes, vigente não só no Brasil, mas no mundo todo.

Segundo FROTA, Alcides da Rocha Miranda afirma em 93 que "acredita que a influência de Wright sobre os arquitetos brasileiros não tenha sido maior, na ocasião por uma questão de dialética: "as pessoas querem a negação absoluta do que havia antes". Assim, as propostas de Le Corbusier, mais racionais por contraponto à organicidade de Wright, se transformariam nas idéias-força que viriam a dinamizar a contribuição que os brasileiros dariam dentro em breve à arquitetura internacional. "20

A última conferência de Wright acontece dois dias antes de sua partida , no Hotel Palace, sede da Associação de Artistas Brasileiros. Talvez tenha sido este o cerne do I Salão de Arquitetura Tropical, organizado pela Associação em 1933, "talvez uma das contribuições mais subestimadas do processo de gestação da arquitetura moderna brasileira" 21

\section{Casa da Rua Toneleros}

Warchavchik em 1928 constrói a primeira casa modernista em São Paulo e que será visitada no ano seguinte por Le Corbusier, em sua primeira vinda ao Brasil. Sua casa modernista no Rio, na Rua Toneleros, em 1931

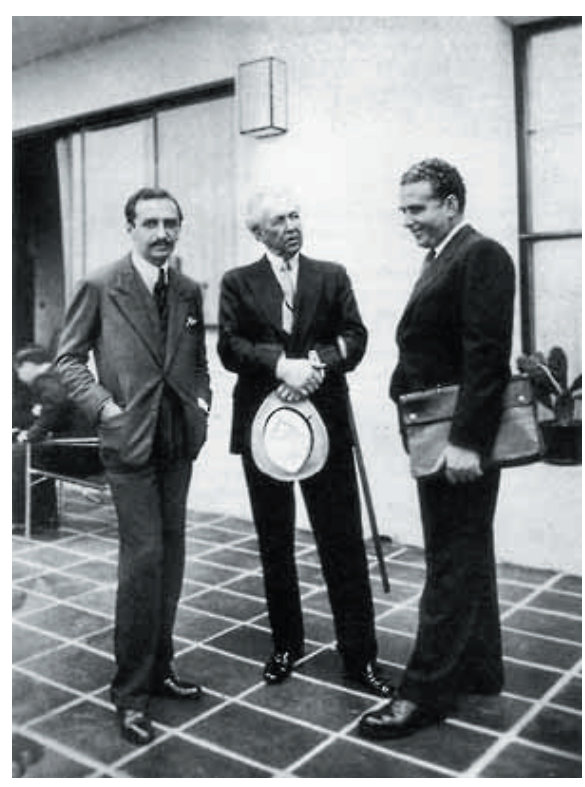

L. Costa, Warchavchik e F.L.W. na casa da Rua Toneleros.
18 Correio da Manhã (1931), 22
out. In IRIGOYEN, Adriana (2002),
Wright e Artigas duas viagens
Ateliê editorial, São Paulo. P.30.
19 "Visionando a arte de amanhã", O
Globo (1931), 17 out., p.1.
20 FROTA, Lélia Coelho.Alcides da
Rocha Miranda caminho de um
arquiteto. Rio de Janeiro: Editora
UFRJ, 1993.232p; il. P.16
21 IRIGOYEN, Adriana (2002), Wright
e Artigas duas viagens.
Ateliê editorial, São Paulo. P.30. 
22 Paula Santos, Frota

${ }^{23}$ SOUZA, Abelardo Riedy de (1978)

Arquitetura no Brasil: depoimentos.

Diadorim/EDUSP, São Paulo.

${ }^{24}$ Acrópole 130, p.299-302. 1949. receberá Frank Loyd Wright. O intérprete entre os dois arquitetos - o russo e o americano- é Alcides da Rocha Miranda.

De acordo com Geraldo Ferraz, em seu livro Warchavchik e a Introdução da Nova Arquitetura no Brasil: 1925 a 1940, a inauguração da casa de Warchavchik abrigou durante duas semanas estudantes e professores que se reuniam na Rua Toneleros, debatendo assuntos da nova arquitetura, com a presença de Frank Loyd Wright. Diversos autores ${ }^{22}$ incluindo o próprio testemunho de Warchavchik no livro de Abelardo de Souza $^{23}$ citam tais encontros, criando uma atmosfera romanceada no surgimento de nossa arquitetura moderna. Irigoyen contesta a probabilidade de tais eventos ao confrontar as datas: a exposição é inaugurada dia 22 de outubro e Wright retorna aos Estados Unidos dia 24, tendo um almoço em sua honra no Instituto dos Arquitetos dia 23, portanto, só poderia ter visitado a casa no dia de sua inauguração.

Os encontros podem não ter acontecido, mas o diálogo entre Wright e Warchavchik se produzirá nas lições deixadas aos estudantes: Warchavchik introduz o pensamento funcionalista, moldado ainda dentro padrões e modelos europeus e Wright, alerta para atenção a ser dada aos fatores naturais dentro da arquitetura. Para os alunos acostumados a copiar os modelos importados, poder caminhar dirigindo seus próprios pensamentos era algo antes imponderável.

Se não há registros uma convivência mais estreita entre Abelardo de Souza e Warchavchik durante a estada deste no Rio, ela ocorrerá com certeza em 1949, quando já em São Paulo Abelardo, juntamente com Hélio Queiroz Duarte, Zenon Lotufo e H. Verona Cristófani irá colaborar no projeto da sede do Clube Atlético Paulistano ${ }^{24}$.

Este clima fértil de renovação, oposição, estudo, luta, informação, irá constituir uma nova mentalidade no meio carioca. Porém, faltava ainda 
o modelo, o paradigma.

Será a presença de Le Corbusier no Brasil, em 1929 e depois em 36, que norteará de maneira definitiva a evolução de quase toda a arquitetura moderna no país.

\section{A visita de Le Corbusier}

Em 1929, Le Corbusier vem de passagem ao Brasil, retornando de uma visita a Buenos Aires. Suas palestras em São Paulo e Rio de Janeiro, encontram uma audiência atenta, que na insatisfação com o ecletismo reinante, passará a acompanhar seu trabalho e suas idéias.

Nas palavras de Paulo Santos ${ }^{25}$ as conferências de Le Corbusier "tiveram efeito equivalente ao de uma introdução à arquitetura de era industrial", formando "de 1931 a 1935 um reduto purista de jovens arquitetos".

Lúcio Costa presenciou uma palestra do arquiteto franco-suíço nos salões da ENBA. As influência das idéias de Le Corbusier não se fez sentir imediatamente mas o levariam a enxergar "possibilidades de expressão e de renovação arquitetônicas até então insuspeitadas"26 e, certamente, esta foi a semente que levou a mudança de ensino que Costa propôs em 31, desligando-se do movimento neocolonial.

Quando Corbusier volta ao Rio em 36 - para apreciar e orientar o partido feito para o Ministério- as idéias modernas já haviam cristalizado, mas o contato direto com o mestre franco-suíço durante o exercício de projeto do Ministério acaba de colher os frutos que havia plantado.

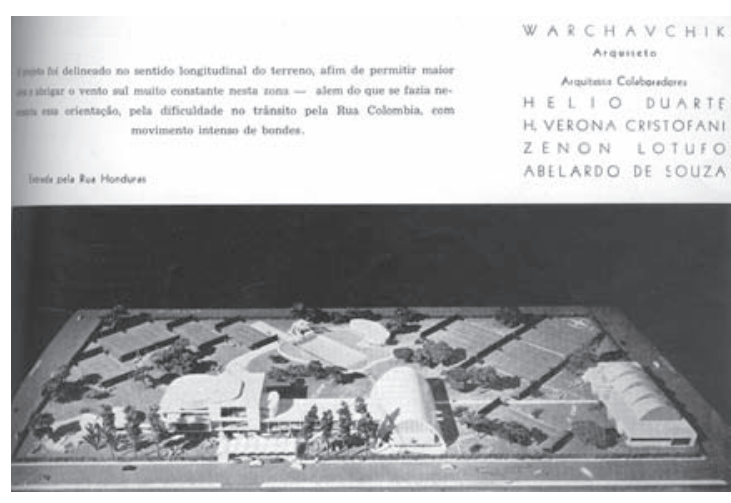

Clube Atlético Paulistano, Projeto de Warchavchik. Acrópole 130, 1949.

25 Santos, Paulo. Quatro séculos de Arquitetura. Rio de Janeiro: IAB, 1981, p.105 in FROTA, Lélia Coelho.Alcides da Rocha Miranda caminho de um arquiteto. Rio de Janeiro: Editora UFRJ, 1993.232p; il) p.14-18)

${ }^{26}$ BRUAND, Yves (1981) Arquitetura contemporânea no Brasil

Editora Perspectiva S.A., São Paulo. $3 a$ edição, 1997. p.72 


\section{Salão Tropical}

Em 1933, é realizado o I Salão de Arquitetura Tropical, organizado no Palace Hotel do Rio por Alcides da Rocha Miranda, João Lourenço da Silva e Ademar Portugal. A visita de Wright é lembrada em uma homenagem a ele prestada nomeando-o como presidente de honra.

A exposição conta com um catálogo que abre com texto de Alcides da Rocha Miranda: "Este Salão de Arquitetura Tropical", afirma ele, "marca o início do movimento que a seção de arquitetura da Associação de Artistas Brasileiros vai desenvolver pela racionalização da arte de construir em nosso país". 27

Segundo Celso Kelly, então presidente da Associação, a lista completa dos participantes inclui: Abelardo de Souza, Ademar Marinho, Ademar Portugal, Affonso Reidy, Alexandre Altberg, Alcides da Rocha Miranda, Anibal de Mello Pinto, Anton Floderer, Ary Paes Leme, A. S. Buddeus, Benedito de Barros, Daniel Valentim Garcia, Emílio Baumgart, Fernando Valentim, George Bandeira de Mello, Gerson Pinheiro, Gregori Warchavchik, Jacy Rosa, João Lourenço da Silva, José Afonso Soares, José Teodulo da Silva, Jorge Mesiano, Jorge Moreira, Lauro Lessa, Lucio

${ }^{27}$ Catálogo. Salão de Arquitetura Tropical. Associação de Artistas Brasileiros, Rio de Janeiro, abril de 1933 in FROTA, Lélia Coelho.Alcides da Rocha Miranda caminho de um arquiteto. Rio de Janeiro: Editora UFRJ, 1993.232p; il. P. 22

${ }^{28}$ IRIGOYEN, Adriana (2002), Wright e Artigas duas viagens

Ateliê editorial, São Paulo. P.63.

29 FERRAZ, Geraldo, Novos Valores da

Arquitetura Brasileira: Abelardo Riedy de Souza, (1957) revista Habitat, no 39, pp. $2-21$
Costa, Luis Nunes, Marcelo Roberto, Nelson Tinoco, Nestor de Figueiredo, Raul Penafirme, Robert Prentice, Ruy Costa, Tomas de Souza e Vicente Batista ${ }^{28}$.

Geraldo Ferraz, em Novos Valores na Arquitetura Moderna Brasileira: Abelardo de Souza, eleva a participação de Abelardo de Souza a de organizador "sob orientação de Warchavchik e em companhia de Oscar Niemeyer e outros." 129

No catálogo, de acordo com Frota, constam : Reproduções de obras 
de Lúcio Costa e Warchavchik, Emílio Baumgart, Affonso Eduardo Reidy e Gerson Pinheiro, Anton Flodderer e Alexandre Buddeus, Marcelo Roberto, Alexandre Altberg, Luis Nunes, Vicente Batista, Ademar Portugal, do próprio Alcides e João Lourenço da Silva. Há também uma tradução de um texto de Walter Gropius acompanhado por uma foto da Bauhaus Dessau, com a seguinte legenda: "fechada pela situação política", no próprio ano em que a Bauhaus fora obrigada a fechar suas portas sob pressão do nazismo. ${ }^{30}$

O catálogo inclui uma transcrição das recomendações dos CIAMS - Congressos Internacionais de Arquitetura Moderna - que se reuniram pela primeira vez no Castelo de La Sarraz, Suíça, com a presença de 24 importantes arquitetos, incluindo Le Corbusier. Os CIAMs objetivam coordenar esforços em todo mundo e divulgar a arquitetura moderna. Seus esforços eram voltados para ações que iam desde o ensino arquitetônico até "conduta Legislativa que impedia o desenvolvimento das construções no sentido racional e moderno". Os braços executivos dos CIAMs, Comitês internacionais para Racionalização dos Problemas de Arquitetura Contemporânea - CIRPACs - ficavam encarregados de educação da opinião pública; relações entre arquitetura , Estado, estandartização.

Irigoyen destaca que o salão é um claro exemplo do espírito antropofágico da modernidade brasileira, já propalado por Osvald de Andrade. Wright, Gropius, os CIAMs juntos, numa ávida demonstração de nossa necessidade de assimilar e incorporar todas as tendências. ${ }^{31}$

Mas, como ressalta Frota, o grande mérito do Salão, foi o de agregar pela primeira vez nomes e obras da geração formada por Lúcio Costa e Warchavchik, os mestres ali se encontravam homenageados juntamente com Frank Loyd Wright que dois anos antes apoiara a greve promovida pelos alunos da ENBA, quando do afastamento de Lúcio Costa da direção da entidade.
${ }^{30}$ FROTA, Lélia Coelho.Alcides da Rocha Miranda caminho de um arquiteto. Rio de Janeiro: Editora UFRJ,

$1993.232 p ;$ il. P.23.
${ }_{31}$ IRIGOYEN, Adriana (2002), Wright e Artigas duas viagens Ateliê editorial, São Paulo. P.63. 


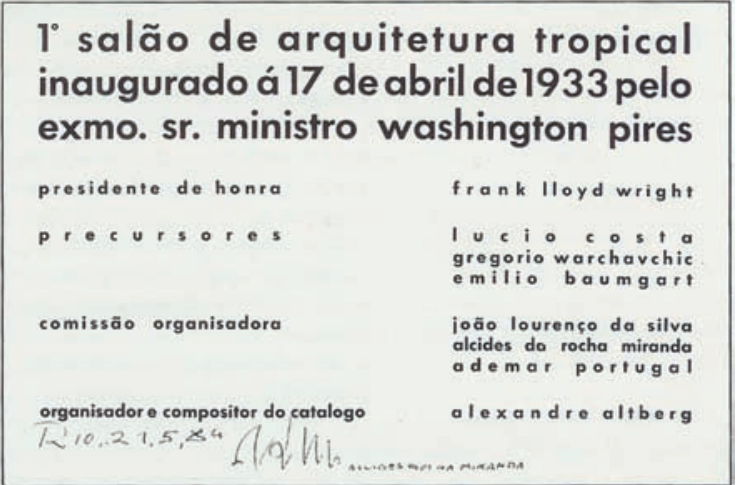

Capa do catálogo do Salão de Arquitetura Tropical.

\footnotetext{
32 IRIGOYEN, Adriana (2002), Wright e Artigas duas viagens

Ateliê editorial, São Paulo. P.65.

33 FROTA, Lélia Coelho.Alcides da Rocha

Miranda caminho de um arquiteto. Rio

de Janeiro: Editora UFRJ, 1993.232p; il. P.16.

${ }^{34}$ FROTA, Lélia Coelho.Alcides da Rocha

Miranda caminho de um arquiteto. Rio de Janeiro: Editora UFRJ, 1993.232p; il. P.22
}

A adjetivação da arquitetura como Tropical era, de acordo com Irigoyen, uma forma de identificar a produção local, sendo o clima o elemento que diferenciaria a produção brasileira da arquitetura moderna internacional. O autor estabelece uma relação com o ideário que Wright pregou em sua passagem pelo Rio nas referências à "arquitetura viva" e destacando a importância do clima como fator determinante. ${ }^{32}$

Frota cita depoimento Alcides da Rocha Miranda comentando como veio a ser útil para ele a preocupação de Wright com o clima na arquitetura. E acrescenta: "O Wright fazia um arquitetura para sombra. Ele tinha muita preocupação com a sombra que chamava de quarta dimensão. Foi a primeira pessoa que eu vi se interessar pela natureza. ${ }^{133}$

Para Alcides o "tropical" representou ali mais uma representação da nova arquitetura racional, utilizando recursos adequados ao clima e vegetação: pelo uso de grandes panos de vidro integrando a paisagem, brises que quando móveis ventilavam, e terraços-jardim nos edifícios, "coerentes com o ideário de Le Corbusier". ${ }^{34}$

Sobre o salão, Geraldo Ferraz afirma: "rumo das pesquisas que não deveria jamais ter sido abandonado, foi uma experiência verdadeiramente extraordinária para a época, e que teve um sucesso destacado"

O tema do Salão Tropical será retomado em 1961, durante o II Congresso Nacional de Críticos de Arte quando Celso Kelly apresenta na comissão sobre "a arquitetura moderna no Brasil e seus traços autóctones", um trabalho intitulado Uma contribuição histórica: o Salão de Arquitetura Tropical.

Nos anais do congresso está a transcrição da sessão plenária reunida com o fim de revisitar a arquitetura tropical. Diz o expositor:

"O salão de arquitetura Tropical influiu(...) no equacionamento de relações entre o projeto e o meio, especialmente na natureza e o clima, 
acentuando o caráter tropical nas soluções brasileiras. A prova do alegado está no pouco, ou quase nada, que nesse sentido se fizera anteriormente a 1933, e no número elevado de ensaios e realizações, logo após aquela data. Algumas dessas soluções se tornariam, com o tempo, traços próprios da moderna arquitetura brasileira. "135

Os integrantes da mesa, especialmente Artigas reagem à exposição, que acaba se tornando um embate entre arquitetura carioca e paulista.

No encerramento das discussões Flexa Ribeiro falando sobre a apresentação de Celso Kelly, confirma que o Salão "constitui apenas um episódio de implantação no país de uma nova arquitetura". A maior ou menor importância outorgada a cada um deles não é outra coisa senão uma questão de ponto de vista. ${ }^{36}$

\section{Revista Base}

1933 também é o ano em que são lançados no Rio de Janeiro, dois números da revista Base.

Como no catálogo do Salão de Arquitetura Tropical, assuntos diversos e tendências apontam "as preocupações estéticas e políticas dos modernistas da época". ${ }^{37}$

O primeiro número de Base traz ampla informação sobre exposições: Guignard organizando o salão da Pro Arte e Portinari na Associação dos Artistas Brasileiros.

Notícias de São Paulo testemunham a proximidade com os modernistas do Rio: Kathe Kollwitz expondo no CAM (Clube dos Artistas Modernos). Uma homenagem a Lasar Segall, como precursor da pintura
${ }^{35}$ IRIGOYEN p.66 -ver a opinião de Artigas

${ }^{36}$ IRIGOYEN p.67

37 FROTA, Lélia Coelho.Alcides da Rocha Miranda caminho de um arquiteto. Rio de Janeiro: Editora UFRJ 1993.232p. P.25 


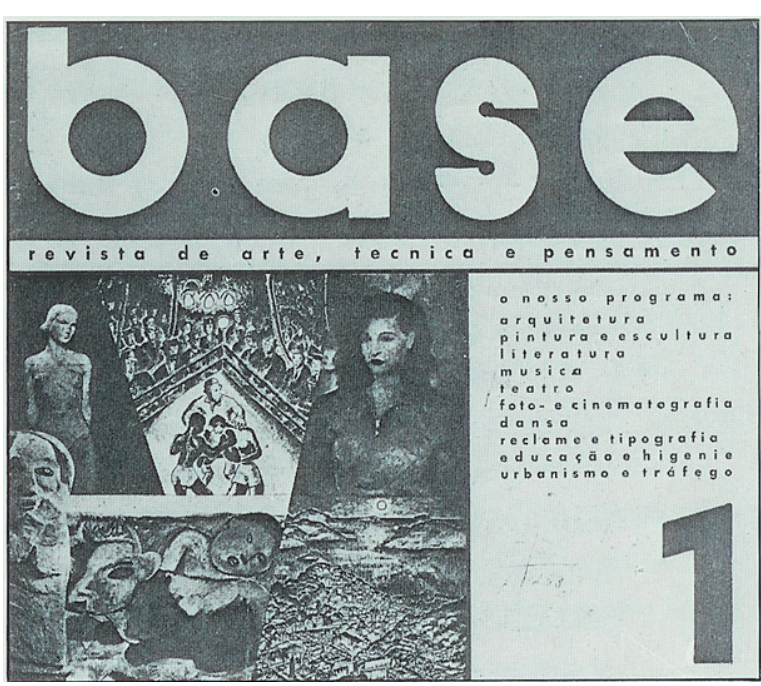

Capa do $1^{\circ}$ número da revista Base

${ }^{38}$ Depois de sua fundação em 28 , já tendo organizado grupos nacionais na Europa, na América e na Ásia, os CIAMs reunidos em Bruxelas, 1929, discutiram questão do "lar para existência mínima"; em Bruxelas, 1930, a divisão mais favorável do terreno para construções; em 31, em Berlim, fixaram-se as normas para o congresso a realizar-se no ano de 1933

39 FROTA, Lélia Coelho.Alcides da Rocha Miranda caminho de um arquiteto. Rio de Janeiro: Editora UFRJ, 1993.232p; il. P.25-28 moderna.

As vilas para operários projetadas por Warchavchik e Lúcio Costa são mostradas em planta baixa e fachada de frente.

Há mais notícias sobre os CIAMS - continuando as que já haviam sido veiculadas no I Salão de Arquitetura Tropical ${ }^{38}$. Base anuncia o congresso de 33, cujo tema será o estudo das funções da cidade. O congresso se realizaria a bordo no navio Patris, O congresso a bordo do Pátris, em excursão turística, em viagem de Marselha a Atenas e volta, e dele resultará na Carta de Atenas e os cinco pontos de Le Corbusier para a arquitetura nova da casa que irão adquirir valor de mandamento. São eles pilotis, planta livre, fachada livre, terraço-jardim e janela rasgada.

O segundo número sai em setembro de $1933^{39}$

Aponta para a melhoria das artes gráficas, notícias de urbanismo com o anteprojeto de Nestor de Figueiredo para a cidade de João Pessoa na Paraíba.

Artes plásticas falam de Di Cavalcanti , Quirino da Silva critica o Salão oficial. Uma resenha sobre Menino de Engenho de José Lins do Rego e Cacau de Jorge Amado. Há mais notícias sobre as atividades do CAM em São Paulo.

Alcides da Rocha Miranda critica a vinda do urbanista francês Alfred Ganache para projetar um bairro particular em São Paulo.

Um artigo do primeiro número de Base, redigido por Mario de Andrade dá indícios da proposta conceitual da revista: a arte penetrar a vida, procurar a "integridade do ser", localizando o homem em seu tempo pelo contato com a arte, ciência, política e economia no Brasil e no Mundo.

Base queria que atingir as mais diversas camadas da sociedade. Com apenas dois números, dificilmente atingiu seu objetivo, mas certamente 
circulou entre os meios mais informados e por seu conteúdo tomamos conhecimento das idéias que circulavam e da existência de um intercâmbio cultural entre Rio e São Paulo.

\section{A Universidade do Distrito Federal}

Abelardo de Souza, termina o curso de arquitetura em 1932 e, depois continuará seus estudos no curso de Urbanismo da Universidade do Distrito Federal. Segundo Geraldo Ferraz, Abelardo termina os estudos na Universidade do Distrito Federal em 1935 quando a instituição é extinta pelo governo Federal.

Há uma contradição nestas datas pois a Universidade do Distrito Federal foi criada em 1935. Abelardo de Souza teria então ingressado na UDF em 1935 e terminado seus estudos dois anos depois em 1937.

A Universidade surgiu por iniciativa do educador Anísio Teixeira, então Secretário da Educação e Cultura do Distrito, um ano após a criação da USP em São Paulo. Foi Pedro Ernesto Do Rego Batista, interventor do Distrito Federal em 1931 quem convidou Teixeira, que representava a corrente meis democrática da Escola Nova, para a Diretoria Geral da Instrução no Rio de Janeiro. Anísio foi também o principal introdutor da obra de John Dewey no Brasil, preconizando uma "educação integral", ou seja além do ensino de conhecimentos básicos a educação como um processo de preparação para o exercício da cidadania.

Gustavo Capanema, do Ministério da Educação e Cultura, não apoiava a criação da Universidade proposta por Anísio, afirmando que as suas idéias contrariavam os padrões estabelecidos pela Reforma Francisco Campos. 
40 Lista completa do corpo docente em VICENZI, Letícia Josephina Braga de. A fundação da Universidade do Distrito Federal e seu significado para a educação no Brasil. Forum Educacional. Rio de Janeiro, v10, n.3. 1986. p.21

${ }^{41}$ FROTA, Lélia Coelho.Alcides da Rocha Miranda caminho de um arquiteto. Rio de Janeiro: Editora UFRJ, 1993.232p; il. P. 18-19
Mesmo assim, Pedro Ernesto, eleito prefeito do Distrito com larga margem de votos, recebeu o apoio de Getúlio Vargas que passando por cima do Ministro da Educação autorizou o decreto de criação da Universidade do Distrito Federal.

De início fixaram-se na instauração dos cursos de preparação para professores primários e secundários, pois Teixeira considerava a formação de professores como um dos pilares da melhoria de ensino. Logo foram criadas as outras unidades e Anísio Teixeira conseguiu reunir em seu corpo docente o que havia de melhor para cada especialidade, "chamando autênticas notoriedades de todo o Brasil, e a todos arrebatando com seu ardente entusiasmo".40

Entre as unidades escolares e de pesquisa havia o Instituto de Arte, que contava entre outros com: Mário de Andrade, que deu um curso de filosofia e história da arte; Villa Lobos; Gilberto Freyre; Andrade Muricy; Lúcio Costa; Carlos Leão; Lorenzo Fernandez; Celso Antonio; Guignard; Portinari. Segundo Frota, No instituto coexistiam todas as artes, visando uma criação unitária, abrangendo a arquitetura, o urbanismo, a escultura, a música. Havia uma unidade de ensino voltada para as artes industriais, em particular as gráficas e de indumentária. Música e arquitetura eram lecionadas em nível de pós-graduação ${ }^{41}$.

Em novembro de 35, houve um período de conspiração que culminou com a "Intentona Comunista". O fantasma do comunismo levou a medidas autoritárias por parte do governo, preparando os caminhos para o golpe do Estado Novo, até a decretação do Estado de Sítio. Anísio Teixeira, que era considerado comunista pelo clero, foi obrigado a refugiar-se no sertão da Bahia. Na UDF iniciou-se censura aos meios de comunicação. Professores simplesmente desapareciam, presos, obrigados a fugir ou simplemente abandonavam o cargo descrentes na continuidade daquela instituição. 
Segundo Vicenzi "a UDF simbolizava o populismo de Pedro Ernesto e o liberalismo democrático de AnísioTeixeira. Para os defensores da ditadura, tudo aquilo foi encarado como um erro a ser eliminado." ${ }^{142}$ Desta forma, o governo Federal fechou a instituição em dezembro de 1938, substituindo-a pela nova Faculdade Nacional de Filosofia, que seria o padrão consentido e modelo oficial para as outras instituições similares.

Foi no curso de Urbanismo que Abelardo de Souza encontrou-se mais uma vez sob a influência do pensamento de Lúcio Costa e outros mestre modernos.

\section{Edgard Vianna e Rafael Galvão}

Como vimos, os eventos que ajudaram a formar o pensamento moderno dentro da arquitetura no Rio de Janeiro _ na conhecida escola carioca _ cercaram a formação de Abelardo de Souza e o marcaram de tal maneira que, durante toda sua carreira, o arquiteto prestará declarações e escreverá sobre este período na forma de personagem/espectador, como na introdução de seu Arquitetura no Brasil - Depoimentos.

Em sua fase de formação no Rio de Janeiro ainda deve-se mencionar seu convívio com os arquitetos Edgar Vianna e Rafael Galvão, com quem trabalhou.

Geraldo Ferraz em seu artigo "Novos valores da arquitetura moderna Brasileira: Abelardo de Souza" comenta que Abelardo de Souza trabalhou no escritório destes arquitetos, sem porém citar datas. Como logo após formado ele passou a trabalhar na prefeitura do Distrito Federal e no Banco Hipotecário Lar Brasileiro até sua vinda à São Paulo, fica a hipótese de que 
${ }^{42}$ VICENZI, Letícia Josephina Braga de. A fundação da Universidade do Distrito Federal e seu significado para a educação no Brasil. Forum Educacional. Rio de Janeiro, v10, n.3. 1986. p.29 43 CONDE, Luiz Paulo Fernandes/

ALMADA, Mauro in Guia da arquitetura Art-déco no Rio de Janeiro

Editora Casa da Palavra/ Secretaria Municipal de Urbanismo/ Centro de Arquitetura e Urbanismo do Rio de Janeiro/ Prefeitura da Cidade do Rio de Janeiro. 2000.164 p.il.

${ }^{44}$ SEGAWA p. 35

${ }^{45}$ Apesar de voltado para busca de elementos autóctones dentro da

Arquitetura Brasileira, Edgar Vianna é também apontado como o responsável pela moda das casas "missão

espanhola", trazida dos Estados Unidos. Ver BRUAND, $p$

${ }^{46}$ BRUAND p.56 este fato tenha ocorrido nos anos da ENBA ou pouco antes de vir a São Paulo.

Raphael Galvão era juntamente com -Lúcio Costa, Attílio Correa Lima, Paulo Antunes Ribeiro parte do grupo que abandonou o chamado movimento neocolonial, tornando-se partidário da nova arquitetura.

Desde a implantação da República, em 1889, havia se iniciado uma busca por valores que trouxessem uma "identidade nacional":

"uma forte corrente intelectual nacionalista que buscava, desde o final do século XIX, uma expressão própria para a cultura brasileira"43

$\mathrm{Na}$ arquitetura, esse pensamento gera duas linhas de desenvolvimento: o movimento neocolonial, lançado pelo português Ricardo Severo, que em 1914 profere na Sociedade de Cultura Artística uma conferência "A Arte Tradicional do Brasil", valorizando a arte tradicional "como manifestação de nacionalidade e como elemento de constituição de um arte brasileira"44, e o estilo Marajoara, de inspiração indigenista, do qual Edgar Vianna ${ }^{45}$ foi criador e que, identificando-se com a temática decorativa Art Déco, irá tornar-se uma variante deste.

Mas o maior divulgador e inclusive responsável pela denominação "neocolonial" foi o médico e historiador da arte José Mariano Filho.

Em 1922, no mesmo ano em que ocorre a Semana de Arte Moderna em São Paulo, Mariano organiza a Exposição Internacional do Centenário da Independência, onde os pavilhões brasileiros apresentavam-se, em sua maioria no estilo "neocolonial". Raphael Galvão e M. Brasil executam a grande porta monumental da entrada norte, "tratada com uma sobriedade que acentuava os elementos tomados de empréstimo à arquitetura tradicional." ${ }^{\prime \prime 6}$ O neocolonial foi o padrão obrigatório para exposições 
internacionais até a Feira Internacional de Nova-York, em 1930-40, quando por determinação às nações estrangeiras que apresentassem projetos em estilo Moderno foi executado o projeto de Costa e Niemeyer.

Em 1926, o Ministério da Agricultura institui um concurso para o anteprojeto do pavilhão do Brasil na Exposição de Filadélfia e uma das condições do programa era a adoção do estilo neocolonial. São apresentados seis projetos, sendo o de Lúcio Costa vencedor. Raphael Galvão e Edgar Vianna concorrem com projeto que segundo Bruand possui "equilíbrio

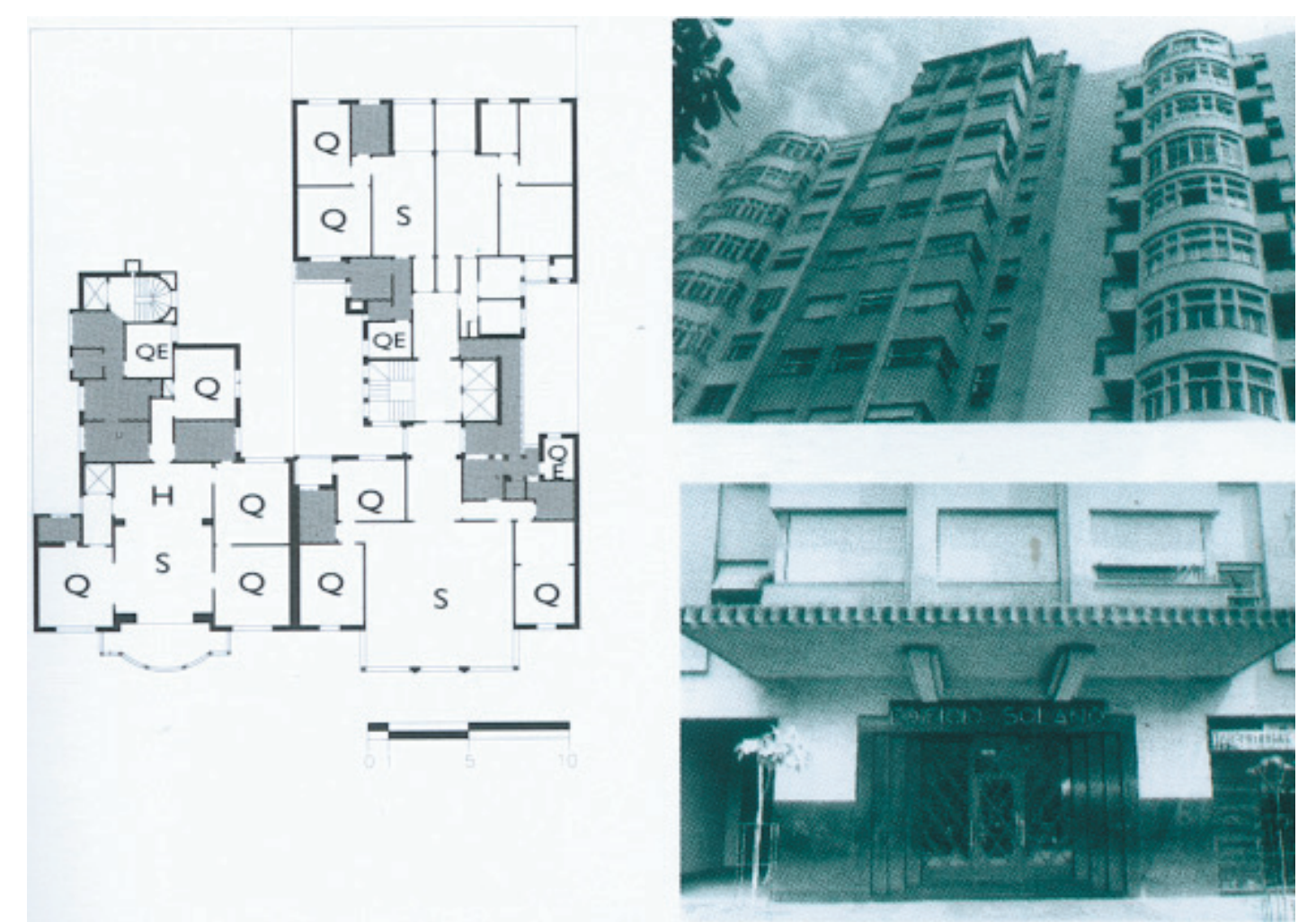

Edifício Solano. 1934. 
47 BRUAND p.56

48 BRUAND p.77; Revista da Diretoria da Engenharia no7 nov 33,p3-6.

Arquitetura e Urbanismo no 3 set 36 p140-44

49 SEGAWA p. 39
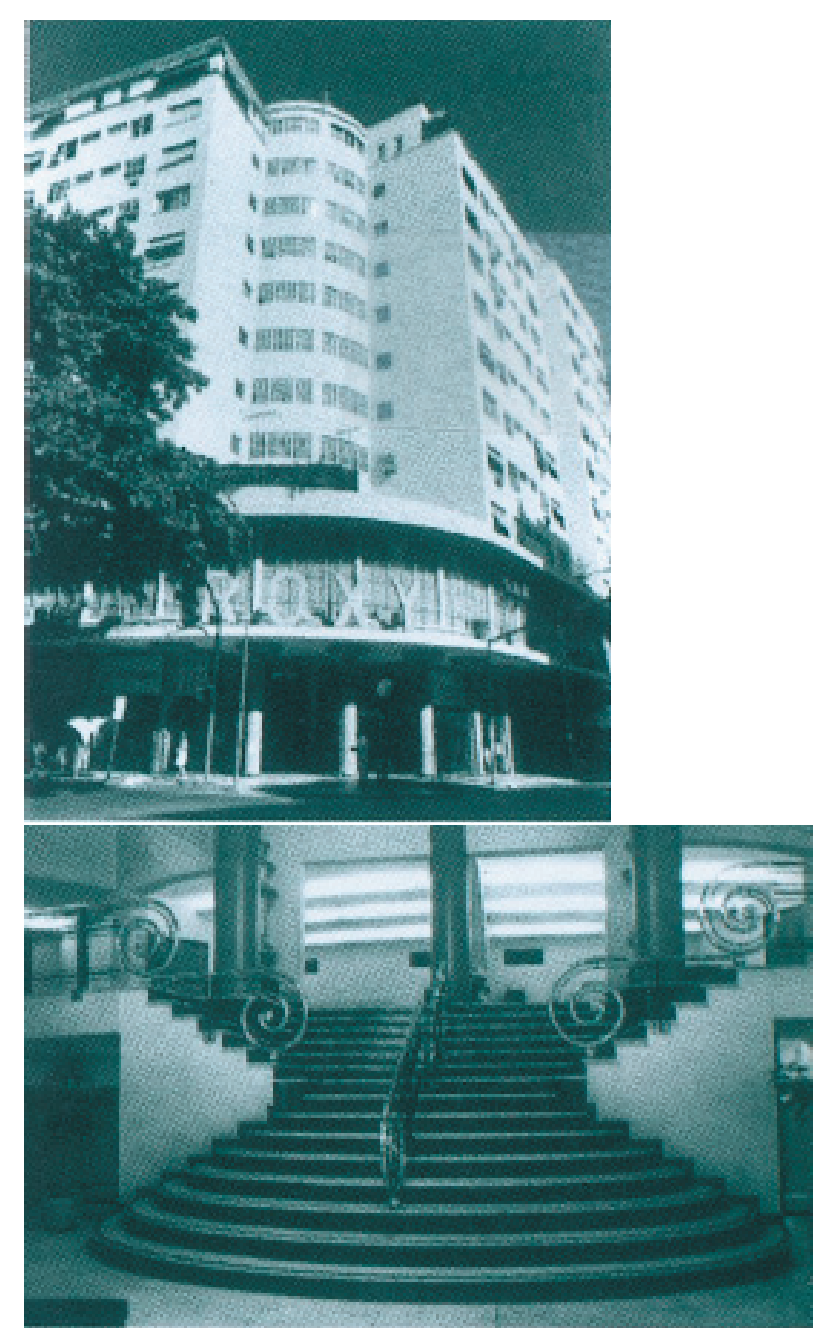

monumental necessário, mas às custas das soluções funcionais". 47

Ao aderir ao pensamento Corbusiano, Raphael Galvão realizará algumas obras de caráter funcionalista numa linha purista ainda com características Art -Déco, como é o caso do edifício Solano em Copacabana (1930) e cine Roxy (1934)

Em agosto de 1933 vence o concurso para construção do cine Ipanema ${ }^{48}$, mas sua obra mais conhecida será o Estádio Mário Filho Maracanã- (1949-50) em conjunto com Pedro Paulo Bastos, Antônio Dias Carneiro e Orlando Azevedo.

Quanto ao neocolonial, não se deve julgar sua importância pelos seus conceitos, mas principalmente por sua contribuição no estudo e aprofundamento do conhecimento que se tinha da arquitetura colonial. Nas palavras de Segawa:

"Independente do referencial de "modernidade" que adotavam, o principal aporte da postura neocolonial foi a introdução do contraponto regionalista - a busca de uma arquitetura identificadora da nacionalidade - como fator de renovação. "49

Alguns dos pioneiros da nova arquitetura brasileira _ Lucio Costa, Attilio Correia Lima, Paulo Antunes Ribeiro, Raphael Galvão e outros passaram por uma fase neocolonial antes de aderirem às idéias de Le Corbusier e certamente a geração de Abelardo, formada pela ENBA, teve uma influência, mesmo que difusa, deste ambiente que os cercava.

Cine Roxy, projeto de Raphael Galvão. 1934. 


\section{Os Primeiros projetos}

Após formar-se Abelardo de Souza permaneceu um ano Departamento de Engenharia do Distrito Federal, e de 1936 a 1939 foi encarregado de conduzir e inspecionar as obras do Banco Hipotecário Lar Brasileiro. Neste cargo, Abelardo de Souza dirigiu a construção de diversos edifícios, entre os quais o Pax Hotel e o ed. Itatiaia no Bairro da Glória, onde o Rio de Janeiro começava a transformar sua edificação.

O edifício residencial constituiu um dos componentes fundamentais da modernidade carioca. Até final da década de 1930, o edifício residencial já havia alterado a feição urbanística da cidade.

Devido a geografia acidentada do território urbano a expansão da casa unifamiliar encontrava-se dificultada, ao contrário do que ocorrera em outras cidades do continente, como Buenos Aires e Cidade do México. O setor residencial mais valorizado - Flamengo, Copacabana, Ipanema e Leblon - possuía um espaço limitado e, a partir da década de 1920, as mansões e chalés foram sendo substituídos por edifícios multifamiliares.

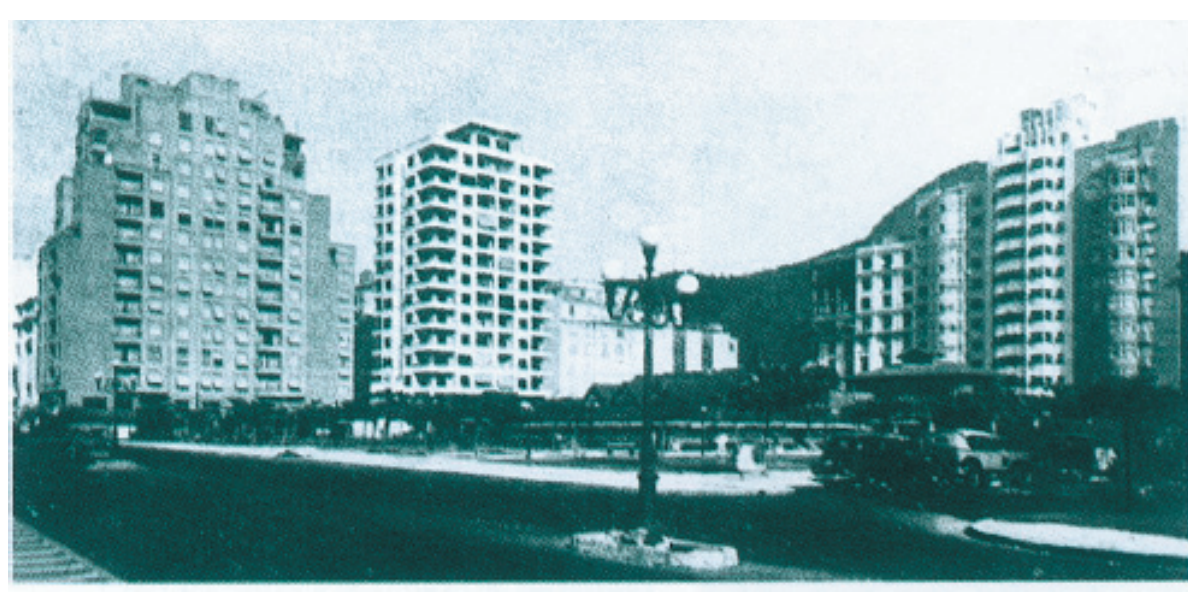


50 SEGRE, Roberto. Introdução in Guia da arquitetura Moderna no Rio de Janeiro

Editora Casa da Palavra/ Secretaria Municipal de Urbanismo/ Centro de Arquitetura e Urbanismo do Rio de Janeiro/ Prefeitura da Cidade do Rio de Janeiro. 2000. 210 p.il. P.14

${ }^{51}$ Arquivo pessoal do arquiteto, artigo sem identificação de 1972
Após o loteamento da área costeira de Copacabana e a construção do Hotel Copacabana Palace, em 1922, começaram a aparecer edifícios de dez a doze pavimentos, principalmente na área em torno do Hotel. De acordo com Segre ${ }^{50}$, até os anos 1960, o bairro crescerá vertiginosamente, com as quadras disponíveis sendo ocupadas por prédios de doze andares, e Copacabana atingiu uma das maiores densidades urbanas do mundo: cerca de mil habitantes por hectare.

Desse cenário é a primeira obra de maiores proporções de Abelardo de Souza: o edifício Cananéia, em Copacabana

\section{Edifício Cananéia - 1938}

Edifício com 9 andares dividido em dois corpos na Av. N. Senhora de Copacabana, em frente ao cine Metro.

O Terreno de proporções restritas sem necessidade de recuos laterais foi ocupado em toda sua extensão. Balcões e amplas janelas garantiam uma adequada iluminação e ventilação

Demonstra linhas nítidas da nova arquitetura, com volumes definidos, linhas horizontais, térreo livre com jardins. Os serviços e circulações verticais encontram-se no miolo do edifício.

Um artigo de jornal de 1972, faz menção ao projeto como sendo "um dos primeiros edifícios do Rio que tinha pilotis como solução para o andar térreo" 51.

Mas os pilotis não duraram muito tempo. Resolveram construir mais apartamentos no térreo, fechando parte da área comum. 


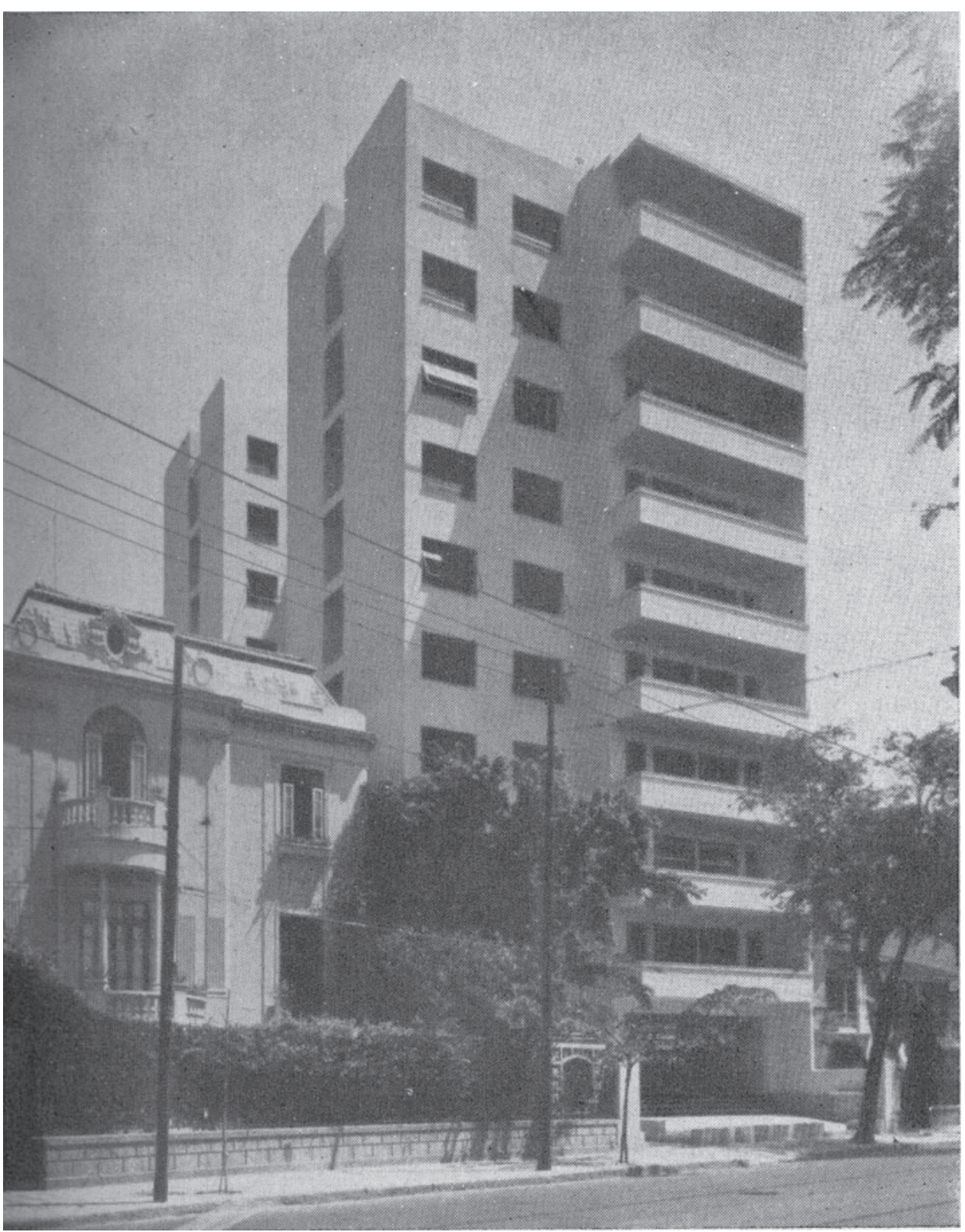

Edifício Cananéia, Rio de Janeiro. 1938. 
Vinda a São Paulo

J)(1) (1) (1) (1) 


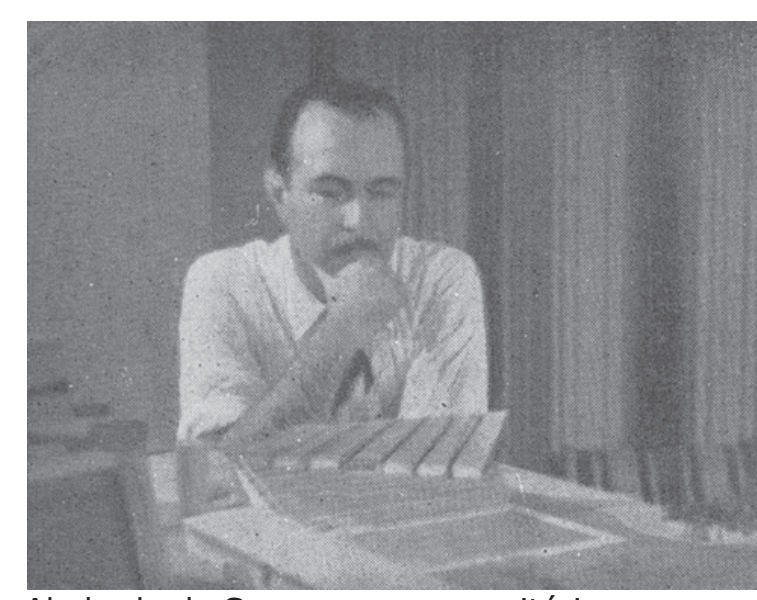

Abelardo de Souza em seu escritório.

${ }^{1}$ Xavier,Britto e Nobre, Arquitetura Moderna no Rio de Janeiro, Rio de Janeiro, 1991, p. 24

2 CAVALCANTI, Lauro (2001) Quando o Brasil era moderno - Guia de arquitetura 1928-1960. Rio de Janeiro, Aeroplano.

${ }^{3}$ Glória Ma Bayeux, O debate da

arquitetura moderna brasileira nos anos 50, São Paulo, 1991,p.55

\section{A arquitetura paulista}

A condição de capital Federal e centro emissor de cultura fazia com que toda produção do Rio de Janeiro fosse absorvida como imagem da arquitetura moderna no Brasil. ${ }^{1}$

"A conquista de um mercado estatal era absolutamente fundamental em um país no qual as elites e empresas privadas apenas adotavam um estilo depois que tivesse sido experimentado e aprovado em obras públicas" ${ }^{\prime 2}$.

Porém, no início década de 50 a produção da arquitetura moderna, não trata somente de uma "arquitetura de exceção"s, patrocinada pelo Estado, na medida que atrai também a iniciativa privada. A produção paulista é bem o reflexo disto

Em São Paulo, diversamente do que ocorreu em Minas e no Rio, os governos locais não realizaram investimentos em grandes obras e a sociedade paulista ainda provinciana também não abre espaço para renovações. Esse quadro será alterado com a expansão da indústria e com as investidas modernizadoras por parte da burguesia industrial, inclusive na área cultural.

A partir da década de 40, arquitetos do Rio de Janeiro são chamados a trabalhar em São Paulo e os arquitetos paulistas, assim como em outros Estados, deixam transparecer em suas obras a influência marcante da "arquitetura carioca". O resultado dessa produção arquitetônica será bastante questionado, visto que estaria se configurando em um "novo 
academismo" ${ }^{\prime 4}$

De acordo com depoimento da arq. Miranda Magnoli, "(...) em S.Paulo, década de 40, as figuras paulistas eram realmente exíguas; Warchavchik, estrangeiro e, além disso, ligado a Lúcio Costa; veja também que $W$ é muito "via" arquitetos cariocas e os Klabin que já tinham estreita e intensa relação com os artistas estrangeiros e nacionais. Assim acontece com o que se divulgou como o primeiro edifício moderno em S.Paulo: o Esther (só muito depois se "achou" o de Julio de Abreu na Angélica), de fato pioneiro nos aspectos principais e básicos do moderno, para o qual foi chamado um arquiteto do "grupo carioca"; Rino Levi, estrangeiro; Pilon, estrangeiro; os irmãos Roberto também são de origem do grupo carioca." 5

Abelardo de Souza tem sua transferência para São Paulo em 1939. Ele muda-se para São Paulo, contratado pela Companhia Asteca de combustíveis, para desenvolver alguns projetos de postos de gasolina. Aqui permanecerá e virá a desenvolver a maior parte de sua obra.

Abelardo irá participar da disseminação da linguagem carioca de arquitetura para além dos limites do Rio de Janeiro.

A produção paulista começará a adquirir novas características, na medida que se encontra fortemente vinculada a iniciativa privada e a arquitetura residencial, e portanto, sujeita a diferentes tipos de enfrentamento. De acordo com Lourival Gomes Machado:

"Em São Paulo se desenvolveu uma arquitetura que, em linhas gerais, não fica a dever ao exemplo carioca. Sua fisionomia topográfica e a ausência de grandes palácios ministeriais talvez levem a cidade a se tornar o centro arquitetônico destinado a resolver os problemas peculiares à casa de moradia"6

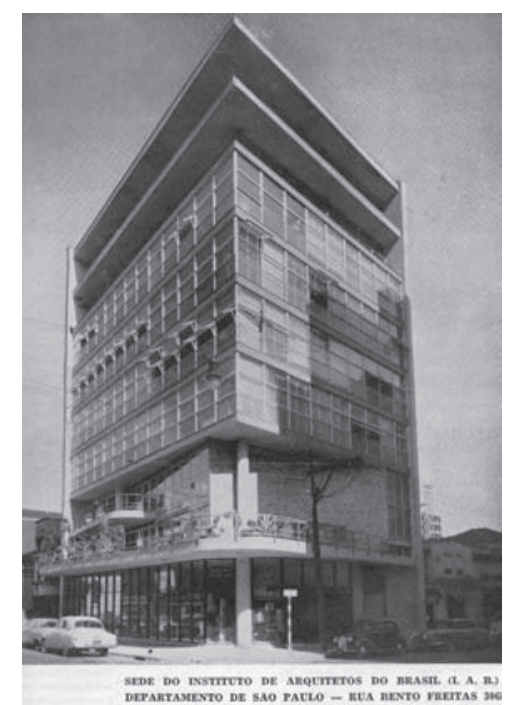

Ed. sede do I.A.B. São Paulo.

${ }^{4}$ Glória Ma Bayeux, op cit, p.48

${ }^{5}$ Depoimento prestado em 18/06/2004.

6 Lourival Gomes Machado, A Renovação

da Arquitetura Brasileira, in: Retrato de

Arte Moderna do Brasil. São Paulo, Depto.

De Cultura, 1947, p79-83. 


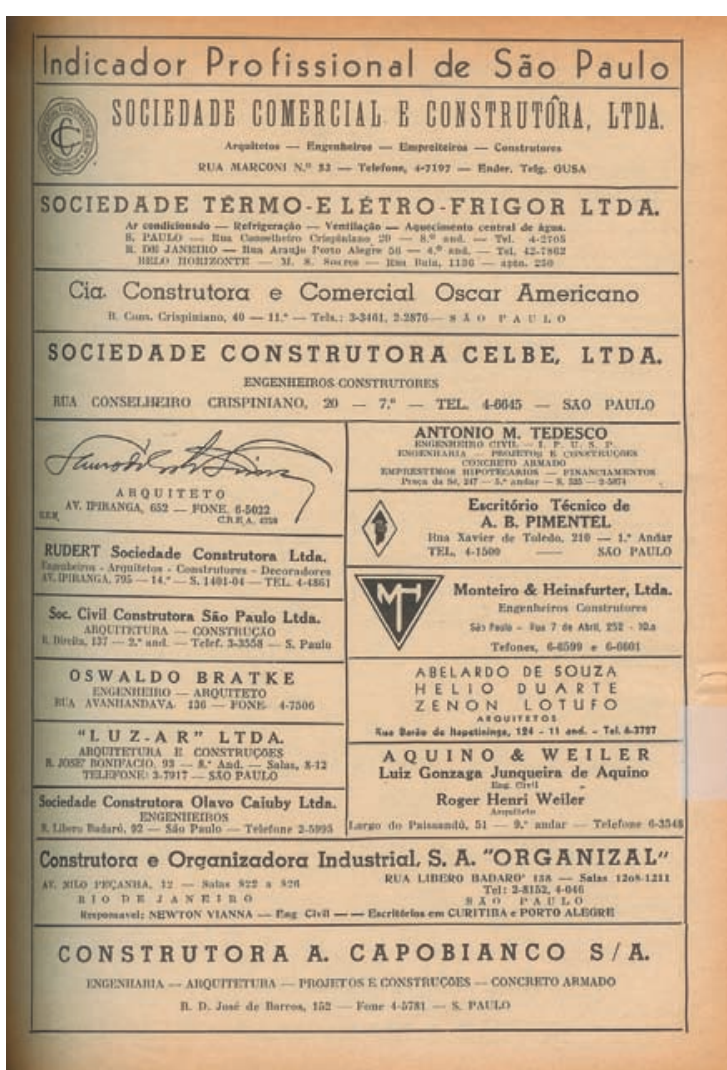

Anúncio do escritório com Hélio Duarte e Zenon Lotufo. Revista Acrópole.

7 Exemplo: Projeto da Sede do Clube Atlético Paulistano in Acrópole 130, p. 299-302. 1949

\section{Primeiros anos em São Paulo}

Após terminar seu contrato com a empresa petrolífera, Abelardo, em 1945, casa-se com Maria Luiza, que havia prestado serviços como desenhista no período de projetos da Companhia Asteca, fixando-se em São Paulo. Neste momento, com Hélio Duarte, também formado pela ENBA (1931), e Zenon Lotufo, engenheiro arquiteto formado pela Politécnica em São Paulo (1936), mantém escritório à Rua Barão de Itapetininga, aonde desenvolveram projetos em conjunto e individuais. Será nesta parceria que participaram do concurso de projeto para a sede do IAB/SP (1946), que posteriormente será realizado pela reunião de todas as equipes concorrentes.

A partir de 1946 a revista Acrópole publica diversos projetos do escritório de Abelardo, Zenon e Hélio. Entre as obras executadas, destacamse os edifícios Hecilda e Pedra Azul, e o edifício sede da Associação Bahiana de Imprensa, todos projetos de 1948.

Associado com Hélio e Zenon, Abelardo ainda colabora com Warchavchik 7 , participando do projeto da sede do Clube Atlético Paulistano (1949). A convivência com Warchavchik é importante, não só por ser o elemento de ligação com os arquitetos cariocas, dada sua amizade com Lúcio Costa, mas também por sua estreita relação com artistas, intelectuais e a sociedade da época em São Paulo.

Neste momento Abelardo amplia seus relacionamentos em São Paulo, assumindo o cargo de vice-presidente do IAB-SP, que ocupará de 47 a 49.

É também a partir de 1948 que ele ingressa como Professor Assistente na FAU/USP, na cadeira de "Composição Arquitetônica de 
Pequenas dimensões". Ele trabalha juntamente com Artigas que já era assistente de Anhaia em desenho arquitetônico.

Não se sabe com certeza que papel Abelardo de Souza desempenhou nesse momento de formação da FAU, mas o fato de ser pregresso da E.N.B.A. e da Universidade do Distrito Federal e ainda como participante das mudanças promovidas por Lúcio Costa, certamente adquiriu relevância, na medida que "implantação do moderno" no ensino de arquitetura no Rio precedeu em 18 anos a São Paulo, que ainda tinha como base o curso de engenharia da Poli. Presume-se que ele tenha atuado com razoável autonomia, conforme depoimento do arquiteto a Lena Coelho Santos:

"Aqui em São Paulo, quando já estávamos na fau lecionando, o Anhaia pediu: "olha, você vai ao Rio, conversa com o Lúcio Costa, para fazer uma nova programação na Faculdade de Arquitetura: nós estamos muito técnicos demais. Eu fui ao Rio, o Lúcio me disse: "olha Abelardo, faz como você aprendeu na Escola de Belas Artes: ligação Belas Artes com arquitetura que, sem isso, não tem sentido." 8

Podemos creditar-lhe, inclusive, autonomia na indicação de professores, como foi o caso de Eduardo Corona que por seu intermédio virá do rio de Janeiro em 1949, saído do escritório de Oscar Niemeyer, para lecionar na FAUUSP, conforme depoimento prestado por Corona a Ricardo Carranza9

"E a uma determinada altura, em 49, o Abelardo de Souza, de São Paulo, passou pelo Rio de Janeiro, procurando um assistente de Teoria de Arquitetura para o professor Anhaia Mello, que era o diretor da FAU. Aí o Oscar chegou para mim e disse:__Olha, quer ir prá São Paulo? Ele estava

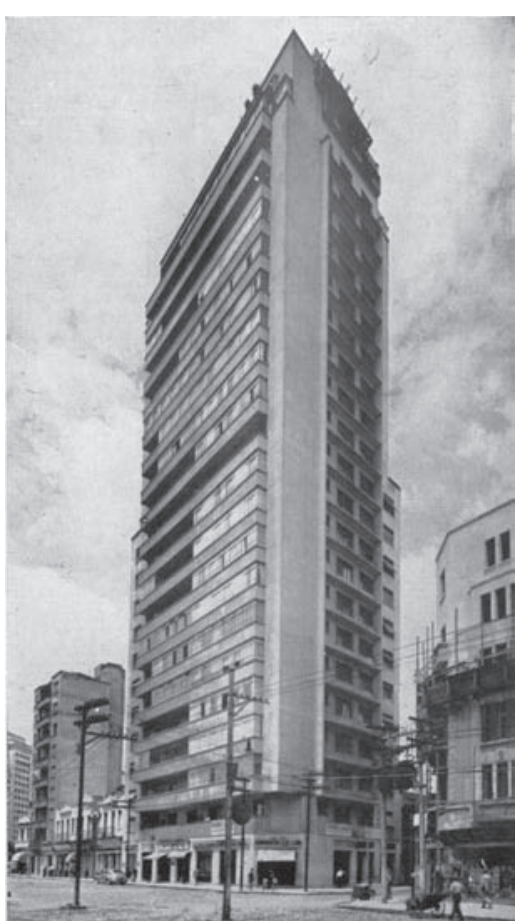

Edifício Conceição. 1942.

${ }^{8}$ Depoimento de Abelardo de Souza in SANTOS, Lena Coelho (1985) Arquitetura Paulista em torno de 1930-40. Orientador : Eduardo Corona.Nível: mestrado FAU/USP, São Paulo. P.79

9 Eduardo Corona in CARRANZA, Ricardo (2000). Eduardo Corona: Arquitetura Moderna em São Paulo.

Orientador: Lúcio Gomes Machado. Nível: mestrado FAU/USP, São Paulo. P.104 
${ }^{10}$ Assim como Hélio Queiroz Duarte. SEGAWA, Hugo (1997) Arquiteturas no Brasil 1900-1990. São Paulo, Editora da Universidade de São Paulo, $2^{\text {a }}$ edição, 1999. p.131

${ }^{11}$ Hugo Segawa, Disseminando a

linguagem arquitetônica carioca em São

Paulo, Projeto no 105, São Paulo, 1987, p.143 meio sem serviço também. Aí eu disse: _ Eu topo. E acabei vindo para São Paulo. Em 49, maio de 49."

Abelardo também será responsável pelas indicações de Jon MaitreJean, Miranda Magnoli,Renina Katz, entre outros, para Universidade. Ele aí permaneceu como professor, até se aposentar em 1978.

Segawa comenta que dos arquitetos saídos da E.N.B.A., que desfrutaram da curtíssima gestão de Lúcio Costa, pouquíssimos nomes seguiram a carreira docente. Podemos incluir Abelardo de Souza entre eles. ${ }^{10}$

São Paulo na década de 40 passa por grande processo de crescimento e a arquitetura moderna começa a sofrer grande influência da escola carioca. Souza foi desde o início um adepto fervoroso dos ideais modernos, seus projetos caracterizam-se pelo uso da linguagem carioca corbusiana, prosseguindo as pesquisas formais iniciadas no Rio, num repertório diferenciado da linguagem corrente em São Paulo no período. Segundo Segawa em artigo para revista Projeto em 1987 "a prática arquitetônica de Abelardo de Souza assinalava uma conviç̧ão pelo moderno que seus colegas paulistas - como Eduardo Kneese de Mello ou Oswaldo Bratke, da mesma geração - não sustentaram no início de suas carreiras". ${ }^{11}$

Seu primeiro projeto conhecido é de 1942, o edifício Conceição, para o Banco Hipotecário Lar Brasileiro.

Abelardo já havia trabalhado para o Banco Hipotecário Lar Brasileiro, quando ainda recém-formado no Rio de Janeiro. Os projetos de habitação coletiva realizados por Abelardo para o Banco Hipotecário e, posteriormente, os realizados para a Companhia Nacional Imobiliária (CNI) durante a década de 50 são a parte mais conhecida e divulgada de sua obra. Ele consegue transpor para os edifícios o repertório carioca, repleto de 
referências a Corbusier e Lúcio Costa, pelo uso dos cinco pontos do primeiro e pela introdução de elementos típicos de nossa arquitetura tradicional do segundo. O uso da policromia retirada do barroco em edifícios, os brises, a integração das artes, cobogós e muxarabis são claramente referências da arquitetura carioca e o diferenciam de seus colegas paulistanos.

Mas em seus projetos para edifícios residenciais passa a incorporar ao repertório carioca soluções típicas da moradia paulistana e das exigências do mercado imobiliário em expansão, o que torna seu trabalho um elemento de conjunção da linguagem formal carioca com funcionalismo paulista.

\section{Verticalização em São Paulo}

O crescimento vertical de São Paulo nas décadas de 40 e 50, foi um dos fatores que levou a um impulso na arquitetura moderna brasileira. As cidades se expandiam e a necessidade de moradia levou a expansão a partir do centro para novos bairros, levando a substituição de casas por edifícios residenciais.

Diversos foram os fatores que levaram e esta expansão, sejam os de ordem econômica gerados pelo processo de substituição de importações iniciado na década de 30 e acentuado com a Segunda Guerra Mundial que impulsionaram o setor de indústria da construção. Seja a política econômica federal, com o plano de metas de Juscelino à partir de 1955; sejam as intervenções municipais, quando a notícia da Lei no 5.261 de 1957, que regulariza um coeficiente máximo de aproveitamento do terreno para capital levará a um pico na verticalização em São Paulo no período que antecede este processo. De acordo com Somekh: 
"A iminência da promulgação de uma lei que reduziria as possibilidades de construção dos terrenos urbanos pode ter provocado uma corrida de aprovação de projetos para escapar às novas sanções. "12

As carteiras hipotecárias e o processo de incorporação também aceleraram o processo de verticalização e não é possível falar da obra de Abelardo de Souza sem se referir a dois grandes grupos financeiros, responsáveis por diversas construções na na capital paulistana: o Banco Hipotecário Lar Brasileiro e o Banco Nacional Imobiliário.

\section{B.H.L.B.}

Durante os anos 40 e 50 o Governo Federal incentivou a criação de carteiras hipotecárias que representaram papel relevante no financiamento de habitações, notadamente para as classes médias urbanas.

Inicialmente, as verbas destes fundos eram destinadas exclusivamente ao fornecimento de moradia dos próprios associados, porém foram introduzidas alterações nestas carteiras (inicialmente no IAPI,

12 SOMEKH, Nadia.(1987) A (des) verticalização de São Paulo

Orientador: Profa Dra Maria Adélia A. de Souza. Nível - Mestrado

FAU/USP, São Paulo.p.102

13 FARAH, Marta Ferreira Santos, Estado, previdência social e habitação

Dissertação (mestrado) Depto de Ciências Sociais da FFLCH/USP. São Paulo, 1983I, p.48)

${ }^{14}$ FARAH, obra citada, p.50 e depois outros aderiram) que permitiam o uso dos fundos em operações imobiliárias variadas, feitas com terceiros, com a finalidade exclusiva de obtenção de bons rendimentos para as reservas acumuladas ${ }^{13}$ :

"Liberadas as taxas de juros nas operações deste Plano, podia o instituto comportar-se como qualquer investidor, selecionando melhores aplicações do ponto de vista do retorno do capital investido" ${ }^{14}$. 


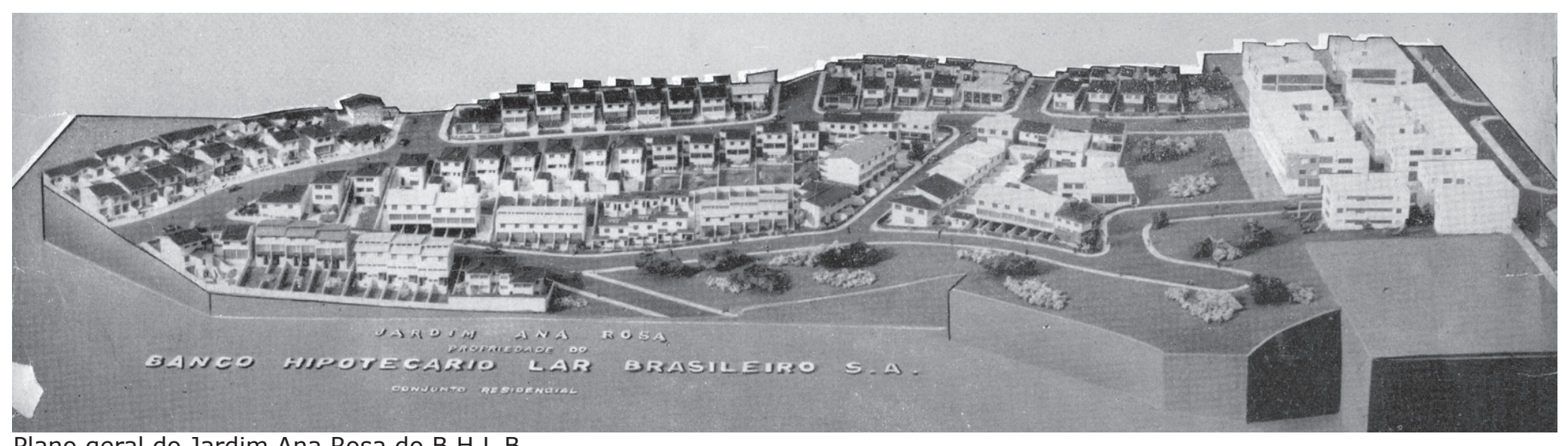

Plano geral do Jardim Ana Rosa do B.H.L.B.

São Paulo experimentará nestas décadas forte verticalização de bairros como Jardins e Paraíso, e ocupação horizontal de outros como Ibirapuera e Itaim.

O Banco Hipotecário Lar Brasileiro destinou grande parte de sua captação de dinheiro à construção com fins imobiliários, realizando os projetos com arquitetos de renome ${ }^{15}$, mais propriamente como um atrativo de mercado que por uma preocupação com boa arquitetura.

Para o Banco Hipotecário, além do Edifício Conceição (1942), Abelardo de Souza projetará, entre outros o Ed. Ana Rosa(1951) e o plano para conjunto residencial em Perdizes, do qual serão construídos os edifícios Franco da Rocha e Ministro Godoi (1954).

Na construção deste período será notável a influência da arquitetura européia, especialmente pelas experiências de reconstrução das cidades destruídas pela guerra. Serão comuns os projetos de prédios de apartamentos ou escritórios, geralmente apoiados em andares comerciais, ocupando toda projeção do terreno, como Van de Broeke e Bakema na reconstrução do centro de Roterdam e outras cidades holandesas.

15 "tendo o capricho de escolher criteriosamente os arquitetos aos quais solicitava projetos"

FAGGIN, Carlos Augusto Mattei, Carlos Millan, itinerário profissional de um arquiteto paulista. .Dissertação (mestrado) FAU/USP. São Paulo, 1992. 


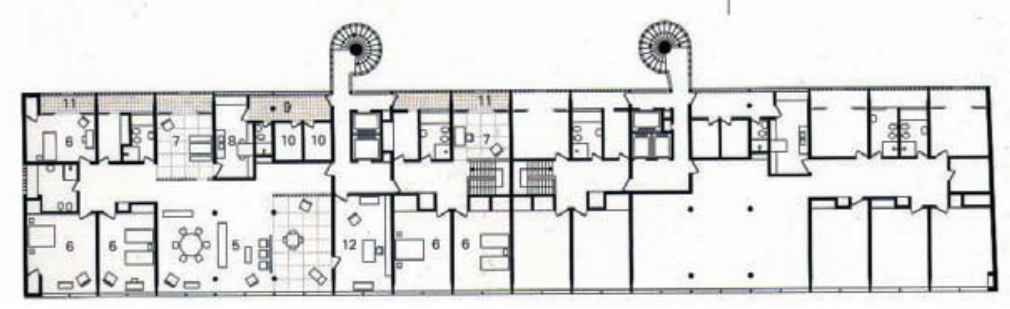

Planta Ed.Nova Cintra, Parque Guinle, RJ

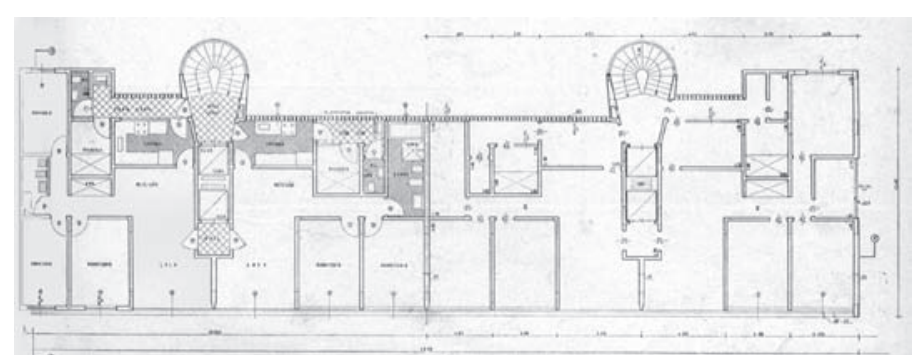

Planta Ed.Ministro Godoy
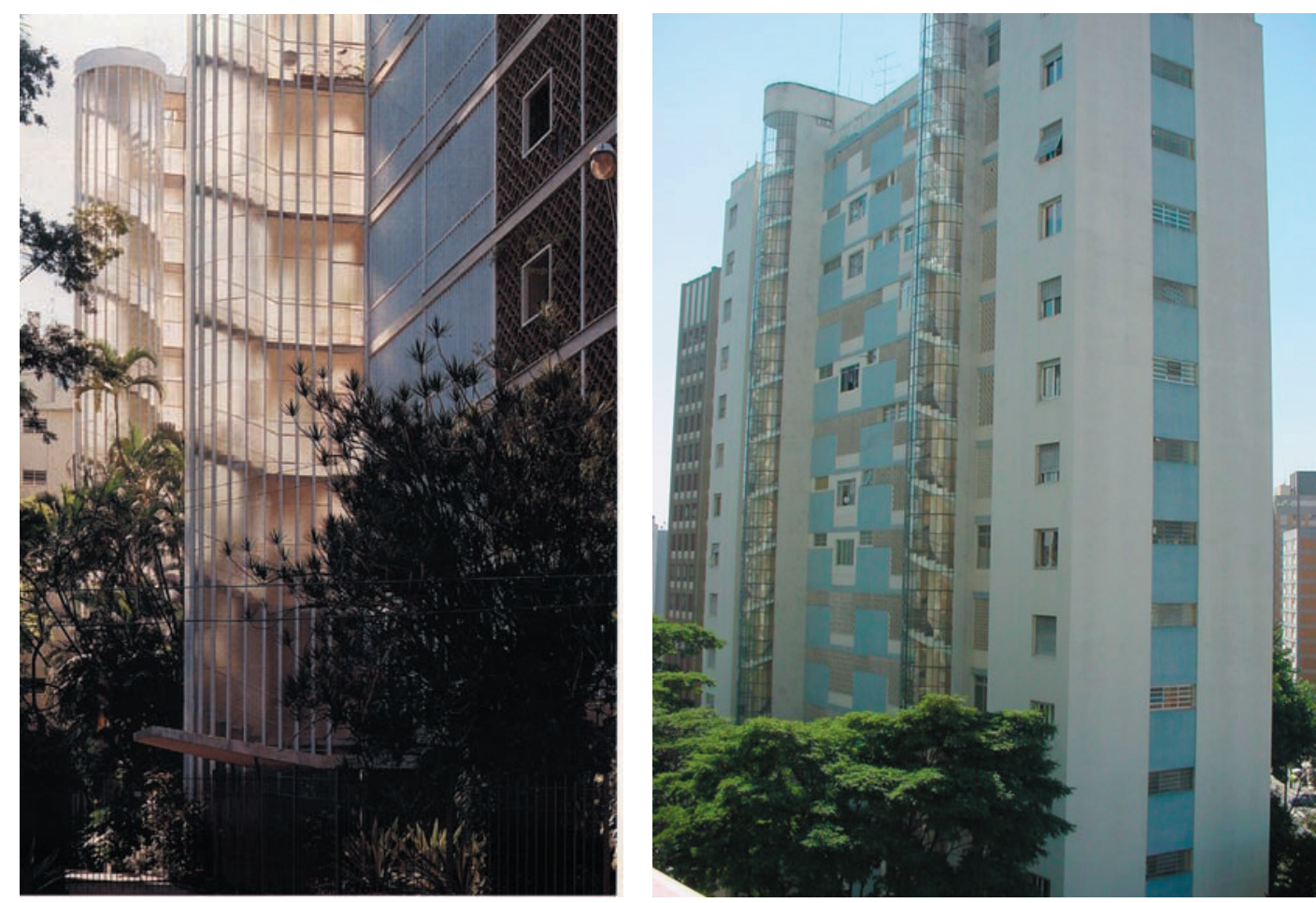

Edifício Nova Cintra e Ed. Ministro Godoy
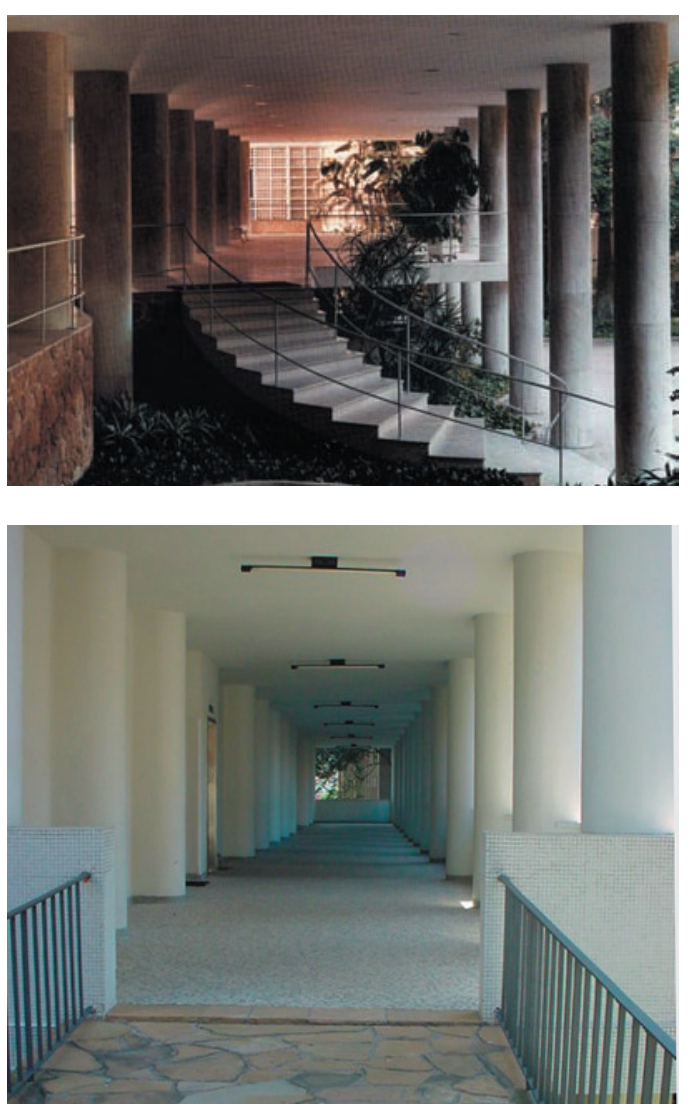


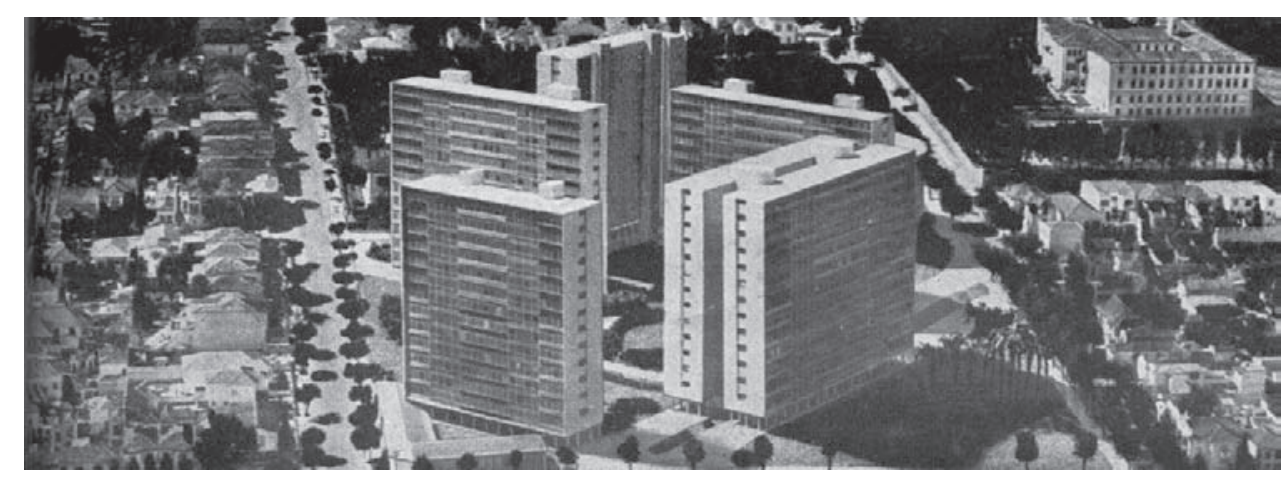

Nos blocos em Perdizes, de Abelardo de Souza, fica clara a referência aos edifícios do parque Guinle de Lúcio Costa - tanto na solução de plantas, como para o tratamento de fachadas e cores. Estes edifícios lamelares, com treze pavimentos sobre pilotis, serão comparados por Paulo Bruna às experiências racionalistas da época, como os blocos construídos em Londres para Westminster City Council ${ }^{16}$, em 1946/47 pelos arquitetos Philip Powell e Hidalgo Moya, devido a clareza compositiva, "em que as funções internas dos apartamentos e as circulações horizontais e verticais são claramente legíveis na articulação da fachada."17

Grande parte dos primeiros edifícios residenciais financiados pelos Institutos de previdência durante o Estado Novo surgiu para fins de locação. Entretanto, com o congelamento dos aluguéis pela lei do inquilinato de 1942 e sendo a inflação do período (até 1950) bastante acentuada, os institutos relocarão seus investimentos para setores de infraestrutura (usinas e hidroelétricas). As unidades de moradia de aluguel serão postas a venda, parceladamente. Os edifícios, antes de um só proprietário, disseminam-se em condomínios.

Essa medida irá afetar a verticalização no sentido de alterar o seu uso e programas.
Abaixo, edifícios em Pimlico, arquitetos Hidalgo e Moya. Ao lado, maquete do conjunto residencial em Perdizes de Abelardo de Souza.

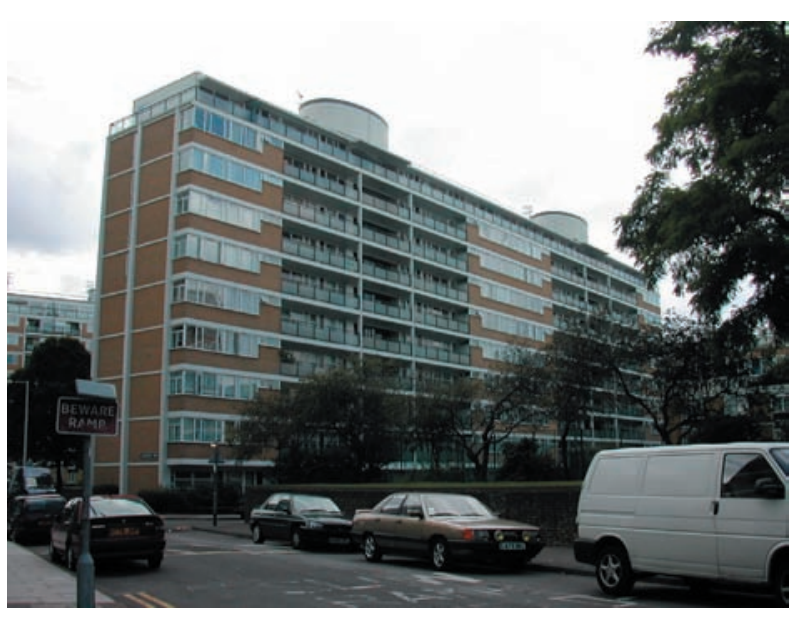

${ }^{16}$ Churchill Gardens em Pimlico

17 BRUNA, Paulo J. V., Abelardo de Sousa,

in Catálogo de desenhos de arquitetura

da biblioteca FAU/USP, p.161 


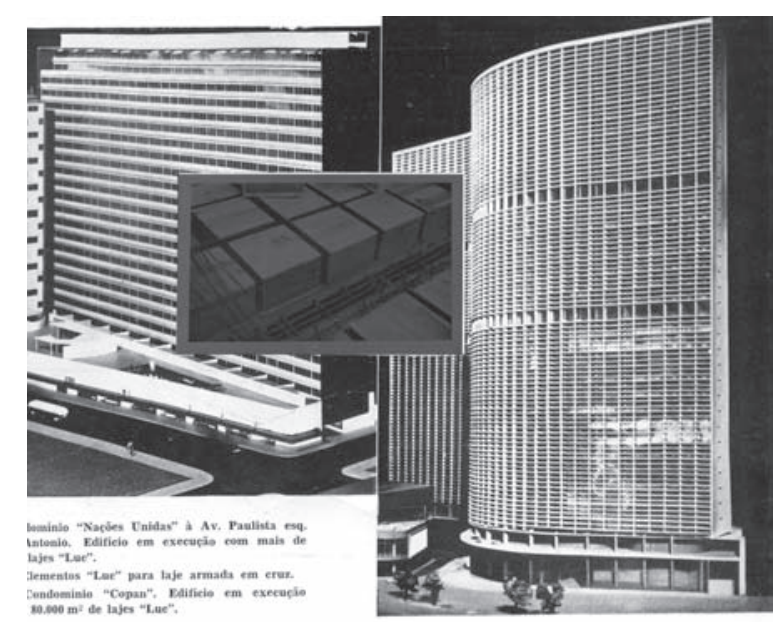

\section{; Granols Estruturas}

\section{LAGES LUC}

Anúncio com Edifício Nações Unidas e Copan.
Abre-se espaço para um novo agente do processo de verticalização: o incorporador.

Segundo Carlos Lemos ${ }^{18}$, o engenheiro Cipriano Marques Filho foi o precursor e idealizador da incorporação na produção de edifícios criando o "condomínio pelo preço de custo". Cabia-Ihe escolher o terreno e encontrar os compradores dos apartamentos que se cotizavam para pagar o terreno, o projeto e a construção, e ele como engenheiro e líder da operação recebia uma taxa de administração. Cipriano Marques Filho irá realizar essa experiência com sucesso em São Vicente.

Conta Lemos que um primo de Cipriano, Carlos Caldeira Filho, interessou-se pelo sistema incorporações em São Vicente e percebendo que se tratava de uma mina de ouro achou que poderia desenvolvê-lo em São Paulo. Então Caldeira Filho registrou como propriedade sua a expressão "condomínio pelo preço de custo" e se apresentou a Octavio Frias, proprietário da Folha de São Paulo, que era diretor do BNI - Banco Nacional Imobiliário, a quem vai propor sociedade, para fazer esses condomínios. Feita a sociedade, ambos começaram a incorporar prédios.

O negócio prosperou e eles foram percebendo que valia a pena fazer edifícios com bons projetos, bons arquitetos, para vendê-los melhor.

"Arquitetos e artistas famosos são convidados a trabalhar em São Paulo, numa perspectiva de valorização da atividade imobiliária. É assim que Portinari, por exemplo, vai executar uma série de painéis em edifícios"19

\section{Incorporações e o B.N.I.}

${ }_{18}$ Carlos Lemos, in SOUZA, Maria Adélia Aparecida de (1994) A identidade da metrópole: a verticalização em São Paulo. Ed. HUCITEC/ EDUSP, São Paulo. P.109-

19 Maria Adélia Aparecida de Souza, obra citada, p.111 
No início dos anos 50 o BNI será o responsável pela vinda de Oscar Niemeyer a São Paulo. O ano de 52 marca o primeiro projeto de Oscar na cidade. Para o BNI, Abelardo de Souza projetará, entre outros, o Ed. Nações Unidas e Edifício Três Marias.

Nessa época o BNI já havia criado uma empresa paralela somente para realizar as incorporações, chamada CNI - Companhia Nacional de Investimentos.

Octavio Frias e Roxo Loureiro, acionista majoritário do BNI, chegaram a constituir uma comissão com engenheiros e arquitetos da Prefeitura de São Paulo que, além de ajudá-los na realização da incorporação dentro da Lei, iria sugerir alterações no Código de Obras para favorecer esse tipo de empreendimento.

Era usual, que um edifício fosse projetado como Hotel _ onde era permitido o uso de banheiros internos com ventilação tubulada e maior coeficiente de aproveitamento _ para depois ser vendido como condomínio. Essa prática será denunciada, mas reverterá numa alteração no código de obras permitindo uso de banheiros internos também em apartamentos particulares. O edifício Copan de 1952 é projetado com base nesse novo código.

Em 1954, o BNI sofre uma intervenção e será comprado pelo Bradesco. O CNI continuará com as obras em andamento. Na década de 1960, Abelardo ainda fará alguns projetos de hotéis e loteamentos para o banco Bradesco e para Roxo Loureiro, porém nenhum se realiza.

As primeiras incorporações eram para apartamentos tradicionais de dois ou três dormitórios para atender à classe média e alta em suas necessidades: dois ou três quartos, entrada social e de serviços separadas, banheiro, cozinha e os edifícios eram verdadeiros "palacetes superpostos ${ }^{20 "}$. Mas elas notabilizaram-se pelos prédios de um quarto, os JK (janela e

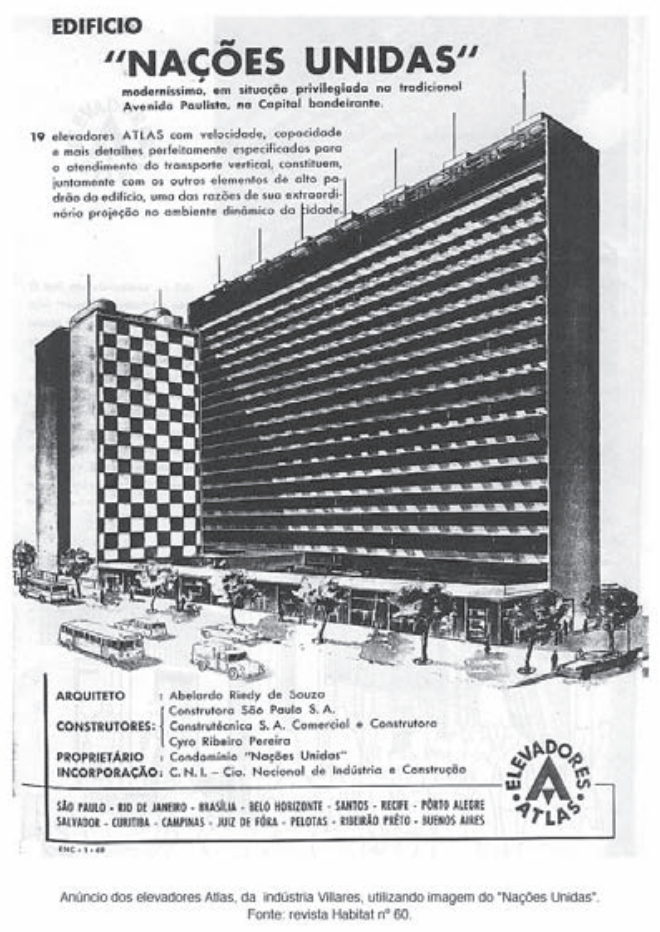

${ }^{20}$ Carlos Lemos, in Maria Adélia Aparecida de Souza, ibiden 


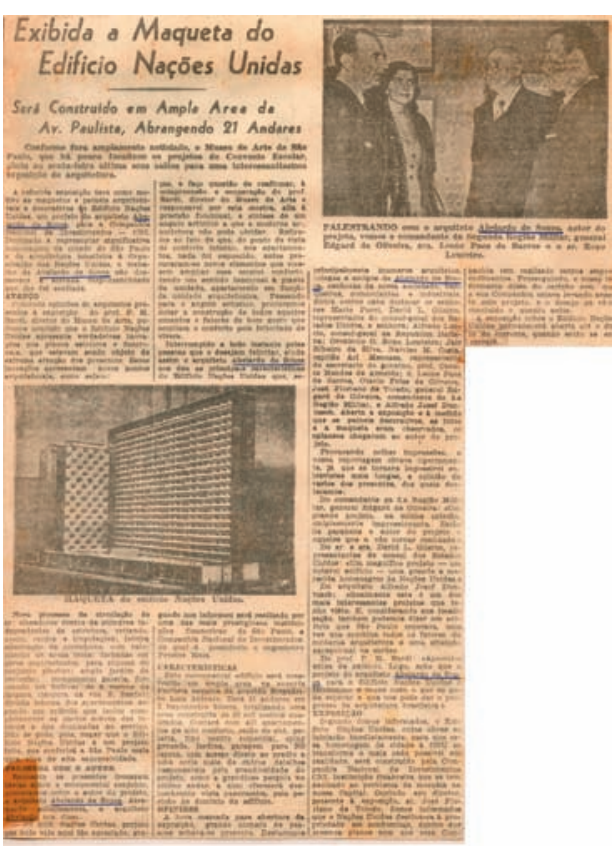

Artigo de jornal informando sobre exposição de painéis e maquetes do $\mathrm{Na}$ ções Unidas no MASP.

Julho/1953.

${ }^{21}$ Maria Adélia Aparecida de Souza, obra citada, p.112

22 XAVIER, Alberto/LEMOS, Carlos A.C./ CORONA, Eduardo(1983) Arquitetura moderna paulistana. Editora Pini, São Paulo, p.35 cozinha), ou kitchenettes.

As incorporações dos anos 50 farão, inconscientemente, uma "revolução do programa da casa mínima para classe média brasileira, e que não havia, até então, sido criado através da habitação coletiva ${ }^{21 "}$.

A carência dentro da classe média baixa das grandes cidades pelo apartamento mínimo havia sido mascarada pela guerra, lei do inquilinato e dificuldade da classe média em ter onde morar.

\section{Edifício Nações Unidas}

A grande obra e também a mais conhecida de Abelardo de Souza para o BNI será o edifício Nações Unidas - conjunto habitacional em dois blocos na Av. Paulista esquina com Brigadeiro Luís Antonio, dotado de galeria de lojas no térreo que servia de acesso aos moradores. As fachadas tratadas com jogo de cores em pastilhas e brise-soleil em concreto são resultado de sua pesquisa formal levada ao extremo.

Localizado na esquina das avenidas Brigadeiro Luís Antonio e Paulista, é fruto de uma incorporação do CNI. Seu programa de uso misto - com térreo ocupado por lojas e galerias de passagem obrigatória para acessar os apartamentos - baseou-se no êxito do edifício Califórnia no centro, que de acordo com Corona "levou seus incorporadores a cogitarem de programa semelhante para terreno à Avenida Paulista, então exclusivamente residencial. Foi este escolhido com critério, pois já se antevia para o local a valorização de atividades comerciais, função tradicional da Brigadeiro, com que fazia esquina. "22

Abelardo realizou uma série de estudos para o terreno, prevendo 
a base comercial e um grande bloco curvo paralelo à Avenida Brigadeiro, porém o custo do terreno fez com que os incorporadores optassem por tirar o máximo proveito da área a construir: $63.000 \mathrm{~m} 2$ de construção distribuídos em 3 blocos com 430 apartamentos, 25 lojas, garagem para 300 carros, galeria com $6 \mathrm{~m}$. de largura, playground, salão de chá etc. Apresenta como inovações elevadores em cilindros independentes, eliminação dos corredores com valorização das áreas úteis, blocos distintos reforçados pelo uso de cores contrastantes na fachada.

A crítica arquitetônica da época, reconhecia que havia um abuso por parte dos incorporadores que para incrementar seus lucros tiravam o maior proveito área a construir, mas a idéia de que a verticalização da Paulista mostrasse os desmandos das incorporadoras e a ausência de uma legislação urbanística efetiva eram desfocadas pelo fascínio provocado no ingresso no âmbito internacional pela metropolização, fato que a arquitetura moderna só vinha a reforçar.

"Mas, fiquemos no plano de nossa atualidade... Sob certos aspectos o "Nações Unidas" acrescenta ao prestígio de sua monumentalidade alguns dados de conjunto residencial organizado, e como unidade residencial embora sujeito aos azares da exploração mercantilista um tanto atrabiliária e arbitrária, emerge no quadro de nossa arquitetura moderna, assim considerada, como uma consequência de categorizada concepção. "23

O projeto de Abelardo foi extensamente comentado, artigos que traziam notícias sobre a "Unidade de Habitação de Marselha", de Le Corbusier faziam-Ihe comparações; a escolha do nome para o edifício_ Nações Unidas_vinha justificada como uma homenagem da cidade a ONU, conforme frisavam seus idealizadores em diversos artigos de jornal; a maquete do edifício e seus projetos ficaram, por decisão de Pietro Maria
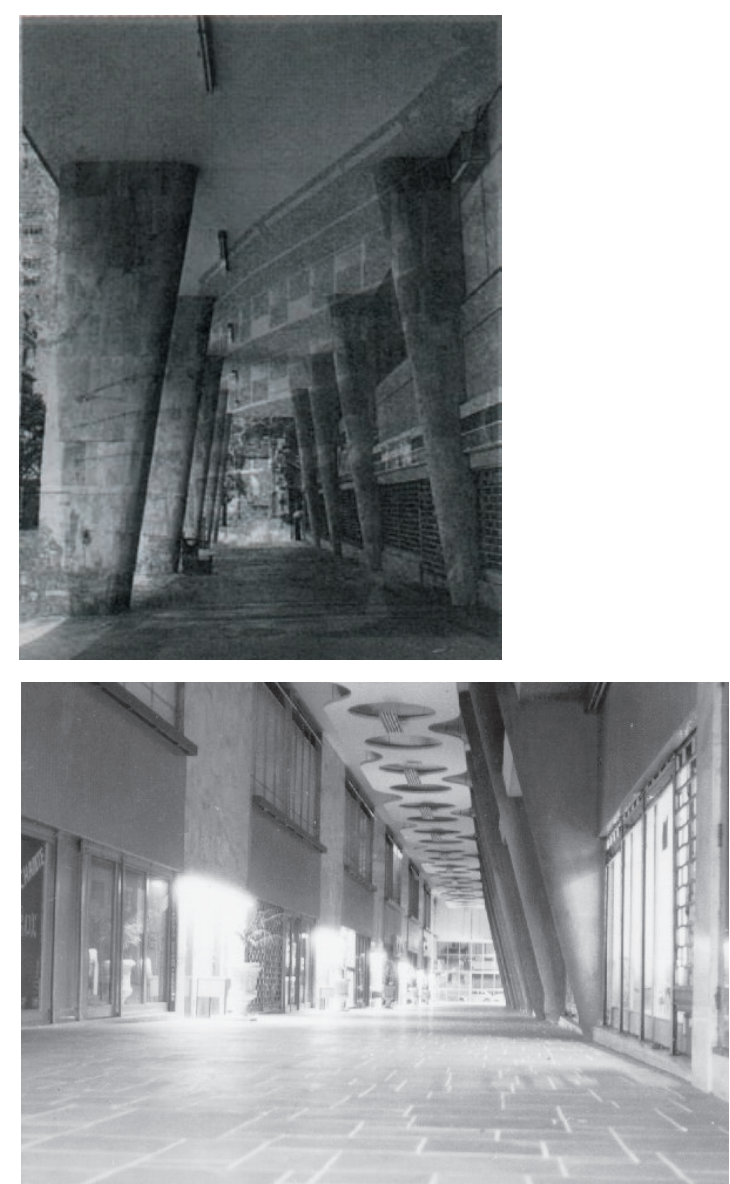

Galeria Ed. Marques de Herval, dos Irmãos Roberto (1952), e galeria do Edifício Nações Unidas (1953).

23 Geraldo Ferraz, Edifício Nações Unidas, Habitat no 57, São Paulo, 1959, p.20 


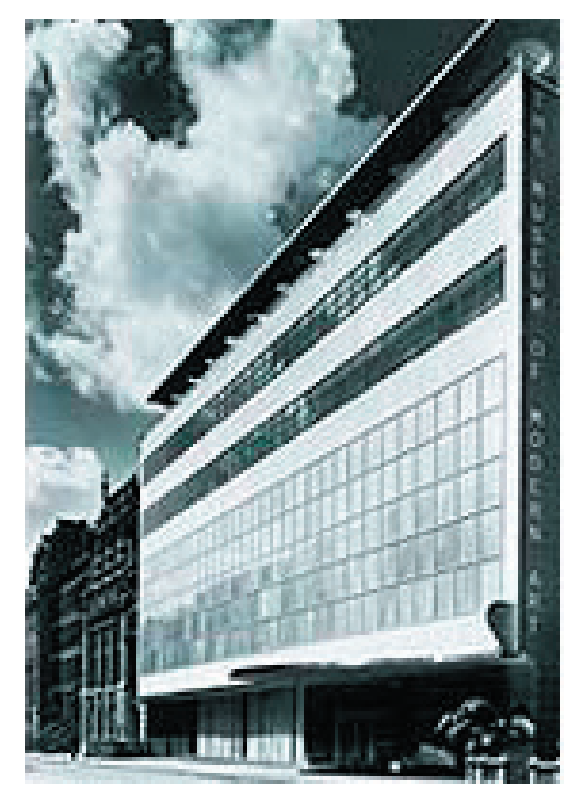

Edifício do MOMA-NY, arquiteto Philip Johnson.

Edifício ABC de Osvaldo Bratke, 1951.

Edifício Nações Unidas de Abelardo de Souza, 1953.

${ }^{24}$ Pietro Maria Bardi, Diário de São Paulo, julho/1954

${ }_{25}$ Os brises e pilares da galeria remetem aos irmãos Roberto, os pilares da entrada em forma e proporção citam Oscar Niemeyer e a cor remete à Lucio Costa.
Bardi, expostos por um mês na Galeria Prestes Maia, sede do MASP

"Aprovei-o antes de exibi-lo. Logo acho que o projeto do arquiteto Abelardo de Sousa para o edifício Nações Unidas é felicíssimo e reune tudo o que se pode esperar e que nos pode dar o progresso da arquitetura brasileira. "24

Apesar de ter como principal fonte a arquitetura carioca, com referências à Lucio Costa e Irmãos Roberto ${ }^{25}$, o edifício é destacado por seu caráter internacional e chega a ter referências neste sentido: o motivo usado na laje perfurada no coroamento do bloco da Avenida Brigadeiro sugere uma citação ao prédio do MOMA de Nova York, projeto de Philip Johnson - note-se que o tema foi recorrente no Ed. ABC de Bratke.

O edifício Nações Unidas foi o grande marco da obra de Abelardo, num momento em que a arquitetura do Brasil também passava por seu grande momento.

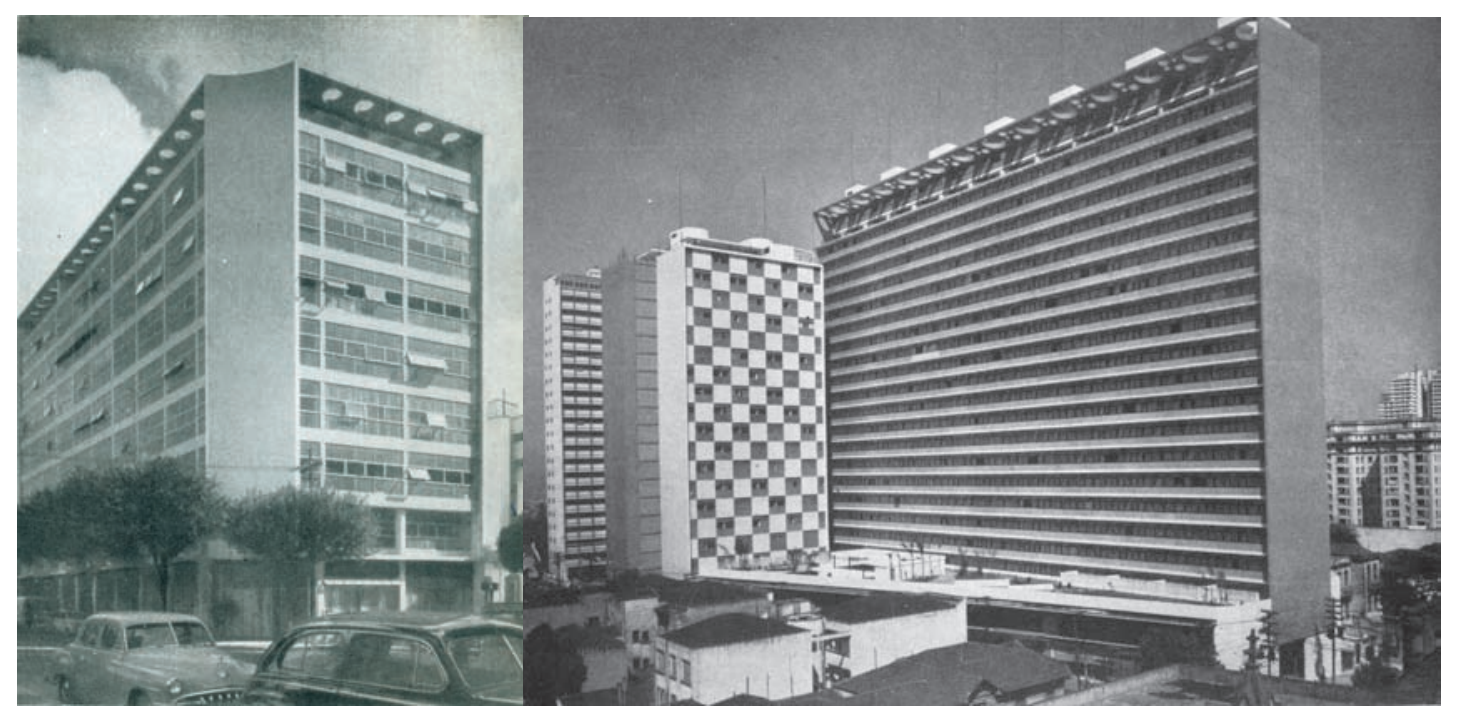




\section{A maturidade do moderno}

"A boa condição econômica do Brasil, o desejo de o governo buscar uma nova face para capital federal e uma brilhante geração de intelectuais e arquitetos com penetração nas brechas do aparelho cultural do estado, que transformaram o estilo em uma nova linguagem, inconfundivelmente brasileira e universal26"

É na década de 1950 que Abelardo de Souza realizará seus principais e mais conhecidos projetos, além da importância dos fatores econômicos é importante avaliar a situação da arquitetura moderna brasileira no período.

A partir dos anos 50, o modernismo que o Brasil havia importado da Europa nos anos 20 retorna na direção de sua origem. O livro e exposição "Brazil Builds" e o pavilhão da feira de Nova York deram consagração e reconhecimento mundial aos arquitetos modernistas brasileiros, "encorajando-os a manter distância dos cânones europeus e criar os seus próprios padrões". 27

Algumas revistas Européias do pós-guerra, como Architecture d'Aujourdhui e Techniques et Architecture ${ }^{28}$, dedicam longas reportagens a arquitetura brasileira.

O desenvolvimento de nossa identidade na arquitetura nos anos cinqüenta, além de conseqüência da situação econômica e fortalecimento de nossa imagem internacional, é um reflexo do fechamento do ciclo da identidade brasileira nas artes.

A identidade nacional que em um primeiro momento se insurge através das artes plásticas, torna-se contraditória na medida em que a realidade do
${ }^{26}$ Lauro Cavalcanti, Quando o Brasil era moderno - Guia de arquitetura 19281960, Rio de Janeiro, 2001, p.13

27 Lauro Cavalcanti, obra citada, p. 21

28 Abelardo de Souza inclui em seu

currículo de projetos publicados o no 3 e 4 da Revista Techniques et Architecture, porém a falta de datas não permitiu a localização de exemplar com publicação sobre seu trabalho. 
29 M.M.M. AZEVEDO, A experiência de Lina Bo Bardi no Brasil (1947-1992), São Paulo, 1995, p.40.

${ }^{30}$ Lauro Cavalcanti, obra citada, p.13

${ }^{31}$ Abelardo de Souza, Nossa Arquitetura

Habitat n02, São Paulo, 1951, p.4

moderno no Brasil impõe que se reconhecesse que este moderno era "antes de tudo, um horizonte possível, e não uma realidade acabada; daí que a identidade nacional passa a incorporar a idéia de desenvolvimento ${ }^{29}$ ". A arquitetura, era o campo mais propício a demonstração de força, prestígio e capacidade prática destas ideologias que tem sua maior expressão na figura de Oscar Niemeyer.

O Serviço de Patrimônio criado pelos modernos constitui um "capital simbólico naciona/ ${ }^{30 "}$ ", através da seleção e guarda das obras consideradas monumentos nacionais (especialmente do nosso passado colonial). O SPHAN cria subsídios e direciona as novas propostas, fortalecendo o nacionalismo como elemento progressista, como diz o próprio Abelardo em artigo da Revista Habitat:

"O serviço do Patrimônio Histórico tem contribuído, graças à boa orientação de Lúcio Costa, de forma decisiva para nossa completa emancipação arquitetônica.(...) conduzindo nossa arquitetura para um caminho certo. ${ }^{131}$

Além disso, o estilo moderno traria, com a simplificação ou massificação das construções, a solução para um problema novo: a criação de casas para abrigar as pessoas pobres que acorriam para as cidades naquele começo de processo de industrialização.

Surgiria um interesse dos arquitetos brasileiros, pelos projetos sociais da arquitetura moderna, assumindo nestas condições o papel de uma envergadura política inédita até então. 


\section{Revistas especializadas}

As revistas e publicações especializadas em arquitetura serão em grande parte responsáveis por disseminar os valores da arquitetura moderna no país. A arquitetura moderna ampliará seus domínios pela divulgação no mercado editorial especializado que começa a surgir. Lina e Pietro Maria Bardi, agitadores culturais responsáveis pela criação do MASP e seus cursos de arte que marcaram o período, se lançam numa empreitada editorial e em 1951 lançam Habitat, onde divulgavam a nova arquitetura e enfocavam também as artes plásticas e artes gráficas numa crítica especializada que neste momento busca elementos autóctones, revendo as manifestações populares de nossa cultura.

Abelardo de Souza que convivia com Lina e Pietro terá suas opiniões divulgadas em alguns artigos nos primeiros números, além diversos projetos publicados e em 1954 passa a colaborar com freqüência nas edições de número 14 a 20, sendo que no exemplar 18 assina um editorial sobre ensino de arquitetura e no vinte é oficialmente o Diretor e Orientador da seção de arquitetura da revista. Segundo Ferraz, não permanecerá no cargo devido ao acúmulo de funções junto à Universidade.

Nos textos não encontraremos muitas declarações de Abelardo de Souza que reflitam diretamente sobre sua própria obra. É contudo um notável entusiasta da arquitetura moderna brasileira, sempre se referindo com admiração a seus criadores, especialmente na figura de Lúcio Costa e citando a obra de Niemeyer como a representação da "verdadeira" arquitetura brasileira e do caminho a ser buscado por ela. Outro aspecto que pode ser detectado através de suas declarações foi a estrutura funcionalista que norteou seus trabalhos, numa viva mostra da influência 
de Warchavchik.

Sobre a academia, sua posição demonstra uma insatisfação com os métodos de ensino adotados, acreditando juntamente com seus colegas que o ensino de "arquitetura moderna", especialmente visando um arquitetura brasileira, deveria fugir dos padrões convencionais, reforçando a base de composição, dando uma formação mais "universal" ao arquiteto deixando o lado técnico mais próximo da engenharia. Sua proposta é de que, não tendo uma tradição quanto aos métodos de ensino, o ensino de arquitetura no Brasil poderia mais facilmente romper com os moldes tradicionais e apresentar um novo modelo.

Mesmo tendo vivido e realizado a maior parte de sua obra em São Paulo, Abelardo de Souza em seus artigos sempre promulgou e exaltou o pensamento - que aliás era o de sua formação- da "escola carioca".

Porém, a grande importância de Habitat diretamente para Abelardo
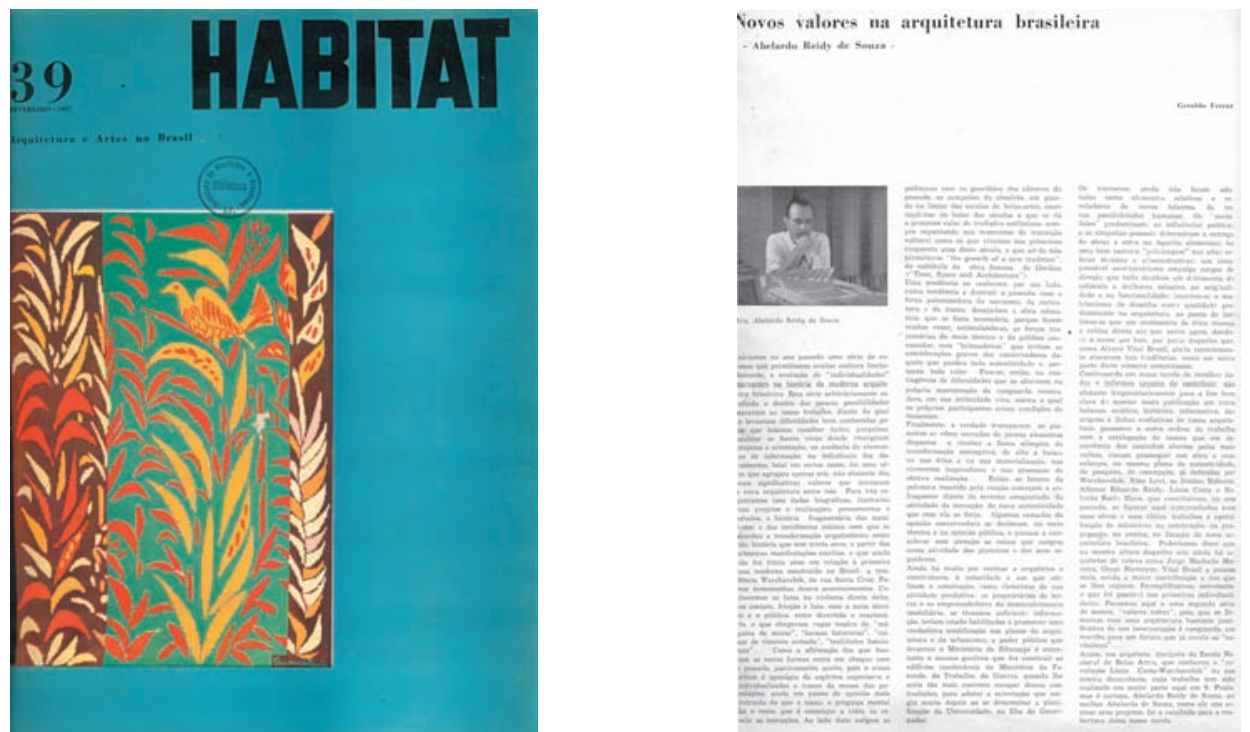

Capa da revista Habitat e artigo de Geraldo Ferraz sobre Abelardo de Souza. 
de Souza será na divulgação de seu trabalho pela publicação de diversos projetos e quando em 1957, o crítico Geraldo Ferraz dedica um artigo exclusivo à sua obra.

Em 1956, Ferraz, responsável pela seção de arquitetura da revista, havia iniciado em Habitat uma série intitulada "Individualidades na história da atual arquitetura no Brasil32". Warchavchik, Affonso Eduardo Reidy, Rino Levi, M.M.M. Roberto, Lúcio Costa e Roberto Burle Marx são os escolhidos sobre os quais o crítico apresentará, além de uma breve biografia, os conceitos e projetos.

Esta seleção possuía caráter totalmente arbitrário, justificado pelo crítico pela necessidade de fazer um balanço "estético, histórico, informativo, das origens e linhas evolutivas de nossa arquitetura", 30 anos após seu primeiro manifesto, assinado por Warchavchik.

Ferraz explica a ausência de nomes de relêvo como Niemeyer, Vital Brasil e Jorge Machado Moreira, pela "impossibilidade" de exemplificá-los.

Na sequência da série, publica então "Novos valores na arquitetura brasileira" cujo teor é apresentar "nomes que em decorrência dos caminhos abertos pelos mais velhos, vieram prosseguir sua obra e seus esforços, no mesmo plano de autenticidade, de pesquisa, de concepção(...)". A nova série contaria com apenas dois arquitetos: Abelardo de Souza e Osvaldo Bratke.

O texto de Ferraz é o único ensaio crítico, existente até hoje, sobre a obra de Abelardo, tornando-o a principal fonte de referência - especialmente biográficas - para execução do presente trabalho.

O artigo apresenta-se mais como uma compilação do que propriamente uma crítica.

Ferraz, em seus artigos indica o que é exemplar, tratatando da arquitetura dentro do debate puramente estético numa visão historicista,
32 Warchavchik(hab28,p.40-1956), Affonso Eduardo Reidy(hab29,p.38-

1956), Rino Levi(hab 30,p.34-1956),

M.M.M. Roberto(hab31,p.49-1956), Lúcio

Costa(Habitat 35, p.28,1956) e Roberto

Burle Marx(habitat 36,p.12,1956). 
${ }^{33} \mathrm{~V}$ seminário de História da cidade e do Urbanismo. Cidades: temporalidades em confronto.

Caderno de resumos, programa de pósgraduação em arquitetura e urbanismo. PUC-Campinas. 1998 ele visa mais educar e referenciar do que questionar.

Tal falta de objetividade revela uma tendência apontada pela professora Clara Luiza Miranda ${ }^{33}$, da UFES, de que "A crítica de arquitetura dos anos 50, é acusada de não contribuir para o desenvolvimento do pensamento arquitetônico brasileiro". Há uma predominância de discussões em torno da expressão plástica e da síntese das artes que dominavam o cenário.

A polêmica que se insere nos artigos de Ferraz publicados em Habitat versa mais sobre o porquê das escolhas, preterimentos e apostas do que a respeito do objeto de estudo que é a arquitetura.

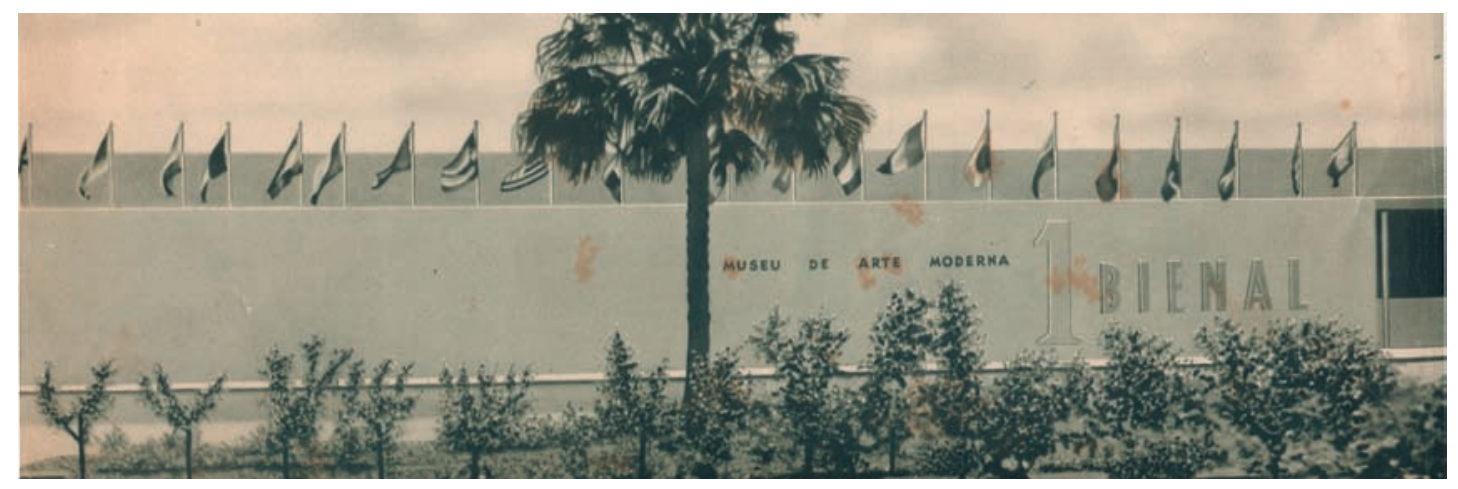

As Bienais de arquitetura

O incentivo da iniciativa privada no desenvolvimento da nova arquitetura não se restringe às construções para moradia e indústria. $\mathrm{Na}$ década de 40, dois museus surgem por iniciativa de particulares, totalmente desvinculados do poder público. Pietro Bardi e Assis Chateaubriand fundam o MASP e Francisco Matarazzo Sobrinho o MAM. Com propostas 
diversas, o primeiro queria constituir um acervo histórico enquanto o MAM visava integrar-se aos movimentos contemporâneos e o circuito artístico internacional. Dentro desta visão, estabelece então intercâmbio com o MOMA de Nova York e organiza uma representação brasileira na Bienal de Veneza. O grupo de críticos, artistas e arquitetos responsáveis por esta representação, vê na Bienal de Arte uma oportunidade de constante intercâmbio entre artistas e obras contemporâneas. Desta maneira a "Bienal do Museu de Arte Moderna de São Paulo" entraria no calendário artístico internacional.

A primeira mostra tem seu projeto lançado em 1949 com exposições e premiações em pintura, escultura, gravura, desenho, cerâmica e arquitetura. É prevista também uma mostra de filmes de arte.

O entusiasmo pela arquitetura brasileira no momento é tão grande, em virtude da divulgação obtida pelo livro e exposição "Brazil Builds", pelas publicações internacionais, Edifício do MES, etc, que a arquitetura assume o mesmo reconhecimento que as artes plásticas e organiza-se a "I exposição Internacional de arquitetura" com participação aberta a arquitetos e estudantes e alguns convidados especiais. Contabilizou-se cerca de 150 arquitetos de 25 países que enviam aproximadamente 400 projetos, em fotografias preto e branco padronizadas no formato $25 \times 30$ $\mathrm{cm}$.

O Grande Prêmio Internacional vai para Le Corbusier, e tem-se a oportunidade de ver pela primeira vez a Capela de Ronchamps e a Unidade de Habitação de Marselha_ daí provavelmente a argumentação para divulgação comparativa com o edifício Nações Unidas.

Abelardo de Souza participa da $1^{\text {a }}$ Mostra em duas categorias: residencial com projeto da residência S.L. (1951) e edifícios de uso público com o projeto de Piscina em Ourinhos (1951), ambos não construídos. Os 


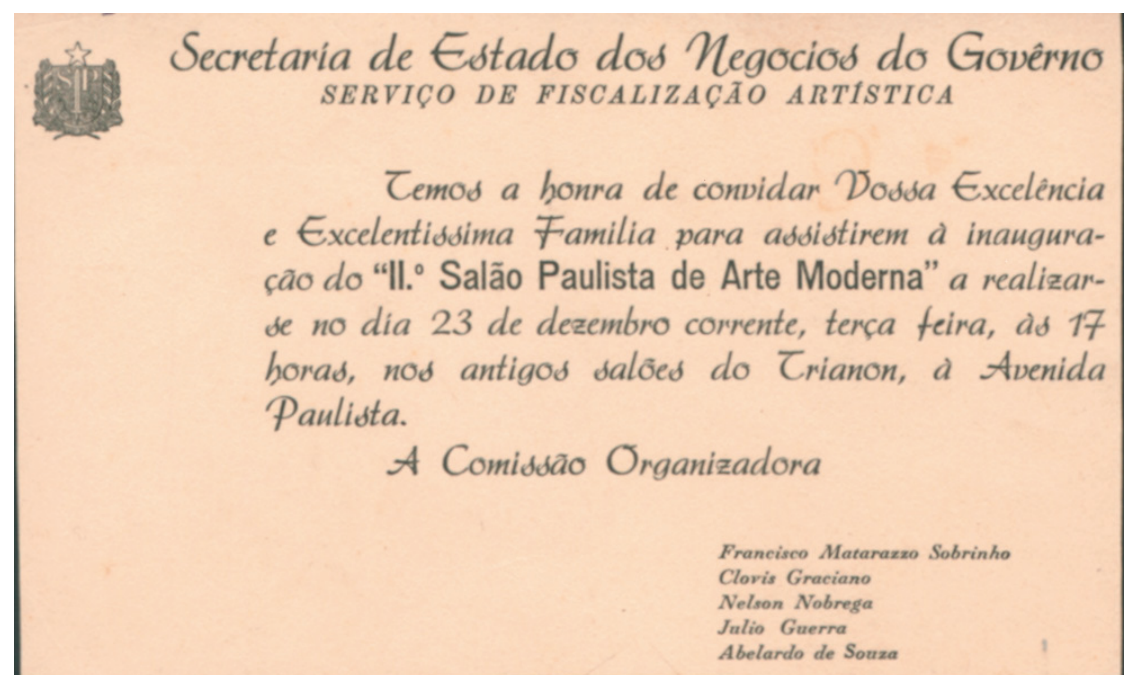

Convite para salão de arte onde Abelardo de Souza faz parte da comissão organizadora com Francisco Matarazzo Sobrinho e outros.

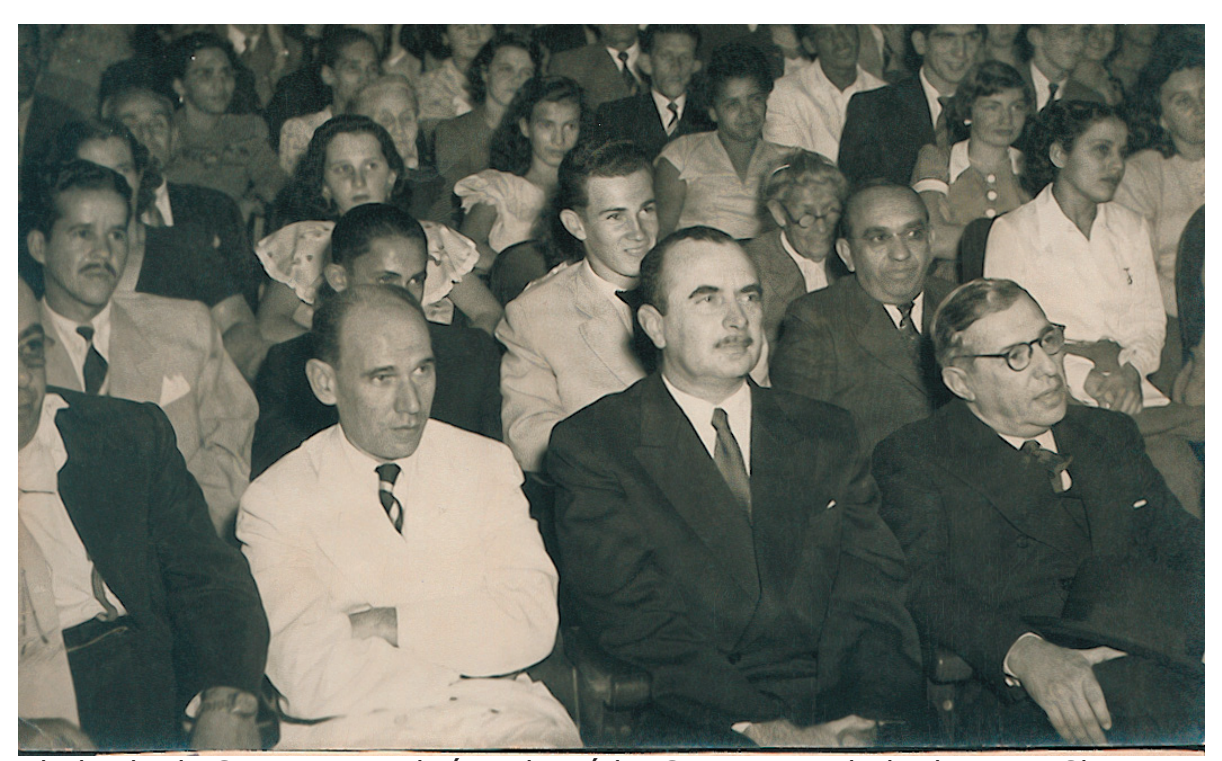

Abelardo de Souza no auditório da Rádio Guarany ao lado de Assis Chateaubriand. 
projetos são apresentados em desenhos e maquete.

A $2^{a}$ Exposição Internacional de Arquitetura realizada dentro da II Bienal já se realiza nos novos pavilhões do Ibirapuera, recém construídos para os festejos do IV centenário.

O evento conta com a participação de 170 arquitetos estrangeiros e júri de premiação composto grandes nomes: Gropius, José Luis Sert, Alvar Aalto, Ernst Rogers, Oswaldo Bratke, Affonso Eduardo reidy e Lourival Gomes Machado. Palestras e conferências coincidindo com o IV Congresso de Arquitetos Brasileiros.

Nesta Bienal foi instaurado o I Concurso Internacional de Escolas de Arquitetura, que se tornaria uma das marcas do evento.

A revista Habitat assume posição extremamente negativa em relação ao evento: criticam o local e criticam os critérios de seleção e premiação, considerados obsoletos

Para a $2^{a}$ Exposição Internacional de Arquitetura, Abelardo envia na categoria Habitação Coletiva o projeto do conjunto residencial em Perdizes (1952).

À partir daí, exposição Internacional torna-se inconstante, o que acontece, segundo os organizadores, pela curto intervalo entre elas para que ocorressem obras consideráveis.

A 4a Exposição Internacional de Arquitetura volta a contar com a presença nomes destacados da arquitetura: Mies Van de Rohe, Kenzo Tange, Marcel Breuer e Philip Johnson, porém o nível médio dos trabalhos é considerado inferior ao das duas primeiras mostras.

Nesta exposição Abelardo apresentará o projeto do Conjunto residencial Três Marias (1952)

A exposição volta a ocorrer em 1961, 65,69.

Em 1971 Abelardo de Souza participa da Bienal com o projeto do

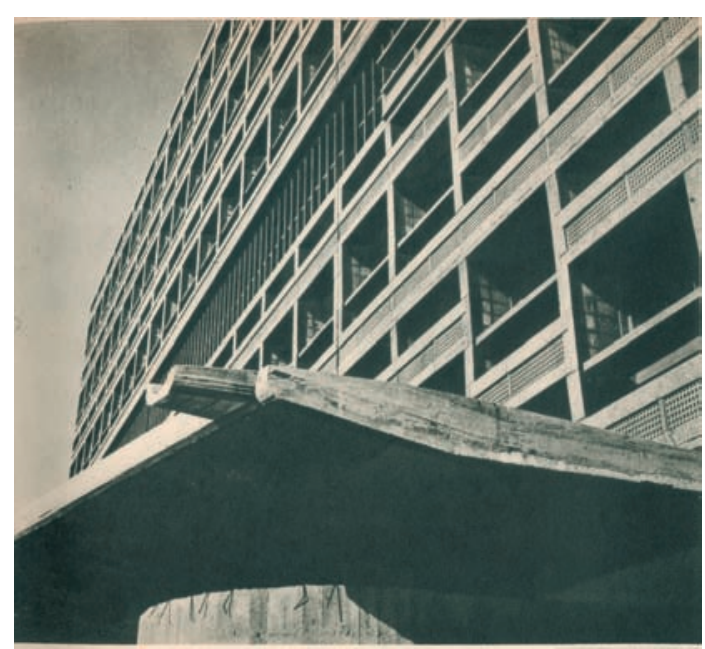

Unidade de Habitação de Marselha, apresentado na $1^{\text {a }}$ Bienal de São Paulo. Julho/1953. 


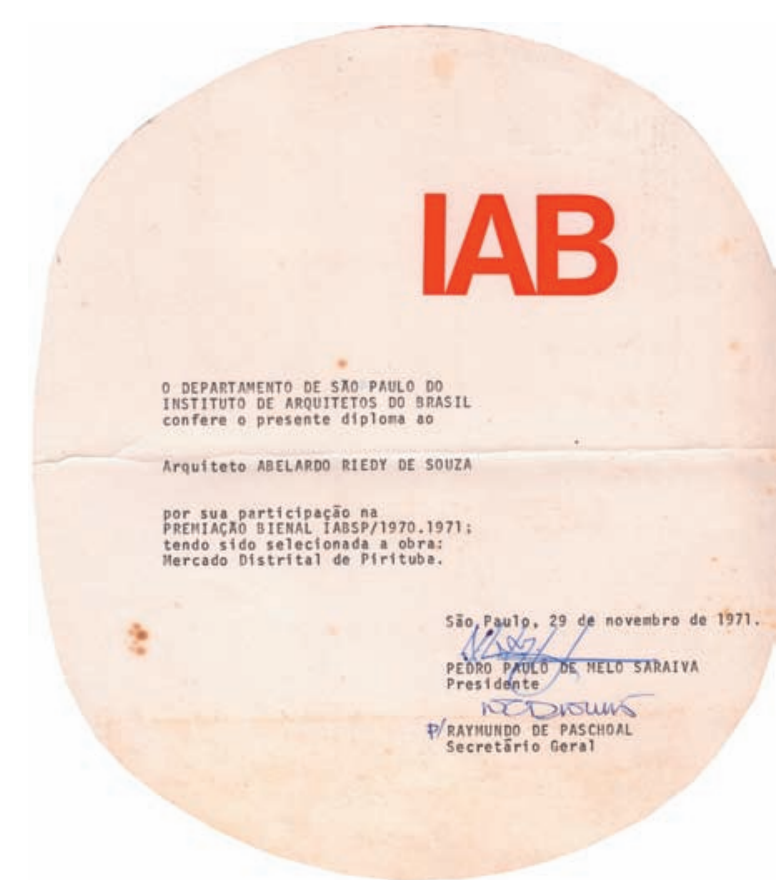

Diploma de participação da Bienal de 1971, com projeto do Mercado de Pirituba.

\section{Mercado de Pirituba.}

Em 1973, a mostra reivindica sua autonomia, com a realização de um evento específico.

Apesar da independência temática, o momento da arquitetura (e do país) era dominado por questões de democracia e justiça social, desta forma, a arquitetura se envolveu em matérias multidisciplinares fora de seu alcance e paradoxalmente a mostra acabou perdendo seu foco ${ }^{34}$.

Após isto, a mostra fica restrita a algumas salas especiais como a de Nervi em 1975, Niemeyer em 1979, Tradição e Ruptura (1984) e Paulo Mendes da Rocha e Artigas em 1989, até voltar a sua periodicidade e independência em 1993 sob o nome de BIA. 
Grandes Estruturas ¿S (1) ¿d 
${ }^{1}$ GIEDION, $\mathrm{S}$ in MINDLIN, Henrique E.(1956). Arquitetura Moderna no Brasil. Aeroplano Editora, Rio de Janeiro.1999.

P.17

2 "(...)no Brasil, desde muito cedo se

havia começado a empregar o concreto armado nas estruturas de grandes obras, em contraste com a tendência reinante nos Estados Unidos, onde a arquitetura de grande envergadura era baseada no emprego de estruturas metálicas." GIEDION, S.idem

3 "Antes de examinar mais de perto as características da arquitetura brasileira dos dias de hoje, convém assinalar dois fatores que contribuiram decisivamente para a sua formação. O primeiro foi a pesquisa sobre os problemas de insolação.

O segundo fator foi o desenvolvimento de uma técnica avançada de uso do concreto armado, que resultou não só em estruturas mais leves e elegantes, mas também em uma economia significativa, em comparação com o custo da construção em outros países."

MINDLIN, Henrique E.(1956). Arquitetura Moderna no Brasil. Aeroplano Editora, Rio de Janeiro. 1999.P.32-3

4 "Esses dois fatores estão associados diretamente às duas características mais diretamente as duas caracteristicas maik salientes da arquitetura moderna no Brasil: o da arquitetura moderna no icies por brise-soleil, o uso de estruturas livres apoiadas sobre pilotis, com térreo livres apoiadas sobre pilotis, com térreo aberto quando possivel. Essas duas marcante influência de Le Corbusier." MINDLIN, idem

\section{Elemento diferencial da arquitetura moderna Brasileira: concreto}

Nas décadas de 40 e 50, diversos fatores fizeram com que a arquitetura brasileira obtivesse destaque e divulgação internacional: a construção do edifício do Ministério da Educação e Saúde(1937-42), Pavilhão na feira internacional (1939-40), publicação e exposição Brazil Builds (1943), culminando com a construção da nova capital.

Discutiam-se nesse período os fatores que caracterizavam esta arquitetura - sejam elementos de construção, linhas estéticas ou de projeto.Entretanto, era claro que o desenvolvimento de uma tecnologia no uso do concreto armado era um fator determinante.

Giedion, em seu texto $O$ Brasil e a arquitetura contemporânea ${ }^{1}$, cita o emprego de concreto em grandes estruturas como elemento característico da arquitetura moderna brasileira, salientando que na América do Norte predominavam as estruturas metálicas. ${ }^{2}$

Na introdução de seu livro Arquitetura Moderna no Brasil, Mindlin enumera os elementos que pesaram no desenvolvimento de nossa arquitetura moderna e distingue os estudos de insolação e a existência de uma avançada tecnologia do concreto ${ }^{3}$. Para ele foi a partir do desenvolvimento destas bases que tornou-se possível a execução de estruturas mais leves, permitindo a ampla aplicação de pilotis, térreo aberto, brise-soleil, e assim utilizando os postulados de Le Corbusier ${ }^{4}$.

O emprego do concreto em larga escala, de acordo com Pedrosa, deveu-se em grande parte à política econômica adotada no entre-guerras, quando o 
"aço se tornou quase inacessível pelo alto preço e, quando a industrialização retomou o seu impulso, desenvolveu-se a indústria do cimento.

A indústria de construção civil conheceu então desenvolvimento sem igual. As técnicas artesanais, já então insuficientes para as necessidades da produção em massa, foram substituídas por novas técnicas de construção, com materiais novos. ${ }^{1 / 5}$

Foi porém, através do desenvolvimento da engenharia do concreto em estruturas inovadoras, que os arquitetos perceberam as possibilidades que Ihes apresentava o material, fazendo das estruturas integradas uma característica intrínseca do projeto.

" E quando os jovens arquitetos revolucionários entraram em cena não Ihes foi difícil encontrar no cimento armado não só as virtualidades reclamadas pela sua imaginação plástica mas também a possibilidade de integrar seus projetos com as estruturas livres que o próprio concreto permitia e que os cálculos dos engenheiros tornavam exequíveis. Esta integração deu à técnica do cimento armado no Brasil tal grau de desenvolvimento e de virtuosidade que essa técnica hoje constitui quase uma "escola brasileira" autônoma de construção civil, e que é objeto de estudo dos engenheiros de todos países, e seus processos utilizados pelo mundo afora."

Neste primeiro momento a maioria dos projetos são instituidos sob uma ótica racionalista7, apesar das curvas "barrocas" de Niemeyer já serem uma referência.

Abelardo de Souza, imbuído dos princípios de Le Corbusier e da formação no ambiente cultural do Rio de Janeiro, lança mão desses recursos na produção de projetos de Clubes, instituições, Igrejas e fábricas. Neles faz uso do repertório da arquitetura moderna brasileira: o pilotis, o telhado borboleta, o elemento vazado, o muxarabi, o jardim interno, mas, principalmente projeta edificações cuja unidade baseia-se na composição
5 .PEDROSA, Mario. Dos murais de Portinari aos espaços de Brasília, org. Aracy A. Amaral. Ed. Perspectiva, São Paulo. 2002. P.325

${ }^{6}$ PEDROSA, obra citada p. 326

7 de acordo com Mindlin: "A estrutura livre ou, quando esta não é a solução natural, a estrutura franca e claramente integrada ao projeto é uma outra característica importante." MINDLIN, obra citada, p.34 

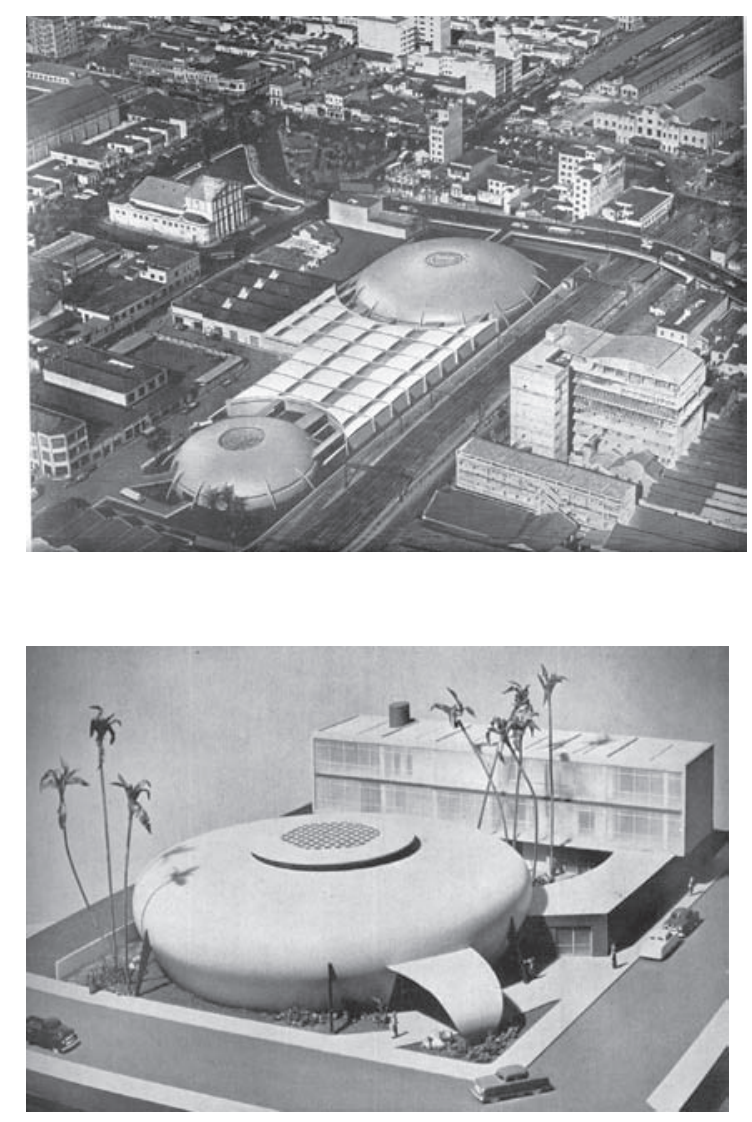

Mercado do Brás de 1954 e Clube Cruzeiro de 1953.

${ }^{8}$ Depoimento em 18/06/2004. de seus volumes componentes. A concepção geométrica de projetos como o do mercado do Brás e Clube Cruzeiro apresenta uma dinâmica em que volumes prismáticos regulares e oblíquos se articulam a cúpulas em concreto e grandes panos com caixilhos dispostos horizontalmente, integrando-os por meio de passeios cobertos e rampas que interligam as edificações. Diferenciam-se dos seus edifícios em que prevalece uma estética baseada na composição de materais, texturas e sombras, ele busca na tecnologia do concreto uma relação de formas, revelando sua clara admiração pelo trabalho de Oscar Niemeyer.

A arquiteta Miranda Magnoli confirma esta relação:

"Fábrica Duchen, infelizmente perdida, foi um marco por anos para todos os arquitetos - A solução curva que explora o concreto foi muito significativa para Abelardo; assim foi com o Copan. Ele exemplificava muito para os alunos." ${ }^{\prime 8}$

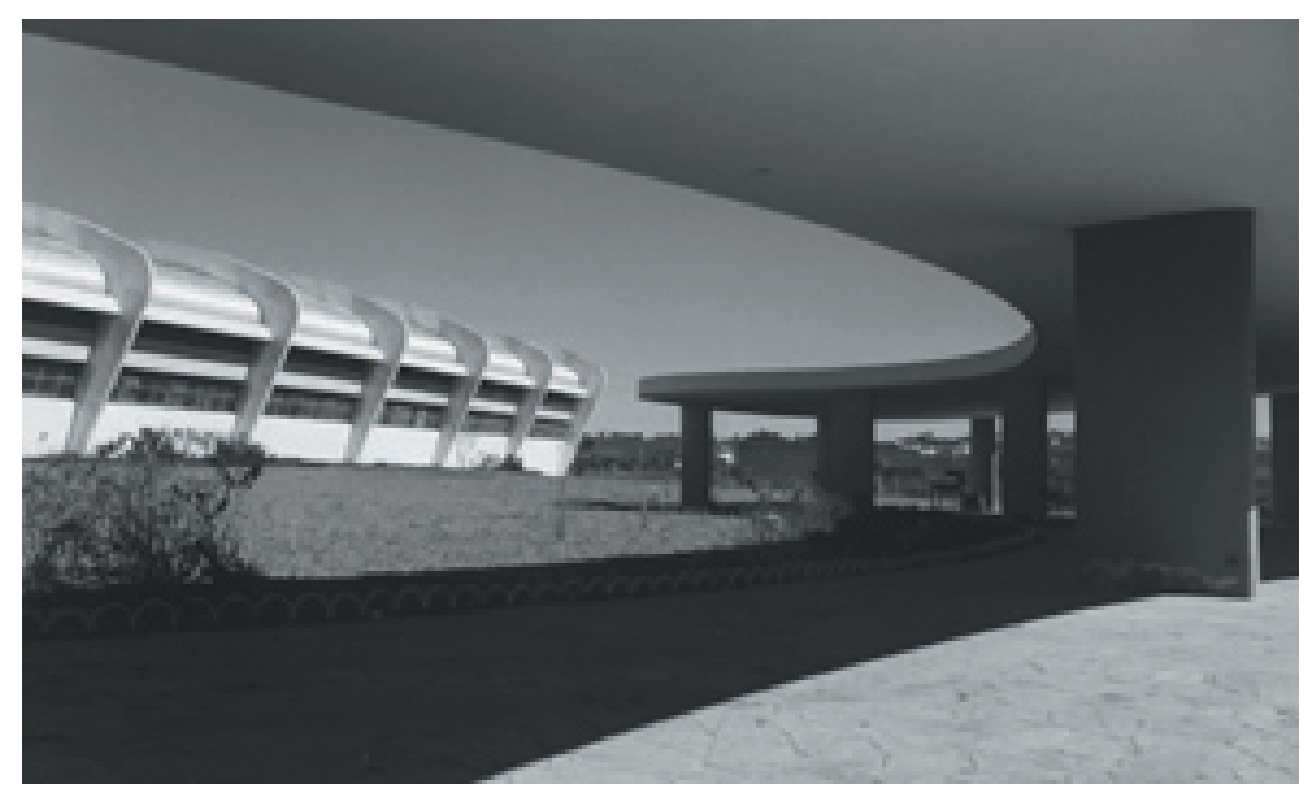

Fábrica da Duchen de Oscar Niemeyer. 


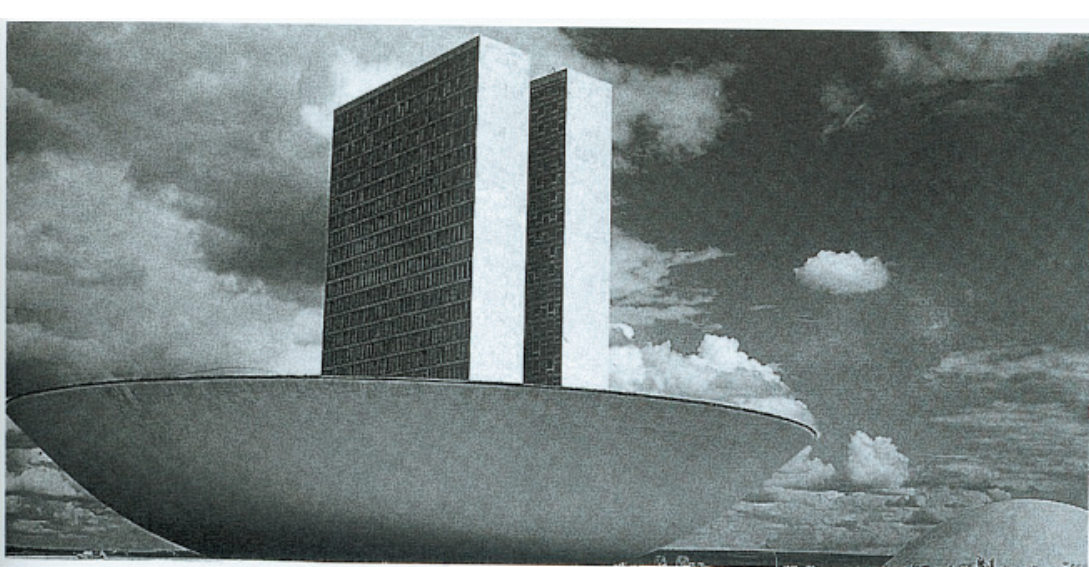

Congresso Nacional em Brasíllia, Oscar

Niemeyer. $\quad 1957$

1960.

\section{Brasilia e Ronchamps}

Com o projeto de Ronchamps(1950-1954) e a arquitetura de Oscar Niemeyer para Brasília (1955-1960), a discussão sobre estrutura, formalismo e funcionalismo adquire uma nova dimensão entre os arquitetos brasileiros. Sobre Ronchamps, Montaner fala da inversão de influência: Ronchamp não seria possível sem as curvas de Niemeyer ou as ondulações de Aalto ${ }^{9}$, mas em seu artigo para revista Acrópole intitulado Uma falsa crise ${ }^{10}$, Artigas comenta a polêmica gerada pela não racionalidade de Ronchamp tratando o arquiteto franco-suíço como mestre e tomando por referência um texto de Niemeyer, reforça suas idéias sobre a relação entre estrutura e arquitetura $^{11}$ que caracterizará a arquitetura que irá se desenvolver como sequência da escola carioca.

Entre as idéias de Niemeyer, citadas por Artigas, ele destaca o uso da estrutura como elemento integrante da solução plástica:

"as soluções compactas, simples e geométricas; os problemas de hierarquia e de caráter arquitetônico; as conveniências de unidade e de
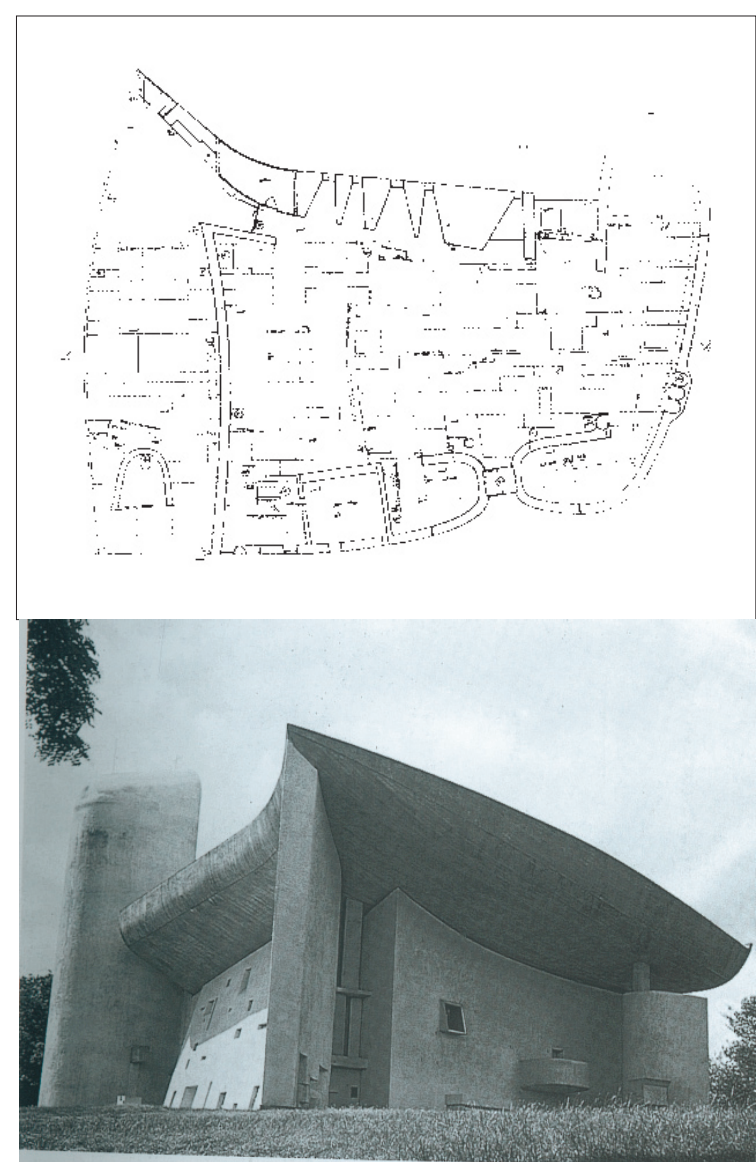

Notre Dame du Haut, Ronchamps - França. Le Corbusier 1950-1954.

9 MONTANER, Josep Maria, Depois do movimento moderno. Arquitetura da segunda metade do séc XX. Editorial Gustavo Gili, Barcelona. 2001 p.46

10 ARTIGAS, Vilanova, Uma falsa crise, Acrópole no 319, p.21-2 
${ }^{11}$ SEGAWA, Hugo (1997) Arquiteturas no Brasil 1900-1990. São Paulo, Editora da Universidade de São Paulo, 2a edição, 1999. 224p.il. p.147-8

12 NIEMEYER, Oscar 1958 "autocrítica"

in ARTIGAS, Vilanova, Uma falsa crise,

Acrópole no 319, p.21-2

13 NiEMEYER, Oscar idem

${ }^{14}$ PEDROSA, obra citada p.293. harmonia entre edifícios e, ainda, que estes não mais se exprimam por seus elementos secundários, mas pela própria estrutura devidamente integrada na concepção plástica original. "12

Niemeyer aponta a possibilidade de encontrar novas soluções dentro do sistema estático não necessariamente funcionalistas, de forma que arquitetura não se reduza a uma questão de engenharia, mas seja uma manifestação do espírito, da imaginação e da poesia. ${ }^{13}$

Os prédios de Niemeyer em Brasília, sobre o plano piloto de Lucio Costa terão uma monumentalidade escultórica, e estabelecerão, além de uma mudança dentro da visão da estética e do racionalismo, uma participação social da arquitetura.

"O equilíbrio entre o social e o profissional se restabelece quando, enfim, uma formidável e nobre missão se oferece ao arquiteto - a construção da utopia Brasília, a Cidade Nova, síntese do político e do social com o estético-profissional."14

\section{Plano de ação Carvalho Pinto}

Brasília, será exemplo de desenvolvimento social e no padrão moderno de arquitetura para as obras governamentais.

No estado de São Paulo, seguindo a proposta instituída por Juscelino Kubtischek com o plano de metas e Brasília que visava impulsionar o desenvolvimento da área central do país, o governador Carvalho Pinto irá criar o seu plano de ação voltado para o desenvolvimento do interior do Estado. 
"Carvalho Pinto contratou mais de 400 obras, entre fóruns, escolas, hospitais, presídios, também valorizando a arquitetura moderna e abrindo campo para consagrados e recém formados arquitetos, na sua maioria paulista. Concebidas como casos isolados, porém, essas obras não conseguiram deflagrar ações que alcançassem uma ação econômica mais duradoura, com vistas a um progresso social mais amplo. ${ }^{115}$

Os projetos eram desenvolvidos de forma indepente, dentro dos escritórios de arquitetura contratados.

No início da década de 60, Abelardo de Souza fará seis projetos para escolas no interior para o Governo do estado: Pres. Venceslau (1960), Jundiaí(1962), Bauru (1962), Suzano (1961), Águas de S. Pedro (1961) e Mogi das Cruzes (1967).

Fica claro nestes projetos para escolas, o conhecimento por parte de Abelardo de Souza, de princípios deflagrados pelo Convênio Escolar desenvolvido pela equipe de Hélio Duarte nas décadas de 40 e 50 e principalmente das teses do educador Anísio Teixeira, com as quais havia tido contato nos tempos da Universidade do Distrito Federal.

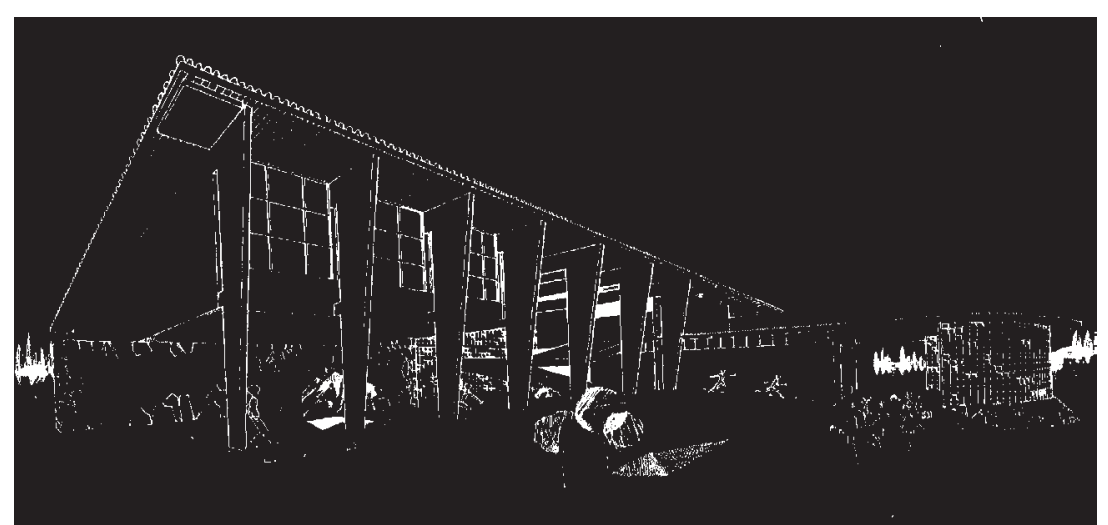

${ }^{15}$ CAMARGO, Monica Junqueira de, 2000 Princípios da arquitetura moderna na obra de Oswaldo Arthur Bratke. P65
Grupo Escolar em Presidente Venceslau. Abelardo de Souza, 1960. 
${ }^{16}$ www.vitruvius.com.br/arquitextos/ arq031/bases/02tex.asp (4/6/2004) 17 Zenon Lotufo, Eduardo Kneese de Mello, Eduardo Corona, Ernst Mange, entre outros ligaram-se ao programa do convênio escolar. convênio escolar. WwW.aprenda450anos. com.br $(4 / 6 / 2004)$

A filosofia de trabalho de Hélio Duarte vinculava-se sempre ao trabalho em equipe.

\section{Hélio Duarte e o convênio escolar}

O convênio escolar, teve o início de suas atividades no final de 1948. Nenhuma criança sem escola - era meta do Convênio para as comemorações do IV centenário da cidade em 1954. "Sua preocupação fundamental era com espaços concebidos dentro da orientação doutrinária do educador Anísio Teixeira, buscando a criação de espaços democráticos e uma escola pública que fosse voltada para a formação integral do cidadão"16

Cerca de cem escolas foram criadas pelo convênio escolar, sob a coordenação de arquitetos Hélio Duarte e uma equipe de arquitetos ${ }^{17}$.

Sua estruturação utilizava um critério de divisão das atividades em zonas: zona de "ensino" com salas de aulas, o museu, a biblioteca e a ginástica; zona "recreação" prevendos o galpão para recreio coberto, com palco para dramatizações e a "administração" dividida em:

a) administração, propriamente dita, com salas para diretoria, secretaria, arquivo, material escolar, sala de professores, biblioteca didática, almoxarifado, e cômodos dos serventes.

b) assistência escolar, abrangendo as assistências: médico, dentária, social e de nutrição.

c) Zeladoria com apartamento próprio.

Os critérios do programa visavam englobar em um mesmo âmbito escolar as atividades normais do aprendizado primário com outras atividades completivas consideradas "socializantes".

Com base nesse critério onde a arquitetura deveria compor uma unidade com o ensino, foram concebidos dois tipos de edifícios escolares: as "escola-classe" e as "escola-parque" As primeiras constituíam-se de edifícios econômicos de 12 salas aula, em terrenos relativamente pequenos 
e destinadas a instrução propriamente dita. O segundo tipo ocuparia terrenos maiores e traria atividades complementares a atividade escolar da criança.

O convênio priorizava a construção das escolas em si, dentro de um planejamento econômico, visando essencialmente a questão social, e neste ponto houveram divergências entre os arquitetos sobre a qualidade final dos edifícios a ser construídos, como declara Corona em depoimento a Ricardo Carranza:

"... a gente propunha alterações, melhores acabamentos, porque a gente defendia um aposição muito correta da União Internacional de Arquitetos. Um prédio escolar deve ser um prédio nobre. De acabamento nobre. Portanto de mateirais de primeira. Por que? Porquê deve atender a muitas gerações de crianças." 18

Abelardo de Souza também acreditava na missão da síntese das artes para educação e apostava na qualidade de materiais, por isso veremos em suas escolas largo emprego de elementos vazados, telhas em concreto, pastilhas cerâmicas e forros em madeira e a inserção de murais realizados por artistas como Renina Katz. As escolas basicamente compõe-se de grandes estruturas com vãos livres em concreto, sob as quais são facilmente observáveis os volumes de salas de aula e de recreação. A prioridade é para as áreas destinadas aos alunos e é dado grande enfoque à interligação com as áreas abertas, através de rampas e pátios ajardinados. O paisagismo é parte integrante do projeto e suas visuais.

Apresenta neste momento uma forte marcação do esquema estrutural, porém, será a partir de 1964 com o projeto para o Clube de Piracicaba e demais projetos realizados em parceria com a arquiteta Miranda Martinelli Magnolli, que se aproxima da linguagem adotada pelos arquitetos paulistas onde a solução estrutural é definidora da composição plástica do edifício.
18 Corona in CARRANZA, Ricardo (2000). Eduardo Corona: Arquitetura Moderna em São Paulo.

Orientador: Lúcio Gomes Machado. Nível: mestrado FAU/USP, São Paulo. P.118 


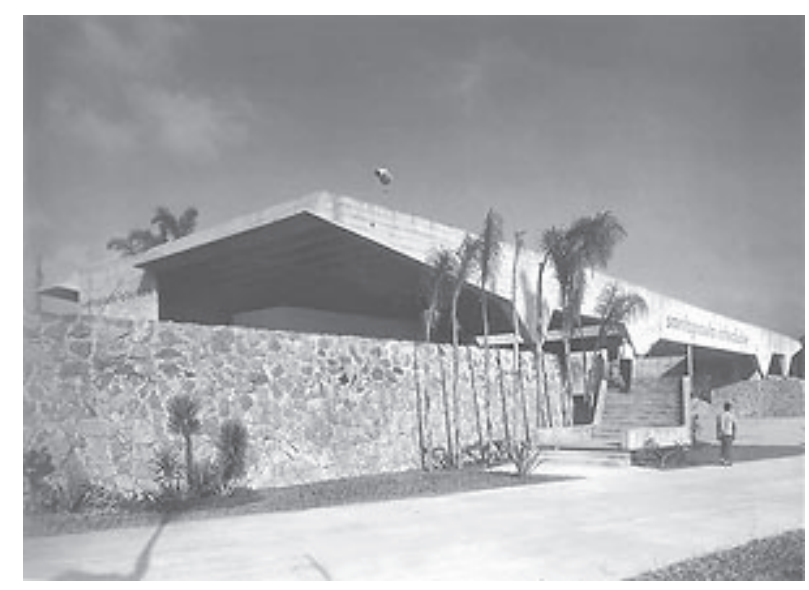

Garagem de barcos Santa Paula Iate Clube. Represa de Guarapiranga, São Paulo.

Artigas, 1961.

19 "Com a deferência de Oscar Niemeyer e sua apologia do material como suporte ideal para suas

arquitetos alinhados com o

pensamento da "escola". Enfim, o

concreto transformou-se na expressão

contemporânea da técnica construtiva

brasileira." SEGAWA, obra citada, p.149

20 SEGAWA, obra citada p.147

21 ARTIGAS, ibidem

\section{Artigas, escola paulista e brutalismo paulista}

O período de 60-70, especialmente na arquitetura desenvolvida em São Paulo, será caracterizado pelo farto uso do concreto de forma aparente em estruturas integradas às resoluções estéticas. Esta arquitetura tornou-se conhecida como escola paulista ${ }^{19}$.

De acordo com Segawa, esta tendência, inicialmente calcada nas declarações de Niemeyer, atingiu em São Paulo uma grande influência devido a uma série de fatores, entre os quais destaca:

"1. as condições políticas de discussão e ação das esquerdas, possíveis nessa passagem de década para os anos de 1960, até o golpe militar de 1964; 2. a arquitetura era um tema presente no debate público cotidiano em função sobretudo da construção de Brasília; 3. o domínio de uma tecnologia própria constituía uma das questões programáticas do nacionaldesenvolvimentismo da época, e São Paulo, como maior pólo industrial do país, enquadrava-se adequadamente ao figurino de centro de pesquisa de soluções técnológicas e industrialização da construção(...); 4. o curso de arquitetura em São Paulo, diferentemente das demais regiões, tinha suas origens não nas belas-artes, mas na engenharia, o que Ihe configurava uma maior familiaridade com a arquitetura enquanto questão tecnológica.

Mas o fator mais palpável para a materialização de uma arquitetura formalmente identificável como "paulista" deveu-se ao seu caráter de continuidade à linha carioca. ${ }^{120}$

João Batista Vilanova Artigas foi o elemento aglutinador desta tendência. Artigas, já em seu artigo Uma Falsa crise dizia que a arquitetura reivindicava "para si uma liberdade sem limites no que tange ao uso formal. Ou melhor, uma liberdade que respeite sua lógica interna enquanto arte. "21 
Além disso ele acreditava que a ação individual traduzida em termos utilitários, deveria refletir uma posição filosófica e que não poderia haver uma separação entre arte e sociedade ${ }^{22}$. Desta forma, num momento de forte repressão como a década de 60 , adquirem um peso muito maior as figuras de linguagem que podem ser encontradas em seus projetos e de seus "seguidores"23.

O uso de uma hipérbole nos elementos estruturais reforçava o esforço e as tensões das estruturas e peso do material ${ }^{24}$; as casas voltavam-se para dentro em empenas cegas, negando o entorno e apresentando interiores totalmente abertos e fluentes "muitas vezes abolindo hierarquizações de uso e convivência tradicionais. Os espaços comunitários eram valorizados; os recantos privados compactados"25. Os edifícios não possuiam fechamento e por vezes vedação, visando ser amplos espaços de reunião e convivência ${ }^{26}$.

Reelaborando o legado de Vilanova Artigas, um grupo de arquitetos se tornará seu interlocutor, propondo na austeridade e no respeito do uso de materiais e instalações à vista (tidos como acabamento em si), uma forma de denunciar os processos que se escondem por detrás da produção da arquitetura. Esta arquitetura será denominada brutalismo paulista.

"As soluções construtivas pesquisadas pela Arquitetura Nova são muito sofisticadas como elaborações de engenharia e arquitetura, mas muito rudes em sua aparência muitas vezes "mal acabada", são soluções, cujo sentido está em repropor a técnica como valor efetivo do homem que usa e que produz esta arquitetura. ${ }^{127}$ e 28

Segawa irá tomar como marco do encerramento desta vanguarda o Pavilhão Brasil em Osaka, em 1970, projeto de Paulo Mendes da Rocha. Na sua descrição:
22 BRUAND, Yves (1981) Arquitetura contemporânea no Brasil . Editora Perspectiva S.A., São Paulo. $3^{a}$ edição, 1997. p.295)

23 "Se antes o uso do concreto aparente, na sua rusticidade, colaborava para uma construção mais franca e econômica, hoje comanda, por razões que ninguém examina, as mais rebuscadas filigranas. A organização diferente de plantas e espaços, fruto de um pensamento atento desemboca no exotismo inconseqüente dos arranjos hiperbólicos. E tudo explicado em função de cuidadosa observação de significação imanente de técnicas ou materiais, sob a proteção da racionalidade própria de sua evolução. A técnica cristalizada assume o papel ativo - ela contém a verdade. De instrumento passa a motivação." Sérgio Ferro in SEGAWA, obra citada, p.154

${ }^{24}$ KOURY, Ana Paula, Grupo arquitetura nova. Tese de Mestrado E.E.S.C., orientador: Prof.Dr. Carlos A. Ferreira Martins. São Carlos. 1999. P.32

${ }^{25}$ SEGAWA, obra citada p. 151

${ }_{26}$ SEGAWA, obra citada p. 151
"...) mesmo distante de qualquer transformação redentora da sociedade brasileira, a arquitetura deveria ensaiar modelos de espaços para uma sociedade democratica, atendendo aos anseios da maioria da população. Para esses arquitetos, a cidade era concebida como um espaço democrático, espaço de

convivência, de encontro." SEGAWA, idem convivência, de encontro." 
28 "O papel da arquitetura como agente de tranformação da realidade é levado ao extremo pelos jovens arquitetos. A intenção didática de caracterizar A intença didática de caracterizar os A espaço construldo é radicalizada para a caracterização dos esforços sociais e econômicos, presentes no processo da construção civil. A crítica ao canteiro de obras e a valorização do trabalho nele envolvido são os desdobramentos da concepção de moral construtiva, presente na obra de Vilanova Artigas." KOURY, obra citada p.34

2 SEGAWA, obra citada, p.157
"Síntese dos aspectos morfológicos mais caros à linha paulista: uma grande cobertura regular, com iluminação zenital em toda sua extensão, apoiada em apenas quatro postos. Espaço coberto, livre; pavilhão que não tem portas, barreiras físicas, o piso "interno" era continuidade do chão comum de toda a Feira; local de encontro, recinto de confraternização." 29

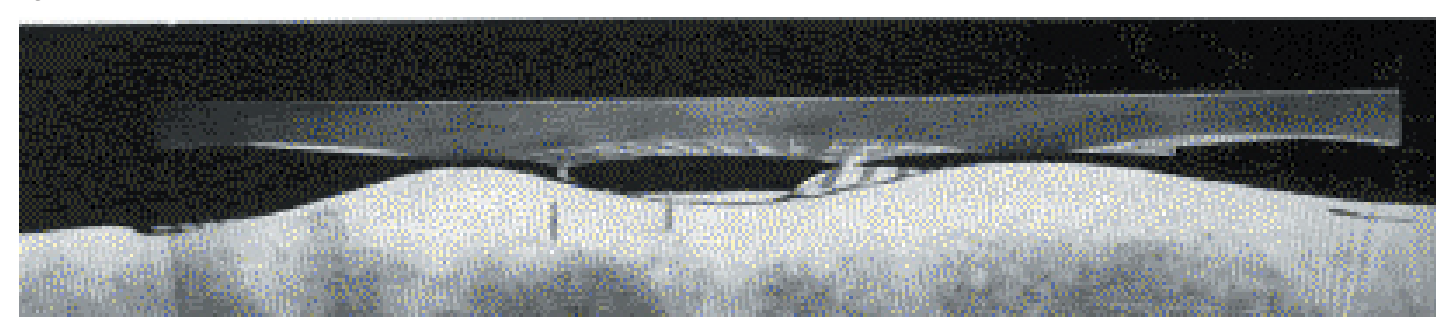

Pavilhão de Osaka. Paulo Mendes da Rocha, 1970

\section{Projetos com Miranda Magnoli}

Em 1963, Abelardo de Souza associa-se a arquiteta Miranda Magnoli, no escritório da Rua Silvia, continuando com ela até 66, em um sobrado da 13 de maio.

Miranda havia sido estagiária de Abelardo em 1951, quando estava no $2^{\circ}$ ano da FAU USP e era sua aluna e de Artigas na cadeira de composição. Daí surgiu uma grande amizade. No ano seguinte ela passou pelo escritório do paisagista Roberto Coelho Cardozo e depois no atelier de Joaquim Tenreiro, ambos amigos de Abelardo.

Abelardo era grande incentivador de seus colaboradores, dessa forma, impulsionou o trabalho de Miranda, Maitrejean, Caron, Rosa Kliass, entre outros.

Deste período pudemos relacionar os projetos: escola em Presidente 
Venceslau (1961); Clube da Cidade de São Paulo (1963); Clube de Campo em Piracicaba(1964); Internacional Golf Club (1964); Lynce Estância Clube, Atibaia (1964); Residência João de Scantimburgo (1963/64); Aproveitamento da Foz do Chopim, SP(1965); reforma e decoração no hotel da Bahia (1966).

Foi possível detectar uma mudança nas características de projeto do escritório, tanto no desenho como na forma de apresentação dos projetos. Abelardo inicia uma pesquisa formal utilizando cascas de concreto pré moldadas suspensas por tirantes de aço; como podemos verificar nos projetos de Piracicaba e Atibaia. Miranda afirma que a pesquisa partiu dele, empolgado com os projetos de Frei Otto na Alemanha e que sua associação era pura generosidade de sua parte.

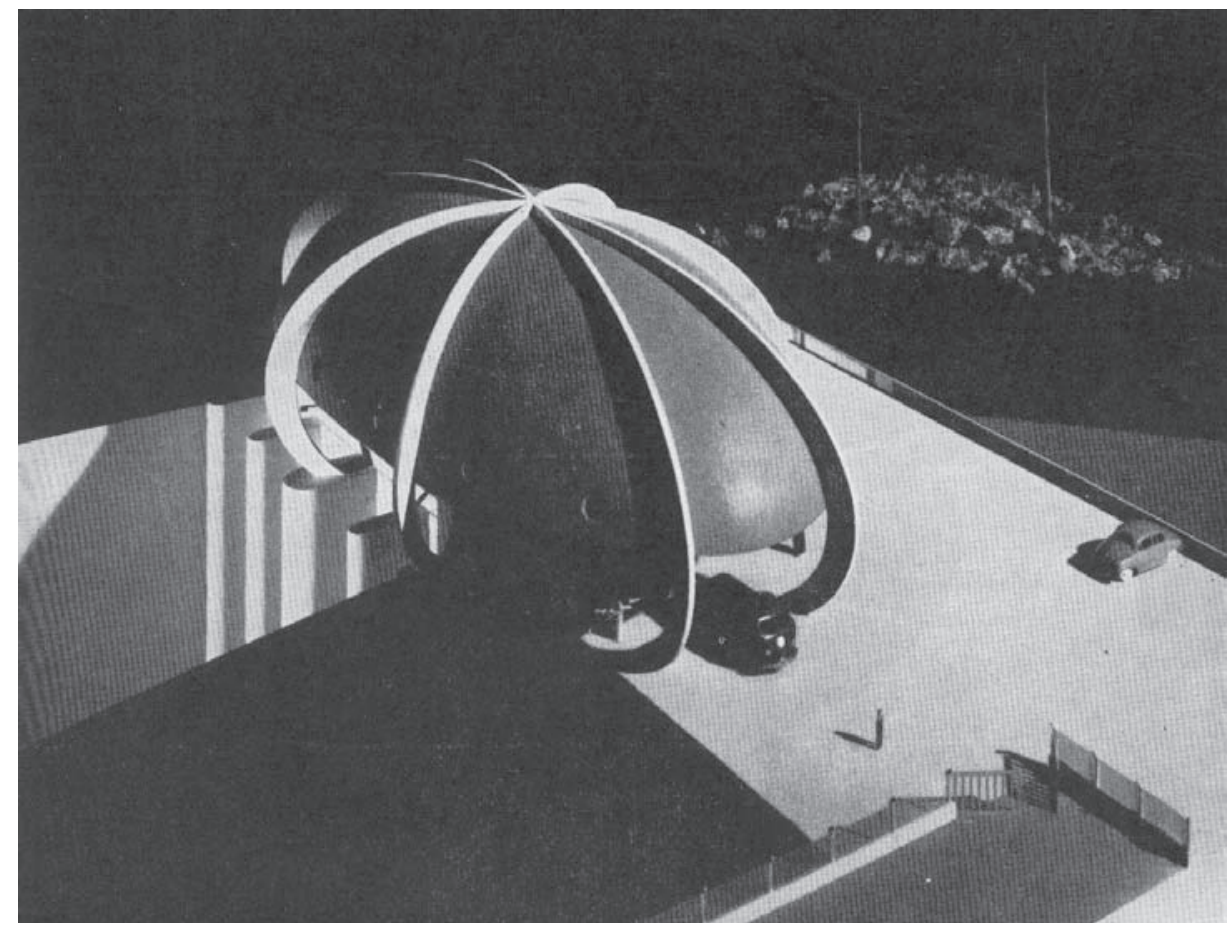

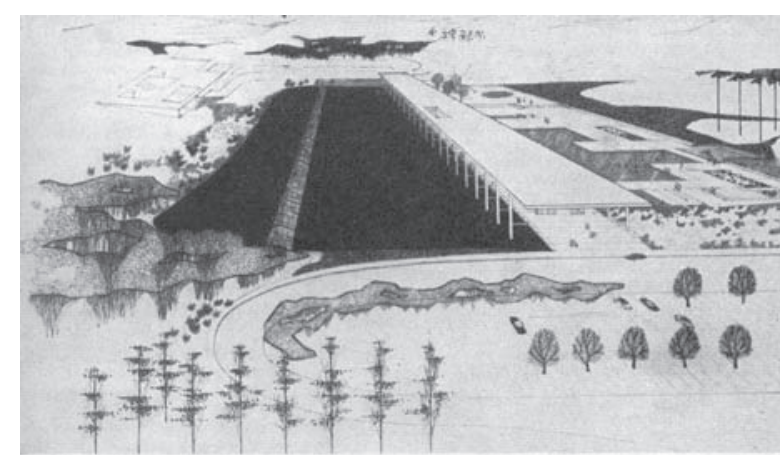

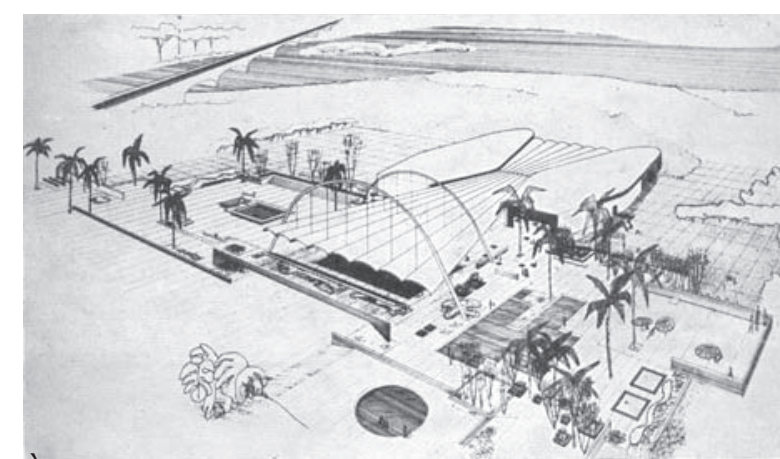

A esquerda, aproveitamento foz do Chopim.

Acima: Lince Estância Clube e CLube de Campo de Piracicaba.

${ }^{30}$ Ver projeto em BRUAND, obra citada, p. 220

31 O projeto de Fonyat possui uma solução engenhosa para a caixa d'água - a cobertura em forma corte possui formato de losango, aonde era possível prever um reservatório em um lugar onde o fornecimento de água não era constante. No projeto de Abelardo a caixa d'água encontra-se na coluna central, o que lhe permitiu maior amplitude na cobertura. 32 Restaurante Los Manantiales. MONTANER, Josep Maria, Depois do movimento moderno. Arquitetura da segunda metade do séc $X X$. Editorial Gustavo Gili, Barcelona. 2001 p.46p.53 


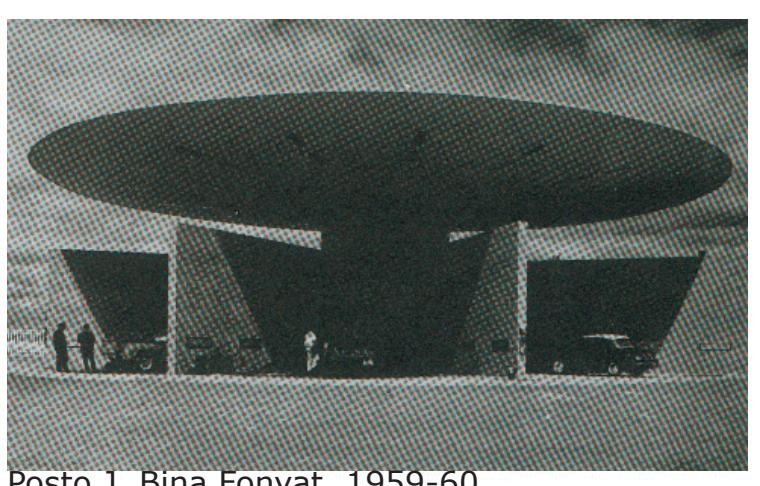

Posto J. Bina Fonyat. 1959-60

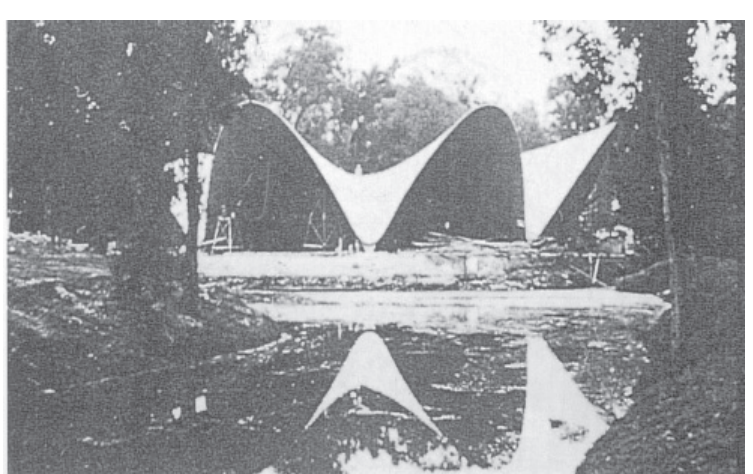

Felix Candela, Rest. los Manantiales. 1957.

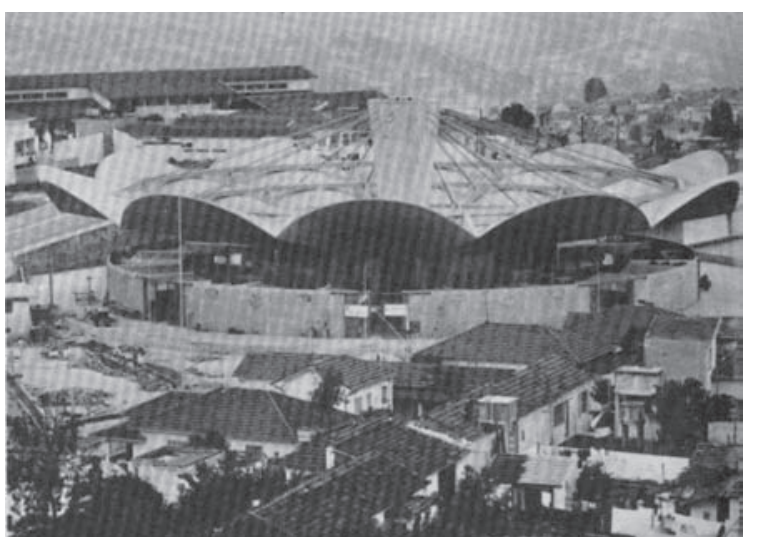

Abelardo de Souza, Merc. Pirituba. 1969-70.
Dessas obras apenas o Clube da Cidade foi concluído, o hotel da Bahia e o Clube de Piracicaba parcialmente..

No final de sessenta Abelardo fica só no escritório novamente e é quando finalmente consegue executar um projeto com estrutura atirantada: o mercado de Pirituba.

\section{O Mercado de Pirituba}

Projeto concebido dentro dos ideais da modernos democrático, um centro de convivência. Sob uma estrutura aparente se desenvolve um ambiente fluído, no qual, de qualquer ponto se tem domínio espacial.

Formalmente, assemelha-se ao Posto de Serviços da Petrobrás em Brasília, de José Bina Fonyat ${ }^{30}$ (1959-1960), porém a cobertura do Mercado de maiores dimensões ${ }^{31}$ e com o movimento das calhas possui maior "tensão".

Em sua expressividade faz supor o conhecimento das formas expressionistas de Felix Candela ${ }^{32}$ e uso de uma arquitetura simbólica: o guarda chuva que acolhe.

Nos materiais utilizados e a ausência de vedação demonstra- se alinhado com as correntes presentes em São Paulo.

Abelardo presta o seguinte depoimento a um jornal em 1972:

"Hoje em dia o concreto aparente está sendo muito usado pelos arquitetos. Eu gosto de jogar com cores, criando um contraste com o cinza do concreto."

"A grande área aberta, entre as paredes dos boxes e a cobertura, não será fechada com caixilhos. Assim haverá muita ventilação. Fazer compras no mercado será quase como numa feira-livre." 
Infelizmente o mercado encontra-se hoje desvirtuado em seu uso e arquitetura, necessitando urgentemente de reparos. 


\section{Fugindo dos padrões}

Foram os edifícios residenciais e comerciais que tornaram conhecida a obra de Abelardo de Souza. Porém, ao longo de sua carreira encontramos por volta de 100 projetos residenciais. São residências para as classes média e alta, em sua maioria na cidade de São Paulo e litorâneas.

Os primeiros projetos localizados datam de 1944. Trata-se de um grupo de casas projetadas para o Banco Hipotecário Lar Brasileiro no Bairro do Paraíso.

Abelardo de Souza, nas residências trabalha com estrutura livre, destacando-se pelo jogo de volumes, fluência espacial, integração interior e exterior, uso de cores e materiais. Procurou sempre optar por elementos padronizados industrializados como janelas, placas de fibrocimento, pastilhas. O pátio interno também é um elemento de seu repertório, numa tentativa de driblar a exigüidade dos lotes urbanos.

Desde o início de sua carreira demonstrou-se um fervoroso adepto modernismo, mesmo quando ainda eram freqüentes os projetos nos padrões dos anos 30, 40.

Neste período, de acordo com Camargo:

"O padrão residencial para as classes média e alta nas décadas de 30 e 40 na cidade de São Paulo era, via de regra, sobrados com edícula e garagem nos fundos. O espaço era fragmentado, constituído de vários cômodos para funções específicas, mas, um único e grande banheiro. Um corredor central distribuía pequenos cômodos pelas laterais, resultando num grande desperdício de área útil. Sacrificavam-se os cômodos em função da 
circulação. A área social voltava-se para frente e por isso era protegida dos olhares dos transeuntes através de pequenas aberturas. Uma edícula nos fundos abrigava a garagem, as dependências de criados e lavanderia, que naquela época resumia-se a um tanque, quase sempre em local aberto, uma vez que não existia a máquina de lavar. As aberturas limitavamse a cumprir a função de ventilação e insolação, sem a preocupação de promover a integração dos espaços ${ }^{1 "}$

Nestor Goulart dos Reis Filho relaciona as soluções de planta desse período - com seus múltiplos cômodos e discriminação das áreas de trabalhoà influência ainda presente do passado colonial, visto que o lote urbano não havia sofrido as transformações compatíveis com o desenvolvimento da cidade e, claro, as mentalidades anacrônicas. ${ }^{2}$

\section{As primeiras casas e a linguagem carioca}

Em sua primeiras casas paulistanas na década de 40, o arquiteto ainda faz o uso de telhados aparentes, ao invés de laje plana ou telhas encobertas por platibandas. Utiliza os volumes puros em sequência, numa linha funcionalista dentro de uma certa organicidade, como ressalta Geraldo Ferraz sobre a casa Oswaldo Young. Isto parece natural, visto que segundo Acayaba :"Nesse tempo era significativo o prestígio do arquiteto americano Frank Loyd Wright entre os arquitetos de São Paulo" ${ }^{3}$. Já neste momento observa-se uma fluidez espacial, limpeza de ornamentos e valorização de todas as fachadas. Alguns brises e terraços em balanço pontuam as aberturas.

A partir da década de 1950, suas residências já apresentam padrões

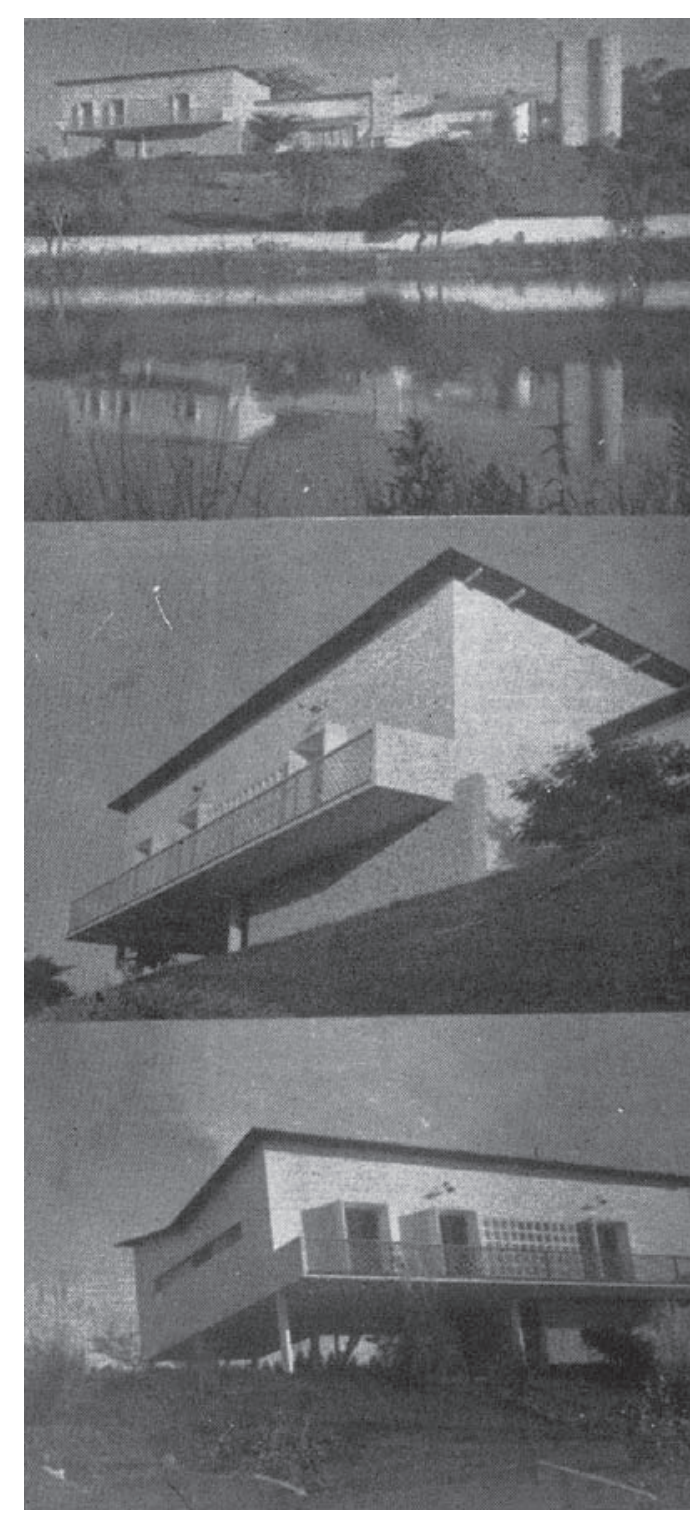

Residência Osvaldo Young. 1944. 


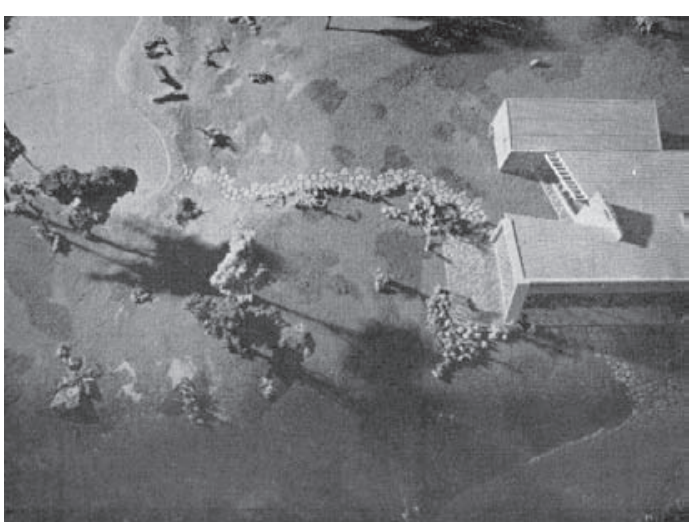

Projeto para Casa de Campo. 1945.
CAMARGO, Monica Junqueira de, 2000 .Princípios da arquitetura moderna na obra de Oswaldo Arthur Bratke p.81 2 REIS, Nestor Goulart do. Quadro da Arquitetura no Brasil.

Editora Perspectiva, São Paulo. 10a edição 2004.

3 ACAYABA, Marlene Milan (1986) Residências em São Paulo

Projeto Editores Associados, São Paulo. ${ }^{4}$ ACAYABA, Marlene Milan (1986) op cit, claramente racionalistas, ligados a Le Corbusier e a exuberância da arquitetura carioca.

O projeto para Casa de Campo, ainda que repleto de um repertório típico do momento da Arquitetura carioca com seus volumes trapezoidais, telhado "asa de borboleta", demonstra uma inventividade estrutural, quando utiliza pilares em madeira não aparelhada. O mesmo material também será utilizado em série, dispostos paralelamente como forma de vedação, numa solução perfeitamente integrada, havendo uma dialética entre tecnologia e materiais naturais, entre o moderno e o tradicional.

Posteriormente, Abelardo começará a repetir soluções para projetos, como se estivesse preso dentro de um estereótipo, contrariando a crença que "Na prática, a casa é muitas vezes a única, a melhor ocasião para o profissional experimentar. Esse projeto, como outro qualquer, o leva a pensar na cidade, na expressão dos espaços e na dinâmica da vida. A casa, já dizia Le Corbusier, é o palácio do séculoXX"4. Portanto, o rótulo "carioca", que o levou a uma inventividade e diferenciação em seus projetos de edifícios multifamiliares e comerciais, o deixará preso quando se trata de projetos residenciais.

Plantas compactas com estruturas livres, a estrutura do volume superior destacada do térreo, uso de pátio interno voltado para o fundo do terreno, janelas guilhotinas com molduras coloridas, serão repetidos a exaustão. Talvez como creditou Reis à repetição de um passado colonial, tenha sido a exigüidade dos lotes que o levou a prescindir de uma fórmula.

Abelardo, diferentemente de seus colegas paulistanos como Levi, Bratke e Artigas, não parecia interessado na busca de novas soluções e parecia fazer aquilo que dele esperavam.

Mesmo fazendo uso do repertório moderno "oficial", Abelardo possuia 
grande preocupação com as condições climáticas, haja vista que ele havia sido um dos integrantes do salão tropical. De tal maneira que as soluções para o Rio de Janeiro nem sempre cabiam de forma direta em São Paulo, sofrendo assim uma adaptação. Assim, podemos ver as composições em madeira, englobando os caixilhos das janelas fazendo-os parecer contínuos, como uma fidelização aos postulados corbusianos.

Os pátios internos, além de garantir a presença da natureza, auxiliavam na procura de melhor climatização e ventilação. Brises, venezianas tratavam do controle de luz.

$\mathrm{Na}$ organização das plantas havia uma procupação com os aspectos funcionais e busca de integração espacial.

Para construção das casas, empregou materiais fornecidos pela indústria, tais como: elementos vazados nas varandas, tijolos nas alvenarias, cerâmicas vitrificadas e madeiras nos pisos e fachadas, além de coberturas planas.

Não falta proporção e qualidade aos projetos e a inventividade acabava ficando por conta da composição no uso de materiais e cores. Assim veremos aplicados pedra, madeira, "muxarabis" e cobogós, que aparecem sobrepostos ao projeto reforçando a composição. Há uma certa ousadia entre materiais naturais e elementos industrializados e prémoldados. As janelas contrapeso "tipo Ideal" são comuns em seu trabalho e de acordo com Miranda Magnoli: "as janelas contrapeso "tipo Ideal" eu já havia conhecido no escritório do Abelardo e do que recordo houve muito de vários croquís do próprio Abelardo para melhorar, corrigir, aperfeiçoar as primeiras janelas que foram executadas pela fábrica "5.

Os projetos eram razoalvelmente detalhados, mas ele fazia questão de acompanhar as obras: "nas residências ele resolvia muitos problemas na obra com os mestres da época que, em serviços de orçamento bastante
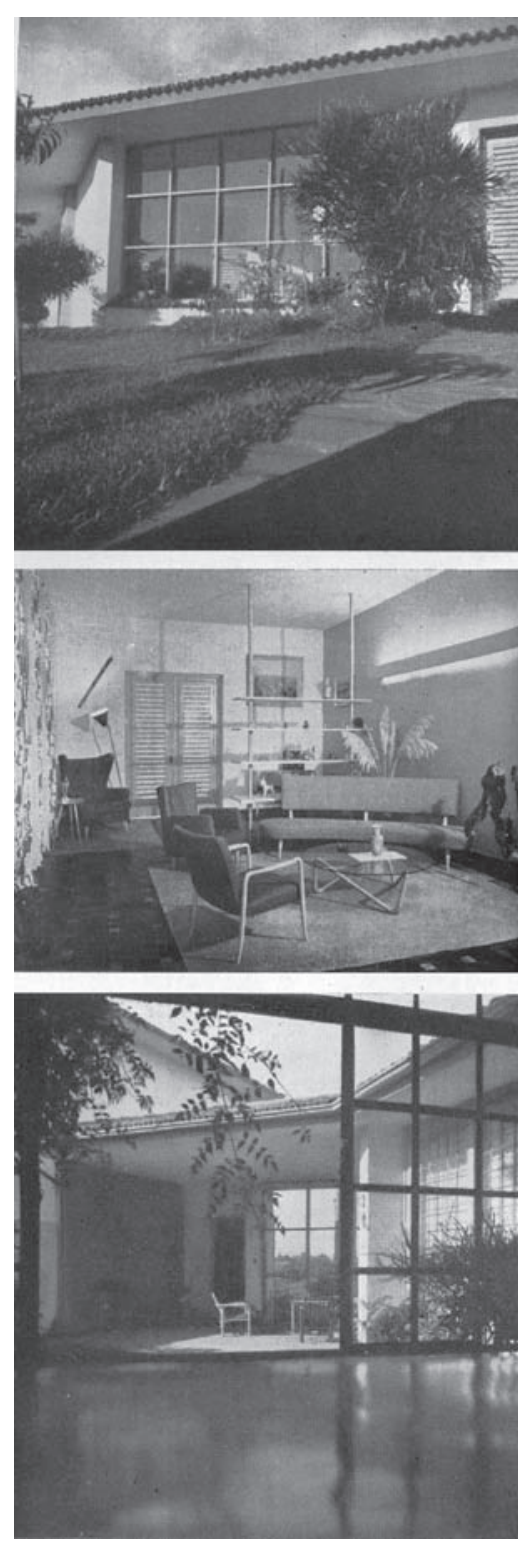

Casa do Arquiteto. 1945 
${ }^{5}$ A arquiteta Miranda Magnoli em depoimento de 18/06/94

6 idem

Depoimento Maria Esther de Souza,

colhido em 23/01/2004

${ }^{8}$ ACAYABA, obra citada, p. 25 limitado, eram pessoas muito simples em que ele ensinava muito do que deviam fazer. Recordo Ribeiro e Bernardo Blay - rua Plínio de Morais. Outro aspecto marcante eram os clientes de residências dele: em geral profissionais liberais com a nossa mesma condição para construirem sua moradia"6

Quanto às cores, Abelardo fazia uso da policromia em caixilhos, escadas e pisos sem temor e ainda complementava com a decoração.

Conforme depoimento de Maria Esther de Souza, filha do arquiteto, sua casa na Av. Anhangabaú possuia uma incomum paleta de cores, definida por Abelardo e Rebolo:

"No começo a porta era amarela da entrada, depois ele pintou de vermelho. E por dentro o Rebolo fez uma bagunça! Foi ele que inventou o jeito de pintar a casa. Indescritível, para o meu gosto indescritível: a parede era ferrugem, onde tinha a lareira o sofá era roxo, foi o Zanine quem fez. Aí tinha uma bergere que era verde preto, aí tinha duas cadeiras redondas que estão na casa da minha filha, uma era vermelho sujo, um tapete redondo cinza e uma cortina em amarelo, preto e ocre."

Móveis de Zanine e do português Joaquim Tenreiro, de quem ele era grande amigo, serão presenças constantes em seus projetos. Na década de 1950 surgiram diversas lojas de móveis e decoração, várias delas de arquitetos, num esforço de criar o móvel brasileiro "aquele que melhor condizia com as condições locais de clima e de uso".8 Podemos destacar: Studio D'Arte Palma, fundado por Lina Bo e Gian Carlo Palanti, Branco\&Preto, fundado por Miguel Forte, Carlos Millan, Roberto Aflalo, Plinio Croce, Jacob Rutchi, Galiano Ciampaglia e Chen y Hua.

A casa José Ribeiro Sobrinho, no bairro do Morumbi, foi decorada com móveis de Tenreiro e prima na composição com materiais.

Em 1965, Souza faz um maravilhoso projeto no Morumbi, com a 
arquiteta Miranda Martinelli Magnoli, para a residência João Scantimburgo, aonde fica clara a preocupação com "o entendimento da vida do cliente" A casa em quatro níveis desenvolvia-se em torno de um salão principal que abrigava uma imensa biblioteca. Passarelas metálicas, farto uso de concreto aparente, aberturas estrategicamente posicionadas marcavam o projeto, infelizmente não executado. Os planos na fachada lembram os volumes da casa Kauffman de Frank Loyd Wright.

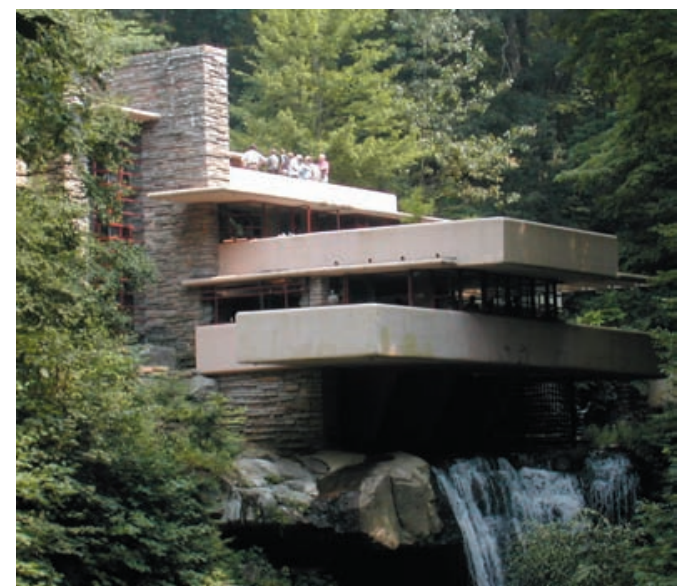

Residência Kauffman, Frank Loyd Wright.1936.

\section{O PCB e a crise de projetos}

Em 1958, o mea culpa de Niemeyer, quando aborda seu trabalho para o setor imobiliário em São Paulo, leva a identificar imediatamente Abelardo de Souza, que teve a maior parcela de sua obra vinculada a este setor, especificamente para o mesmo contratante de Niemeyer, o Banco Nacional Imobiliario.

Neste momento, como afirma Acayaba $^{10}$, convivia-se com a
Miranda Magnoli, depoimento em $18 / 06 / 2004$.

ACAYABA,op cit, p.19 


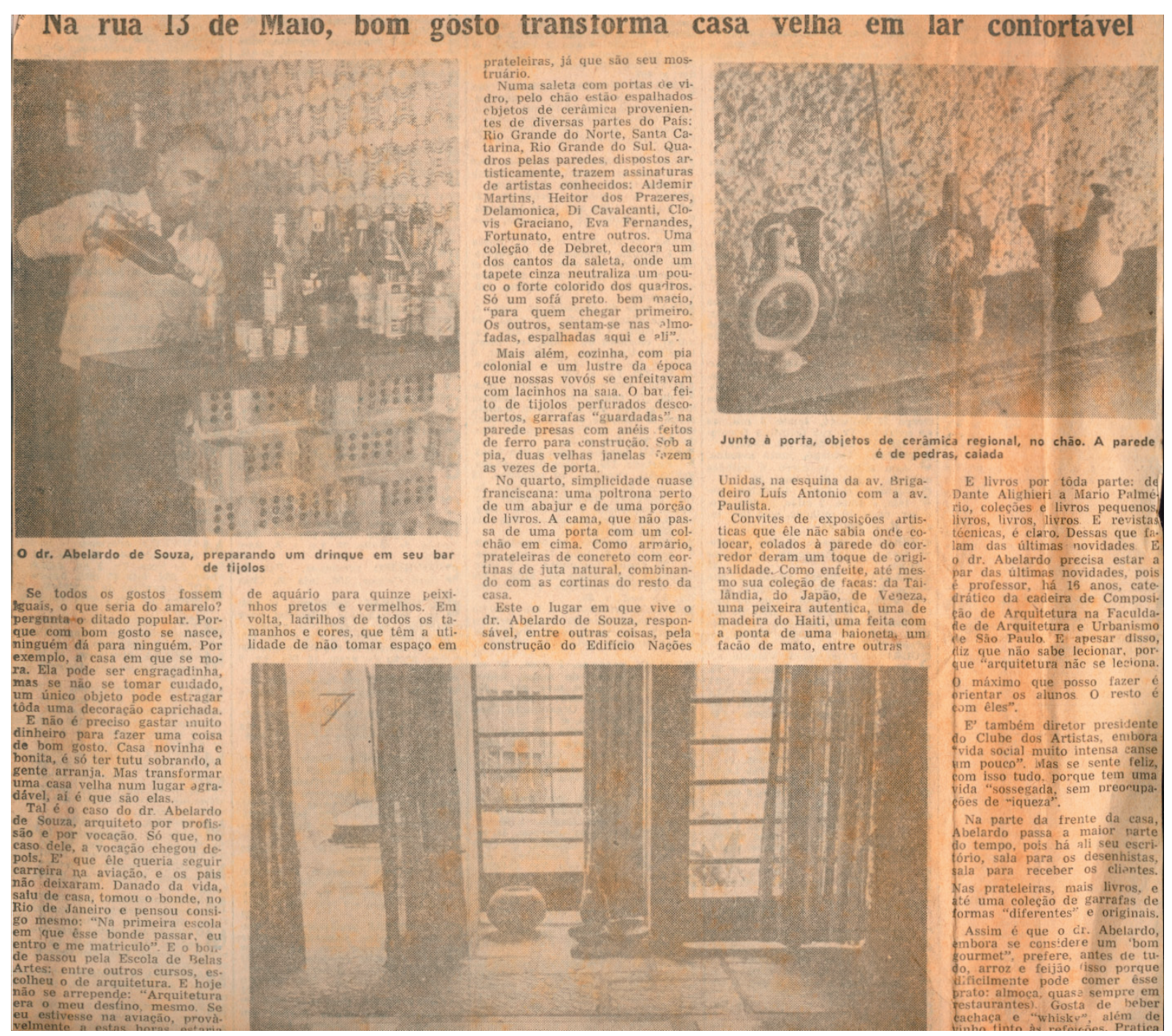

Abelardo em sua casa na 13 de maio. Artigo de 1966, não identificado. 
expectativa da mudança de capital para Brasília e o Rio de Janeiro perdia sua posição de difusor cultural. Paralelamente, São Paulo crescia com novos museus e a Bienal e seus arquitetos, encabeçados por Artigas, passaram a combater o dogmatismo carioca, "como uma adaptação da arquitetura corbusiana aos trópicos". ${ }^{11}$

O escritório de Abelardo entra em crise, coincidindo com um desentendimento entre ele e o partido comunista, que o afastará de suas atividades no PCB e, consequentemente, dos membros e amigos que acabavam por constituir seu círculo de clientes.

Abelardo era membro ativo do partido comunista, não era da linha de batalha, mas trabalhava na administração recolhendo fundos para o partido. Na casa da Av. Anhangabaú sempre se realizavam reuniões, a filha Ma Esther lembra que ela e a avó ficavam isoladas no quarto, mas sabiam que estavam presentes inclusive perseguidos como Marighela e que havia perigo naqueles encontros.

Apesar de afastado do partido desde o início da década de 60, em 1965 Abelardo será acusado em inquérito como responsável pelas atividades comunistas na Faculdade de Arquitetura juntamente com os professores: Artigas, Renina Katz e Candido Lima Dias Silva.

Abelardo sofre considerável queda no número de projetos.

Em 1963 acaba por separar-se de sua esposa, mudando-se para um sobrado na Bela Vista, à Rua 13 de maio. Era um antigo cortiço que ele recupera de forma descomprometida. A frente será ocupada por seu escritório, com um sala de projetos e uma de reuniões para receber clientes e nos fundos ficava sua residência. Uma atmosfera displicente, aonde materiais diversos são aplicados tanto como motivo de decoração como para servir de mostruário. Uma antiga banheira faz as vezes de aquário, com tijolos vazados construiu seu bar. Poucos móveis e almofadas no chão 
misturam-se a antiguidades e cerâmicas brasileiras. Nas paredes obras de artistas consagrados, amigos de seu convívio: Rebolo, Di Cavalcanti, Aldemir Martins, Belloni, Clovis Graciano, Heitor dos Prazeres, gravuras de Renina e de Lamonica. Abelardo apreciava arte e era presença constante como júri em salões.

Rapidamente o local tornou-se um ponto de encontro para amigos e boêmios e de acordo com artigo publicado em 1970, a "casa Hippie" era um dos recantos prediletos de Rubem Braga quando em São Paulo.

Esta nova fase será marcada principalmente pela intensa atividade que passa a desenvolver no chamado "Clubinho".

\section{O Clubinho}

Fundado em 1945, o "Clubinho" fez parte da crônica da cidade de São Paulo e da vida de Abelardo de Souza.

" Durante o período das festas carnavalescas de 1945, achandose reunidos os artistas Paulo Rossi Osir, Alfredo Volpi, Francisco Rebolo Gonçalvez, Nelson Nóbrega, Quirino da Silva, Mário Zanini, por proposta de Paulo Rossi Osir, resolveu-se fundar o "Clube dos Artistas e Amigos da Arte".

Assim se inicia o primeiro livro de atas, que conta como surgiu a entidade que logo passou a ser chamada de "Clubinho".

Para obter os recursos necessários às primeiras despesas, os associados fundadores cotizaram-se com os lucros obtidos na decoração de uma sala, próxima ao antigo Cine Ipiranga - para um baile carnavalesco. 
Foram muitas as adesões: Sérgio Milliet, Arnaldo Pedroso D'Horta, John Graz e outros, organizando-se uma lista de subscrições que logo atingiu 120 filiados.

A assembléia para a eleição do primeiro conselho diretor, que formaria uma diretoria e um conselho deliberativo, aconteceu na noite de 16 de outubro de 1945, na sede do IAB (então localizado na Praça da República), elegendo-se o seguinte conselho diretor: presidente, Tarsila do Amaral; secretários, Waldemar da Costa e Berco Udler; tesoureiros, Gregori Warchavchik e Paulo Rossi Osir; conselheiros, Pola Rezende, Sérgio Milliet, Clóvis Graciano, Aldo Bonadei e Arnaldo Pedroso D'Horta.

O pós-guerra foi um período de inércia e as atividades do "Clubinho" que apenas se reativaram em meados de 1947, com uma assembléia geral realizada na Biblioteca Municipal, em sala cedida por Sérgio Milliet (então seu diretor). Foi eleito novo conselho e aprovados os estatutos do $\mathrm{Clube}^{12}$ que, segundo o art 10 "tem por objetivo o desenvolvimento das artes em geral e a defesa do patrimônio artístico brasileiro".

Em 1952, o "Clubinho" tranferiu-se para a sede própria, no subsolo do prédio do IAB, na rua Bento Freitas 306. Era então seu presidente o arquiteto Rino Levi. O ano de 1957 foi dos mais brilhantes, animado pela intensa atividade de sua presidenta, a pintora e escultora Pola Rezende, à qual sucedeu o pintor Clóvis Graciano. Atravessa época de pleno apogeu, renovando-se as exposições individuais e coletivas, promovendo-se a Feira Nacional dos Artistas e um Festival de Música Popular Brasileira. O baile das quatro artes era o maior acontecimento carnavalesco da cidade, com salões decorados pelos próprios artistas associados.

Segundo João Leite, presidente em 1965, a idéia padrão de sua origem era:

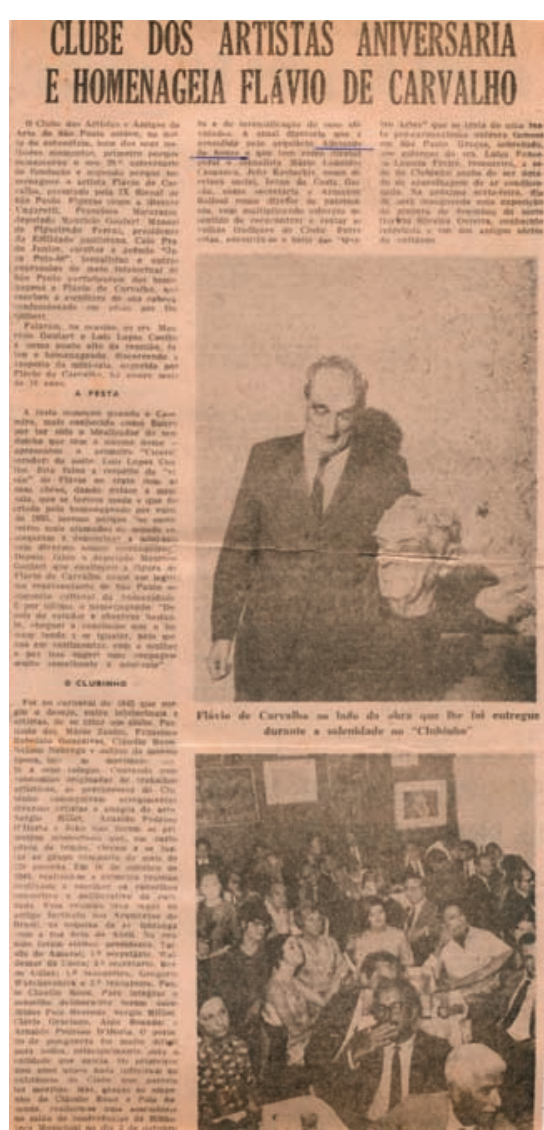

Evento no Clubinho home-

nageando Flavio de Carvalho. Outubro de 1967.

${ }^{12}$ De acordo com o artigo do Shopping News de 22/05/1966, o estatuto foi aprovado "após acalorados debates recompensados depois por generosos copos de uísque" 
${ }^{13}$ artigo de Quirino da Siva, retirado do arquivo pessoal do arquiteto, jornal não identificado, setembro de 1966 .

${ }^{14}$ Em junho de1966, Giancarlo Palanti preparou um risoto a milanesa para os associados

15 "O desafio " de Paulo Cesar Sarraceni maio 66 e "Viridiana", entre outros

${ }^{16}$ Entre os que foram homenageados no

"Clubinho" estavam: Flavio de Carvalho,

Ungaretti e Procópio Ferreira.
"A de um clube pequeno, intimista, fechado, decente, de gosto, onde intelectuais e pessoas de sensibilidade às coisas do espírito possam se encontrar, discutir, se informar, beber, comer, namorar e se divertir em ambiente indiferente à vida comum". ${ }^{13}$

Abelardo de Souza exerceu o cargo de diretor geral durante o mandato de João Leite que, tendo encontrado o clube em declínio devido à saída de diversos membros, trabalhou para recuperar suas finanças. Após isto, os sócios então, na tentativa de devolver o prestígio da entidade, congregaram-se em torno de uma chapa única, cuja formação era: presidente, Abelardo de Souza; vice, Mauríco Goulart; conselheiros, Clóvis Graciano; Gerda Brentani, Giancarlo Palanti, Francisco Fanuelli, Myriam Magda Nogueira, Ignacio de Loyola, Francisco Luis de Almeida Salles, e outros.

A eleição da nova diretoria obteve grande divulgação. Entre suas metas estavam a reforma da sede prevendo um bar, restaurante, biblioteca, sala de reuniões e sala de espera. As obras seriam financiadas pelos próprios associados através da venda de 200 quotas de sócios proprietários. Outra forma de arrecadação seria reviver o "Baile das Quatro Artes", com baile a fantasia nos jardins do Ibirapuera.

Abelardo foi presidente do Clubinho por três mandatos tendo, neste período, realizado atividades dos mais diversos gêneros: jantares ${ }^{14}$, Festa da música popular brasileira (apoiado por emissora de tv), Debates sobre filmes ${ }^{15}$, palestras, homenagens a artistas ${ }^{16}$, Shows, lançamentos de livros, etc. Foi ele quem realizou o projeto de reforma do imóvel em 1965.

Amplamente divulgado pela mídia por sua atividade frente ao "Clubinho", Abelardo frequentava círculos políticos, artísticos e da sociedade paulistana, sendo convidado entre outras coisas a participar da comissão de Carnaval da Prefeitura de São Paulo (1968). 
Em 1973 planeja sua reeleição e a mudança da sede, pois o centro já não era mais um ponto de encontro para os artistas e boêmios. Infelizmente, não teve seus planos concretizados, pois de acordo com artigo do Estado de São Paulo de 2002, o "Clubinho" acabou terminando melancolicamente, devendo aluguéis para o IAB. 
FI(Gichas 


\section{Edifício Conceição}

1942

Publicações:

Acrópole 126, p.187-9.

1946.

\section{DADOS DO PROJETO:}

Execução: S.A.C.I.L. Soc. Americana Construtora

Imobiliária Ltda

Incorporação:

Banco

Hipotecário Lar Brasileira S.A.

Entrega da Obra: 1946

Local: Rua da Conceição esquina com Rua Washington Luiz

\section{DESCRIÇÃO DO PROJETO:}

Situado a cinquenta metros da Avenida Ipiranga, trata-se de edifício de 20 pavimentos para uso misto ocupando todo - lote. É composto de dois blocos distintos com entradas separadas sendo: um bloco para escritório e o outro para residência, cada qual dotado de dois elevadores.

Área do Lote:

Área Construída:

No de pavimentos: 20
SUBSOLO: Aí localizam-se: depósito das 4 lojas com acesso individual por escadas internas, reservatório d'água, casa de bombas e inspeção dos elevadores.

PAVIMENTO TÉRREO: Três lojas com entrada direto pela rua sendo: duas voltadas para Rua Washington Luiz e uma para Rua Conceição. O hall de entrada para os escritórios dá para a rua Conceição e através dele se tem acesso à $4^{a}$ unidade comercial. A entrada do bloco residencial se faz pela Rua Washington Luiz, havendo distinção para a entrada de serviço.

PAVIMENTO TIPO: As unidades residenciais são voltadas para face norte e leste. Cada pavimento tipo possui duas unidades residenciais e duas comerciais, com áreas variando

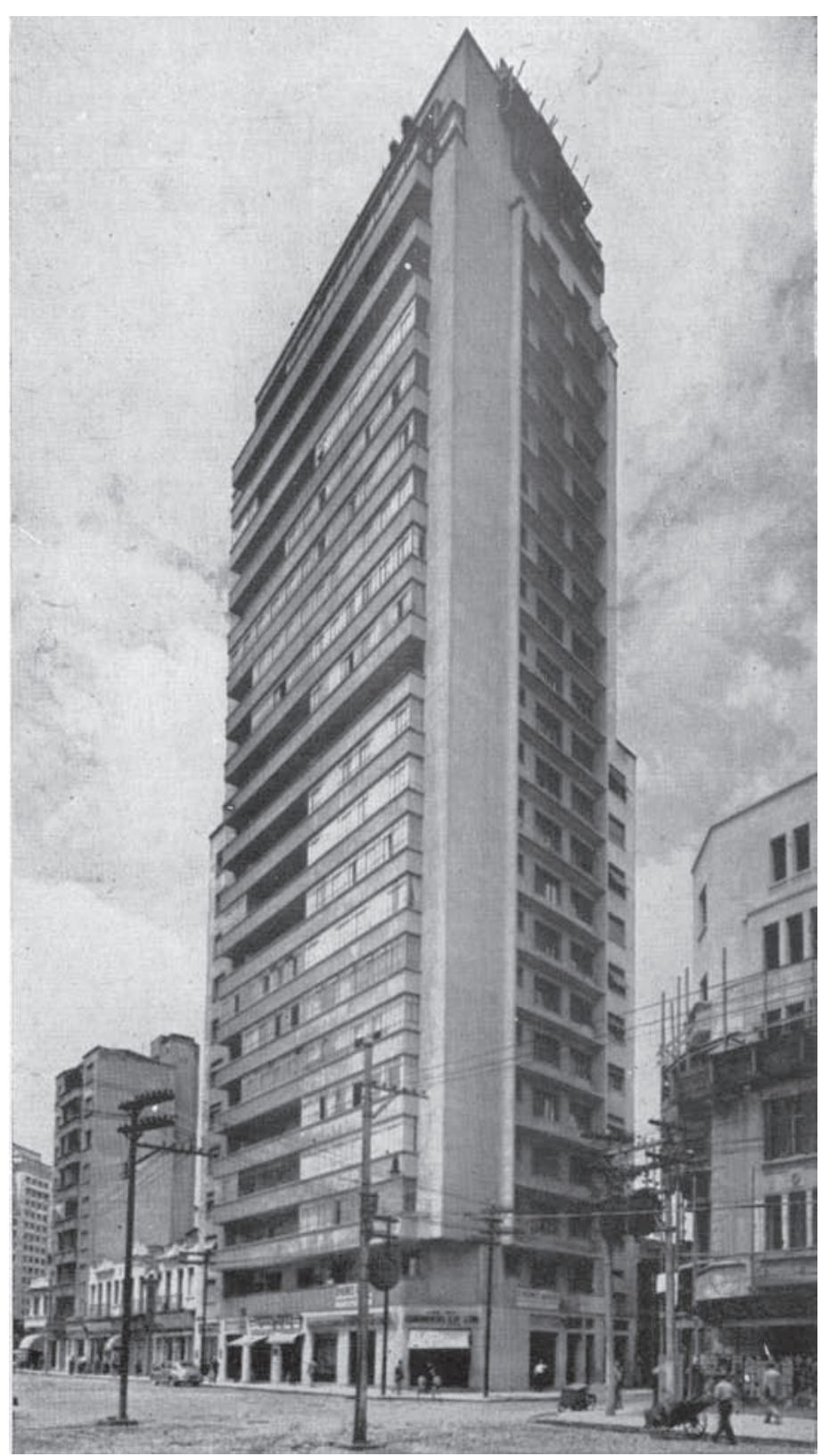




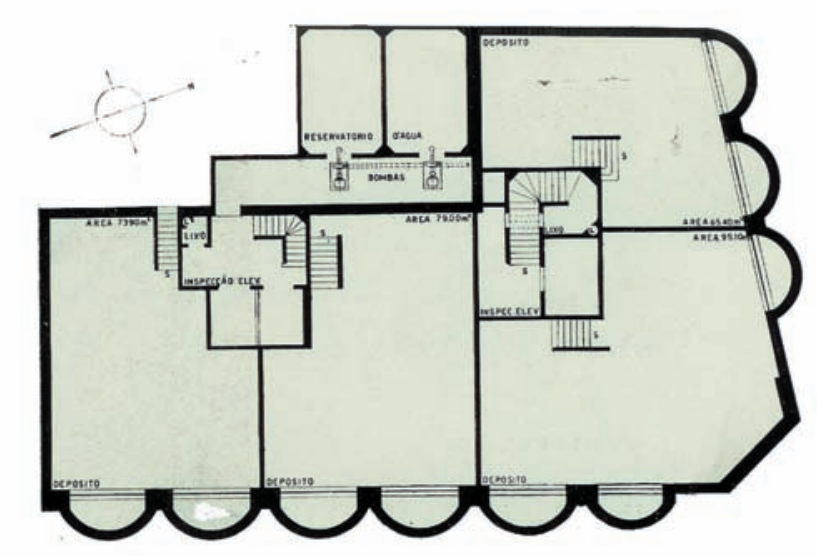

Planta do subsolo.

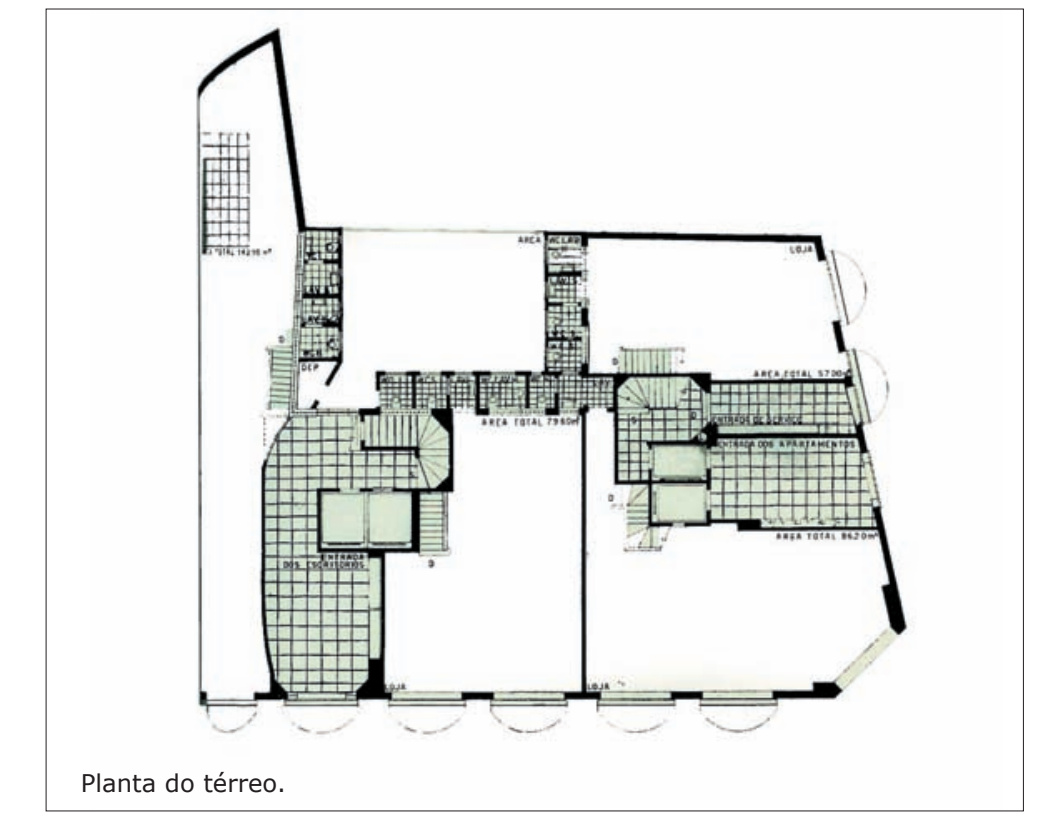

Planta do térreo.
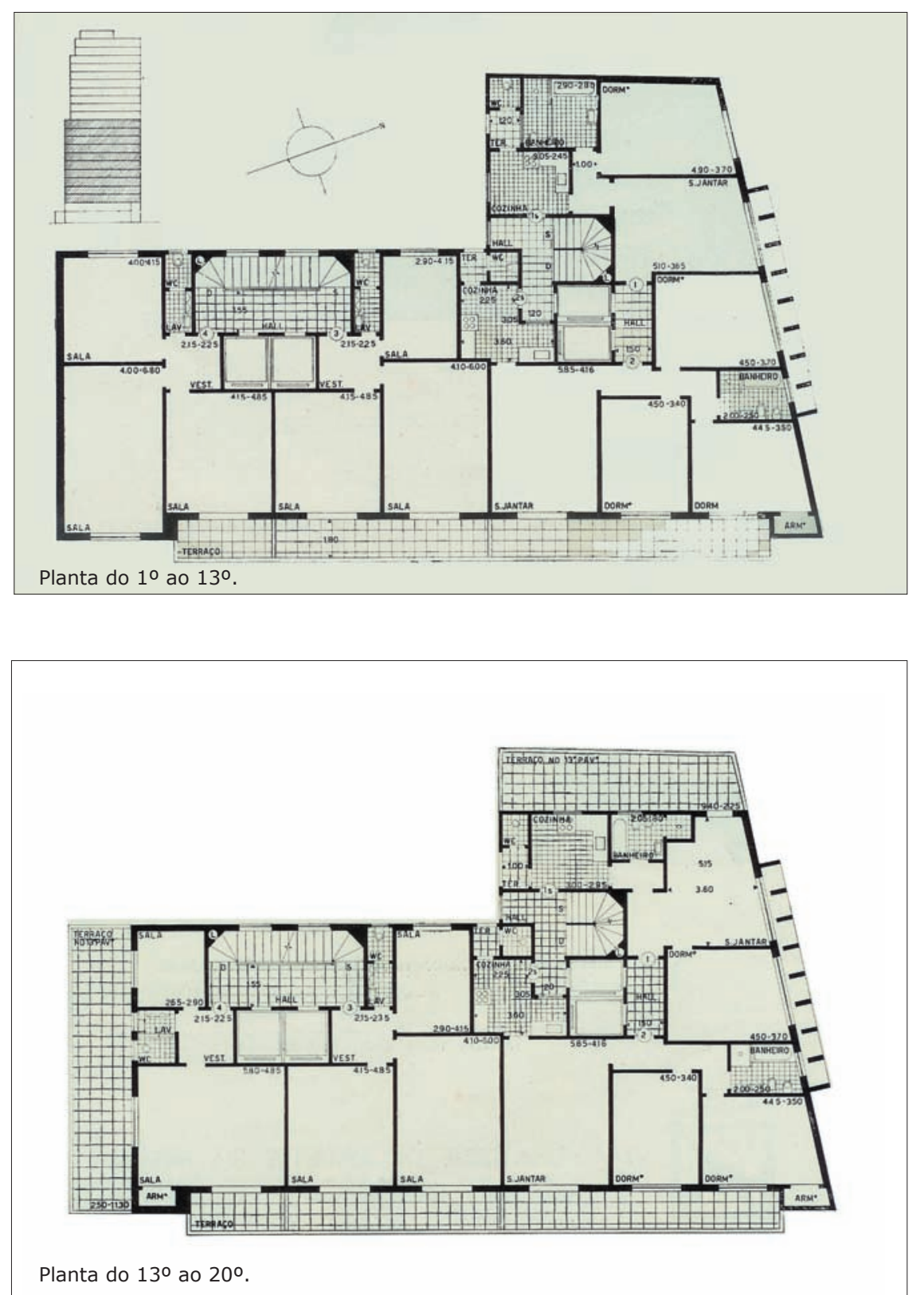
entre 50 e $100 \mathrm{~m} 2$ nas residências e 80 e 45 m2 nos conjuntos.

Os apartamentos voltados para rua Conceição são dotados de terraços. As áreas de serviço e banheiros concentram-se em um pátio interno

Há um recuo no corpo do edifício à partir do $13^{\circ}$ pavimento.

TRATAMENTO DE FACHADAS: A entrada dos apartamentos e escritórios receberam destaque pelo revestimento em mármore travertino romano. O corpo do edifício é em argamassa com cor.

O arquiteto realiza um jogo compositivo onde os terraços em balanço formam uma constante horizontal em direção ao ângulo agudo da esquina, contrapondo-se a empena cega que acentua a verticalidade da composição. $\mathrm{Na}$ fachada da Rua Washington Luiz, um requadro na estrutura compõe uma moldura para as janelas de diferentes ambientes.

Verifica-se já nesta obra a busca de Abelardo de Souza por rítmos variados em suas composições, à qual irá agregar
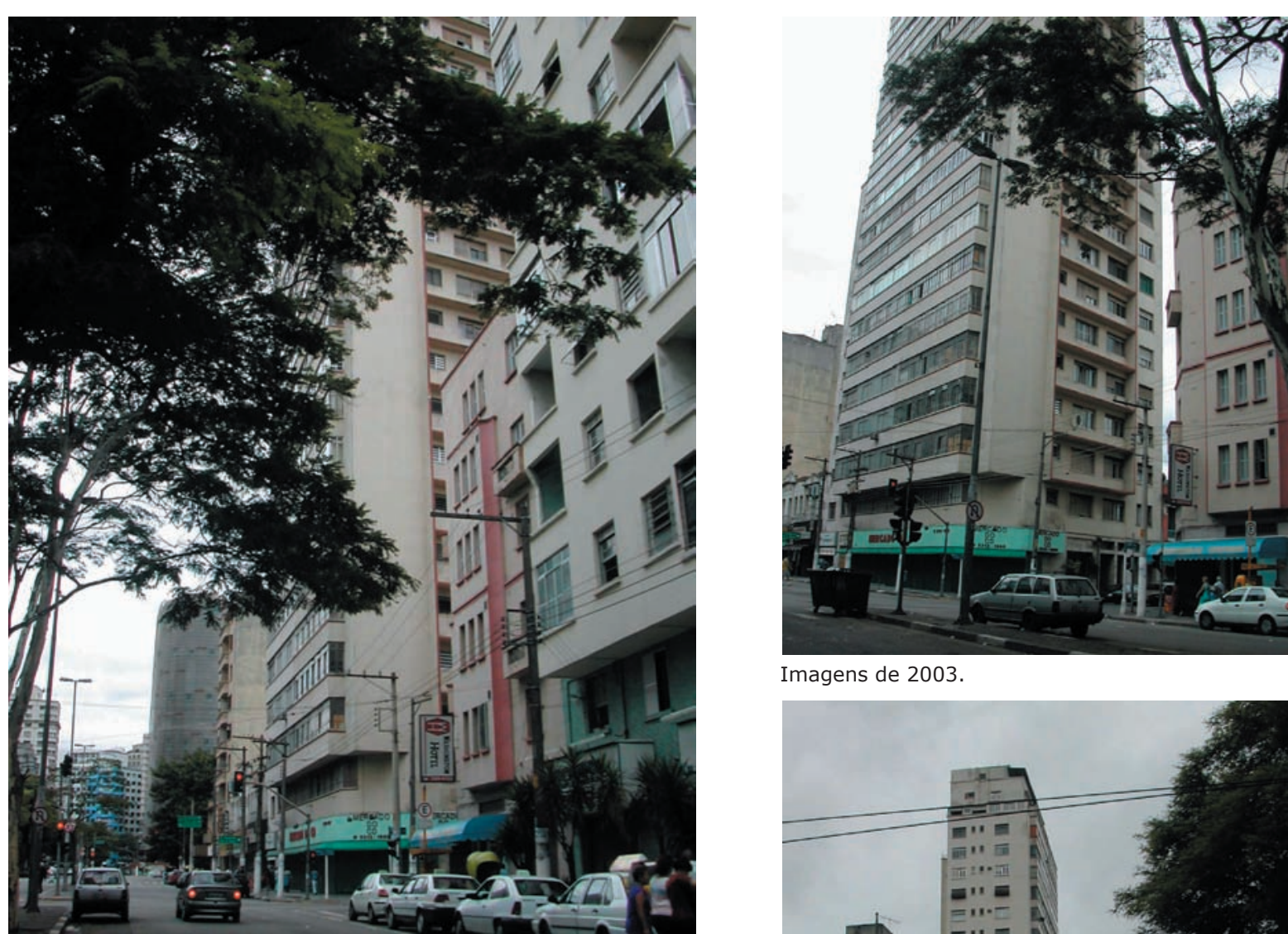

Imagens de 2003.

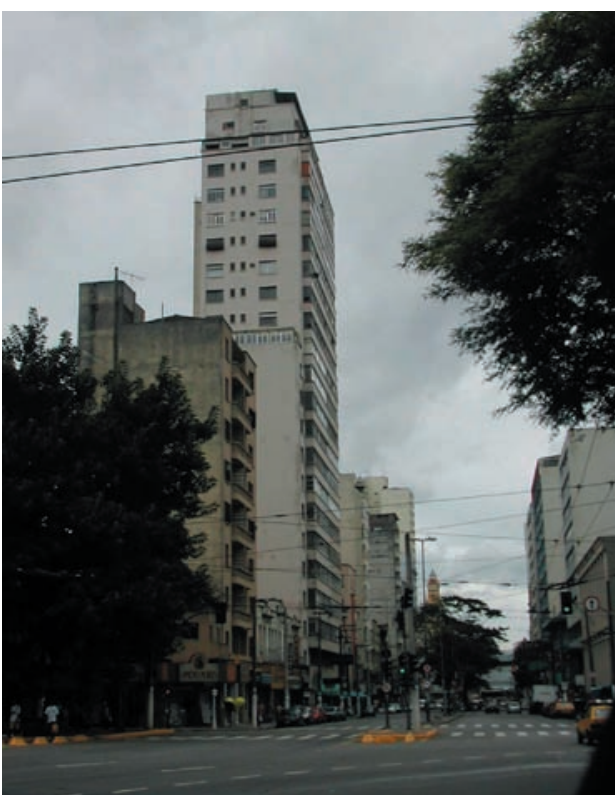




\section{Edifício Hecilda $\quad \begin{aligned} & \text { Publicações: } \\ & \text { Acrópole 120, p.321-3. }\end{aligned}$ 1948}

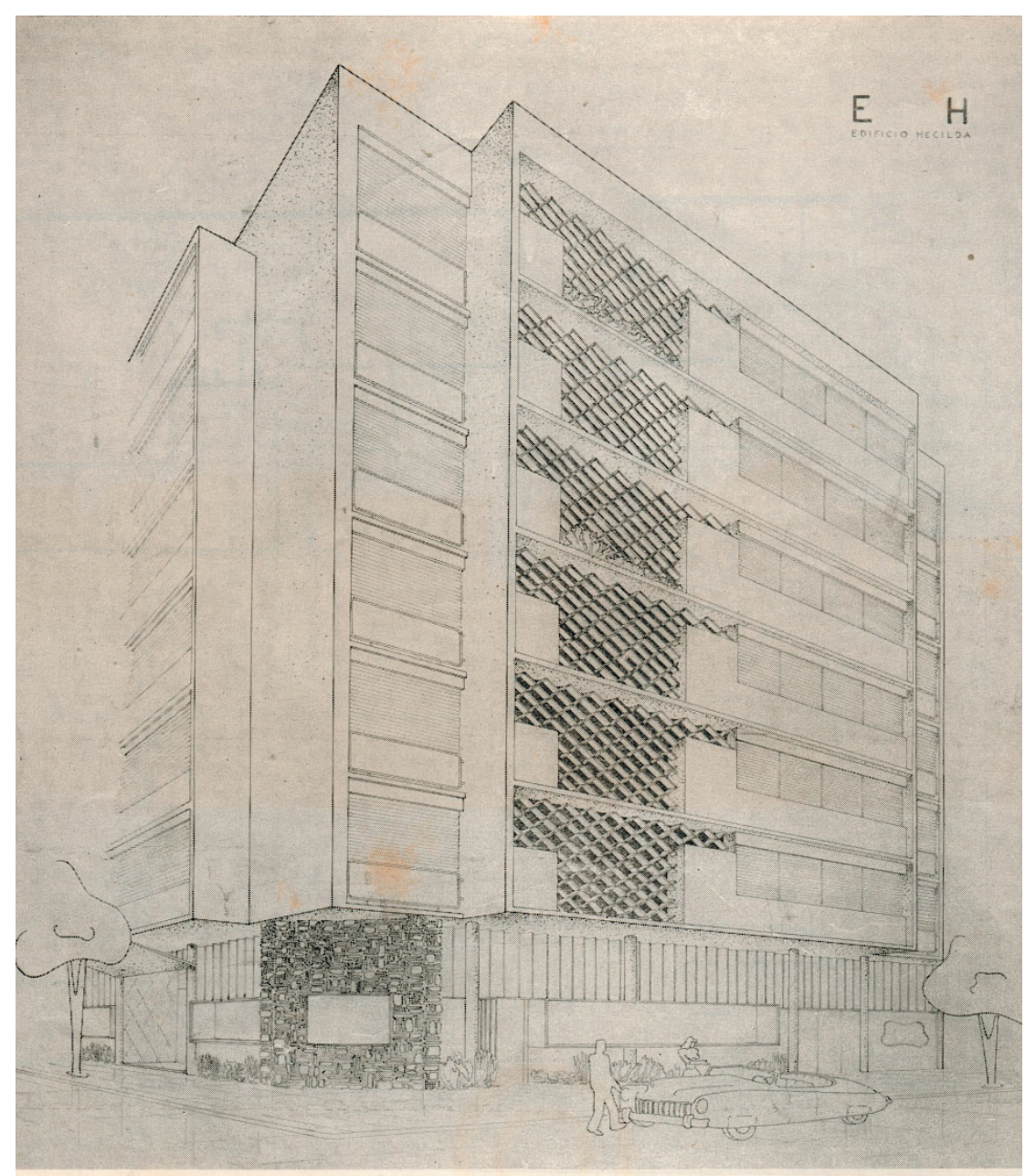

EDIFICIO HECILDA

RUA CEZARIO MOTTA ESO. MAJOR SERTORIO
DADOS DO PROJETO:

Arquitetos: Abelardo de Souza, Hélio Queiroz Duarte e Zenon Lotufo

Incorporação: Sr. Thimoteo José Cezário de Campos e Dr. Armando Moura Bitencourt Entrega da Obra

Local: Rua Cezário Motta esquina Rua Major Sertório 475.

\section{DESCRIÇÃO DO PROJETO:}

Bloco em L com 10 pavimentos, ocupando praticamente todo o lote, com o térreo destinado a lojas e os demais pavimentos para moradia. Um recuo na base em relação ao alinhamento da rua forma pequeno jardim e destaca térreo do corpo do edifício. $O$ uso de materais diversificados reforça a composição.

Área do Lote: 439,50 m2 Área Construída: $2.345 \mathrm{~m} 2$ No de pavimentos: 10 pavimentos

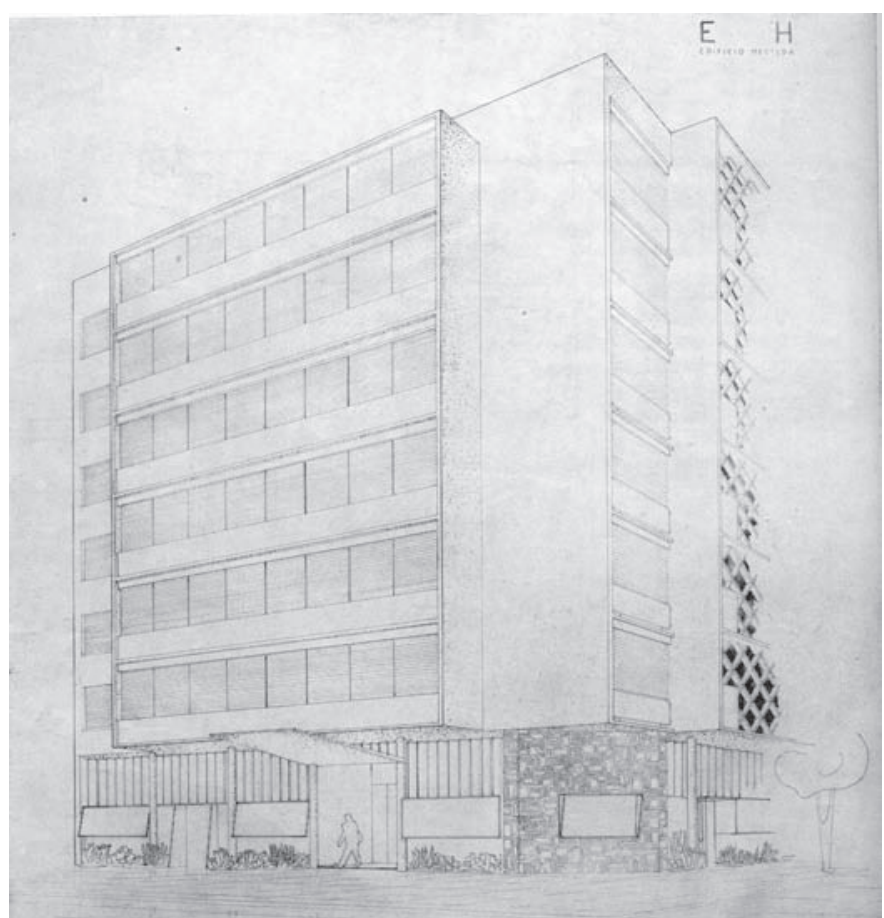


Planta do térreo. Planta $8^{\circ}$ pav.
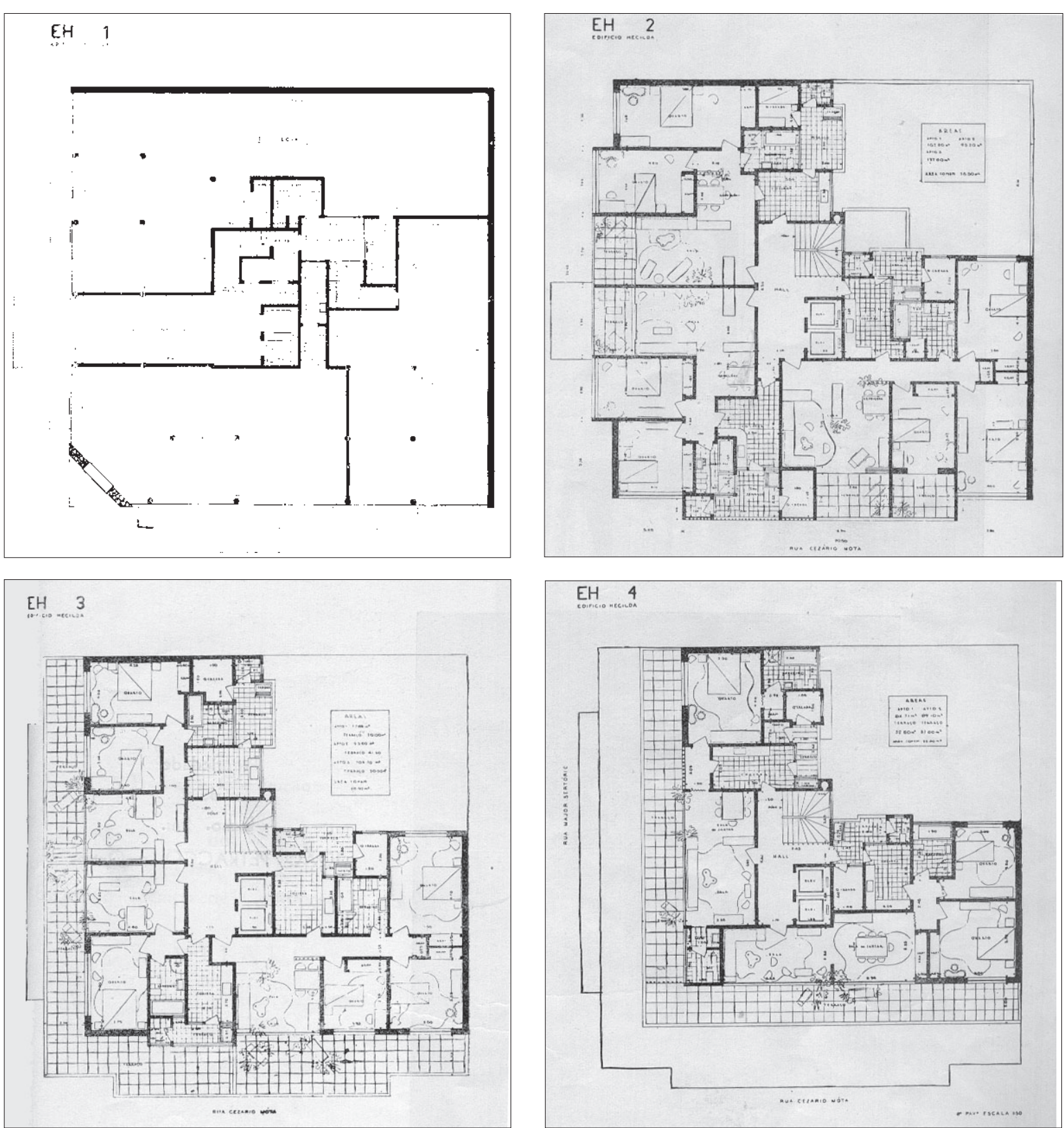

Planta do tipo.

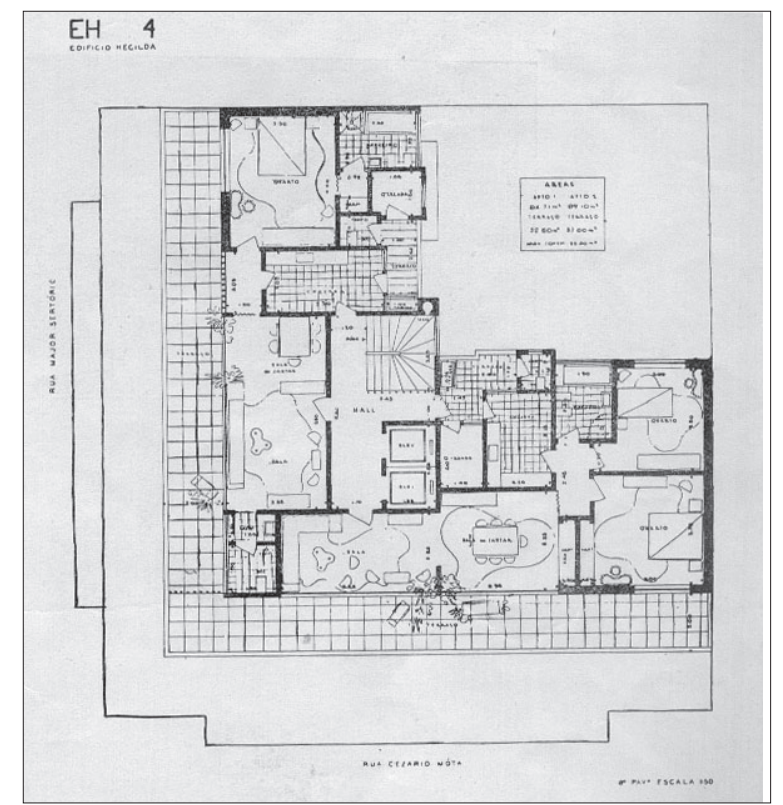


PAVIMENTO TÉRREO: Três lojas com entradas independentes pela rua. A marquize voltada para Rua Major Sertório pontua o acesso ao bloco residêncial.

PAVIMENTO TIPO: Duas unidades com 2 dormitórios voltadas para Rua Major Sertório e uma unidade de três para Rua Cezário Mota, com áreas variando de 80 e $108 \mathrm{~m} 2$ respectivamente.

TRATAMENTO DE FACHADAS: A estrutura do edifício é claramente marcada na fachada, fazendo parte de sua composição. Os elementos vazados são uma boa solução para as aberturas da áreas de serviço na fachada, ao mesmo tempo que reiteram o interesse pelo uso componentes de uma arquitetura tradicional preconizado pelo movimento carioca. A planta livre no térreo permitiu um recuo nas alvenarias que se destaca pelo uso de materiais naturais e janelas contínuas.

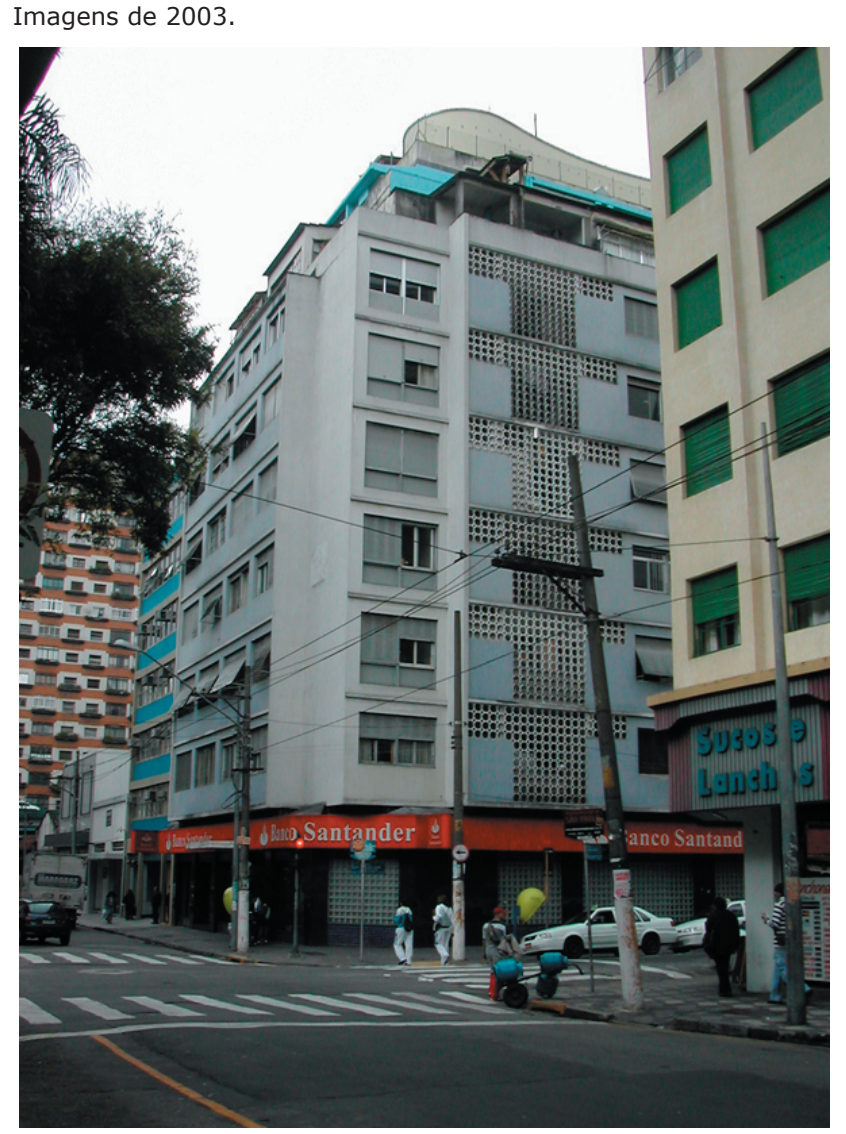

ESTADO ATUAL DO CONJUNTO: $O$ térreo do edifício foi ocupado por agência bancária que alterou todos os acabamentos. Os andares, apesar de necessitarem limpeza e reparos mantém seu aspecto original. Apenas a cobertura com alguns acréscimos ganhou um ar de "favela". 


\section{Edifício Pedra Azul}

1947

Publicações:

Acrópole 114 p.165-7.

1947.

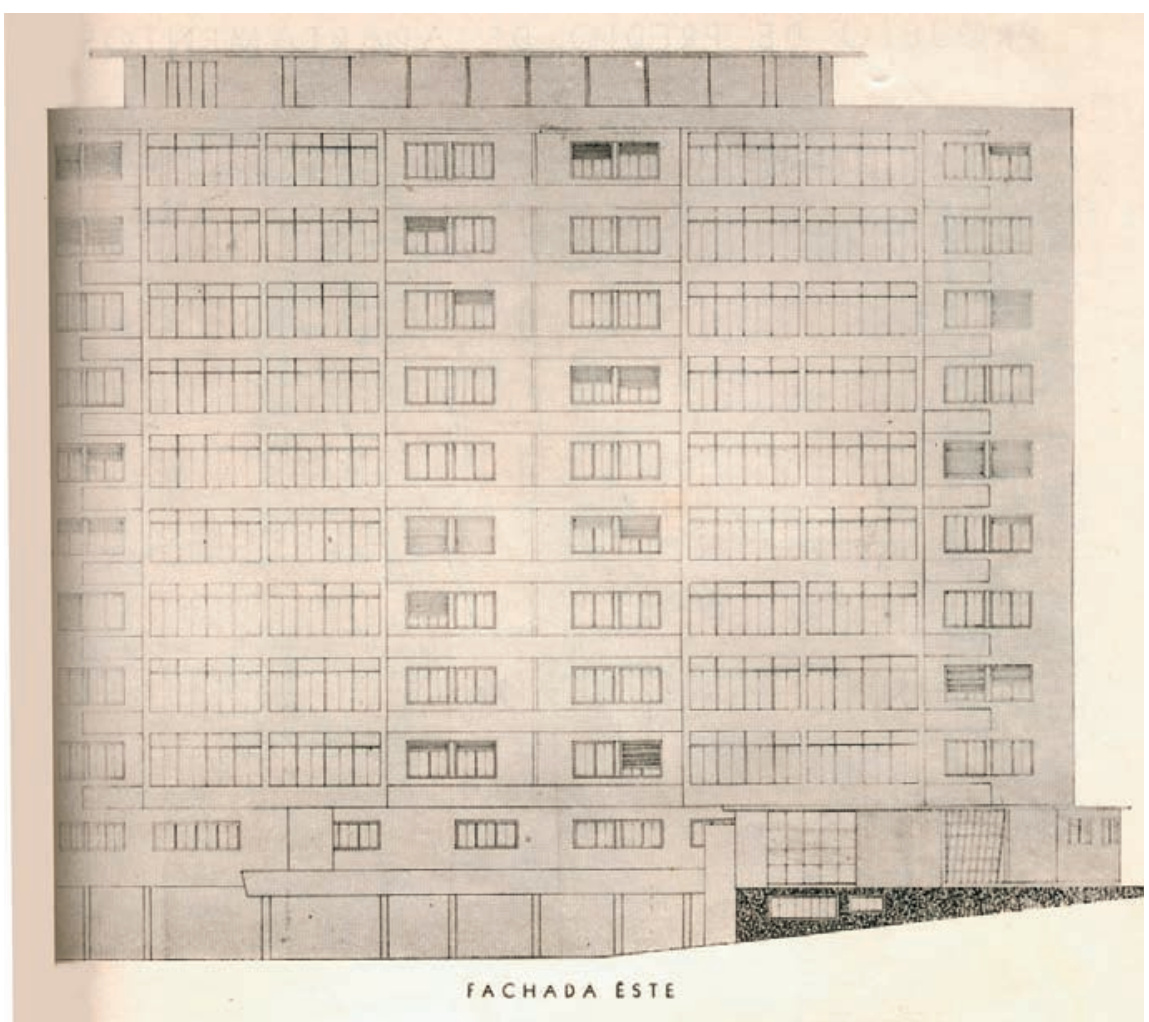

Fachada Leste.

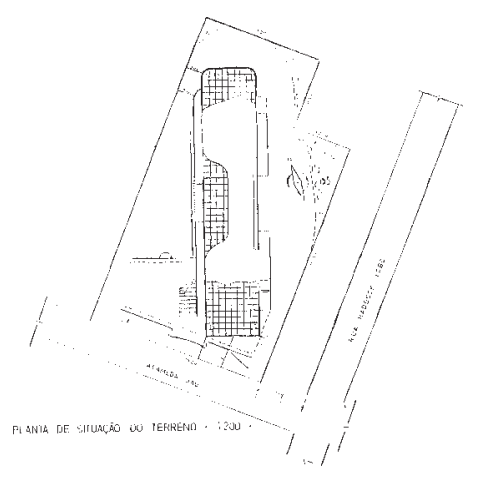

Planta situação e planta subsolo.

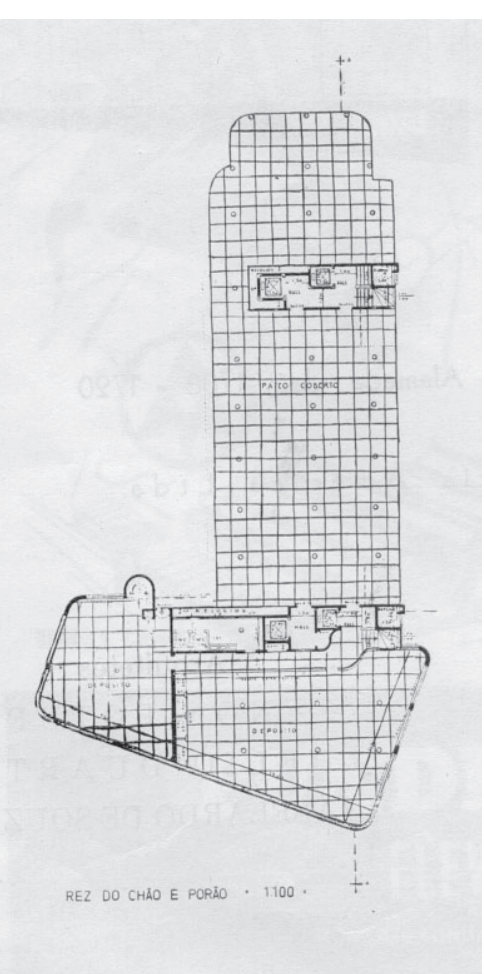

\section{DADOS DO PROJETO:}

Arquitetos: Abelardo de

Souza, Hélio Queiroz Duarte e Zenon Lotufo

Incorporação: Sociedade Imobiliária América Ltda.

Local: Alameda Jaú 17081720

\section{DESCRIÇÃO DO}

PROJETO:

O edifício de tipo lamelar foi implantado em uma diagonal cortando o terreno. Desta forma o lote não tem aproveitamento total, mas como situação tornase extremamente agradável, propiciando a todos os apartamentos uma visão da rua e do jardim de ingresso.

\section{Área do Lote:}

Área Construída:

aproximadamente $5900 \mathrm{~m} 2$.

Laje tipo: $490,40 \mathrm{~m} 2$.

No de pavimentos: 9

SUBSOLO: Área livre com pilotis sob a projeção do edifício. 

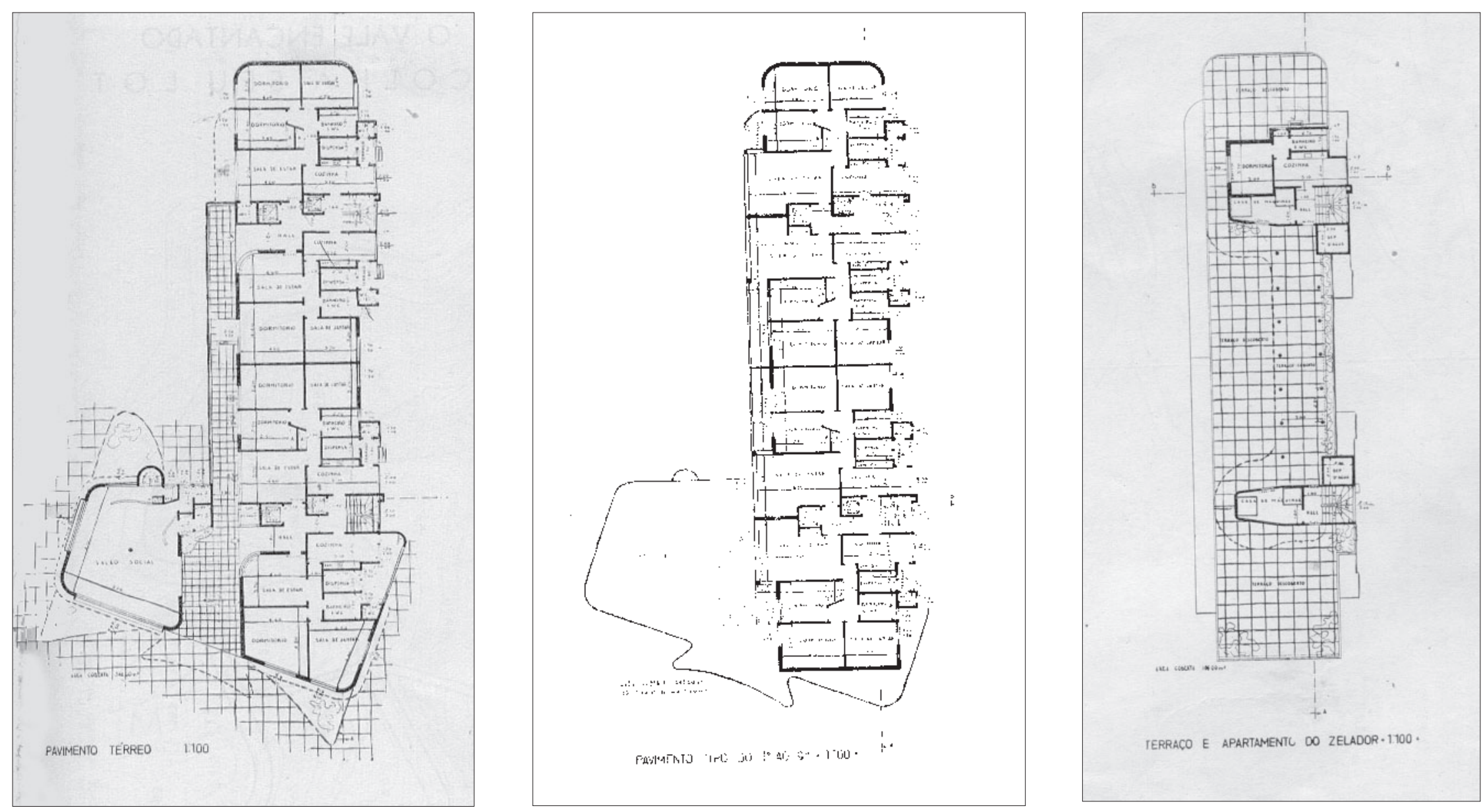
PAVIMENTO TÉRREO:

conjunto constituí-se de 2 blocos espelhados possuindo entradas separadas e 2 apartamentos por bloco. $\mathrm{O}$ acesso aos halls se faz pelo térreo através de um passeio coberto. Uma marquise compõe a entrada e abriga o salão de festas.

PAVIMENTO TIPO:

4 apartamentos de dois dormitórios por andar. Os quartos e estar ficam voltados para fachada leste. No lado oposto cozinha, dependências de serviço e a sala de jantar, estranhamente mais próxima dos quartos que da área social. COBERTURA: Terraço com ampla cobertura em linhas orgânicas sobre pilotis, clara menção aos terraços-jardim propostos por Le Corbusier. Neste piso encontra-se o apartamento do zelador.
TRATAMENTO DE FACHADAS: As parede receberam aplicação de pastilhas mescladas em bege e branco. A composição regular alternando terraços e janelas evidencia a estrutura.

ESTADO ATUAL DO CONJUNTO: O edifício encontra-se em uma região extremamente valorizada da cidade e a qualidade dos apartamentos fez com que se mantivesse um público de bom poder aquisitivo estando o conjunto no seu aspecto geral bem conservado. Alguns dos terraços foram fechados, e as janelas dos apartamentos baixos ganharam grades, descaracterizando a fachada.

A marquize do salão de festas recebeu uma cobertura em telha de fibrocimento, em virtude de vazamentos.

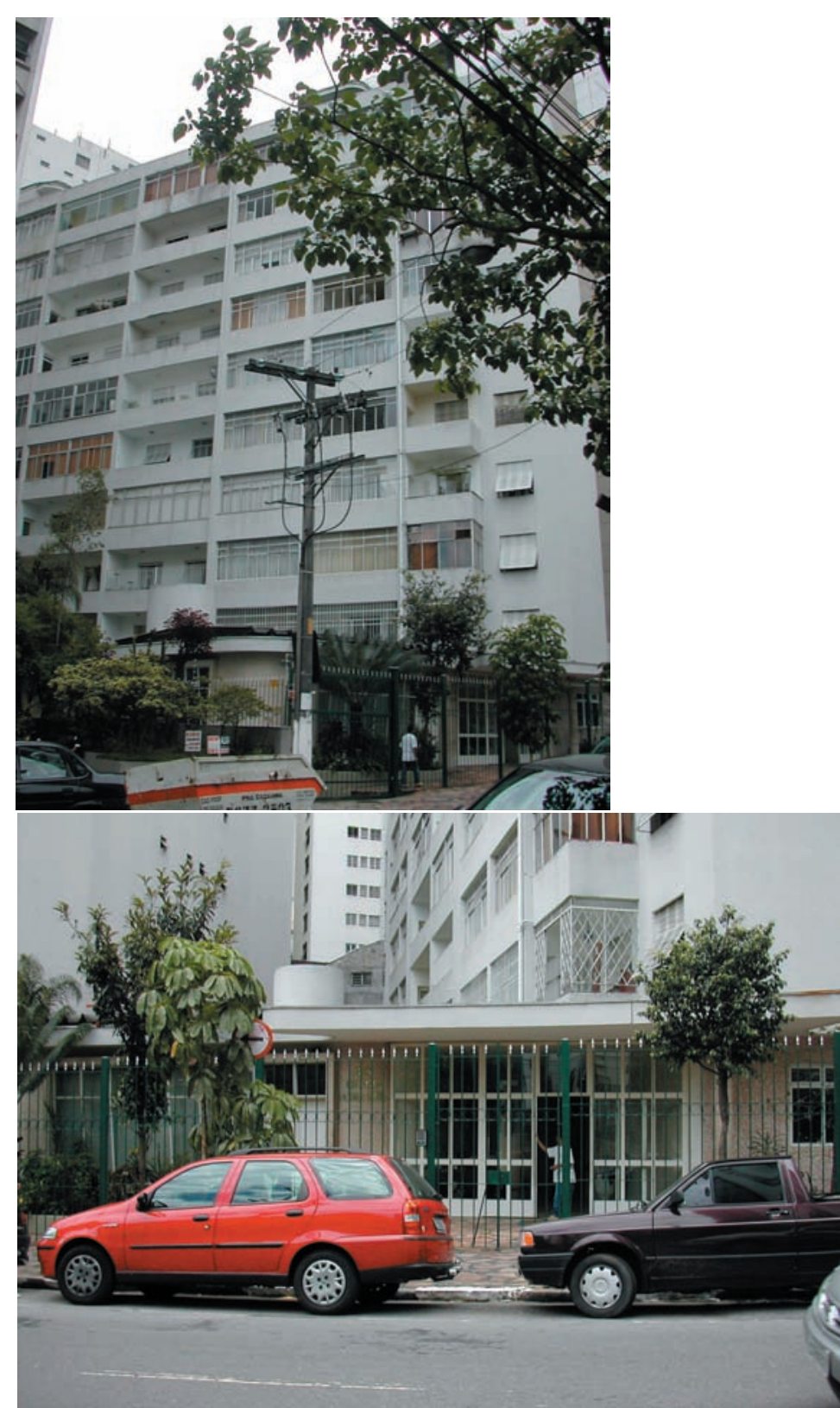




\section{Sede da ABI Salvador}

\section{8}

Publicações:

Acrópole 98, p.52-4.

1946.

Acrópole 117, p.249-51.

1948.

Acrópole 259, p.176-7.

1960

DOCOMOMO-Brasil/UFBA. 1966

\section{DADOS DO PROJETO:}

Arquitetos: Abelardo de Souza, Hélio Queiroz Duarte e Zenon Lotufo

Projeto: 1948

Execução: Cia. Comércio,

Imóveis e Construção

Engenheiro: E.R. Carvalho

Mange

\section{Incorporação}

\section{Entrega da Obra: 1960}

Local: Rua Guedes de Brito no 1 - Praça da Sé, Salvador

\section{Bahia}

Premiações: Projeto Vencedor

do Concurso para sede da Associação Bahiana de Imprensa

\section{DESCRIÇÃO DO PROJETO:}

Em 1941 foi instituido concurso de projetos para construção da casa do jornalista, sede da ABI,

em terreno as Ruas Visconde de Rio Branco e Rui Barbosa. A equipe de Abelardo de Souza, Hélio Queiroz Duarte e Zenon Lotufo saiu vencedora, porém, posteriormente, o local de sede foi transferido para as Ruas Guedes Brito e José Gonçalves. Manteve-se o programa previsto para o primeiro edital, mas o projeto deveria adequar-se ao plano de urbanização da Praça da Sé, seguindo a "indicação dos eixos, largura, grade dos logradouros; a da altura, tipo e condições outras de ordem construtiva e arquitetônica dos edifícios bem como as demais limitações que um ambiente histórico e artístico a preservar possam impor as construções". De acordo com DOCOMOMO, relatos de jornais da época dão conta que a sede da ABI bahiana

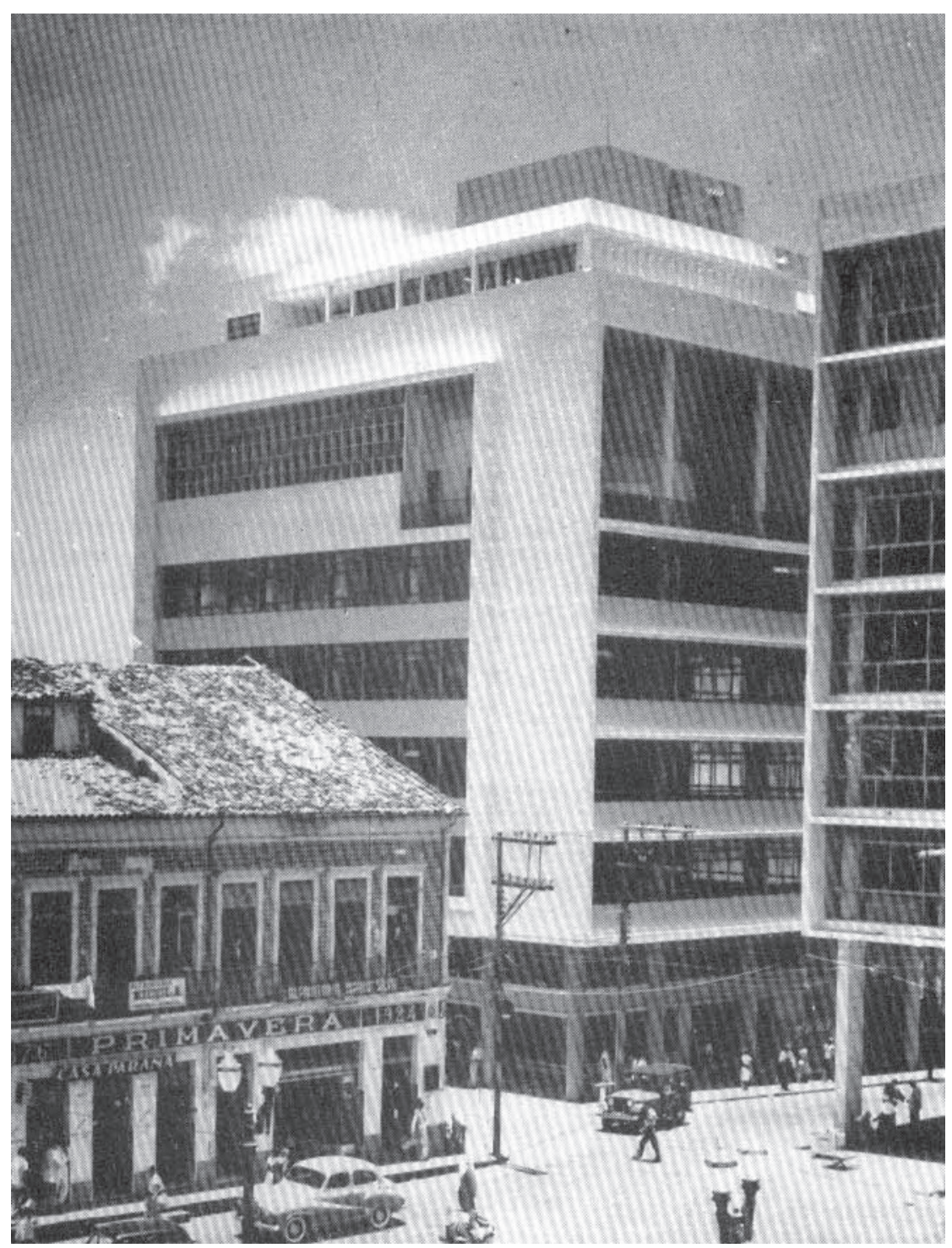




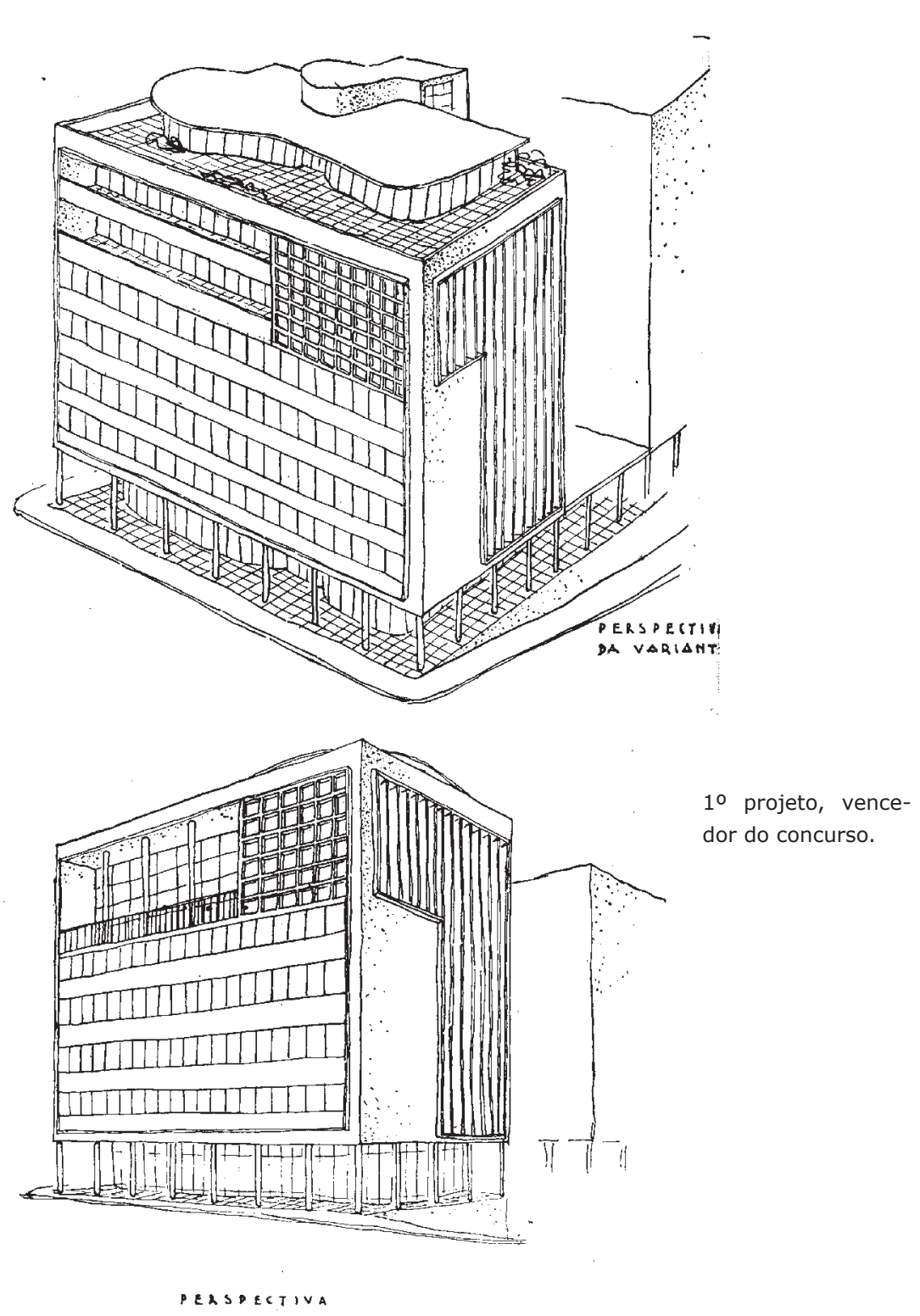

era bastante aguardada, e que isto estaria refletido na aceitação por parte do público, de uma obra de tendências tão modernas em um local de caráter hitórico, chegando a ser exaltada pela crítica como: "imponente edifício da Praça da Sé" ou ainda o "belo edifício de linhas modernas".

O edifício segue as linhas canônicas de Le Corbusier na volumetria simples e rítmo das janelas, mas apresenta elementos da arquitetura moderna brasileira como parede curva confrontando os volumes regulares, azulejos, integração exterior-interior.

O prédio da $A B I$ da Bahia apresenta alguma influência do prédio da sede da $A B I$ no Rio de Janeiro, projeto de M.M.Roberto, um dos primeiro a seguir os princípios da arquitetura moderna ressaltando o uso de quebra-sol vertical, pilotis e terraço jardim.

O artista baiano Mário Cravo Junior, realizou painel em mosaico com características locais.

\section{Área do Lote:} Área Construída:

\section{No de pavimentos: 8}

SUBSOLO: $\mathrm{Na}$ planta do subsolo são apresentados casa de bombas, depósito e depósito de lixo, sendo a entrada de serviços através da galeria no andar térreo.

PAVIMENTO TÉRREO

O

pavimento térreo possui hoje a mesma estrutura do projeto, ou seja, galeria com pilotis duas lojas com instalações sanitárias. Do lay-out origina apenas a portaria foi deslocada para o lado esquerdo junto ao pilar. Os dois elevadores e a escada imponente continuam os mesmos e servem a todos os andares. Onde seriam colocados tubos, hoje encontrase uma meia parede curva em blocos de vidro ocultando parte da escada, o que vai de encontro a proposta inicial de ser uma escada monumental e aparente.

SEGUNDO AO QUARTO PAVIMENTOS: Planta livre com a presença de quatro pilares apenas, com núcleo central formado pelo hall de elevadores, 
escada e sanitários.

QUINTO PAVIMENTO: O quinto pavimento previa estrutura para 0 atendimento médico dos associados. Hoje a planta encontra-se modificada pela colocação de divisórias inclusive ocupando parte do hall.

\section{SEXTO E SÉTIMO PAVIMENTOS} No sexto andar localizava-se auditório com foyer integrado ao hall, chapelaria, dependências sanitárias; além de terraço com pé direito duplo de traçado curvo que mais tarde seria decorado com um painel mosaico de pastilhas coloridas de autoria do artista plástico Mario Cravo Junior.

O sexto e sétimo pavimentos tem estruturas diferentes dos demais, pois tanto o auditório como o terraço tem pé direito duplo.

OITAVO PAVIMENTO: Era proposto um restaurante com cozinha, vestiários adjacentes e bar. Podia contar inclusive com serviços de barbearia com acesso pelo hall de elevadores bem como as dependências sanitárias. Possuía ainda varanda e amplo terraço descoberto com parte coberta com pérgola. Com a transferência do auditório para este andar, parte da estrutura foi modificada, mantendo apenas varanda e terraço.

TRATAMENTO DE FACHADAS: $O$ edifício possui estrutura em concreto armado com pilotis. Os elementos vazados, cobogós de concreto estão presentes na fachada e internamente em louça, no hall de entrada.

Na época da construção foram removidas as grades de ferro deo 60 e 70 pavimentos que constam do projeto, sendo substituídas por elementos vazados. A fachada da rua José Gonçalves sofreu mudanças significativas em relação ao projeto inicial pois não foram colocados os brises do $2^{\circ}$ ao $5^{\circ}$ andar.

Muitas da modificações que descaracterizaram alguns aspectos do projeto original do edifício são provavelmente decorrência da longa duração da obra.

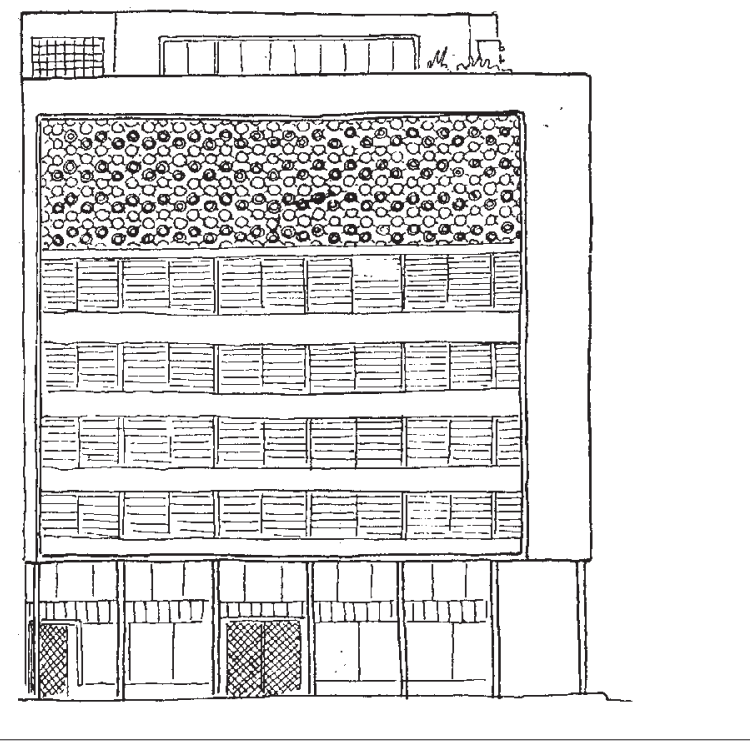

Fachadas do $2^{\circ}$ projeto.

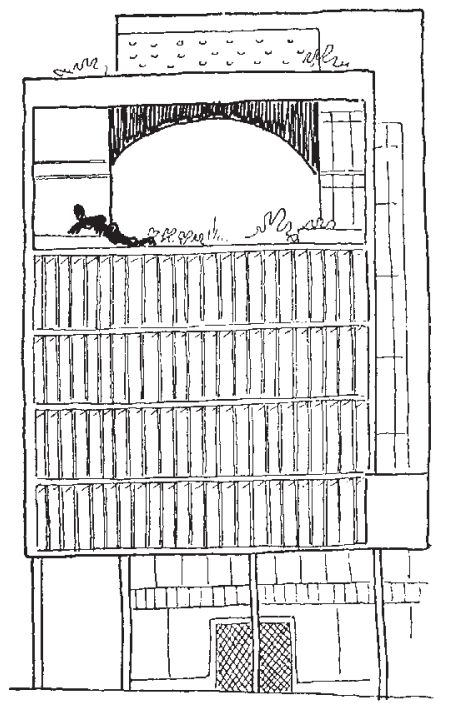



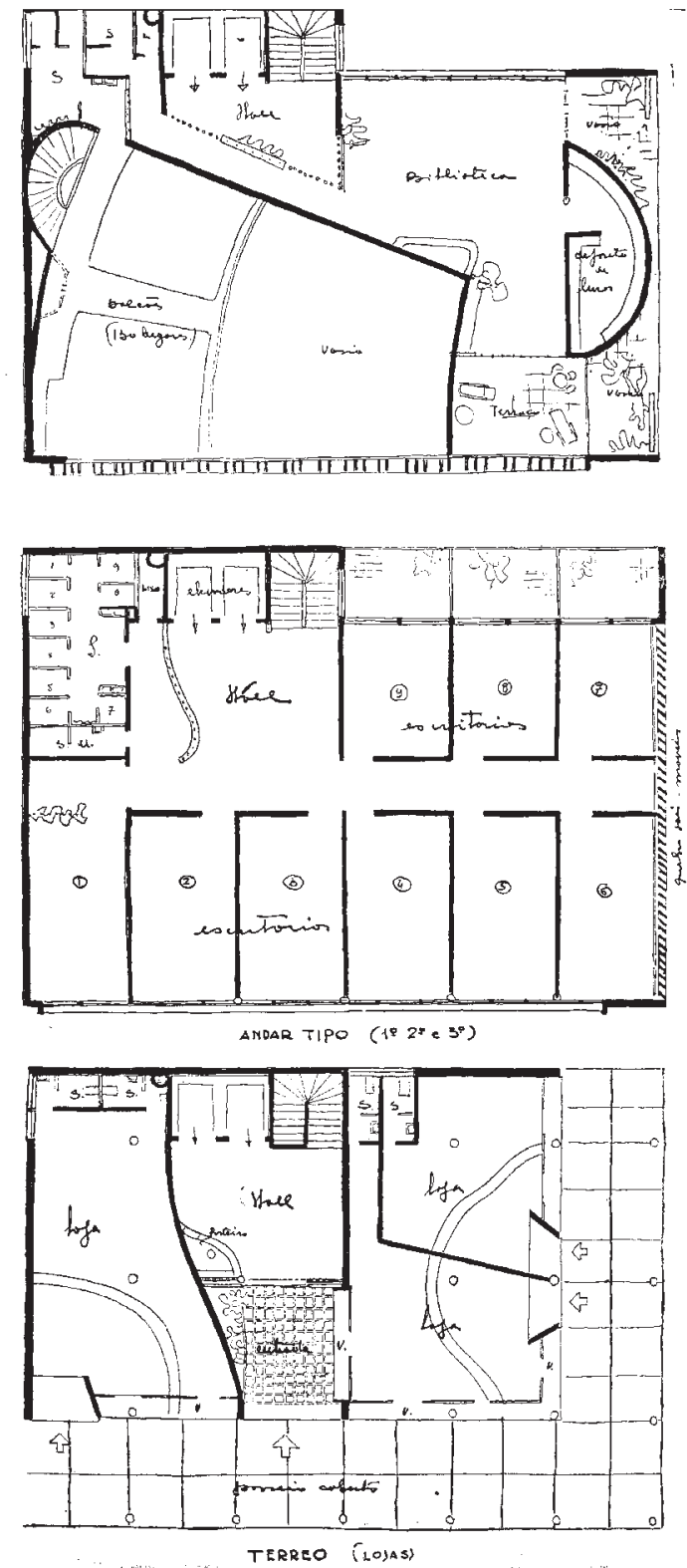

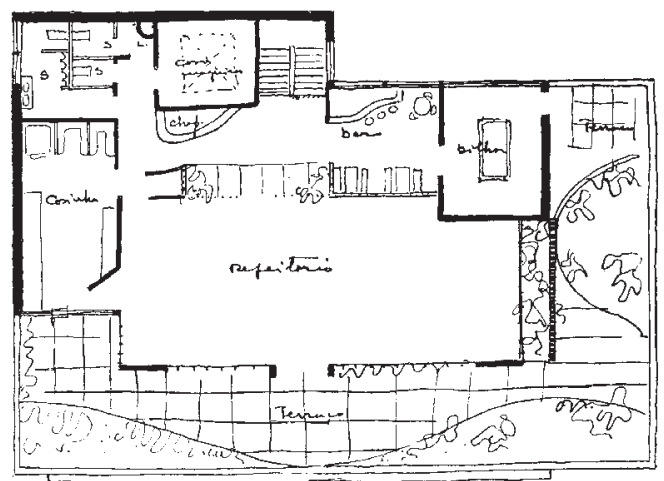

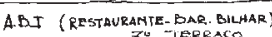

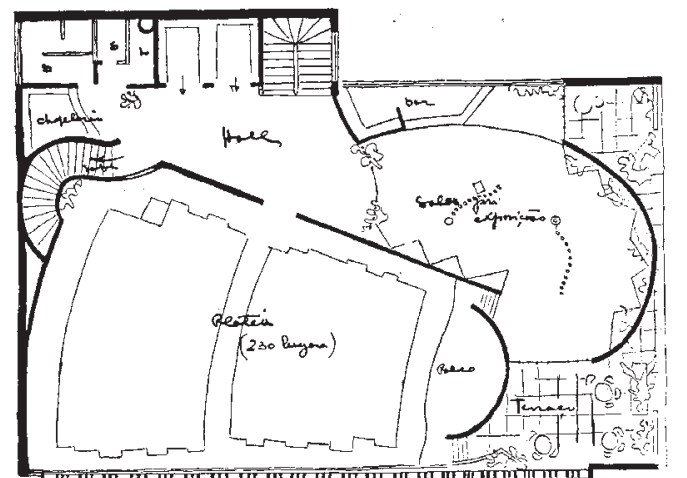

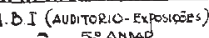

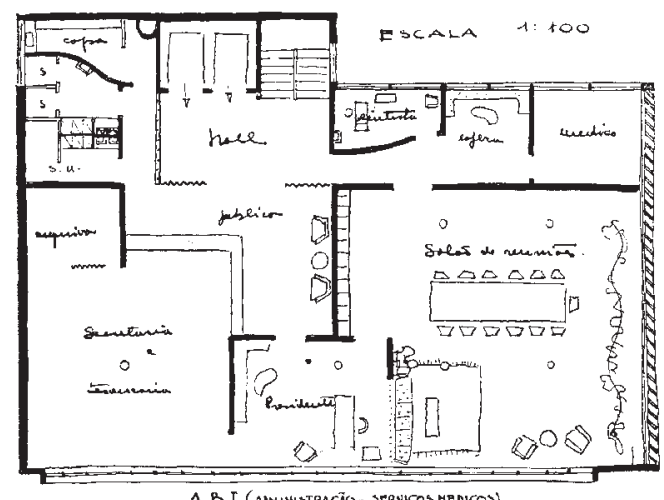

ESTADO ATUAL DO CONJUNTO: Atualmente o edifício é ocupado pela empresa Correios e Telégrafos em uma de suas lojas e a outra pela Secretaria de Transportes da Prefeitura. O primeiro andar corresponde às sobrelojas, sendo que o hall de entrada tem pé direito duplo. A ABI ocupa todo o segundo pavimento mantendo auditório no oitavo andar. Os demais pisos estão alugados para Secretaria de Transportes da Prefeitura, com uma cantina no sexto andar.

O edifício não passou por reformas significativas na estrutura e elementos decorativos no decorrer dos anos desde sua inauguração e podese dizer que se encontra em bom estado de conservação. Em 1966 o prédio sofreu reformas para solucionar problemas de infiltrações. As esquadrias de ferro foram substituídas por alumínio. A pintura e pastilhas externas necessitam reparos.

Projeto da sede para o novo terreno. 
Imagens de 2004.
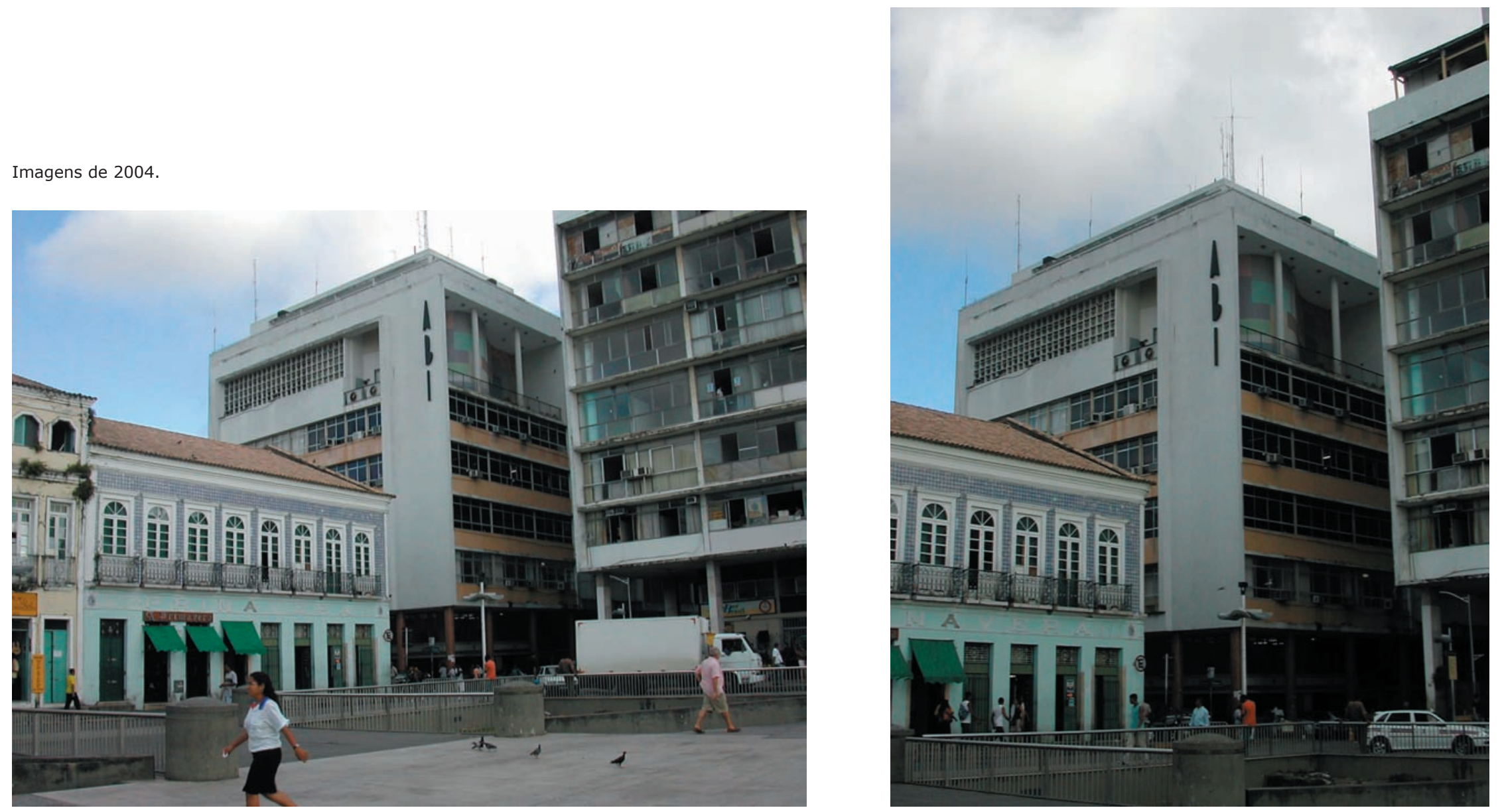


\section{Ed. Largo Ana Rosa} 1951

Publicações:

Acrópole 158, p.58.

1951.

O Jardim Ana Rosa foi construído em terreno com mais de dois alqueires que abrigava o Instituto $D^{a}$ Ana Rosa, em Vila Mariana.

Em junho de 1951, a revista Acrópole ${ }^{1}$ dedica capa e artigo a este empreendimento do Banco Hipotecário Lar Brasileiro. Outras duas áreas urbanizadas pelo banco ${ }^{2}$ também foram mencionadas.

O programa de base, de acordo com a revista, previa a construção de "558 metros de galeria de águas pluviais, de 1040 metros de rêde de esgotos, e 971,80 metros para o prolongamento da de água potável, prevê também a pavimentação de 9200 metros quadrados a asfalto e a paralelepípedos. "3

Foram traçadas ruas e uma avenida (Lar Brasileiro) que ligaria Vila Mariana à Aclimação, e prevista para toda a gleba a construção de "300 apartamentos residenciais e lojas, nas proximidades do Largo Ana Rosa, de 55 residencias unifamiliares na Av. Lar Brasileiro e 80 casas geminadas em grupos de 3, 5 e 6 , prédios nas demais vias."

Para os edifícios eram previstos inicialmente seis blocos de uso misto, com projeto de Abelardo de Souza

Em 1953 Plinio Croce e Roberto Aflalo, através de concurso ${ }^{5}$, projetarão uma unidade de uso exclusivo para habitação e no mesmo ano Eduardo Kneese de Mello projetará um conjunto com seis edifícios, ocupando uma das quadras residenciais (apenas dois serão realizados). Outros três conjuntos de edifícios serão construídos também nas áreas inicialmente previstas para residências unifamiliares. ${ }^{6}$

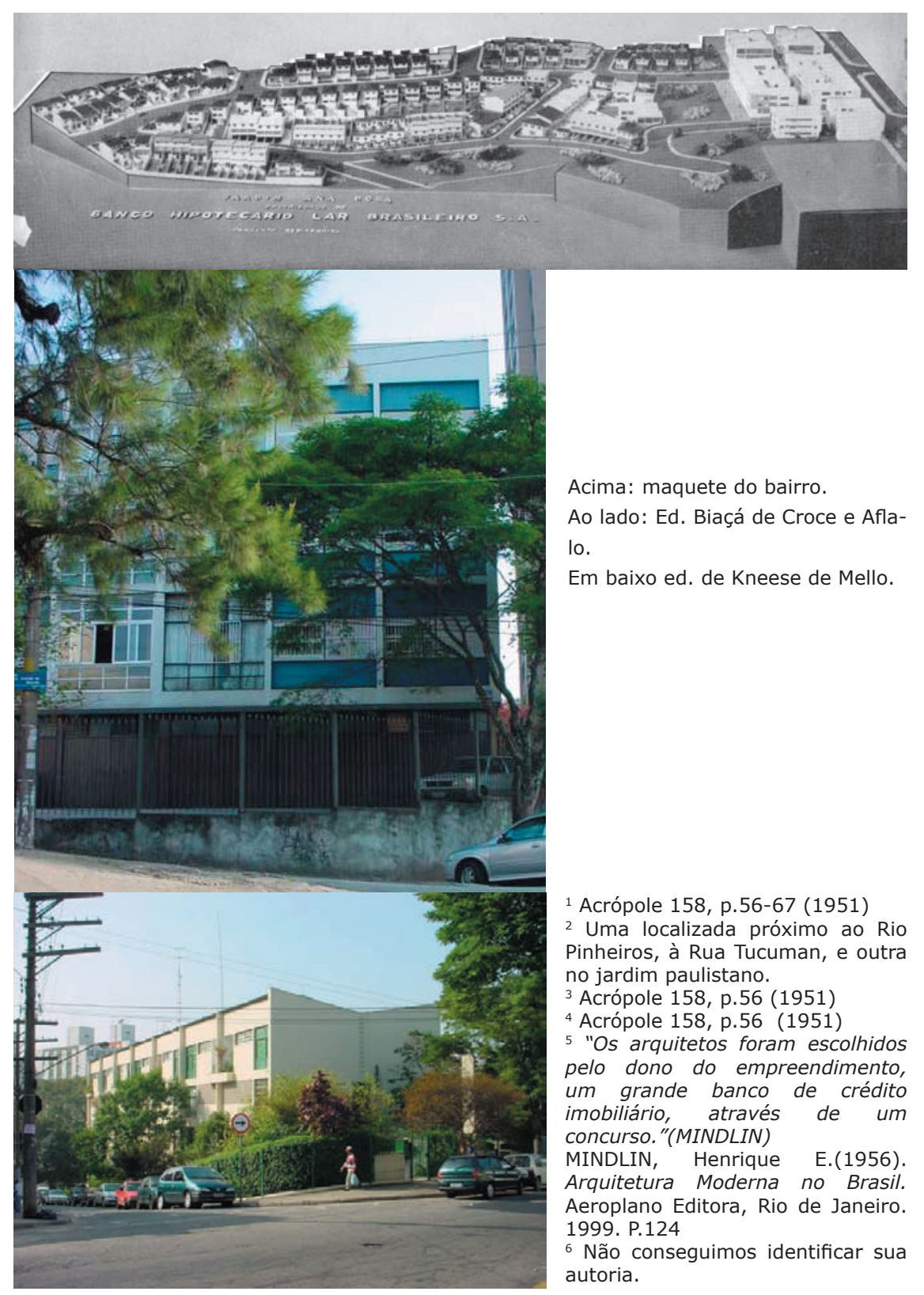




\section{DADOS DO PROJETO}

\section{Incorporação:}

Hipotecário Lar Brasileiro

Local: Largo Ana Rosa

Banco

DESCRIÇÃO DO PROJETO:

São oito blocos, com térreo e

dois pavimentos, distribuidos em três quadras voltadas para

- largo Ana Rosa. Edifícios compactos e sem recuo, ocupando grande porção do terreno.

\section{Área do Lote:}

\section{Área Construída:}

No de pavimentos: 2

PAVIMENTO TÉRREO: Foram previstas lojas para térreo, por serem as edificações próximas zona de grande movimentação. Com 40 lojas direcionadas para rua formaram-se no interior do edifício pátios internos com jardins e play-ground.

PAVIMENTO

TIPO

Nos pavimentos, cinco apartamentos por laje, com plantas diferentes. São no total cerca de 80 apartamentos. 0 programa para classe média contemplava: sala, dois dormitórios, um banho, cozinha e dependências de empregada, com áreas de serviço. $O$ setor de serviço fica voltado para o pátio interno

A circulação vertical é feita por escadas que servem grupos de três ou quatro apartamentos.

TRATAMENTO DE FACHADAS: O prédio é revestido em pastilhas vitrificadas tons de cinza, rosa e amarelo. As áquas do telhado foram usadas como elemento da fachada. Janelas em madeira com venezianas em cima foram dispostas alternadamente na fachada ritmando a composição.

ESTADO ATUAL DO CONJUNTO: O conjunto não se encontra bem conservado, com exceção do bloco voltado para Rua Dr. José de Queiroz Aranha.

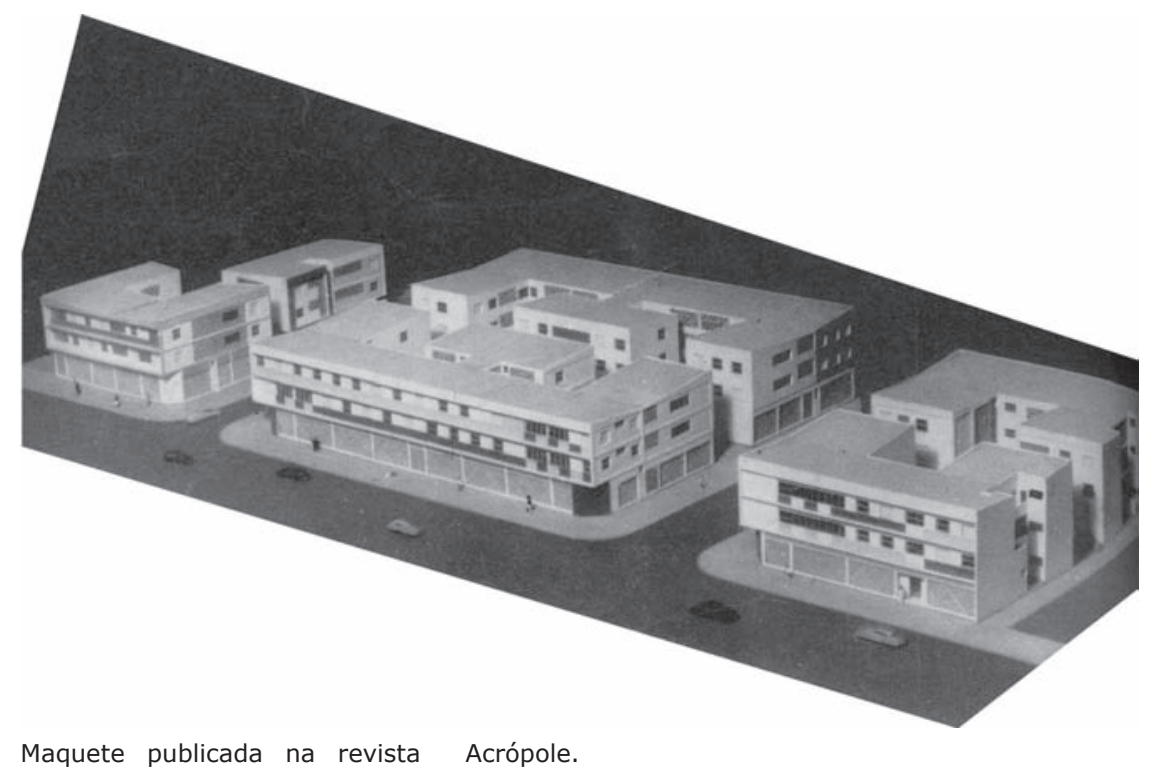

1951.

Imagens de 2002

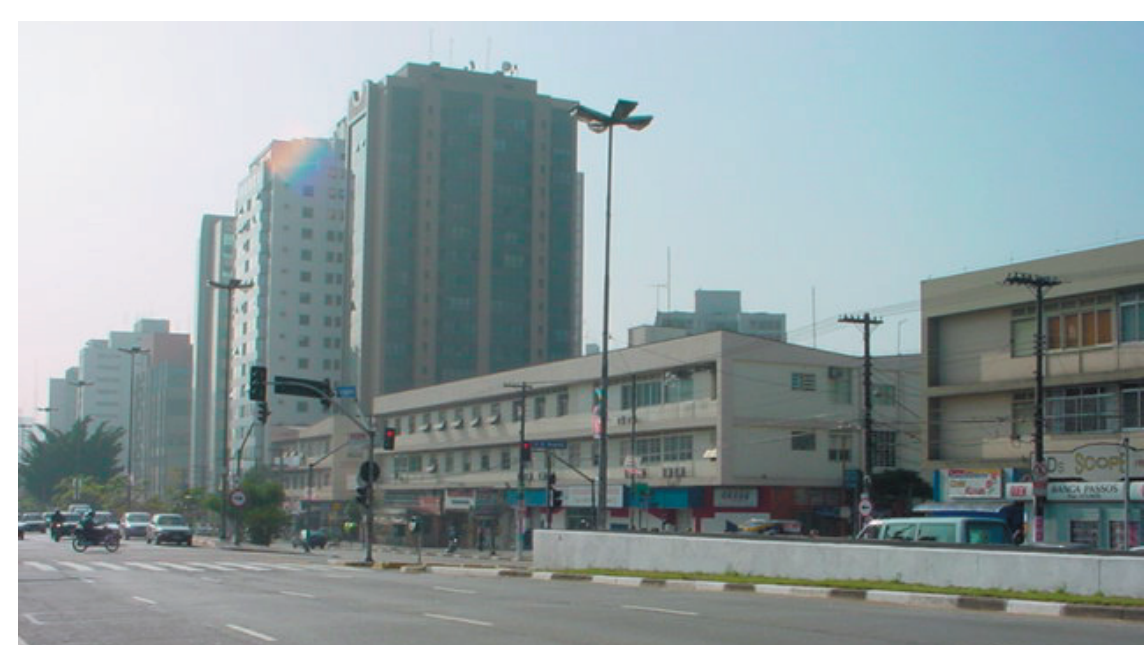




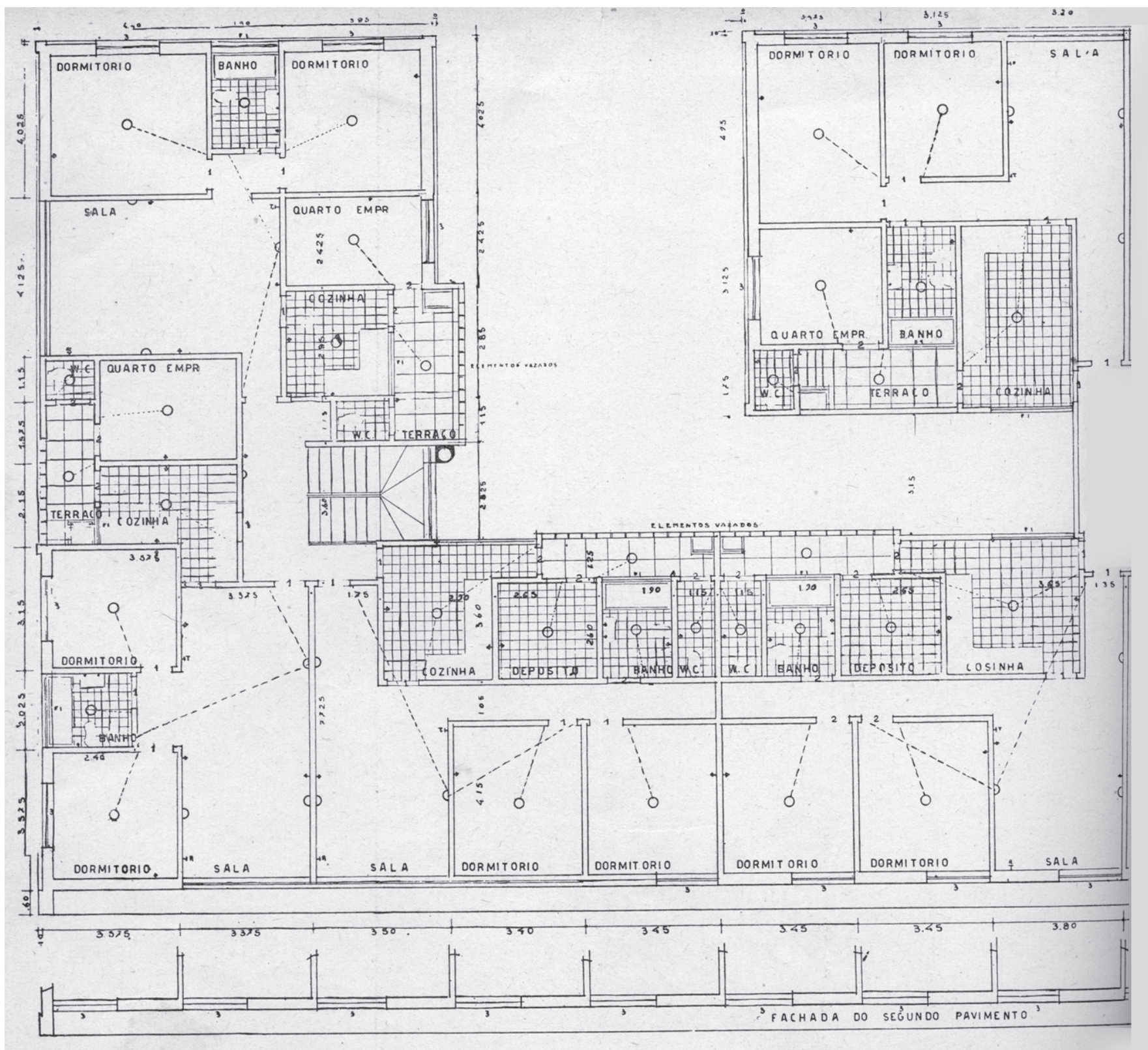



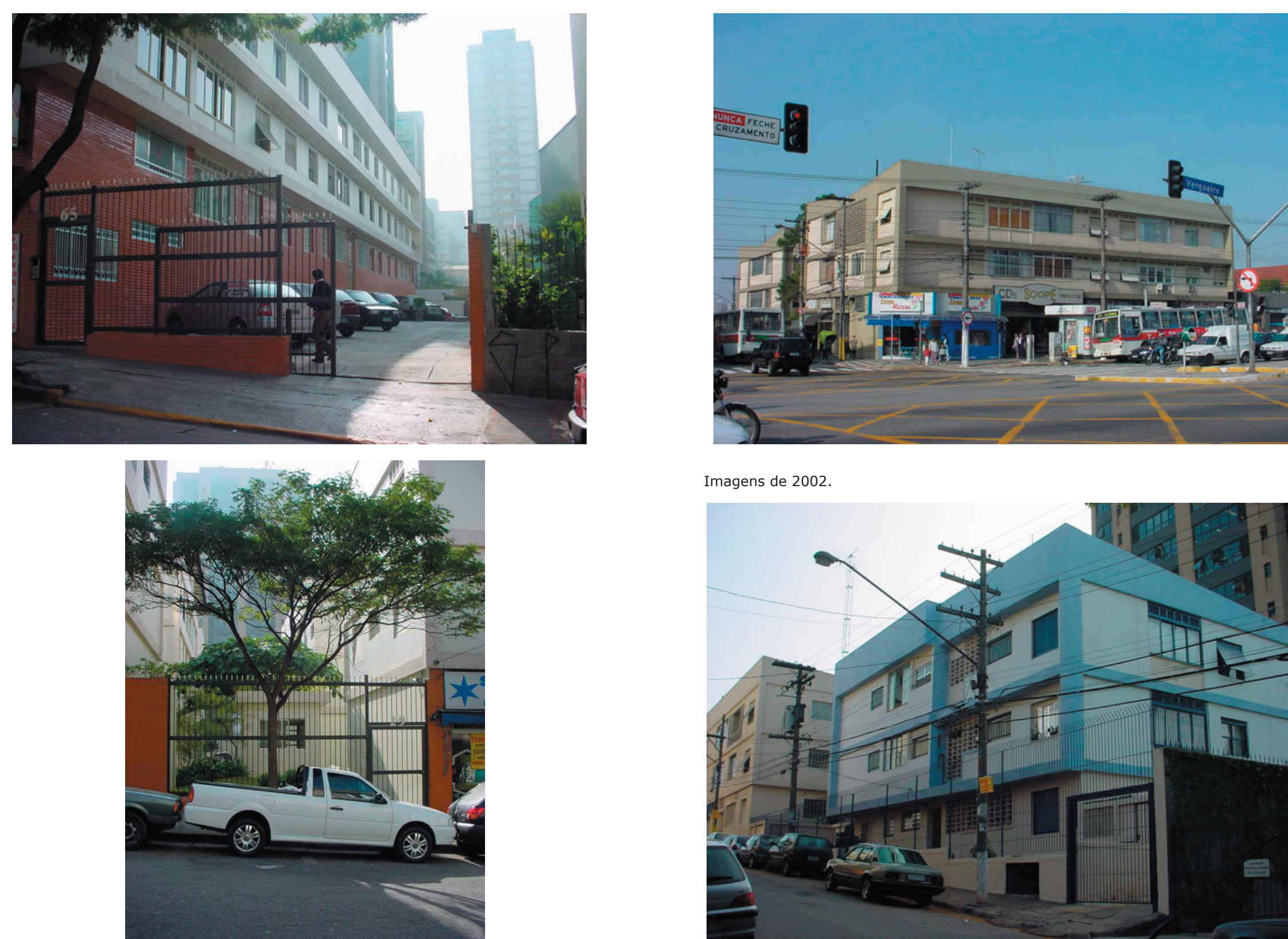
Dois Edifícios em Santos

\section{2}

Publicações:

Acrópole 184, p.172.

1953.

Habitat 39, p.10.

1957.

\section{DADOS DO PROJETO:}

Local: local da antiga Casa de Misericórdia e a cavaleiro da Praça dos Andradas em Santos

\section{DESCRIÇÃO DO PROJETO:} Dois grandes blocos, um com 15 e outro com 20 pavimentos seriam localizados ao pé do morro, dando vista sobre a Praça dos Andradas. Um bom aproveitamento do terreno com a interligação em rampas, solucionando a exiguidade de espaço e aproveitando a declividade topográfica acentuada.

Os acessos, à meia altura do bloco frontal curvo e ao pé do segundo, seriam atingidos através de uma rampa muito bem articulada em relação ao terreno exíguo e de acentuada declividade.

o movimento

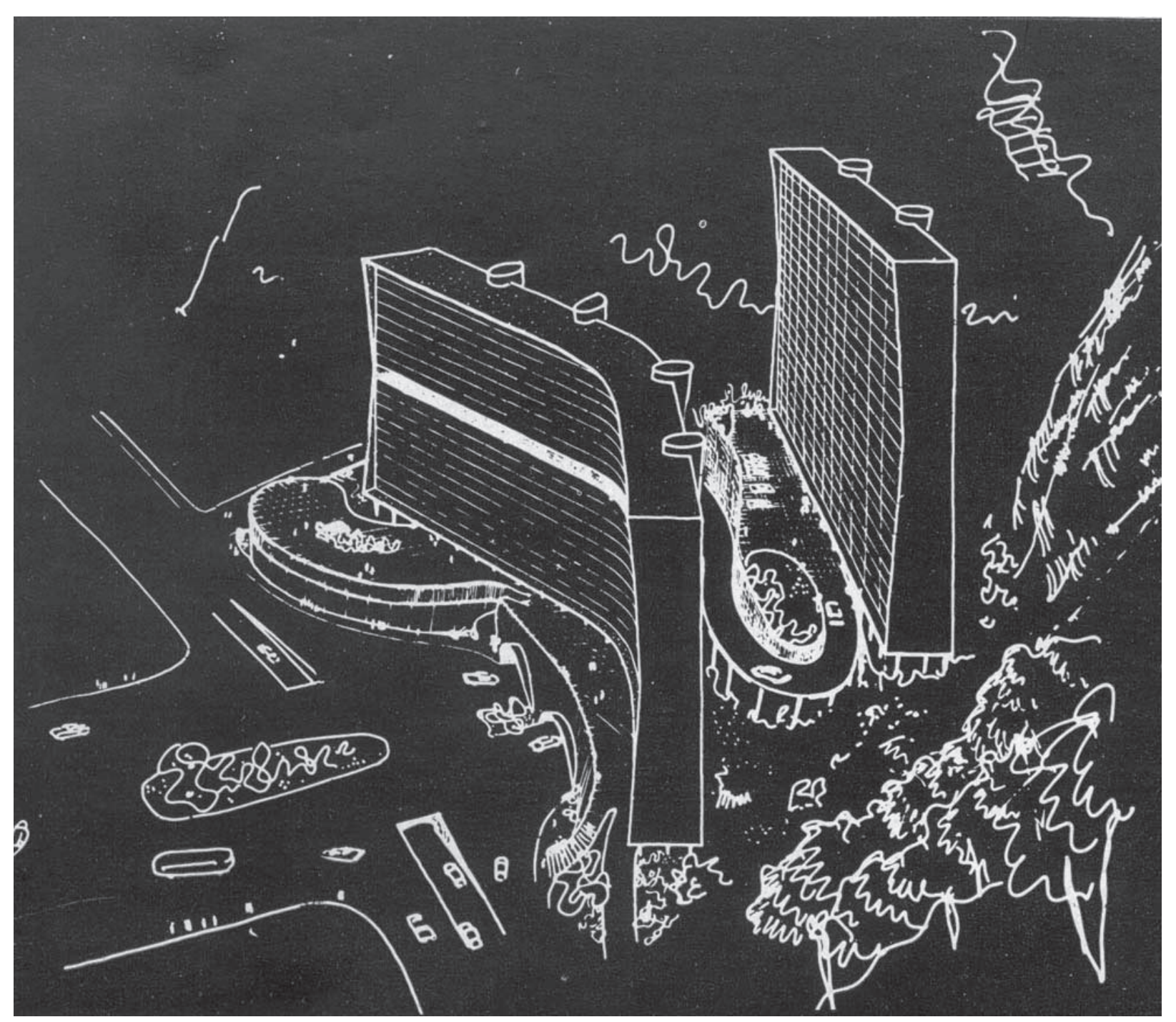


curvo dialogando com a encosta fazendo amplo uso das possibilidades do concreto lembram as pesquisas cariocas para conjuntos habitacionais.

\section{No de pavimentos: 15 e 18}

\section{PAVIMENTO}

TIPO:

Os apartamentos previstos eram tipo duplex com área social e cozinha no primeiro piso e 3 dormitórios e um banheiro no nível superior. Era comum o uso de dois pisos neste tipo de habitação para o período, sendo inclusive recomendadas por Sérgio Porto para os projetos dos IAPs.

1 "Entre os tipos de apartamentos, adotamoso do sistema 'duplex'pelas reais vantagens que apresenta (...). Oferece uma economia de $15 \%$ de espaço e $20 \%$ nas despesas com corredores, móveis, luminação, etc. A grande vantagem, no entretanto, é a decorrente da instalação em dois pisos, que traz a real separação da parte de uso diário da outra, havendo assim mais tranqüilidade e intimidade (PORTO 1938:43) in FIGUEROA p.109.

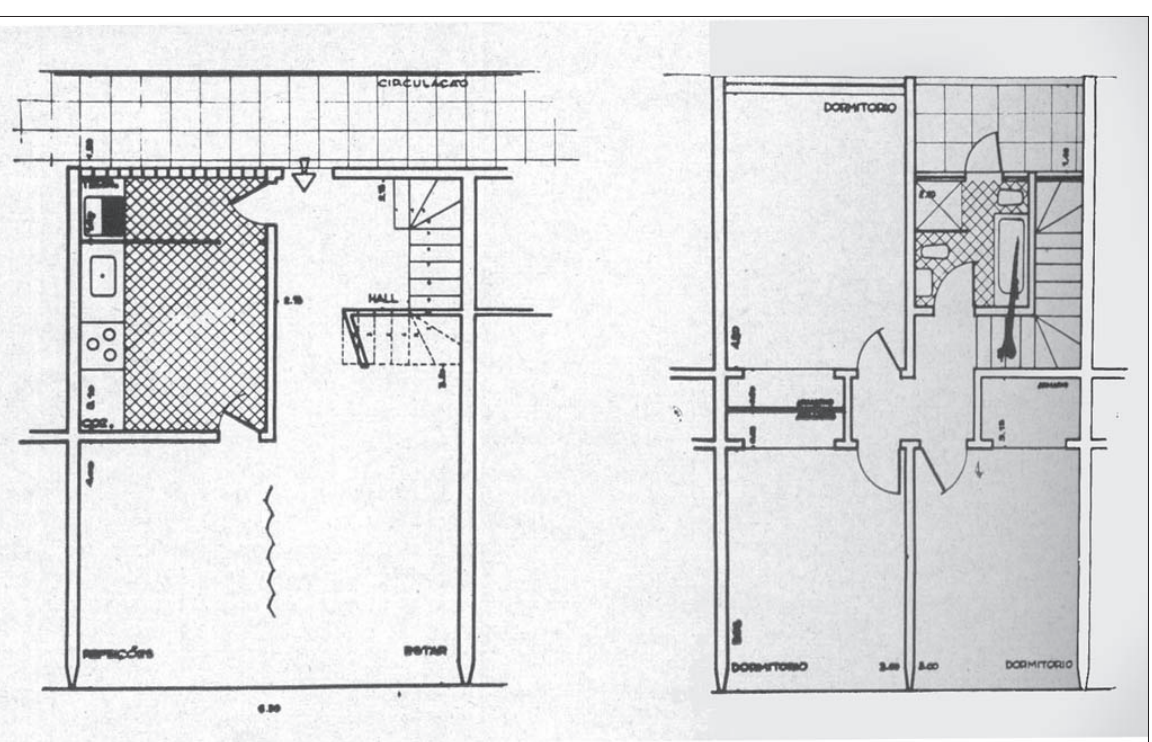

Plantas apartamento duplex
Implantação

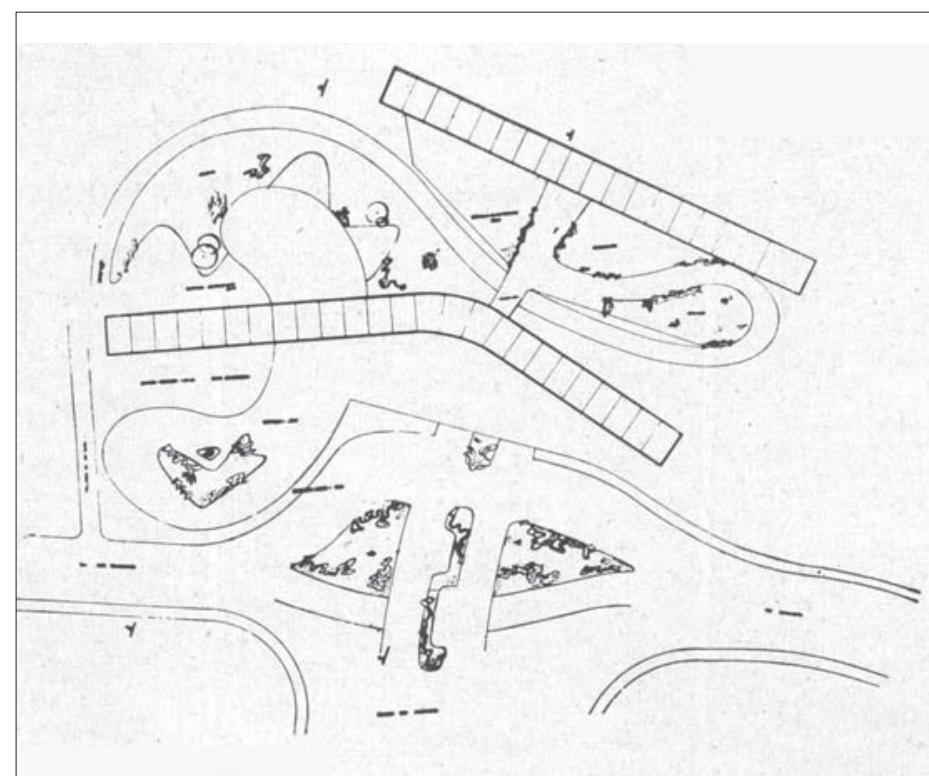

Corte

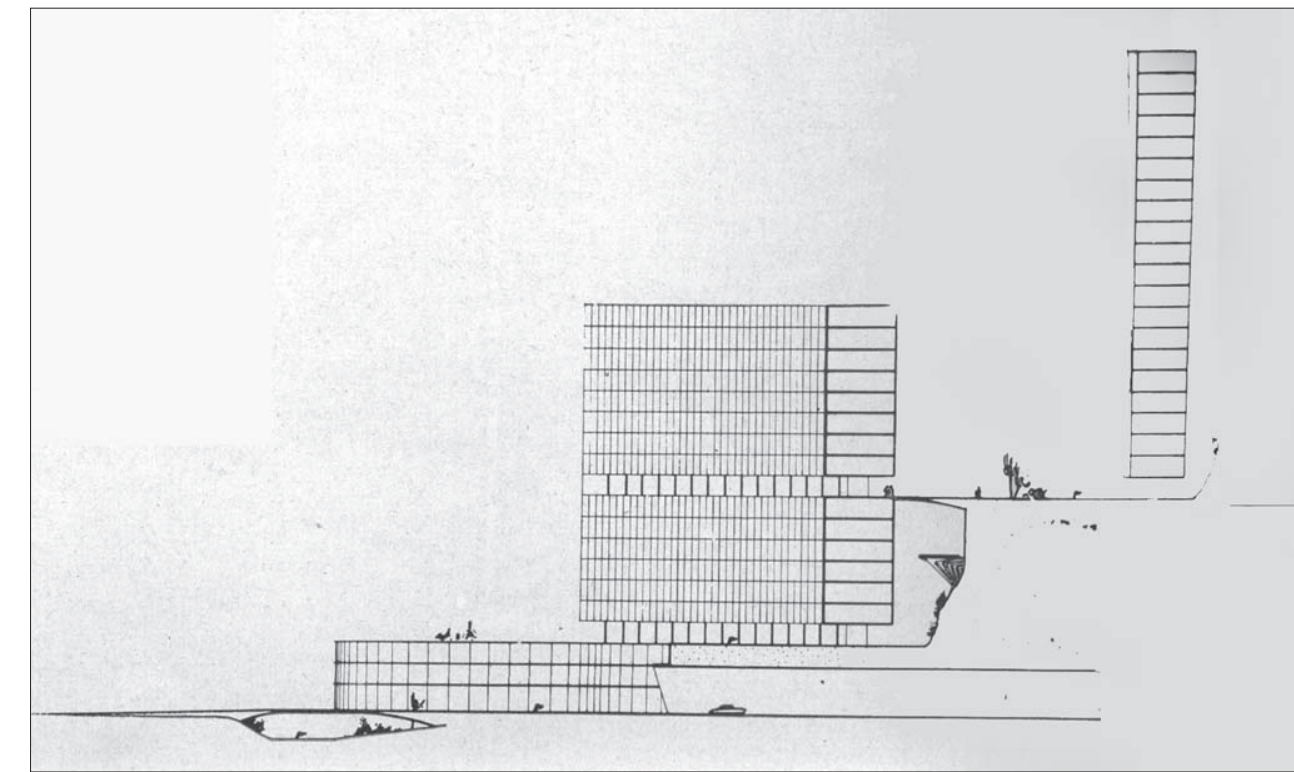




\section{Plano Diretor para Conj. Residencial de Perdizes}

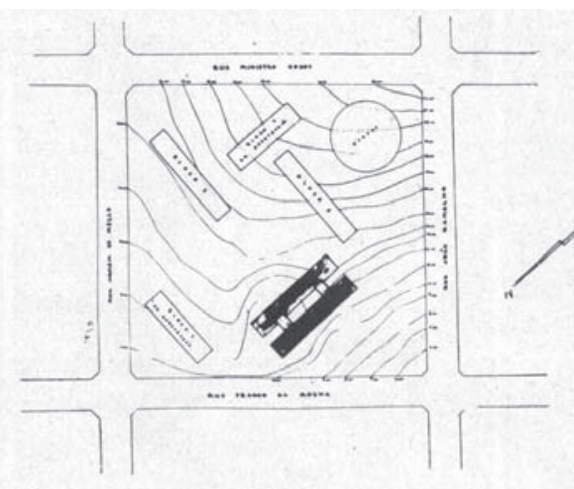

Situação

1 XAVIER, Alberto/LEMOS, Carlos A.C./ CORONA, Eduardo.(1983) Arquitetura moderna paulistana. Editora Pini, São Paulo. $1^{\text {a }}$ edição, 1983

2 FERRAZ, Geraldo, Novos Valores da Arquitetura Brasileira: Abelardo Riedy de Souza,(1957) revista Habitat, no 39, p.7 3 Os blocos eram mais longos e altos.

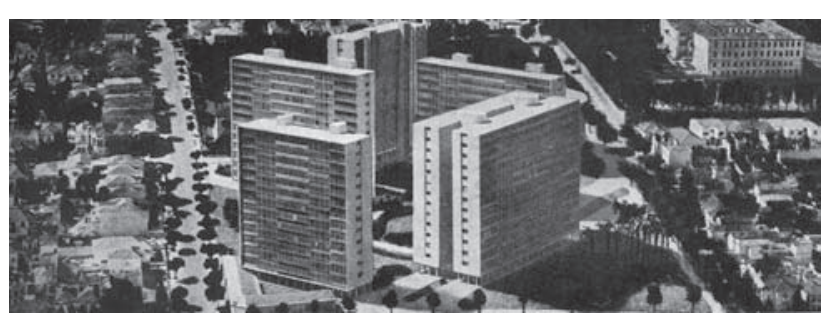

Em 1953 o BHLB lança o Plano diretor para o grande Conjunto Residencial de Perdizes, com projeto de Abelardo de Souza. Desse conjunto, apenas dois blocos foram realizados por Abelardo.

O terreno, adquirido pelo Banco Hipotecário Lar Brasileiro com cerca de 14000 m2, abrigava a Clínica Psiquiátrica Dr. Homem de Mello.

"O surto imobiliário em São Paulo, iniciado após a II Guerra, favoreceuagrande especulação. Aproveitaram-se para tais terrenos estrategicamente situados em esquinas de ruas comerciais, sempre prevendo edifícios mistos. Somente no começo da década de 50 é que se cogitou da execução de grandes conjuntos residenciais instalados em quarteirões inteiros"

Este foi o caso deste conjunto de Perdizes. O projeto de Abelardo de Souza previa quatro edifícios, lamelares, sobre pilotis, com garagem, área livre e equipamentos em comum. Este projeto foi amplamente divulgado nas revistas da época.

Geraldo Ferraz, em artigo dedicado à obra do arquiteto, destaca o projeto:

"Mas o grande projeto de um conjunto residêncial em Perdizes, cuja construção parcial já terminou, marca o melhor acontecimento na vida do arquiteto, e uma inteligente possibilidade aproveitada pelo empreendimento imobiliário trabalhando uma área ampla e reservando seus espaços a proporcionar uma elasticidade à posição dos blocos, abrindoIhes, dentro do valor do terreno, pleno uso sem o exclusivo fim do "empilhamento humano", tão condenado. Esse conjunto, verdadeiramente admirável, foi teóricamente encarado e concluida em parte na sua execução, teve-se um exemplo efetivo de que é possível conciliar os interesses da arquitetura com os de habitação e lucros imobiliários. "2

Foram construídos apenas os blocos da Rua Ministro Godoy e Franco da Rocha.

Em 1958, Plínio Croce, Roberto Aflalo e Salvador Candia a pedido dos incorporadores realizaram novo projeto para a área, acrescentando 3 edifícios lamelares. O programa se assemelhava ao primeiro, porém com maior ocupação do terreno e maior densidade ${ }^{3}$. Como solução para as áreas de estacionamento e comerciais, aproveitando o desníve existente, foi prevista uma laje que nivelava o terreno, ampliando a área comum de lazer.

Deste novo projeto um edifício foi construído à Rua Ministro Godoy, o Edifício João Ramalho. Os arquitetos receberam por esta obra o prêmio internacional da categoria habitações 
coletivas na IV bienal de $\mathrm{S}$ Paulo.

$\mathrm{Na}$ década de 60, Aflalo e Croce, desta vez associados a Giancarlo Gasperini realizarão para o banco mais dois blocos, voltados para Rua Dr. Homem de Mello, em forma de torres. ${ }^{4}$ Note-se que em nenhum momento o projeto de quadra aberta se realizou, desde o início os terrenos foram mantidos separados.

Por fim foram construídas mais três torres, desta vez com incorporação da Zarzur, que comprou o lote voltado para Rua João Ramalho. A laje idealizada por Croce e Aflalo foi realizada para uma área comercial.

Apesar das alterações do conceito inicial e de arquitetos, a quadra regular delimitada pelas ruas Ministro Godoy, João Ramalho, Franco da Rocha e Dr Homem de Mello, com suas amplas áreas verdes tornou-se um modelo de referência e vem servindo de residência a diversos arquitetos e artistas $^{5}$, tendo se tornado conhecida como "Superquadra de Perdizes", numa alusão às quadras de uso misto do plano piloto de Brasília.

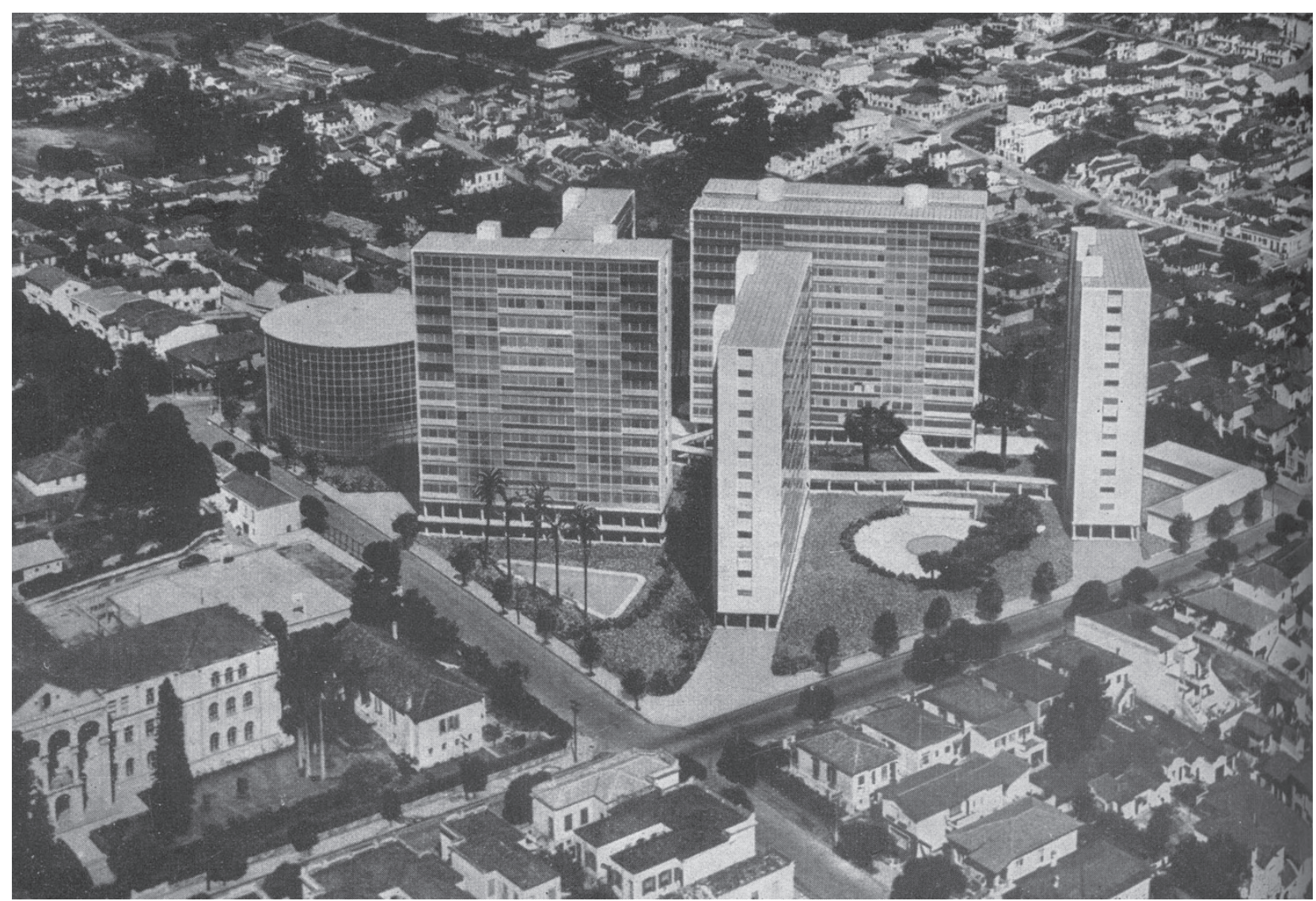

${ }^{4}$ Uma tendência que vinha crescendo, visto que nas torres havia uma entrada única e nos edifícios lamelares uma para cada bloco

5 Carlos Millan, Hélio Duarte e Tom Zé, moraram na superquadra, Décio Tozzi ainda vive lá. 


\section{Edifícios Ministro Godoy e Franco da Rocha}

\section{4}

Publicações:

Acrópole 184, p.174.

1953.

Habitat 39, p.12-3.

1957.

Acrópole 200, p.366-7.

1955.

Arq. e Engenharia 31, p.52-3.

1954.

Arq. e Decoração 4, p.

1954.

Ed. não identificada no acervo

do arquiteto

1 Ver edifícios delúcio Costa para o Parque Guinle de 1948 em: Lauro Cavalcanti, Quando o Brasil era moderno - Guia de arquitetura 1928-1960. Arquitetura Moderna no Rio de Janeiro, Rio de Janeiro, 1991, p.67

Ed. Min. Godoy, foto de 1954.
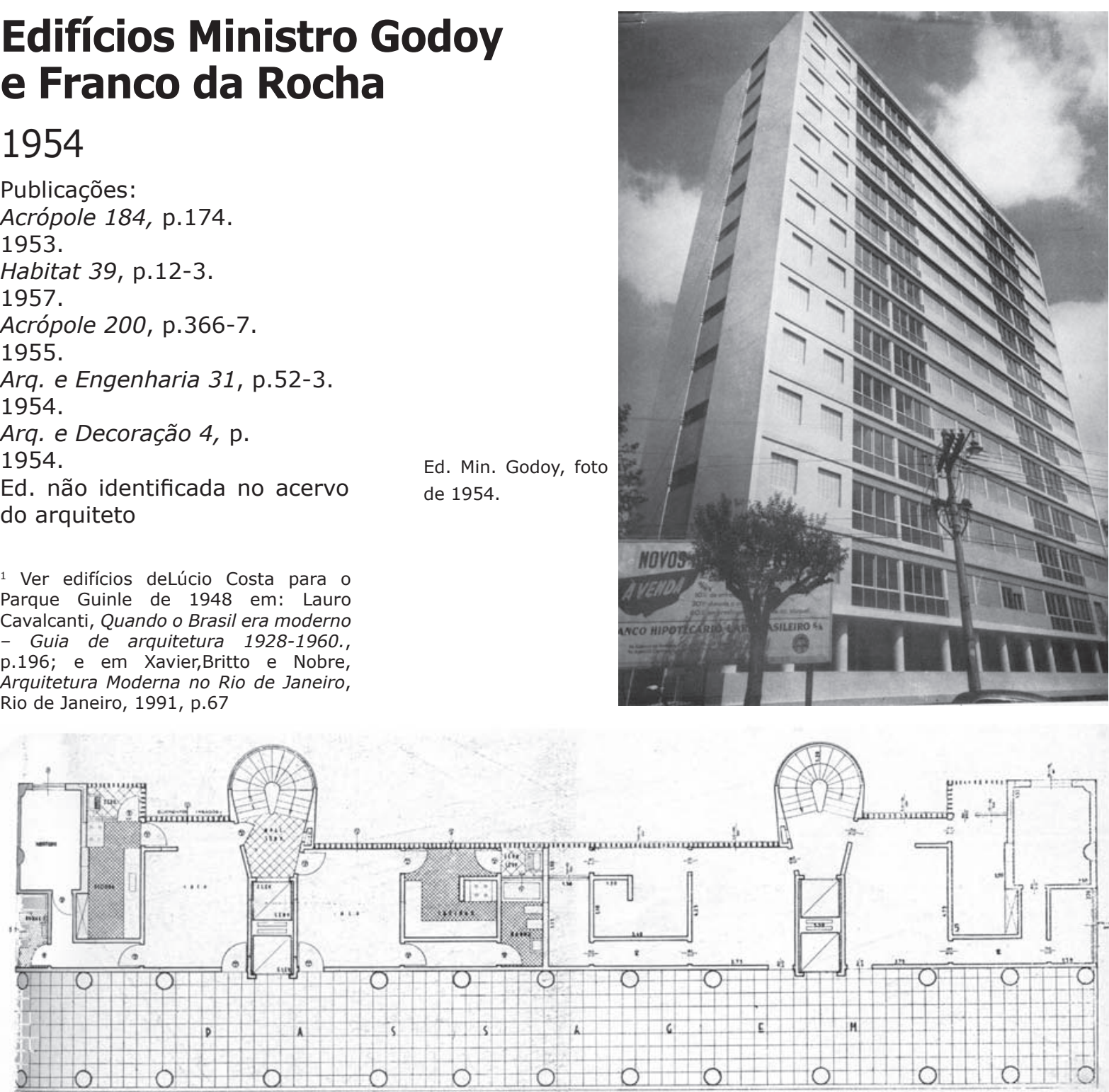

Planta térreo Ed. Min. Godoy

\section{DADOS DO PROJETO:}

Execução: Construtécnica Ltda.

Incorporação:

Banco

Hipotecário Lar Brasileiro

Entrega da Obra

Local: Rua Ministro Godoy e

Franco da Rocha, Perdizes

Exposições: Selecionado para a $2^{a}$ Exp.Internacional de Arquitetura em 1953/54.

\section{DESCRIÇÃO DO}

PROJETO:

Nos edifícios de Perdizes, Abelardo tem clara influência dos padrões urbanísticos estabelecidos pelo CIAM e pela "Carta de Atenas", porém sempre sob uma ótica do moderno carioca, utiliza-se de elementos comuns a tradição construtiva no Brasil: espaços generosos, varandas e áreas abertas e emprego de cores. Podemos ainda notar uma semelhança com os edifícios de Lúcio Costa para o Parque Guinle, quanto ao uso de cores, a distribuição de áreas dos apartamentos e escadas destacadas do bloco, revestidas em estrutura de metal e vidro. ${ }^{1}$ 
Área do Lote:

Aproximadamente $2250 \mathrm{~m} 2$ por edifício

Área Construída: Franco da Rocha : $5.887 \mathrm{~m} 2$

\section{No de pavimentos:}

Edifício Ministro Godoy - 14

pav. -56 aptos.

Edifício Franco da Rocha - 13

pav. -52 aptos.

PAVIMENTO TÉRREO No terreno comum aos edifícios, $O$ térreo livre sob pilotis, visava a integração entre os lotes.

PAVIMENTO TIPO São 4 apartamentos por andar, divididos em dois blocos espelhados, com plantas de 2 e 3 dormitórios.

TRATAMENTO DE FACHADAS: As fachadas revestidas em pastilha rosa e azul para o Ministro Godói e em Terracota para o Ed. Franco da Rocha fazem pleno uso da policromia do barroco, invocada por Lúcio Costa nos Edifícios do Parque Guinle.

TRATAMENTO PAISAGÍSTICO: Os edifícios, previstos para ocorrer em quadra aberta, foram implantados sobre pilotis, sem sub-solo e haveria um bloco de forma circular apenas para garagem, de forma que no térreo ocorressem grandes áreas ajardinadas, comuns à todos os blocos. Com a divisão dos lotes e não construção da garagem, as áreas destinadas a jardim dividem seu espaço com os veículos

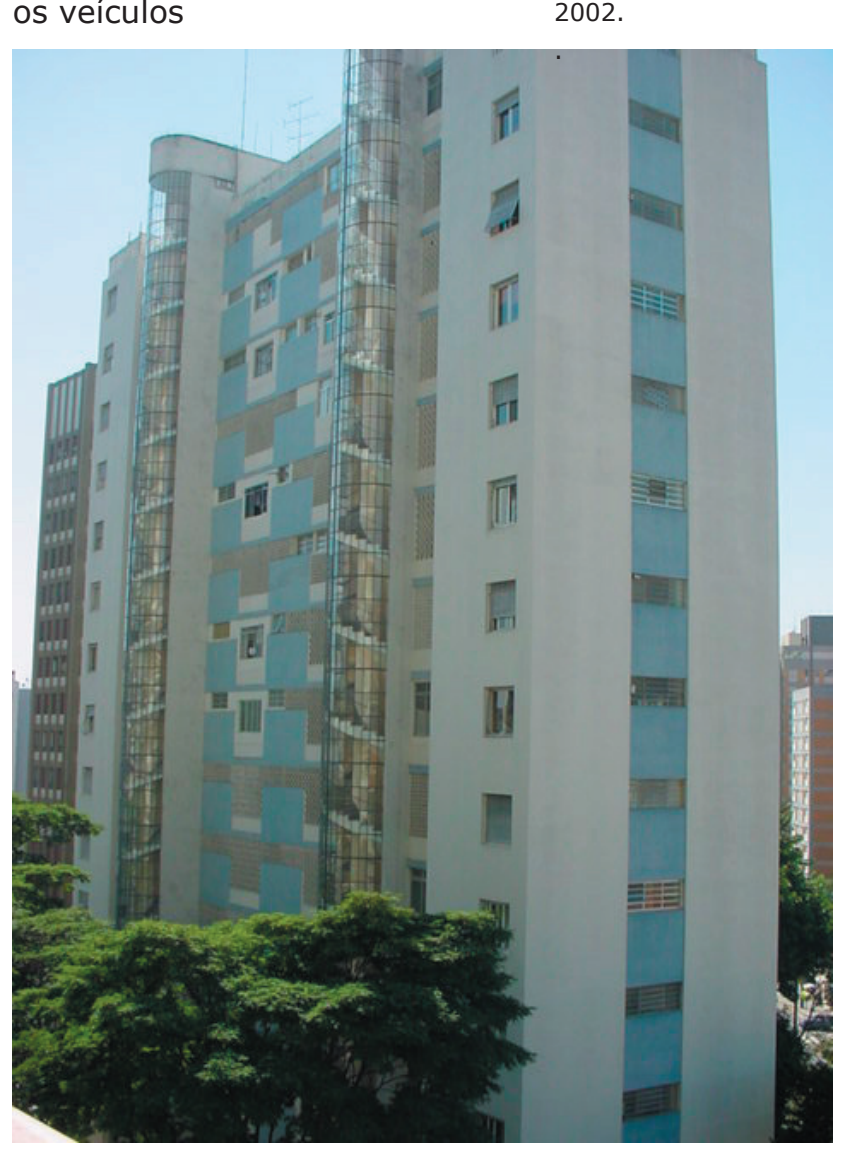

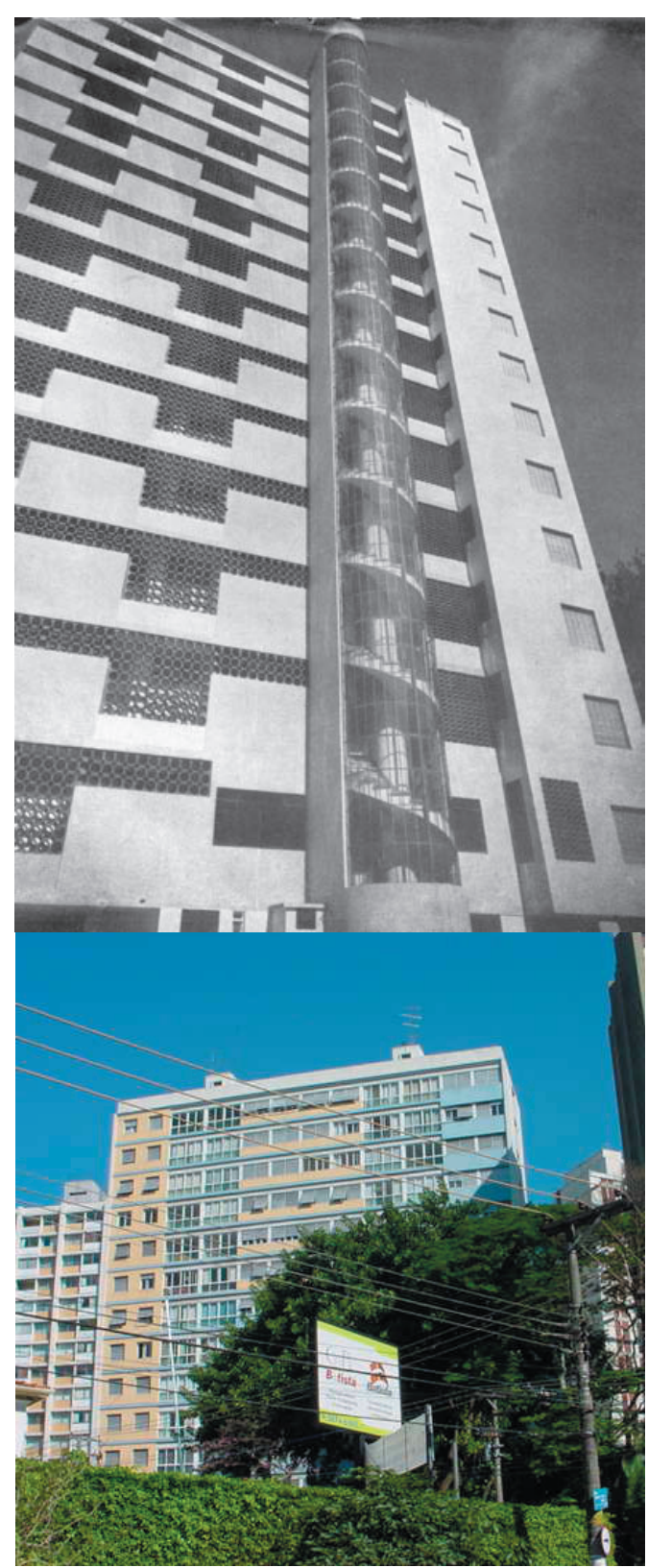


ESTADO ATUAL DO CONJUNTO

Os edifícios encontram-se em

bom estado de conservação.

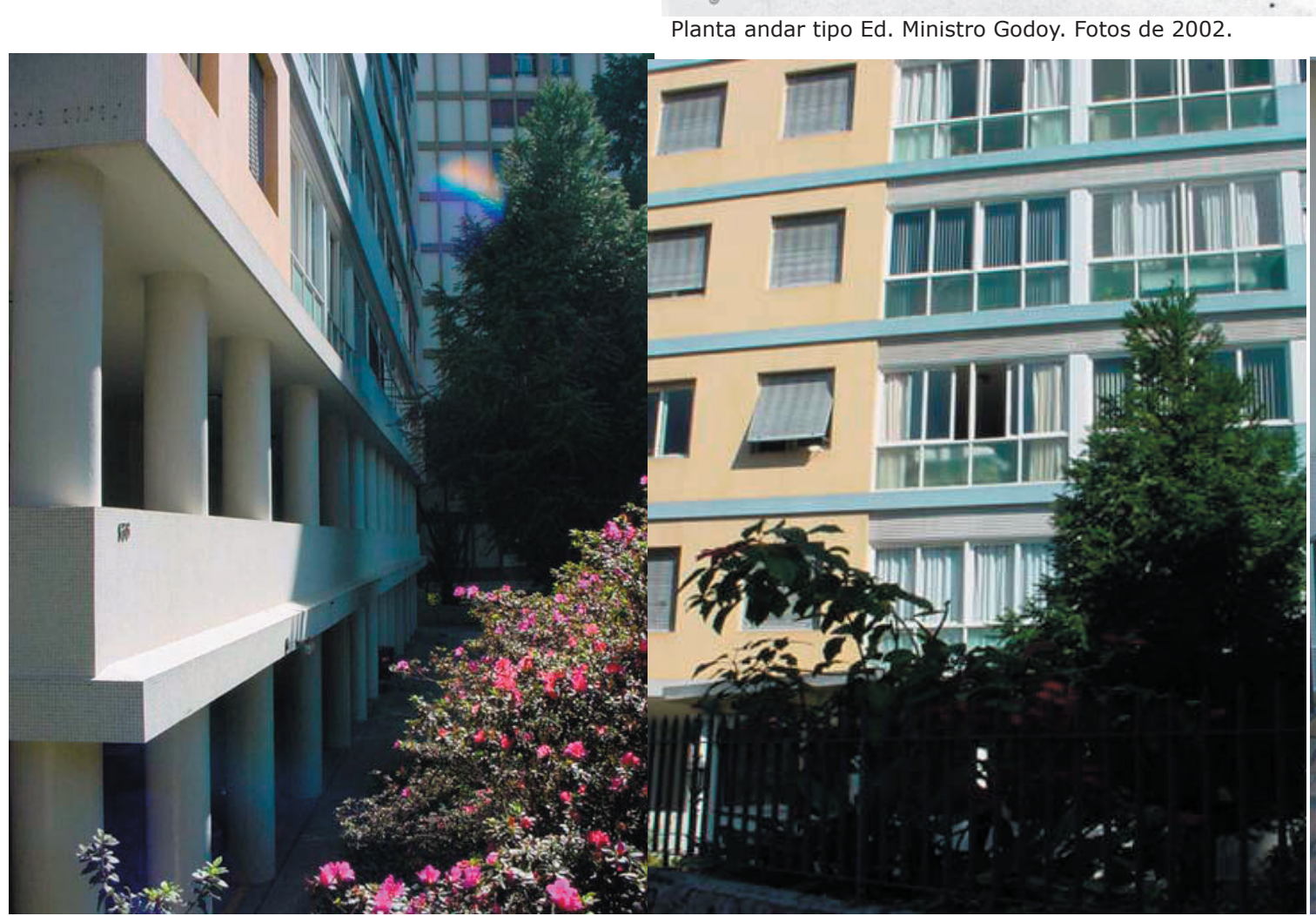

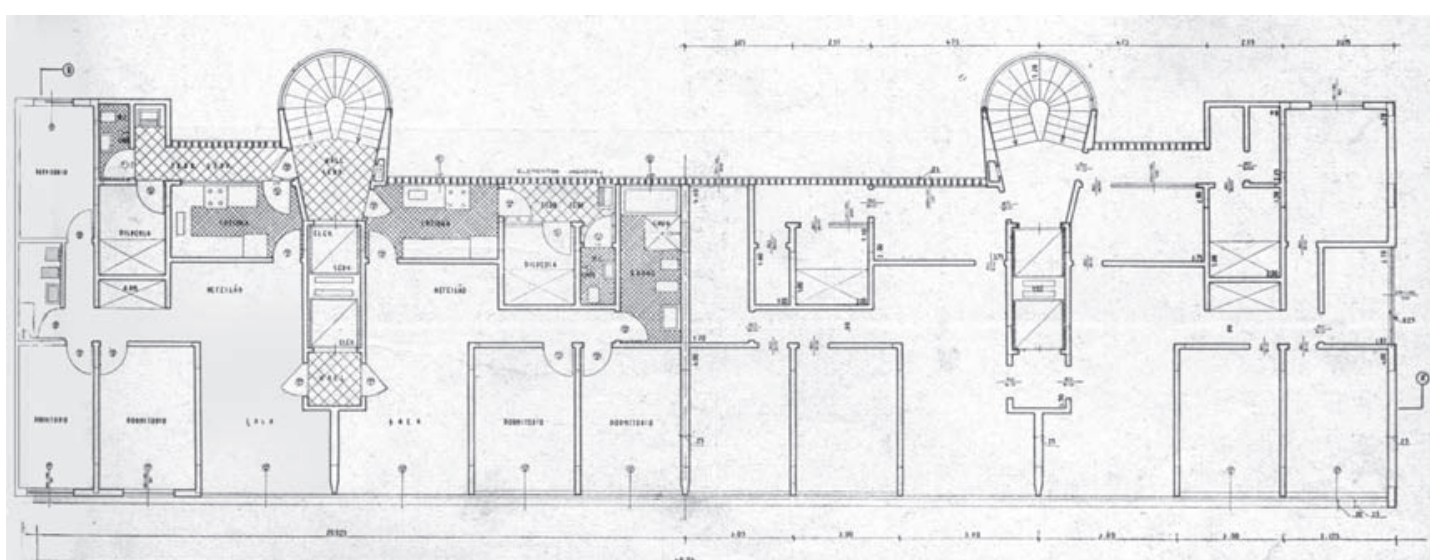

Planta andar tipo Ed. Ministro Godoy. Fotos de 2002.

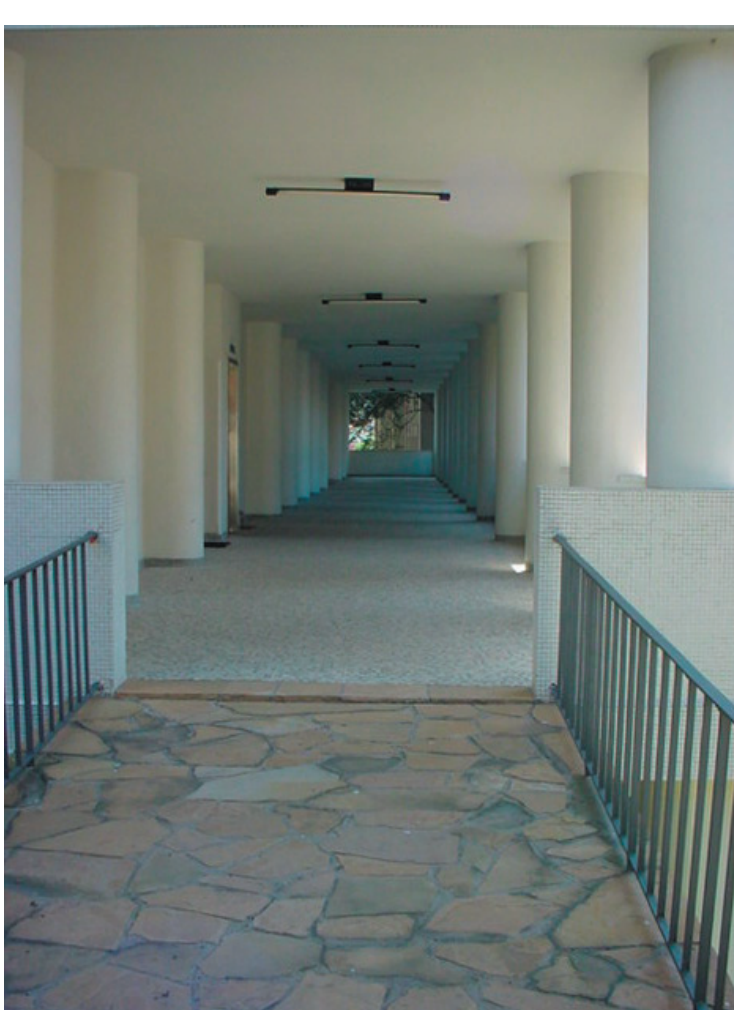



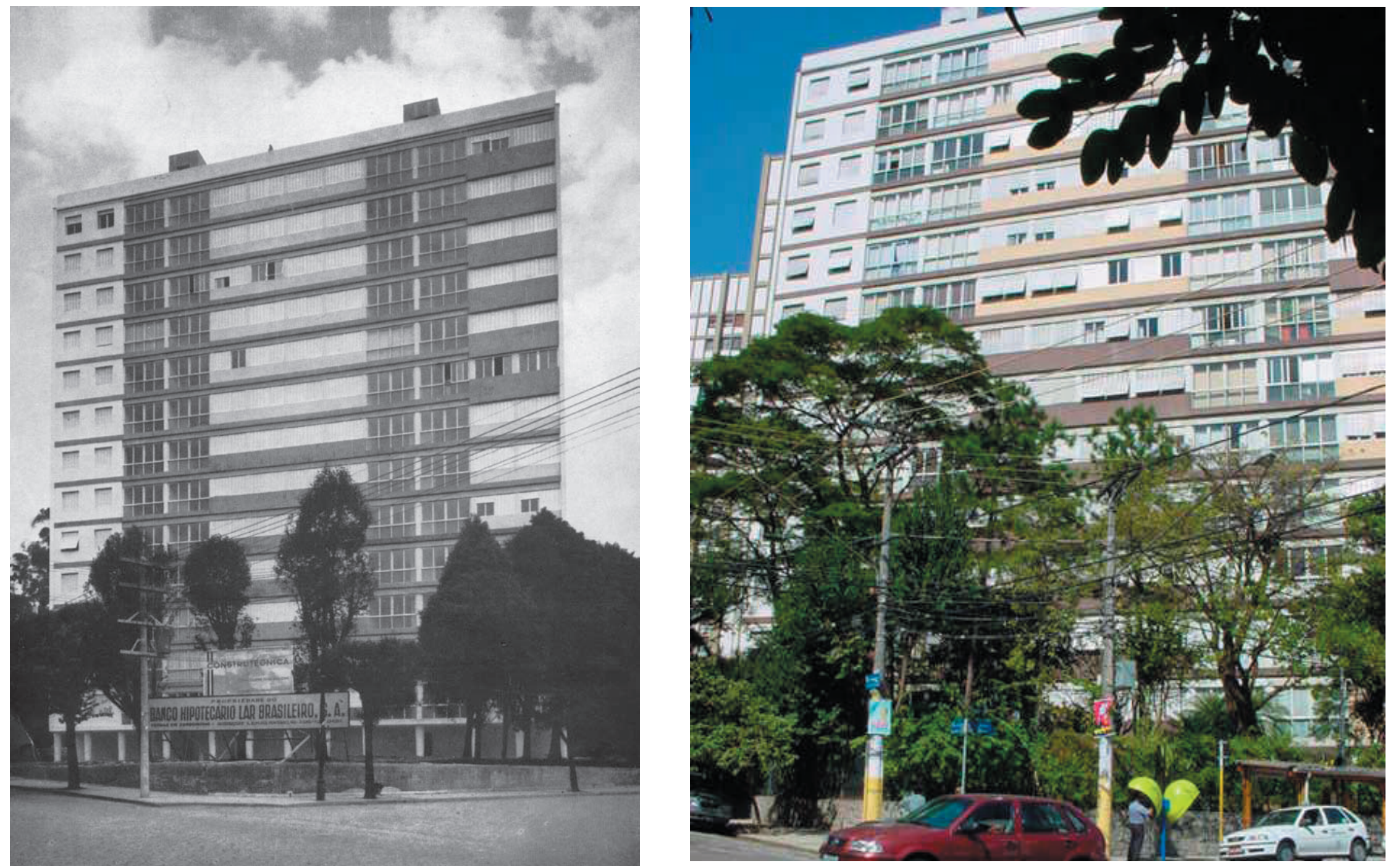


\section{Edifício Nações Unidas}

\section{4}

Publicações:

Acrópole 184, p.171.

1953.

Habitat 39, p.15-6.

1957.

Habitat 12,p.10-11.

1953.

Habitat 57, p.20-4.

1959.

Acrópole 262, p.270-2.

1960.

Arq. E dec. 1

1953.

Xavier, Lemos e Toledo, p.35

.1983.

\section{DADOS DO PROJETO:}

Projeto: 1952

Execução:Soc. De Eng. Cyro

Ribeiro Pereira Ltda

Const. São Paulo S.A.

Construtécnica Ltda.

Incorporação: CNI

Entrega da Obra:1959

Local: Av. Paulista 620-648

\section{DESCRIÇÃO DO}

PROJETO:

O Edifício Nações Unidas é um conjunto habitacional em dois blocos na Av. Paulista esquina com Brigadeiro Luís Antonio. Suas fachadas tratadas com jogo de cores em pastilhas e brise-soleil em concreto são que os incorporadores tirassem - máximo proveito da área a construir: $63.000 \mathrm{~m} 2$ de construção distribuidos em 3 blocos com 430 apartamentos, 25 lojas, garagem para 300 carros, galeria com $6 \mathrm{~m}$. de largura, playground, salão de chá etc. Apresenta como inovações elevadores em cilindros independentes, eliminação dos corredores com valorização das áreas úteis, blocos distintos reforçados pelo uso de cores contrastantes na fachada.

O projeto efetivamente possui uma arquitetura de linhas marcantes e plantas com uma boa distribuição de áreas. Uma para acessar os apartamentos baseou-se no êxito do edifício Califórnia no centro, que de acordo com Corona "levou seus incorporadores a cogitarem de programa semelhante para terreno à Avenida Paulista, então exclusivamente residêncial. Foi este escolhido com critério, pois já se antevia para o local a valorização de atividades comerciais, função tradicional da Brigadeiro, com que fazia esquina."1

O custo do terreno fez com
Maquete da 1 a versão do Nações Unidas.

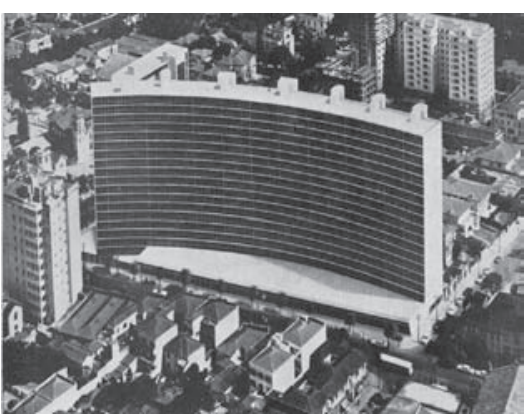

peculiaridade deste edifício, é o grande número de elevadores: o Nações Unidas para cada dois apartamentos de dois quartos, conta com dois elevadores sociais e um de serviço. Isso se justifica não somente pelo baixo custo dos elevadores na época, mas como uma forma de minimizar o caráter ainda novo, de habitação coletiva, prevalecendo "a noção paulista da intimidade, na individualização do abrigo, que requer que a casa, a moradia não seja "devassada."

Importante ressaltar o uso de materiais padronizados da indústria da construção que vem se desenvolvendo. ${ }^{3}$
LEMOS, Carlos, CORONA, Eduardo, Arquitetura Moderna Paulistana, Editor Pini, São Paulo. 1ª edição, 1983, p.35. Geraldo Ferraz, Habitat, 57. Geraldo Ferraz, Habitat, 57 p.21 "sublinhando a imponência do cimento armado, do vidro, dos elementos padronizados, das inúmeras possibilidades que se apresentam à intenção do harmonizador 
Área do Lote: $4.940 \mathrm{~m} 2$

Área Construída: $48.664 \mathrm{~m} 2$ No de pavimentos: Bloco Paulista 18

Bloco Brigadeiro 21

SUBSOLO: Dois subsolos com garagem para 300 carros

\section{PAVIMENTO TÉRREO:}

Galeria com $6 \mathrm{~m}$. de largura

e 25 lojas com segundo

piso para depósito, sendo 9

com acesso apenas pela Av.

Brigadeiro e 4 com frente para galeria e para rua.

A entrada dos apartamentos com os elevadores dando diretamente para galeria gera um problema de segurança pequenas cabines de vidro cercam os elevadores, numa tentativa de minimizar o fato. Diversamente, seu contemporâneo o Conjunto Nacional ${ }^{4}$, que previa de início halls privativos na galeria para as entradas dos blocos comerciais e o bloco residencia tem seu acesso separado feito pela Rua Augusta. ${ }^{5}$

A galeria é marcada pelos pilares revestidos em granilite cinza, que afunilam na base, em estrutura muito semelhante a usada pelos irmãos Roberto na galeria do edifício Marquês do Herval $(1952)^{6}$, e é enriquecida pelos detalhes de iluminação e forro.

PAVIMENTO TIPO: Na laje sobre a galeria foi destinada área de jardim e play-ground.

São apresentadas três soluções de plantas por andar com:

4 apartamentos tipo A com dois dormitórios, voltados para Paulista

5 apartamentos tipo B, com um dormitório sendo 4 voltados para São Carlos do Pinhal e um para Paulista

12 apartamentos tipo C, com dois dormitórios face Brigadeiro.

Há ainda opções de plantas com junção de Apartamentos tipo A$B$ e CC, resultando em unidades com três dormitórios.

COBERTURA: Na cobertura havia salão com terraço ajardinado. TRATAMENTO DE FACHADAS: Solução original para uma questão apresentada pela arquitetura carioca foram os brises fixos em concreto. De forma quadrada, dispostos com as lâminas alternadas,

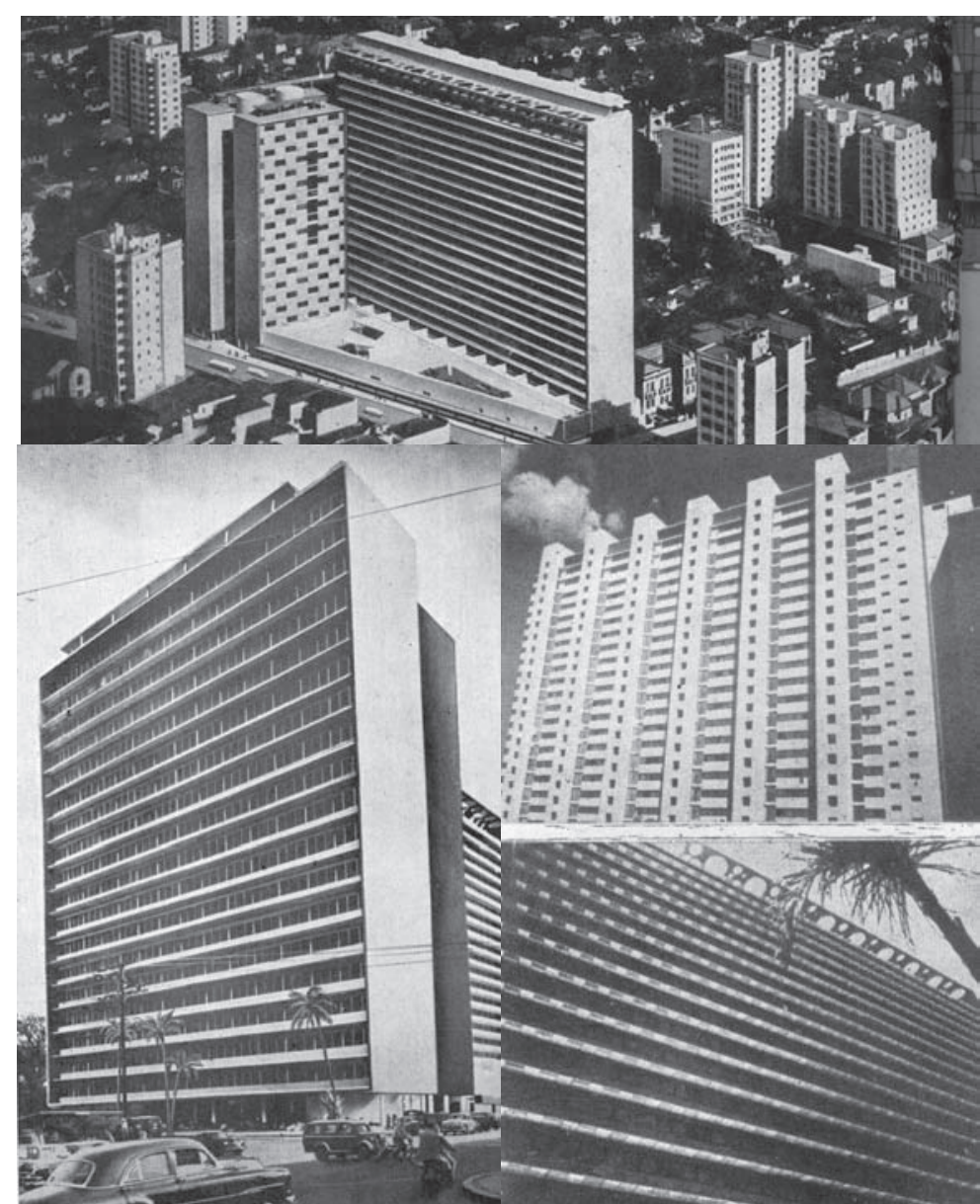

4 Impossível não fazer comparações com este conjunto da mesma epoca, Segawa faz o seguinte comentario"num programa que encontraria similar numa escala pouco maior no Conjunto Nacional, na mesma Av. Projetado por David Libeskind em 1955. Edifíios que assinalavam uma transição para a nova vocação da Paulista. do original retiro da alta burguesia paulistana com seus palacetes alinhados ao longo de seus $3 \mathrm{~km}$, Edificios como o Nações unidas introduziram nos anos 50 a verticalização da artéria com o uso do solo tendendo para o comércio e serviços." Hugo Projeto no 105, São Paulo, 1987, p.143 5 Inclusive as garagens residencial e comercial possuem entradas distintas pela Al.Santos e R. Pe. João Manuel respectivamente.

6 Ver Xavier,Britto e Nobre, Arquitetura Moderna no Rio de Janeiro, Rio de Janeiro, 1991, p.81. arquitetônica carioca em São Paulo 

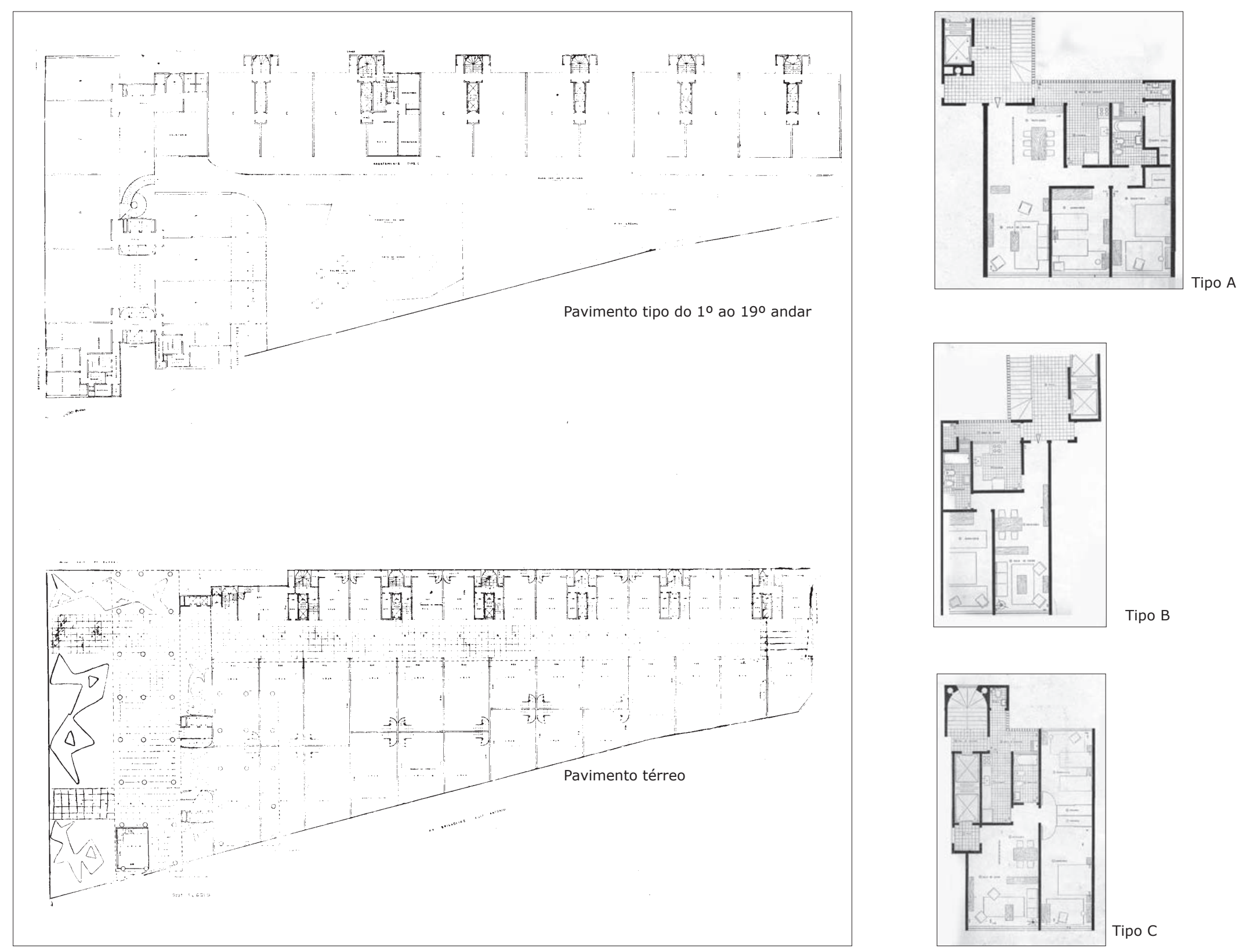


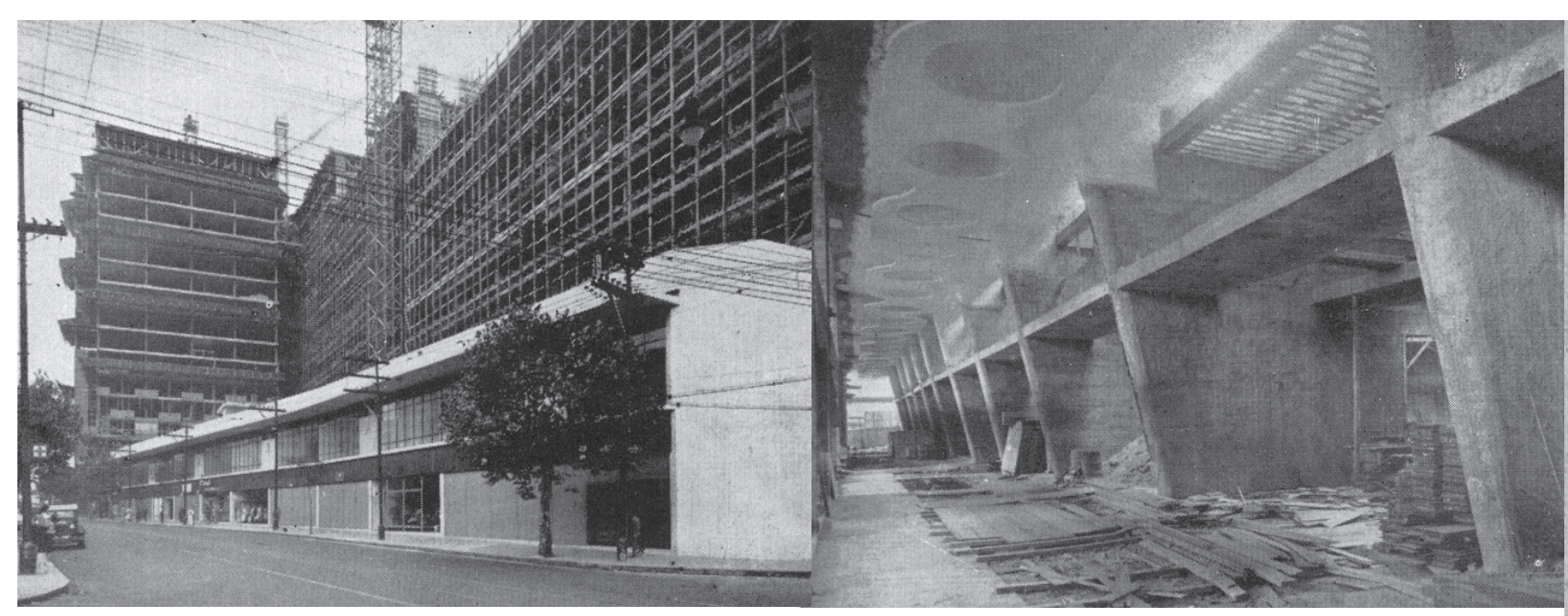

Fotos da construção e com os brises na fachada.
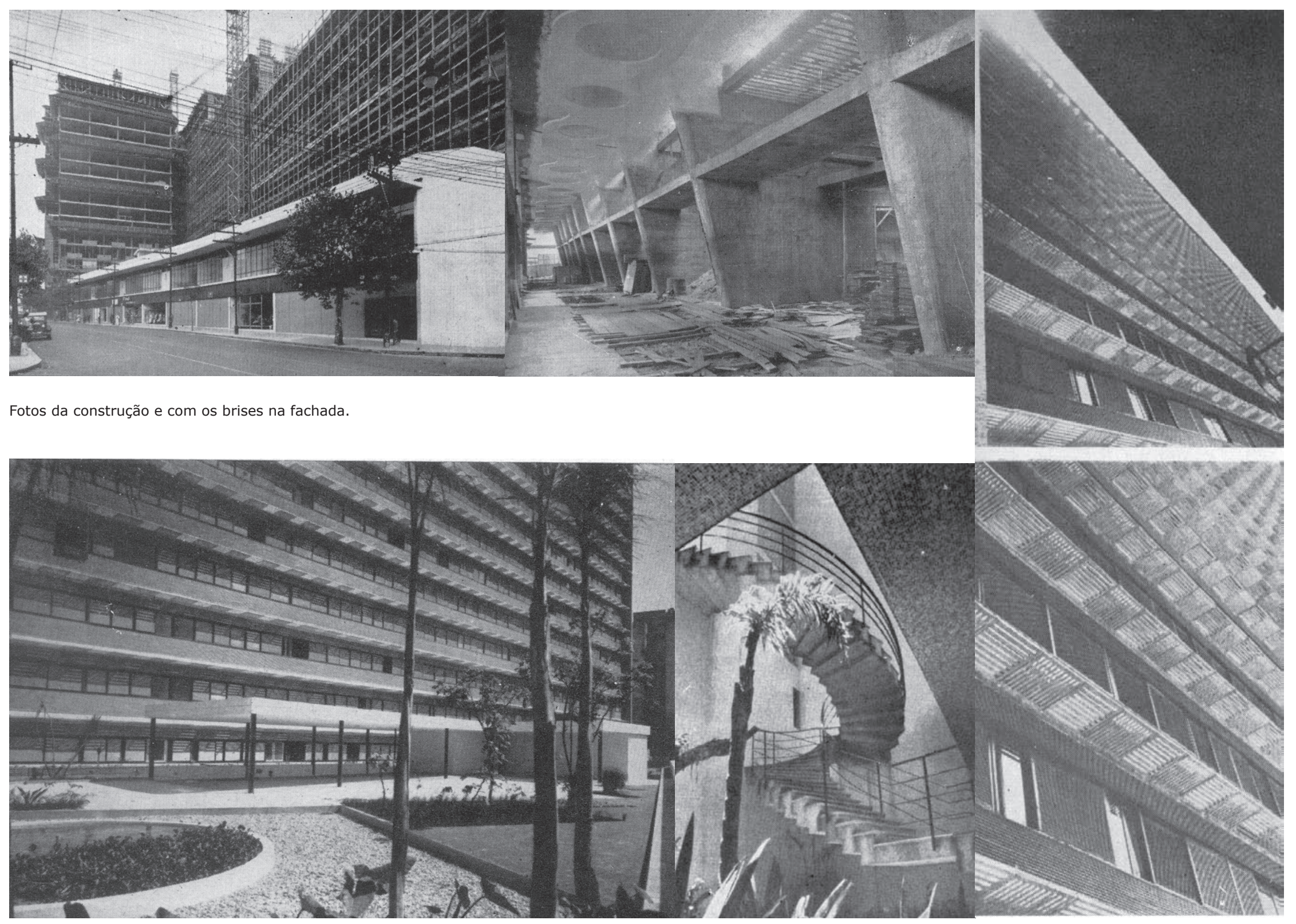

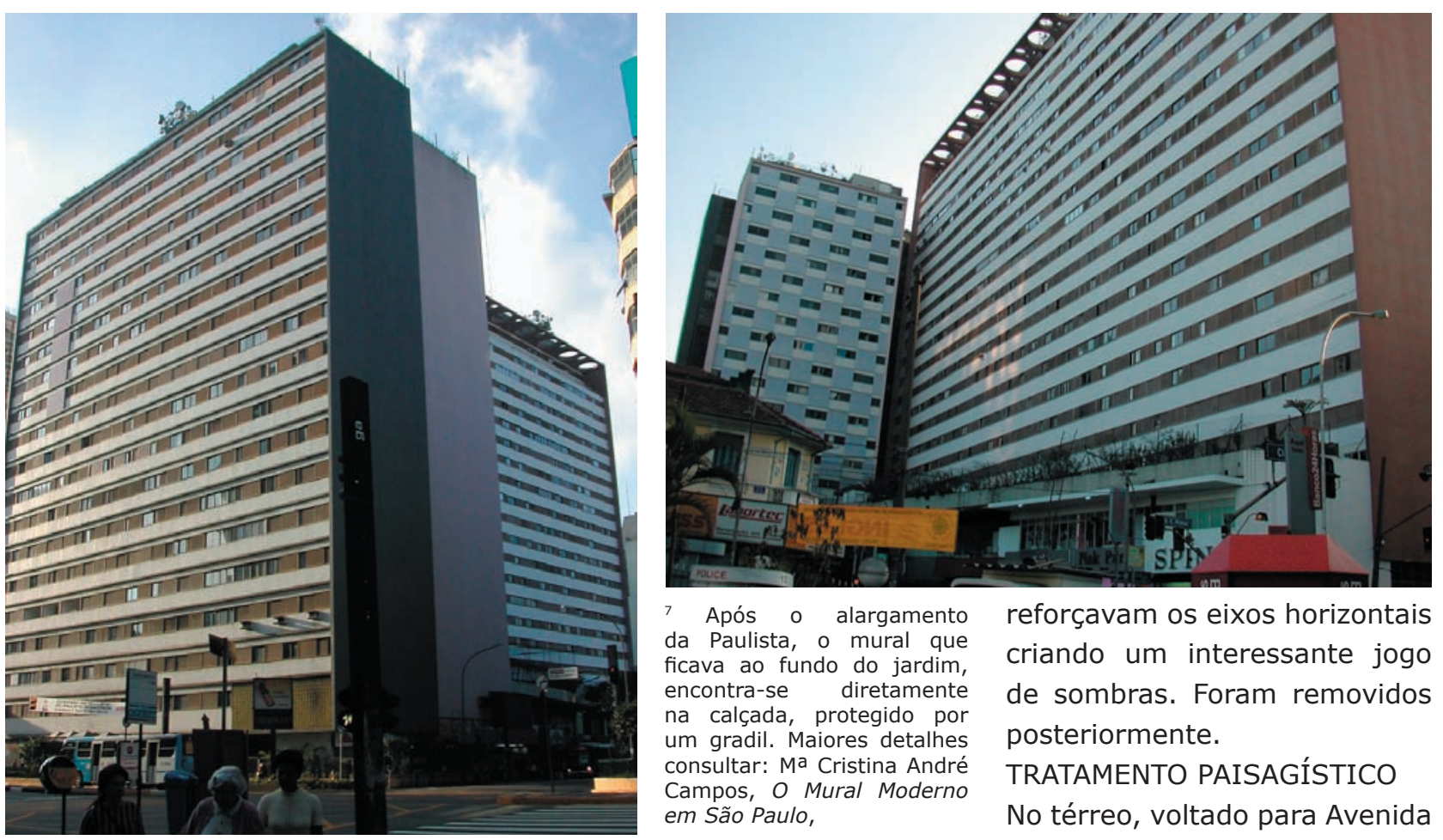

7 Após o alargamento da Paulista, o mural que
ficava ao fundo do jardim, encontra-se diretamente na calçada, protegido por um gradil. Maiores detalhes consultar: Ma Cristina Andre Campos, O Mural Moderno em São Paulo, reforçavam os eixos horizontais criando um interessante jogo de sombras. Foram removidos posteriormente.

TRATAMENTO PAISAGÍSTICO

No térreo, voltado para Avenida
Paulista, havia jardim com palmeiras e parada rápida para veículos. Com o alargamento da via em 71 o jardim foi removido restando apenas um pequeno canteiro cercado, aonde encontraremos um mural em cerâmica de Clóvis Graciano ${ }^{7}$ dentro da aplicação do conceito moderno de integração das artes.

No piso de mezzanino e cobertura também havia canteiros e áreas ajardinadas. ESTADO ATUAL DO CONJUNTO O edifício está de forma gera preservado, ocupado e mantido em suas funções. As lojas da Av. Brigadeiro, sem padronização e o gradil na laje sobre elas dão um aspecto de descuido.

Imagens de 2004

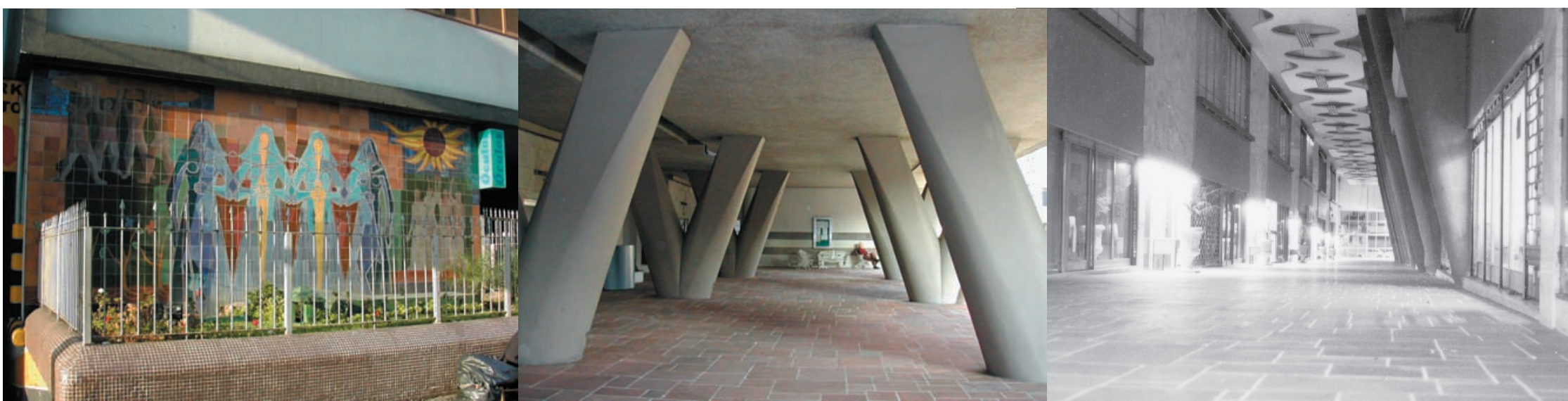




\section{Edifício Três Marias}

\section{2}

Publicações:

Acrópole 184, p.172-3.

1953.

Habitat 7, p.18-20.

1952.

Habitat 39, p.15.

1957.

Habitat 30, p.62-4.

1956.

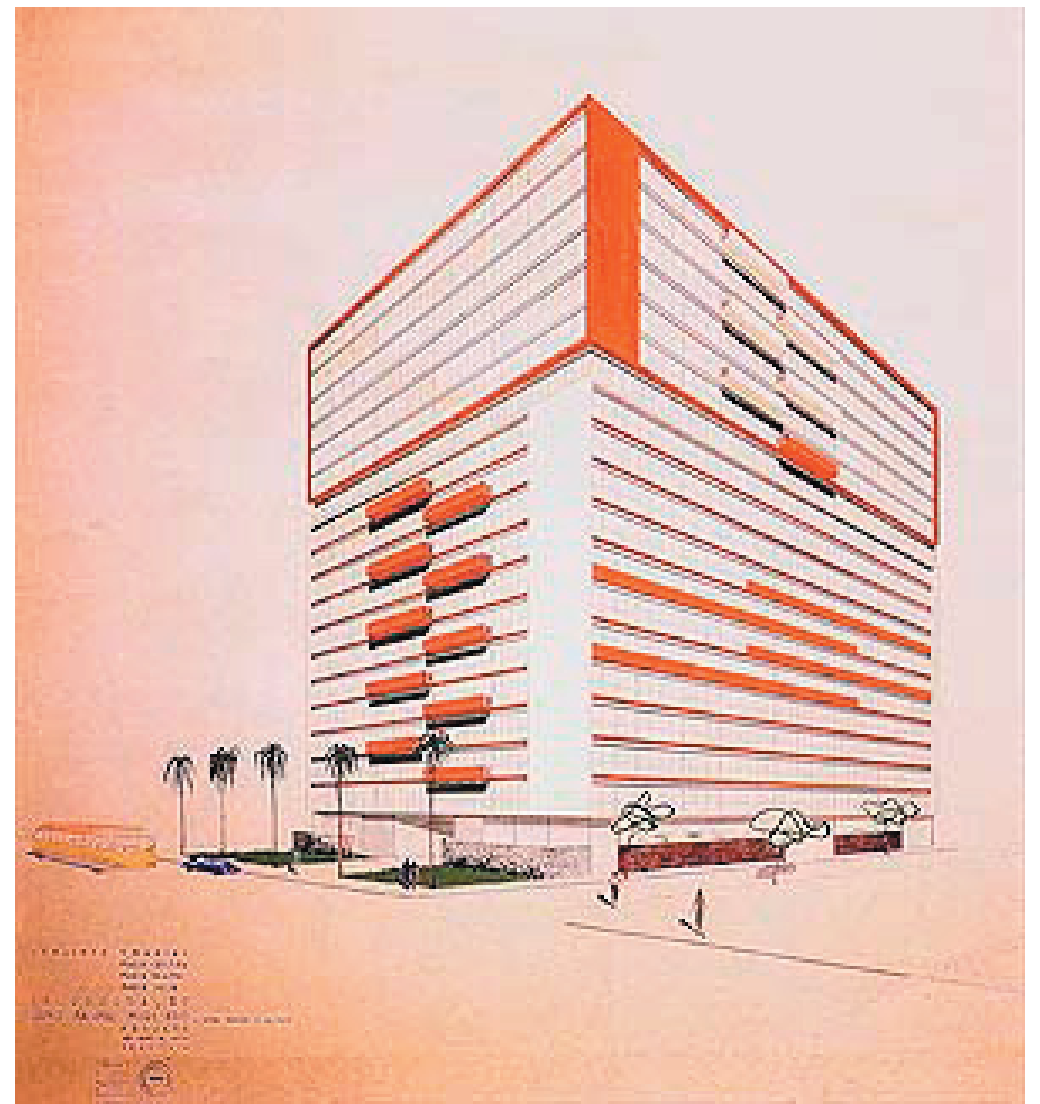

\section{DADOS DO PROJETO:}

Execução: 1952

Incorporação: CNI

Entrega da Obra: 1956

Local: Av. Paulista 2.239

Exposições: Participou da $4^{a}$ Exposição Internacional de Arquitetura, 1957.

\section{DESCRIÇÃO DO \\ PROJETO:}

Localizado na esquina da avenida Paulista com rua Haddock Lobo, considerado "Modelo de bom-gosto" segundo o crítico Yves-Bruand ${ }^{1}$. O bloco em $L$ que visto da rua parece um cubo é rompido no $12 \circ$ andar por uma faixa contínua em madeira e parece rotacionado pela disposição dos balcões em balanço pelo uso de faixas alternadas de pastilhas nas cores rosa e azul.

Apesar de não ser tão celebrado quanto o polêmico Nações Unidas, o edifício Três Marias, de 1954, é um dos mais belos exemplares dessa fase da arquitetura brasileira em São Paulo.

A obra é imponente mas respira um ar de serenidade.

São três blocos de apartamentos com entradas separadas num total de 95 apartamentos, distribuídos em 18 andares, com metragens de a 140 a 270 $\mathrm{m} 2$.

Neste edifício, a incorporadora CNI optou por apartamentos de alto padrão, provavelmente devido a localização em trecho mais nobre da avenida, por isso não há uma ocupação tão ostensiva do terreno quanto no Nações Unidas.

"A estruturação do edifício Três Marias se fez dentro de um risco bastante simples; o que a enriqueceu foi a distribuição dos espaços,(...), aproveitando tôdas as oportunidades de luz e de ventilação, favorecendo a insolação, protegendo as funções."

\section{Área do Lote: $2.580 \mathrm{~m} 2$}

Área Construída: 20.785 m2 No de pavimentos: 18

SUBSOLO: Garagem para 100 carros com acesso aos blocos pelo elevador de serviço. Uso de laje tipo cogumelo.

PAVIMENTO TÉRREO

Nas portarias dos três edifícios foi usado travertino romano 
paginado no piso e paredes, e as luminárias para luz fluorescente delinhashorizontais desenhadas pelo arquiteto criam uma atmosfera "miesiana". As caixas de elevador em mogno com parede do fundo em réguas como venezianas também foram especialmente desenhadas pelo escritório de Abelardo. ${ }^{3}$

Pelas perspectivas originais, vê-se que inicialmente no térreo eram previstas lojas dando para rua. No projeto executado, ao invés das lojas foram realizados apartamentos: os da Paulista com área ajardinadas muradas e nas unidades da Haddock Lobo com elementos vazados até o chão e jardim "interno". Como estes apartamentos ficaram extremamente devassados, os elementos vazados foram posteriormente removidos e substituídos por gradis semelhantes aos utilizados nas portarias.

A entrada do bloco da Paulista (onde ficam os apartamentos com maior metragem) se fazia através de marquize em concreto revestida de pastilhas ${ }^{4}$, com o alargamento da Paulista, a marquize e
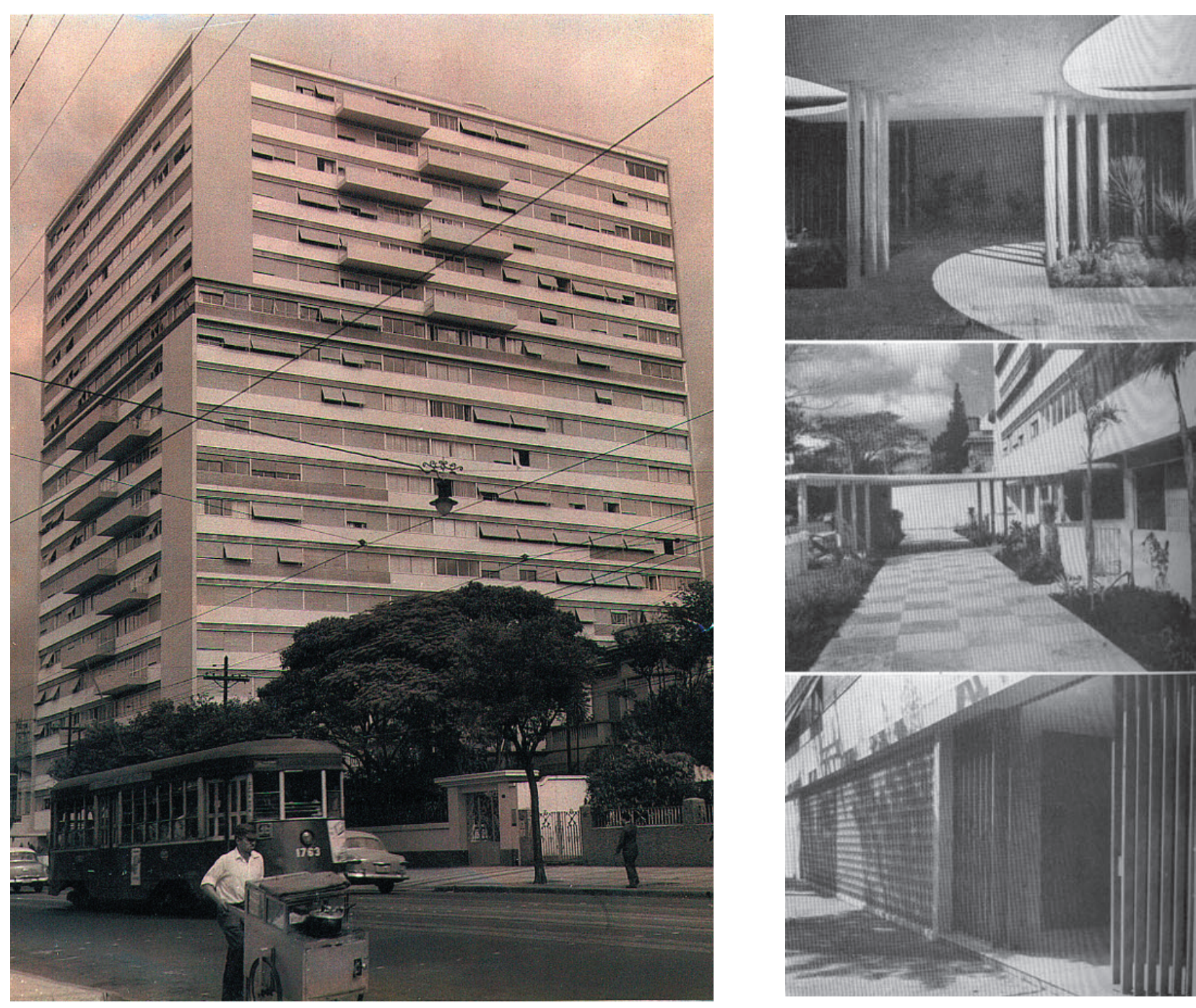

3 Por imposição da cia. Vilares de elevadores estas cabines foram removidas, caso contrário não efetuariam a troca do maquinário.

projeto original previa marquize em alumínio conforme desenhos publicados na revista Habitat n07, 1952, p.20 

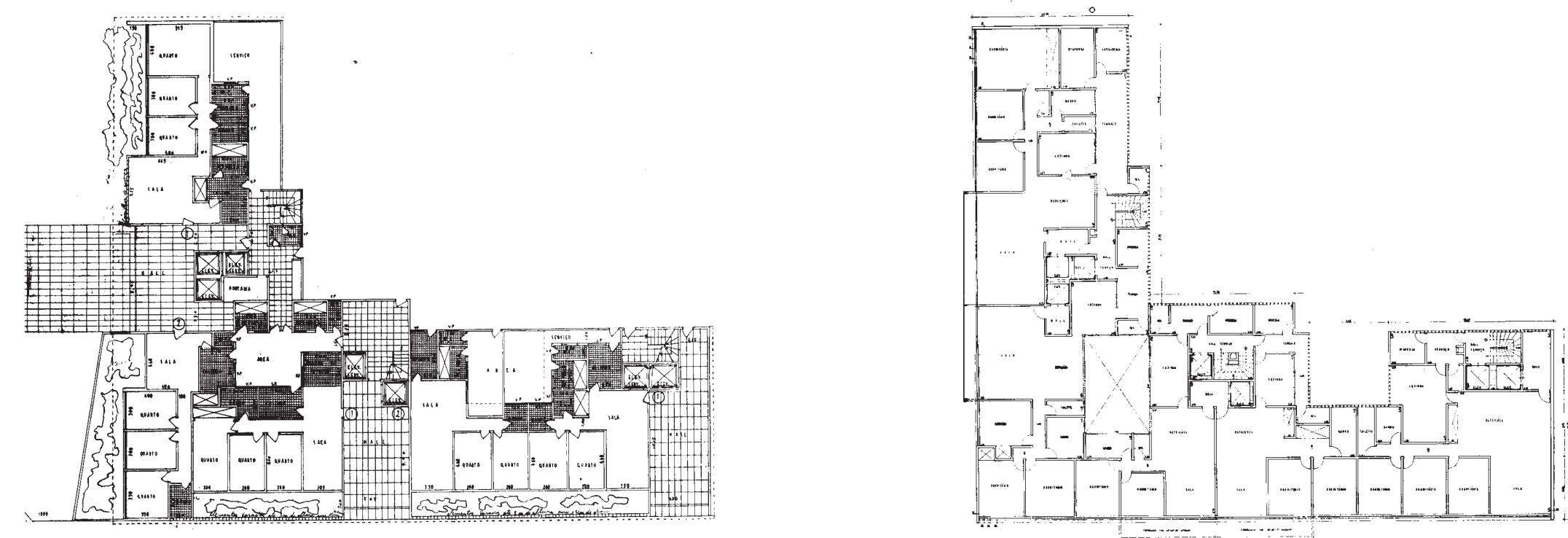

nta do pavimento térreo.
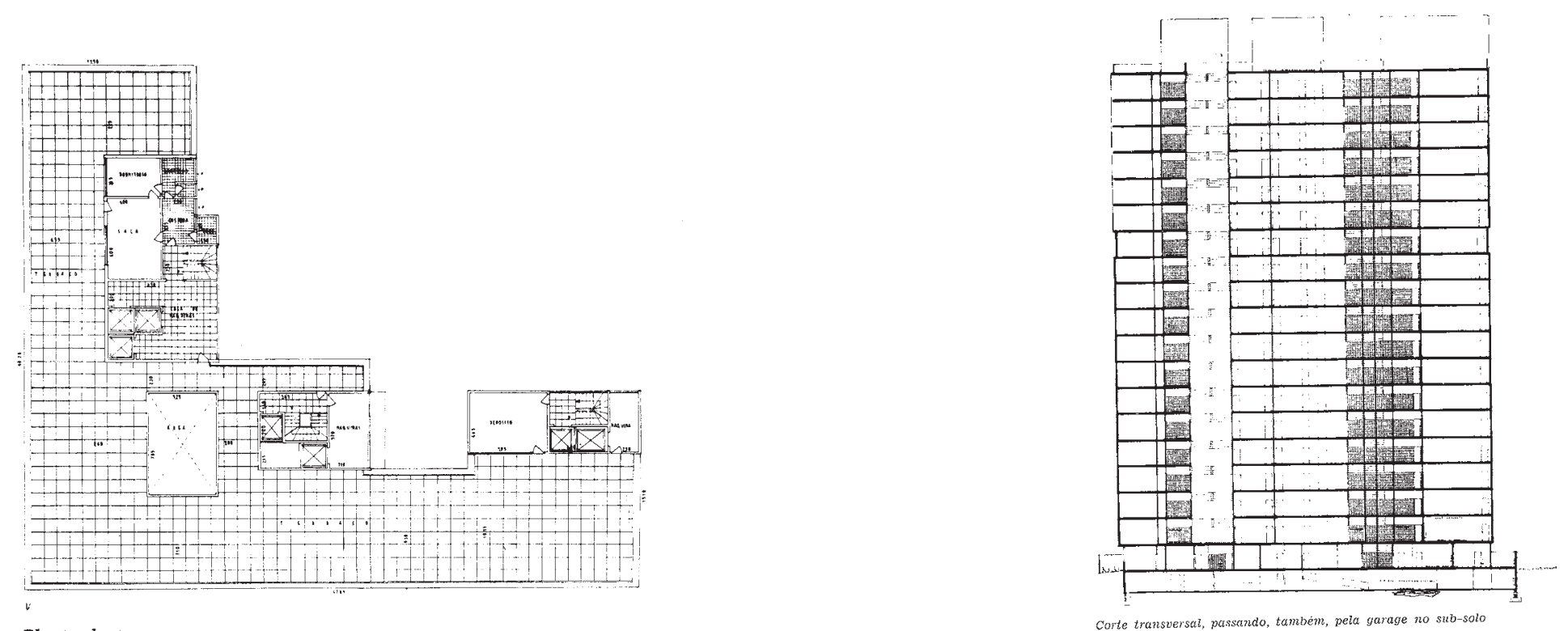

Planta do terraço. 


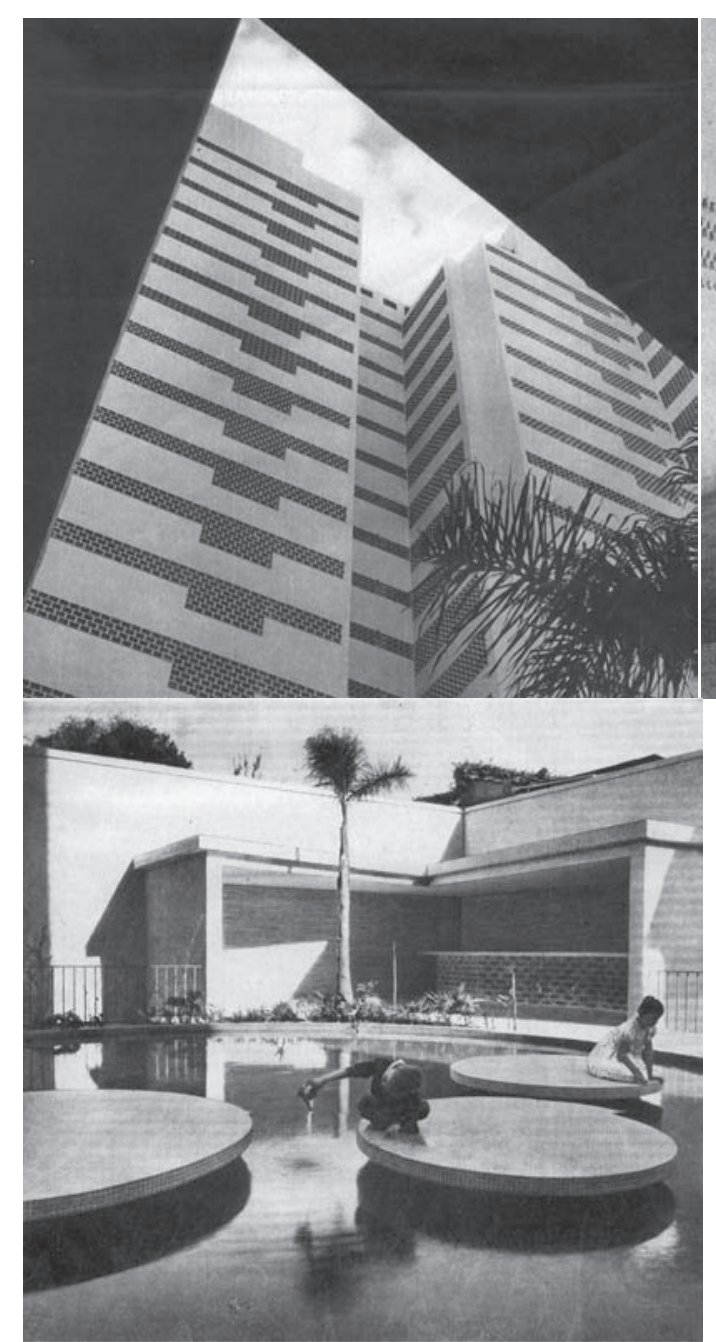

Planta e imagens do Jardim interno, projeto de MIranda Magnoli.

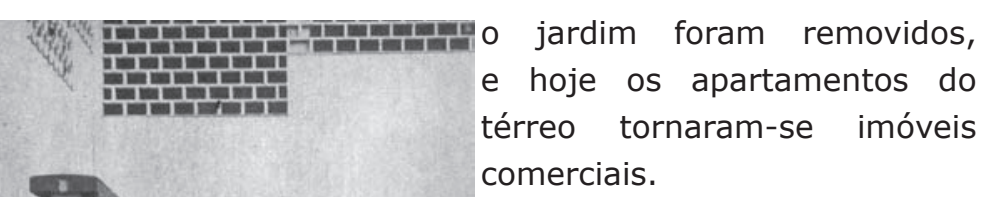

PAVIMENTO TIPO

무몸미 Bloco Paulista

apartamentos com elevadores

independentes. O primeiro

com três dormitórios e dois

banheiros, sala, cozinha, área

de serviço, quarto e banheiro de

empregada. O outro com três

dormitórios, sala, escritório,

cozinha, área de serviço,

dois quartos de empregada e banheiro. Áreas 200 e 270m2

Bloco Haddock Lobo 1 -

Dois apartamentos de dois

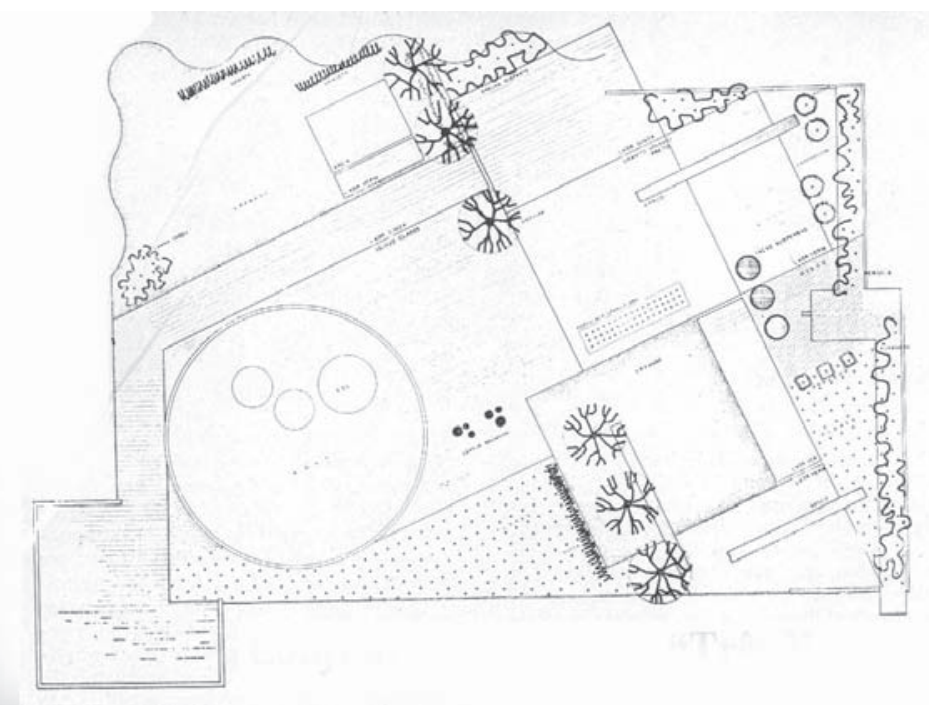

dormitórios com elevador comum. Áreas a 140 e 160 m2 Bloco Haddock Lobo 2 - Um apartamento com sala, três quartos, dois banheiros, cozinha, área de serviço quarto e banheiro de empregada. Área 200m2

Os dormitórios e living possuem vista para rua e ampla iluminação pelo uso de caixilhos contínuos em madeira. Voltadas para o pátio interno concentram-se as áreas de serviço, hall dos apartamentos e banheiros. Neste pátio, Abelardo de Souza conseguiu harmoniosa composição pelo uso de diversos elementos vazados, amenizando os diferentes formatos de janelas e novamente lembrando os edifícios do Parque Guinle. TRATAMENTO DE FACHADAS este projeto de características marcadamente brasileiras, constitui-se de dois volumes em $\mathrm{L}$, formando um volume único que é rompido na altura do $12^{\circ}$ andar pela rotação dos balcões em balanço que passam da fachada da Av. Paulista para a fachada da Rua Haddock Lobo. Essa ruptura da composição é 
reforçada pelo uso alternado de pastilhas nas cores azul e rosa, repetindo as cores dos edifícios do Parque Guinle, de Lúcio Costa.

Foram utilizados materiais sofisticados na construção que também possui soluções interessantes na estrutura permitindo as grandes janelas de correr com caixas de venezianas em ipê em forma contínua, marcando faixas horizontais.

TRATAMENTO PAISAGÍSTICO No pátio formado pelos dois blocos, havia área comum de churrasqueira, jardim e playground, com projeto paisagístico das Arquitetas Miranda Martinelli Magnoli e Rosa Grena Kliass, então colaboradoras de Abelardo. A churrasqueira hoje se tranformou em guarita e o jardim deu lugar a uma área de estacionamento.

Na cobertura, comum aos três blocos, devido a vista magnífica foi realizado também tratamento paisagístico, o jardim suspenso de Le Corbusier elevado às alturas.

ESTADO ATUAL DO CONJUNTO: O conjunto encontra-se mal preservado, com as esquadriase as venezianas de ipê em estado bastante deteriorado e inclusive perigosas. O condomínio estuda sua substituição por outro material.

Algumas obras de segurança foram feitas, mas algumas de caráter "estético" vem sendo realizadaspeloscondôminossem critério. Precisa urgentemente de apoio ou incentivo para sua preservação.

Imagens de 2004
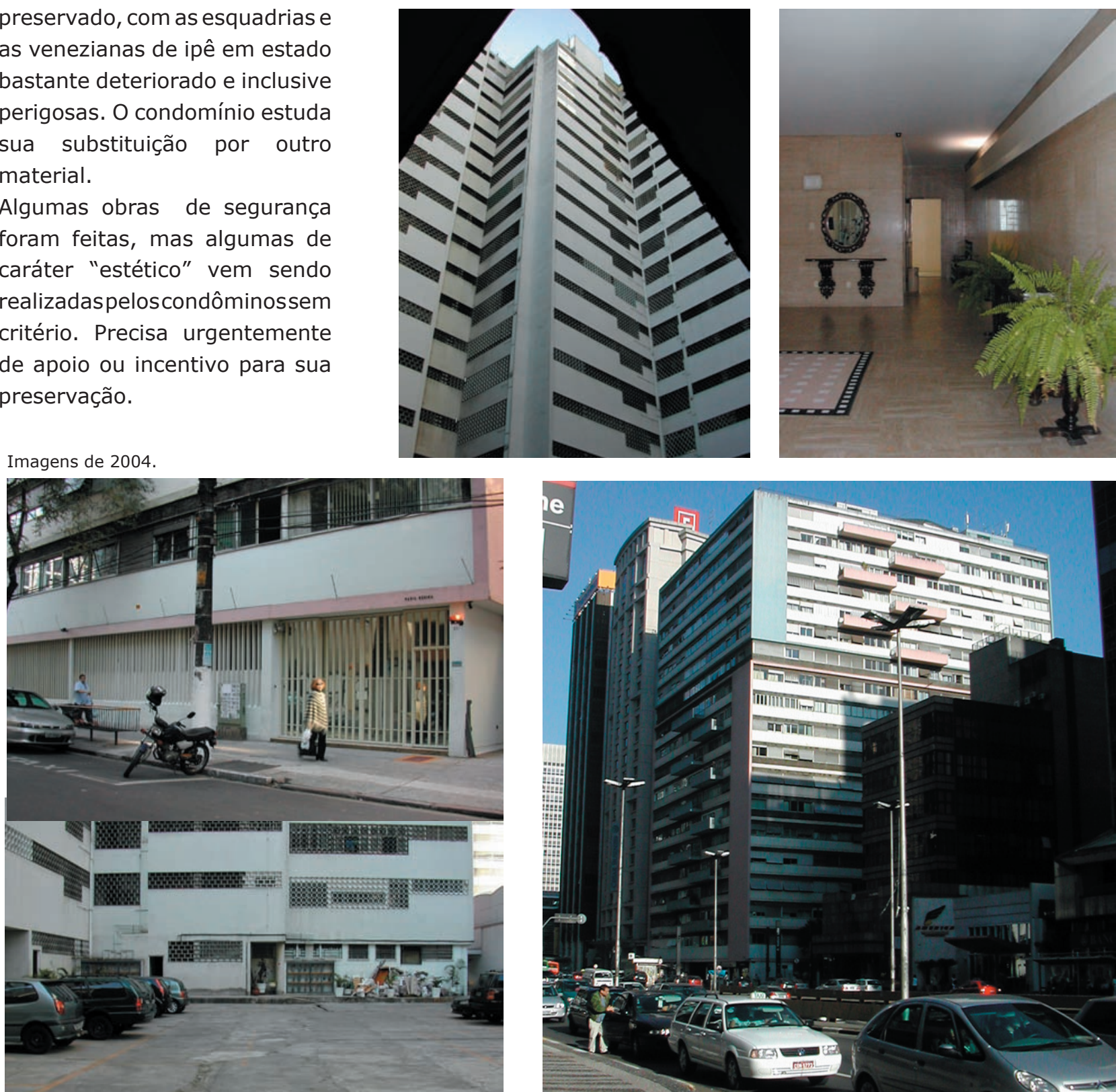


\section{Edifício Bienal} 1955

Publicações:

Arquitetura e Decoração 11, p 8-10.

1955.

Habitat 39, p19.

1957.

CAMPOS, Maria Cristina André O Mural Moderno em São Paulo, mestrado FAU/USP, São Paulo. V2p.20.2001.

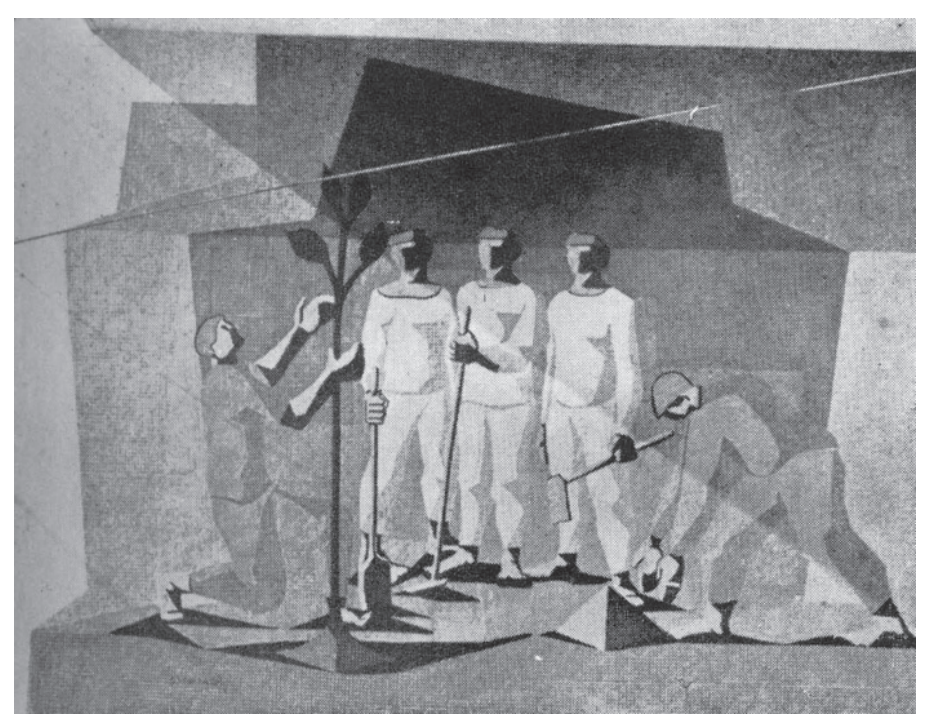

DADOS DO PROJETO:

Incorporação: Proprietário Sérgio Page

Entrega da Obra: 1955

Local:Rua João Lourenço 797/ Av. Santo Amaro. V. N. Conceição - São Paulo

\section{DESCRIÇÃO DO PROJETO:}

Prédio de 3 pavimentos para uso misto: loja, escritórios e moradia. Localizado em terreno de esquina, ocupa toda extensão do terreno.

Área do Lote: $240 \mathrm{~m} 2$ Área Construída: $987 \mathrm{~m} 2$ No de pavimentos: 3
PAVIMENTO TÉRREO: Grande loja voltada para Av. Santo Amaro com salão, copa e dois banheiros. Na sua lateral direita fica escada de acesso independente para conjuntos comerciais no $1^{\circ}$ pavimento.

A parte residencial do edifício possui entrada pela R. João Lourenço. No hall fica a escada de acesso para os demais anadares e entrada do apartamento no térreo, que possui: dois dormitórios voltados para Rua, cozinha e banheiros com ventilação para pátio interno.

10 PAVIMENTO: Projeta-se em balanço fazendo proteção sobre
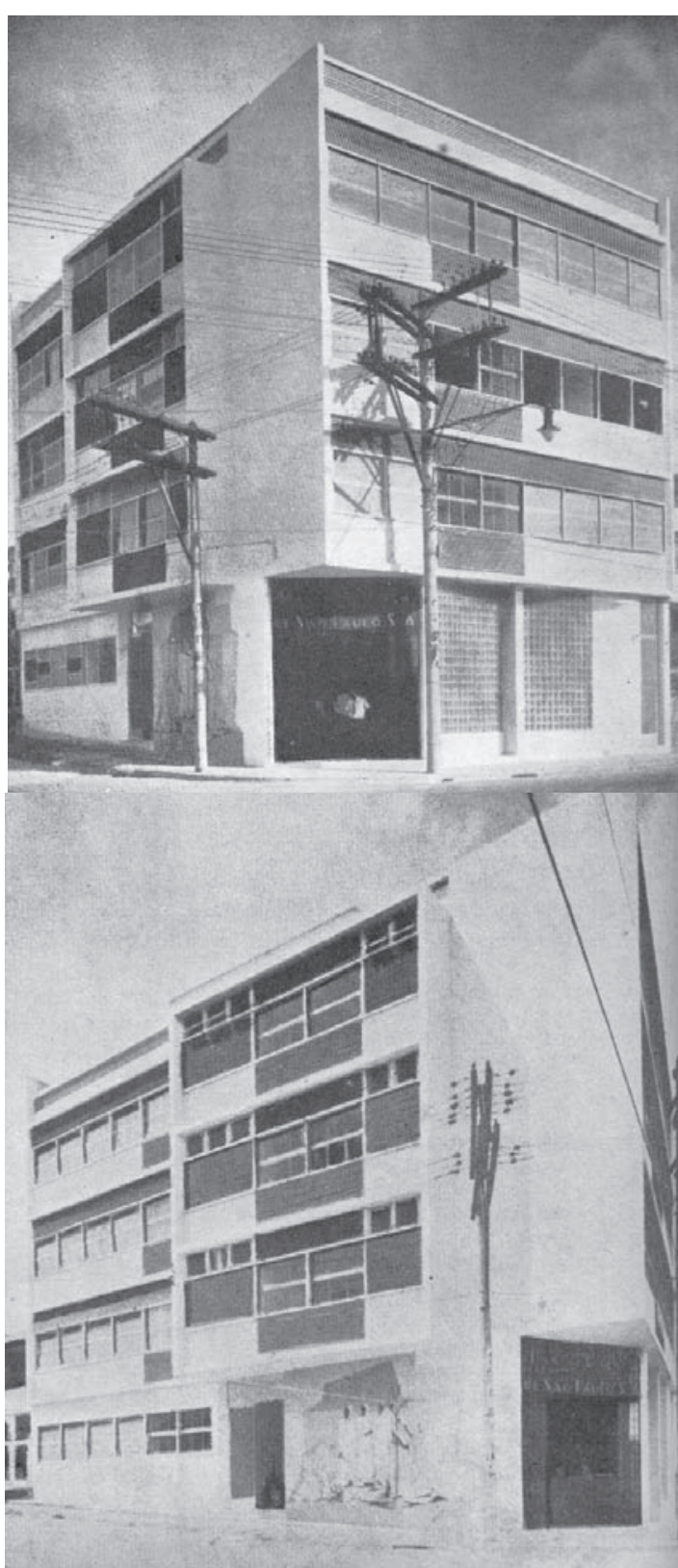


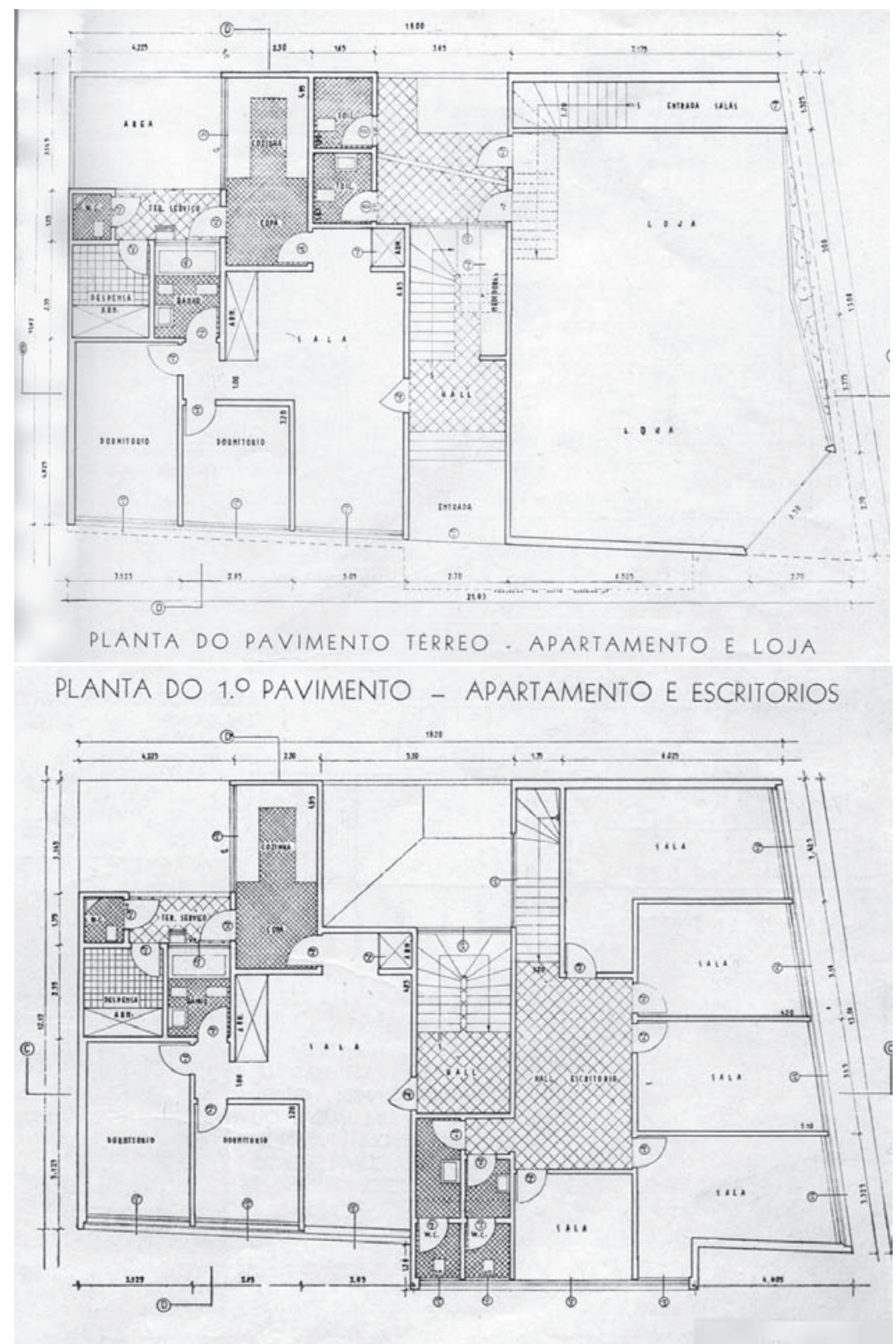

a entrada da Rua João Lourenço o painel mural do térreo.

$\mathrm{Na}$ área comercial apresenta 5 salas e dois banheiros de uso comum no corredor.

$\mathrm{Na}$ zona de moradia repete-se planta do apartamento térreo.

PAVIMENTO TIPO: Três apartamentos sendo um deles repetição da planta do piso térreo; um dois dormitórios voltado para Av. Sto. Amaro e um apartamento de um dormitório na esquina.
TRATAMENTO DE FACHADAS: Repete o padrão usado pelo arquiteto de pastilhas nas cores rosa e azul.

O primeiro e demais pavimentos em leve balanço destacam-se do térreo, numa composição que evidencia a estrutura. Caixilhos de madeira com composição de cores. Fachada da Rua João Lourenço apresenta mural em mosaico de pastilhas, autoria de Clóvis Graciano abordando a vida no campo.

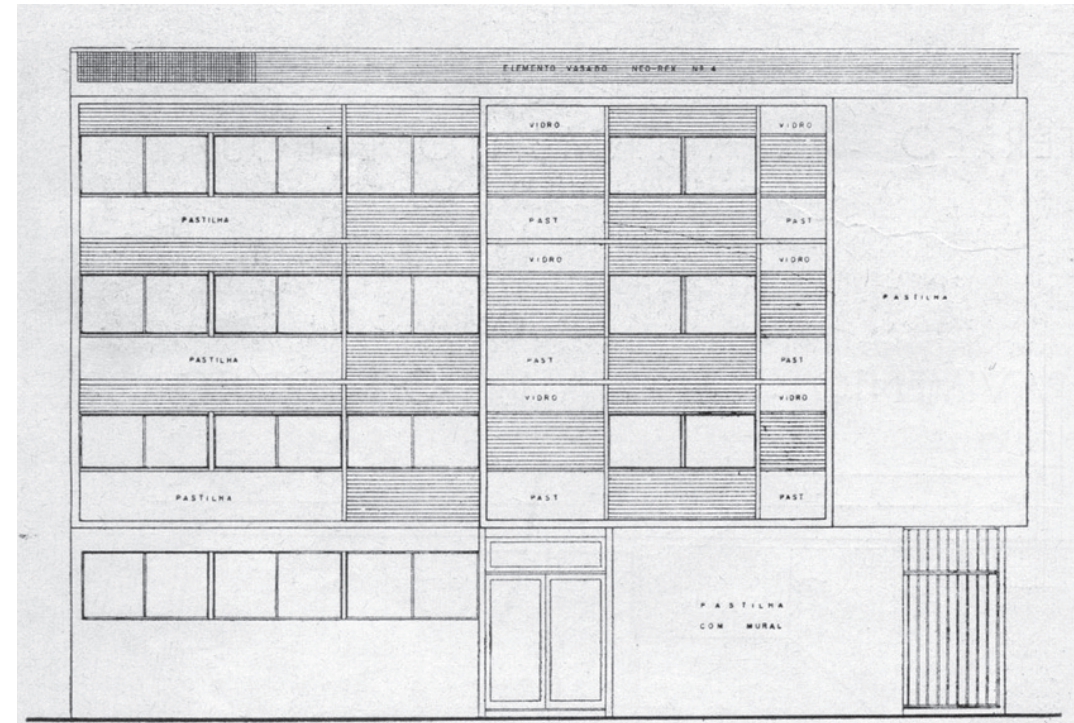

RUA JOAOO LOURENCO 


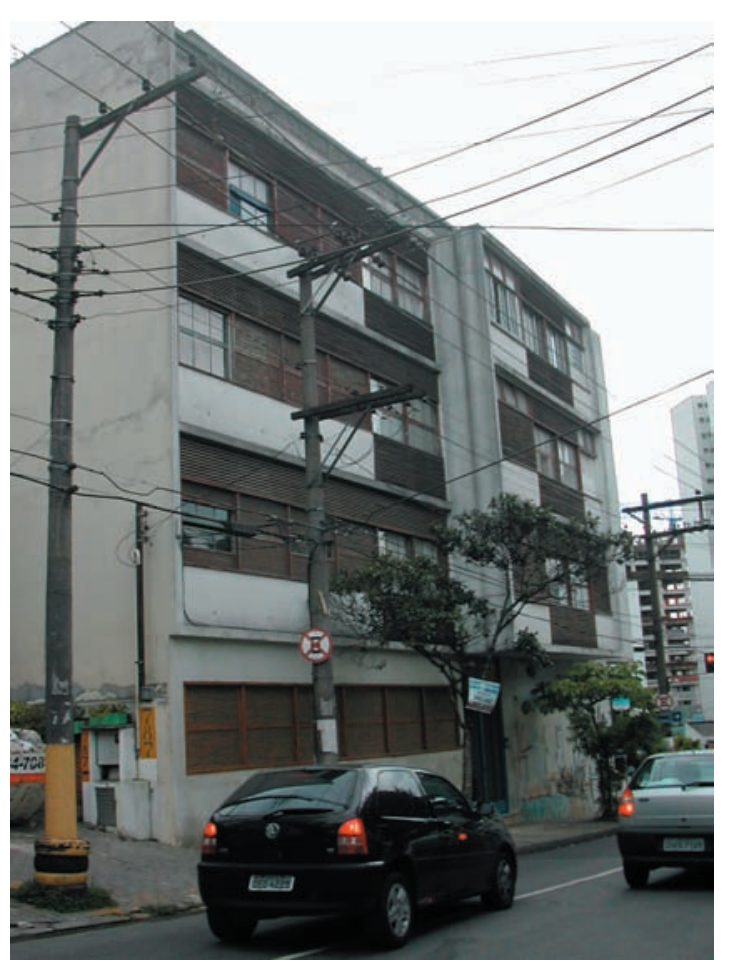

TRATAMENTO PAISAGÍSTICO: Consiste apenas em algumas jardineiras no alinhamento da calçada na fachada da Rua João Lourenço.

ESTADO ATUAL DO CONJUNTO: O conjunto encontra-se bastante deteriorado, especialmente na face voltada para Av. Sto. Amaro e coberto por pichações, inclusive no painel.

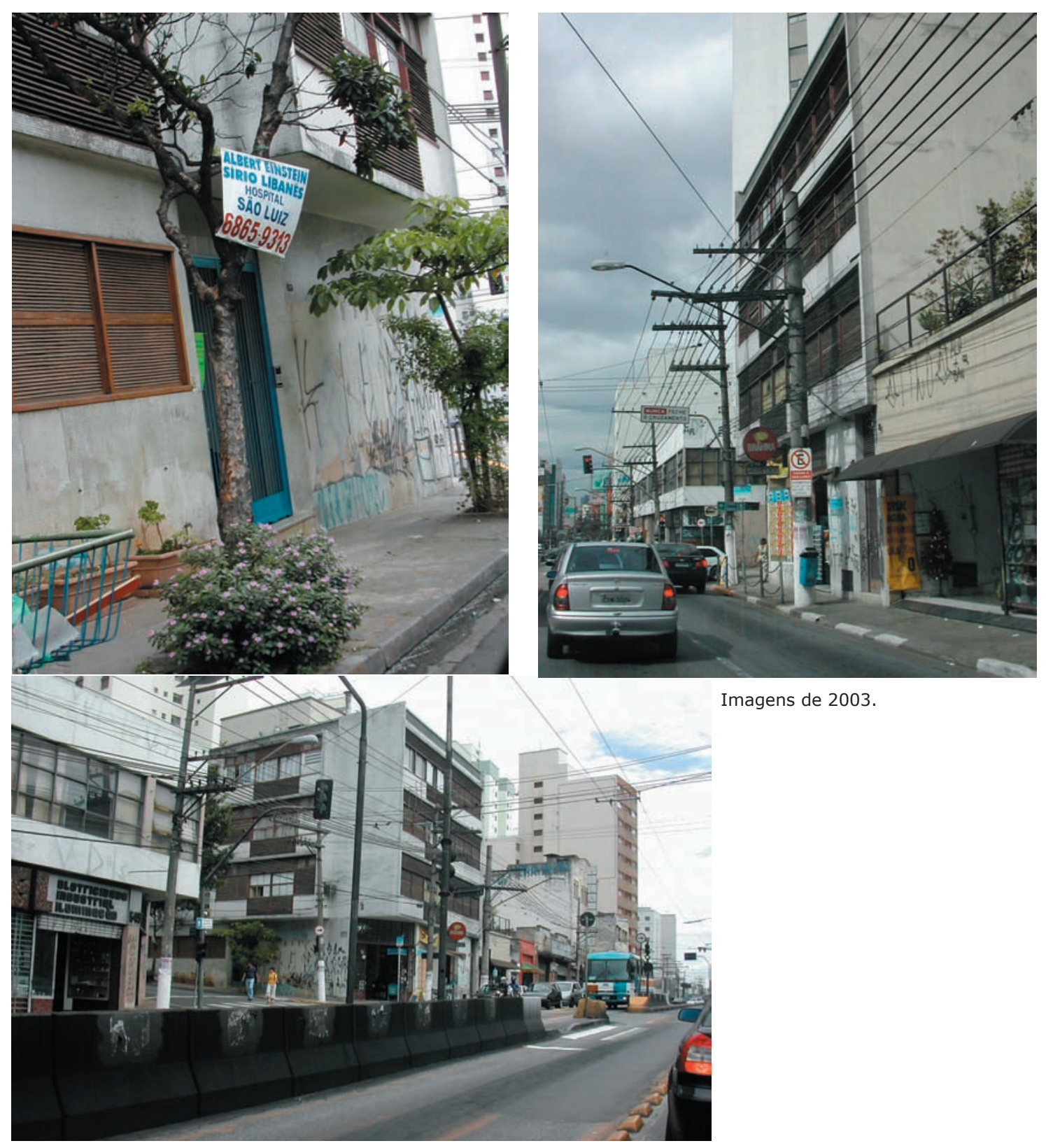




\section{Hotel e aptos. em Goias}

\section{0}

Publicações:

Habitat61, p.3-6.

1960.

\section{DADOS DO PROJETO:}

Incorporação: Salim Caed

Local: Anápolis- Goiás

\section{DESCRIÇÃO DO}

PROJETO:

O projeto lembra muito as linhas do Nações Unidas, principalmente na volumetria e em alguns pontos do programa, como a adoção de bloco para galeria comercial no térreo. Cabe notar que algumas questões foram melhor resolvidas neste projeto como a independência da entrada do hotel e apartamentos em relação à galeria.

Área do Lote:

Área Construída: $14.2000 \mathrm{~m} 2$ $N^{\circ}$ de pavimentos: 14

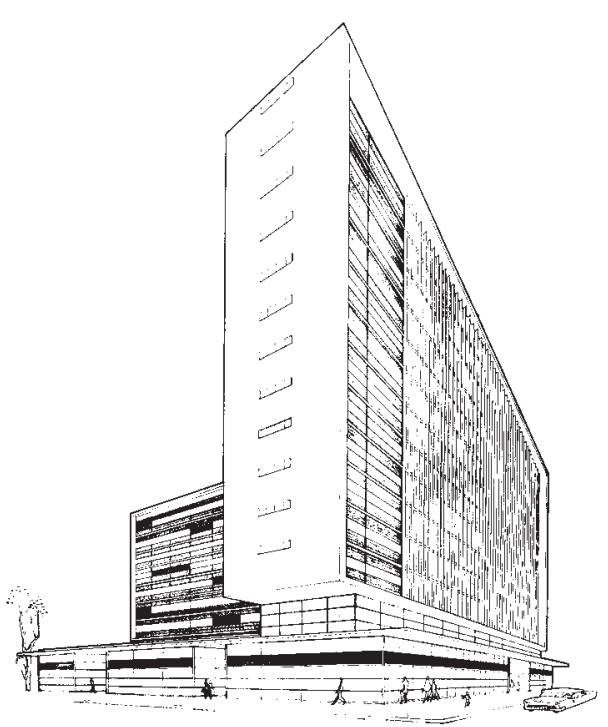

Plantas: Entrada e Galeria, Andar Tipo e Salão Social

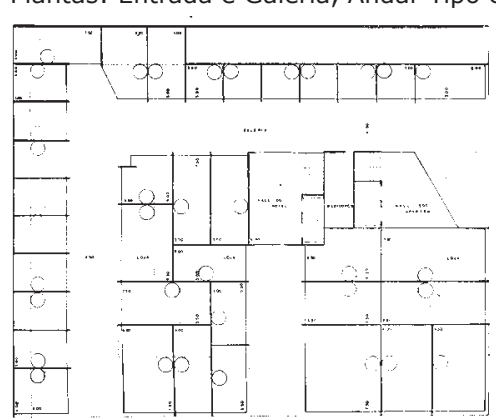

SUBSOLO: dois andares para garagens

PAVIMENTO TÉRREO: Neste piso localizam-se a entrada e hall do hotel, hall dos apartamentos e uma galeria com lojas comerciais.

PRIMEIRO PAVIMENTO:

Ocupado pela parte propriamente hoteleira; encontram-se aí os salões abertos para o jardim, bar, terraços, serviços e alojamentos para empregados,

$3^{\circ}$ ao $9^{\circ}$ PAVIMENTO: 14 suítes de hotel e 3 apartamentos de dois dormitórios, 2 apartamentos de um dormitório e um com 3 dormitórios. $10^{\circ}$ ao $14^{\circ}$ PAVIMENTO $\grave{A}$ partir deste piso, o bloco do hotel é interrompido e prossegue apenas o andar tipo de apartamentos.

TRATAMENTO DE FACHADAS $O$ edifício adquire leveza pelo volume do o bloco de apartamentos encontrar-se pousado sobre um pavimento todo de vidro e ainda afastado em relação ao alinhamento da rua. $O$ arquiteto seguiu sua tendência na composição de cores prevendo o uso de pastilhas coloridas. Para 0 bloco de apartamentos de pastilhas esmaltadas, "siena", com lâminas curvas de fibrocimento, azul claro e janelas brancas; no bloco do Hotel, pastilhas verde claras, janelas brancas e montantes cinza. A parte térrea foi toda trabalhada em caixilhos de alumínio, vidros azulados e uma faixa de venezianas vermelhas.

A fachada do bloco de apartamentos foi protegida com brises verticais de concreto.
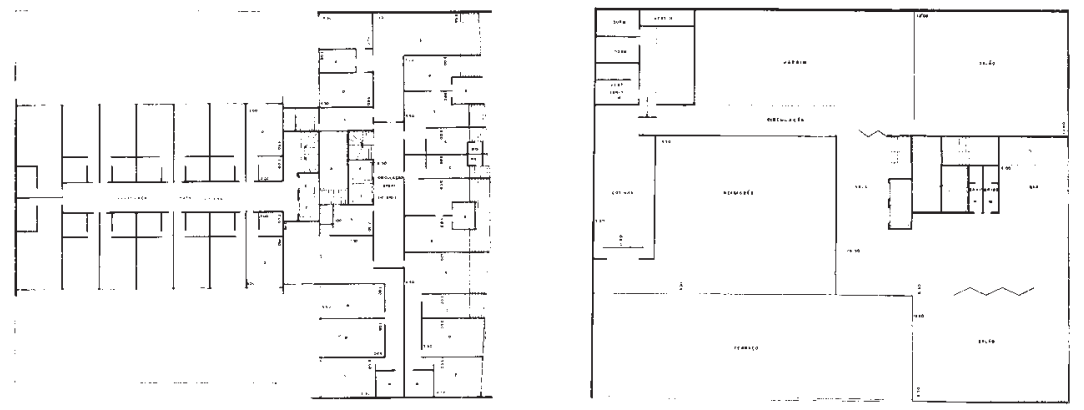


\section{Hotel Tropical Palace São Paulo}

\section{0}

Publicações:

Habitat62, p.7-18.

1960.
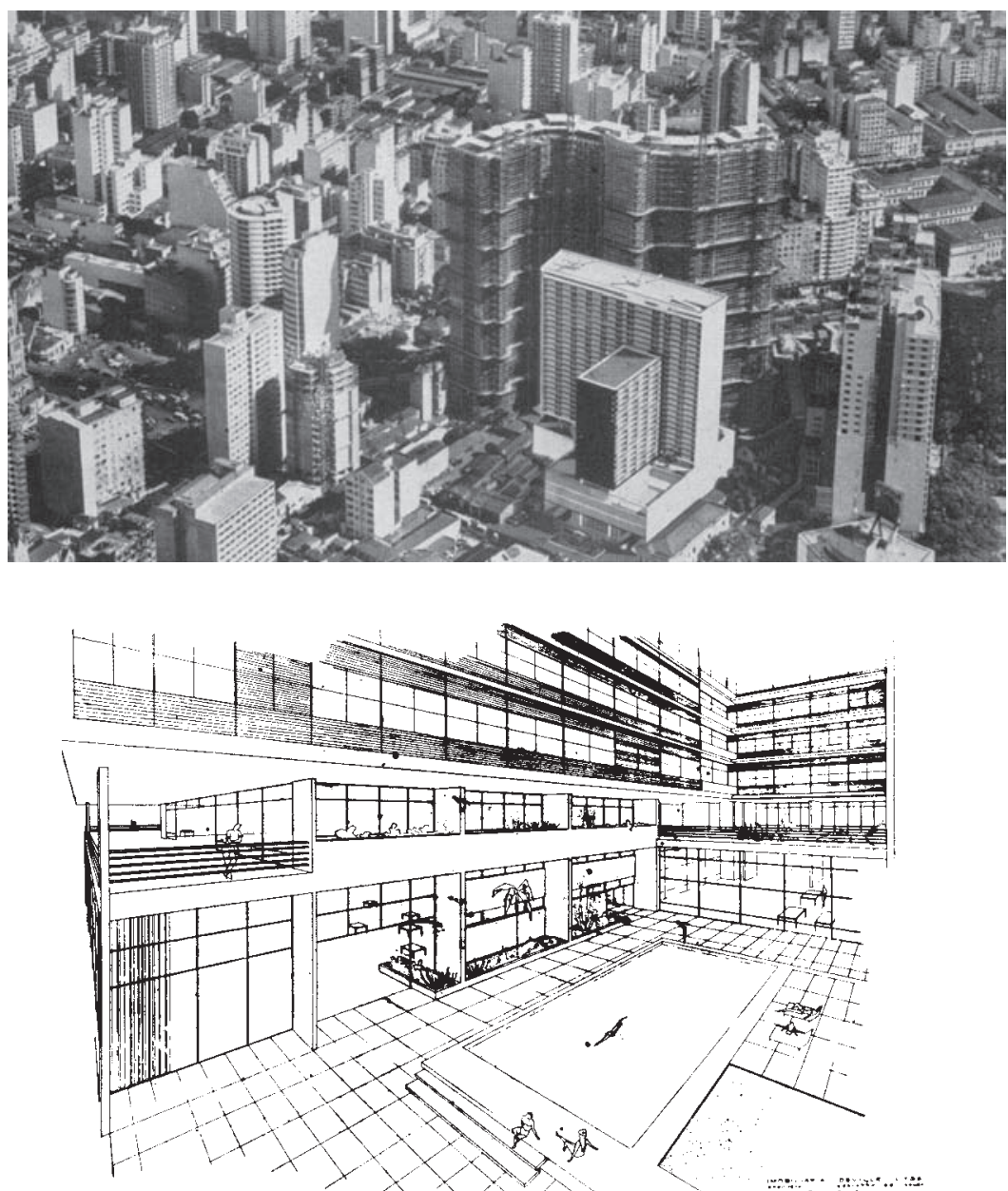

\section{DADOS DO PROJETO:}

Incorporação: Imobiliária

Deville

Local: Rua da Consolação

\section{DESCRIÇÃO DO}

\section{PROJETO:}

Este projeto de Hotel, com programa complexo, seria realizado em terreno no centro de São Paulo, aonde localizava-se o antigo cine Odeon, em frente ao edifício Copan. O empreendimento visava aproveitar lei que favorecia a construção deste tipo de empreendimento na época. Apesar da ampla divulgação em jornais, o projeto não saiu do papel.

Área do Lote: $4.450 \mathrm{~m} 2$

Área Construída: $96.000 \mathrm{~m} 2$ No de pavimentos:

SUBSOLO: Com 4 pisos, sendo os três primeiros para automóveis e, no 40 sub-solo localizamse os serviços gerais do hotel: lavanderia, confeitaria, adega, despensa, cozinha e refeitório para empregados, garagem para carro dos hóspedes, central telefônica, cabine de força.

PAVIMENTO TÉRREO : Previa uma galeria de $10 \mathrm{~m}$ de largura e $150 \mathrm{~m}$ de comprimento para onde dão 44 lojas com mezzaninos; o grande hall do hotel com cerca de 650 $\mathrm{m} 2 ; 4$ escadas rolantes que comunicam com os dois andares de sobre-lojas e mezzaninos num total de 192 unidades.

40 PAVIMENTO: No $4^{\circ}$ pavimento concentrava-se a parte social do hotel com um salão para refeições, uma galeria com lojas, uma piscina com vestiários, um restaurante com cozinha privativa, 2 amplos salões de festas e convenções, etc., com serviço separado e um salão de chá ou "boite", com elevador privativo.

50 PAVIMENTO: $0 \quad 5^{\circ}$ pavimento com cerca de $4.450 \mathrm{~m} 2$ compunha-se de um grande jardim, um instituto de fisioterapia, um restaurante, uma creche e jardim de infância para filhos dos hóspedes. 


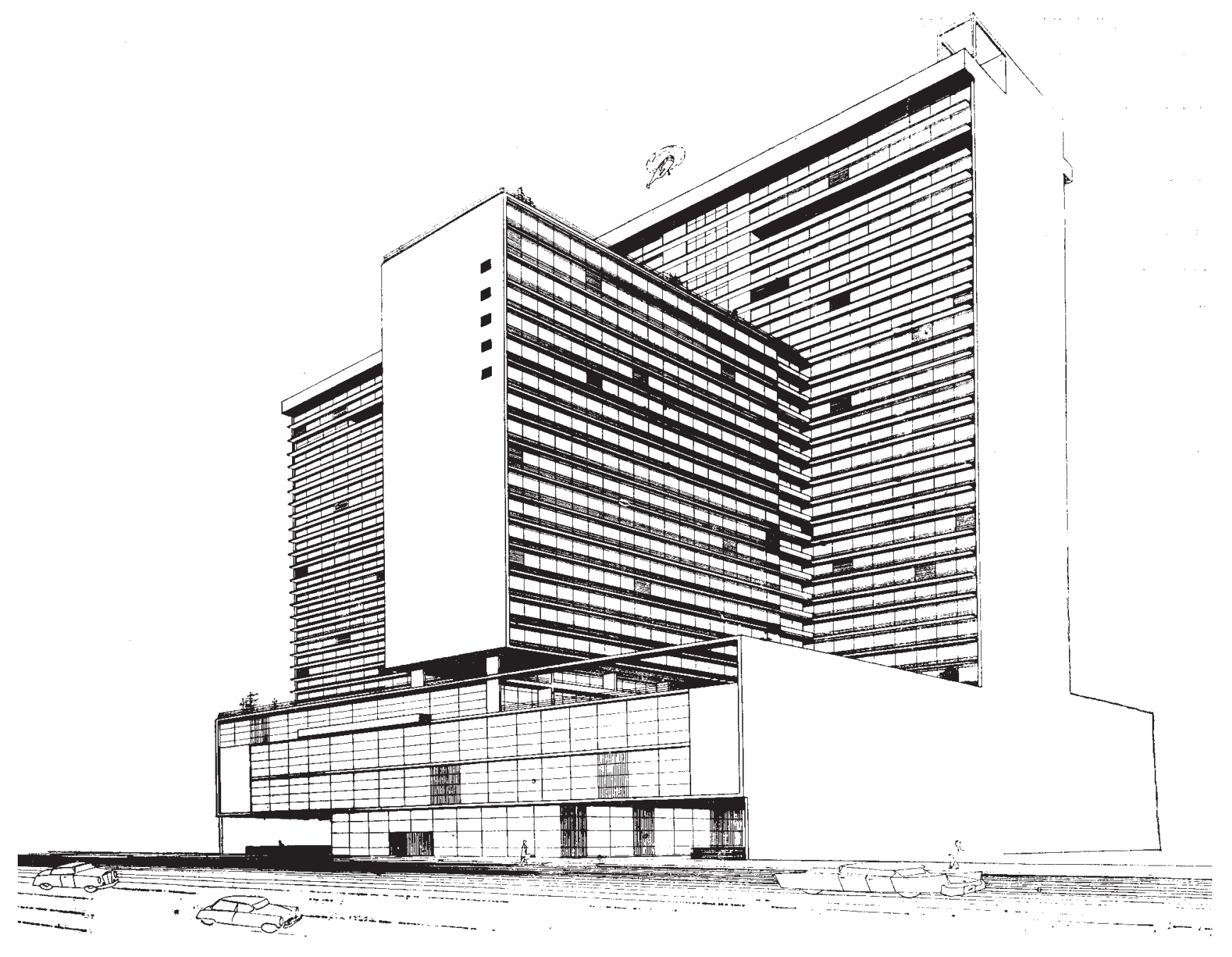

PAVIMENTO TIPO: Foram previstos 30 andares com 1230 apartamentos, sendo todos dispostos de frente

$26^{\circ}$ e $28^{\circ}$ PAVIMENTOS:Ai localizava-se o heliporto, para embarque e desembarque de passageiros, e uma ampla galeria com as 7 lojas de serviços como: agência de turismo, banco, restaurante, etc, a $115 \mathrm{~m}$ acima da rua

COBERTURA: A cobertura locava uma pista de pouso com $20 \mathrm{~m}$ por 80 .

TRATAMENTO DE FACHADAS: Para Todas as fachadas foi previsto revestimento com pastilhas esmaltadas coloridas. A fachada da Consolação no térreo, seria revestida com granito verde Ubatuba polido, e na primeira sobreloja com mezzanino havia caixilharia de alumínio.

TRATAMENTO PAISAGÍSTICO: Um andar ajardinado com $4.450 \mathrm{~m} 2$ 

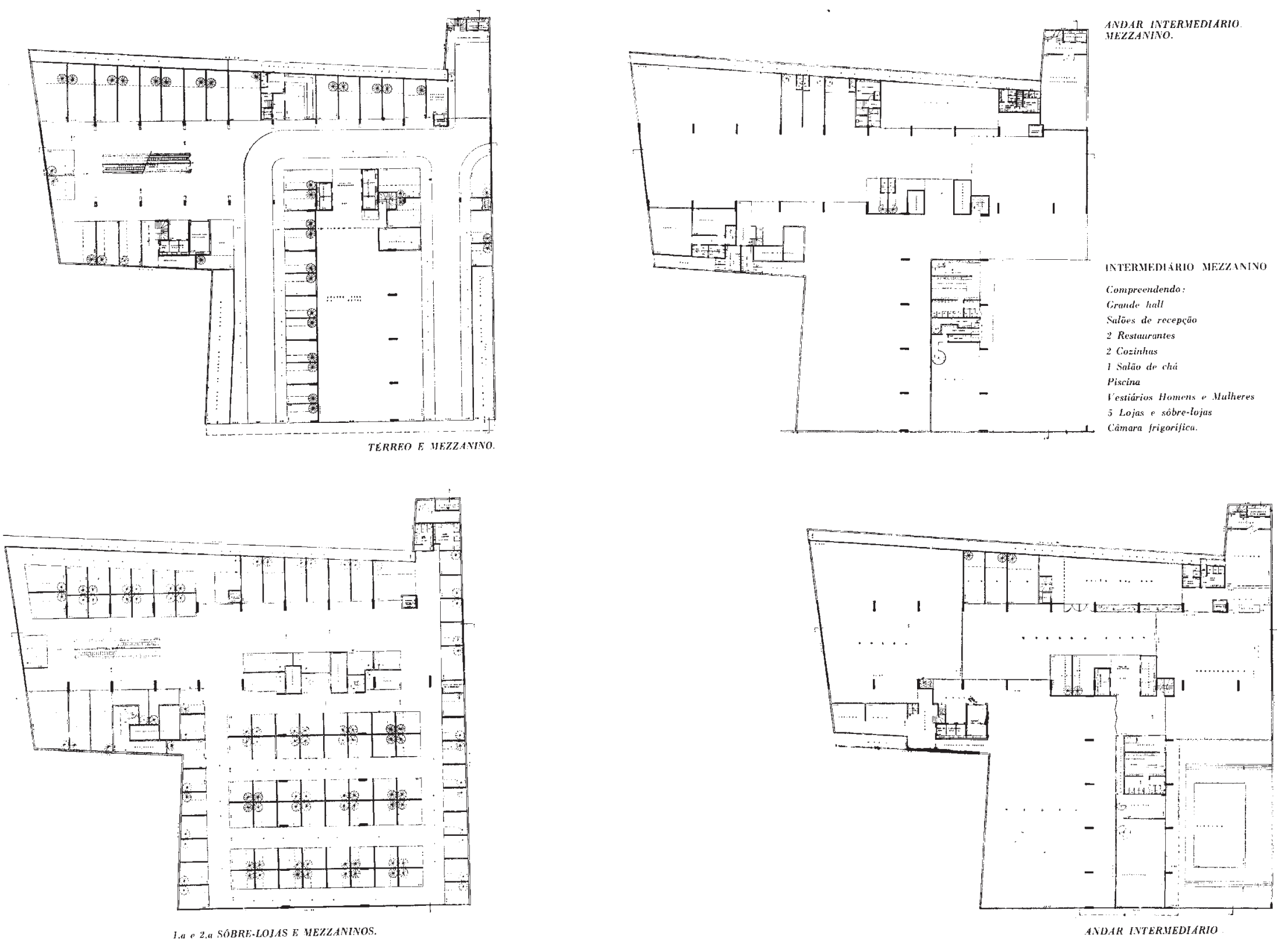

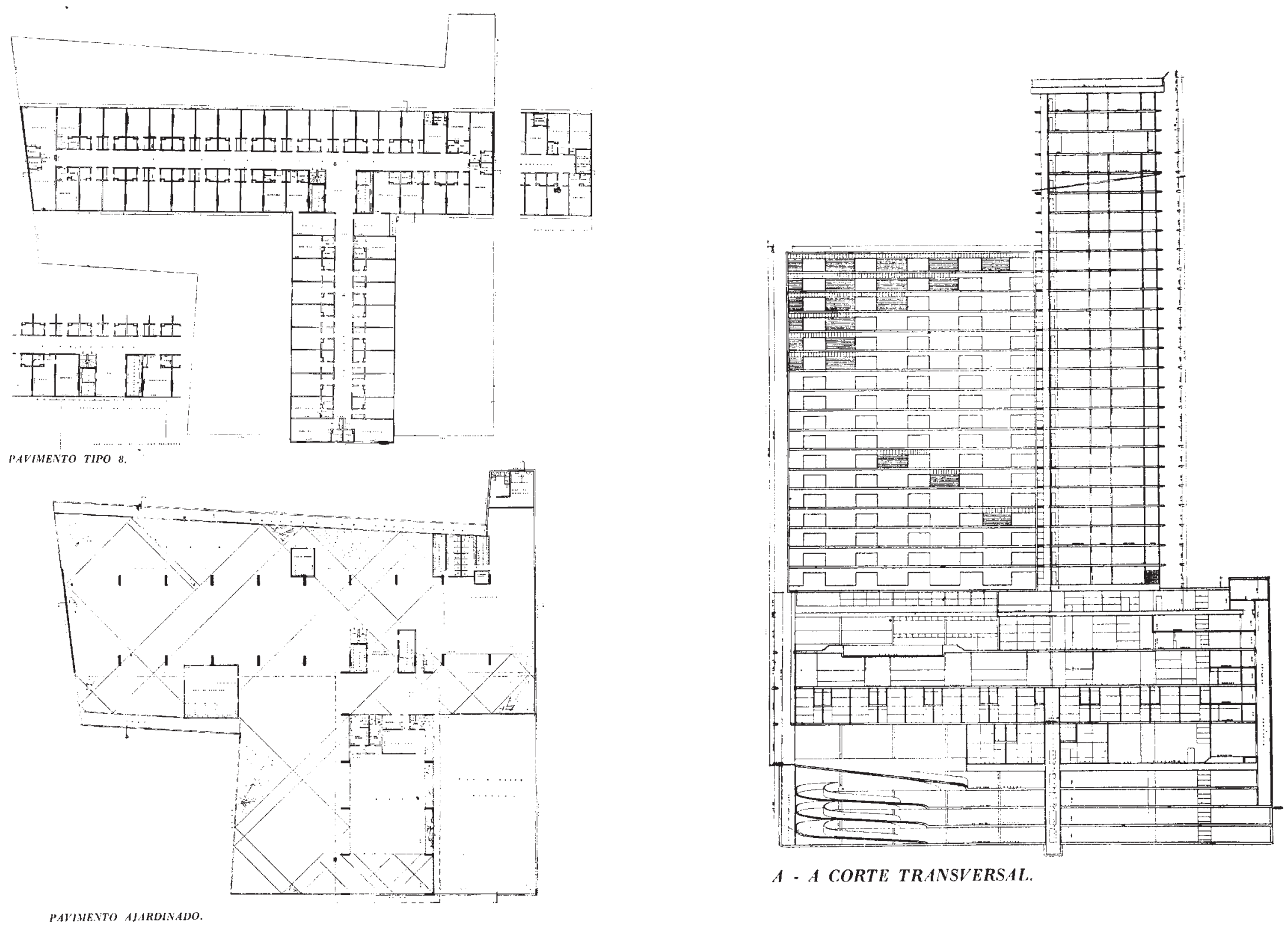

AVUEVTO AJARDINADO 


\section{Cobertura de piscina Clube Atlético Ourinhense}

\section{5}

Publicações:

Habitat 2, p.12-13.

1951.

Acrópole 184, p.172.

1953.

Habitat 39, p.7.

1957.
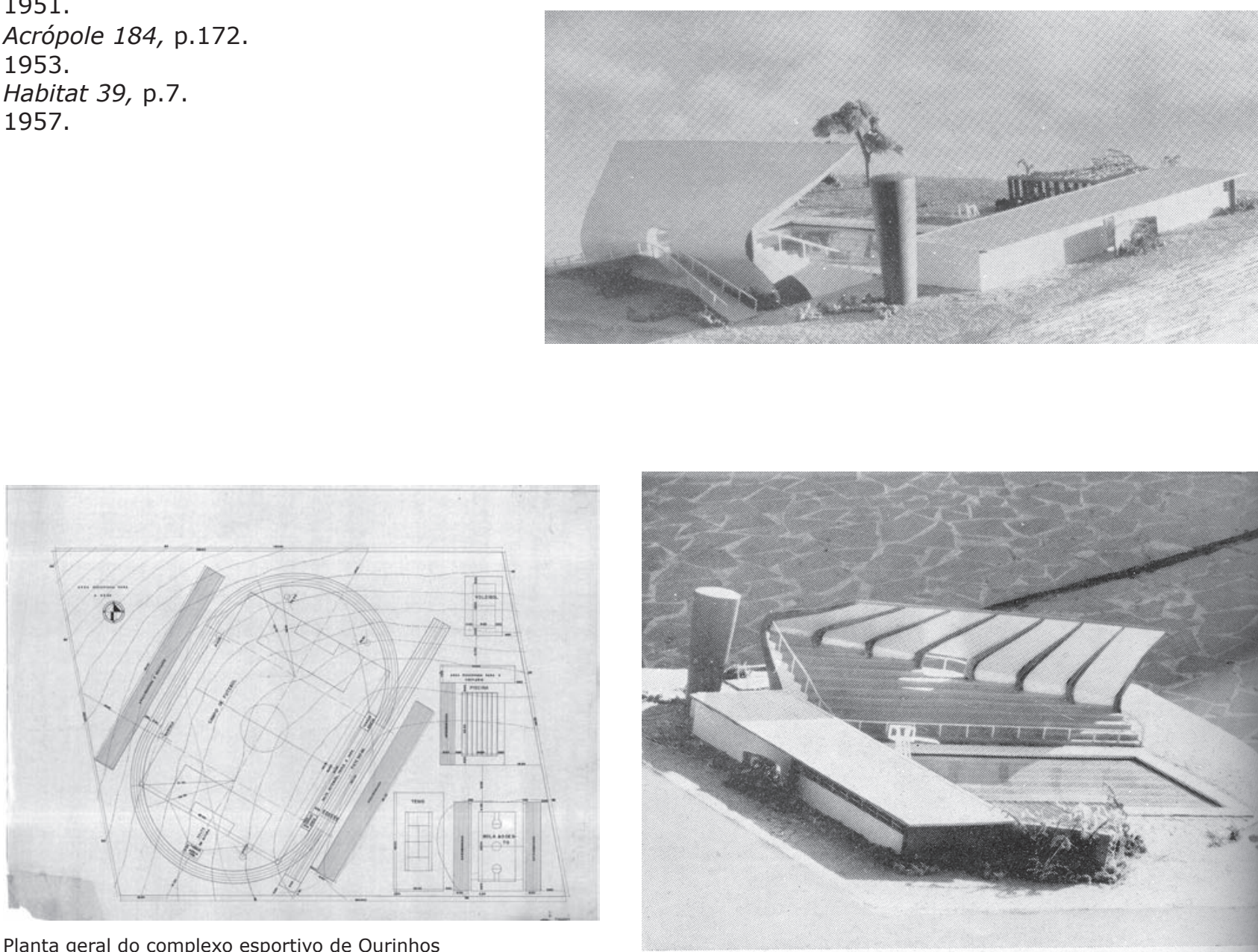

\section{DADOS DO PROJETO:}

Projeto: 1945

Execução: NE

Local: Ourinhos SP

Exposições:

Projeto

selecionado para $1^{a}$ Exposição Internacional de Arquitetura

(Bienal 1951)

\section{DESCRIÇÃO DO}

PROJETO:

Conjunto

esportivo

compreendendo piscina

arquibancada, vestiários $e$

um bar. A irregularidade do

terreno levou à solução da

arquibancada: os degraus

foram cobertos com uma forma continuada, dobrada em sentido oblíquo, obtendo assim um relevo diferente. A arquibancada é alcançada por meio de duas rampas convergentes que sobem do lado de trás.

Área do Lote: $20.5560 \mathrm{~m} 2$ Área Construída:

aproximadamente $1.000 \mathrm{~m} 2$

TRATAMENTO DE FACHADAS: O projeto aposta na plasticidade do concreto armado, pelo uso de curvas e balanços, dentro de uma geometria simples e bem elaborada. 

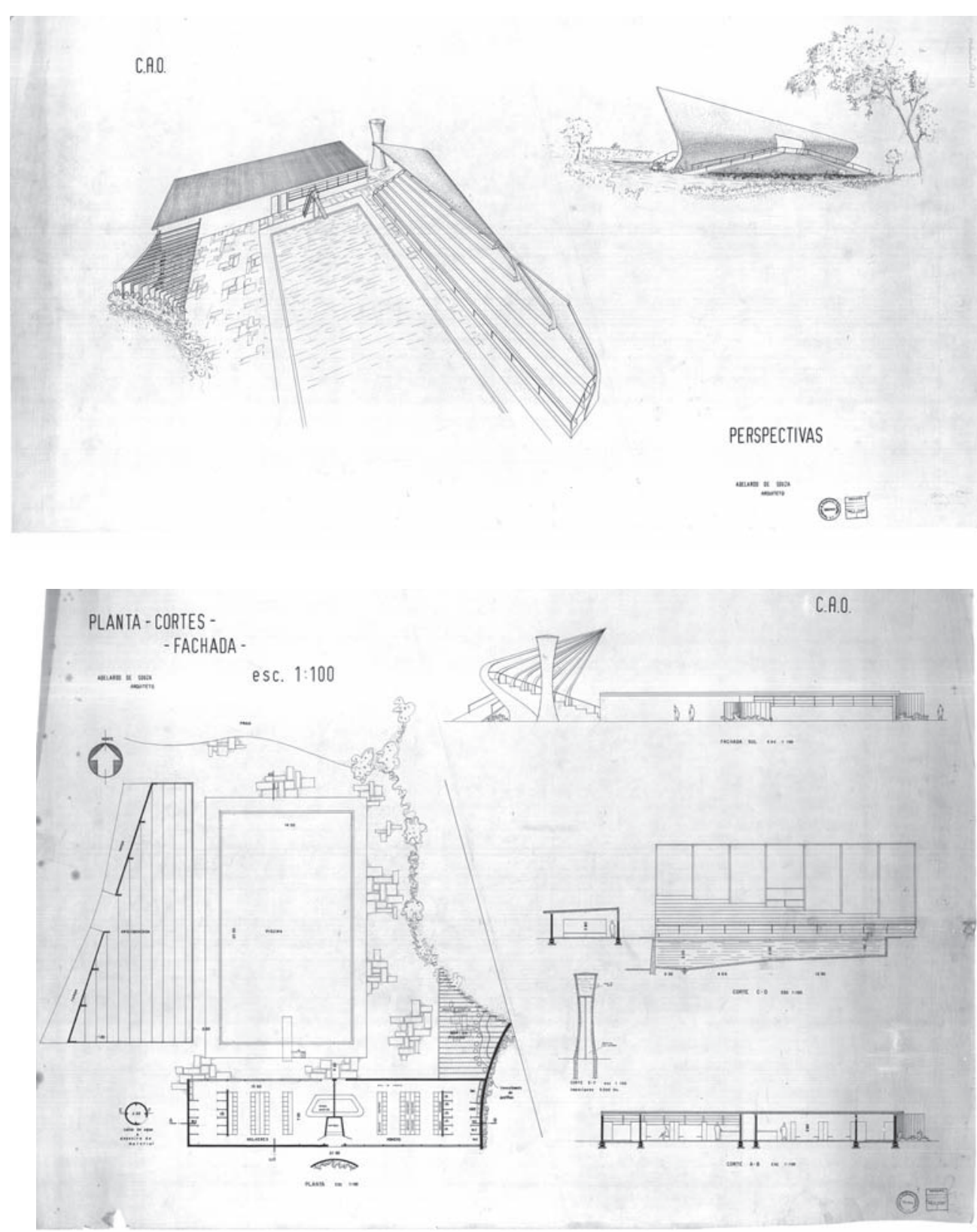


\section{Estúdios Tupã Filmes}

1948

Publicações:

Habitat 39, p.9.

1957.

DADOS DO PROJETO:

Execução: NE

\section{DESCRIÇÃO DO}

PROJETO:

O projeto para os estúdios da Tupã filmes foi um estudo de 1948. De acordo com

Geraldo Ferraz: "Resultou esse aglomerado de massas levemente onduladas, judiciosamente distribuídas numa larga combinação de linhas em que as retas horizontais não se chocam, antes se entrosam na interação orgânica do funcionamento."

(FERRAZ in Habitat 39, 1957)

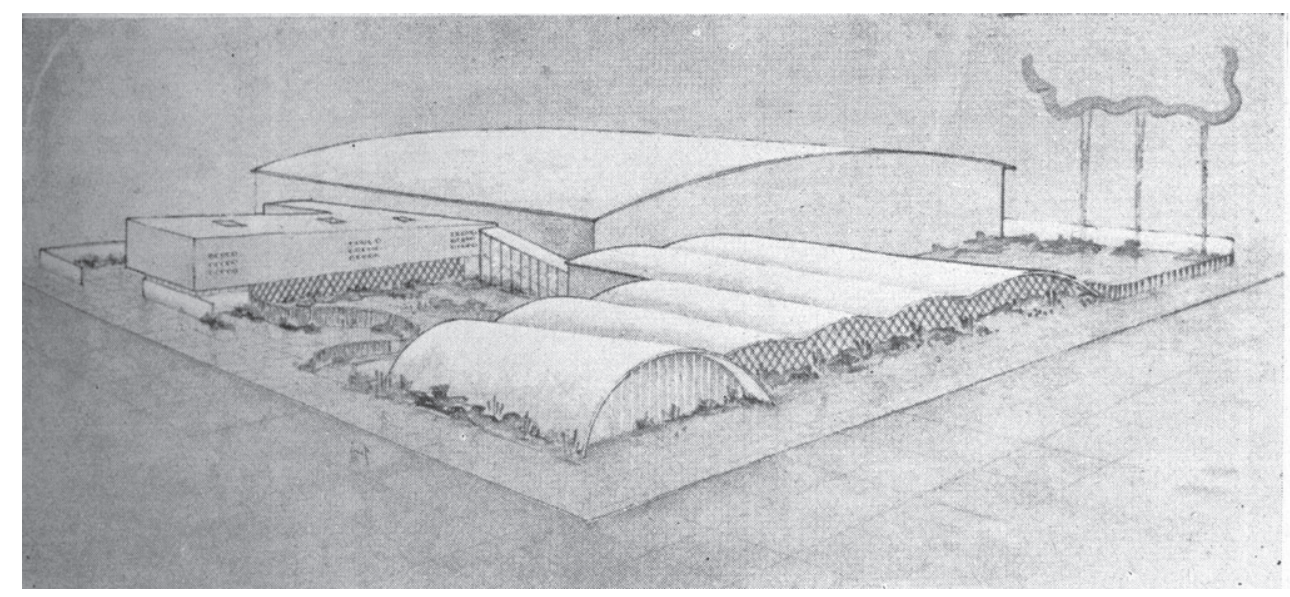




\section{Igreja na Rod. Pres. Dutra}

\section{3}

Publicações:

Habitat 17, p.18/9.

1953.

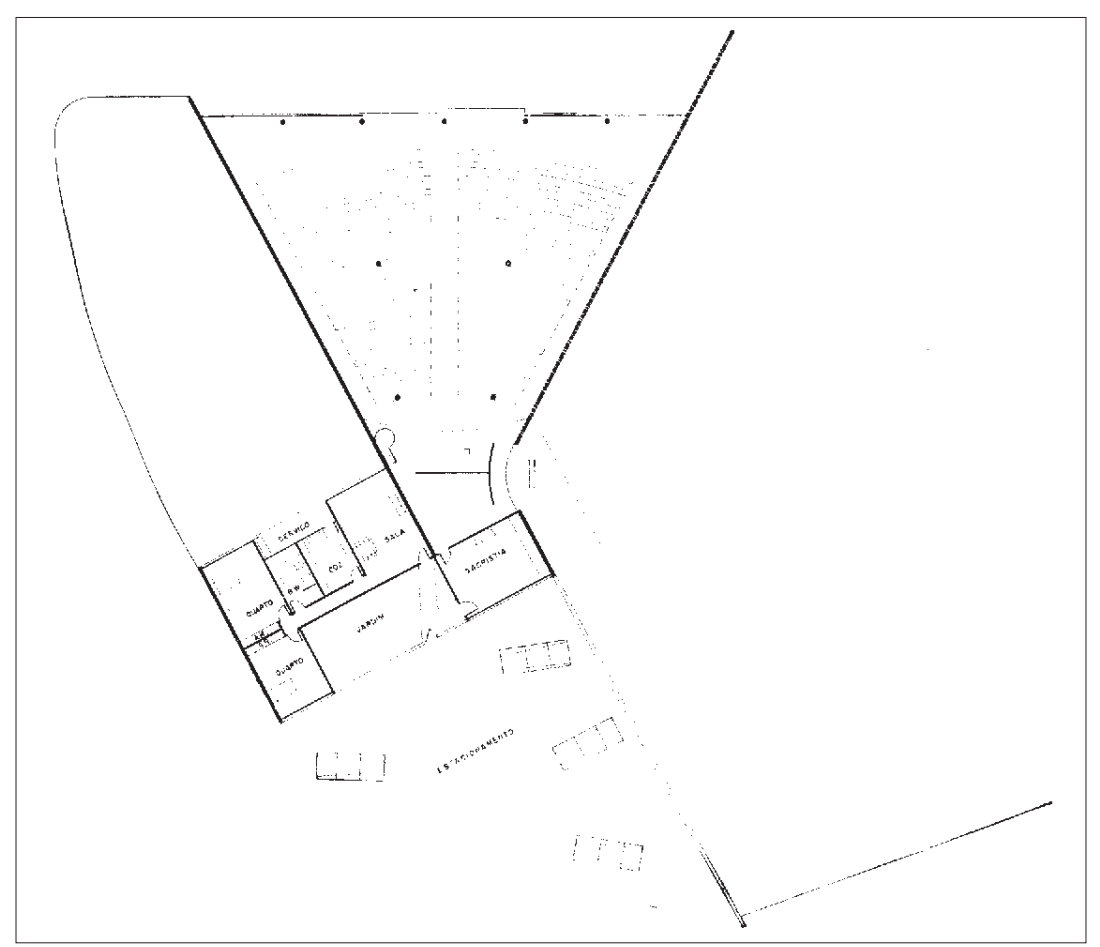

\section{DADOS DO PROJETO:}

Execução:NE

Incorporação: Roxo Loureiro

Local: Rod. Pres. Dutra. Mun.

de Guaratinguetá- SP

\section{DESCRIÇÃO DO PROJETO:}

Igreja a ser construída no núcleo residencial, também projetado por Abelardo de Souza, na Via Presidente Dutra (Clube dos 500), entre as cidades de Guaratinguetá e Lorena.

Esta pequena igreja foi planejada para uma comunidade com população de aproximadamente de 5.000 pessoas.

\section{Área do Lote: \\ Área Construída:}

PAVIMENTO TÉRREO: O projeto apresenta um acerta tranparência pelo uso de elementos vazados e venezianas, visando integrar exterior e interior. A planta tem formato de polígono irregular. Estruturalmente a cobertura se apoia em pilares distribuidos regularmente e alvenarias estruturais.

A área de serviço tem bom isolamento das áreas públicas.
Com relação à parte construtiva foi previsto o uso de materiais locais como tijolo, pedra, madeira, etc.

Uma vedação móvel em veneziana de madeira na fachada principal permite sua completa abertura para o exterior. Era prevista uma cobertura feita em treliça de ferro redondo soldado com placas de material isolante.

TRATAMENTO PAISAGÍSTICO A igreja encontrava-se inserida no loteamento do clube dos 500, dentro de uma das áreas destinadas 'a praça pública e atividade de lazer. Não existia ainda um projeto definido de paisagismo, mas eram previstas, além das atividades no interior da igreja, solenidades e festas ao ar livre integrando a praça fronteira, onde seriam realizadas. 


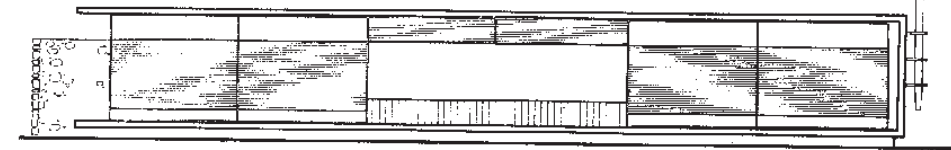

Fachater wrincipal.

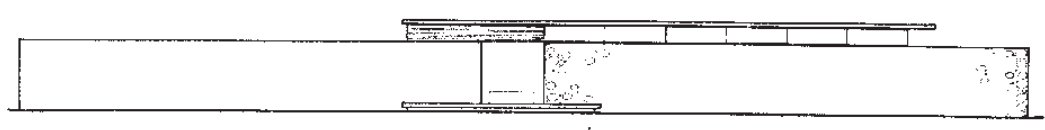

Fachada lateral.
$\bar{L}$
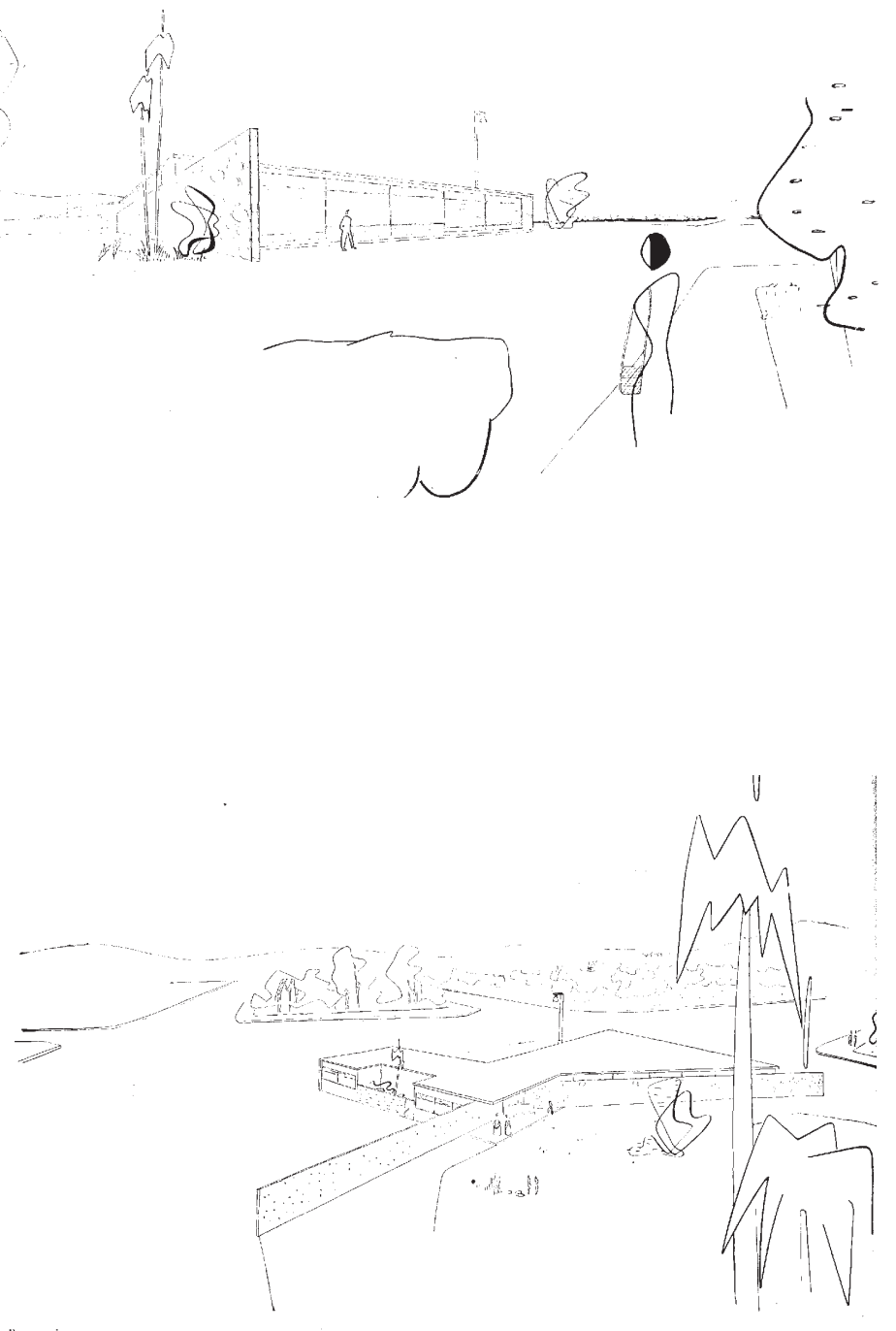


\section{Cruzeiro Futebol Clube}

\section{3}

Publicações:

Habitat 12, p.28.

1953.

Acrópole 184, p.173.

1953.

Arquitetura e Engenharia 32,

p.26-7.

1954.

Habitat 39, p.11.

1957.
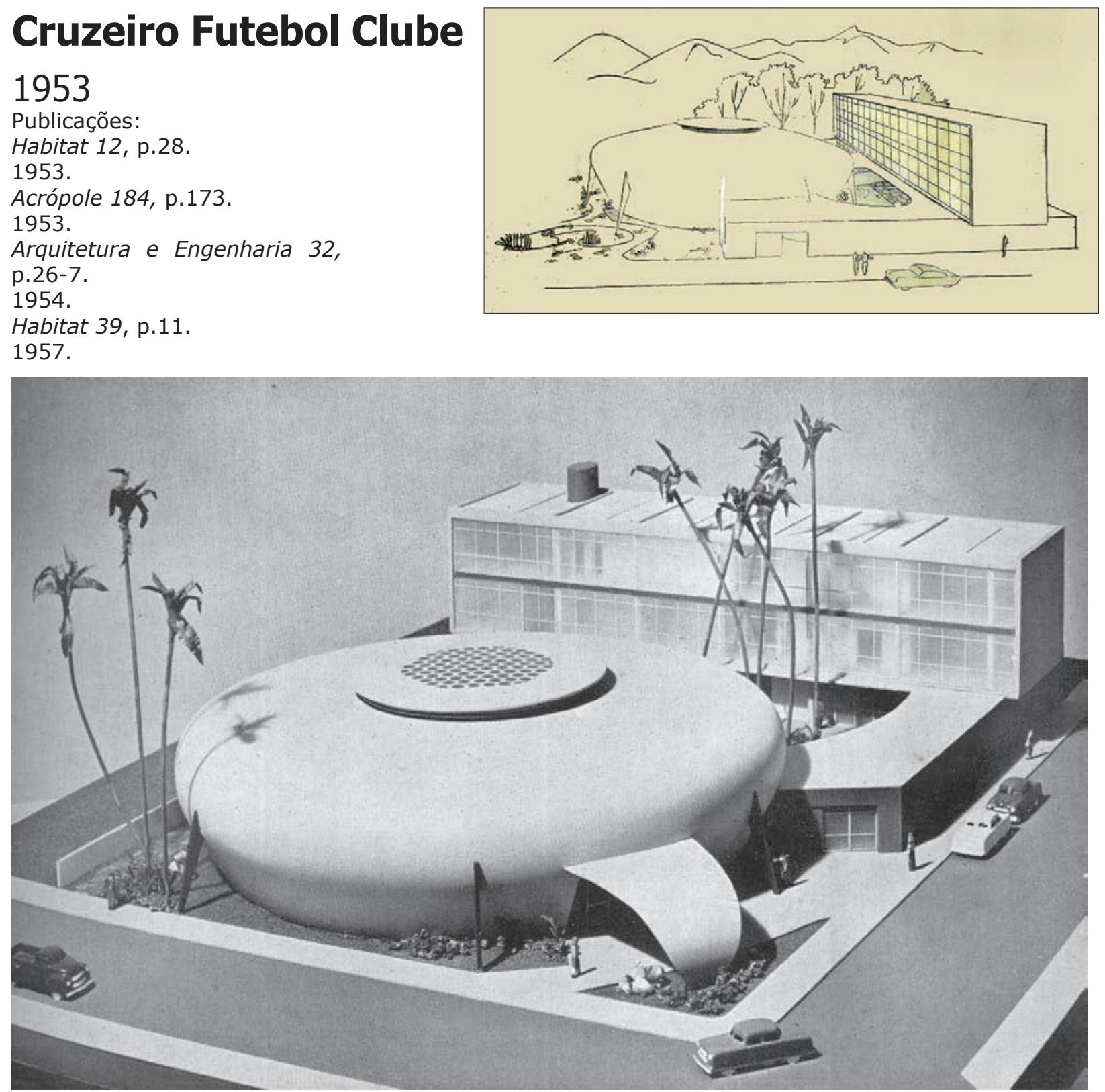

\section{DADOS DO PROJETO:}

Execução:NE

Incorporação: Cruzeiro

Futebol Clube

Local: Rua Major Hermógenes

com Rua Cap. Avelino Bastos.

Cruzeiro

\section{DESCRIÇÃO DO PROJETO:}

Este projeto com um denso aproveitamento do terreno constitui-se basicamente de dois blocos, um do tipo lamelar com 2 pavimentos e o outro uma ampla cúpula, que são interligados por rampas e com um sistema de circulação interna bem definido. Tratase do projeto estudado para - Cruzeiro Futebol Clube, da cidade de Cruzeiro, norte do estado de São Paulo. O arquiteo faz neste projeto a aplicação formal de diversos índices de modernismo: disposição funcional da planta, estrutura livre marcada na fachada, grandes panos de vidro, uso do concreto em toda sua plasticidade.

\section{Área do Lote:}

Área Construída: 2181,71m2 No de pavimentos: 2 
PAVIMENTO TÉRREO: Toda parte social para os associados com: portaria, salão de festas, restaurante, sanitários o grande bloco abrigava o salão de baile, com dois acessos pelo clube através de braços circulares que ligam os dois prédios e uma entrada diretamente pela rua realizada através de marquise em que a estrutura curva de cobertura apóia-se diretamente no solo. A iluminação deste bloco é feita através de domo em concreto "vazado", coberto com elemento translúcido e a ventilação pelas laterais deste domo.

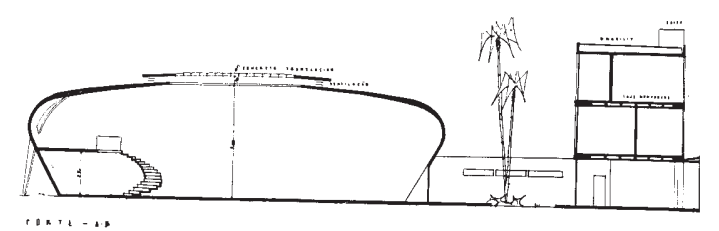

Corte

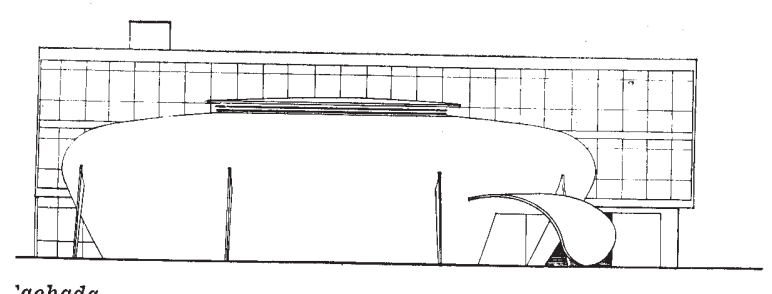

10 PAVIMENTO Abriga hall, balcão de atendimento sala de jogos e 2 sanitários.

20 PAVIMENTO: Destinado à administração do clube

TRATAMENTO DE FACHADAS: $O$ arquiteto brinca com os contrastes de forma e de materiais contrapondo o volume cerrado que compõe o salão com a transparência do bloco administrativo, que possui vedação em vidro, ao fundo. Joga com os pesos de forma equilibrada obtendo assim uma

composição harmônica.

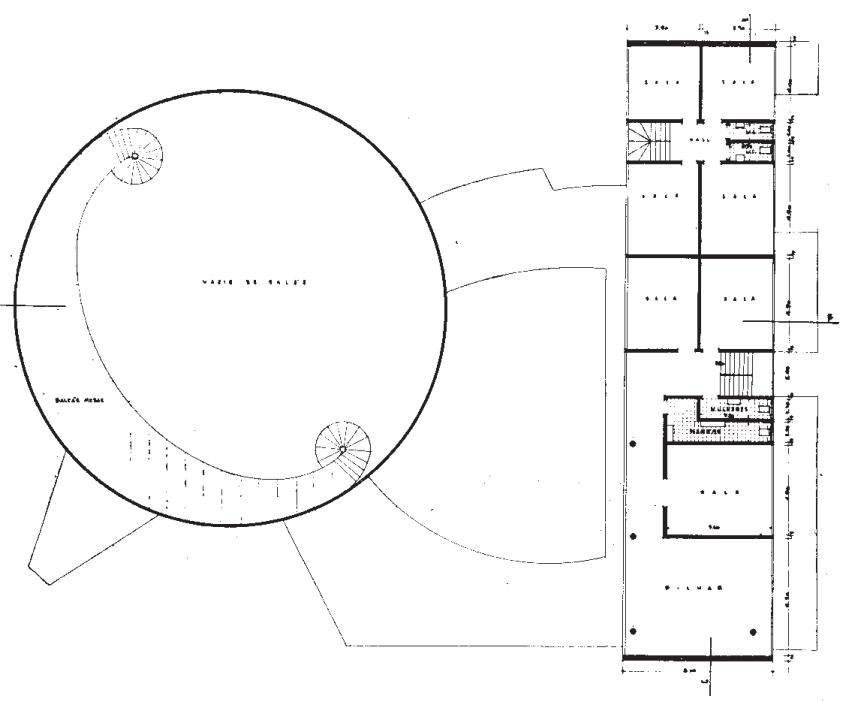




\section{Mercado do Brás}

\section{4}

Publicações:

1956.

Habitat 39, p.17.1957.

MINDLIN, The Architecture

in Brazil .p.41
Habitat 33, p.50-3.

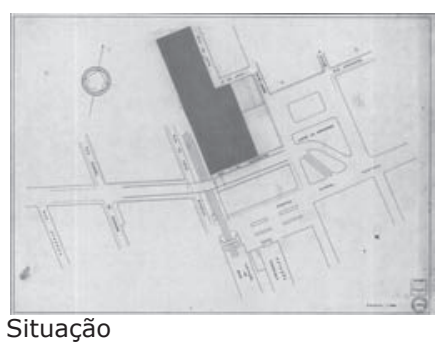

Situação

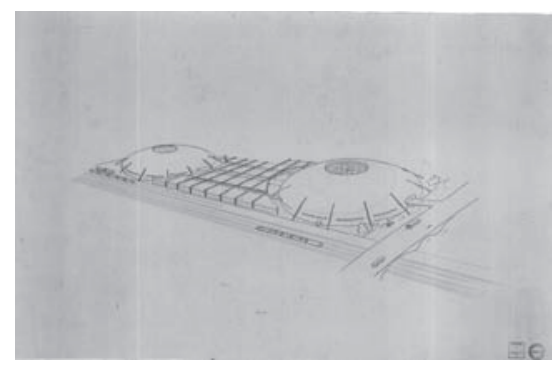

Fotomontagem com maquete

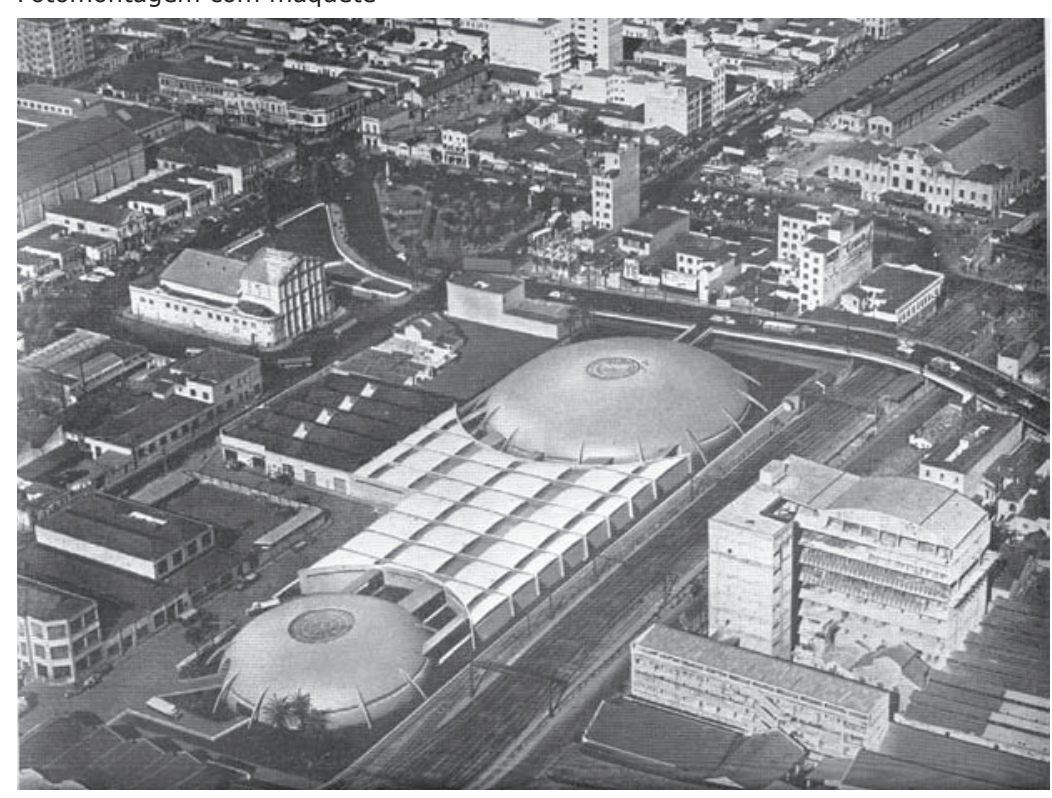

\section{DADOS DO PROJETO:}

\section{Execução: NE}

Local: Rua do Gasômetro e largo da Concórdia. São Paulo. SP

\section{DESCRIÇÃO DO \\ PROJETO:}

Este projeto de 1956, não construído, localizava-se em terreno na Rua do Gasômetro, próximo ao largo da Concórdia no Bairro do Brás, o arquiteto visava resolver um problema de abastecimento em grande escala devido a alta densidade populacional do Bairro ${ }^{1}$.

Centrou-se na resolução dos problemas de circulaçãofornecedores e público, sendo que o terreno com duas frentes facilitou a solução para os dois tipos de tráfego: duas entradas em dois níveis. A solução claramente racionalista, com funções distintas reveladas pelos volumes interligados, não acarretou em tensões nas estruturas, que apresentam-se leves, utilizando formas puras. O projeto incluia também uma área de lojas no quarteirão entre as Ruas Barão de Ladário, Muller e o Largo da Concórdia.

Área do Lote: 9.406,50m2

Área Construída: 28.000m2 No de pavimentos: 2

SUBSOLO: Destinado a estacionamento com aproximadamente 388 vagas sendo 318 para visitantes e 70 para abastecimento. O acesso de usuários do mercado é feito sob o Viaduto pela Rua do Gasômetro e o de fornecedores pela Rua da Juta na parte de trás do terreno.

PAVIMENTO TÉRREO E MEZZANINO: Ingresso para pedestres através de rampa pelo viaduto sobre a rua do Gasômetro e também pela Rua da Juta. As grandes áreas destinadas aos boxes não possuem divisão. O mezzanino é sustentado pelas colunas que compõem os boxes e sua área central é vazada, permitindo entrada de luz natural no piso inferior. 
TRATAMENTO DE FACHADAS:

Para o grande entreposto comercial o arquiteto aproveitou toda extensão do terreno, mas escapou à formação das caixas. A estrutura em "casca", que lembra os volumes de Niemeyer para o Museu da Aeronáutica no Ibirapuera, visava melhor aproveitamento interno com redução do número de colunas, obtendo um vão livre de 75 m, com altura de $18 \mathrm{~m}$ e também uma plasticidade original que permitia uma fácil leitura do projeto.

A ventilação e iluminação seriam feitas através de óculos Laterais e pela abertura na parte superior.

Não há maiores informações sobre acabamentos.

O projeto arrojado obteve ampla divulgação em revistas e em Mindlin, no seu Arquitetura Moderna no Brasil.

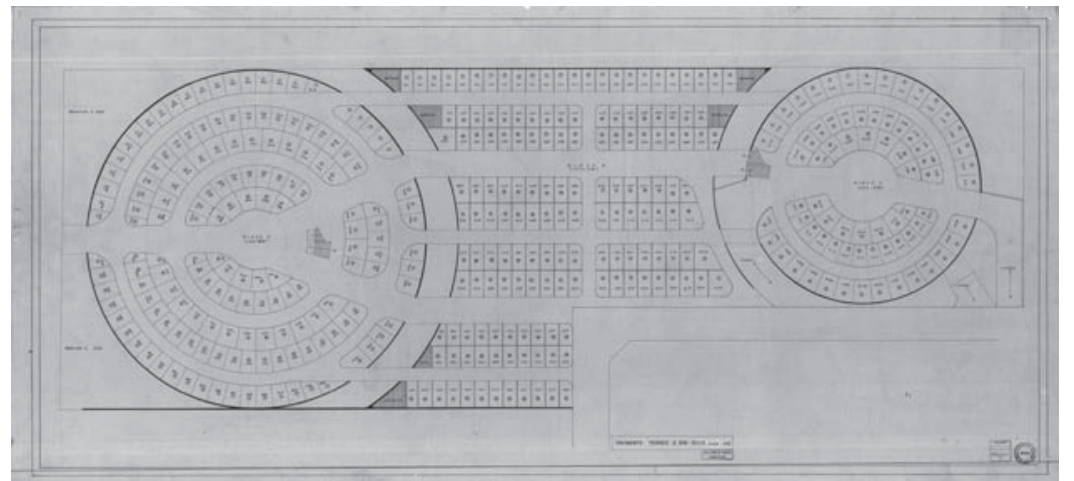

Planta subsolo.

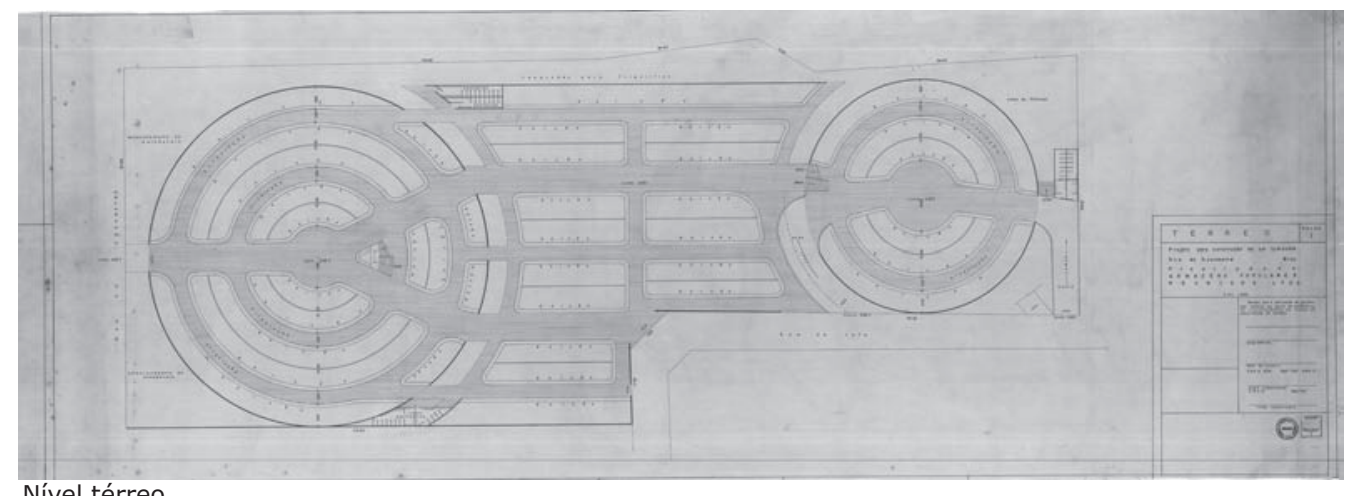

térreo.

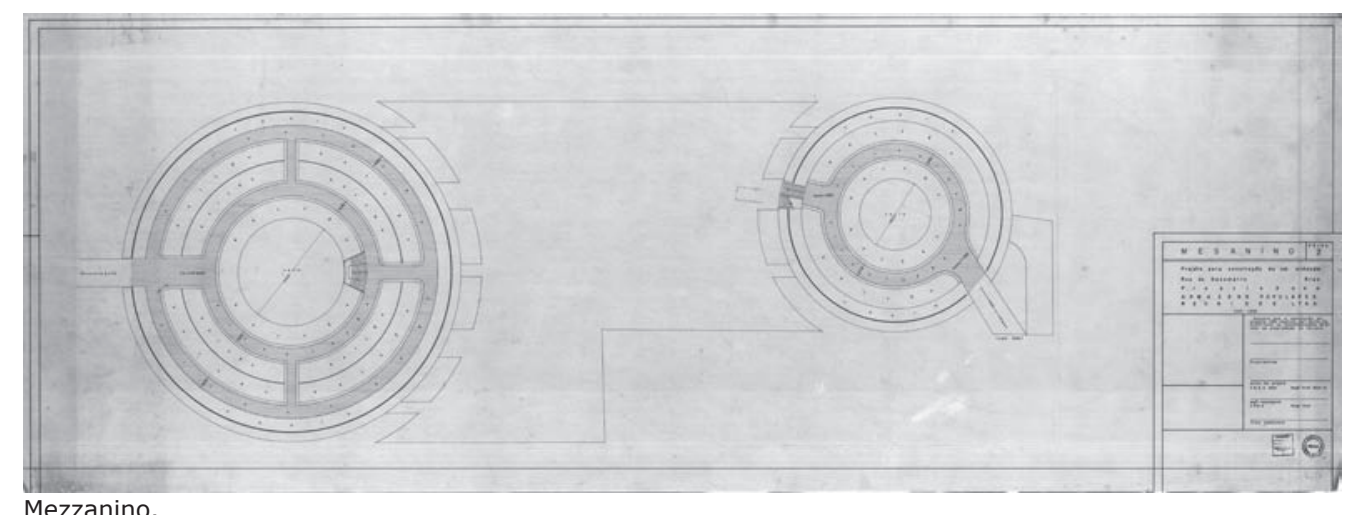




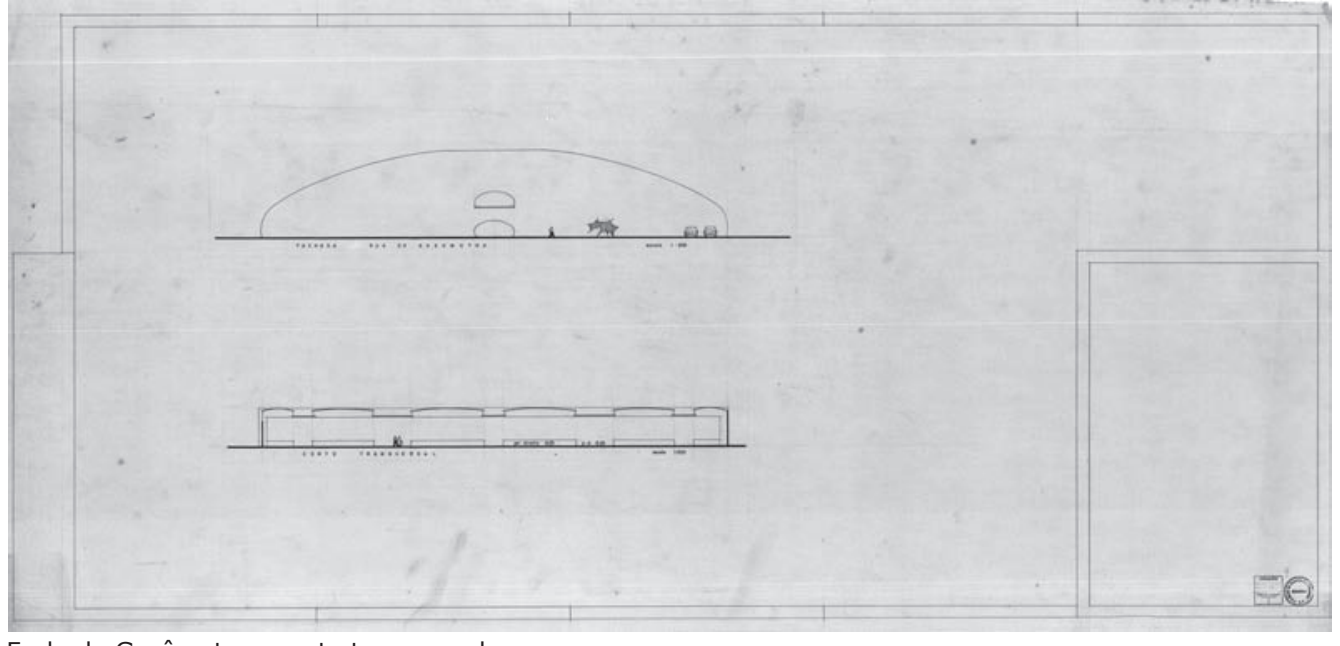

Fachada Gasômetro e corte transversal.

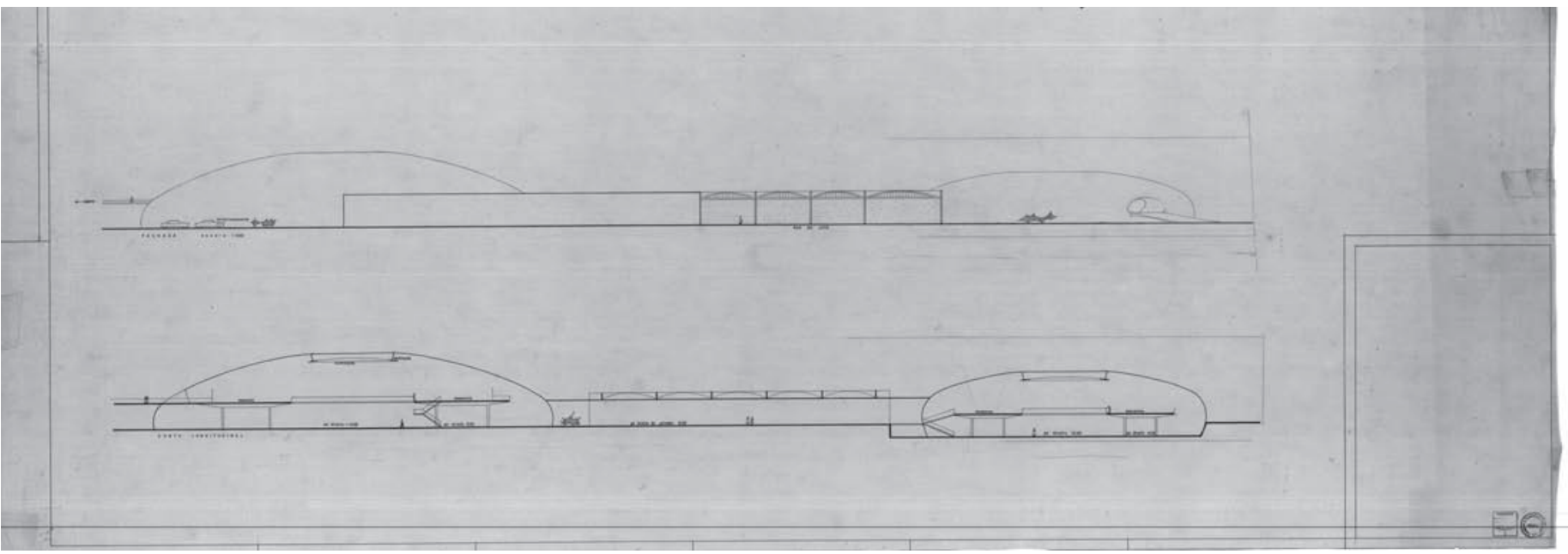


Boxes para lojas no largo da Concórdia.
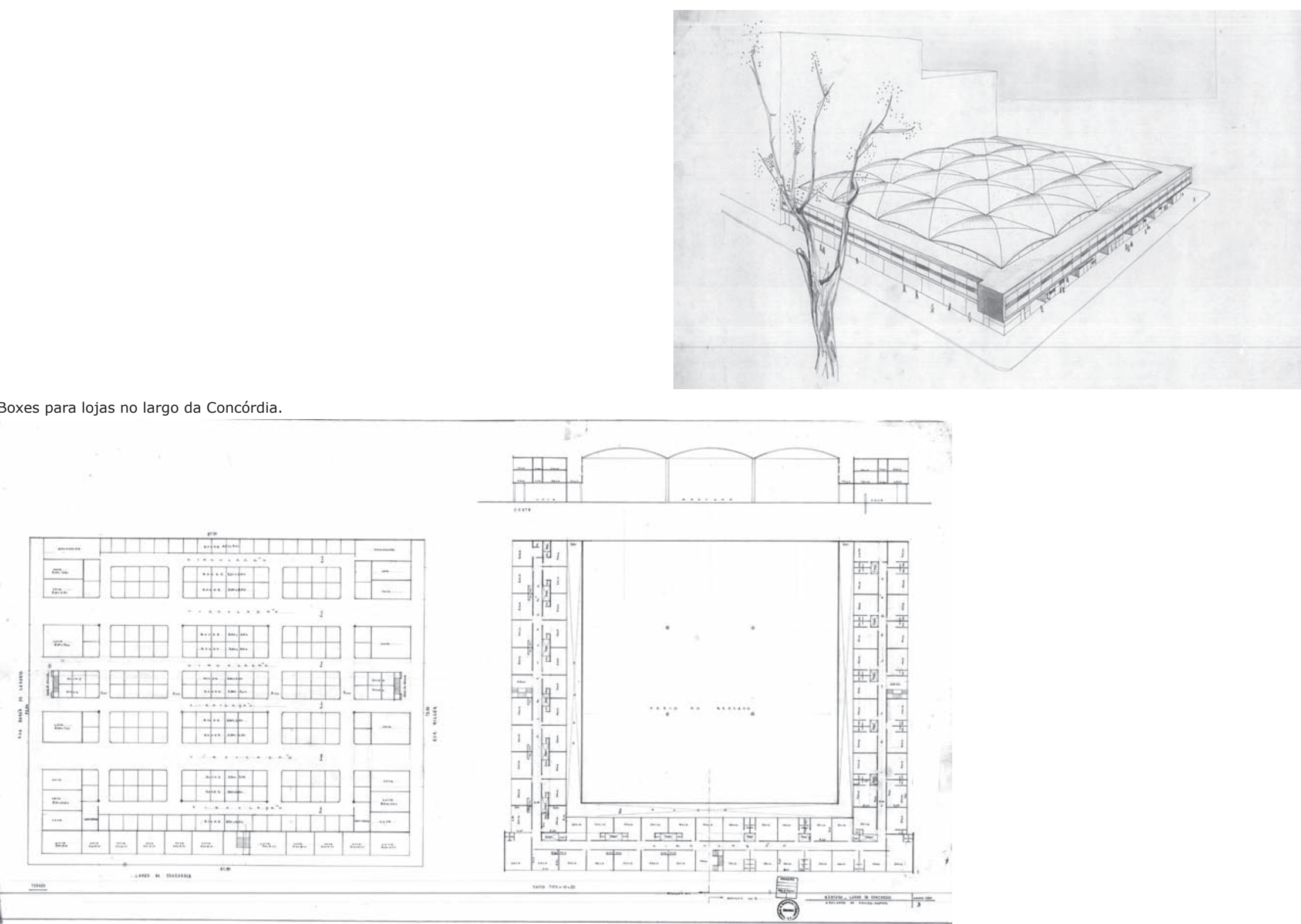


\section{Teatro Thalia}

\section{9}

Publicações:

Habitat 54, p.8-12.

1959.

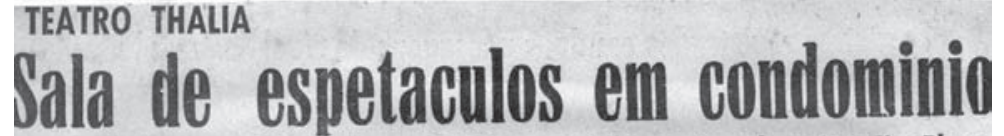

No proximo mês será feito o lançamento do novo edíficio, na área do extinto Cine Plaza - Carateristicas da arquitetura - Participaçáo do espectador na propriedade do imovel

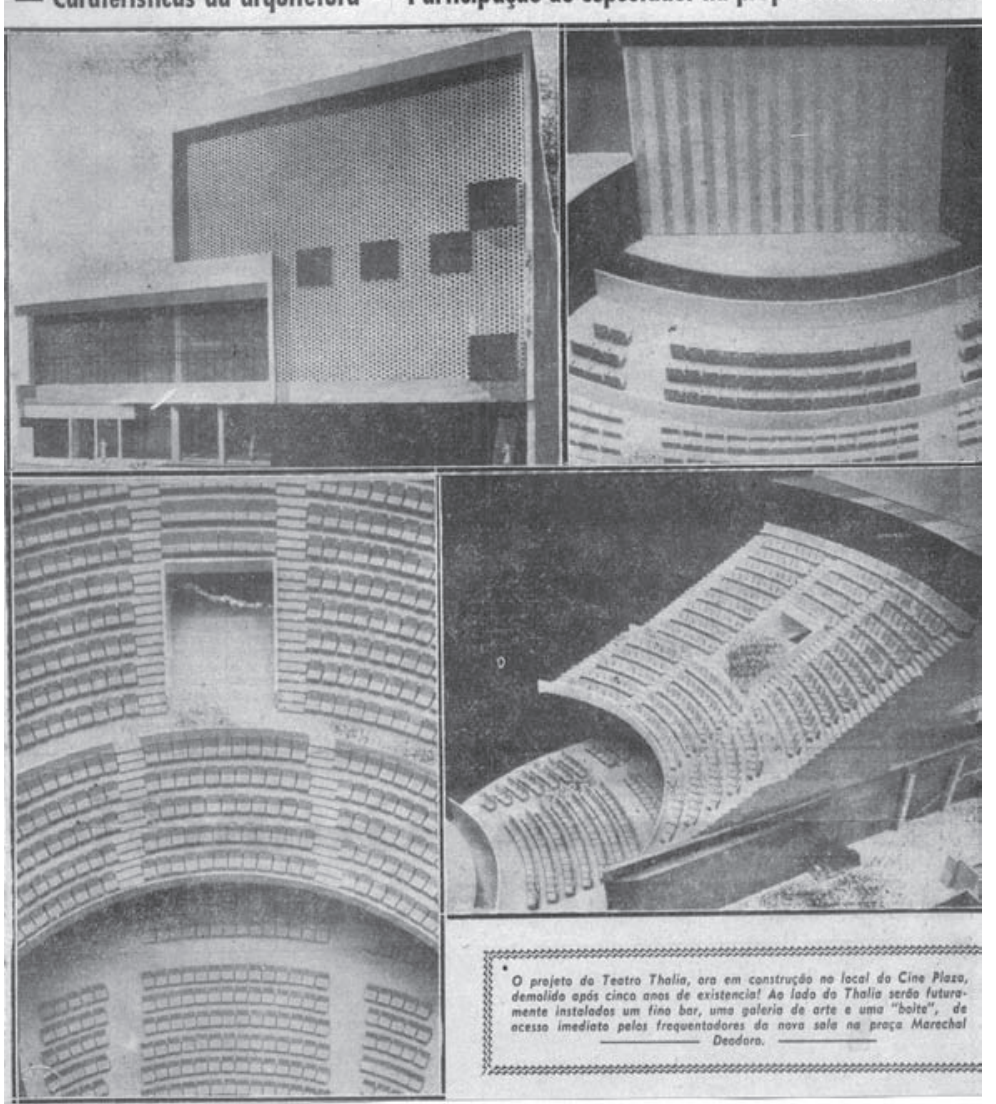

DADOS DO PROJETO:

Colaborador: Jorge Caron

Estrutura: J.C. Figueiredo

Ferraz

Acústica: Igor Sresnewsky

Assessor técnico: Aldo Calvo.

Execução: NE

Incorporação: proprietário:

Mario Bartholo; incorporação:

Mario de Miranda Valverde e

Alcides Procópio; presidente:

dr. Edmundo Monteiro; vicepresidente: Francisco Matarazzo Sobrinho.

Local: Pça.Mal.Deodoro 340-

Sta.Cecília. São Paulo-SP.

Publicações:

\section{DESCRIÇÃO DO}

PROJETO:

Edifício destinadoaserum centro de arte, mas principalmente um centro teatral: o teatro Thalia, que compreendia no mesmo edifício uma Galeria de Arte, Bar e Boite.

Com uma platéia côncava proporcionava uma visão ampla de seus 828 lugares. O palco, proporcional ao número de lugares era, segundo matéria publicada em Habitat "o terceiro em dimensões" no mundo, possibilitando dessa maneira a apresentação de grandes montagens, sem qualquer dificuldade de ordem técnica.

Localizado no imóvel pertencente ao cine Plaza, o plano para execução do projeto era "vender o teatro (imóvel inclusive) em condomínio para cerca de oitocentos quotistas, que teriam lugares privativos, cadeiras cativas, para todas as estréias. Seriam donos do teatro, do edifício, com direito também ao lucro proveniente da sua exploração." (Fonte: arquivo pessoal do arquiteto, artigo sem indicação e sem data)

\section{Área do Lote:}

Área Construída:

No de pavimentos: 6

FOYER: Grande Hall de entrada que conduz à platéia e acessos ao balcão. Num prédio anexo, ligado ao teatro por paredes e portas de vidro, projetou um pequeno bar, uma galeria de arte e uma "boite", com palco independente e pista de dança com capacidade para duzentas pessoas.

A decoração ficaria à cargo 
dos artistas: Noemia, Renina Katz, Arnaldo Pedroso D'Horta e Caetano Fracarolli. Para uma das paredes da sala de espera da platéia era previsto um grande painel de Di Cavalcanti.

PLATÉIA E PALCO: O teatro previa um palco dentro das exigências das companhias. Além de "passarela" desmontável (para revistas), fosso de orquestra, um palco com doze metros de boca de cena, com fugas laterais de três metros e meio para cada lado. A altura da boca era de nove metros, com urdimento na altura de quinze metros. Três elevadores no palco, além de giratório. A platéia do teatro comportaria 481 espectadores.

BALCÕES: Amplo hall e uma sala de espera no andar superior. Lotação de 347 nos lugares no balcão.

TRATAMENTO DE FACHADAS: O espaço escolhido para o teatro abrigava o antigo Cine Plaza, mas a reforma não se constituía apenas a uma adaptação superficial. Praticamente

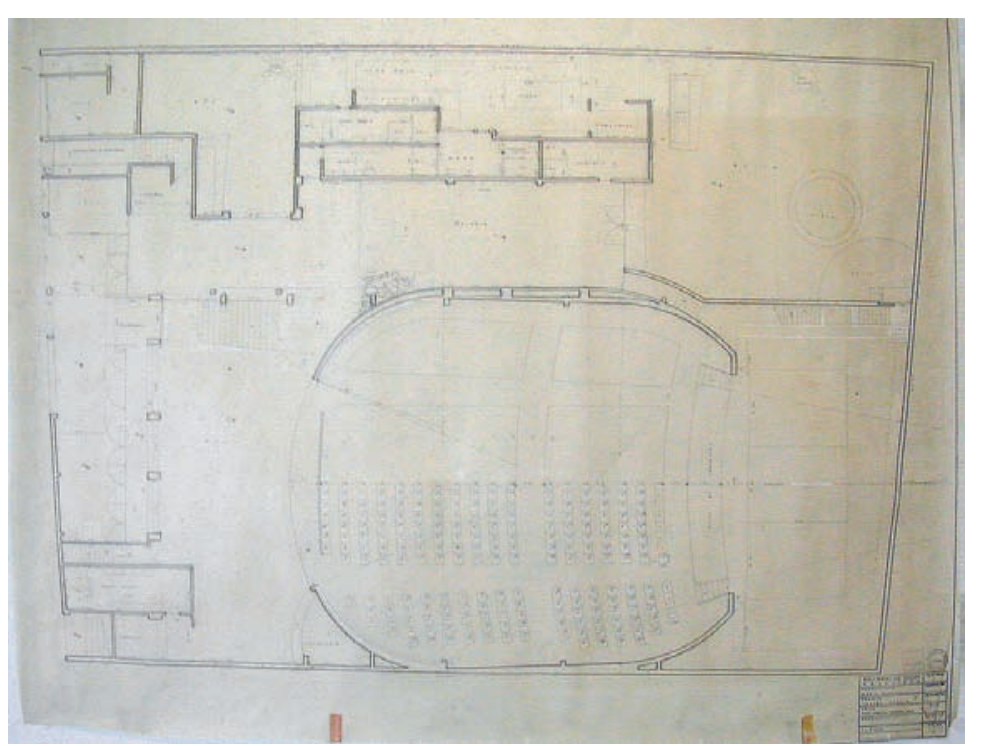

\section{Planta balcão}

Planta platéia e anexos.

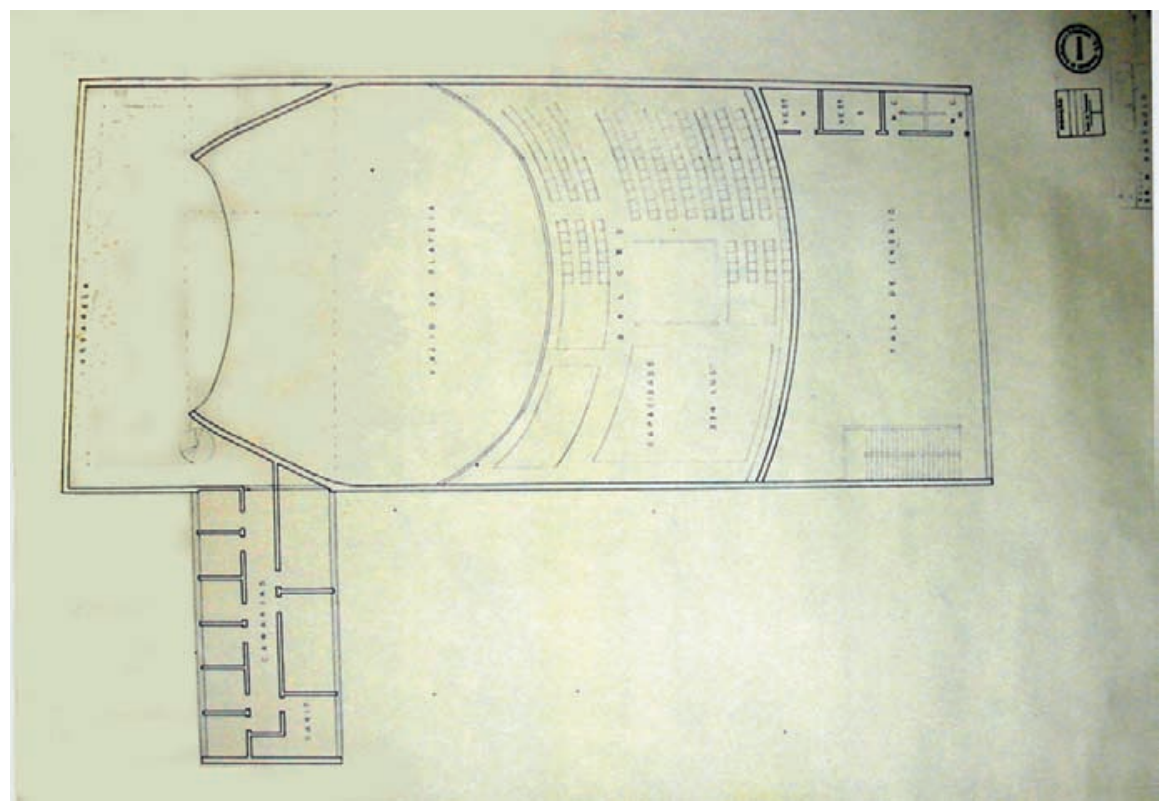


somente as paredes exteriores do "Plaza" continuariam de pé Do antigo cinema nada seria aproveitado. A fachada ganhou linhas moderna, sendo a caixa do teatro destacada e revestida em de tijolos de cerâmica. Uma grande "marquise" pontuava a entrada e um prédio anexado compunha o volume menor na fachada, com terraço de pé direito duplo no nível do balcão.

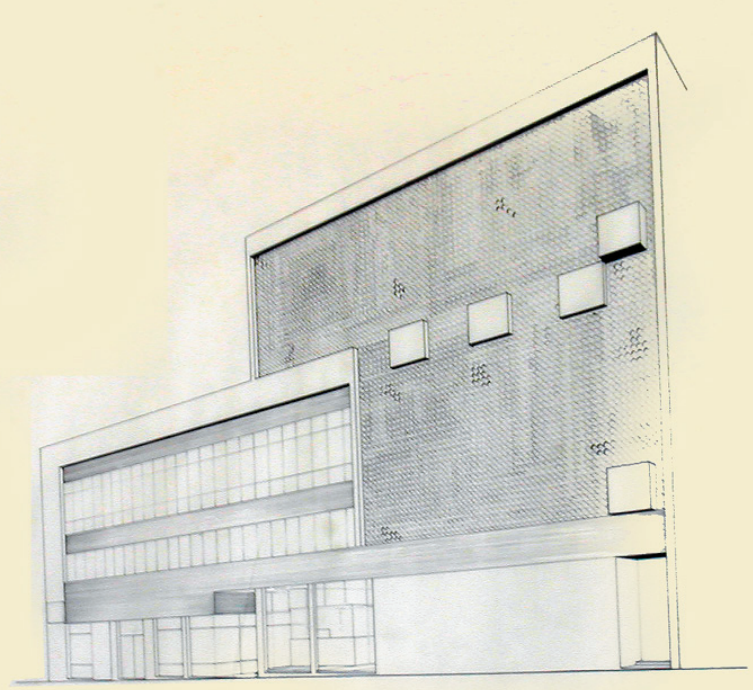

Corte longitudinal.

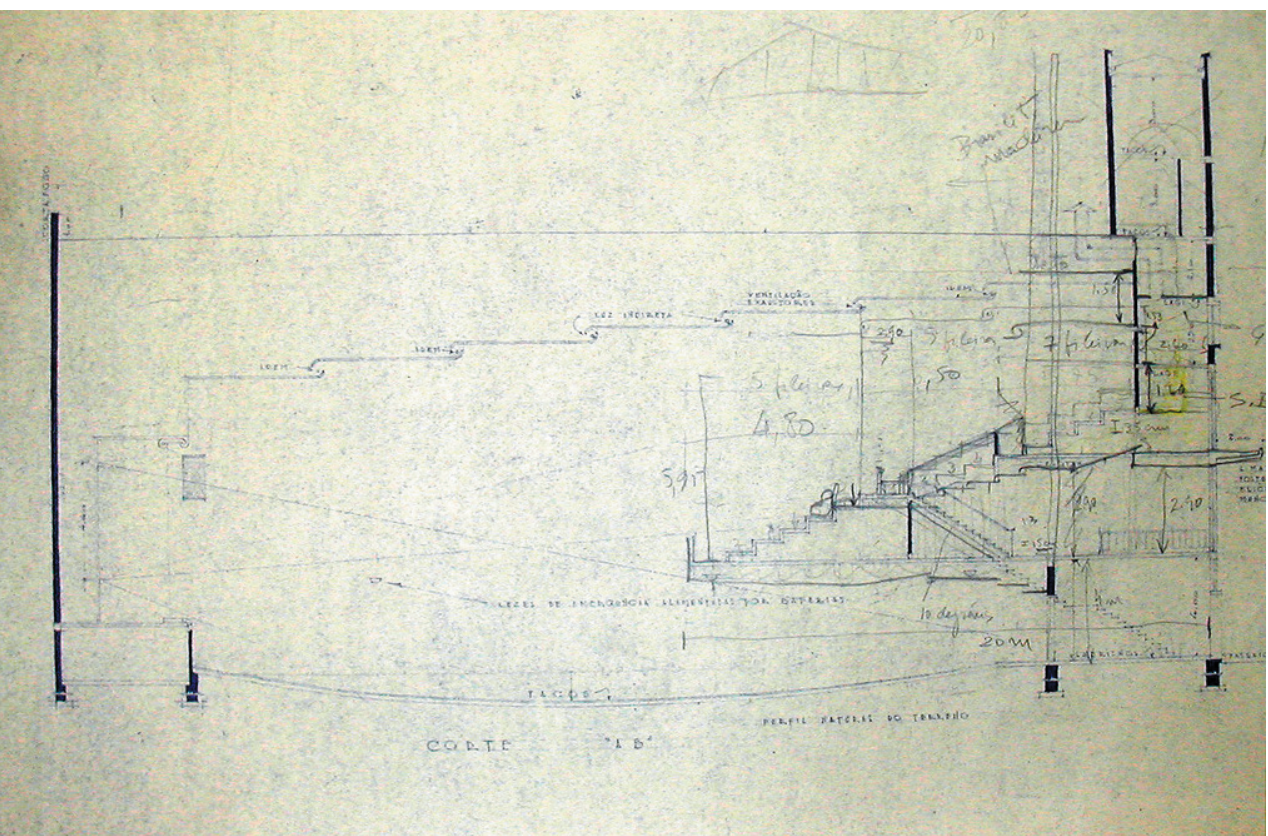




\section{Escola em Presidente Venceslau}

\section{0}

\section{Publicações:}

Habitat 60, p.11-12.

1960.

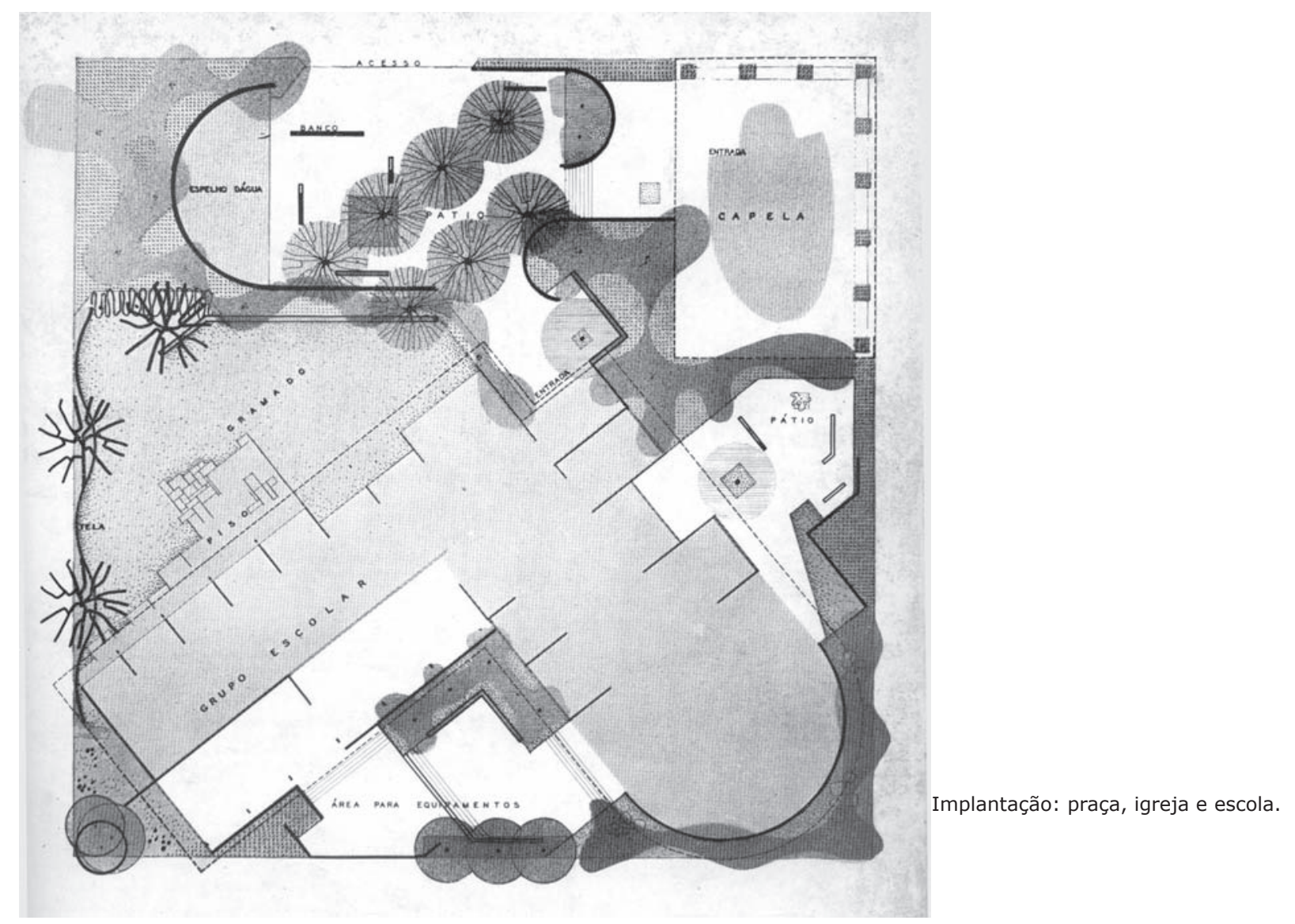

\section{DADOS DO PROJETO:}

Execução:

Incorporação: Ipesp

Entrega da Obra:

Local:Rua Tiradentes, Rua Anita Garibaldi, Rua Cel. Antenor Pereira e Rua Fernão Dias. Presidente Venceslau. SP

\section{DESCRIÇÃO DO}

\section{PROJETO:}

Na década de 60 , o governo do Estado de São Paulo, administrado por Carvalho Pinto, implementou uma política de construção visando desenvolver o interior, numa complementação do plano de metas de Juscelino. O grupo esolar de Presidente Venceslau foi uma das 5 escolas projetadas por Abelardo de Souza para - Governo do Estado neste período. Destaca-se por formar conjunto com Capela e praça que receberá tratamento paisagístico de Miranda Magnolli, então associada de Abelardo Souza.

O conjunto compreende administração, sanitários e salas aula sendo, o acesso ao pavimento superior é feito por rampa aberta. A estrutura em 

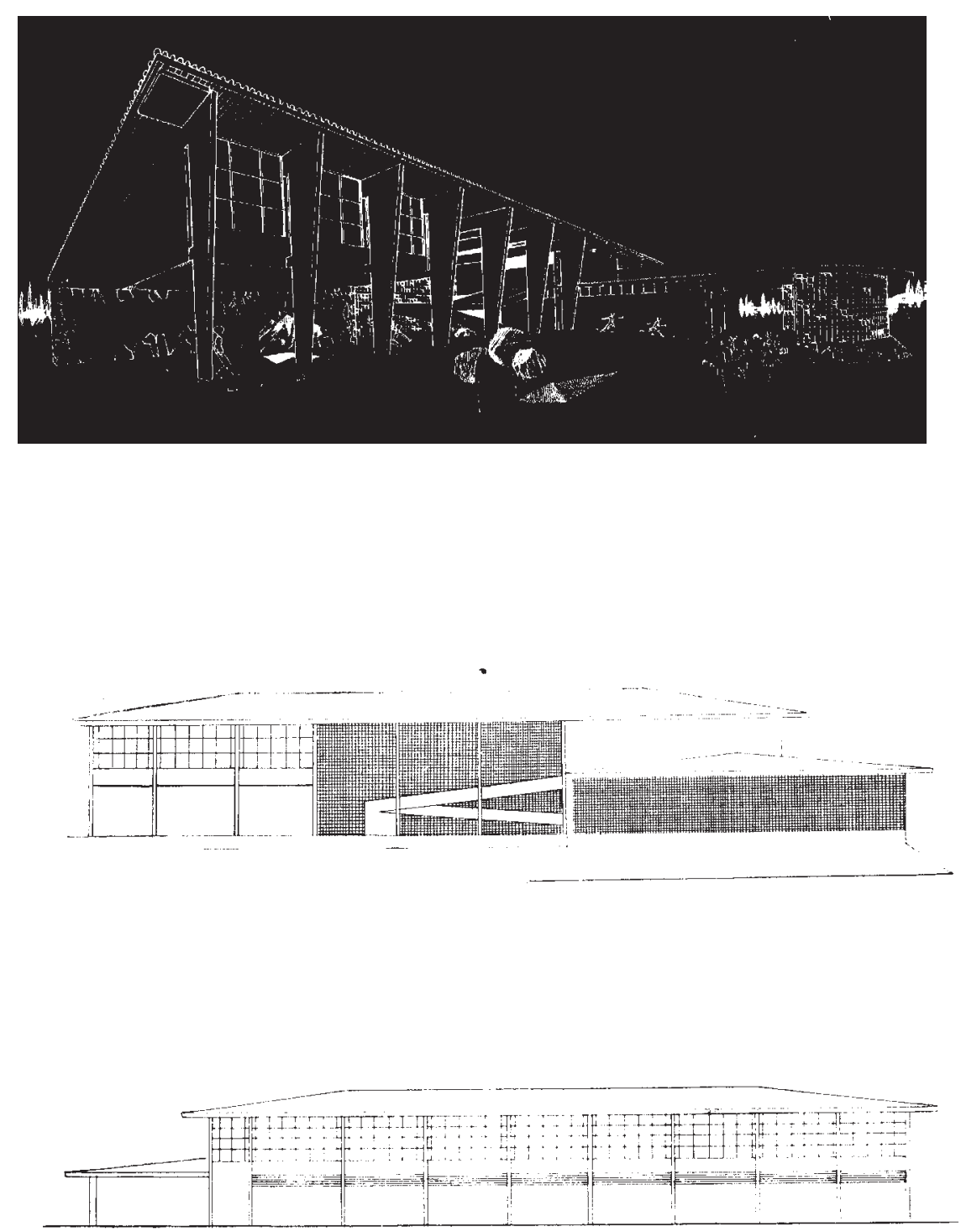

pórtico, permitiu a criação de vários locais para recreação. 0 recreio coberto constitui volume independente. A implantação foi feita em diagonal para acompanhar as curvas de nível do terreno e acabou por formar um triângulo que constitui a área de recreação para escola. Esta forma de ocupação permitiu que grande parte do terreno fosse liberado para praça pública.

\section{Área do Lote: \\ Área Construída:}

No de pavimentos: 1

PAVIMENTO TÉRREO: O térreo abriga todo setor administrativo, sanitários e 7 salas de aula voltadas para a praça. 0 recreio coberto é destacado do corpo principal. A rampa de acesso ao $1^{\circ}$ piso é solta, formando átrio de distribuição com pé direito duplo.

PAVIMENTO SUPERIOR: No pav. Superior encontraremos 7 salas aula também voltadas para a praça e 3 para o recreio. Há também instalações sanitárias masculina e feminina e uma sala administrativa.
TRATAMENTO DE FACHADAS: O projeto compunhase basicamente de ampla estrutura de cobertura, sob a qual distribuiu livremente o programa. A mistura de materiais e texturas mantinhase dentro de sua característica projetual. Dos acabamentos originais conhecemos: o beiral com 2 metros de balanço que foi revestido com tábuas enceradas tendo ao canto dele luminárias de acrílico; o muro de concreto ciclópico que se prolongava até o limite do terreno e a parede do recreio coberto em tijolos furados.

TRATAMENTO PAISAGÍSTICO: A escola pertencia ao complexo composto por Capela e praça, de forma que era integrada no paisagismo geral. 


\section{Capela em Presidente Venceslau}

\section{1}

Publicações:

Habitat 65, p.4.

1961

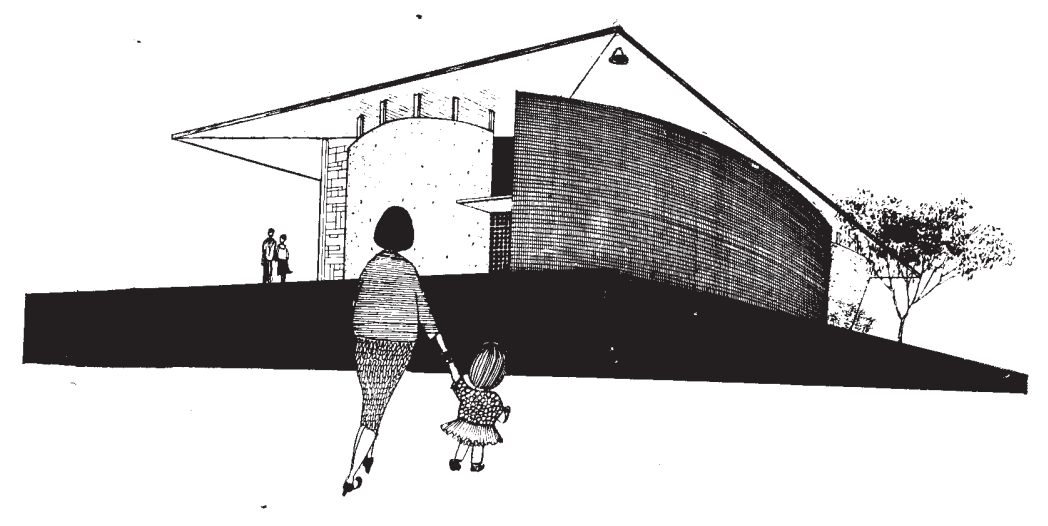

\section{DADOS DO PROJETO:}

Execução: NE

Local: Rua Tiradentes, Rua Anita Garibaldi, Rua Cel. Antenor Pereira e Rua Fernão Dias. Presidente Venceslau. SP Publicações:

\section{DESCRIÇÃO DO PROJETO:}

Capela situada no canto da praça que abriga grupo escolar projetado pelo arquiteto. Em formas curvas, lembra uma semi-espiral. Esta versão é o segundo projeto para área, sendo que o $1^{\circ}$ dialogava melhor com o conjunto. Nítida influência das formas de Ronchamps de Le Corbusier. As diversas partes - coro, sacristia, parede curva - funcionam como elementos estruturais.

\section{Área do Lote:}

Área Construída: 460m2 (área aproximada projeção da cobertura)

TRATAMENTO DE FACHADAS: A nave da Capela é formada por uma parede curva de tijolos furados de forma a obter uma luminosidade difusa. Marcando a porta de entrada uma alvenaria de forma curva, pintada de azul claro.

A cobertura em telha canal receberia externamente pintura em tom rosa e o forro interno receberia tábuas tipo macho e fêmea.

O coro em concreto aparente sem revestimento e todo o piso em lajotas de arenito irregulares, com juntas de marmorite branco.

O piso interno e externo se fundem dando a capela uma maior amplitude.

TRATAMENTO PAISAGÍSTICO: A capela fica situada no canto de uma praça onde se localiza um grupo escolar. Ao conjunto foi dado o mesmo tratamento paisagístico, com projeto de autoria de Miranda M. Magnoli. Visto que o terreno possui uma grande diferença de nível em relação às calçadas, foi adotada uma entrada única para a praça, localizada de modo a permitir a entrada ao grupo escolar.

Foram criadas áreas para toda comunidade e um pátio separado para festas escolares, num caráter mais íntimista. 

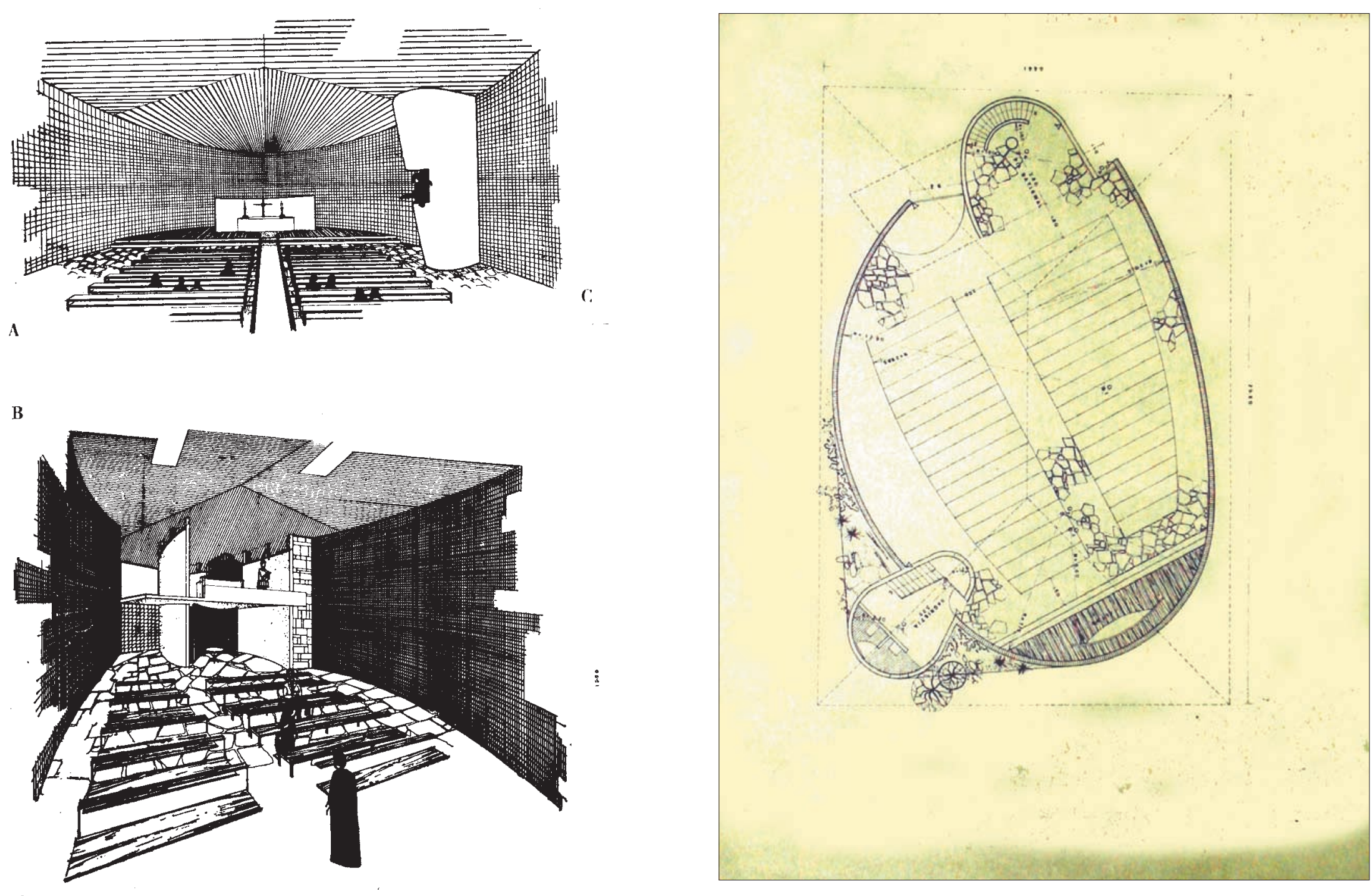


\section{Estação Rodoviária em Presidente Venceslau}

\section{1}

Publicações:

Habitat 64, p.10-13.

1961

\section{DADOS DO PROJETO:}

Execução:

Incorporação:

\section{Entrega da Obra:}

Local:Rua Tenente Osvaldo Presidente Venceslau. SP

\section{DESCRIÇÃO DO} PROJETO:

Cinco locais destinados ao acostamento de ônibus, um restaurante e outras dependências constituitam o programa proposto pela Municipalidade de Presidente Venceslau para a elaboração do projeto da estação rodoviária da cidade. O terreno de pequenas dimensões é limitado em um de seus lados por uma propriedade particular. Para proporcionar circulação mais generosa para veículos e passageiros o arquiteto buscou uma solução capaz de ampliar o pavimento

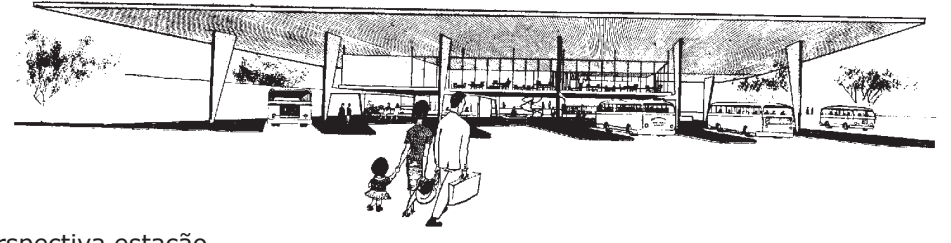

Perspectiva estação.
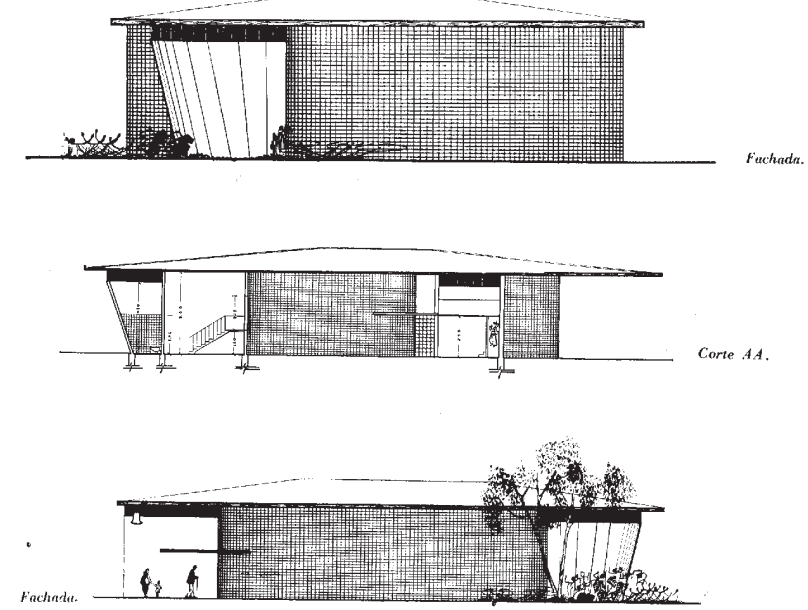

Vistas albergue.

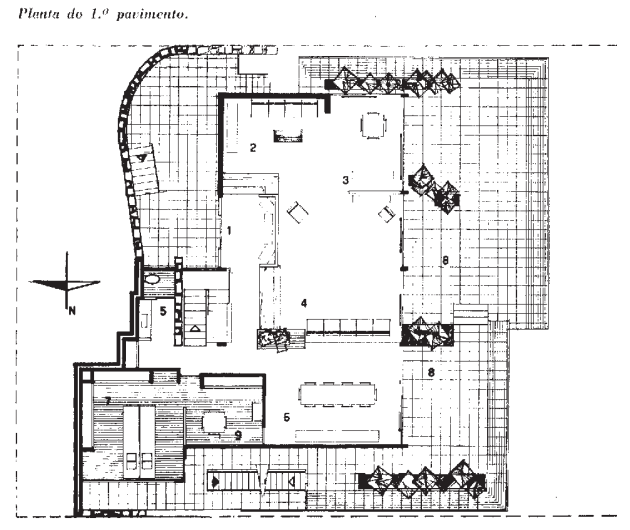

Plantas albergue.

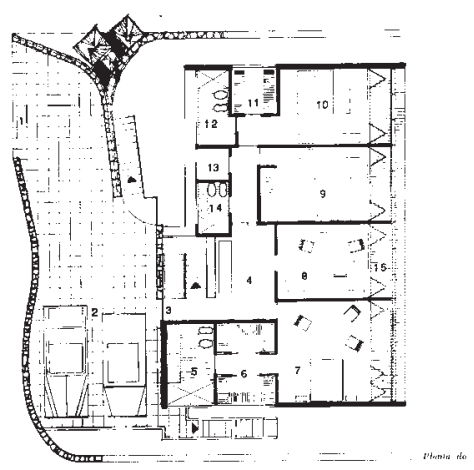



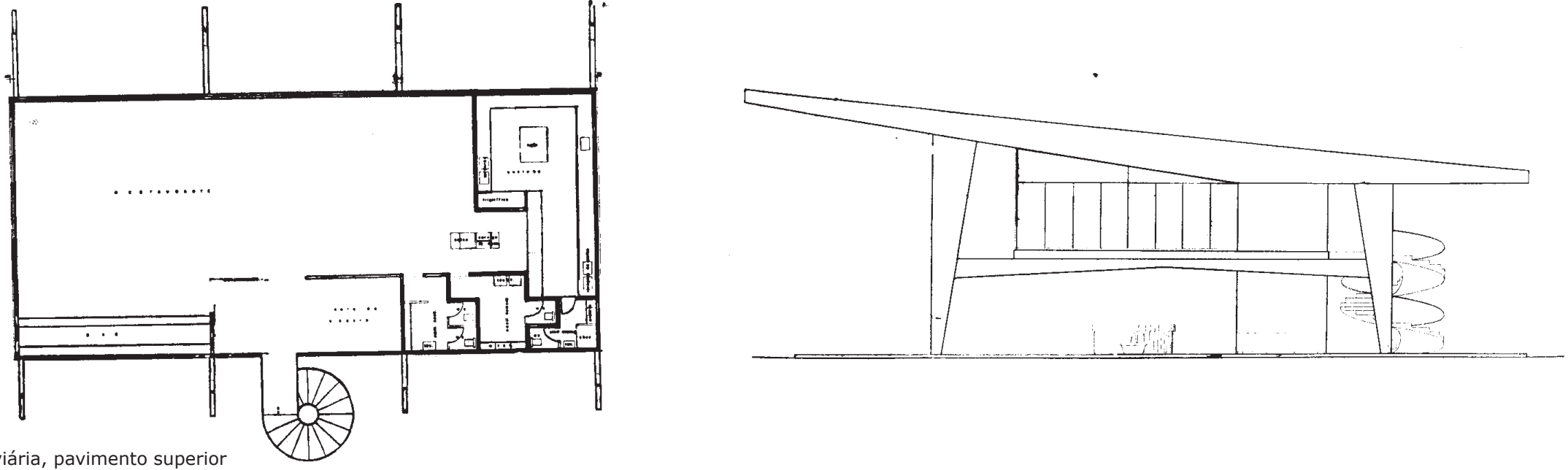

Rodoviária, pavimento superior

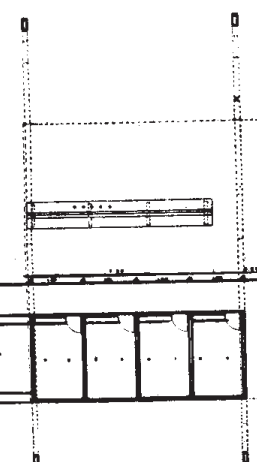

- Es

Rodoviária, pavimento térreo.

(U) $:+$

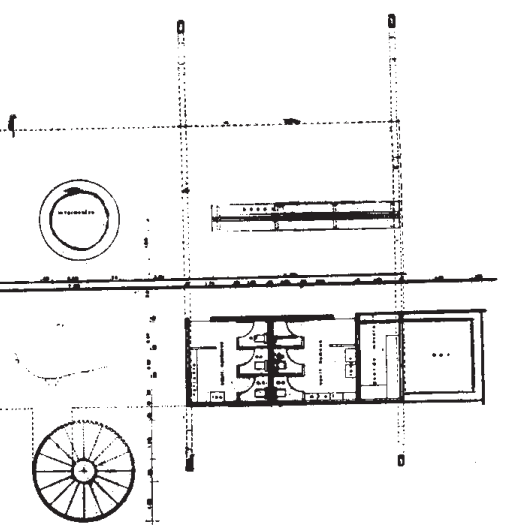

Fachadas laterais. 
Área do Lote:

\section{Área Construída:}

\section{No de pavimentos: 1}

\section{PAVIMENTO}

TÉRREO:

Centralizaram-se neste piso todos os serviços ligados à Estação Rodoviária: posto de controle, boxes de transportadoras, sanitários, guarda-volumes, café, banca de jornal.

PAVIMENTO SUPERIOR: O restaurante e demais serviços foram dispostos no pavimento superior, possibilitando independência de circulação para seus usuários, e proporcionando, com o salão de refeições inteiramente envidraçado, ampla visão sobre o pavimento térreo.

TRATAMENTO DE FACHADAS A ampla estrutura em concreto armado coberta com telhas de fibrocimento e revestidas internamente em madeira permitiu que as demais áreas possuissem grandes superfícies envidraçadas. Nos pisos fol previsto ladrilho hidráulico.
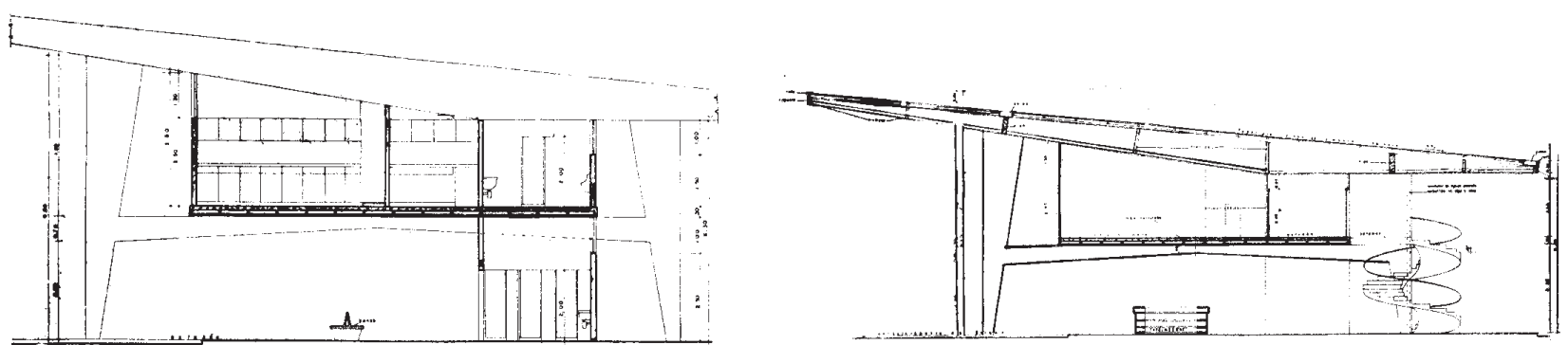

Cortes.
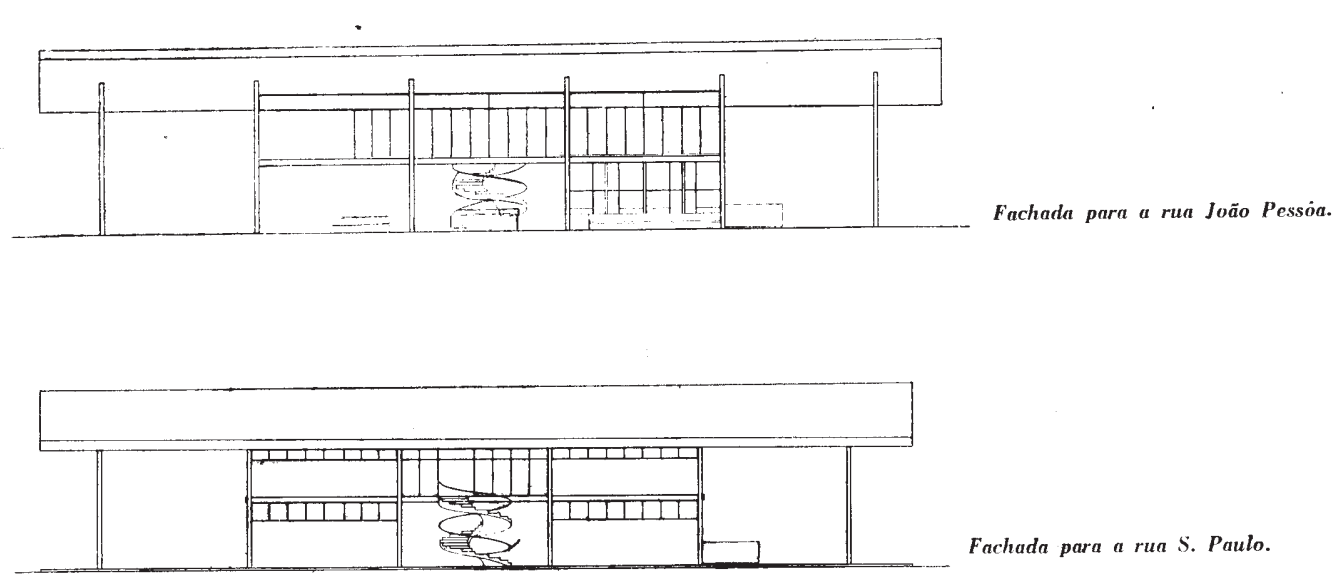

Fachada para a rua S. Paulo.

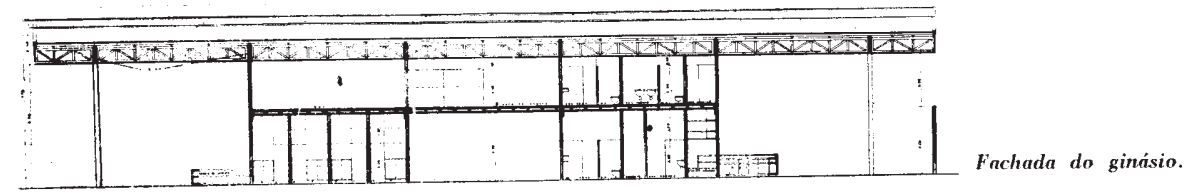




\section{Paço Municipal Prefeitura de Valinhos}

\section{3}

\section{DADOS DO PROJETO:}

\section{Execução: NE}

Local: R. Antonio Carlos/ Av. Independência. Valinhos-SP

Premiações: Vencedor do

Concurso para o Paço Municipal

Prefeitura de Valinhos

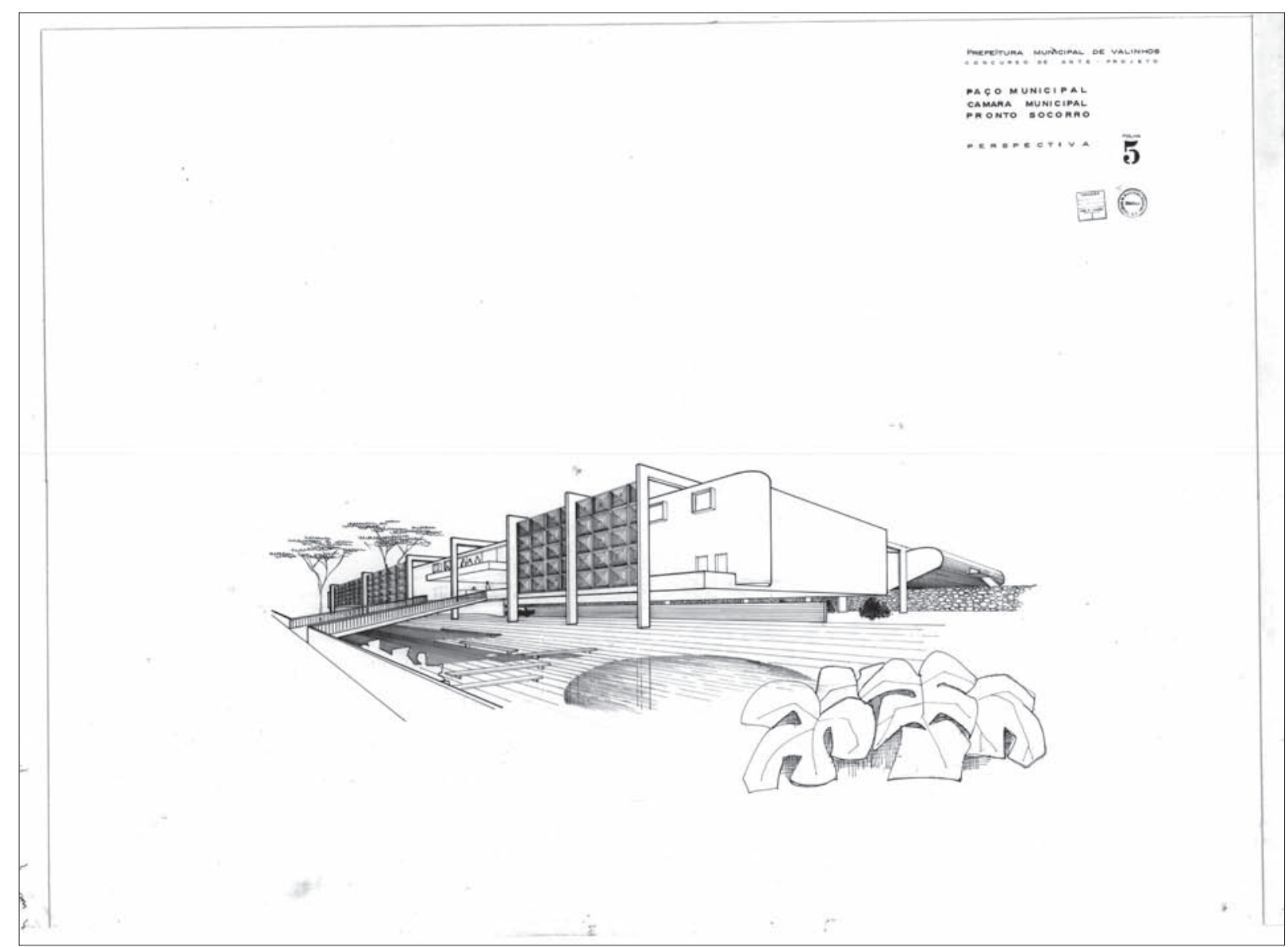

\section{DESCRIÇÃO DO}

\section{PROJETO:}

Este projeto vencedor do concurso para cidade de Valinhos deveria incluir: Paço Municipal, Câmara Municipal e Pronto-socorro.

O projeto tem como base uma estrutura aparente que unifica todo o conjunto e três volumes distintos, separados por pátios internos, para cada função distinta, tornando o projeto claramente legível de seu exterior.

As entradas para público, funcionários e autoridades, em cada um dos blocos, por prévia determinação do edital, são completamente separadas.

Foi conservado o nível do terreno $(-1,50)$, sendo feito nos fundo, um aterro na parte correspondente à Câmara e Pronto-Socorro, que serviria também, para contenção de enchentes.

Área do Lote: $14.300 \mathrm{~m} 2$ Área Construída: $10.115 \mathrm{~m} 2$ No de pavimentos: 2

PISO SEMI ENTERRADO: Nesse piso se localiza o estacionamento 
dos médicos, e da câmara.

Sob o edifício do palácio foi prevista área de uso público.

10 PAVIMENTO: Acesso público ao Paço feito através de rampa que marca a entrada principal. O funcionamento do paço está caracterizado pela total separação do público e funcionários. O atendimento ao público seria feito através de balcões. Às dependências da "Comissão Municipal de Esportes" e "I.B.G.E." foi dado, para cada uma, um acesso privativo. Para todas as seções esquematizadas foi projetada uma área útil superior à demandada pelo organograma fornecido, prevendo uma natural expansão das atividades municipais.

O acesso ao pronto-socorro é feito por uma rampa suave com 6 metros de largura que liga a rua ao pátio coberto. No piso de cota 2,50 fica a entrada de público, de médico e ambulâncias, entradas essas perfeitamente caracterizadas. Nesse piso ainda se localiza o estacionamento de autos dos médicos e ambulâncias.
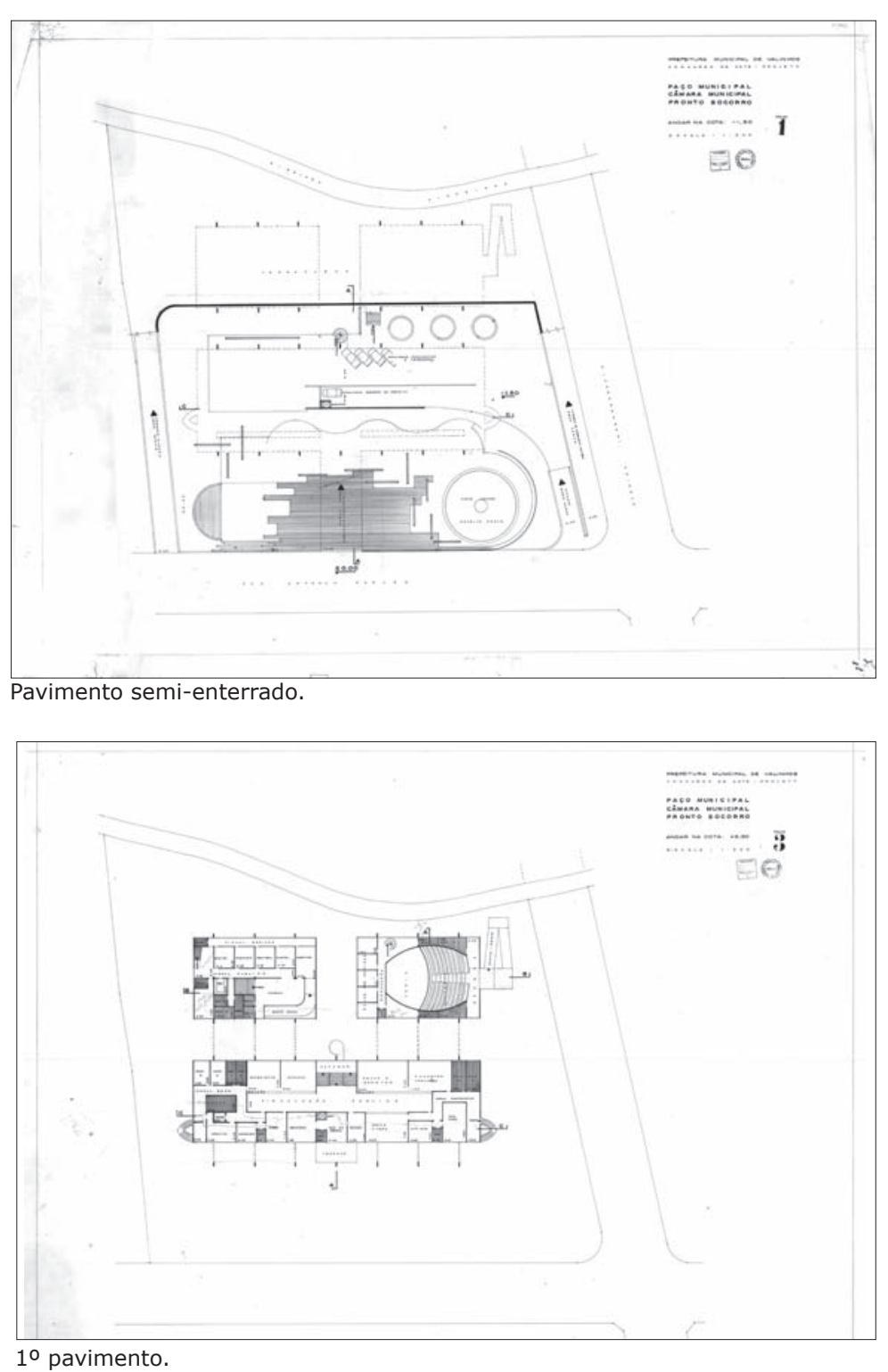
20 PAVIMENTO: Neste pavimento localiza-se 0 Gabinete do prefeito e demais setores ligados diretamente à ele. O prefeito possui acesso direto e privativo através de elevador

No piso de cota 6,00 do pronto-socorro fica localizado todo 0 atendimento de público, seguindo o programa apresentado.

O acesso ao plenário na Câmara é feito por rampa externa.

TRATAMENTO DE FACHADAS O partido adotado foi o de um só sistema estrutural aparente bastante simples e blocos, com vazios para iluminação. $\mathrm{Na}$ parte correspondente ao paço todo o terreno foi deixado livre, podendo, em horas apropriadas, ser de uso público. As diferentes funções podem ser lidas claramente da fachada.

A cobertura do conjunto seria

de "calhas planas" de concreto ou fibro-cimento.

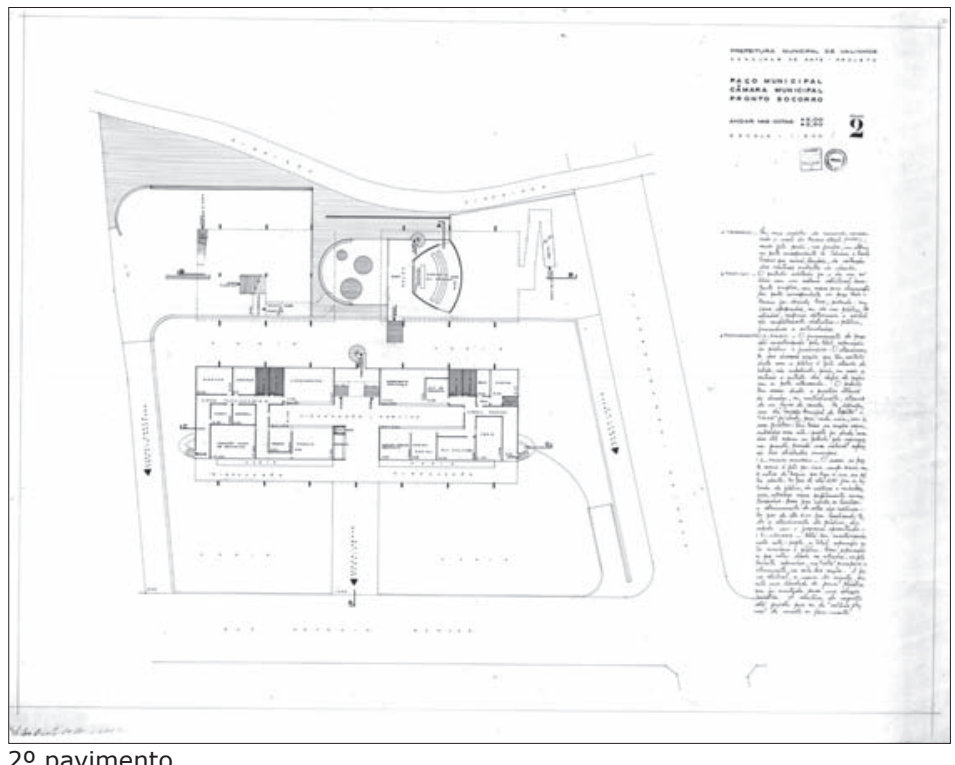

$2^{\circ}$ pavimento.

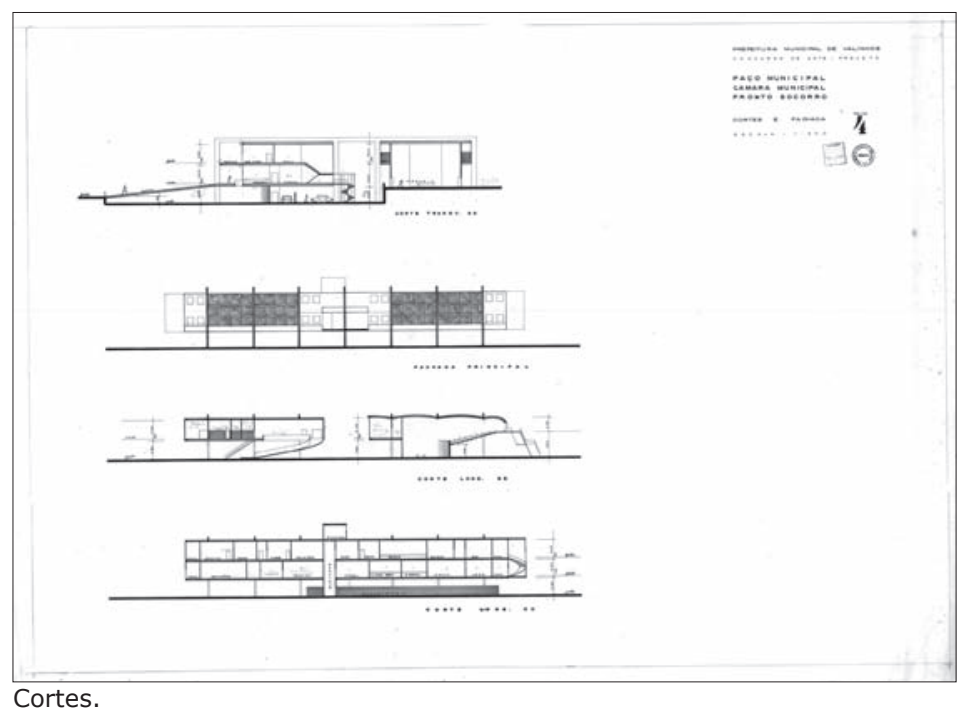




\section{Clube de Campo de Piracicaba}

\section{4}

Publicações:

Habitat 75, p.19-20. 1964.
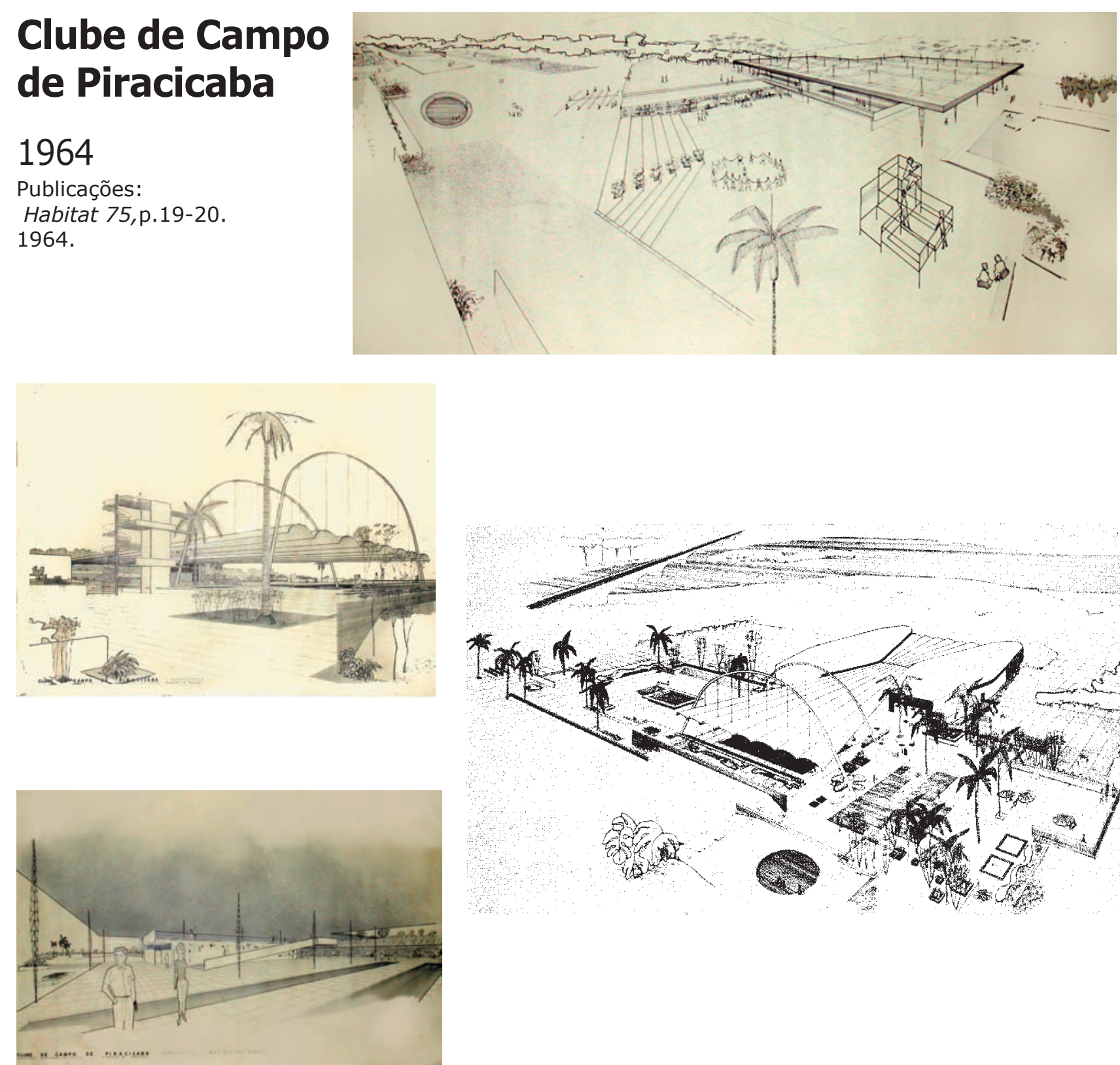

\section{DADOS DO PROJETO:}

Arquitetos: Abelardo de Souza e Miranda Martinelli Magnoli

Projeto:1963/64

Execução: Parcial

Incorporação:

\section{Entrega da Obra:}

Local: Av. Torquato Silva Leitão.

Piracicaba-SP

\section{DESCRIÇÃO DO}

\section{PROJETO:}

O ponto de partida para a elaboração deste projeto, como condição principal apresentada pela diretoria do clube, era a piscina existente no local.

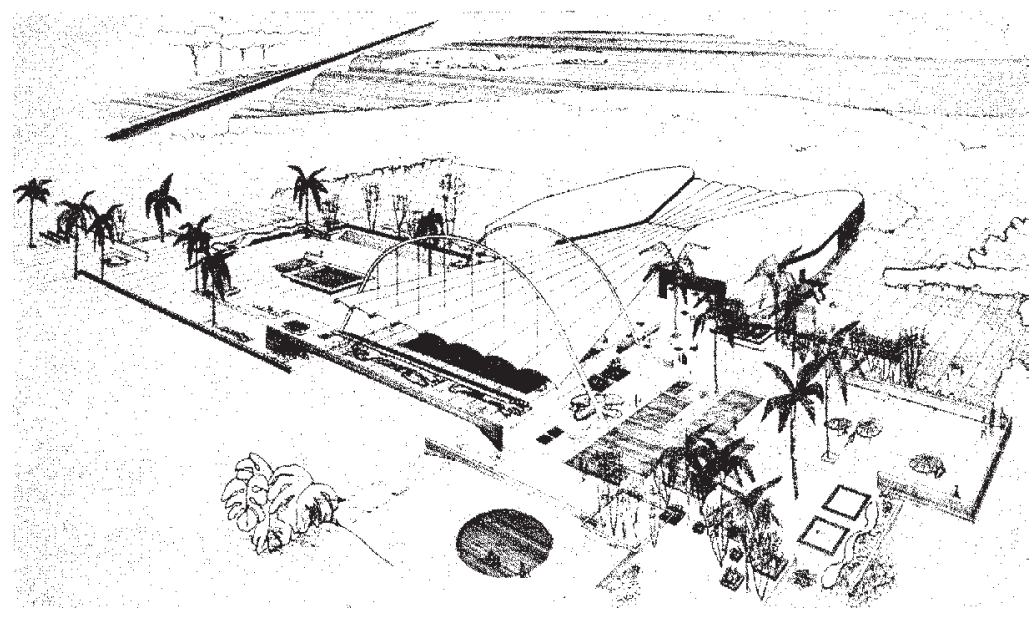

A passagem pelo terreno de uma linha de alta tensão, impunha sua divisão em duas partes.

O Clube tem duas atividades distintas: a esportiva e a social. A parte esportiva ocupa maior parte do terreno, distribuida em diversos blocos e a parte social concentrou-se em sede de $6.000 \mathrm{~m} 2$.

Área do Lote: $78.520 \mathrm{~m} 2$ Área Construída:8.900 m2

PAVIMENTO TÉRREO: Natação, tênis, e "boccias" foram os três 
fatores primordiais no setor esportivo que pesaram no desenvolvimento do projeto. Assim sendo, para natação, além de ter sido conservada a piscina existente, esta foi coberta e terá água aquecida, ficando dentro do conjunto "piscinas", somente para competições. Junto a este, fica localizada, de um lado, a piscina social destinada à recreação e do outro o tanque para saltos, com trampolim de 10 metros de altura.

Para tênis foram criadas mais duas quadras, sendo uma com arquibancada coberta.

O setor "boccias" foi planejado tendo em vista um verdadeiro ginásio com "canchas" para malha, "boccias" e boliches, além de bar, vestiário, etc.

Foi feita uma quarta piscina somente para crianças, com vestiários, bar, salão para recreações, play-ground, etc.

Para a parte social propriamente dita, foi planejada uma sede com aproximadamente $6.000 \mathrm{~m} 2$ de área. Um dos pontos principais dessa sede é o salão de festas que pode ser ampliado quando ligado à parte coberta externa,
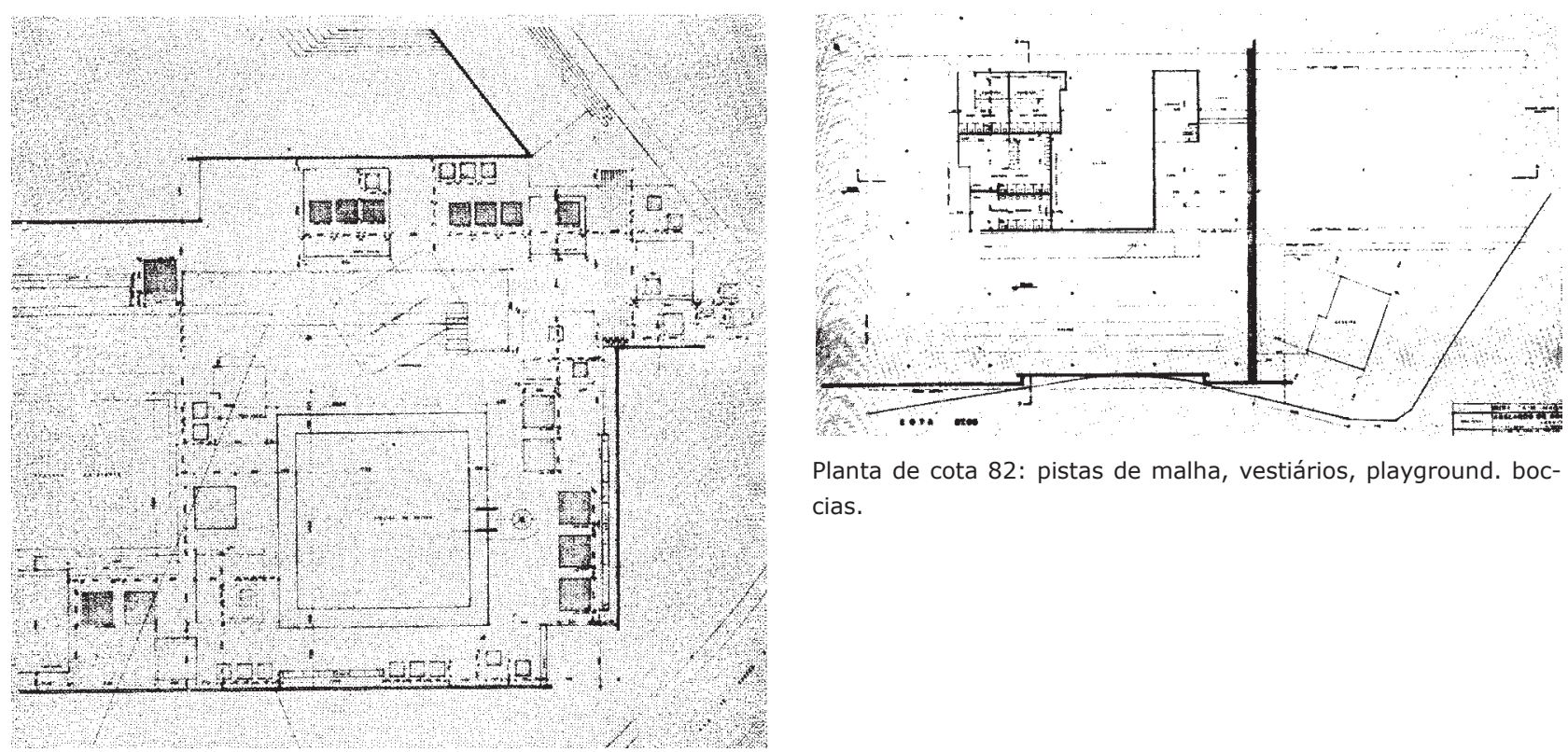

Planta de cota 82: pistas de malha, vestiários, playground. boccias.

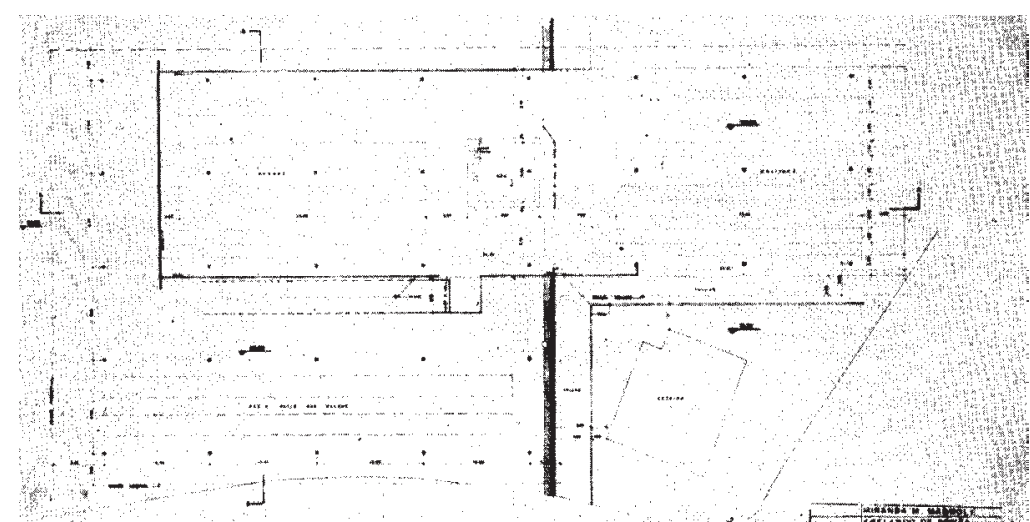

Piso das bocias e boliches 


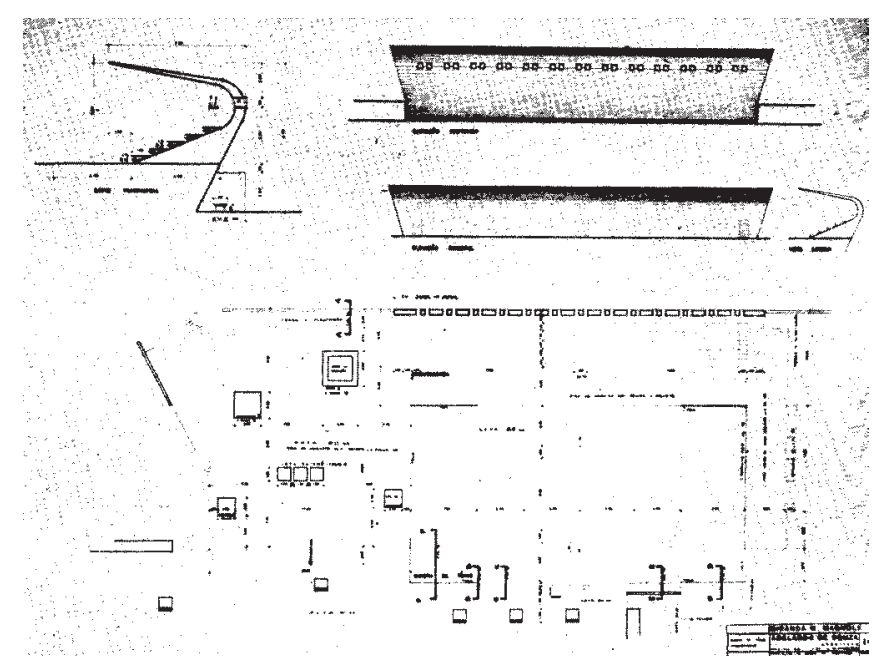

Arquibancadas cobertas do tênis.

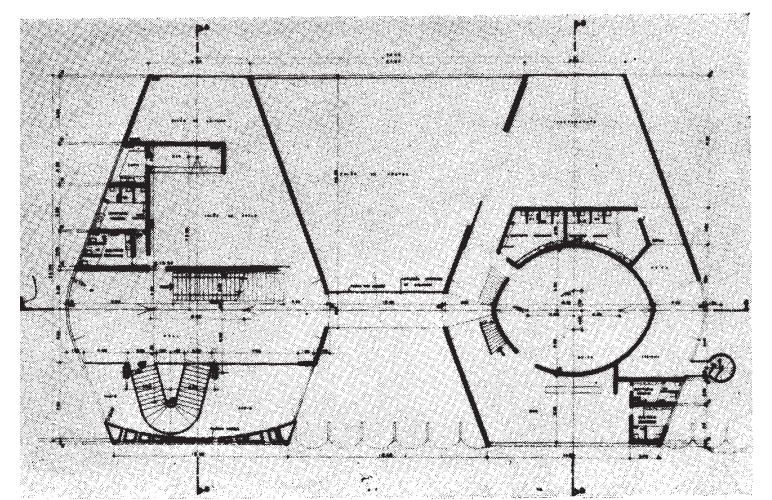

Sede $1^{\circ}$ pavimento. Na ala esquerda ficam sala de estar, bar e sanitários; na ala direita, restaurante, serviços, boite e bar ligado às piscinas. formando um ambiente junto às piscinas. Complementando a sede, há um salão para restaurante, "boite", bar ligado às piscinas, salão de estar, salão para leitura, auditório, salas para jogo carteado, copa, cozinha, parte administrativa e um instituto de fisioterapia completo.

TRATAMENTO DE FACHADAS: Projeto faz uso de estruturas metálicas, estruturas de concreto e mistas.

A arquibancada para as quadras de tênis, em casca de concreto curvada em balanço, lembra a estrutura projetada para

Trampolins piscina.

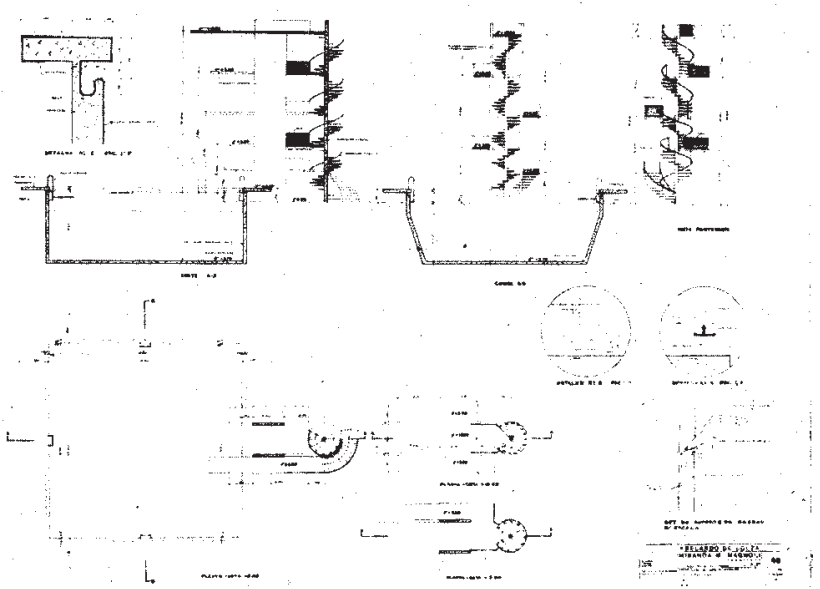

Ourinhos.

Soluções fazendo uso de tirantes de aço foram sugeridas como no ginásio de boccias, numa solução leve para grande área coberta.

Para a cobertura da piscina foram propostos grandes arcos metálicos segurando cascas pré-moldadas em concreto que seriam atirantadas à estrutura numa inovação dos projetistas. O vão obtido é de 42 metros. Abelardo de Souza posteriormente aplicará este tipo de estrutura na obra do Mercado de Pirituba.

O conjunto possui grande harmonia entre os edifícios e ligações entre estes.

A maioria das construções eram galpõesabertos, proporcionando uma "transparência" na obra.

TRATAMENTO PAISAGÍSTICO Apesar da diversidade de atividades das condições topográficas do terreno, os arquitetos conseguiram estabelecer um conjunto harmonioso para distribuição dos vários setores e pelo tratamento paisagístico. 

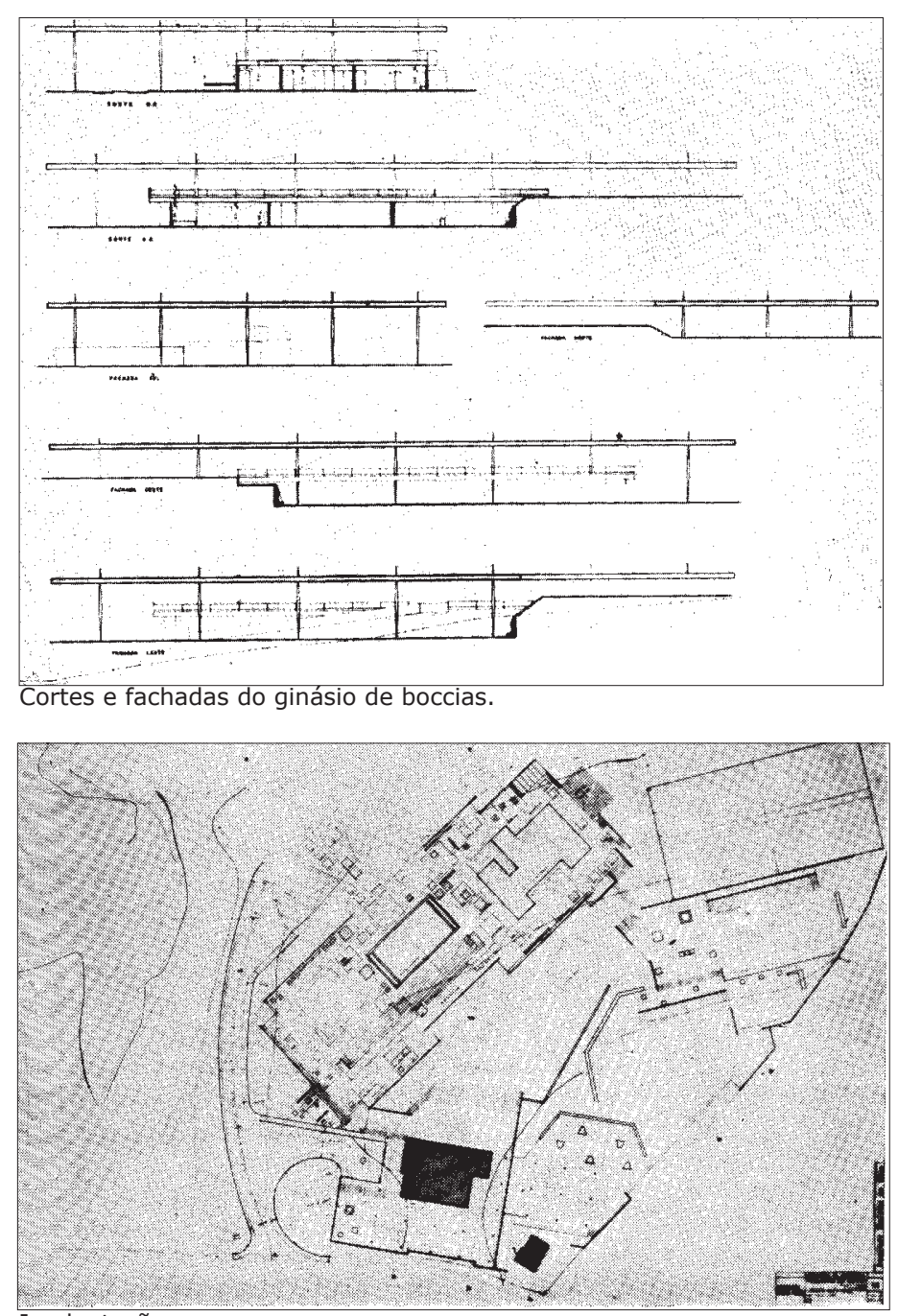

Implantação.
Nível de acesso à sede: acesso à sede e campo de futebol de salão.
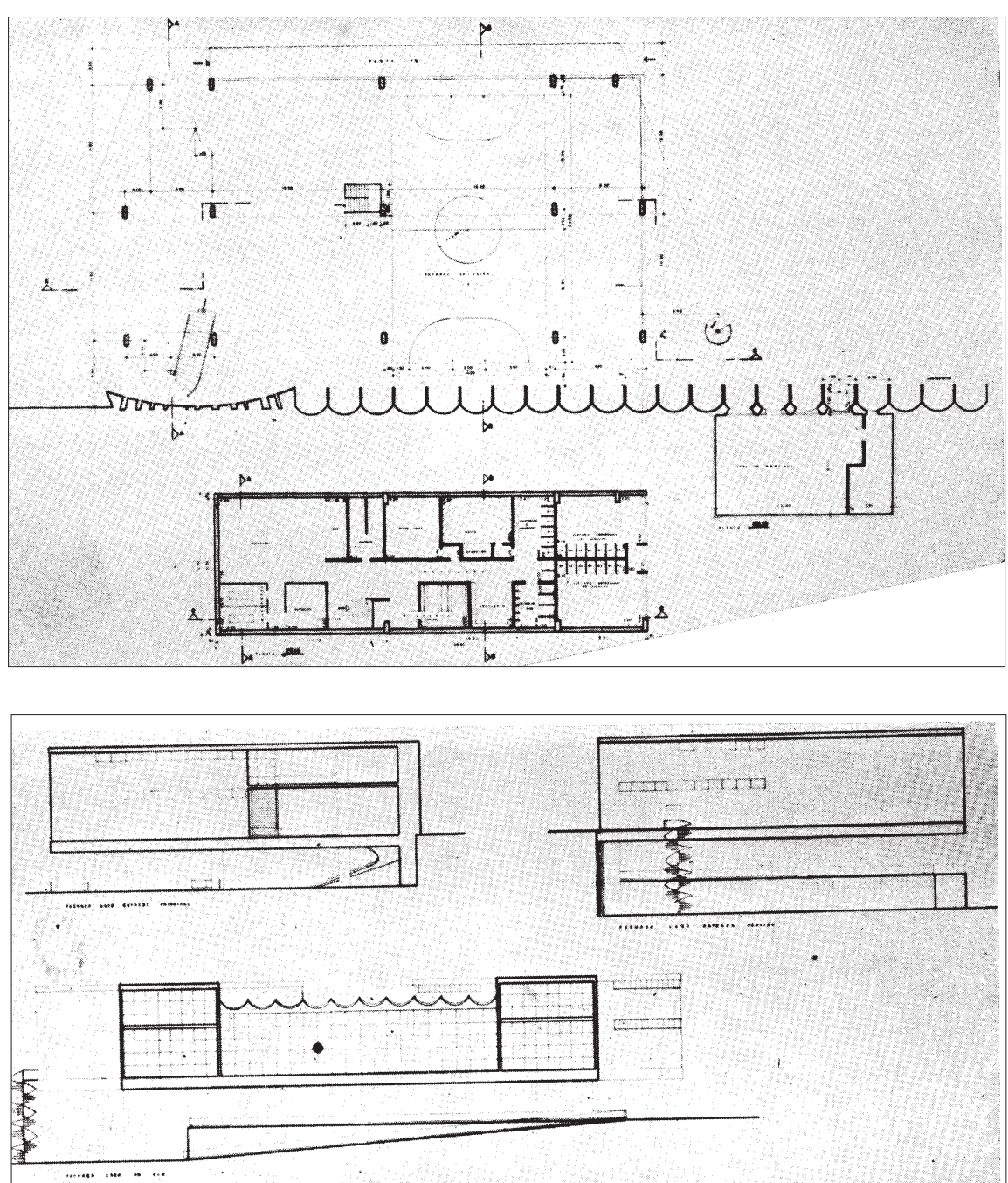

Cortes e fachadas da sede.

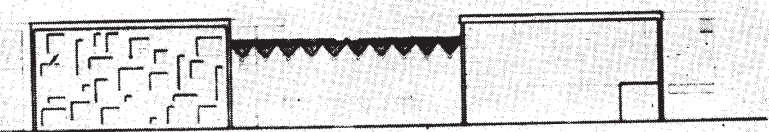




\section{Aproveitamento Foz do Chopim}

\section{5}

Publicações:

Habitat 81, p.15-21.

1965.
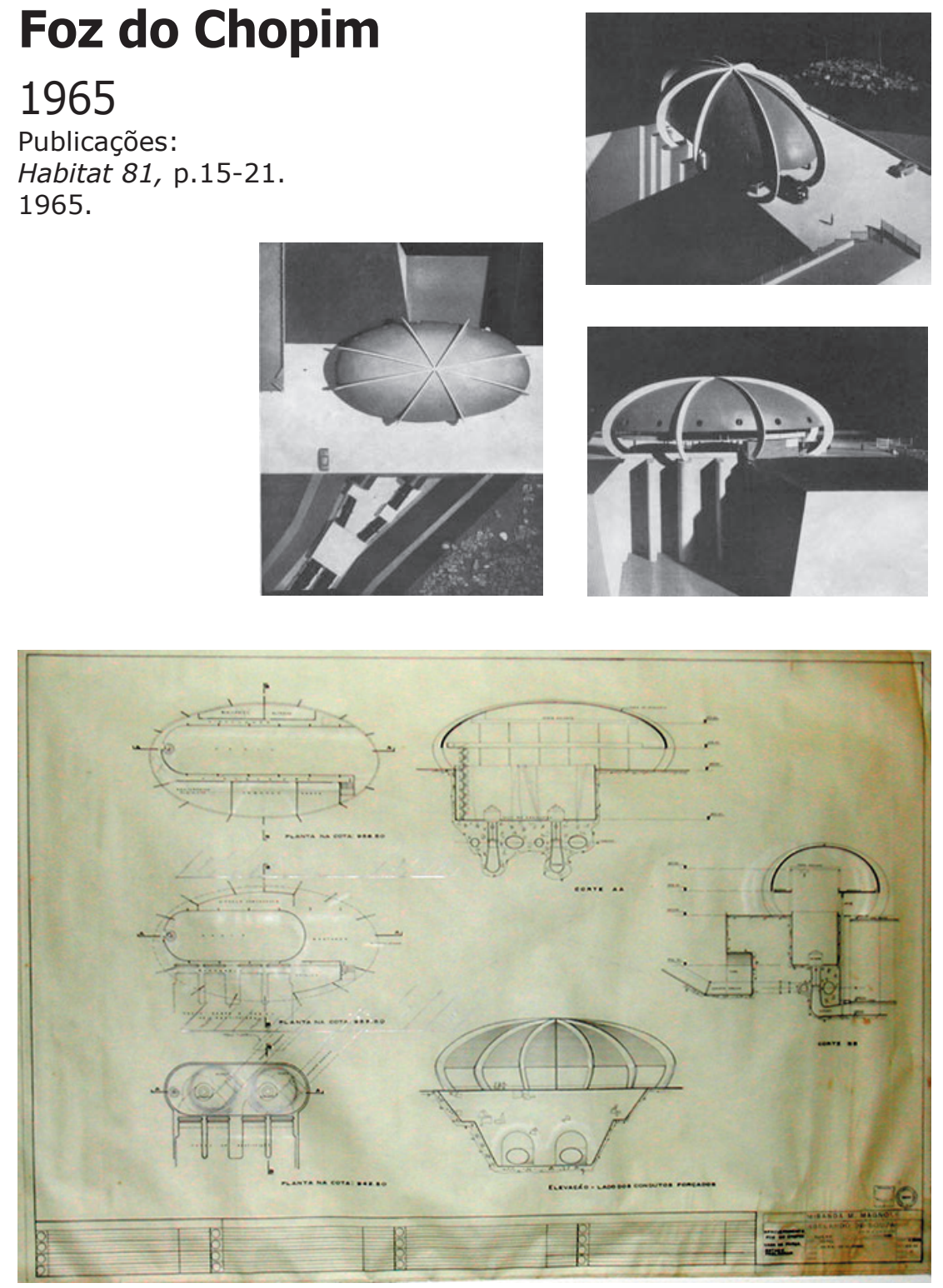

DADOS DO PROJETO:

Arquitetos: Abelardo de Souza

e Miranda Martinelli Magnoli

Execução: NE

Incorporação: COPEL

Local: Foz do Rio Chopim Paraná

\section{DESCRIÇÃO DO} PROJETO:

O aproveitamento hidroelétrico da Foz do Chopim, São Paulo, destinava-se a abastecer 0 último quadrante do Estado do Paraná ainda não atendido em energia elétrica.

Para realização da primeira etapa do aproveitamento da Foz do Chopim, o conjunto do aproveitamento consistia em pequena barragem de derivação de águas, canal adutor, tomada de águas, dois condutos e usina de força.

Com relação à última, a solução técnica encontrada foi de realizá-la semi-enterrada tendo em vista grandes variações de nível de água existentes.

\section{Área do Lote:}

Área Construída:

PAVIMENTO TÉRREO: Em tais condições firmou-se a escolha do partido arquitetônico com planta livre coberta por uma casca de concreto ou alumínio, suportado por pórticos Projetou-se uma casa de força nos moldes usuais com quase todos os serviços executados em compartimentos enterrados Para a realização e a operação do aproveitamento, previu-se um grupo de obrascomplementares, compreendendo: as instalações da COPEL e do empreiteiro, alojamentos provisórios de operários; aeroporto; hotel; residência do engenheiro superintendente; casas para operadores; escola; armazém de abastecimento.

TRATAMENTO DE FACHADAS: A volumetria do projeto consiste em uma casca de concreto em forma elípitica, apoiada por pórticos, com opção de alumínio e pórticos em treliças no mesmo material, sob a qua se encontram as turbinas e equipamentos. $\mathrm{O}$ projeto tem linhas ousadas visando reforçar um aspecto "tecnológico" do conjunto. 


\section{Mercado de Pirituba}

\section{DADOS DO PROJETO:}

Projeto: 1968

Execução: Enbase-Engenharia

e Comércio S.A.

Cálculo estrutural: Figueiredo

Ferraz

Incorporação: PMSP

Entrega da Obra: 1972

Local: Rua Gabriel Cotti, Rua Almirante Isaias de Noronha, Rua Luis de Andrade. PiritubaSP

Exposições: Bienal de 1971. Premiações: Prêmio de estrutura no México para o calculista Figueiredo Ferraz $(1971)^{1}$

\section{DESCRIÇÃO DO \\ PROJETO:}

Localizado no bairro de Pirituba, zona oeste de São Paulo, no quarteirão formado pelas Ruas Isaias de Noronha e Gabriel Cotti. A obra teve início em fevereiro de 1969 na administração Faria Lima e sua
Publicações:

A construção em São Paulo 1253; p.10-14

1972

construção se estendeu por quatro anos.

Sua principal característica é a cobertura formada por 12 cascas de concreto moldadas no próprio local. Cada casca é suspensa por um conjunto de quatro cabos de aço, ancorados na torre central, de $20 \mathrm{~m}$ de altura, em forma de tronco de cone que também abriga a caixa d'água para 45 mil litros. A prefeitura municipal gastou, na época, $\mathrm{Cr} \$ 2,7$ milhões.

De acordo com Abelardo, a proposta do projeto era dar ao mercado a forma mais próxima de uma feira livre:

"O prédio do mercado de Pirituba tem a forma circular justamente para proporcionar maior facilidade de movimentação aos usuários. Internamente, afora a divisão em 40 boxes, o espaço é todo livre. Não há colunas de sustentação como é comum nas construções do gênero, apenas uma coluna central que se afina de cima para baixo (...)

Da Grande coluna central pendem os tirantes de aço que sustentam as 12 cascas de laje que dão à cobertura o formato semelhante a uma armação de guarda-chuva aberto. Cada laje pesa 480 toneladas e tem $30 \mathrm{~m}$ de comprimento ou balanço. $O$ diâmetro da cobertura é de 70 $m$. Dessa forma, no ambiente haverá ventilação e iluminação totais. Como numa feira livre. (...)

o piso do interior do mercado é em declive, em forma de anfiteatro, e isso proporciona a quem entra, por qualquer uma das portas, uma visão geral do ambiente, box por box. Nenhum box se destacará mais que outro. ${ }^{\prime 2}$

Ao lado do mercado era prevista uma feira livre, com cobertura plástica removivel e inflável ${ }^{3}$ porém esta área foi usada para estacionamento.

Habitat33 p.51

Declaração prestada a jornal, 1971

Abelardo cita estádio de Munique na Alemanh

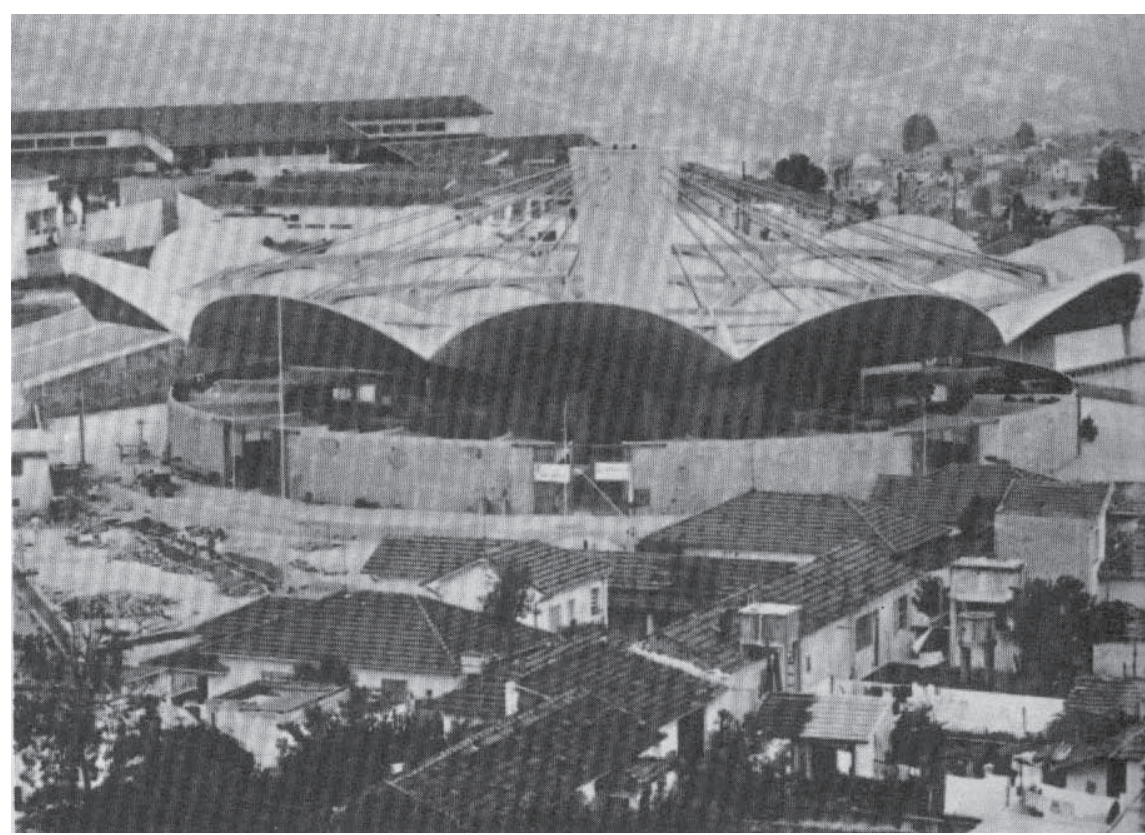




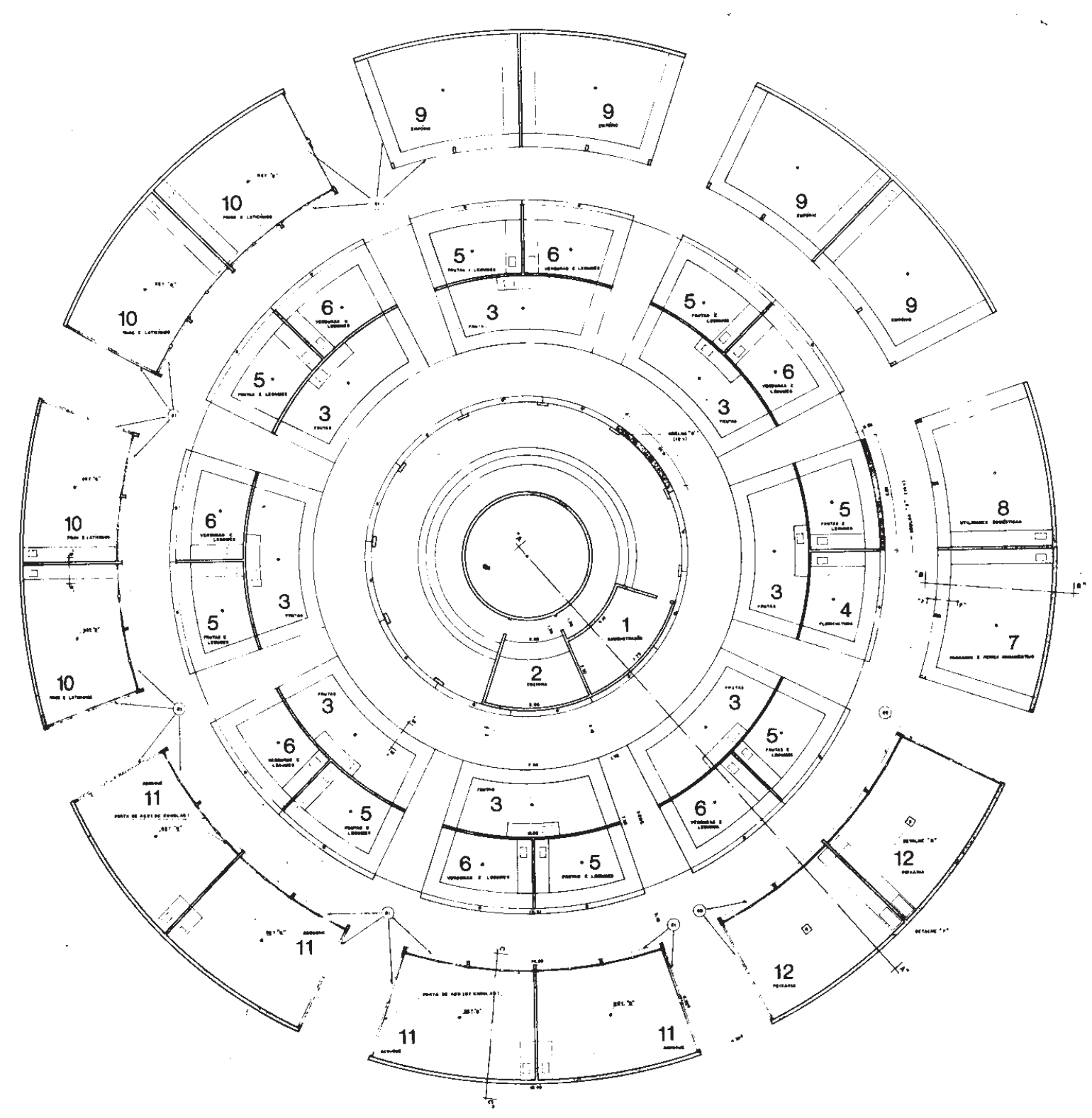

\section{Área do Lote:}

Área Construída: $4500 \mathrm{~m} 2$

PAVIMENTO TÉRREO O mercado

de pequeno porte possui quarenta boxes concêntricos, distribuidos de acordo com sua área: na periferia os maiores, com $52 \mathrm{~m} 2$ cada, destinados ao comércio de peixes, carnes, laticínios e artigos domésticos. Em seguida, na carreira intermediária, boxes com $20 \mathrm{~m} 2$ para frutas e verduras. No último círculo, os boxes menores, com $15 \mathrm{~m} 2$, para frutas. Ao redor da coluna central concentram-se administração, sanitários e uma lanchonete. Os boxes foram revestidos em resina epoxi e a área de circulação recoberta de piso de alta resistência.

Além deste bloco, a obra conta ainda com: vestiários e sanitários, $4000 \mathrm{~m} 2$ de estacionamento, $1000 \mathrm{~m} 2$ pátio de carga e descarga, cabine de força para $300 \mathrm{Kva}$.

A iluminação foi feita com lâmpadas a base de vapor de mercúrio, com instalações subterrâneas e holofotes de iluminação indireta.

TRATAMENTO DE FACHADAS 
Sob a cobertura aberta convidando para entrar como um grande guarda-chuva que abriga a todos, ainda são visíveis conceitos dos primeiros ideais da arquitetura brasileira: o uso da cor e a distribuição de áreas dentro de uma hierarquia lógica programática denotam a formação carioca de Abelardo.

"Eu sempre gostei muito da cor. Há 15 anos, muita gente criticou meu projeto para o Edifício Três Marias, na Avenida Paulista. Eu escolhi para fachada as côres azul e cor-de-rosa. Foi um dos primeiros edifícios coloridos da cidade."

As mesmas cores estão no mercado de Pirituba. Por dentro e por for a, o mercado é bastante colorido. Apenas a cobertura ficou em concreto aparente."

TRATAMENTO PAISAGÍSTICO: Não foi encontrado nenhum paisagismo. $\quad O$ arquiteto projetou para os muros externos de contenção, painéis em relêvo à serem executados na própria concretagem. Estes muros hoje estão pintados em branco com propagandas políticas ou comerciais, que impedem a visão dos relêvos.

ESTADO ATUAL DO CONJUNTO: Em 1976, de acordo com declarações em artigo publicado pelo Jornal da Tarde, o Mercado de Pirituba não havia tido total ocupação de seus boxes, e apresentava problemas de funcionamento:

"Entretanto a causa do fracasso no Mercado Municipal de Pirituba parece ser outra: as más condições que o prédio tem para funcionamento.

Entre a parede que circunda o prédio e o teto há uma parte aberta. E é por essa abertura em volta do prédio que passa uma constante e incômoda corrente de ar. Quando chove, cai água dentro do prédio, molhando as pessoas e mercadorias.

Outra reclamação dos donos das bancas é que pela abertura entram também pássaros, que comem cereais e frutas. No verão o material isolante da cobertura derrete e prende os pássaros que pousam nele. Segundo alguns funcionários da prefeitura, no teto há um verdadeiro cemitério de passarinhos. "16

${ }^{6}$ JT- 20/12/1976

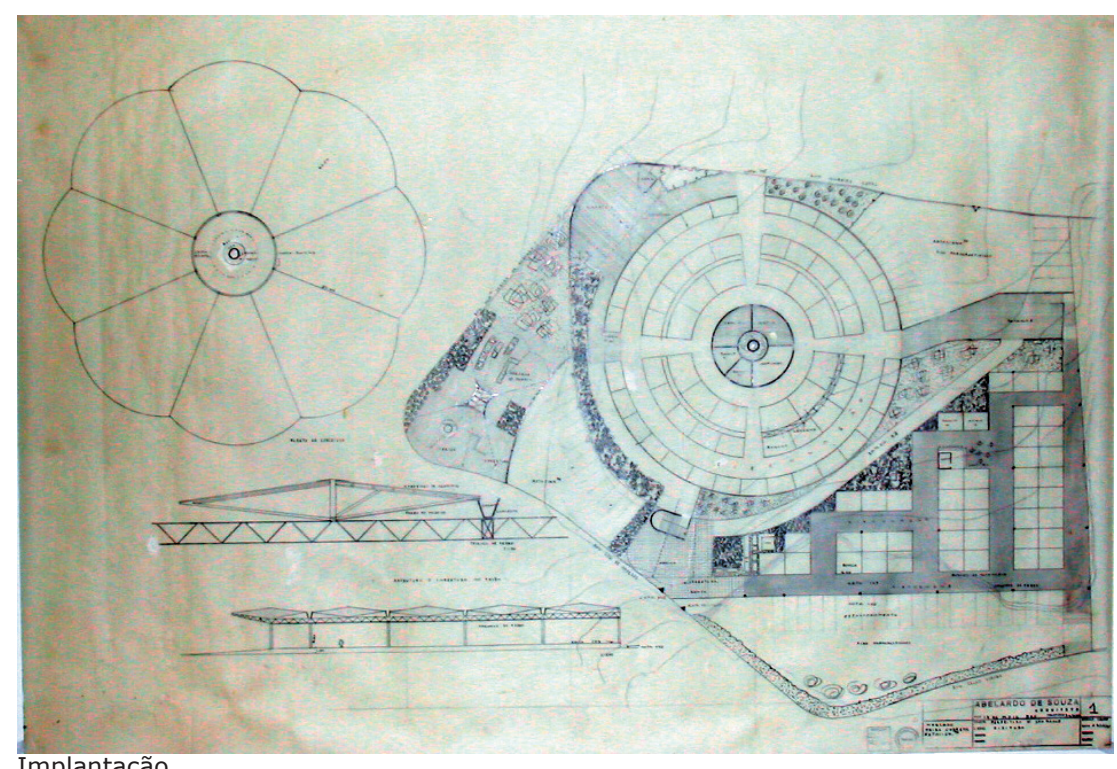

Implantação.

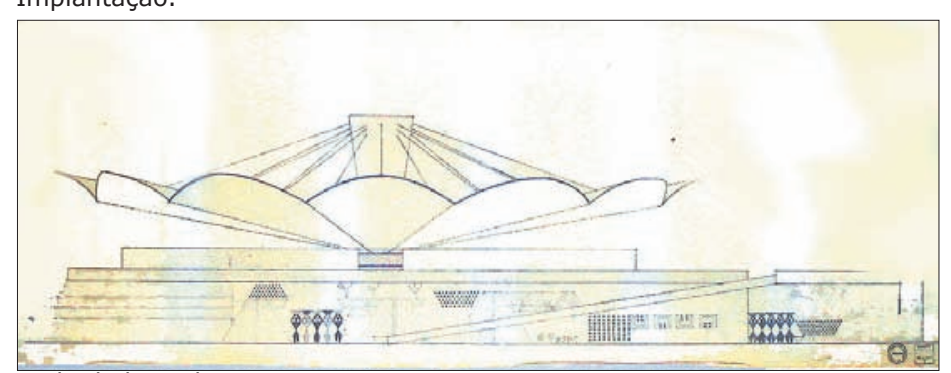

Fachada lateral.

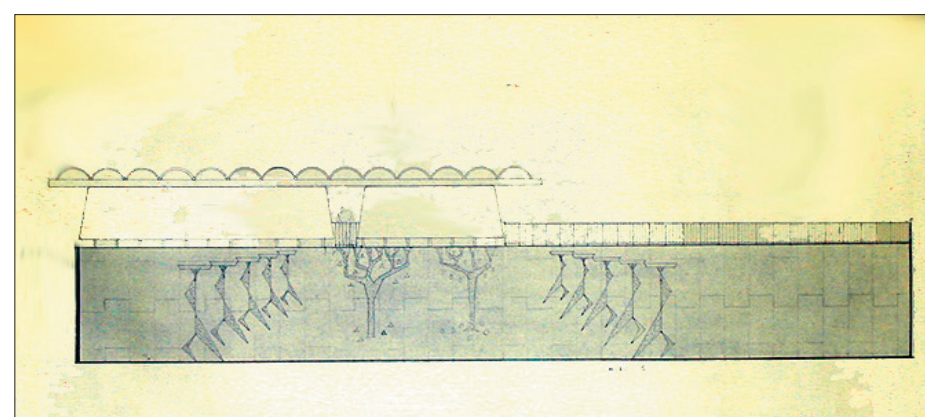

Sanitários e muro com relêvos. 

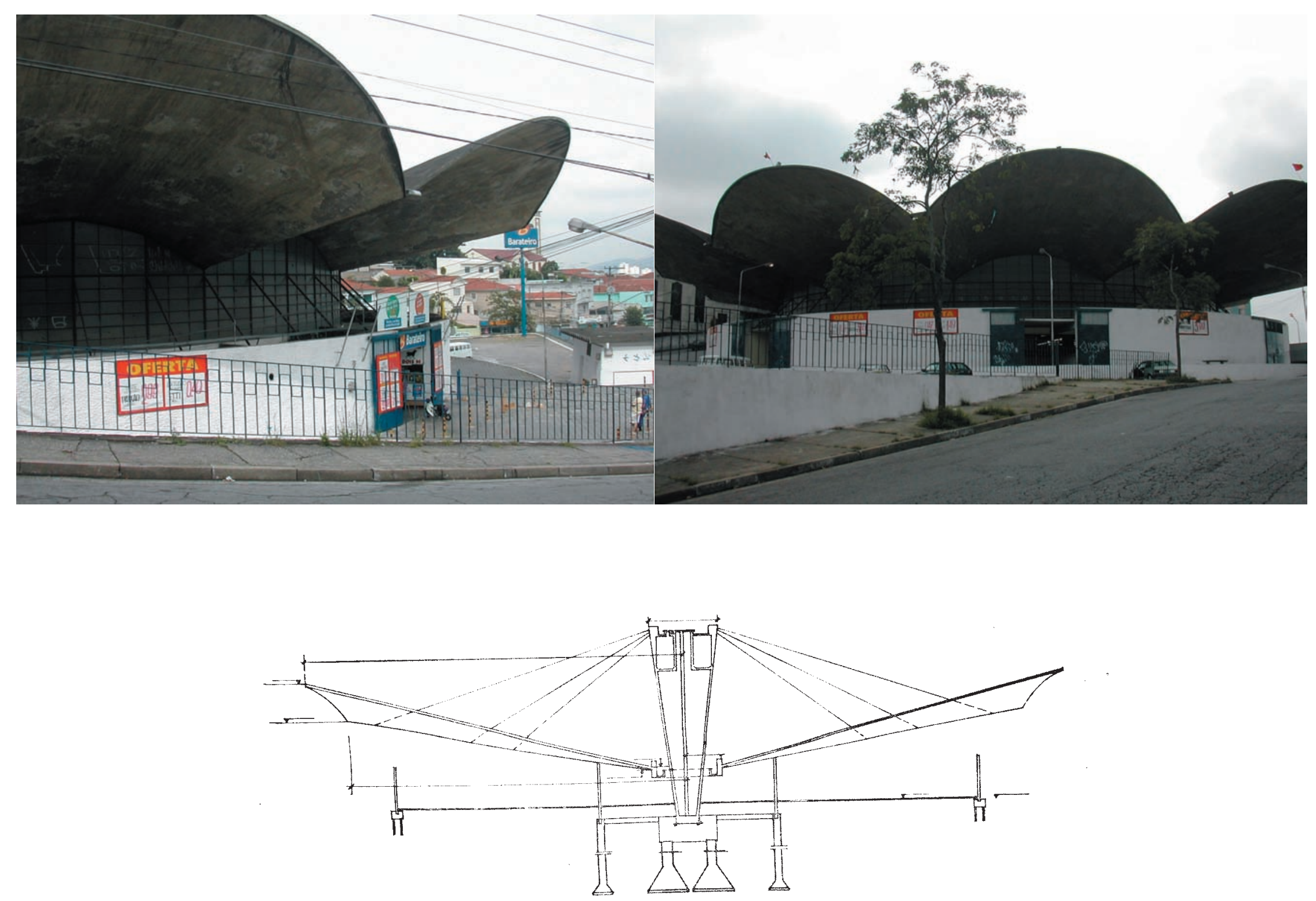


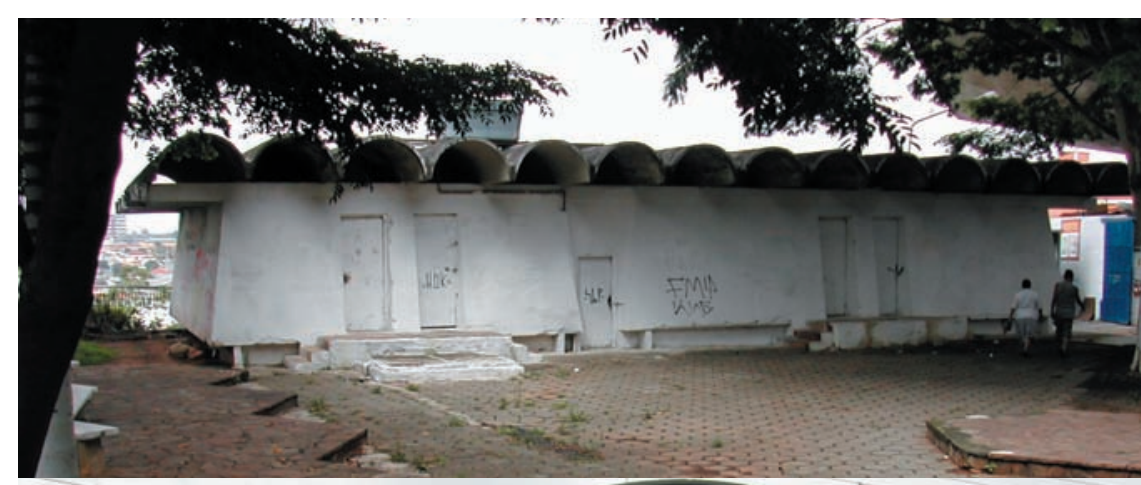

Em virtude deste quadro, a prefeitura promoveu uma licitação na qual permitia que parte do mercado fosse ocupada por um Supermercado:

Segundo Flavio Cappelletti, chefe de Gabinete do Secretário doAbastecimentoa concorrência para ocupar o mercado (vencida pelo Morita) foi a "única formula encontrada para dinamizar aquele mercado, que nunca teve bom movimento e contava com poucos permissionarios".

Foi construida uma parede separando o Supermercado dos boxes remanescentes, instalados vitrôs em ferro e vidro para vedação.

Hoje o mercado encontrase dividido, descaracterizado e, ainda, numa situação de descaso. 


\section{Residência Osvaldo Young}

1944

\section{DADOS DO PROJETO}

Local: Represa Guarapiranga, São Paulo - SP

Publicações:

\section{DESCRIÇÃO DO}

PROJETO:

A notável residência em Santo Amaro, de 1944, é resultado de um programa sem limitações em amplo terreno. A residência Oswaldo Young, excelentemente inserta na paisagem obteve tal organicidade e sequência de seus componentes que Ferraz considera que Abelardo atingiu neste projeto um resultado raramente atingido em exemplos ulteriores ${ }^{1}$.

Há grande predomínio da zona de estar sobre as demais e uma clara busca de continuidade entre o interior e o exterior. Do deslocamento do volume que comporta a zona íntima situada no segundo pavimento sustentada independentemente por colunas de concreto resultou um amplo terraço coberto.
Publicações:

Acrópole 101, p.143-5. 1946.

Acrópole 184, p.171. 1953. Habitat 39, p.4-5. 1957.

Grandes placas de vidro isolam este terraço do salão de bilhar ou jogos, que por sua vez unese ao resto da zona de estar pelo "hall".

A topografia do terreno foi otimamente aproveitada. A casa ficou montada numa encosta, sobre um lago de carpas, de onde se descortina a magnífica paisagem.

\section{Área do Lote: \\ Área Construída: 450m2 No de pavimentos: 1}

PAVIMENTO TÉRREO Terreno a beira da represa levou a uma implantação da casa predominantemente horizontal, voltada para a água. $\mathrm{O}$ acesso de carro é feito pela parte da trás da residência.

A planta do térreo abriga sala de jogos, páteo coberto, estar, cozinha, dependências de empregada e de serviço.

' FERRAZ, Geraldo in Habitat 39, 1957
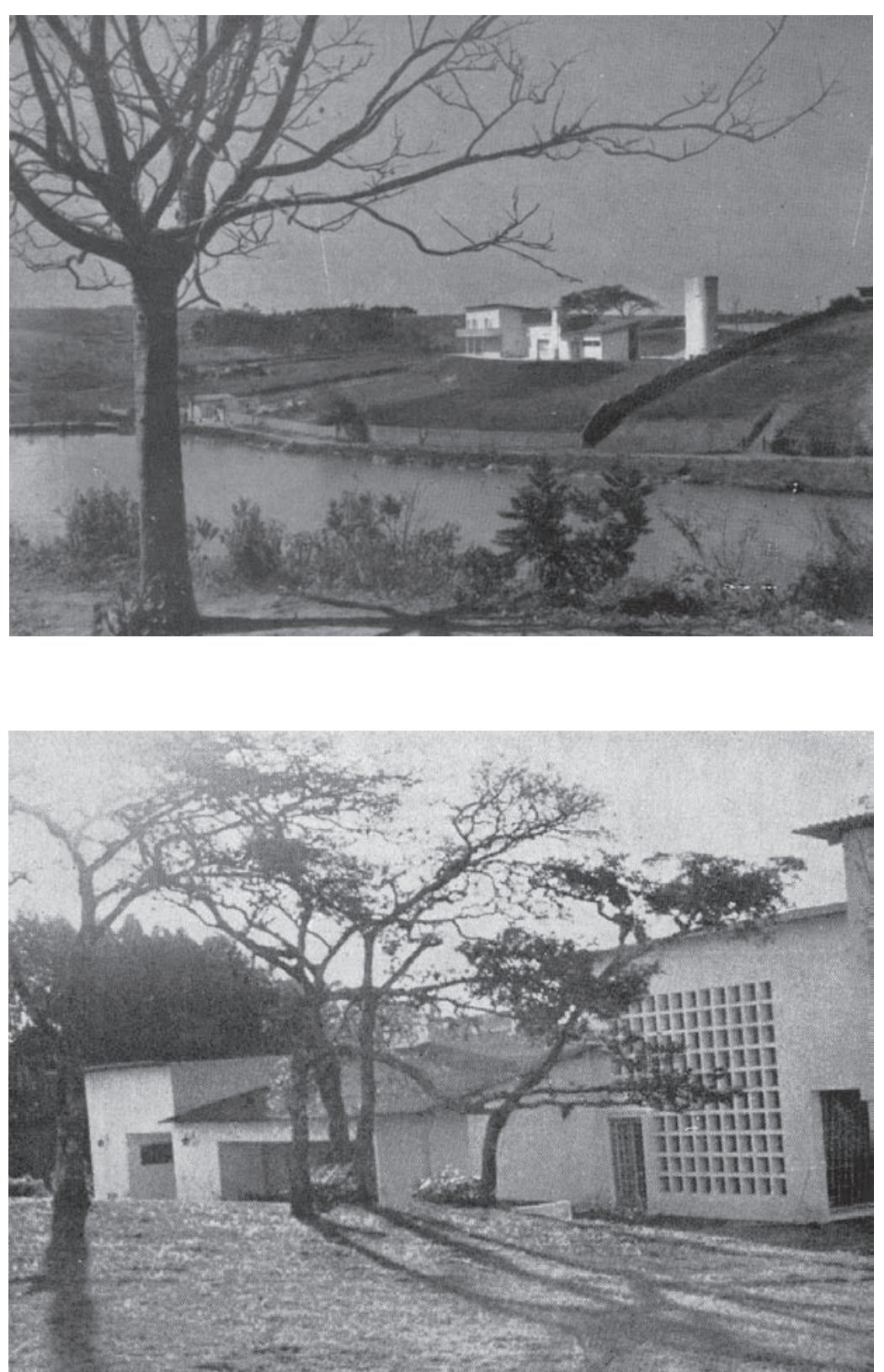
PAVIMENTO SUPERIOR O pavimento superior comporta quatro quartos e dois banheiros, distribuidos em volume em L sobre o salão de jogos e encontra-se deslocado em relação ao corpo principal, formando um pátio sombreado sobre pilotis. Os quartos possuem terraço em balanço voltado para represa.

TRATAMENTO DE FACHADAS Há uma forte marcação de portas, janelas e jogo de sombras pelo uso de elementos vazados e brises, sobre grandes panos brancos de alvenaria.

Quanto a distribuição de volumes, o corpo destacado da lareira equilibra as alturas, juntamente com o volume da caixa d'água que é separado da casa.

TRATAMENTO PAISAGÍSTICO A execução dos jardins ficou à cargo da Casa Flora.

Sobre este trabalho, ressalta Paulo Bruna: "Nessa obra, como de resto na maior parte de suas obras residenciais está evidente a preocupação de integrar o exterior com o interior $e$ a valorização dos jardins."
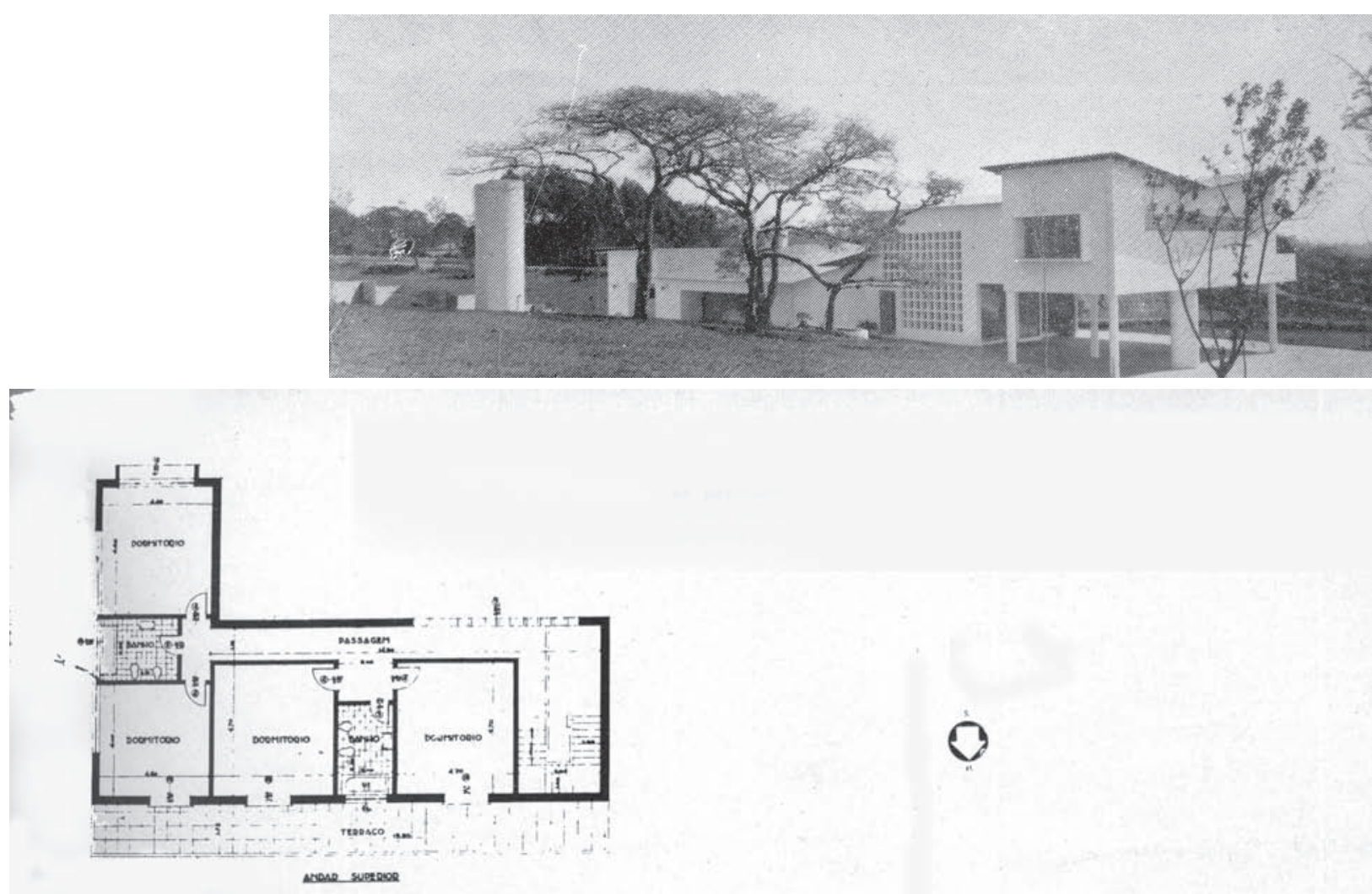

0

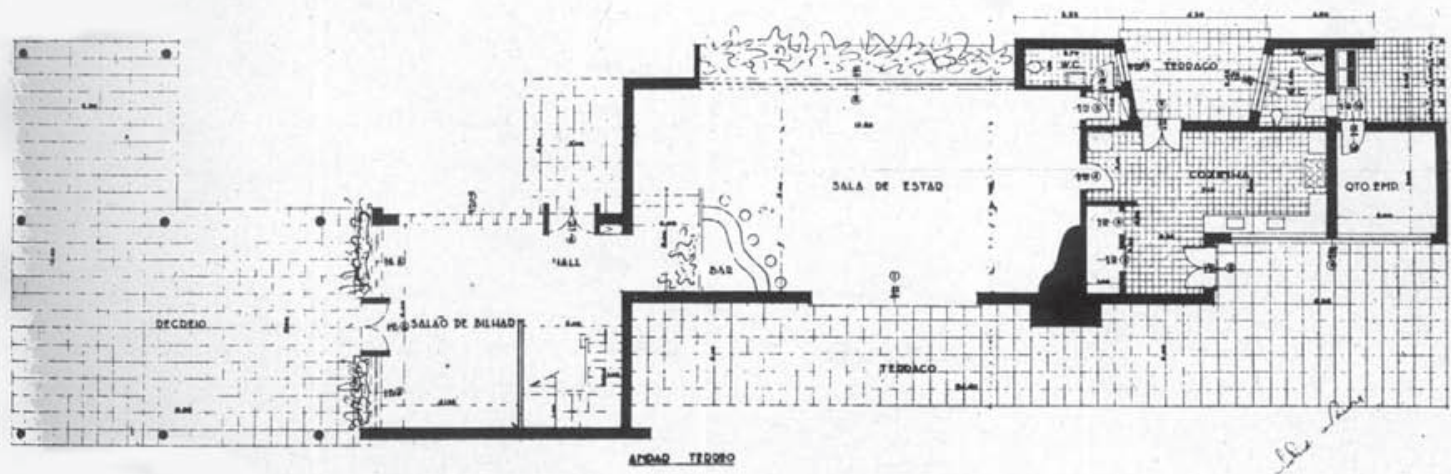



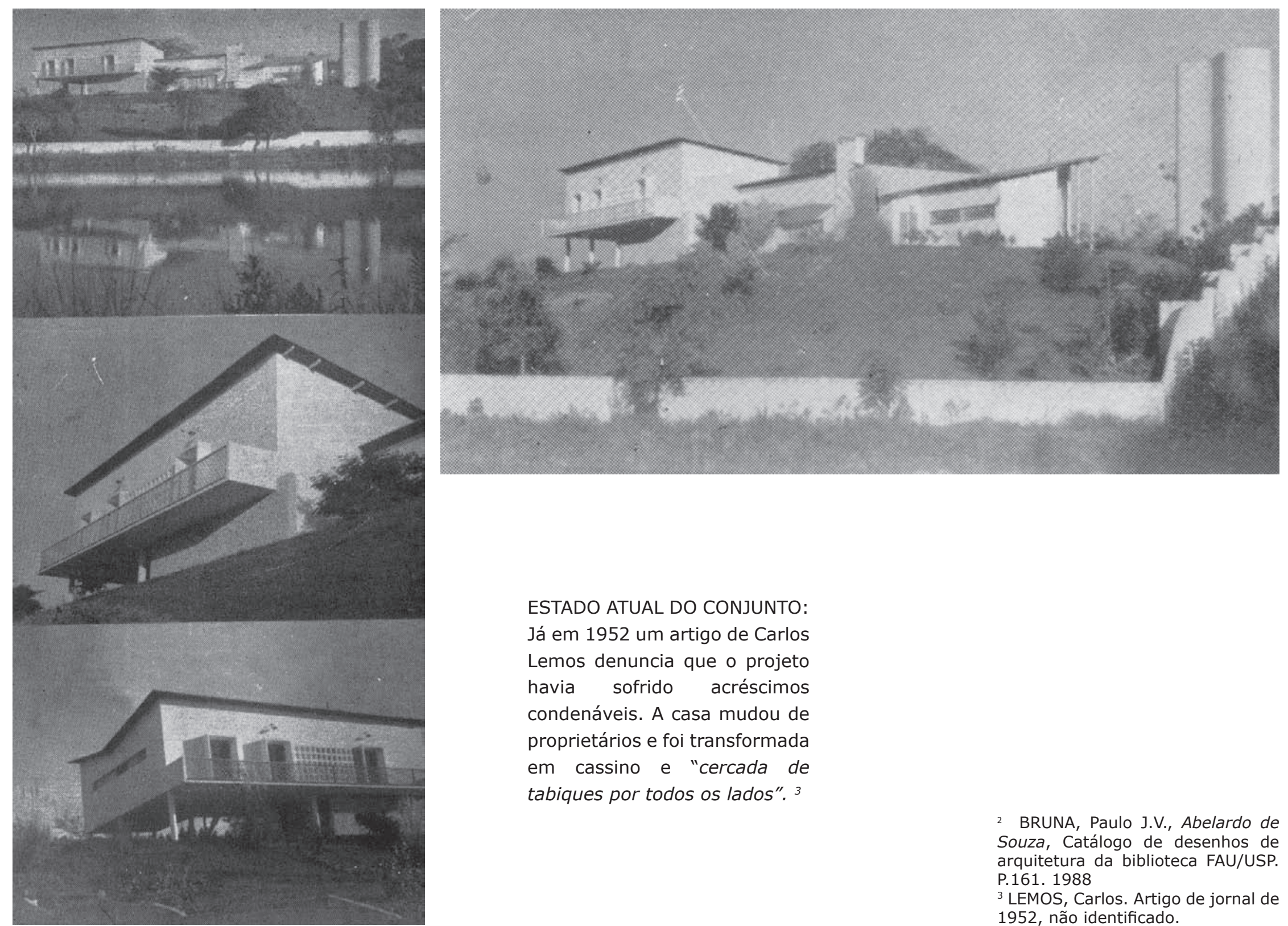

ESTADO ATUAL DO CONJUNTO: Já em 1952 um artigo de Carlos Lemos denuncia que o projeto havia sofrido acréscimos condenáveis. A casa mudou de proprietários e foi transformada em cassino e "cercada de tabiques por todos os lados". 3

BRUNA, Paulo J.V., Abelardo de Souza, Catálogo de desenhos de arquitetura da biblioteca FAU/USP. P.161. 1988

3 LEMOS, Carlos. Artigo de jornal de 1952, não identificado. 


\section{Residência do Arquiteto}

\section{5}

Publicações:

Acrópole 184, p.171.

1953.

Arquitetura e Decoração 1

p. 20-1.

1953.

Habitat 39, p.8.

1957.

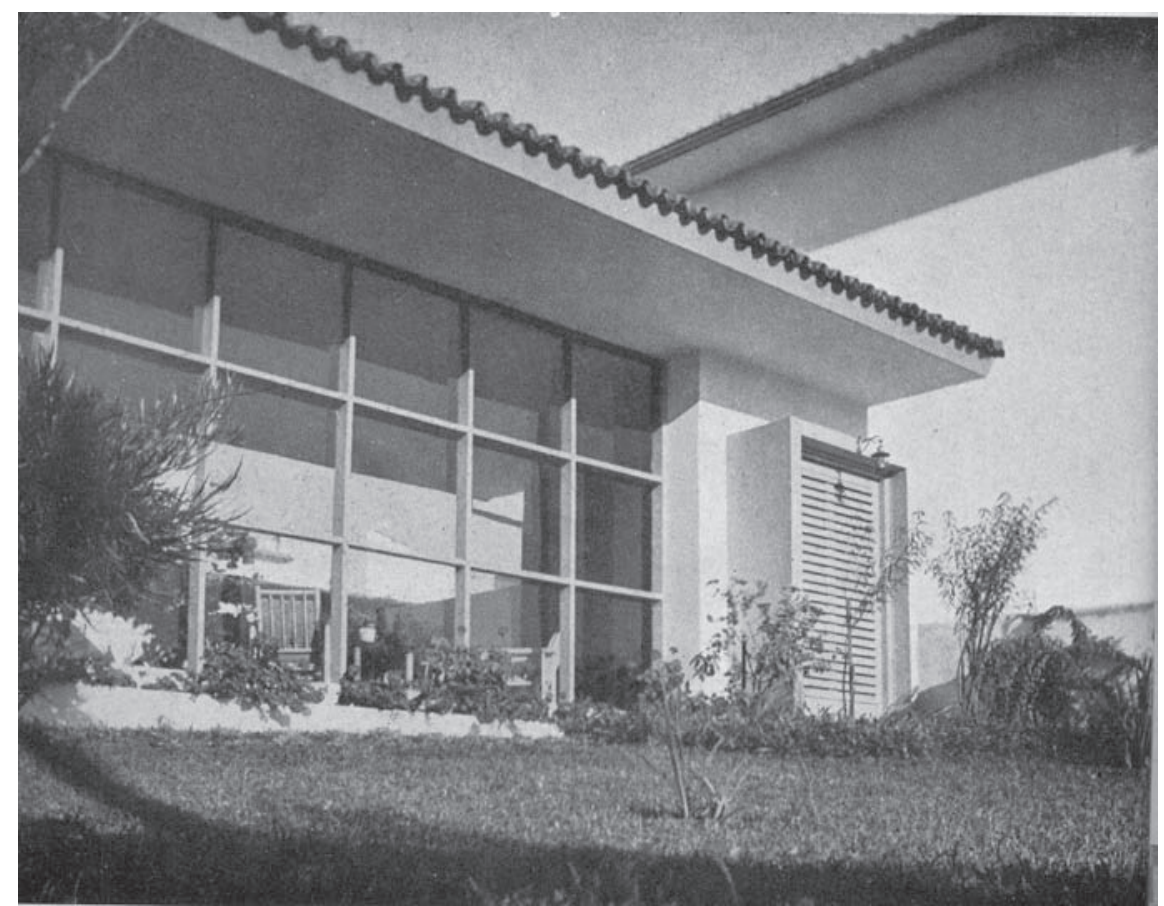

\section{DADOS DO PROJETO:}

Local: Rua Curitiba/Av. Itororó

\section{DESCRIÇÃO DO PROJETO:}

Residência de um pavimento no bairro do paraíso que o arquiteto construiu para si. No lote de esquina alinhou a casa com o muro de divisa na lateral esquerda e o projeto desenvolveu-se de forma orgânica, deixando generosas porções de terreno e pátios internos destinados à jardim.

Amplas áreas de esquadrias, reforçando a ligação interiorexterior, jogo de volumes com deslocamento da área de quartos para o fundo do terreno.

Área do Lote: $~ 800 \mathrm{~m} 2$ Área Construída: 250m2 No de pavimentos: 1

PAVIMENTO TÉRREO: As zonas de estar ficam paralelas à frente do terreno, porém voltadas para pátio interno.

Cozinha e serviços foram distribuídos de forma alinhada ao fundo do lote, com aberturas para circulação de carro.
O projeto de interiores foi feito pelo próprio Abelardo, com móveis de Joaquim Tenreiro e escolha de cores com Rebolo que usou em sua paleta: ferrugem em uma das paredes, nos móveis roxo, verde, preto vermelho, tapete em cinza e cortina tricolor amarelo, preto e ocre.

PAVIMENTO SUPERIOR: Dois quartos e dois banhos completos, sendo que nenhum é suíte. A disposição inclinada da escada forçou forma irregular dos banheiros.

TRATAMENTO DE FACHADAS: Com uma volumetria clara, a casa desenvolve-se de forma organicista. O arquiteto utiliza cores ousadas nas esquadrias e portas, mas com certa parcimônia. 

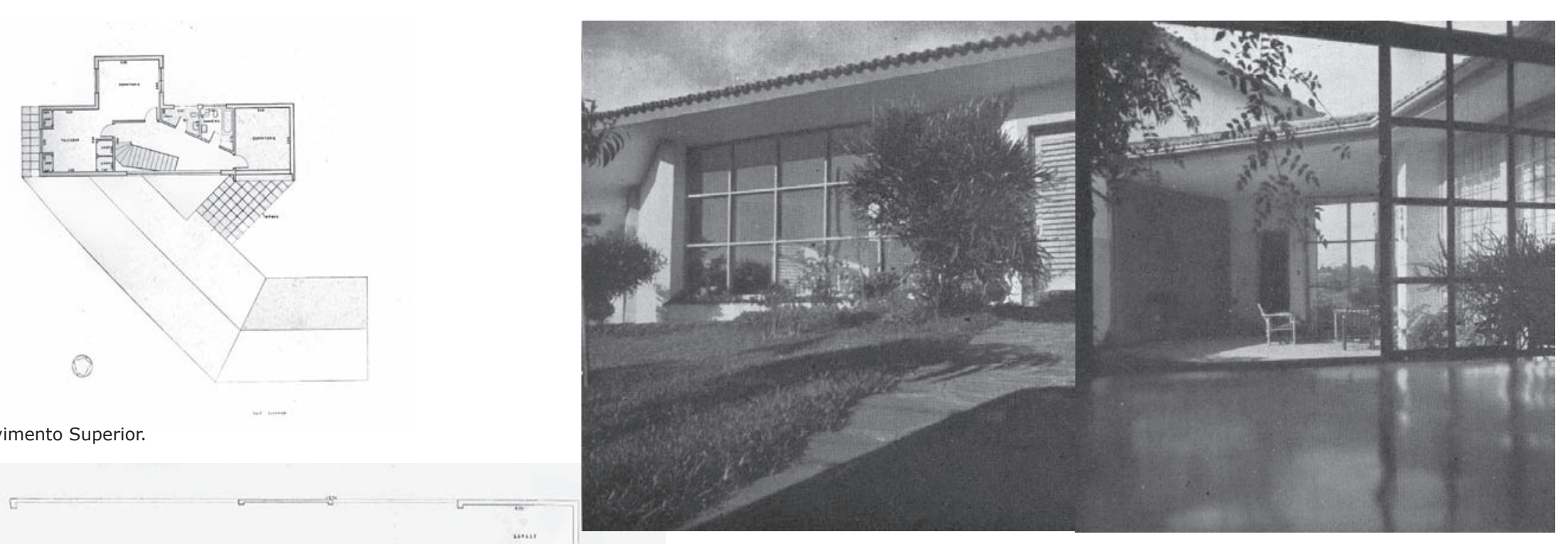

Pavimento Superior
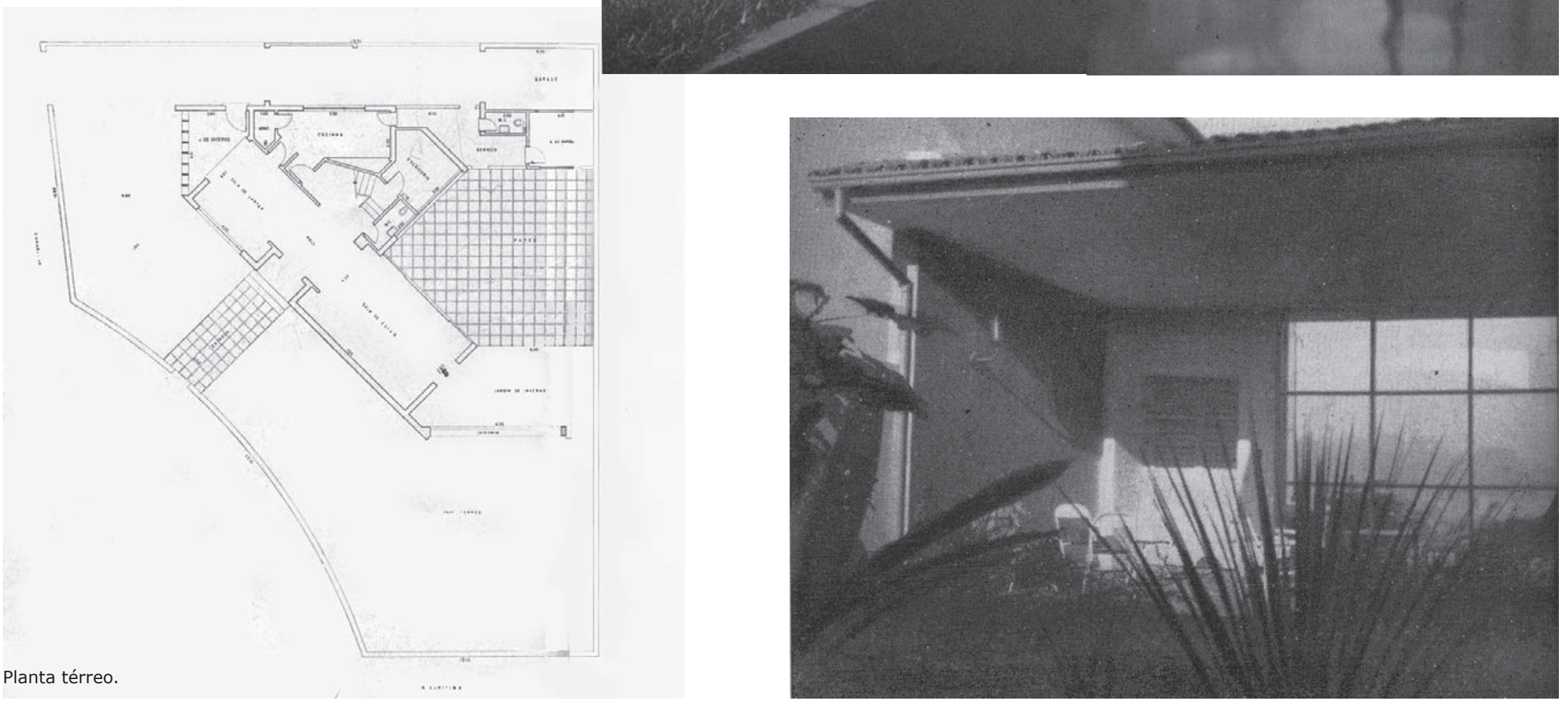


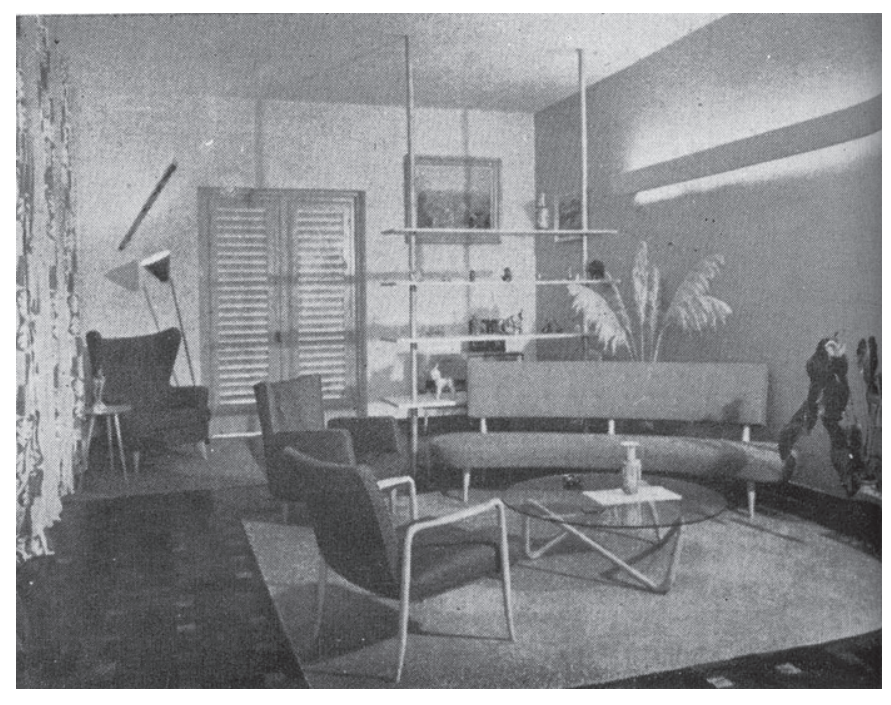

Interior decorado com móveis de Joaquim Tenreiro.
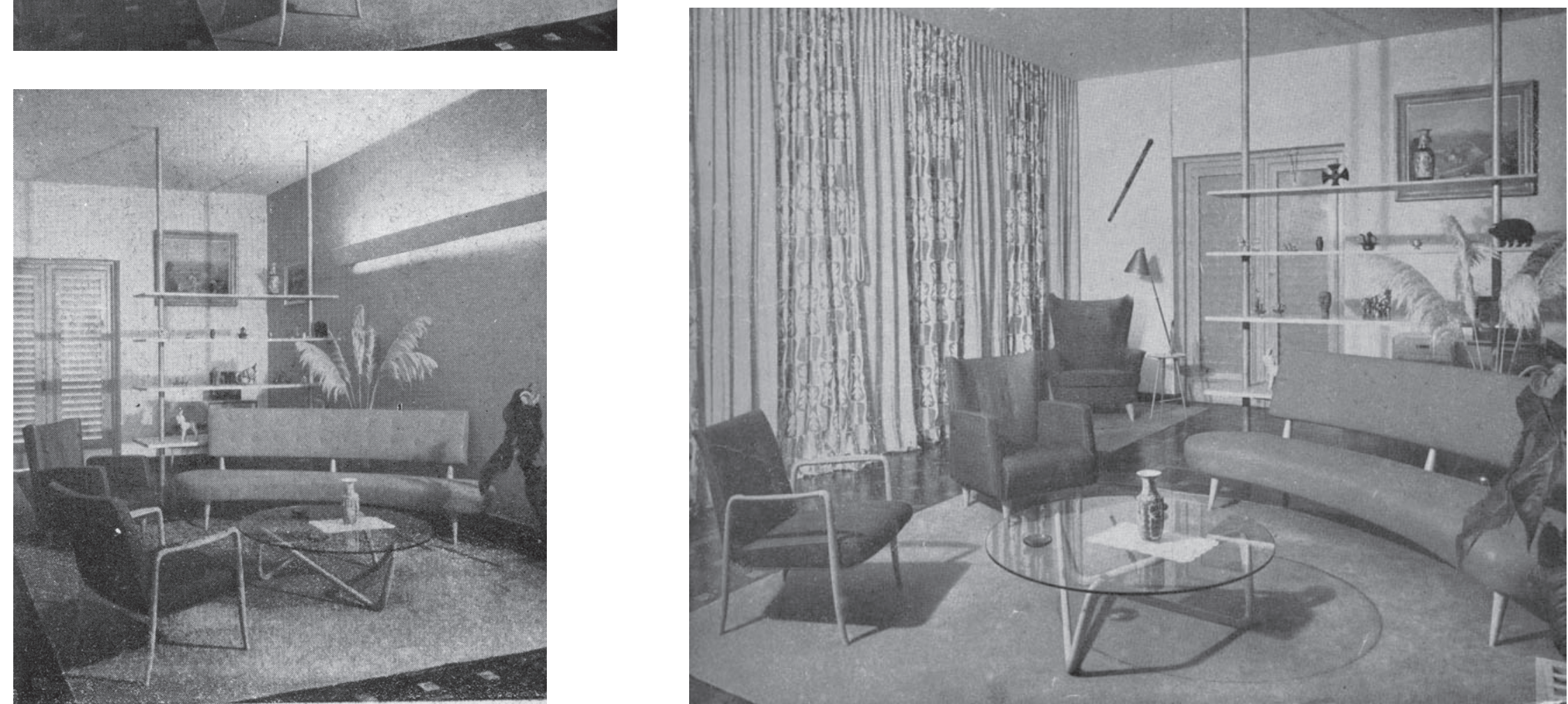


\section{Casa de Campo}

1945

Publicações:

Acrópole 184.

1953.

Habitat 39, p.6.

1957.

LEMOS, Carlos, Folha da

Manhã.

1952.

\section{DADOS DO PROJETO}

Local: Este projeto aparece em artigo de Carlos Lemos para Folha da Manhã de 1952, referindo-se a uma casa nas proximidades da represa de Sto. Amaro. Em matéria da Revista Acrópole de 1953, imagens da maquete desta casa tratam de uma Casa de Campo em Minas Gerais.

Premiações: XV salão paulista de belas Artes de 1949. ${ }^{1}$

DESCRIÇÃO DO PROJETO:

Este projeto para casa de campo reforça a tendência do arquiteto de estabelecer a relação entre o interior.

Como trata-se de uma residência de fim de semana as zonas de serviço e habitação assumiram papel secundário, valorizando a zona de estar.

Telhado em forma de borboleta e diversidade no uso de materiais seguem 0 pensamento da escola carioca.

No de pavimentos: térrea

PAVIMENTO TÉRREO Como residência de campo. o arquiteto previu pequenos dormitórios, banheiro mínimo, zona de serviço necessária e dedicou o resto da construção à zona lazer.

TRATAMENTO DE FACHADAS: Foram previstos materiais de construção adequados ao ambiente e com a função da casa. A zona de estar foi dividida em duas partes, uma interna e outra externa ou varanda, ambas com o mesmo tratamento de materais. O piso contínuo em pedra de arenito integra as áreas. A estrutura e uma das paredes, foi executada com madeira natural, não aparelhada, em forma de troncos ou galhos.
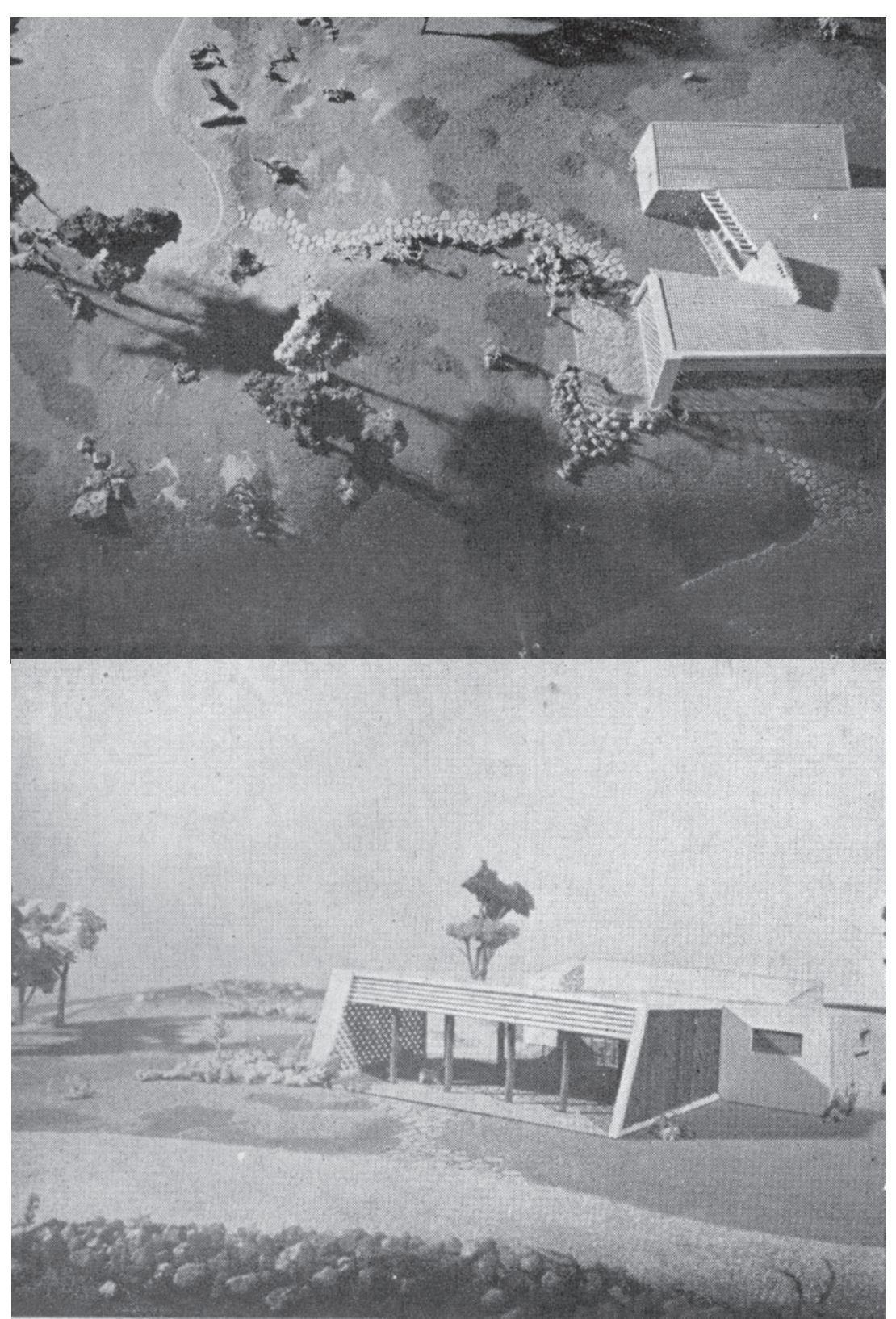

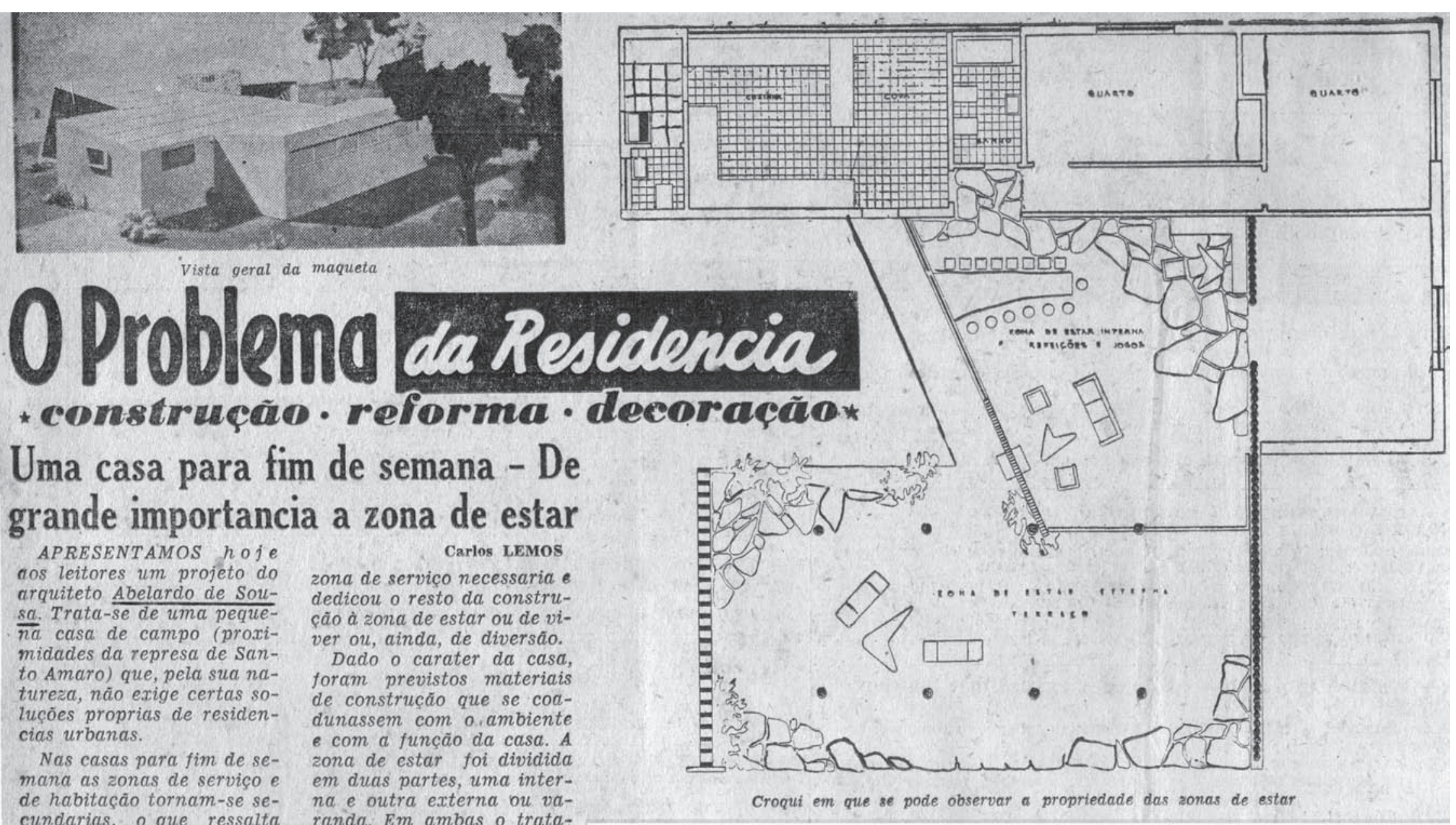

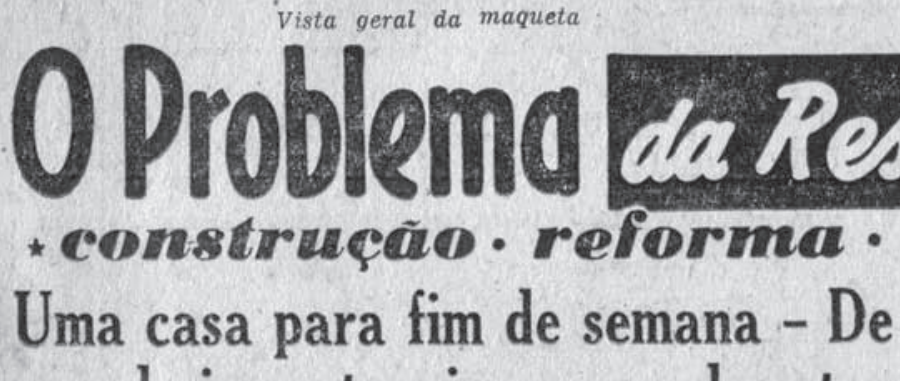
grande importancia a zona de estar APRESENTAMOS hoje aos leitores um projeto do arquiteto Abelardo de Sousa. Trata-se de uma pequena casa de campo proximidades da represa de Santo Amaro) que, pela sua natureza, náo exige certas solucóes proprias de residen cias urbanas.

Nas casas para fim de semana as zonas de serviço e cundarias, o que ressalta mais a importancia da zona de estar. Isto é logico, por que a funcão das casas de campo é servir de local pa ra repouso são casas de estar e ño de morar. Seguindo esta orientacếo, o grquitoto previut pequenos dorteto previu pequenos doredicou o resto da constru ção à zona de estar ou de vi ou, ainda, de diversáo. Dado o carater da casa. oram previstos materiais de construcão que se coa dunassem com o,ambient e com a função da casa. A zona de estar foi dividid. em duas partes, uma inter na e outra externa $b u$ va randa. Em ambas o tratamento e igual. O piso continuo é de pedra lajes de arenito) e a estrutura, as sim como uma das paredes, foi executada com madeira om aparelhada, melhor 政 estado natural, em tromos ou galhos.
${ }^{4}$ Acredito que este tenha sido o projeto premiado no XV salão paulista de belas Artes de 1949 de acordo com artigo de jorna de Quirino da Silva, de 1949. 


\section{Residência Zoroastro Leme}

1947

Publicações:

Acrópole 105, p.244-5.

1947.

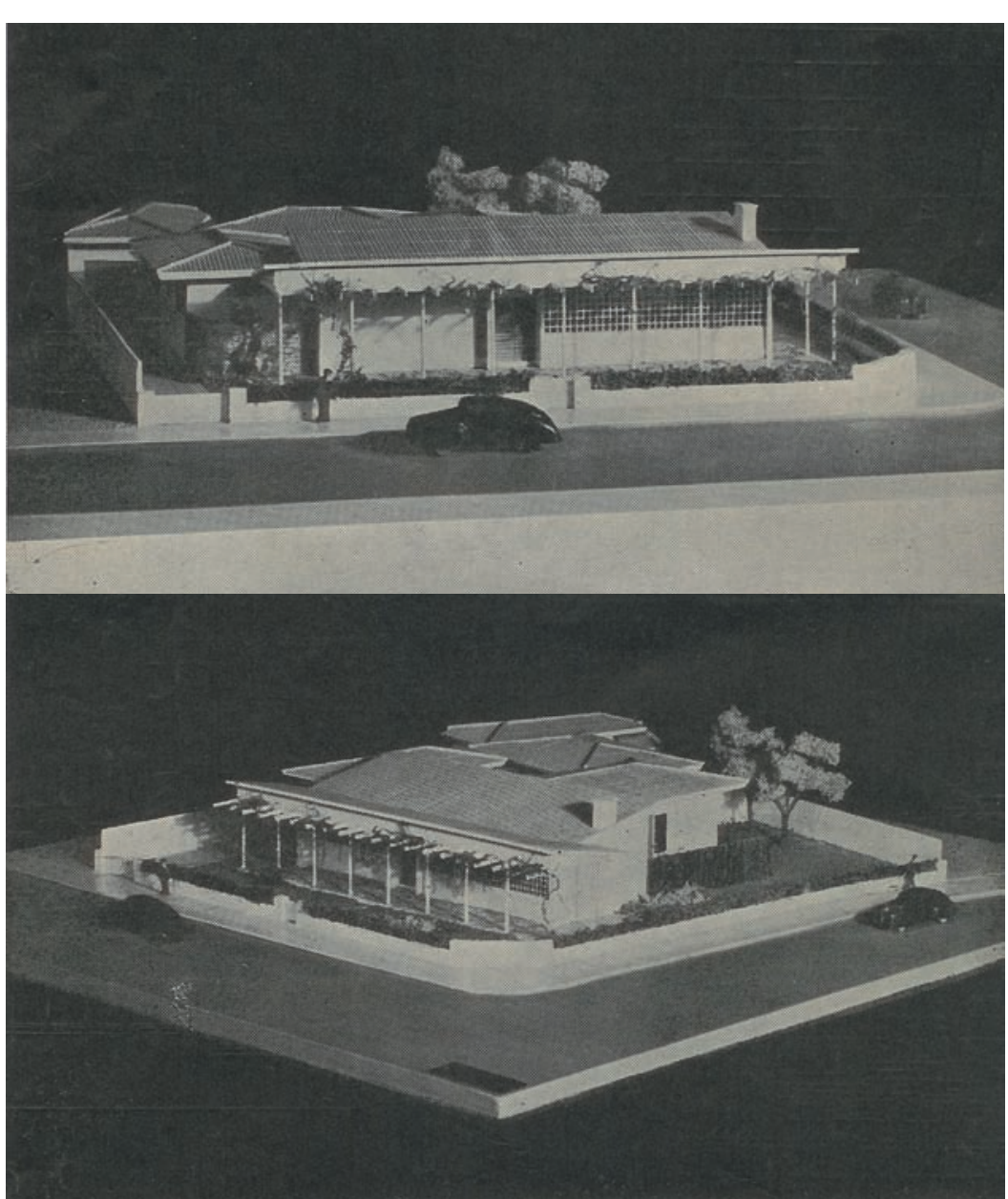

\section{DADOS DO PROJETO}

Local: Av. Sagres/ R. D. Henrique. Vila Nova Conceição, São Paulo-SP

\section{DESCRIÇÃO DO \\ PROJETO:}

Projeto de residência térrea em São Paulo, localizado em lote de esquina. A distribuição de áreas e volumes acontece de forma orgânica, ocupando o centro do lote.

\section{Área do Lote:}

Área Construída:

No de pavimentos: térrea

PAVIMENTO TÉRREO: Parte social da casa fica localizada para Rua D. Henrique, mas as aberturas são feitas com elementos vazados, no intuito de voltar a casa para o interior. Entrada de carros pela lateral, um jardim murado isola sala de jantar da circulação de carros. Os dormitórios tem aberturas voltadas para as divisas e a circulação de acesso para eles é feita em corredor vazado voltado para páteo interno. Com quatro dormitórios, a casa possui apenas um banheiro completo e dois w.cs., sendo um na parte íntima e um para visitas.

Dependência de empregada na edícula junto à garagem.

TRATAMENTO DE FACHADAS: $O$ arquiteto faz uso de telhado convencional com telha e calhas. Unidade na fachada principal obtida pelo uso de pergolado em madeira. Elementos vazados foram usados sem cerimônia.

TRATAMENTO PAISAGÍSTICO: O arquiteto destina grandes porções do terreno para execução de jardins, que praticamente participam do projeto. Apesar disto, não determina nas plantas sua intenção nesta área. 


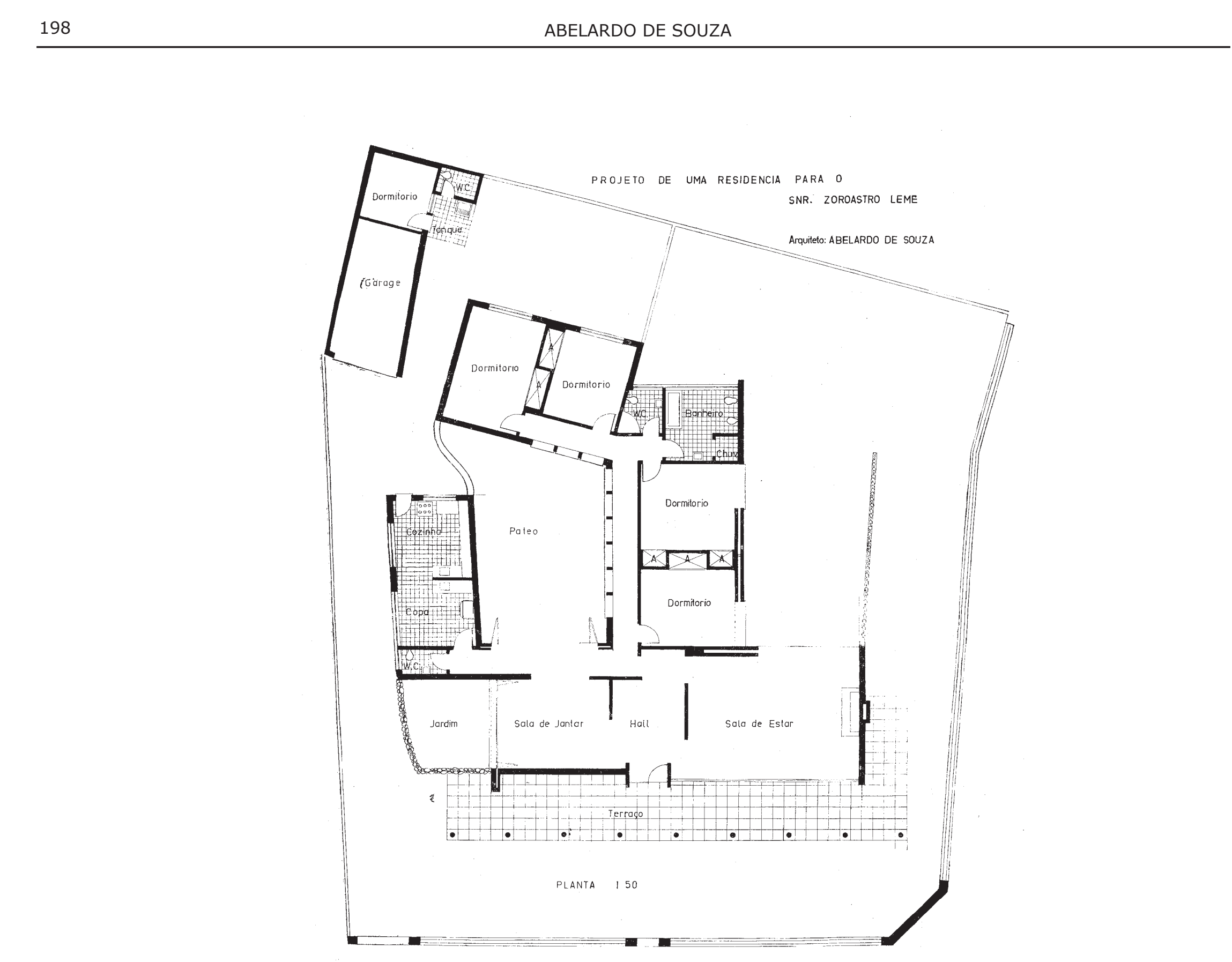




\section{Residência Waldomiro Delboni}

\section{8}

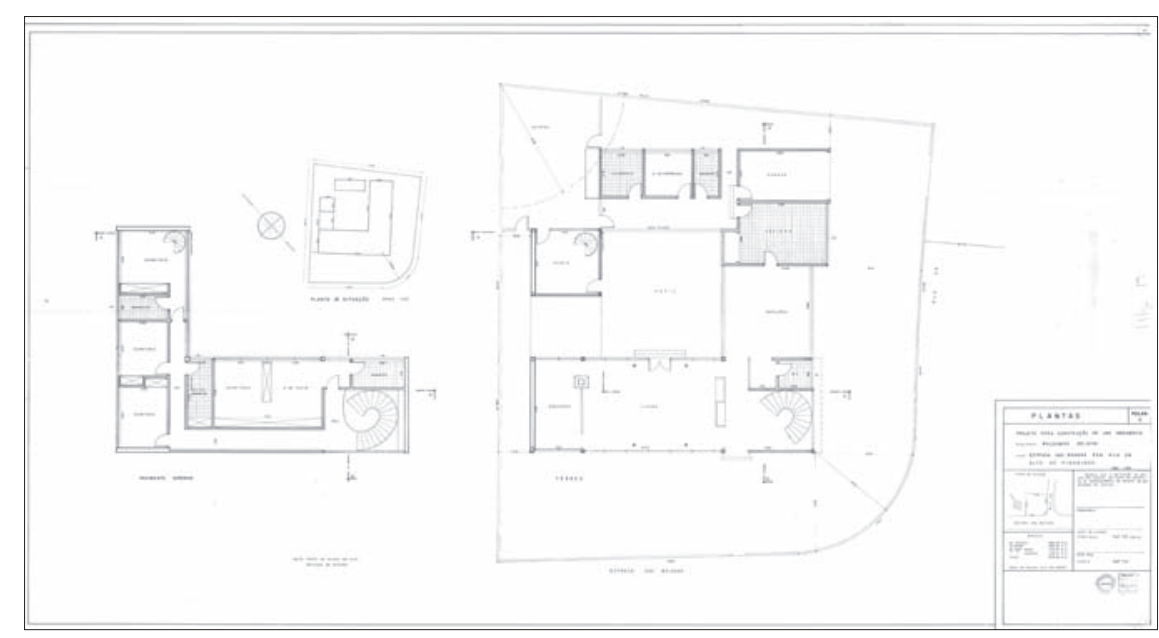

Situação e projeto completo.

\section{DADOS DO PROJETO}

Execução: Construtora Edifica

Ltda

Local:Av. Diógenes Ribeiro de Lima, Alto de pinheiros. São Paulo, SP

\section{DESCRIÇÃO DO PROJETO}

Localizada em terreno de esquina, a casa encontra-se locada em direção às divisas de fundo. Desenvolve-se em torno de um pátio central com jardim e espelho d'água. Sua característica mais interessante é jogo que o deslocamento de dois volumes em L conseguiu, de forma a produzir áreas abertas sombreadas.

Área do Lote: 780m2 Área Construída:376,56m2 No de pavimentos: 1

PAVIMENTO TÉRREO: Estrutura livre criando amplo living e áreas integradas no térreo

A escada localizada no canto do living tem status de um elemento escultórico. No fundo do terreno existe um estúdio que liga-se a um dos quartos no primeiro piso através de escada caracol.
PAVIMENTO SUPERIOR:

Compreende a área íntima com quatro dormitórios, sendo que dois deles são suítes e mais um banheiro. Quantidade de banheiros incomum em projetos desta época. Apenas um dos quartos é voltado para o pátio interno, sendo os demais com vista para o recuo de divisa lateral.

TRATAMENTO DE FACHADAS: A estrutura recuada permitia total liberdade na disposição de aberturas. Note-se que há vários estudos de fachadas, sendo que entre os primeiros encontramos a parte térrea inteiramente envidraçada, numa linguagem "miesiana". Os demais estudos apresentam face voltada para rua fechada com alvenaria e diferentes composições de janelas e materiais.

Tijolo aparente, pastilhas brancas e pintura, madeira, venezianas de alumínio foram indicados. 


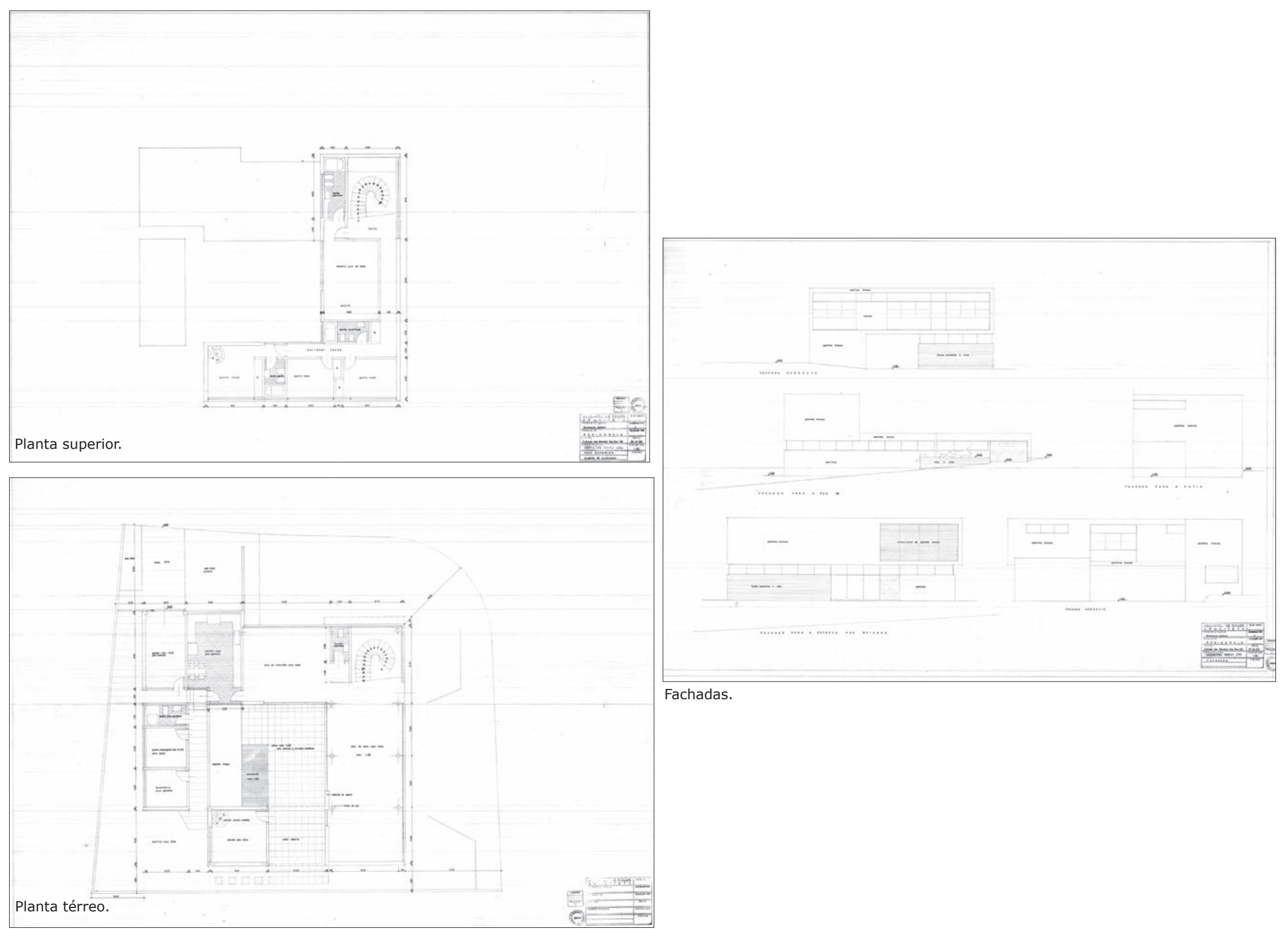




\section{Residência Aldo Bove e Carmem Arruda}

\section{2}

Publicações:

Acrópole 184, p.173.

1953.

Habitat 39, p.9 .

1957.

\section{DADOS DO PROJETO: .}

Local: Rua Dr. Oliveira Pinto/ Rua Sampaio Vidal, Jardim Paulistano. São Paulo - SP

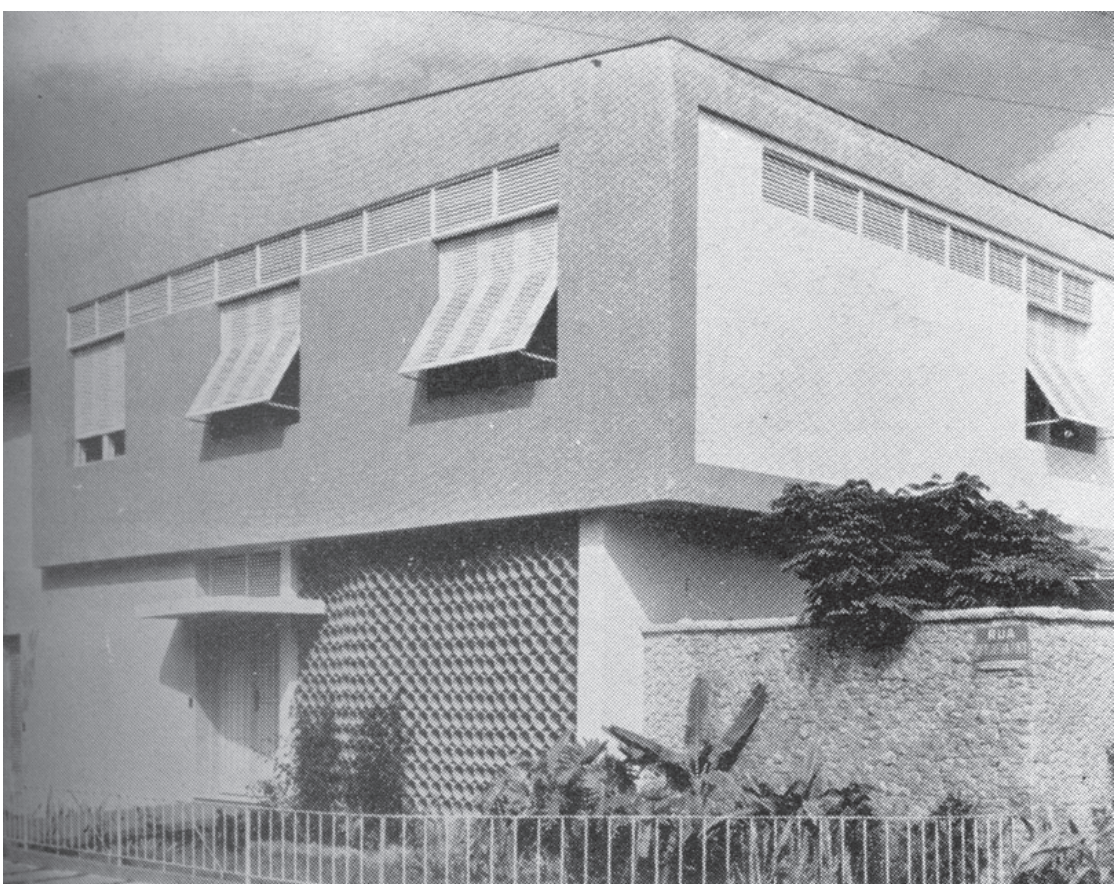

\section{DESCRIÇÃO DO}

PROJETO:

Projeto de residência no jardim Paulistano em São Paulo, para família de classe média. O arquiteto conseguiu total aproveitamento do pequeno lote de esquina, sem sacrifício das áreas internas que foram dotadas de soluções de ventilação e distribuição adequadas.

Área do Lote: $296 \mathrm{~m} 2$

Área Construída: 261,30m2 No de pavimentos: 1

PAVIMENTO TÉRREO: Mesmo em um lote compacto que não permitia muitas alternativas, 0 arquiteto conseguiu uma solução interessante com a criação de um jardim de inverno cercado por muro vazado de forma a obter isolamento satisfatório em relação ao pequeno recuo com a rua, um pano envidraçado faz a integração com o interior.

As áreas de serviço foram deslocadas para o fundo do terreno, mas possuem acesso independente através da garagem.

\section{PAVIMENTO}

SUPERIOR:

Máximo aproveitamento da

laje com quatro quartos e dois banheiros. O projeto respira pela inserção de terraço que amplia iluminação e ventilação

TRATAMENTO DE FACHADAS: $O$ uso de balanço destacando a volumetria do pavimento superior constitui-se em uma das características do trabalho de Abelardo e Souza. Mantém as características racionalistas trabalhando com prismas regulares.

Rica composição de cores e materiais e integração com paisagismo.

Há uma grande preocupação com ventilação dos ambientes tendo sido utilizadas venezianas em madeira sobre os caixilhos.

ESTADO ATUAL DO CONJUNTO: O projeto encontra-se descaracterizado em sua fachada. A casa recebeu muros altos no seu perímetro e teve seus revestimentos alterados. Com a substituição das janelas, as venezianas foram removidas e a sob cada abertura fo aplicada uma pequena jardineira em cimento com ornamentos "clássicos". 


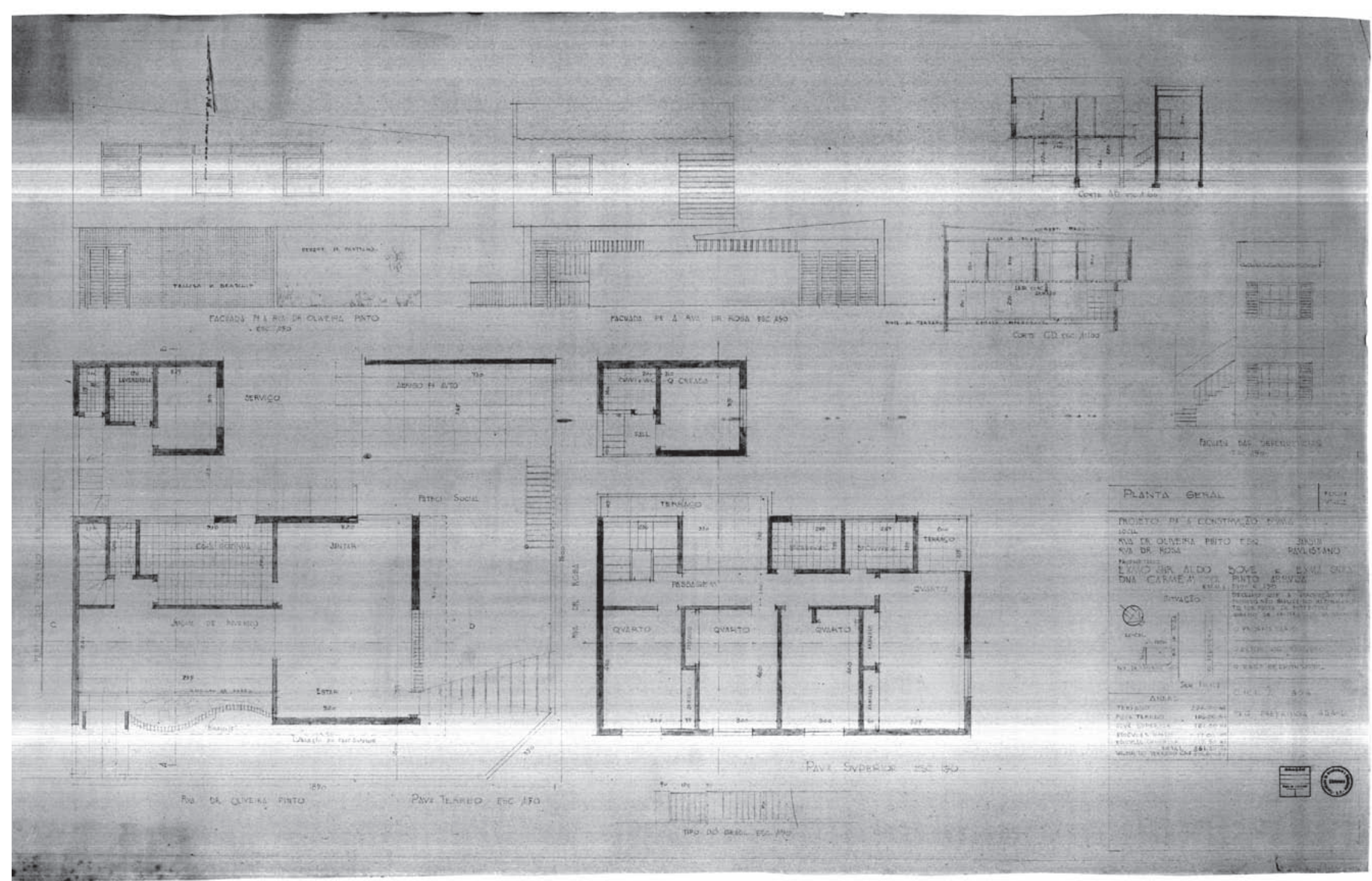




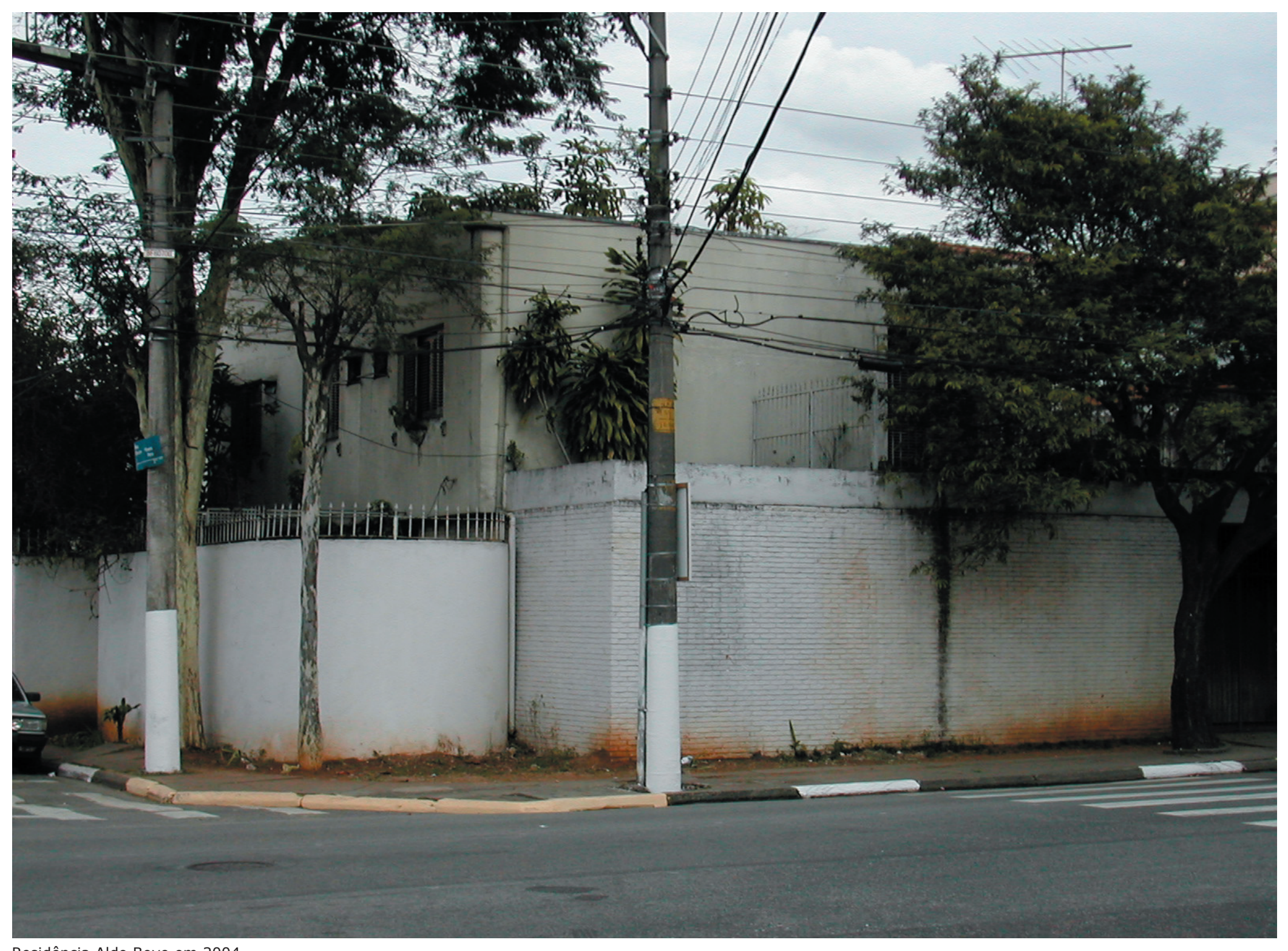




\section{Residência Chaim} Goldenstein

\section{4}

Publicações:

Acrópole 209, p.172-5.

1956.

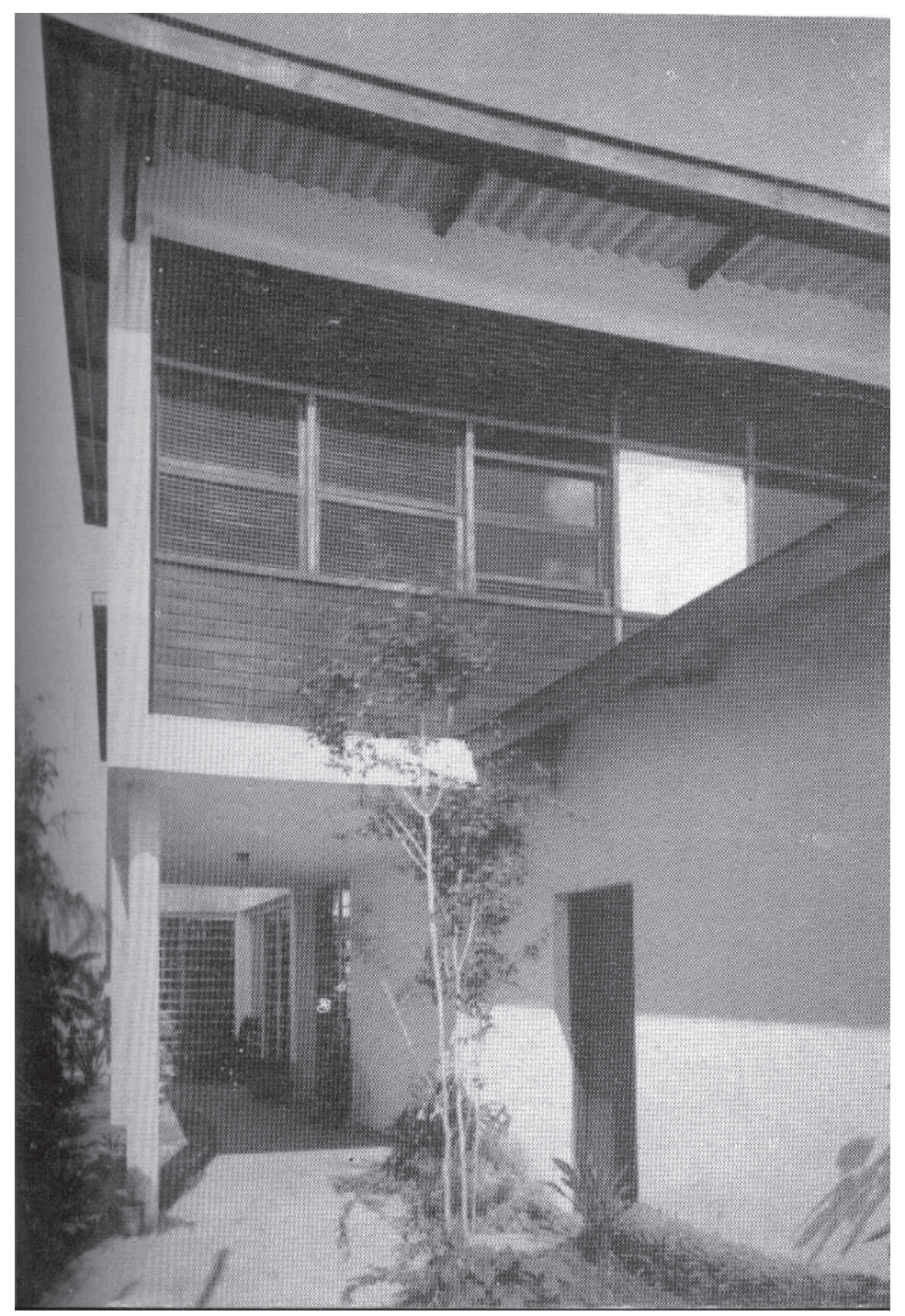

\section{DADOS DO PROJETO}

Calculista: escritório eng ${ }^{\circ}$ A. Carlos de Vasconcelos/Luiz G.M. Vieira

Local: Rua Vanderlei/Rua Heitor de Morais. Pacaembu, São Paulo - SP

\section{DESCRIÇÃO DO} PROJETO:

Esta casa no bairro do Pacaembu teve como desafio vencer um terreno com acentuada declividade e fazendo frente para duas ruas ( Vanderlei e Heitor de Morais). $\mathrm{O}$ arquiteto tomou como partido não voltar a casa para rua, utilizando-se de jardins internos e aproveitando a vista para o vale no fundo do terreno.

Área do Lote: $459 \mathrm{~m} 2$

Área Construída:338,50m2 No de pavimentos: 1

SUBSOLO: garagem, depósito, escada e área livre em piso semi enterrado.

PAVIMENTO TÉRREO: Acesso a este piso por lance de escada em relação ao nível da rua. Compõe-se da parte social com 


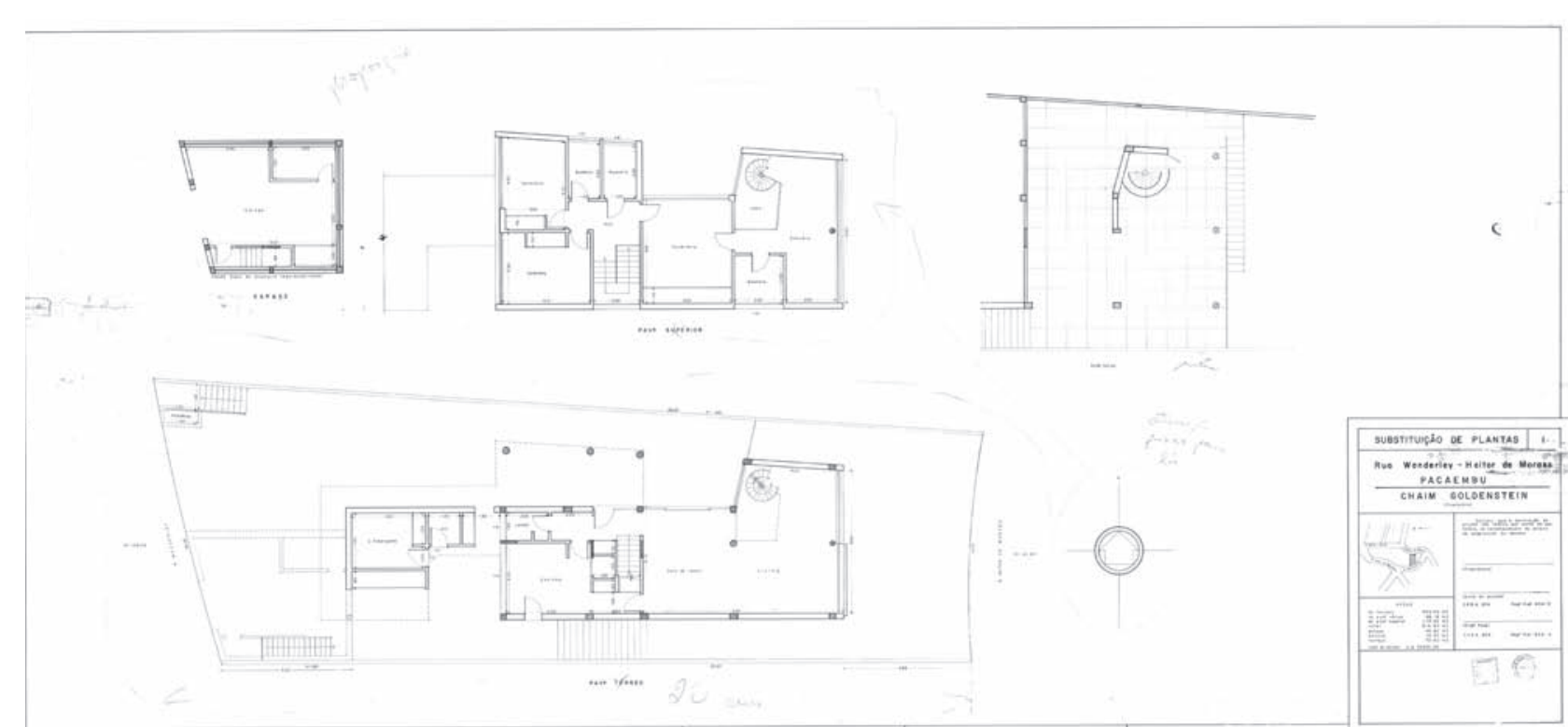

Garagem, pav. térreo e superior.

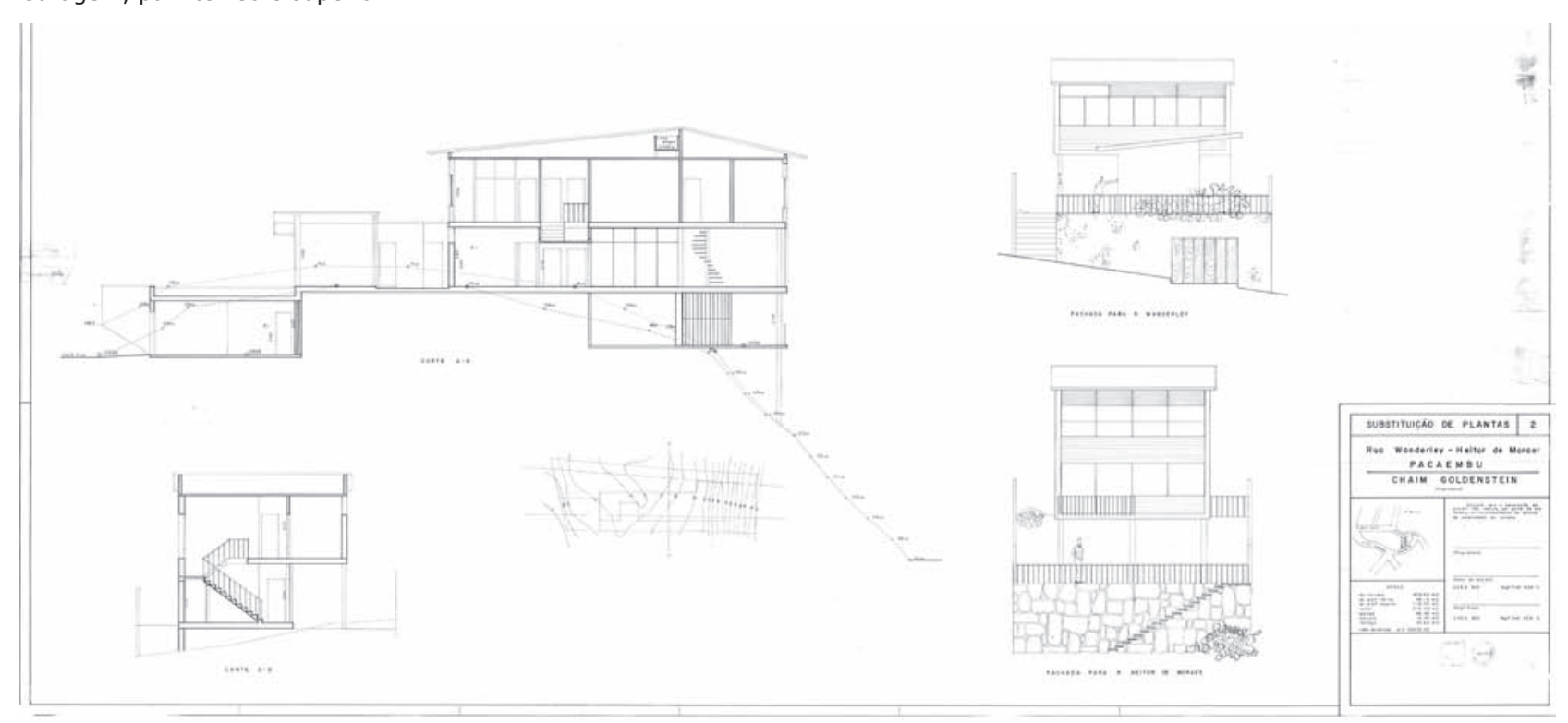

Cortes e fachadas. living, sala de jantar, lavabo; e serviços cozinha dormitório e banho de empregada

Foi prevista uma área para crianças entre o quintal de serviço, e a circulação principal de acesso à casa.

A escada de acesso aos quartos localiza-se próxima da entrada e no living, uma escada caracol acessa o estúdio, proporcionando uma área com pé direito duplo em parede de tijolo aparente. O estar tem vista panorâmica sobre o vale do Pacaembú.

PAVIMENTO SUPERIOR: 3 dormitórios, 1 banheiro, rouparia, estúdio com banheiro integrado à sala e ao dormitório principal. O quarto principal possui aberturas voltadas para recuo lateral e o estúdio voltase para o vale.

TRATAMENTO DE FACHADAS: Pintura e pastilhas marrom, esquadrias azul, reboco nas cores brique e branco, muro com seixos, muro com pedras. Piso: arenito polido e apicoado.

TRATAMENTO PAISAGÍSTICO 

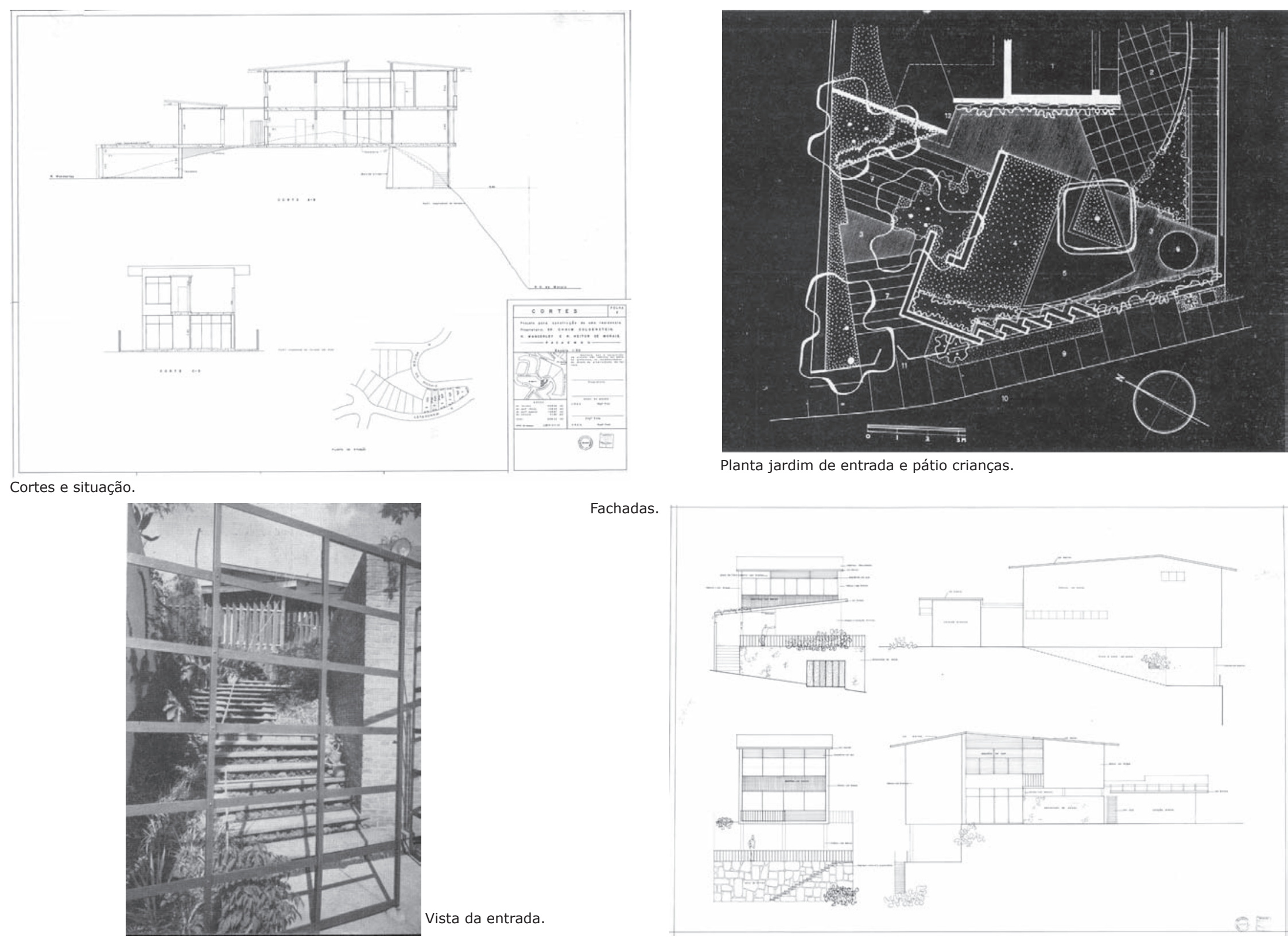

Planta jardim de entrada e pátio crianças.

Fachadas.

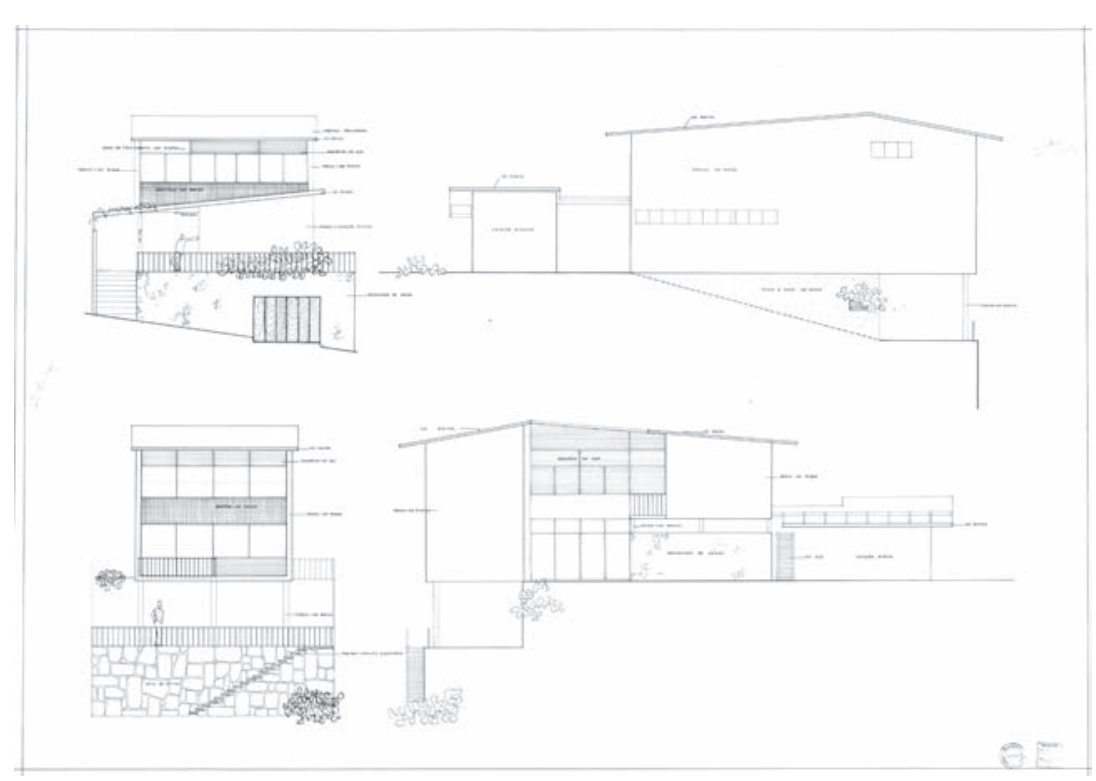




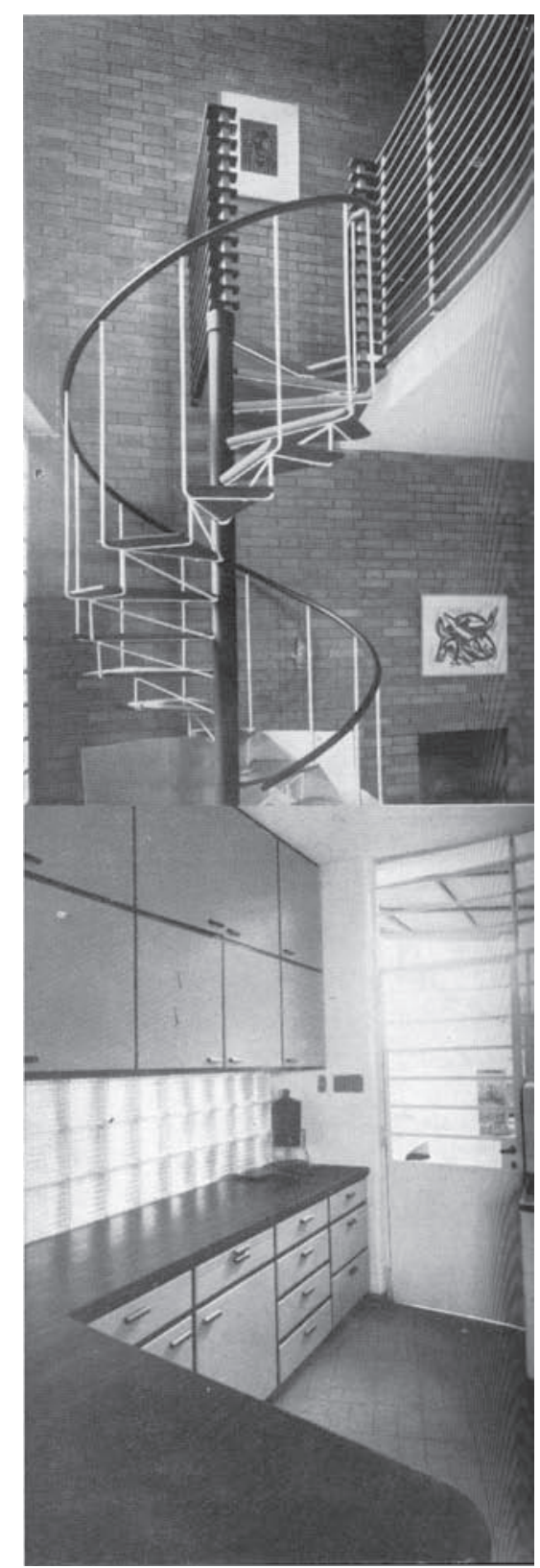

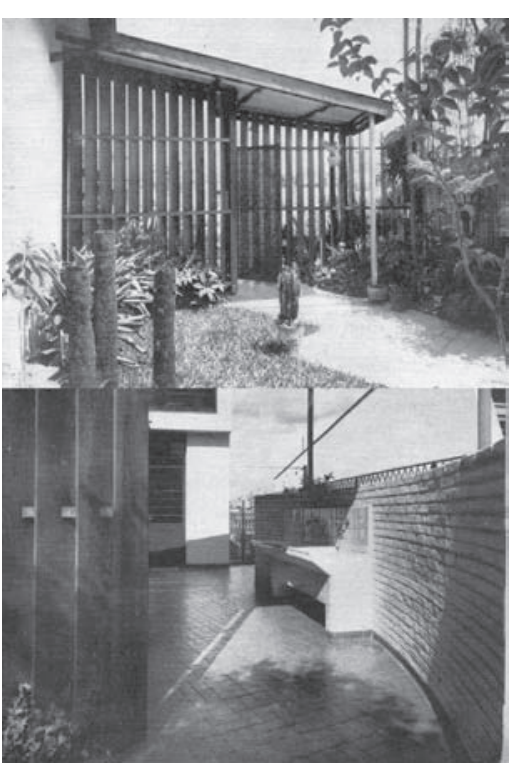

projeto recebeu paisagismo de Paisagismo - Osborn Coelho Cardozo que teve Miranda Martinelli Magnoli como colaboradora.

Uso de pedra, tijolo e madeira na composição paisagística contribuem para o projeto assim como aberturas estratégicamente posicionadas o integram no conjunto.

O jardim para crianças recebeu especial atenção.

ESTADO ATUAL DO CONJUNTO: A casa foi descaracterizada em sua fachada e seu jardim, com troca de materiais, remoção do jardim e portão principal. A fachada voltada para Rua Heitor de Morais encontra-se bastante deteriorada, porém ainda é possível observar traços do projeto original.

Acima e à esquerda fotos de 1954.

Abaixo a res. Goldensteim em 2004.

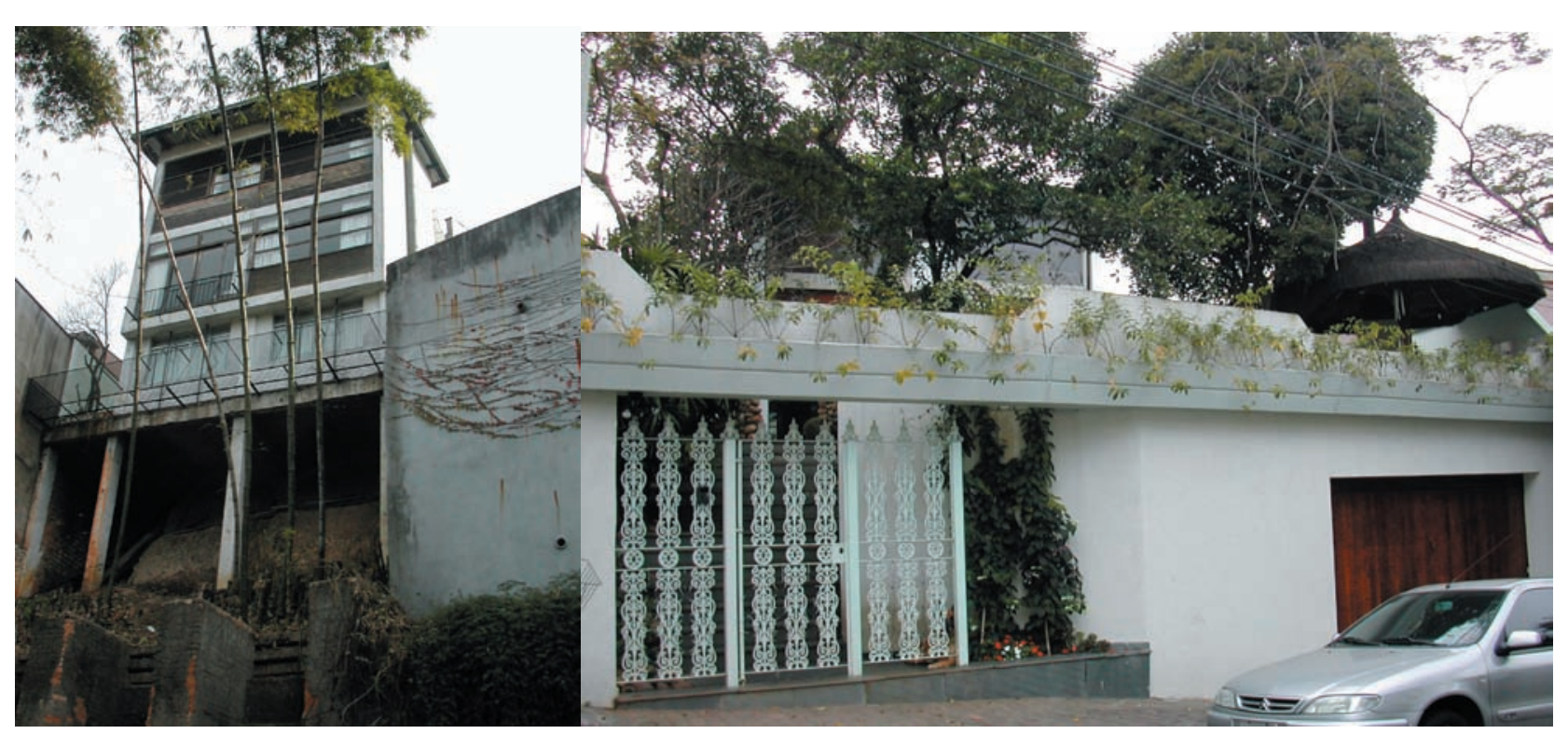




\section{Residência Francisco Mosetic}

\section{4}

Publicações:

Habitat 39, p.21.

1957.

\section{DADOS DO PROJETO}

Projeto: 1954

Entrega da Obra: 1955

Local: Rua Luis Góes 431, V.

Mariana. São Paulo-SP

\section{DESCRIÇÃO DO \\ PROJETO:}

Projeto de duas casas geminadas na Vila Mariana São Paulo. O programa simples apresenta fachada bem trabalhada com ampla frente de vidro e pavimento superior com composição de cores na caixilharia e no revestimento externo em madeira pintada.

Área do Lote: $300 \mathrm{~m} 2$ Área Construída: 270m2 No de pavimentos: 1

PAVIMENTO TÉRREO:

Concentram-se as zonas de estar, área de serviço foi isolada por jardim interno.
PAVIMENTO TIPO: Dois banheiros completos e Quatro dormitórios sendo três na fachada principal, face norte e o último voltado para o jardim interno no fundo com um pequeno terraço. A edícula conta com dois quartos e um banheiro.

TRATAMENTO DE FACHADAS Fachada principal recebeu revestimento de madeira pintada, formando conjunto, integrando as janelas As duas casas possuem composição contínua, diferenciando-se no uso da cor sendo a casa à direita com esquadrias amarelas com montantes brancos e à esquerda: esquadrias briques e azuis com montantes brancos.
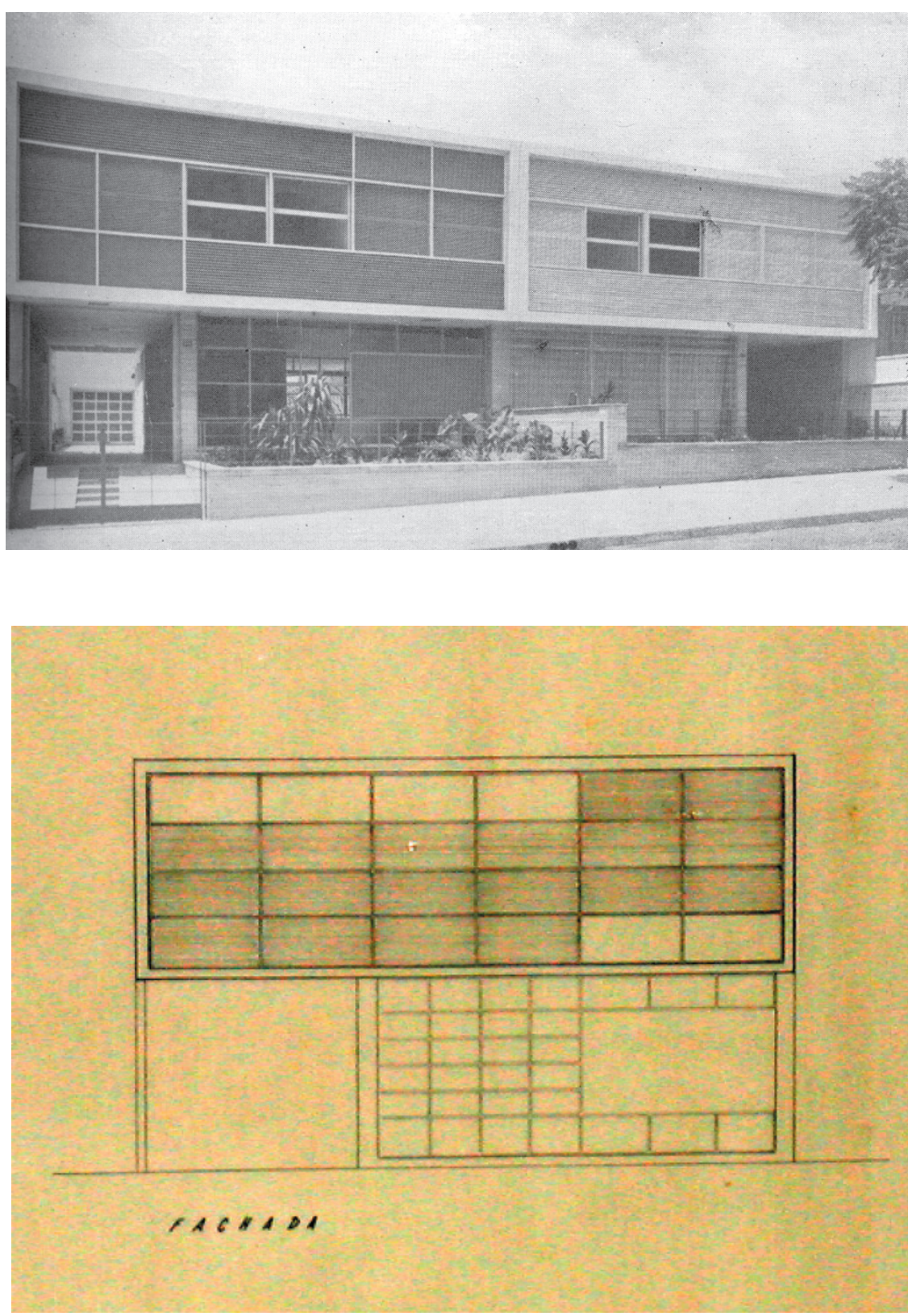

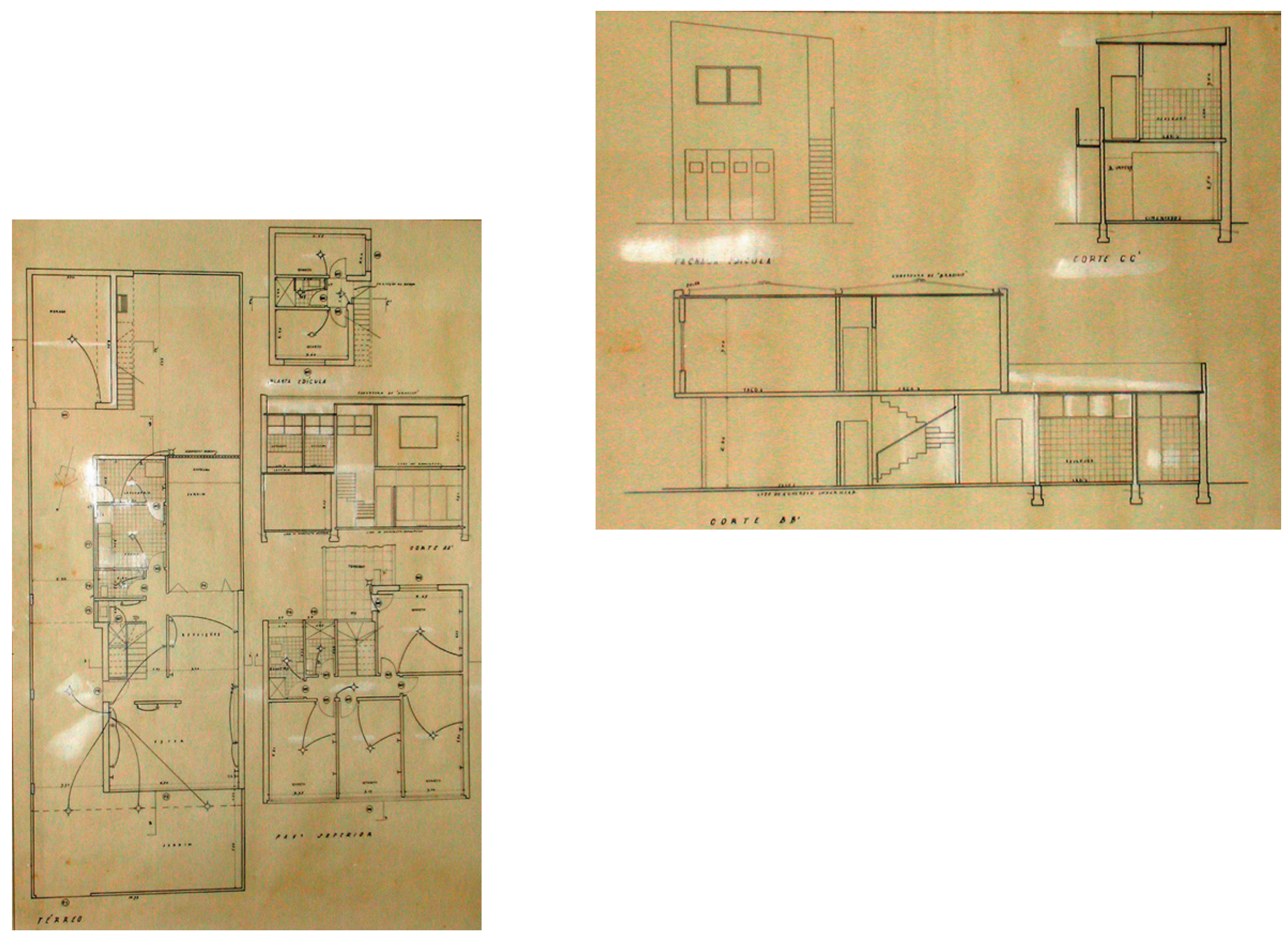


\section{Residência Bernardo}

\section{Blay}

\section{4}

Publicações:

Habitat 39, p.21 .

1957.

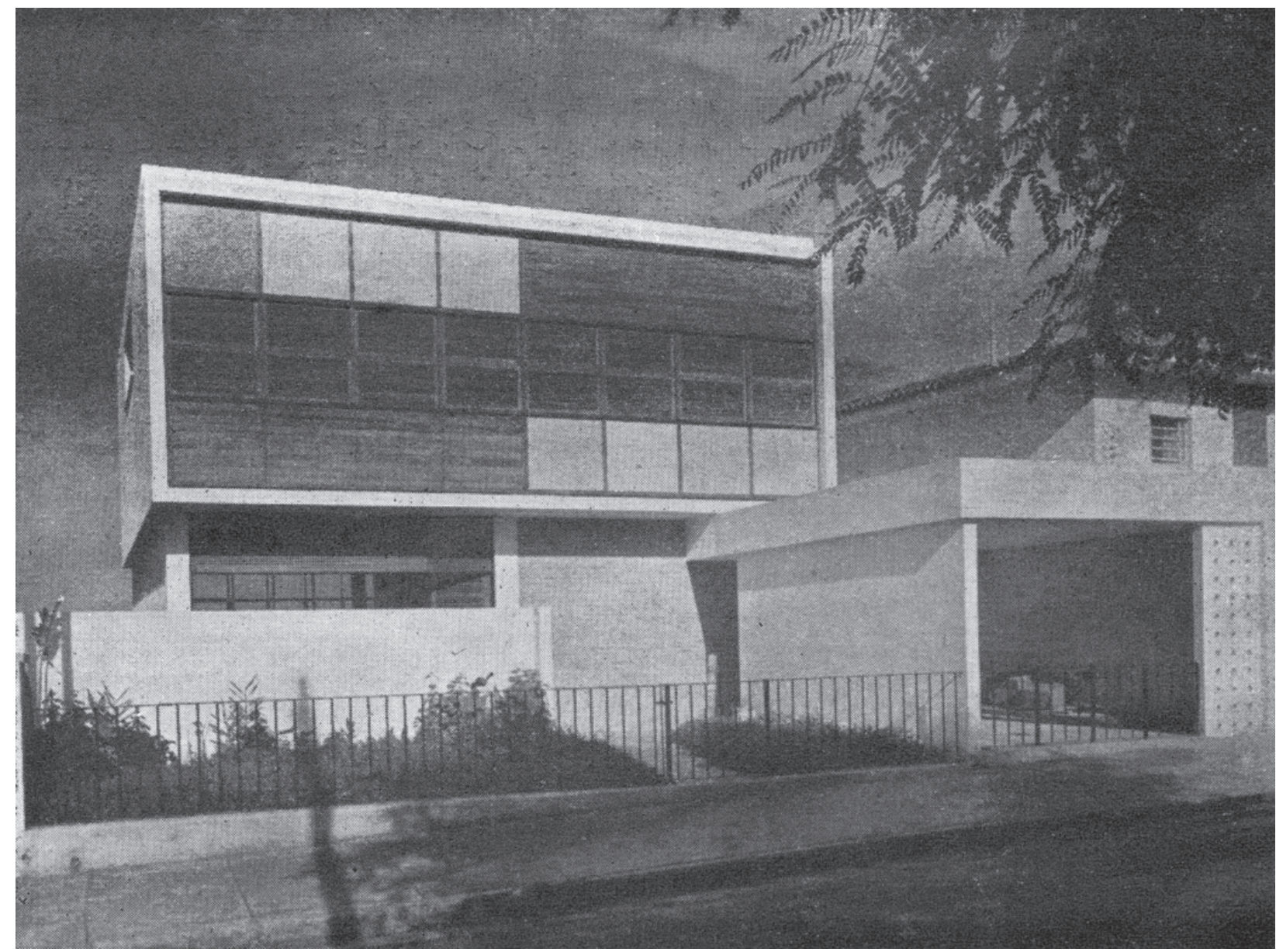

\section{Res. Sumaré} Bernardo Blay

Residência no Sumaré, 1956. Terreno acidentado. A parte social localiza-se no térreo e os serviços no andar inferior, abaixo do térreo. Os dormitórios situam-se no andar superior. Frente revestida de madeira aparentemente envernizada. Placas de fibro-cimento colorido, com revestimento de pastilhas brancas. (FERRAZ1957)

\section{DADOS DO PROJETO}

Local: Rua Plínio de Morais, Sumaré. São Paulo- SP 


\section{Residência José Ribeiro Sobrinho}

\section{5}

Publicações:

Habitat 54, p.23-7.

1959.

\section{DADOS DO PROJETO}

Projeto: 1955

Entrega da Obra: 1959

Local: R. Adalívia de Toledo Leite, Morumbi. São Paulo - SP

Paisagismo e colaboração: arquitetas Miranda $M$.

Magnoli e Rosa Kliass.

\section{DESCRIÇÃO DO PROJETO:}

O projeto desta residência no Morumbi teve como fator determinante o panorama soberbo que se apresentava na frente do terreno, fazendo

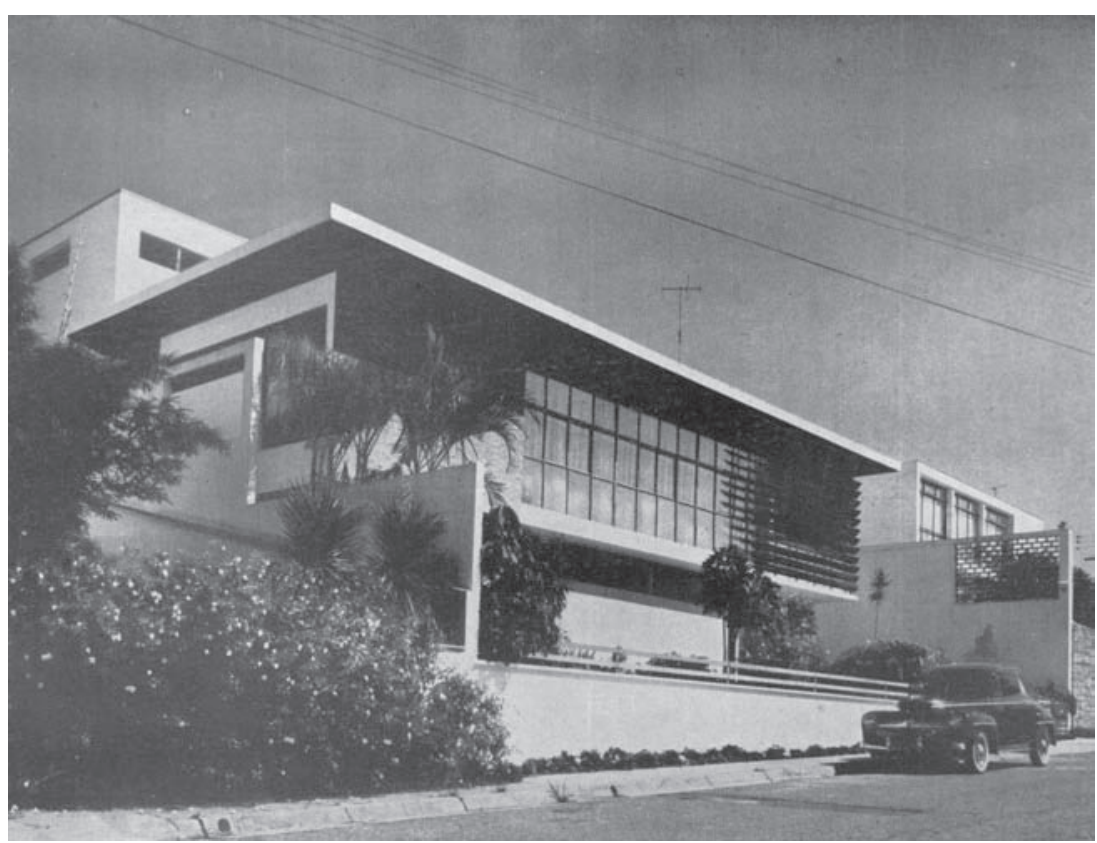

o projeto voltar-se para o vale. O programa a solucionar era de habitação para família de cinco pessoas com intensa vida social.

Aproveitando-se do desnível do terreno, o arquiteto levantou a casa três metros acima da rua, colocando-a no nível do fundo do terreno, compondo um pátio interno. De tal forma, a parte social da casa abria-se para vista do vale e pela integração com o pátio, ampliava-se, num excelente aproveitamento do terreno.

\section{Área do Lote: 700 m2}

Área Construída:

No de pavimentos: 2 pavimentos

PAVIMENTO TÉRREO: Na parte térrea localizam-se serviços: lavanderia, garagem para carros, quartos de empregados e um estúdio de fotografia, que é um anexo da residência.

10 PAVIMENTO: No setor correspondente ao pátio interno toda a parte social, cozinha e dois quartos com banheiro $A$ área social totalmente aberta com ambientes integrados. Todos tem vista para o vale e para o pátio. Jogo de forros e paredes divisórias demarcando as áreas gera movimento, criando zonas de interesse e dotando-a de certa organicidade. $\mathrm{Na}$ sala de estar foi desenvolvido um painel por Renina Katz.

20 PAVIMENTO no pavimento superior encontram-se mais dois quartos com banheiro.

TRATAMENTO DE FACHADAS O pátio dos carros e entrada da casa são pavimentados com arenito. As paredes internas, na garagem foram são revestidas de seixos em tamanhos e cores diversos. A escada de acesso à casa é em concreto armado revestido de madeira e independente da parede de seixos. Na composição Abelardo investe numa ousada mistura de materais, mas sempre de forma conciliadora.

A crítica da revista Habitat refere-se à construção como "a meio caminho entre um racionalismo funcional e a plasticidade da chamada "escola brasileira". 

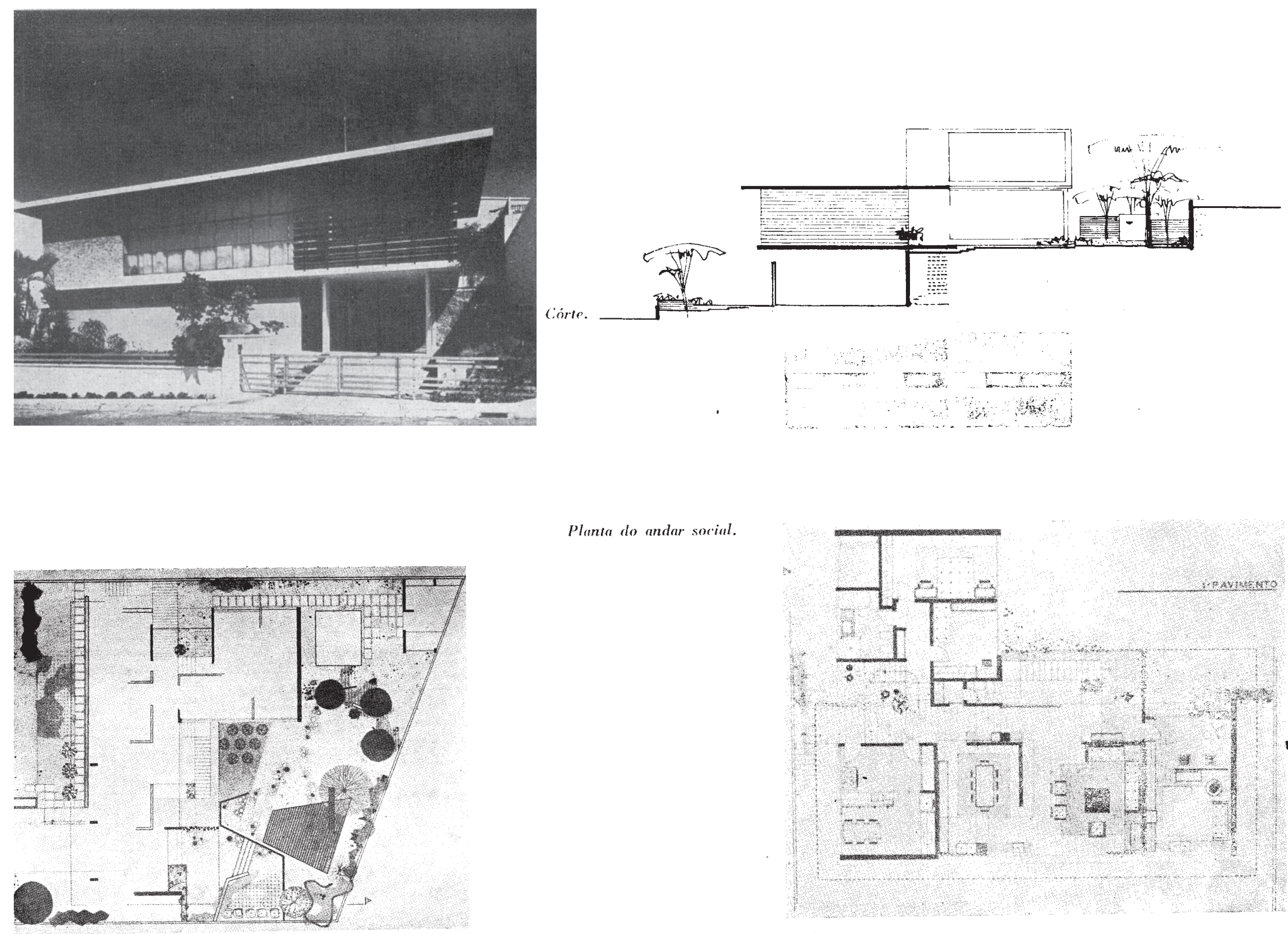

Plinta do andar social

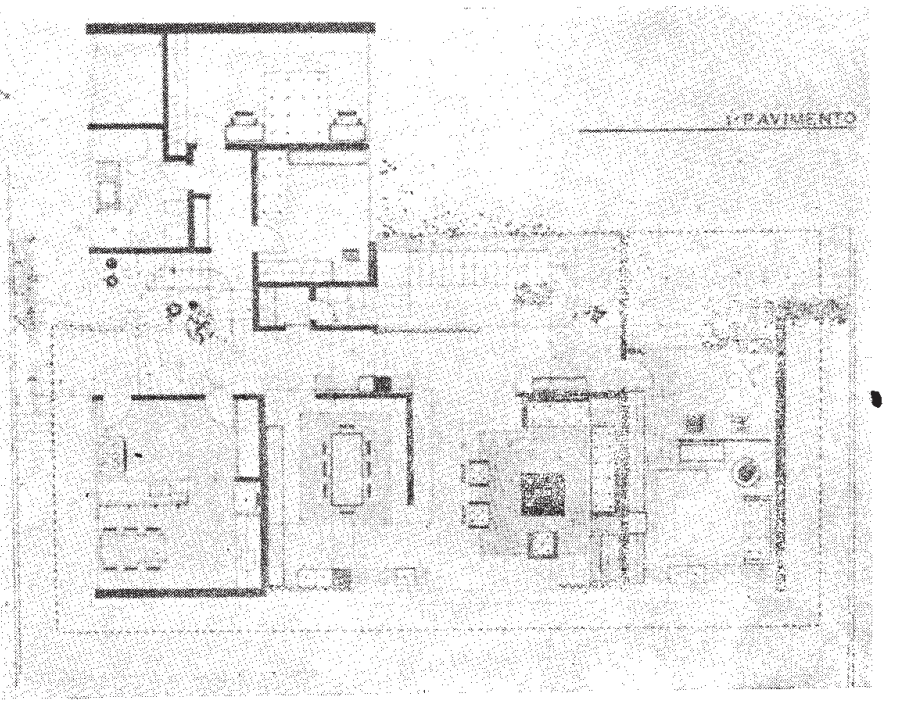



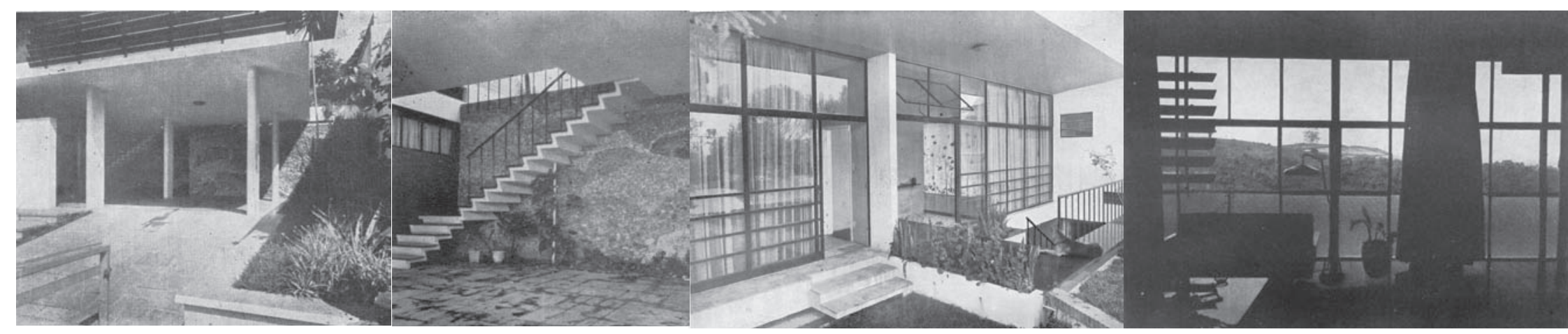

Fotos da casa e interiores. 1955.

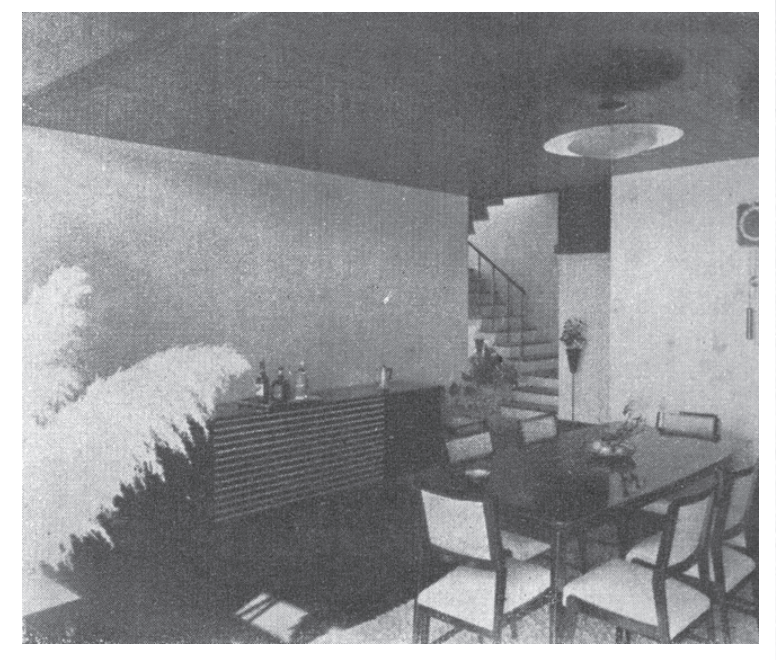

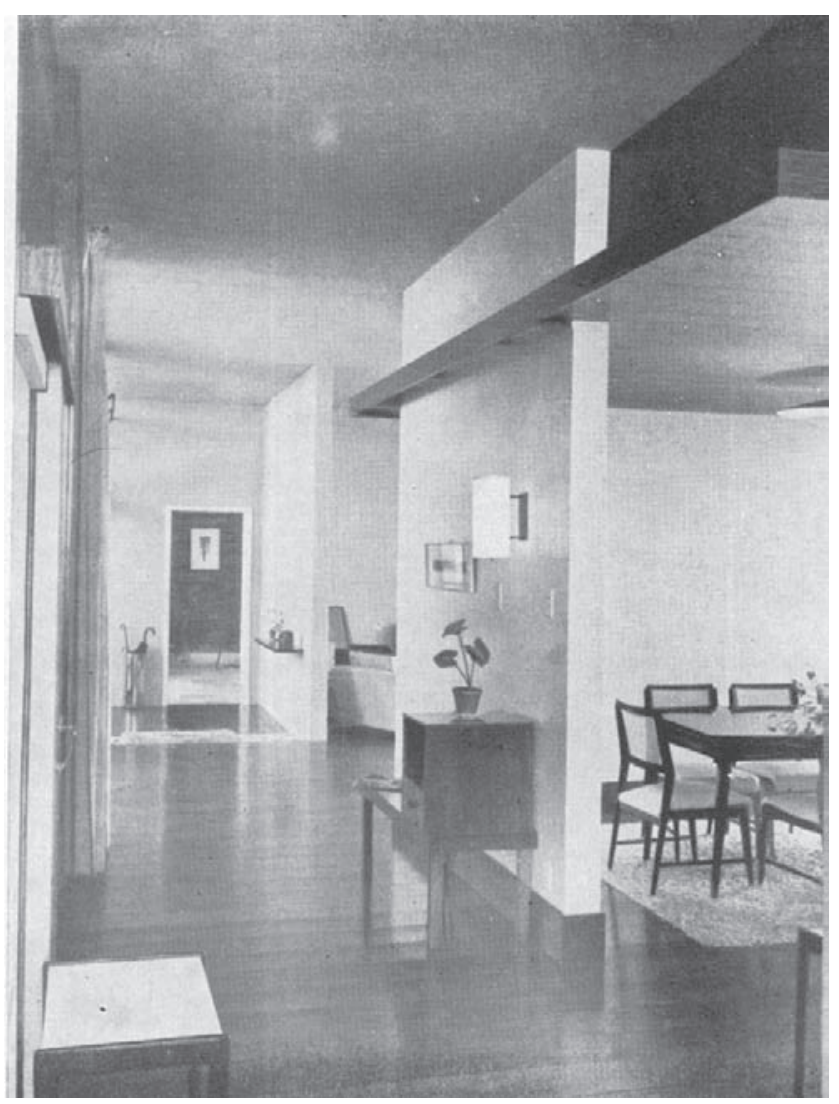

TRATAMENTO PAISAGÍSTICO O projeto de paisagismo foi realizado por Miranda Martinelli Magnoli e Rosa Grena Kliass. A maior parcela diz respeito ao pátio de fundo dividido em zonas de interesse, com canteiros, espelho d'água e deck.

$\mathrm{Na}$ entrada, canteiros escalonados diminuem 0 desnível em relação ao primeiro piso.

ESTADO ATUAL DO CONJUNTO Apesar da eleveção do muro e do aparato de segurança sinais de nosso tempo - a casa encontra-se bem preservada mantida em sua integridade, com manutenção de caixilhos, tijolos, madeiras, a entrada de carros, sua parede de seixos e fundamental: a vista para o vale. 

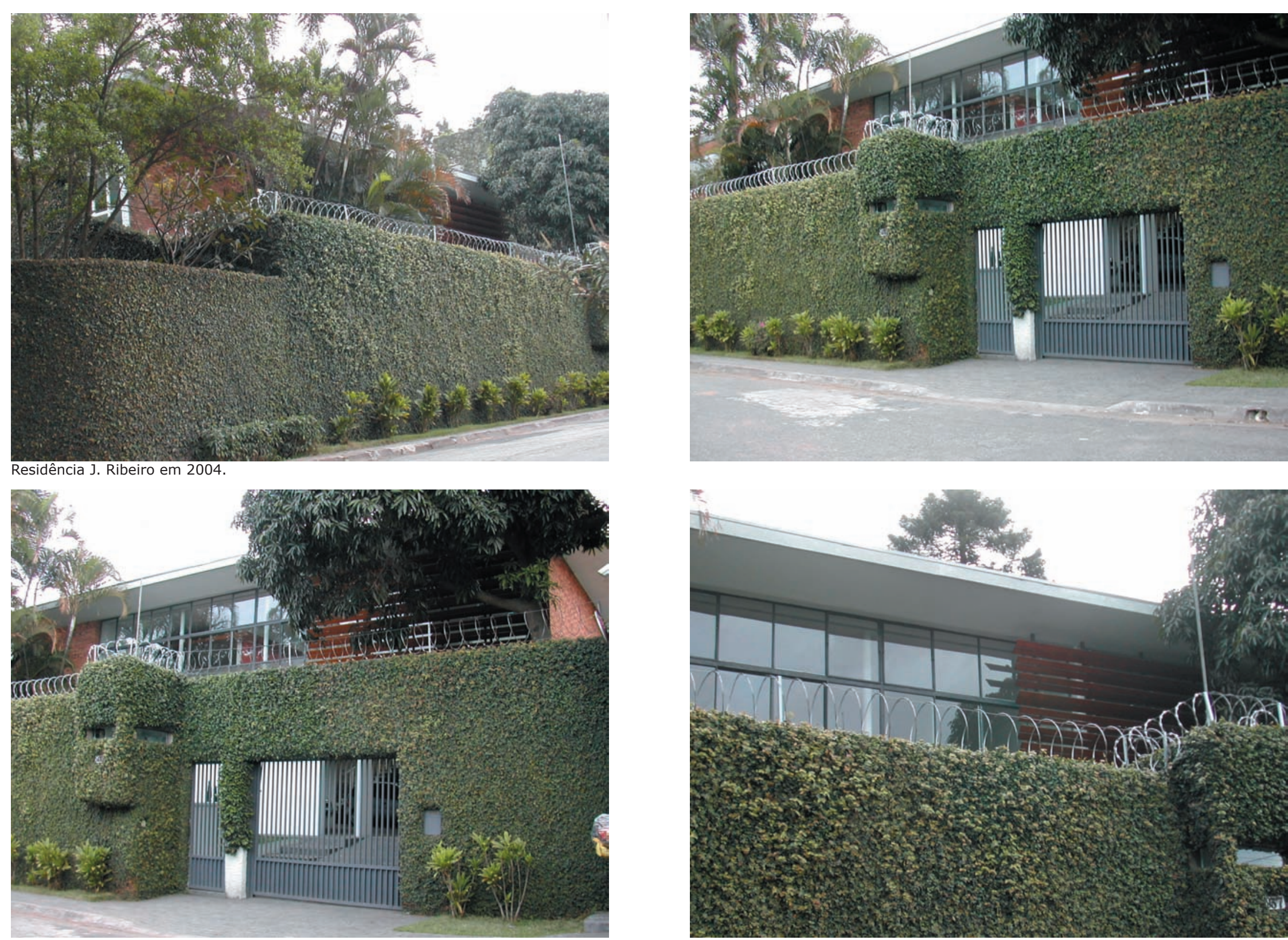


\section{Residência em São Paulo} 1959

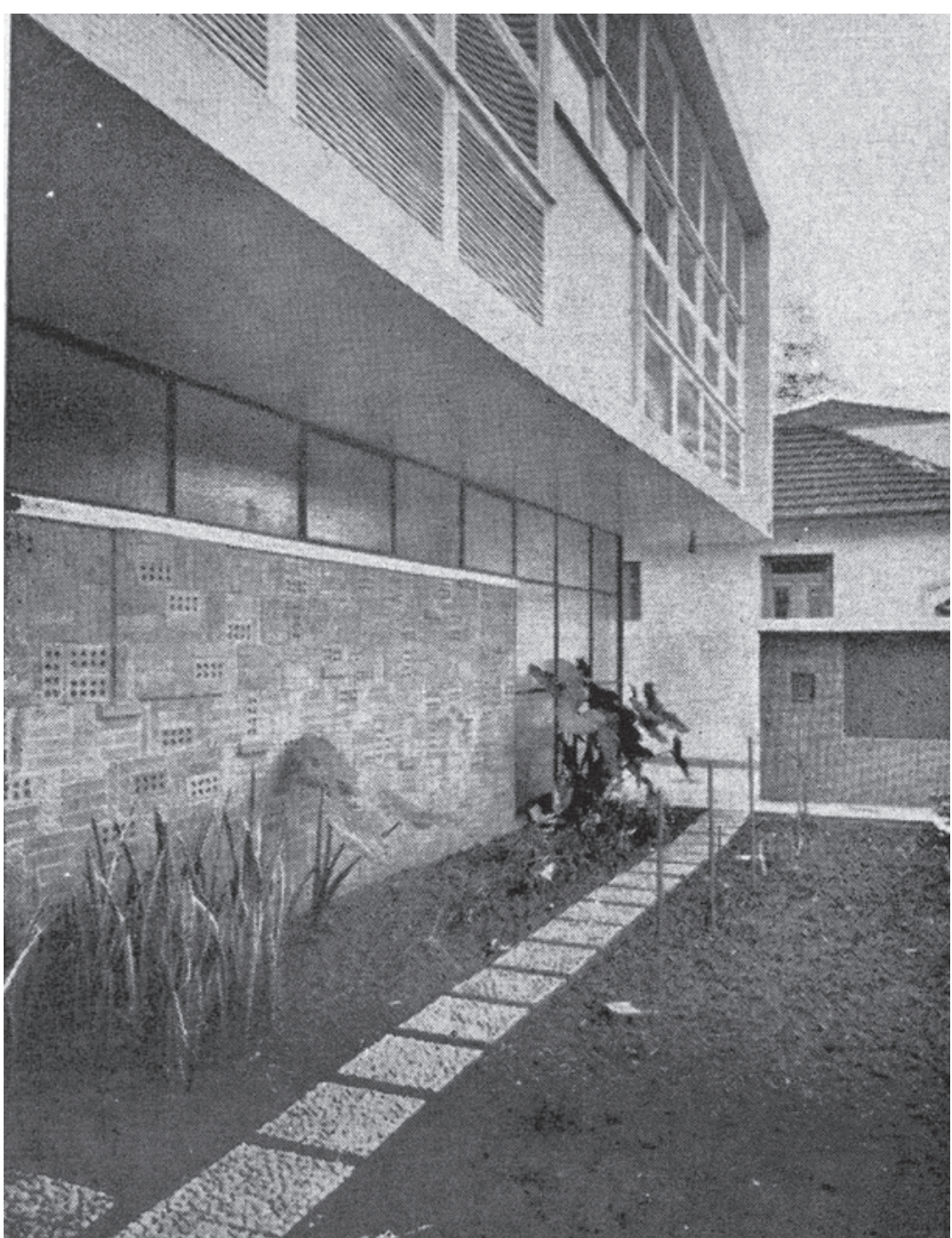

Publicações:

Habitat 51, p.6-7. 1959.

\section{DADOS DO PROJETO} Local:

\section{DESCRIÇÃO DO PROJETO}

Residência para classe média, em terreno de dimensões limitadas. Abelardo faz uso do pátio interno, deixando um pequeno jardim à frente $e$ voltando a casa para os fundos do terreno conseguindo uma valorização dos ambientes internos e integração com o paisagismo.

Houve uma grande preocupação com os espaços internos com a realização do projeto de interiores e intenso uso de cores e materiais.

O projeto de características racionalistas é pontuado por materiais e detalhes de natureza brasileira.

\section{Área do Lote:}

Área Construída:

No de pavimentos: 1

PAVIMENTO TÉRREO A principal preocupação do arquiteto foi unir a parte social ao pátio interno. o uso de piso contínuo em tábuas de gaviúna contribuiu na integração. O restante do pátio recebeu piso formando mosaico com ladrilhos e arenito.

A escada de acesso ao pavimento superior, em estrutura independe, recebeu tratamento escultórico, sendo seus degraus revestidos de mármore de carrara e a viga de mármore preto. No hall da escada as paredes laterais foram revestidas de pastilhas brancas e 0 piso de pastilhas vitrificadas vermelhas.

Um móvel com estrutura de ferro e prateleiras de madeira e vidro serve como divisória entre a sala de estar e a de jantar. De acordo com a revista Habitat ${ }^{4}$, havia uma extensa cortina nas côres cinza e branca e na sala de estar um bar com piso em granito polido de cor cinza.

Abelardo faz intenso uso da cor como forma de valorizar os interiores, tanto em materiais como no mobiliário, investe em propostas arrojadas.

PAVIMENTO SUPERIOR:

Planta compacta ocupando a posição relativa ao estar, na frente do terreno. Compõe-se de três quartos, dois banheiros 


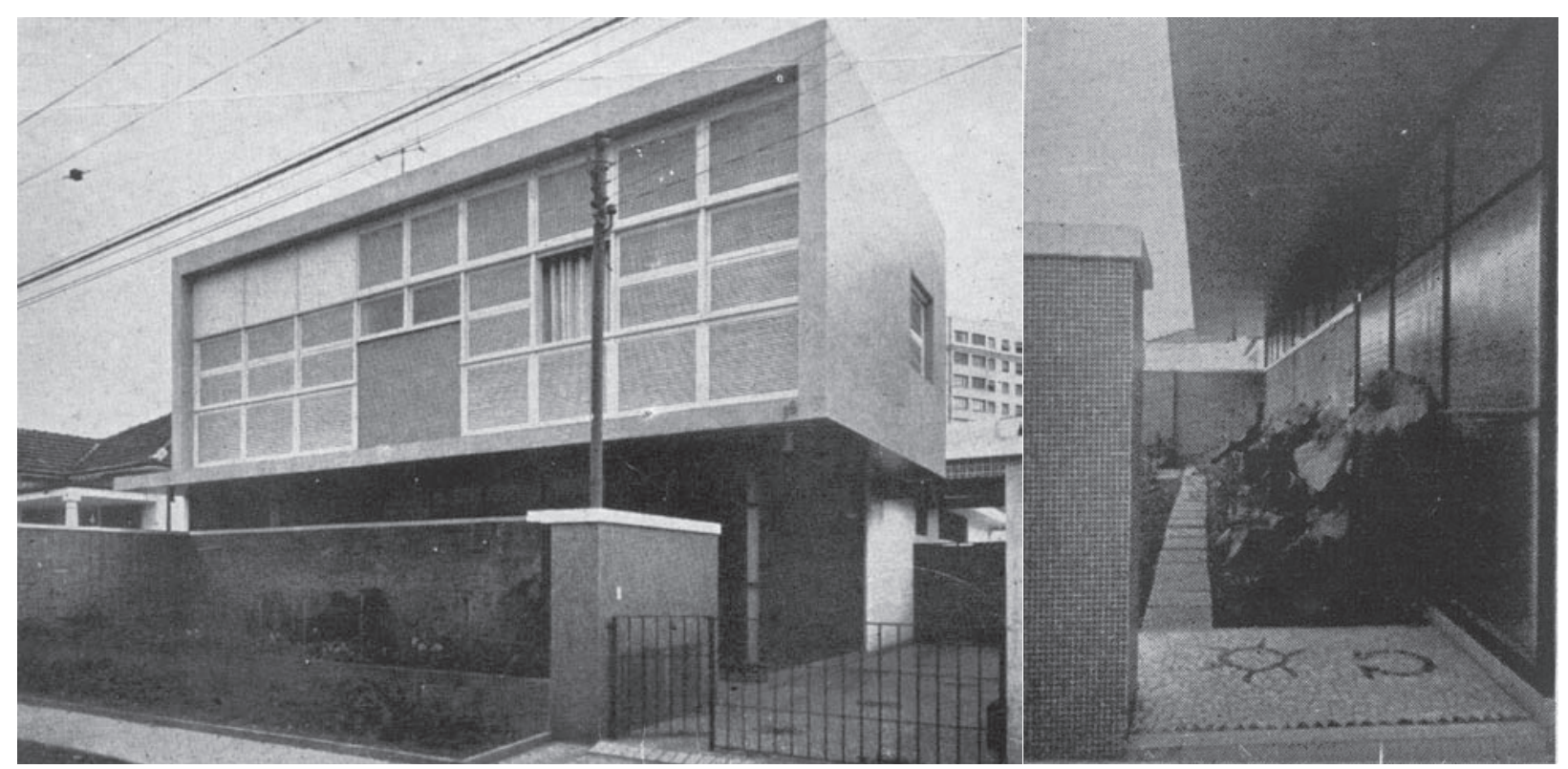

Planta do andar térreo bem assim do jardim em pátio interno.

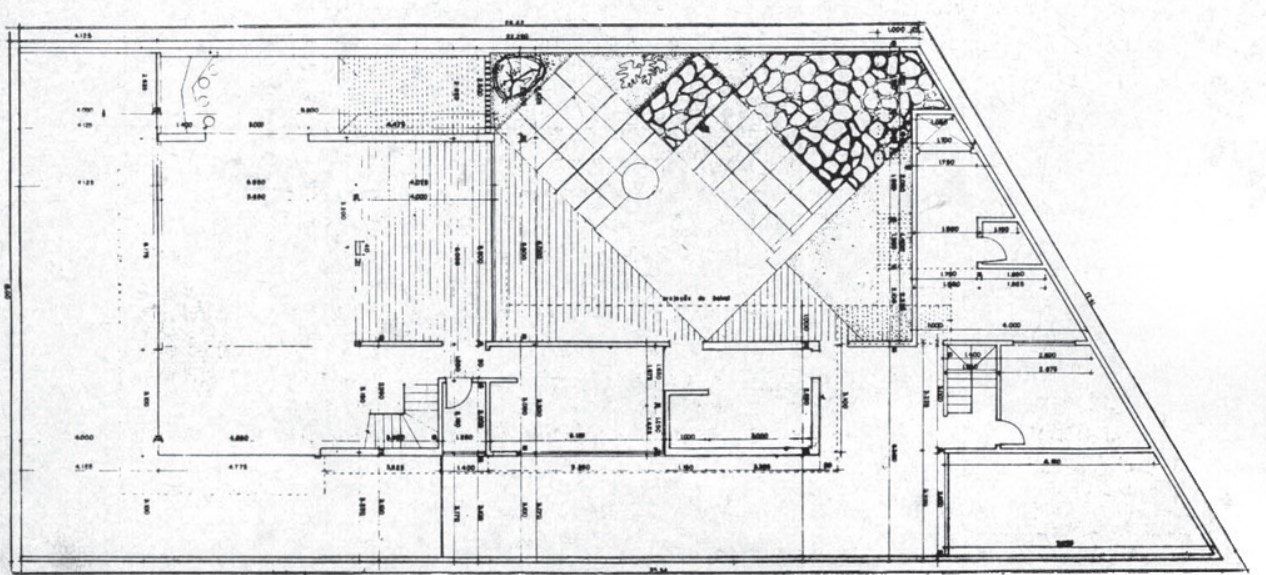

e uma rouparia.

TRATAMENTO DE FACHADAS O exterior foi revestido, no andar superior, com pastilhas verde claro enquanto as esquadrias foram pintadas em cinza claro com montantes brancos.

A estrutura permitiu liberdade nas aberturas, que são altas e contínuas destacando os volumes. A parede inferior formou uma composição abstrata com tijolos furados ao natural.

No piso da calçada e entrada de carro foi utilizado mosaico português e um portão em veneziana de madeira isola a a parte de serviço.

Planta do andar superior.

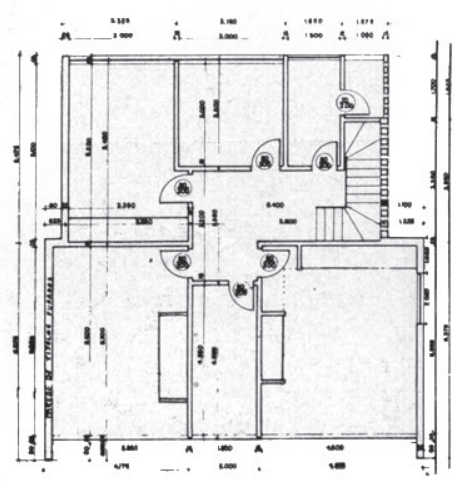

${ }^{4}$ HABITAT 51 

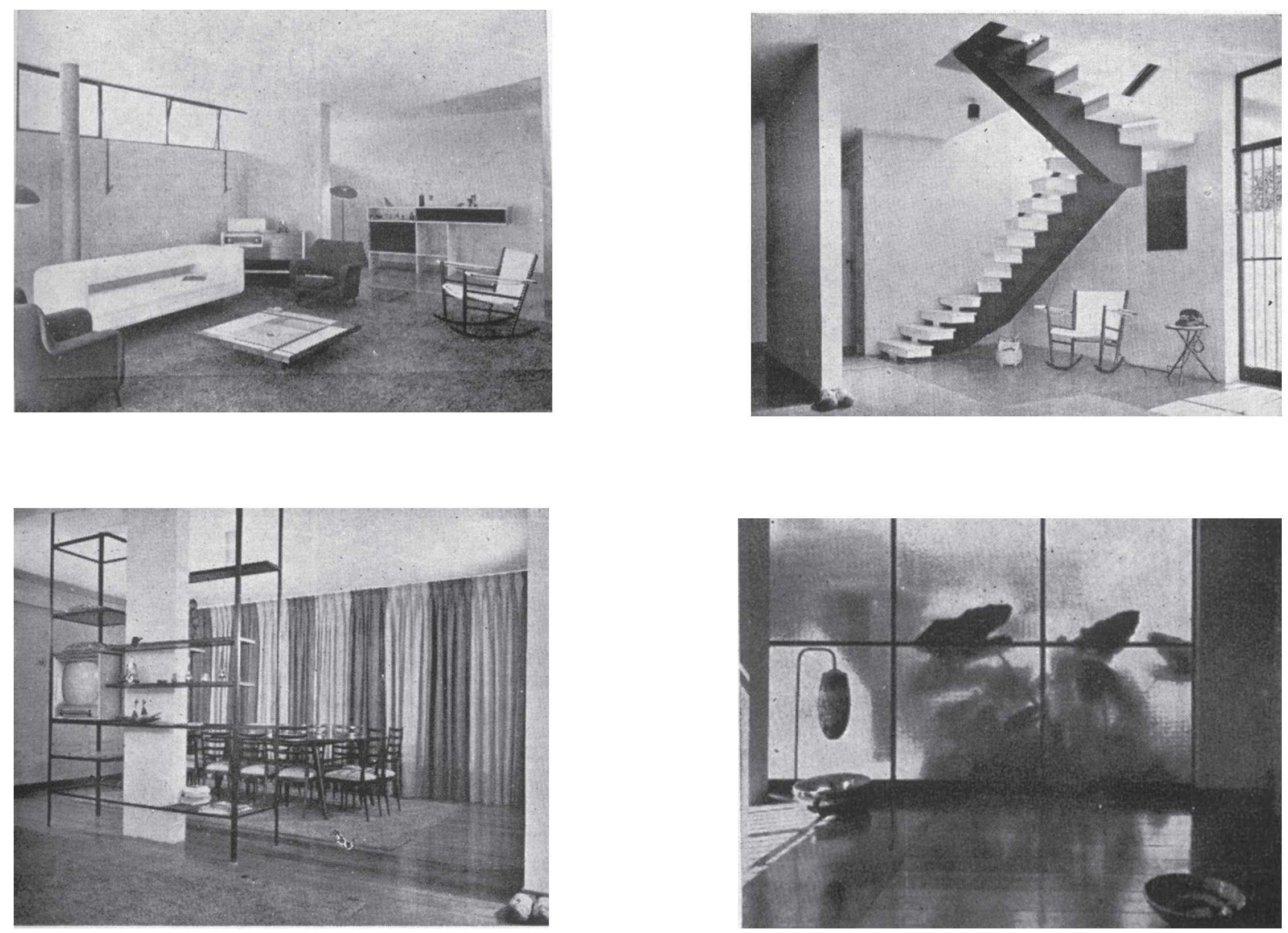


\section{Residência Ma Ricardina Mendes Gonçalves}

1962

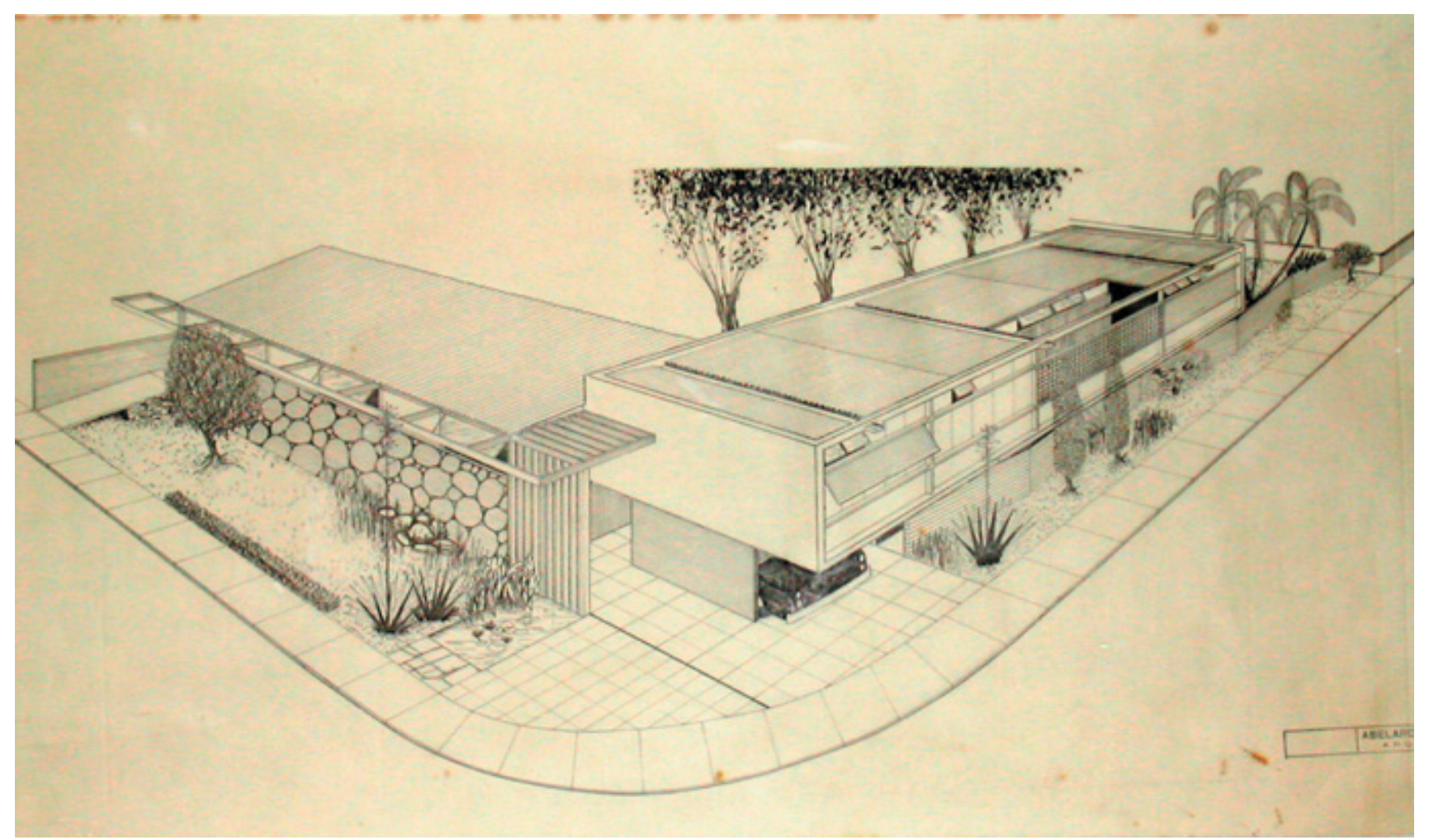

Perspectiva do $1^{\circ}$ projeto, sem os quartos de hóspedes.

\section{DADOS DO PROJETO}

Projeto

Execução

Incorporação

Entrega da Obra

Local: Jardim Virgínia Guarujá

DESCRIÇÃO DO PROJETO

Esta residência, localizada no jardim Virgínia, Guarujá, apresenta boa solução projetual, mas destaca-se principalmente pelo uso de madeiras e cor nos acabamentos e revestimentos. Área do Lote:

Área Construída:

No de pavimentos: 1 pav. 

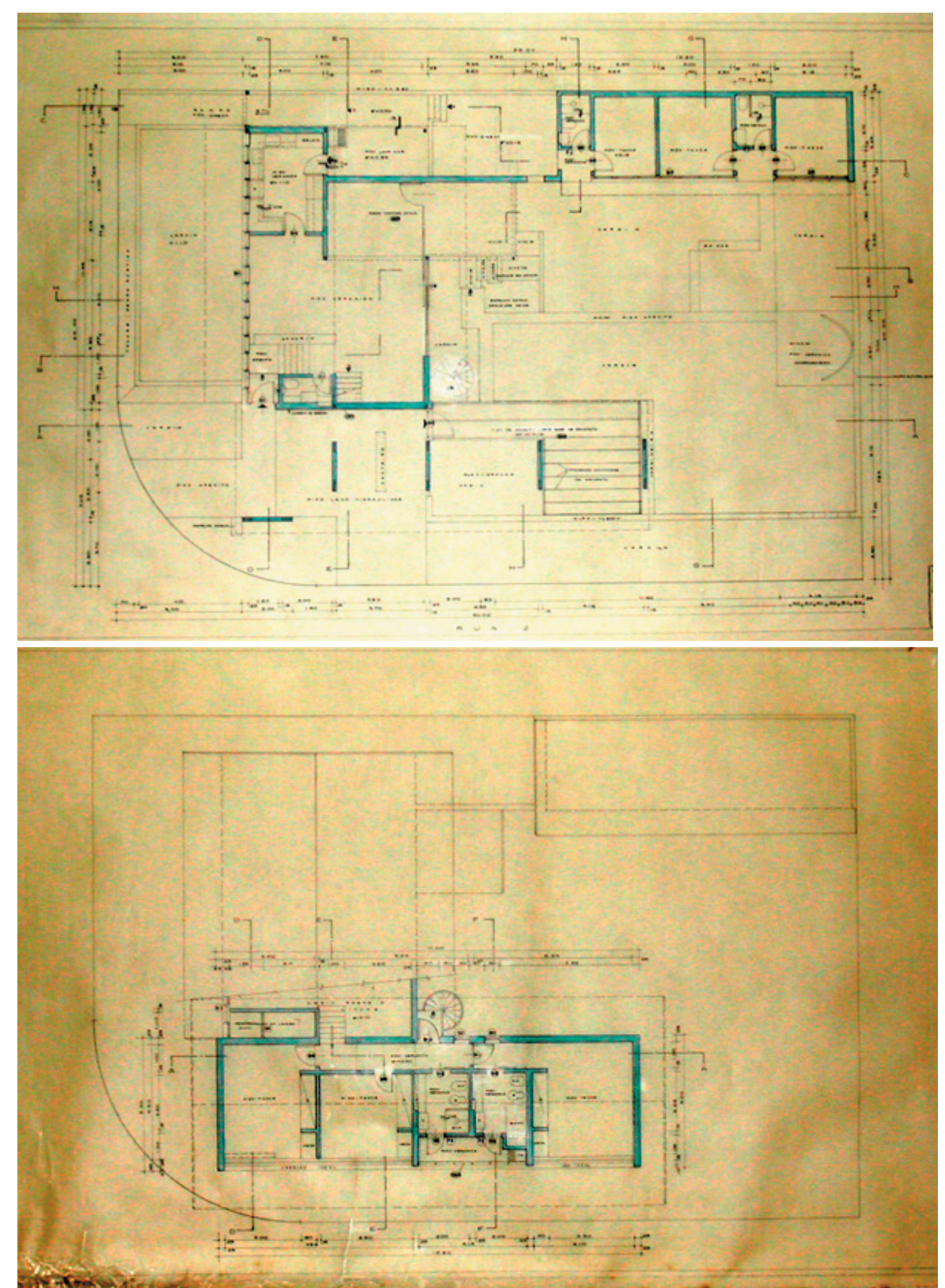

PAVIMENTO TÉRREO: O grande lote de esquina foi ocupado pelo arquiteto em forma de " $u$ ", deixando grande porção de terreno para jardim e piscina. Houve uma grande ênfase na parte social, que ocupa a parte central deste $U$ com pé direito duplo. Próximo a divisa localizamp-se entrada de serviço e cozinha, voltados para o jardim 3 dormitórios e dois banheiros.

10 PAVIMENTO: Apenas dois dormitórios e 1 suíte, todos voltados para rua e por ser uma residência voltada para o lazer, os quartos possuem dimensões precisas.

TRATAMENTO DE FACHADAS: Os blocos são claramente legíveis na fachada, mas se articulam de maneira harmoniosa. $O$ arquiteto lançou mão de grandes panos de vidro, paredes em pedra e alvenaria, madeira como vedação e acabamento e destaque para a estrutura pela inserção de cor.

TRATAMENTO PAISAGÍSTICO: Houve uma grande valorização do pátio interno, prevendo projeto paisagístico. $\mathrm{O}$ muro externo receberia mural. 

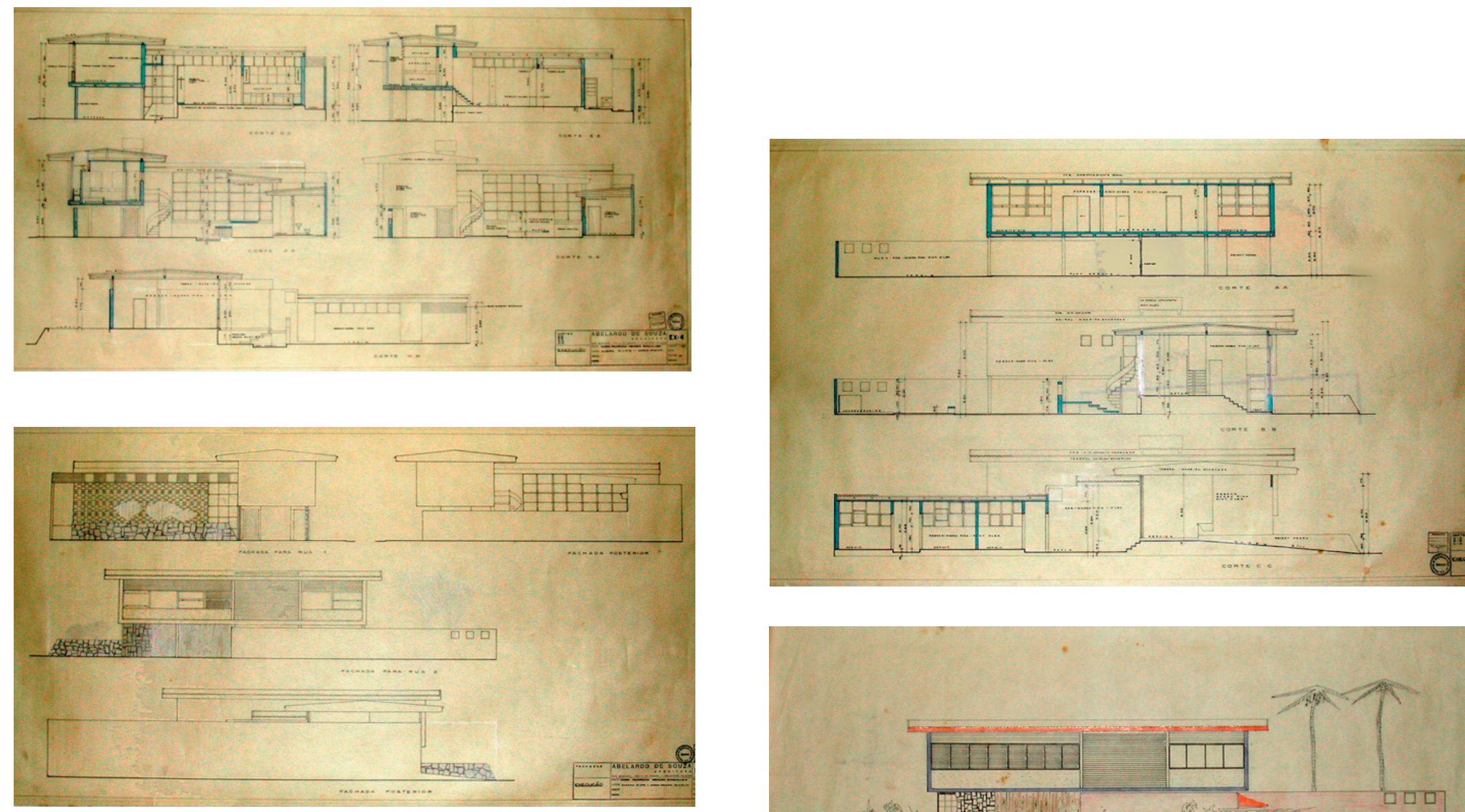

Cortes e fachadas.

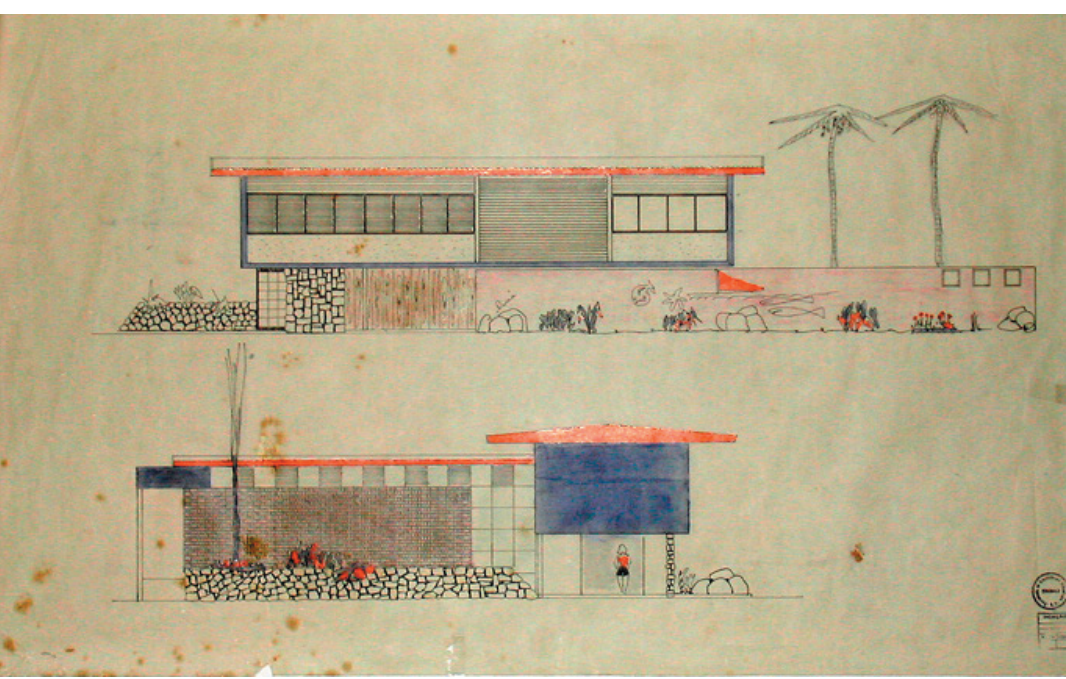




\section{Residência João de Scantimburgo}

1962

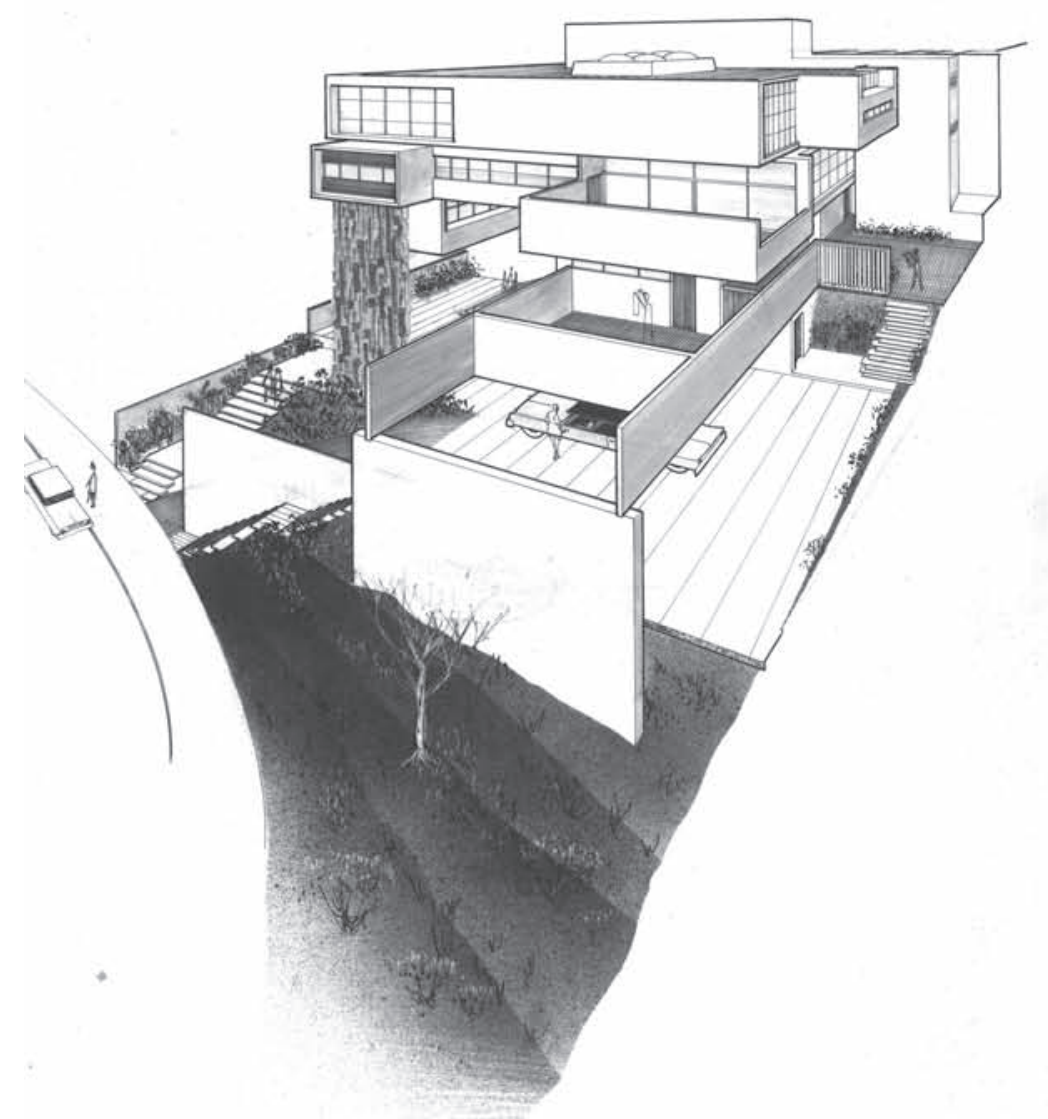

\section{DADOS DO PROJETO}

Arquitetos: Abelardo de Souza e Miranda Martinelli Magnoli Local: Lote 13-Q-17 Paineiras do Morumbi

\section{DESCRIÇÃO DO PROJETO}

Este projeto realizado em parceria com a arquiteta Miranda Magnoli não foi publicado nem construído. Esta residência no bairro do Morumbi em São Paulo, possuía um programa diferenciado, onde o principal foco de atenção era uma biblioteca para muitos volumes. A casa se desenvolve em torno deste bloco central, tendo sido as áreas sociais deslocadas para o nível mais alto da residência. As soluções projetais e o jogo de volumes resultante chamaram atenção sobre o projeto.

Interessante ressaltar uma associação com os volumes da casa Kauffman de Frank Loyd Wright.

\section{Área do Lote:}

Área Construída:

No de pavimentos: 3

PAVIMENTO TÉRREO: acesso à entrada social se faz por escada em três lances, chegando a átrio aberto, com pé direito triplo e acessando jall interno com escada, lavabo elevador.

A rampa da garagem fica ao lado do acesso de pedestres $e$ ela comporta 3 veículos.

10 PAVIMENTO: Neste níve fica o grande salão em $L$ da biblioteca, que possui dois níveis, em virtude da declividade do terreno.

$\mathrm{Na}$ parte de serviços temos dois quartos de empregados, lavanderias e pátio de serviços 2OPAVIMENTO: Aqui concentrase a parte íntima da casa com 3 suítes, sendo que a principal possui dois banheiros e uma sala de estar íntima. Na suíte principal há um acesso direto para biblioteca.

O pé direito duplo da biblioteca ocupa parte deste nível.

30 PAVIMENTO: Toda vida social está neste piso, com amplas salas interligadas e transparencia visual em direção à piscina que fica sob larga pérgola em concreto. No piso externo, vazios cobertos com vidro permitem uma visão da biblioteca. 


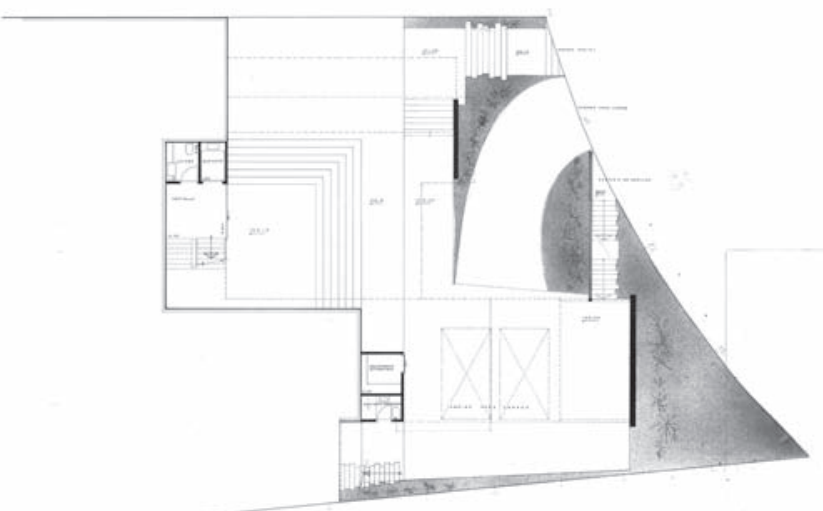

Planta térreo

Planta $2^{\circ}$ pavimento.

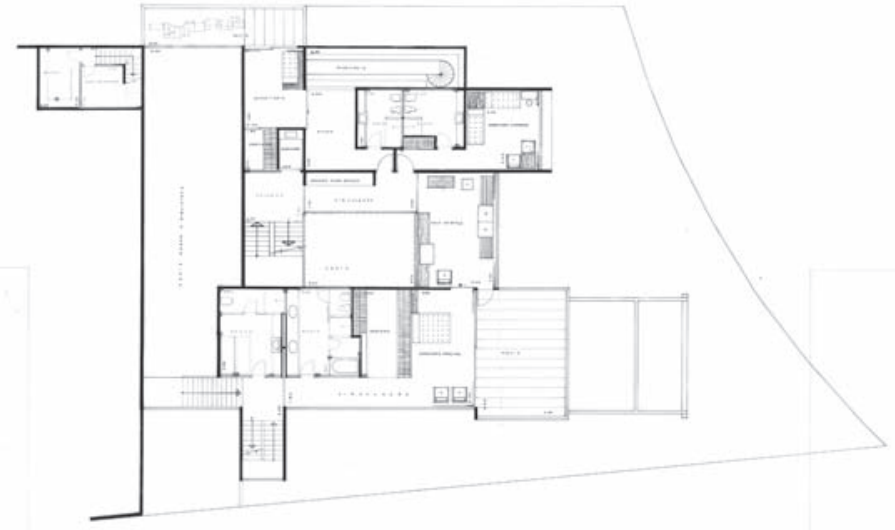

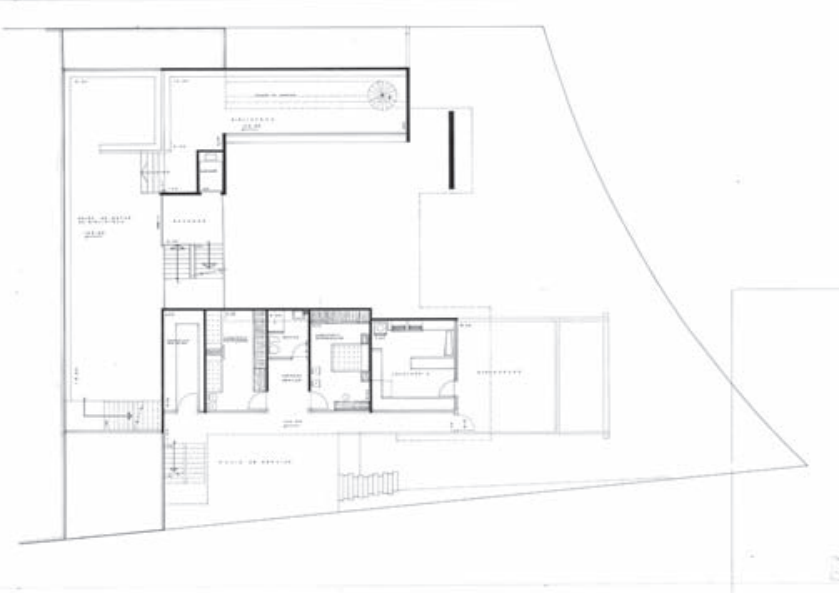

J6

Planta $1^{\circ}$ pavimento.

Planta $3^{\circ}$ pavimento.

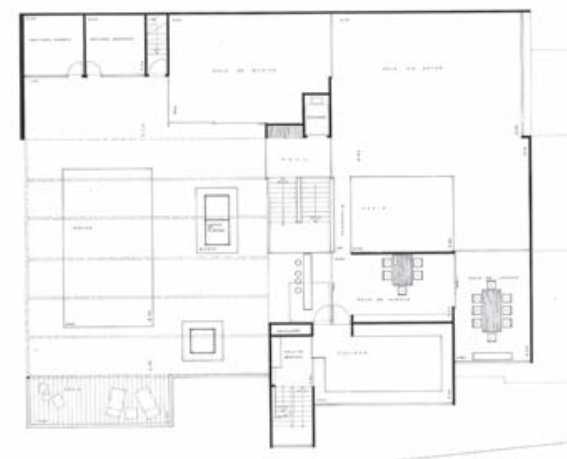




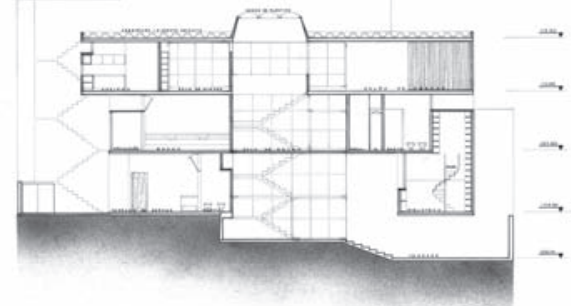

sio

Corte transversal.

Fachada principal.

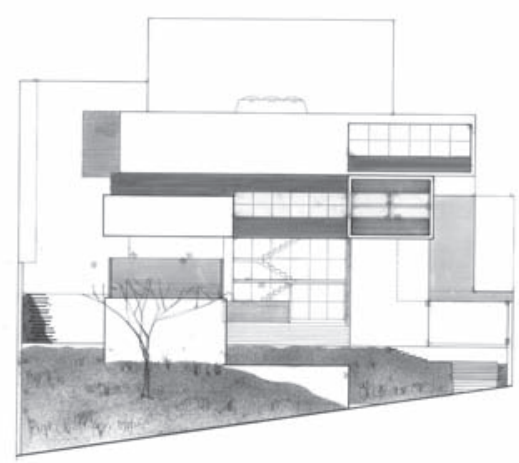

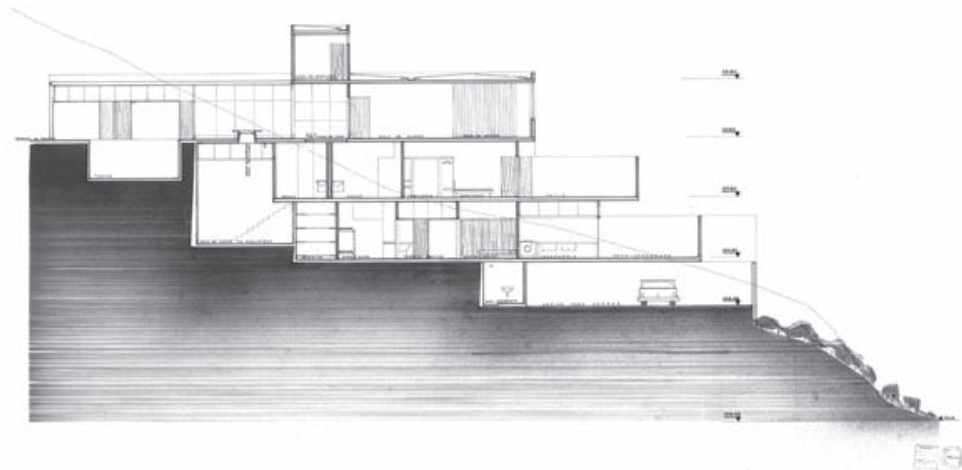

Corte longitudinal.

Fachada lateral.

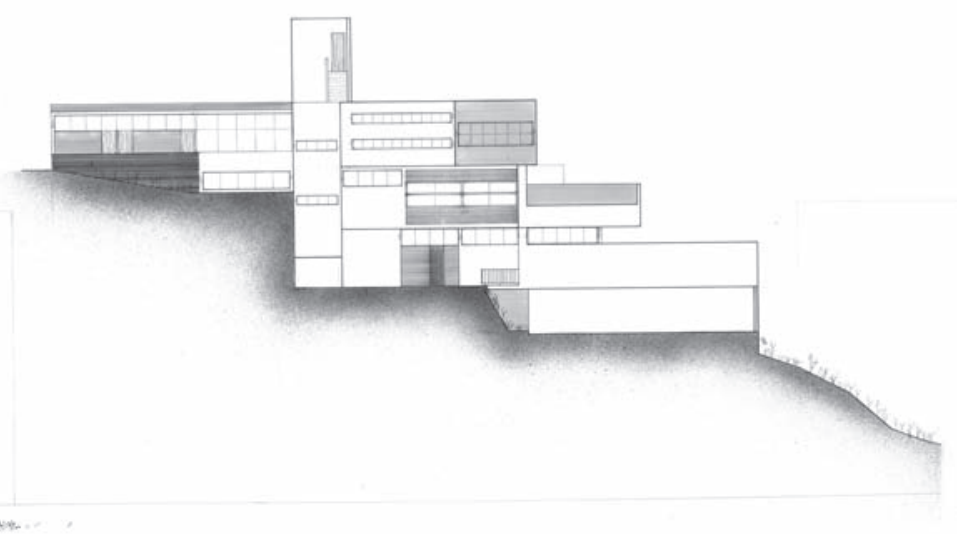


TRATAMENTO DE FACHADAS:

$O$ projeto indica largo uso de concreto e pedras aplicadas em "canjiquinha". O conjunto com seus terraços e panos de vidro, como já foi dito, alude

à residência Kauffman e o uso

de pedra desta forma reforça a

semelhança.

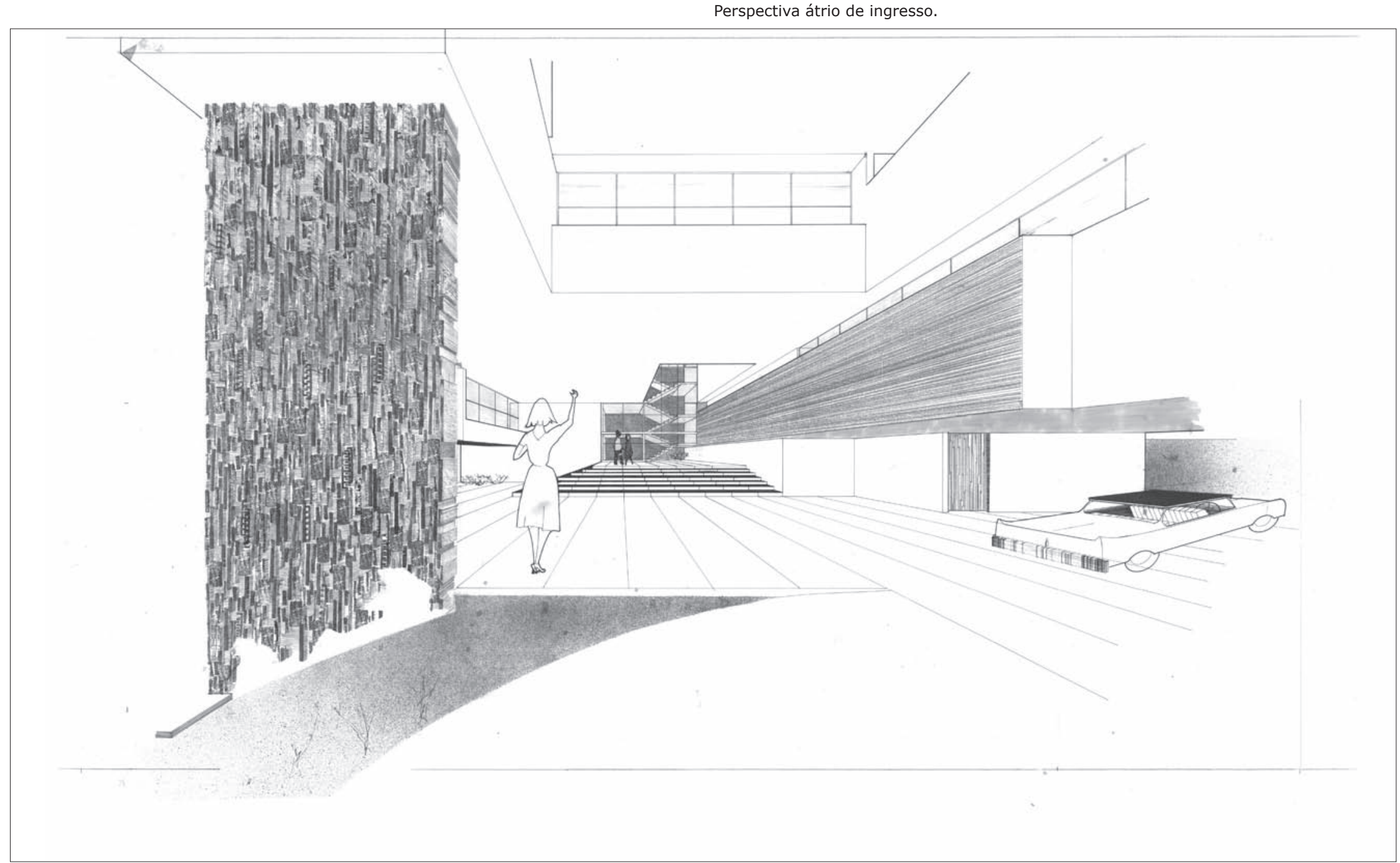


Perspectiva plano da piscina.

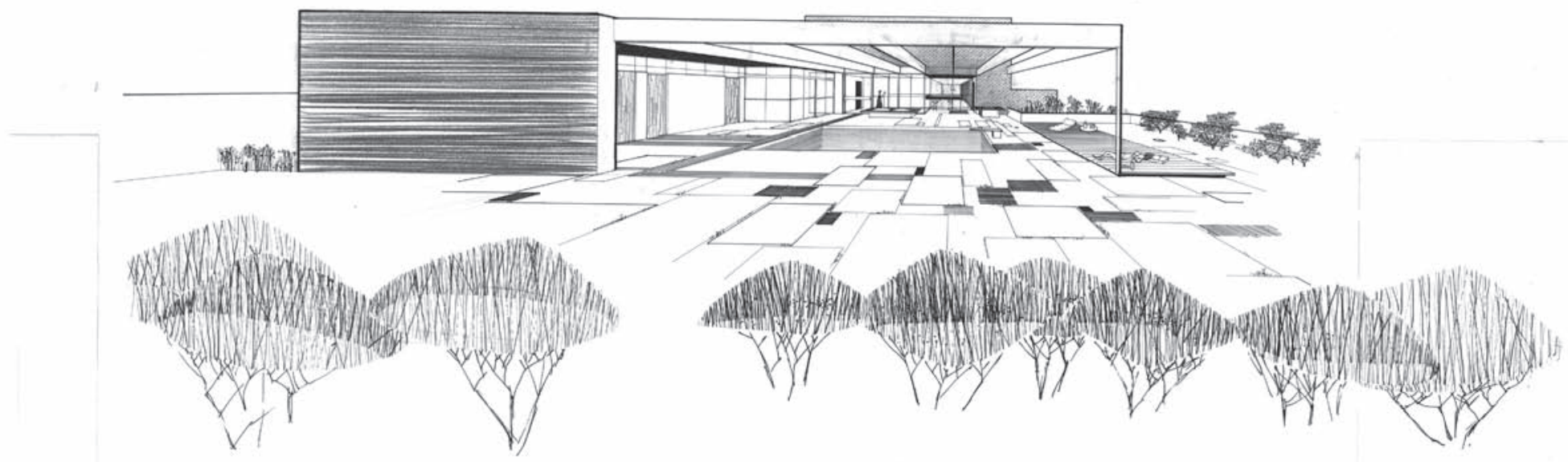


(1) Conclusão 


\section{Conclusão}

A motivação da presente pesquisa, como foi dito na introdução veio inicialmente de uma curiosidade pessoal e da crença de que havia muito a descobrir na obra deste arquiteto.

Durante o processo de pesquisa da obra de Abelardo de Souza, em diversos momentos surgiram dúvidas sobre a representatividade de seu trabalho, e quais elementos o diferenciavam. Isto porque, via de regra sua leitura mantém-se condicionada à análise de poucos edifícios e principalmente, pela a ausência de suas obras na literatura existente sobre arquitetura brasileira, específicamente em São Paulo, o que coloca em um status "inferior" em relação à outras obras de contemporâneos.

Em uma das discussões sobre Abelardo, foi dito que sua pouca representatividade era por tratar-se de um maneirista, que projetava numa repetição de Lúcio Costa e da escola carioca.

Foi então que surgiu a questão: por que considerar demérito aquilo que talvez seja uma de suas principais qualidades? E paradoxalmente, as características atribuídas a seu modelo se tornaram a idiossincrasia que o fez ser refutado em favor de outros, predominantemente o modelo desenvolvido por Artigas, que deixou a influência de outras vertentes formadoras do quadro da arquitetura paulista tanto tempo na sombra.

Abelardo nunca negou suas origens cariocas, ao contrário, em todos seus depoimentos as expunha e, claramente, os princípios adquiridos pela ENBA pontuaram com regularidade seu trabalho. Havia uma estreita 
ligação sua com artistas, designers e paisagistas, num convívio intenso tanto profissional como pessoal, num reflexo da dinâmica que existia entre arquitetura e Belas Artes na citada escola. Não se pode também prescindir do dado de que a ENBA como escola de arquitetura precedeu em dezoito anos a formação da FAU e que esta por sua vez era uma ramificação da politécnica, muito mais ligada as cadeiras de engenharia. Portanto a ligação com as artes plásticas na arquitetura paulistana na década de 40 de só aflorou pelo intermédio pioneiro de arquitetos de formação estrangeira ou da ENBA e a presença deles em São Paulo realmente abriu um repertório novo.

Quando inicia seu trabalho na capital paulistana, Abelardo será parte da "diáspora" do ideário carioca, porém num segundo momento sofrerá adaptações da nova realidade, principalmente no que se refere aos programas de projetos e referências climáticas, tornando sua obra um elo entre a corrente "oficial" existente (carioca) e a arquitetura que começava a se desenvolver em São Paulo.

Este sentido de referência que estamos apontando em seu trabalho é compreensível quando pensamos no surgimento dos edifícios projetados por Abelardo. Quando ocorreu a mudança de feição da cidade de São Paulo, com a intensificação da verticalização na década de 50, eram poucas as obras desse porte. Os primeiros grandes edifícios da cidade, pela própria complexidade financeira, de aprovação, de organização de obra (construtora, pessoal, etc - tudo muito precário ainda) levaram muito tempo de gestação. Os arquitetos neste momento foram pioneiros e o repertório trazido por Abelardo realmente era uma referência no período.

Nesse processo ainda cabe notar a rápida assimilação por parte do arquiteto dos novos materiais industrializados em seu trabalho, chegando inclusive a colaborar para o desenvolvimento de alguns elementos. Muitas 
das obras de Abelardo serviram como vitrine para estes materiais, como bem demostram os anúncios em revistas especializadas de arquitetura e engenharia da época.

A pesquisa de materiais ele aliou sua busca pessoal de diferentes soluções compositivas, trabalhando com materialidades, inserção de cor ou pela criação elementos volumétricos e recuos produzindo efeitos de luz e sombra. Exemplo mais conhecido é o Três Marias, aonde fazendo uso destes recursos ele que consegue inclusive transmitir uma sensação de movimento, como se o volume tivesse sido rotacionado, efeito obtido pela transposição dos balcões na fachada aliada a quebra do volume pelo uso contínuo de madeira no $12^{\circ}$ andar.

Sua rica pesquisa formal prosseguiu nos projetos de edifício da década de 60 , dos quais nenhum exemplar foi executado.

Se exíguas são as citações de seus edifícios, os projetos de casas são francamente menos conhecidos não tendo participado de nenhuma compilação para o gênero.

Nas primeiras casas de Abelardo, realizadas na década de quarenta, quando trabalha uma certa organicidade, já apresentam soluções diferenciadas de seus colegas paulistas. Na década de 50 ingressa no racionalismo corrente, dentro da qual manterá sua linearidade. Fica claro uso dos postulados de Le Corbusier: volumes regulares, uso de pilotis, planta livre, horizontalidade nas aberturas. Observa-se que a pesquisa formal realizada por Abelardo realmente é mais rica em se tratando de edifícios do que em casas, onde por vezes as limitações de terreno ou dificuldades com clientes o levavam a soluções repetidas.

Como características constantes podemos citar: a preocupação com os fatores climáticos e sua adequação pela busca de soluções em caixilhos com venezianas e brises, inserção de elementos de ventilação 
e especialmente pela criação de pátios internos de forma a promover integração entre interior e exterior.

Porém já no fim da década de 50 , no projeto da casa de J.Ribeiro Sobrinho, reconhece-se dentro da volumetria rígida uma liberdade nas soluções espaciais que se entrelaçam num todo mais harmonioso. Além disso apresenta uma rica mescla de materiais e soluções de insolação adequadas, numa composição absolutamente harmônica que, felizmente, até hoje se mantém.

Nos projetos em que faz uso de grandes estruturas, surge uma manifestação mais explícita de uma influência de Oscar Niemeyer, ao qual faz claras referências especialmente nos projetos com casca de concreto.

Mas sua pesquisa formal adquire caminhos próprios quando já no final da década de 60 , busca através de uma tecnologia que misturava o uso de concreto armado com cabos tensionados uma maior expressividade maior dentro de soluções plásticas, num misto de soluções brasileiras com influência externas. Interessante notar que ele não vincula seu trabalho a correntes ideológicas ou sectarismos que surgem então.

Neste modelo relacionamos os projetos para o Clube de Piracicaba, Lynce e Mercado de Pirituba, sendo que só o último conseguiu ser concretizado.

No encerramento desta pesquisa cumpre ainda citar a intensa participação de Abelardo nos primeiros anos da FAUUSP. Chamado por Anhaia Mello para ingressar como assistente da cadeira de composição, sua experiência dos anos de ENBA e da extinta UDF, Ihe rendiam o crédito de ter participado de uma instituição onde já se lecionava dentro dos padrões modernos. O apoio do prof Anhaia Mello, fica claro quando o sabemos que ele foi ao Rio enviado como emissário para falar com L. Costa em nome da 
${ }^{1}$ Habitat no 18 , set/out 54.

2 O CREA teve a primeira regulamentação da profissão de engenheiro e arquiteto

em 1933, mas o título exclusivo veio em 1966. universidade, e de sua liberdade na indicação de alguns nomes.

Nas questões de educação convém citar o Editorial da Revista Habitat em $54^{1}$ em que ele fala sobre o ensino de arquitetura.

Ele cogita o aumento do número de anos do curso e como deveriam ser enfatizados os conhecimentos teóricos, e desenho: desenho abundante para obtenção de técnica durante primeiros anos. Orientação das demais cadeiras em função da cadeira de composição, inclusive as disciplinas técnicas e teóricas. Maior proximidade com a construção, numa estrita ligação "projeto-obra".

Como se sabe, o ensino de arquitetura em São Paulo, apesar de se desvincular do de engenharia em 48, permaneceu atrelado a este, na medida em que todos recebiam o título de engenheiros ${ }^{2}$.

Em 1957 Abelardo de Souza participa de uma comissão interna da FAUUSP encarregada de examinar e propor reformas com o objetivo de aperfeiçoar o ensino. Juntamente com Vilanova Artigas, Hélio Duarte e Rino Levi propuseram, com modesta objetividade uma redistribuição das disciplinas ao longo do curso. Cadeiras técnicas nos primeiros anos, práticas (composição) ao longo do curso e históricas nos três anos centrais. Há ainda considerações muito interessantes com relação à seriação do curso, com relação à composição do curso que enfatizava o atelier como linha mestra do ensino, com relação à prática da construção, com relação à pesquisa e ao apoio financeiro ao corpo discente.

Em 57, as propostas que visam instituir um "ensino brasileiro" paradoxalmente tem como base o pensamento da Bauhaus. Seu grande mérito vem do ponto de vista profissional da "arquitetura para os arquitetos".

Em 1962 a estruturação do curso da FAUUSP se apoiou em um tripé: os três departamentos Projeto, estrutura e tecnologia, unidos pelo Atelier 
interdepartamental, que embora tivesse a princípio a mesma importância dos outros três, nunca se realizou praticamente. ${ }^{3}$

As mudança das regras incluiam a obrigatoriedade de obtenção de titulo. Renina Katz em seu depoimento comenta que Abelardo tinha restrições ao academicismo, acreditando que as pessoas ficariam muito mais preocupadas com a carreira do que com o ensino propriamente dito, e que quem tinha título não necessariamente estava apto. ${ }^{4}$

Era uma posição compartilhada por outros professores, inclusive Artigas, mas no fim Renina acabou fazendo a Pós e o doutorado. Artigas acabou tendo sua titulação resolvida bem mais tarde.

Abelardo se aposentou então em 78 como "instrutor", ele que havia batalhado pela escola e pela profissão! Mas ele manteve a posição "artiguiana" de não se submeterem às mudanças da Universidade. ${ }^{5}$

Neste momento ele lança o livro "Arquitetura no Brasil: Depoimentos".

É uma homenagem àqueles cujo trabalho admirava onde na introdução encontramos um delicioso relato sobre o período em que Lúcio Costa dirigiu a ENBA. Este texto foi diversas vezes republicado em compilações sendo um dos poucos que relata esta momento.

Abelardo de Souza faleceu em 1981, ainda morando no sobrado da Bela Vista. Sua obra na década de 50 mantém-se, ainda, como a de maior visibilidade, apesar de indicar novas pesquisas em seus últimos trabalhos. Ele com certeza influenciou e continua a influenciar uma geração de arquitetos e o debate da arquitetura brasileira.
3 FAGGIN, Carlos Augusto Mattei (1992). Carlos Millan, itinerário profissional de um arquiteto paulista.

Nível: Mestrado. FAU/USP, São Paulo.

${ }^{4}$ Renina Katz depoimento em 24/06/2004.

${ }^{5}$ Miranda Magnoli, depoimento em

18/06/2004. 


\section{Bibliografia}




\section{Bibliografia}

ACAYABA, Marlene Milan (1986), Residências em São Paulo. Projeto Editores Associados, São Paulo.

ANELLI, Renato (2001), Rino Levi arquitetura e cidade.

Romano Guerra Editora, São Paulo.

Arquitetos Brasileiros, Affonso Eduardo Reidy.

Editorial Blau/Instituto Lina Bo e P.M.Bardi. São Paulo. 1999.

Arquitetos Brasileiros. Lina Bo Bardi.

Editorial Blau/Instituto Lina Bo e P.M.Bardi. São Paulo. 1993.

Arquitetos Brasileiros, Vilanova Artigas.

AZEVEDO, Aroldo(1954), A cidade de São Paulo,vol. III.

Associação dos Geógrafos, São Paulo, 1954.

AZEVEDO, M.M.M. (1995), A Experiência de Lina Bo Bardi no Brasil (19471992)

Orientador: Prof. Dr. Júlio Roberto Katinsky. Nível - Mestrado

FAU-USP, São Paulo.

BAKER, Geoffrey H. (1998), Le Corbusier- Uma análise da forma.

Martins Fontes, São Paulo.

BAYEUX, Glória Maria (1991), O debate da arquitetura moderna brasileira nos anos 50. Dissertação (mestrado) FAU/USP. São Paulo. 387p.

BENEVOLO, Leonardo. História da arquitetura moderna

Editora Perspectiva S.A., São Paulo. 1976.

BRUAND, Yves (1981), Arquitetura contemporânea no Brasil .

Editora Perspectiva S.A., São Paulo. 3a ed ição, 1997.

CAMPOS, Candido Malta (2002), Os rumos da cidade. Urbanismo e modernização em São Paulo. Editora Senac, São Paulo.

CAMPOS, Maria Cristina André (2001), O Mural Moderno em São Paulo 
Orientador: Ma Cecília França Loureiro. Nível: mestrado FAU/USP, São Paulo.

CARRANZA, Ricardo (2000), Eduardo Corona: Arquitetura Moderna em São Paulo.

Orientador: Lúcio Gomes Machado. Nível: mestrado FAU/USP, São Paulo.261p.

CAVALCANTI, Lauro (2001), Quando o Brasil era moderno - Guia de arquitetura 1928-1960. Rio de Janeiro, Aeroplano.

CAVALCANTI, Lauro (2001)organizador. Quando o Brasil era moderno: artes plásticas no Rio de Janeiro 1905-1960. Rio de Janeiro, Aeroplano. CONDE, Luiz Paulo Fernandes/ ALMADA, Mauro in Guia da arquitetura Art-déco no Rio de Janeiro

Editora Casa da Palavra/ Secretaria Municipal de Urbanismo/ Centro de Arquitetura e Urbanismo do Rio de Janeiro/ Prefeitura da Cidade do Rio de Janeiro. 2000.164 p.il.

CONDURU, Roberto (2000), Vital Brazil.

Cosac\&Naif Edições, São Paulo.

CURTIS, William J.R. (1982), La Arquitetura Moderna desde 1900.

Editorial Hermann Blume, Madrid. 1986

Fabio Penteado: ensaios de arquitetura

Empresa das Artes. São Paulo. 1998.

Instituto Lina Bo e P.M.Bardi/Fundação Vilanova Artigas. São Paulo. 1997. FAGGIN, Carlos Augusto Mattei (1992), Carlos Millan, itinerário profissional de um arquiteto paulista.

Nível: mestrado FAU/USP, São Paulo.

FARAH, Marta Ferreira Santos (1983), Estado, previdência social e habitação

Nível: mestrado. Depto de Ciências Sociais da FFLCH/USP, São Paulo. 
FICHER, Sylvia/ACAYABA, Marlene (1982), Arquitetura Moderna Brasileira. Projeto Editores Associados Itda., São Paulo.

FRAMPTON, Kenneth (1981),História Crítica da Arquitetura Moderna.

Editora Martins Fontes, São Paulo. $1^{\text {a }}$ edição, 1997.

FROTA, Lélia Coelho, Alcides da Rocha Miranda caminho de um arquiteto.

Rio de Janeiro: Editora UFRJ, 1993.232p; il

Guia da arquitetura Moderna no Rio de Janeiro

Editora Casa da Palavra/ Secretaria Municipal de Urbanismo/ Centro de Arquitetura e Urbanismo do Rio de Janeiro/ Prefeitura da Cidade do Rio de Janeiro. 2000. 210 p.il. P.14

HERBST, Helio (2002), Promessas e conquistas: arquitetura e modernidade nas Bienais. Orientador: Profa. Dra. Maria Cecília França Loureiro. Nível - Mestrado FAU-USP, São Paulo.

IRIGOYEN, Adriana (2002), Wright e Artigas duas viagens.

Ateliê editorial, São Paulo.

JAUSS, Hans Robert (1994), A história da Literatura como provocação à teoria literária.

Editora Ática, São Paulo.1967

KOURY, Ana Paula (1999), Grupo arquitetura nova.

Orientador: Prof.Dr. Carlos A. Ferreira Martins. Nivel: Mestrado E.E.S.C.,São Carlos.

KOPP, Anatole (1985), Quando o Moderno Não Era Um Estilo e Sim Uma Causa.

Livraria Nobel, São Paulo. 1990.

LEUPEN ET AL, Bernard (1999). Proyecto y análisis- Evolución de los principios en arquitectura

Editorial Gustavo Gili, SA, Barcelona. 1993.

MACHADO, Lúcio Gomes (1992), Rino Levi e a Renovação da Arquitetura 


\section{Brasileira.}

Orientador: Prof. Dr. Benedito Lima de Toledo. Nível - Doutorado

FAU-USP, São Paulo.

MENDONÇA, Denise Xavier de (1999). Arquitetura Metropolitana São Paulo década de 50: Análise de 4 edifícios; Copan; sede do jornal O Estado de São Paulo; Itália; Conjunto Nacional

Nível: mestrado, Escola de Engenharia de São Carlos - USP, São Carlos.

MINDLIN, Henrique E.(1956), Arquitetura Moderna no Brasil.

Aeroplano Editora, Rio de Janeiro. 1999.

MONTANER, Josep Maria (1993), Después del Movimiento Moderno: Arquitetura de la segunda mitad del sigloXX

Editorial Gustavo Gili, S.A., Barcelona

PIÑON, Helio (2002), Paulo Mendes da Rocha, Documentos de Arquitetura Moderna 1. Romano Guerra Editora, São Paulo.

REIS, Nestor Goulart do. Quadro da Arquitetura no Brasil.

Editora Perspectiva, São Paulo. 10a edição 2004.

ROSALES, Mario Arturo Figueroa (2002), Habitação coletiva em São Paulo 1928>1972. Orientador: Prof. Dr. Paulo J.V.Bruna. Nível: Doutorado FAU/ USP, São Paulo.

SANTOS, Lena Coelho (1985), Arquitetura Paulista em torno de 1930-40. Orientador : Prof. Dr. Eduardo Corona .Nível: mestrado FAU/USP, São Paulo.

SEGAWA, Hugo (1997), Arquiteturas no Brasil 1900-1990.

São Paulo, Editora da Universidade de São Paulo, 2a edição, 1999.

SEGAWA, Hugo/Dourado, Guilherme Mazza (1997), Oswaldo Arthur Bratke.

Pro Editores Associados, São Paulo.

SOMEKH, Nadia.(1987) A (des) verticalização de São Paulo. 
Orientador: Profa Dra Maria Adélia A. de Souza. Nível - Mestrado FAU/USP, São Paulo.

SOUZA, Abelardo Riedy de (1978), Arquitetura no Brasil: depoimentos. Diadorim/EDUSP, São Paulo.

SOUZA, Maria Adélia Aparecida de (1994), A identidade da metrópole: a verticalização em São Paulo. Ed. HUCITEC/ EDUSP, São Paulo.

$V$ seminário de História da cidade e do Urbanismo. Cidades: temporalidades em confronto. Caderno de resumos, programa de pós-graduação em arquitetura e urbanismo. PUC-Campinas. 1998

Vilanova Artigas, arquitecto: onze textos e uma entrevista.

Casa Cerca/Fundação Vilanova Artigas. Almada. 2000.

Vilanova Artigas, arquitecto. A cidade é uma casa. A casa é uma cidade. Casa Cerca/Fundação Vilanova Artigas. Almada. 2000

XAVIER, Alberto/LEMOS, Carlos A.C./CORONA, Eduardo(1983), Arquitetura moderna paulistana. Editora Pini, São Paulo.

XAVIER, Alberto (org.)(1987), Arquitetura Moderna Brasileira - Depoimento de Uma Geração. Co-edição ABEA/FVA/PINI,São Paulo.

XAVIER, Alberto; BRITTO, Alfredo.; NOBRE, Ana Luiza (1991), Arquitetura moderna no Rio de Janeiro. Pini, Fundação Vilanova Artigas, São Paulo; RIOARTE, Rio de Janeiro.

\section{Sites}

www.luxalon.com.br/htmls/213lux.html (30/4/2004) www.vitruvius.com.br/arquitextos/arq031/bases/02tex.asp (4/6/2004) www.aprenda450anos.com.br (4/6/2004) 


\section{Textos}

BRUNA, Paulo J. V., Abelardo de Souza, Catálogo de desenhos de arquitetura da biblioteca FAU/USP, p.161

FERRAZ, Geraldo, Novos Valores da Arquitetura Brasileira: Abelardo Riedy de Souza,(1957) revista Habitat, no 39, pp.2-21

SOUZA, Abelardo Riedy de,

Revita Habitat, Nossa Arquitetura, n02, 1951, pp.4-5

Revita Habitat, Programa de melhoramentos para São Paulo, n02, 1951, p. 14

Revita Habitat, IV Congresso Brasileiro de Arquitetos, n¹4, 1954, p.23

Revita Habitat, Crítica de Arquitetura, n¹6, 1954,p.2

Revita Habitat, Núcleo de estudo e divulgação da Arquitetura Brasileira, n017, 1954, p.2

Revita Habitat, Um pouco de História, n¹9, 1954, p.32

Revita Habitat, Debate sobre Arquitetura, no 20,1955, p.63

\section{Projetos Publicados}

Revista HABITAT:

(02):12-03_ Projeto de piscina (1951)

(07):18-20_ Prédio de aptos em São Paulo (1952)

(12):10-01_ Edifício Nações Unidas (1953)

(12):28_ Centro Esportivo Cruzeiro (1953)

(17):18-9_ Igreja na Rodovia Pres. Dutra (1954)

(17):22-5_Clube dos 500 (1954)

(27):42_ Urbanização e loteamento de terreno em Ubatuba (1956) 
(30):62-4_Edifício Três Marias (1956)

(33):50-3_ Projeto de um mercado (1956)

(51):6-7_ Residência em São Paulo (1958)

(54):23-7_ Residência no Morumbi (1959)

(54):8-12_ Thalia: Centro Nacional de Arte (1959)

(57):20-4_Edifício Nações Unidas (1959)

(60):11-25_ Escola em Presidente Venceslau (1960)

(61):3-6_ Hotel e aptos em Goiás (1960)

(62):7-18_ Tropical Palace Hotel em São Paulo (1960)

(64):10-3_ Estação Rodoviária em Presidente Venceslau (1961)

(65):4_ Capela em Presidente Venceslau (1961)

(70):20-4_ Internacional Golf Club

(73):13-7_ Clube de C. de São Paulo (1963)

(75):19-20_ Clube de Campo em Piracicaba (1964)

(76):18-23_ Lynce Estância Clube, Atibaia, S

(80):28-33_ Nova Decoração para Hotel da Bahia

(81):15-20_ Aproveitamento da Foz de Chapim, SP(1965)

\section{Revista ACRÓPOLE}

(158):58- Jardim Ana Rosa: grupo de aptos.

(184):171-4_Abelardo de Souza, arquiteto (1939-1953)

(200):366-7_ Edifício Franco da Rocha e Min. Godoy

(209):172-5_ Residência no Pacaembú; paisagismo de Roberto Coelho Cardozo (1956)

(262):270-2_Edifício Nações Unidas (1960)

(110):64-5_Residência E.O.(1947)

(109):36-7_ Estudo para parque infantil(1947)

(106):256-7 _ Orfanato Amando de Barros (1947) 
(118):272-3_ Estudo para residência em São Paulo (1948)

(114):165-7_Edifício Pedra Azul (1947)

(120):321-3_Ed. Hecilda (1948)

(98):52-4 _ Projeto ABI Salvador (1946)

(117):249-51_ Projeto ABI Salvador (1948)

(259):176-7_Edifício ABI Salvabor (1960)

Revista ARQUITETURA E ENGENHARIA

(31):52-3_ Edifício Fco. Da Rocha e Min. Godoy (1954)

(32):26-7_ Clube em São Paulo (1954)

AC - ARQUITETURA E CONSTRUÇÃO

(1):22-6 _ Paisagismo: arquitetura de exterior(1966)

AD_ ARQUITETURA E DECORAÇÃO

(1)_ Edifício Nações Unidas (1953)

(1)_ Residência em São Paulo, móveis de Joaquim Tenreiro

(4) _ Conjunto residencial em construção(1954)

(7)_ Belvedere _ Clube dos 500(1954)

(11)_ Aptos na Estrada de Sto. Amaro(1955)

A CONSTRUÇÃO EM SÃO PAULO

(1253):10-1,14-2_ Pirituba _ Mercado Distrital (1972)

(1627):18,16-4_Edifício sede do IAB (1979)

\section{CASA \& JARDIM}

(208): 106 _ Pirituba _ Mercado Distrital (1972) 
Projetos Originais

Acervo de projetos da biblioteca FAU/USP 


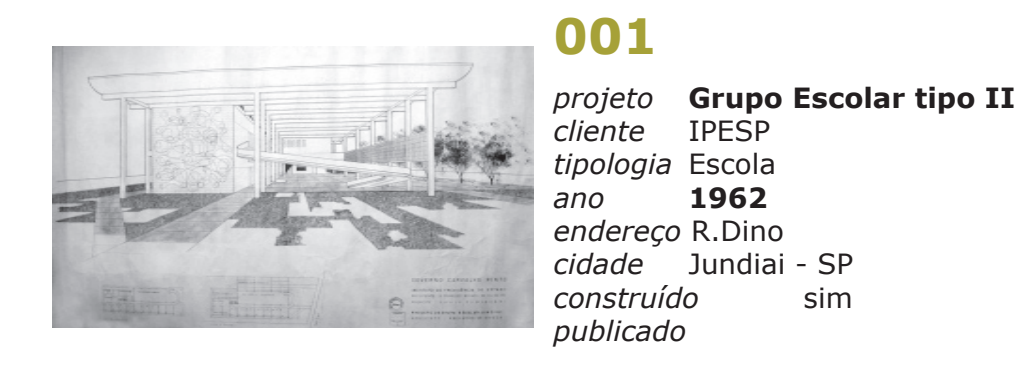

\section{2}

projeto Grupo Escolar de Bauru cliente IPESP

tipologia Escola

ano 1962
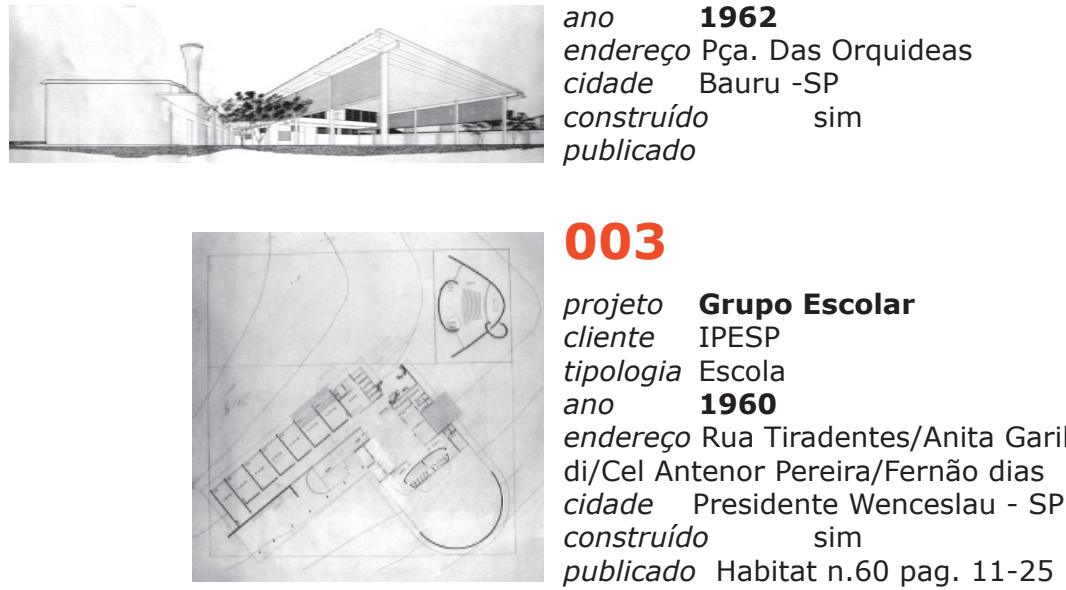

\section{3}

projeto Grupo Escola

cliente IPESP

tipologia Escola

Tiradentes/Anita Garibat-

di/Cel Antenor Pereira/Fernão dias

di/Cel Antenor Pereira/Fernão dias
cidade Presidente Wenceslau - SP

cidade Presidente W
construído sim

publicado Habitat n.60 pag. 11-25

- 1960

\section{4}

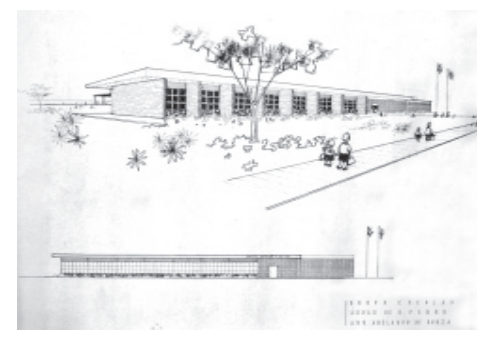

004

projeto Grupo Escolar

cliente IPESP

tipologia Escola

ano 1961

endereço Rua 27c/av. 3

cidade Águas de São Pedro

construído

$\operatorname{sim}$

\section{5}

projeto Esc. de Com. Alvares Pen-

teado

cliente Fundação Alvares Penteado

tipologia Escola

ano

endereço Lgo. S. Francisco com R. Sen.

Feijó

cidade São Paulo - SP

construído

publicado

\section{6}

projeto Escola Paulista de Medi-

\section{cina}

cliente

tipologia Escola

ano

endereço Av. Paulista

cidade São Paulo -SP

construído

\section{7}

projeto Grupo Escolar

cliente IPESP

tipologia Escola

ano 1961

$\begin{array}{ll}\text { ano } & \mathbf{1 9 6 1} \\ \text { endereço } & \text { R.Gastão Vidigal }\end{array}$

cidade Suzano - SP

construído

publicado

\section{8}

projeto Grupo Escolar Vila Indus-

trial

trial

Fundo Estadual de Constru-

ção Escolar

tipologia Escola

ano $1967 / 68$

endereço Av.Cav.Nami Jaffet

cidade Mogi das Cruzes - SP

construído

$\operatorname{sim}$

publicado 


\section{9}

\section{projeto Estação Rodoviária}

cliente

tipologia Estações

ano

endereço Praça Júlio Prestes

cidade São Paulo - SP

construído

publicado

\section{0}

projeto Parada de Ônibus

tipologia Estač̃os

ano

endereço R.Tenente Oswaldo x R.São

Paulo

cidade Pres. Wenceslau-SP

construído

publicado Habitat n. 64 pag. 10-13

- 1961

\section{1}

projeto Fazenda Bom Descanso

cliente Pado S/A

tipologia Fazendas

ano

endereço

cidade Ubatuba - SP

construído

\section{2}

projeto Fazendas Unidas

cliente Fazendas Unidas

tipologia Fazendas

ano

endereço

cidade Loanda - SP

construído

construído

\section{3}

projeto Fazendas Reunidas Agro-

pec. Ltda

cliente

tipologia Fazendas

ano

endereço

cidade

construído

publicado

Bataiporãn - MT

\section{4}

projeto Plano de Urb. De Vila

Sertaneja

cliente Dr. Henrique Ma dos Santos

tipologia Fazendas

ano

endereço

cidade Sertãozinho - SP

construído

publicado

\section{5}

projeto Fazenda Taquari

cliente Luiz Marcio Ribeiro Caldas

tipologia Fazendas

ano

$$
1972
$$

cidade

construído

publicado

\section{6}

projeto Sítio Eduardo

cliente Casas Eduardo - Calç.e Cha-

péus

tipologia Fazendas

ano

endereço

cidade Sta. Izabel - SP

construído

publicado 


\section{7}

$\begin{array}{ll}\text { projeto } & \text { Sítio SP } \\ \text { cliente } & \text { Hermes Barreto } \\ \text { tipologia } & \text { Fazendas } \\ \text { ano } & \\ \text { endereço } \\ \text { cidade São Paulo - SP } \\ \begin{array}{l}\text { construído } \\ \text { publicado }\end{array}\end{array}$

\section{8}

projeto Santa Casa de Misericórdia cliente

tipologia Hospitais

ano

endereço

cidade Santos-SP

construído

construido

\section{9}

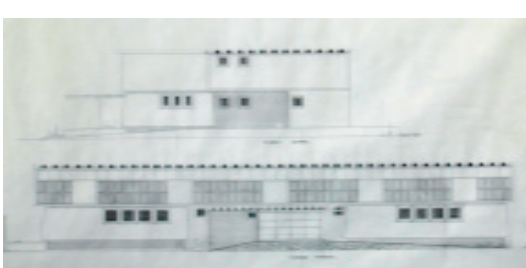

projeto

cliente

ano

endereço

cidade Osasco/Barueri - SP

construído

publicado

\section{0}

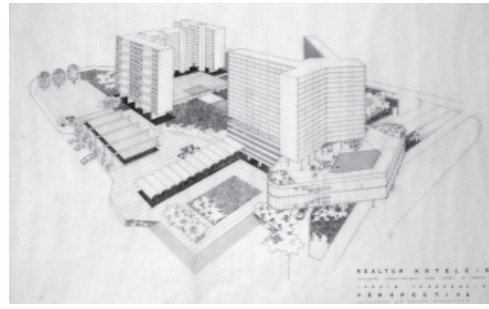

\section{projeto Conjunto hoteis e aptos.}

cliente Realtur Hoteleira S.A.

tipologia Hotéis /Pousadas

ano 1964

endereço Jd. Tegereba

cidade Guarujá - SP

construído

publicado

\section{1}

projeto Colônia de Férias - Vila

Tupi

cliente S.E.C.R.A.S

tipologia Hotéis /Pousadas

ano 1967

endereço

cidade

construído

publicado

\section{2}

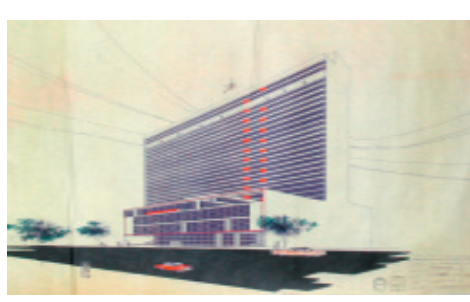

projeto Tropical Palace Hotel

cliente Imobiliária Deville Ltda

tipologia Hotéis /Pousadas

ano 1960

endereço R. da Consolação 282 a 320

cidade São Paulo - SP

construído

publicado Habitat n. 62 pag. 7-18

$-1960$

\section{3}

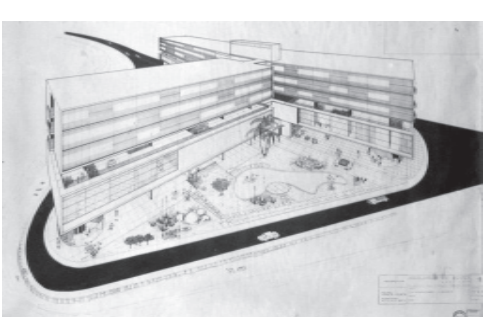

projeto Hotel Areias Negras

cliente Realtur S.A.Agenciamentos

tipologia Hotéis /Pousadas

ano 1963

endereço Praia da Areia Preta

cidade Guarapari- ES

construído

publicado

\section{4}

projeto Hotel em Ouro Preto

cliente Cia.Tropical de Hotéis

tipologia Hotéis/Pousadas

ano

1970

endereço Morro da Forca

cidade Ouro Preto - MG

construído

publicado 


\section{5}

\section{projeto Clube dos $\mathbf{5 0 0}$}

cliente Cia. de Hotéis Bradesco

tipologia Hotéis/Pousadas

ano

$$
1954
$$

endereço

cidade Guaratinguetá - SP

construíd

publicado Habitat n.17( 1954); Arq. e Dec. (1955)

\section{6}

projeto Internacional Golfe Clube cliente SEMPAR

tipologia Hotéis/Pousadas

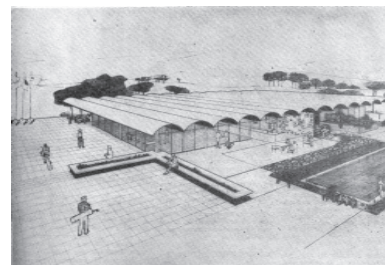

\section{ano 1963}

endereço Rod.Pres.Dutra km.232,

vizinho ao clube dos Clube dos 500

cidade Guaratinguetá - SP

construído

publicado Habitat 70 p.20-4

\section{7}

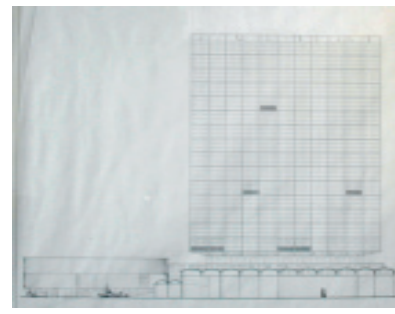

cliente Hotel Brad.Aerop.de S.Paulo

SA

tipologia Hotéis/Pousadas

ano

endereço Av. Washington Luis 1576

cidade São Paulo - SP

construído

publicado

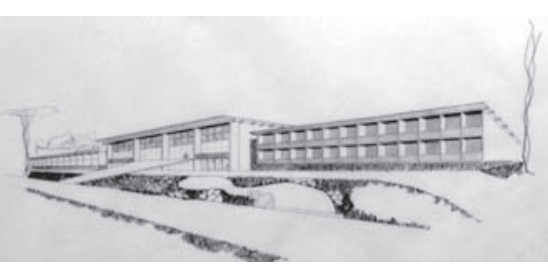

\section{9}

\section{projeto Pousada}

cliente Cia.Tropical de Hotéis

tipologia Hotéis/Pousadas

ano

endereço R.13 de maio 14

cidade Cachoeira - Ba

construído

publicado

\section{0}

projeto Tropical Hote

cliente Cia.Tropical de Hotéis

tipologia Hotéis/Pousadas

ano

endereço Ponta Negra

cidade

construído

publicado

\section{1}

projeto

Cj. Vale do Ipê

cliente

tipologia Hotéis/Pousadas

ano

endereço

cidade

construído

publicado

\section{2}

\section{8}

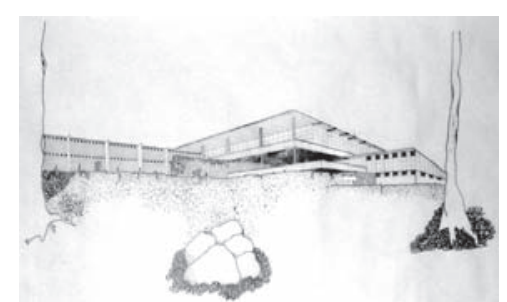

\section{projeto Hote}

cliente Dr. Carlos Vergueiro

tipologia Hotéis/Pousadas

ano 1967

endereço R. 13 de maio 846

cidade Foz do Iguaçú

construído

publicado cliente

tipologia Hotéis/Pousadas

$$
\text { ano }
$$

endereço

cidade Ribeirão Preto - SP

construído

publicado 


\section{3}

projeto Hotel com lojas

cliente Parque Balneário Hotel

tipologia Hotéis/Pousadas

ano

endereço Av. Ana Costa 555

cidade Santos - SP

construído

publicado

\section{4}

\section{projeto Hotel em São Paulo}

cliente Gerard Georges Valentin e

outros

tipologia Hotéis/Pousadas

ano
endereço Al.Casabranca/Av.Paulista/

endereço

Al.Santos

cidade São Paulo - SP

construído

publicado

\section{5}

projeto

cliente

tipolog
ano

endereço Av.Presidente Vargas

cidade

Salvador-BA

construído

publicado

\section{6}

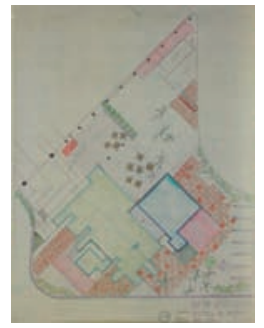

projeto Dec. do Hotel da Bahia

associado a Miranda M.M.

cliente Realtur Hoteleira S.A.

tipologia Hotéis/Pousadas

ano 1966

endereço Pça dois de julho/7 de se-

tembro

cidade Salvador-BA

construído sim

publicado Habitat 80 p.28-33 (1965)

\section{7}

projeto Hotel

cliente Cia. de Hotéis do Norte

tipologia Hotéis/Pousadas

ano 1969

endereço Av. Pres.Vargas/Carlos Go-

mes

cidade Belém - PA

construído

publicado

\section{8}

projeto Hotel e Aptos.

cliente Salim Caled

tipologia Hotéis/Pousadas

ano

endereço

cidade Anápolis - GO

construído

construido
publicado Habitat 61 pg.3-6 (1960)

\section{9}

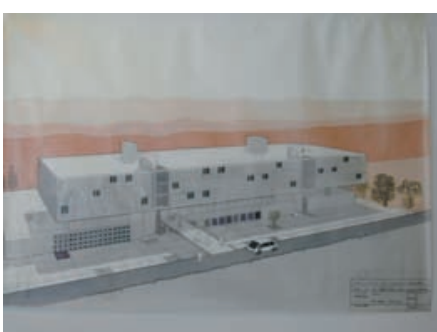

projeto Hotel

cliente Bel-Campo Emp.Tur. S/A

tipologia Hotéis/Pousadas

ano

endereço Rod. Raposo Tavares Km.66 cidade Mairinque/S.Roque -SP construido publicado

\section{0}

projeto Reforma de um hotel cliente Hotel Pão de açucar S/A tipologia Hotéis/Pousadas

ano

endereço R.Conselheiro Nébias 314 cidade São Paulo - SP

construído

publicado 


\section{1}

projeto Hotel em Foz do Iguaçu

cliente Carlos Vergueiro

tipologia Hotéis/Pousadas

endereço Rartolomeu Gus

mão/R.Missões

cidade Foz do Iguaçu - PR

construído

publicado

\section{2}

\section{projeto Hotel}

cliente Rodolfo Triebe

tipologia Hotéis/Pousadas

ano

endereço Av. Washington Luiz

3691

cidade São Paulo -SP

construído

publicado

\section{3}

\section{projeto Hote}

cliente Cia. de Hotéis Bradesco

tipologia Hotéis/Pousadas

ano $\quad 1974$

cidade Caraguatatuba-SP

construído

publicado

\section{4}

projeto Gleba para loteamento

cliente Conrado Sorgenicht e outros

tipologia Loteamentos

ano

endereço Praia Grande

cidade São Sebastião - SP

construído

publicado

\section{5}

projeto

Italia

cliente Mario Bartholo

tipologia Loteamentos

ano

endereço

cidade Itapetininga - SP

construído

publicado

\section{6}

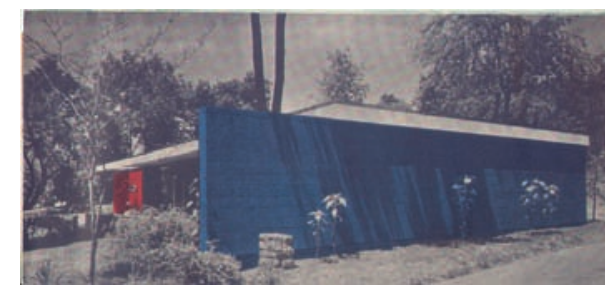

\section{projeto Cidade Tallavasso}

cliente José Schwarzmaier e Filhos.

Ltda.

tipologia Loteamentos

ano

endereço

cidade Taquaritinga - SP

construído

publicado folder

\section{7}

projeto Loteamento Rural

cliente Salvate Carnicell

tipologia Loteamentos

ano

endereço

cidade São Roque - SP

construído

publicado

\section{8}

projeto Centro de Atração Tur. e

Lot.

cliente Nadir Lima Cardoso

tipologia Loteamentos

tipologia
ano

endereço Pqe. Agua Santa

cidade Campos do Jordão - SP

construído

publicado 


\section{9}

projeto Divisão de quadras em

lotes

cliente

tipologia Loteamentos

ano

endereço Jd.Guilhermina-Boqueirão

cidade Praia Grande - SP

construído

publicado

\section{0}

projeto Loteamento popular

cliente Mario Bartholo, Armando

Santos

tipologia Loteamentos

ano

endereço Estrada de Campininha- Sto.

Amaro

cidade São Paulo - SP

construído

publicado

\section{1}

projeto Cond. Irmãos Pires do Rio

cliente Sta.Paula Melhoramentos

$\mathrm{S} / \mathrm{A}$

tipologia Loteamentos

ano

endereço

cidade

construído

publicado

Aparecida do Norte - SP

\section{2}

projeto

cliente

\section{Loteamento}

tipologia

ano

LAteamentos

ender

Eldorado

cidade

Diadema -SP

construído

publicado

\section{3}

projeto Integr. de linhas de su-

burbio

cliente Prefeitura de SP

tipologia Acessos

ano

endereço

cidade São Paulo - SP

construído

publicado

\section{4}

\section{projeto Loteamento}

cliente S.C.Pontal da Lagoinha Ltda.

tipologia Fazendas

ano

endereço Praia de Maranduba

cidade Ubatuba - SP

construído

publicado Habitat 27 p.42 (1956)

Habitat 39 p.18 (1957)

\section{5}

projeto Urbanização de São Lou-

renço

assoc. a Miranda Magnoli

cliente

tipologia Loteamentos

ano

endereço

cidade Bertioga-SP

construído

publicado

\section{6}

projeto Cj.Hab. Praia do Tombo

cliente Antoni Brandão

tipologia Loteamentos

ano

endereço

cidade Guarujá -SP

construído

publicado 


\section{7}

projeto Mercado de Pinheiros

cliente C.C.Bonfigliol

tipologia Mercados

ano

endereço Av.Eusébio Matoso/R.Bento

Freitas

cidade São Paulo - SP

construído

publicado

\section{8}

\section{projeto Mercado}

cliente Fazendas Unidas

tipologia Mercados

ano

endereço Rua Liberdade e Av. Itororó

cidade São Paulo - SP

construído

publicado

\section{9}

projeto Campos Novos do Empyreo

cliente Yolanda Penteado Matarazzo

tipologia Mercados

ano 1959

endereço

cidade Leme-SP

construído

publicado

\section{0}

projeto Armazém/mercado

cliente Armazens Populares Reuni-

dos

tipologia Mercados

ano 1954

endereço R.do Gasometro - Bras

cidade São Paulo - SP

construído não

publicado Habitat 39 p.17 (1957).

Habitat 33 p.50 (1956) ; Mindlin-"The

architecture in Brazil" p.41

\section{1}

projeto Mercado

cliente Mario Bartholo

tipologia Mercados

ano

endereço

cidade

construído

publicado

orocaba - SP

\section{2}

projeto Merc. Distrital do Morum-

bi

cliente

tipologia Mercados

ano

endereço

cidade

construído

publicado

\section{São Paulo - SP}

063

projeto Mercado

cliente

tipologia Mercados

ano 1954

endereço R.do catete

cidade Rio de Janeiro - RJ

construído

publicado

\section{4}

projeto Prédio de Aptos e Arma-

zem

cliente Maria S.Russo

tipologia Mercados

ano

endereço R.Bela Cintra, 483

cidade São Paulo - SP

construído

publicado 


\section{5}

projeto Prédio para mercado

cliente CNI

tipologia Mercados

ano

endereço Rua Augusta

cidade São Paulo - SP

construído

publicado

\section{6}

projeto

Esp.

cliente

tipologia

ano

endereço Av. Siqueira Campos/

R.Figueiredo Magalhães

cidade

construído

publicado

\section{7}

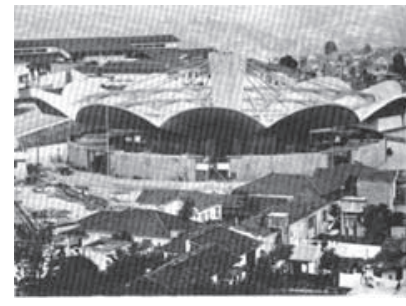

projeto

cliente

tipologia

ano 1969

endereço R.Gabriel Cotti/Alm Isaias de

Noronha / R. Luis de Andrade e R. Celso

Vieira

cidade São Paulo - SP

construído sim

publicado "A construção em SP" p.10 14 (1972)

\section{8}

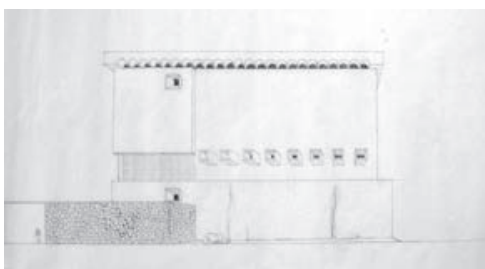

projeto Lab. Fot. e Estúdios

cliente LYNX film

tipologia Comerciais

ano 1965

endereço R.São Francisco de Assis

cidade São Paulo - SP

construído

publicado

\section{9}

projeto Lab. Fot. e Estúdios

cliente

YYNX film

Comerciais

ano

\section{2}

endereço R.Frei Caneca

cidade São Paulo - SP
construído

construído

publicado

\section{0}

projeto Loja de Roupas Femininas cliente Mme.Ruth

tipologia Comerciais

ano $\mathbf{1 9 7 4}$

endereço R.Barão de Capanema

cidade São Paulo - SP

construído

publicado

\section{1}

projeto Posto de Gasolina

cliente Fco.J.da Nova/Guapaúva Ltda

tipologia Comerciais

ano

endereço Av Rebouças

cidade São Paulo - SP

construído

publicado

\section{2}

projeto Loja em Buenos Aires

cliente

tipologia Comerciais

ano

endereço R.Florida c/Tucuman

cidade Buenos Aires - Argentina

construído

publicado

\section{3}

projeto Cia.Importadora Notar

cliente

Sr. Notari

tipologia Comerciais

ano

endereço Rua Rocha

cidade São Paulo - SP

construído

publicado

\section{4}

projeto Lojas

cliente Fco.Giaffone

tipologia Comerciais

ano

endereço R.dos Ingleses 23,27,29,33

e Cons.Carrão493

cidade São Paulo - SP

construído

publicado

\section{5}

projeto Casas Eduardo

cliente João di Pietro

tipologia Comerciais

ano

endereço

cidade

construído

publicado

\section{6}

projeto Pça de retornoV.Normanda

cliente

tipologia Acessos

ano

endereço R.Consolação/R.Araujo/

S.Luiz/Ipiranga

cidade São Paulo - SP

construído

publicado 


\section{7}

projeto Viaduto Rio Pinheiros

cliente Prefeitura de São Paulo

tipologia Acessos

ano

cidade São Paulo - SP

publicado

\section{8}

projeto Tunel sob o Mont Serrat cliente Pref.Mun.Santos

tipologia Acessos

endereço Monte Serrat

cidade Santos - SP

construído

publicado

\section{9}

projeto Alargamento R.do Catete cliente

tipologia Acessos

ano

endereço

cidade

construído

publicado

\section{0}

projeto Acesso Via Anchieta km28 cliente DER

tipologia Acessos

ano

endereço Rio Grande

cidade - SP

construído

publicado

\section{1}

projeto Bco.da América S/A

cliente Bco.da América S/A

tipologia Bancos

ano

endereço R.Clélia/R.Aurélia

cidade São Paulo - SP

construído

publicado

\section{2}

projeto Bco.Auxiliar de SP

cliente Cia.Paulista de Seguros

tipologia Bancos

ano

endereço R.Libero Badaró

cidade São Paulo - SP

construído

publicado

\section{3}

projeto Caixa Econômica Federa

cliente Caixa Econômica Federal

tipologia Bancos

ano

endereço

cidade Jaboticabal-SP

construído sim

publicado

\section{4}

projeto Mon.Pedro de Toledo cliente

tipologia Concurso

ano

endereço R.Curitiba/Av.Brasil

cidade São Paulo - SP

construído

publicado

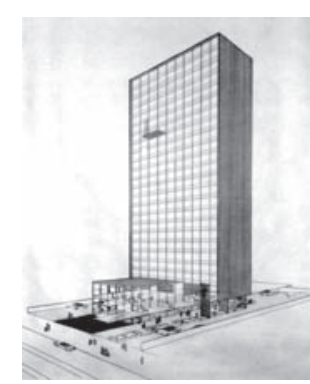

\section{5}

projeto Edifício na Av. Paulista

cliente Invicta S/A

tipologia Concursos - $2^{\circ}$ lugar

ano

endereço Av.Paulista

cidade São Paulo - SP

construído não

publicado

\section{6}

projeto Paço Municipal

cliente Pref. Municipio Valinhos

tipologia Concursos ( $1^{\circ}$ lugar)

ano

endereço

cidade Valinhos - SP

construído não

publicado

\section{7}

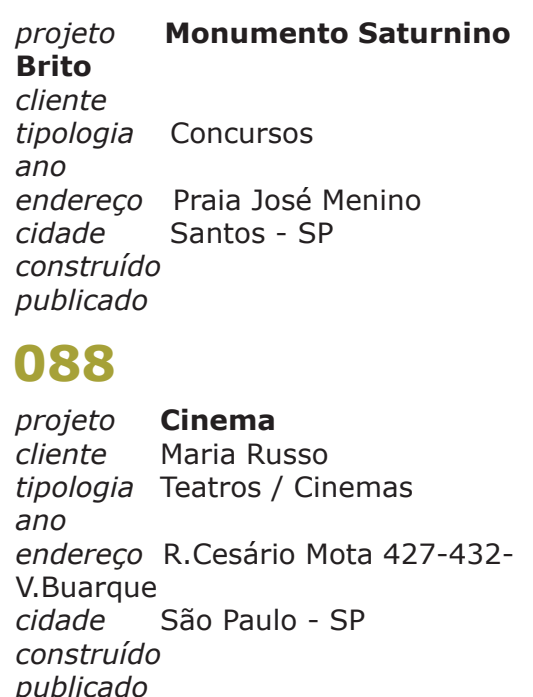


089

projeto Cine Sorocaba
cliente
tipologia
ano
endereço
cidade
construído Sorocaba - SP
publicado

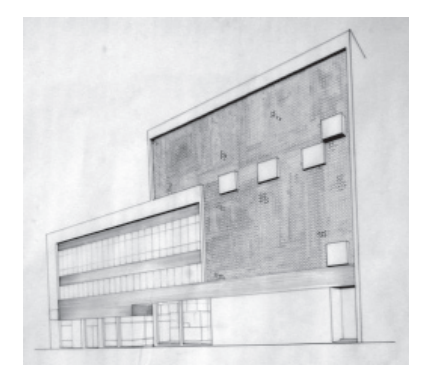

\section{0}

projeto Teatro Thalia

cliente Mario Bartholo

tipologia Teatros / Cinemas

ano 1959

endereço Pça.Mal.Deodoro 340-Sta.

Cecília

cidade São Paulo - SP

construído não

publicado Habitat 54 p 8-12 (1959)

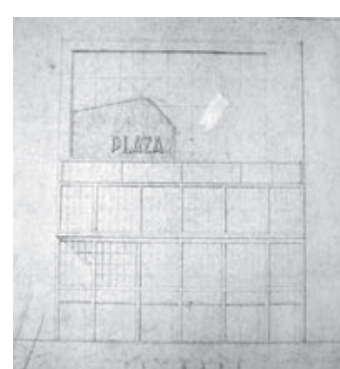

\section{1}

projeto

\section{Cine Plaza}

cliente Mario Bartholo

tipologia Teatros / Cinemas

ano $\mathbf{1 9 5 8 / 5 9}$

endereço Pça.Mal.Deodoro 340-Sta.

Cecília

cidade

construído

publicado

\section{2}

projeto Teatro Leopoldo Fróes-

Cia.Nydia L.

cliente PMSP

tipologia Teatros / Cinemas

ano

endereço Major Sertório e Gal.Jardim

cidade

São Paulo - SP

construído

publicado

\section{3}

projeto

Teatro

cliente Montezzo

tipologia Teatros / Cinemas

ano

endereço Lgo.do Arouche

cidade São Paulo - SP

publicado

\section{4}

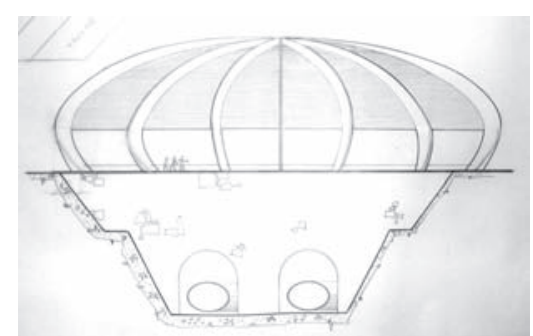

\section{projeto Casa de Força}

assoc. a Miranda M.M.

cliente COPEL

tipologia Gerais

$\mathbf{1 9 6 5}$

endereço Foz do Chopim

cidade

PR

publicado Habitat 81 p 15-20 (1965)

\section{5}

projeto

tipologia Gerais

ano

$\mathbf{1 9 6 1}$

endereço Via Anchieta

cidade - SP

construído

publicado

\section{6}

projeto

Antonio Rosa

tipologia Gerais

ano

1958

endereço Estrada Piraporinha

cidade - SP

construído

publicado sim 

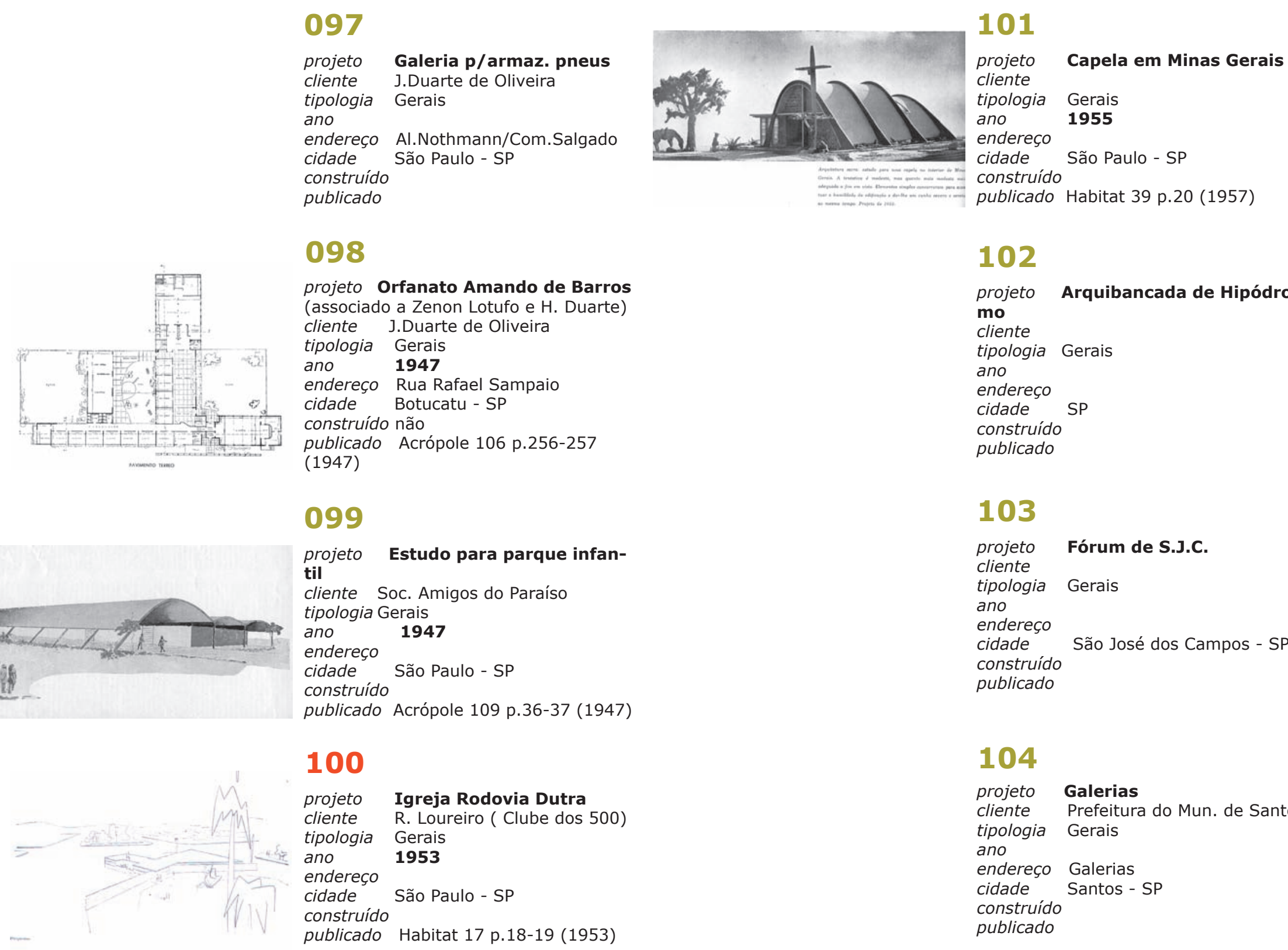

\section{2}

projeto Arquibancada de Hipódromo

cliente

tipologia Gerais

ano

endereço

cidade SP

construído

publicado

\section{3}

projeto

cliente

tipologia Gerais

ano

endereço

cidade

construído

publicado

São José dos Campos - SP

\section{4}

projeto

Prefeitura do Mun. de Santos

tipologia Gerais

ano

endereço Galerias

cidade Santos - SP

construído

publicado 

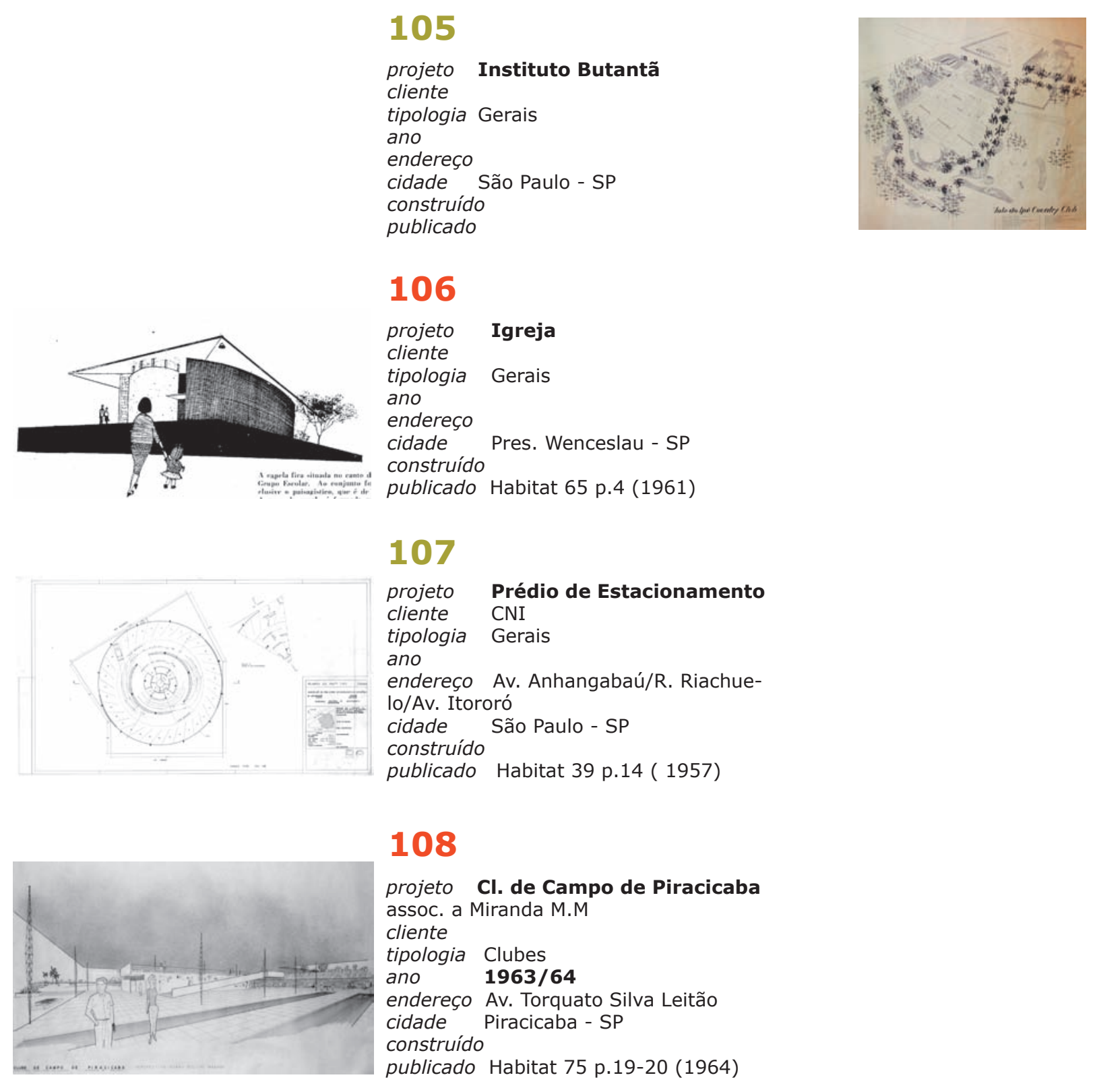

\section{9}

projeto Vale do Ipê Country Club

cliente Sr. Santos Afonso

tipologia Clubes

ano

endereço Belford Roxo

cidade

construído

publicado

\section{0}

projeto

cliente

tipologia

ano

endereço

cidade

construído

publicado

\section{Clube de campo}

Clubes

Belem - PA

111

projeto

Clube

cliente

tipologia

ano

endereço

cidade

construíd

publicado

\section{2}

projeto

cliente

Sta.Paula Country Club

tipologia

ano

do Alto

cidade

construído

publicado
Sta. Paula Melhoramentos

\section{Campos do Jordão Tênis}

Clubes

Campos do Jordão - SP

Clubes

Jd Sta Paula-Estr.Caucaia $\mathrm{SP}$

publicado Habitat 75 p.19-20 (1964) 


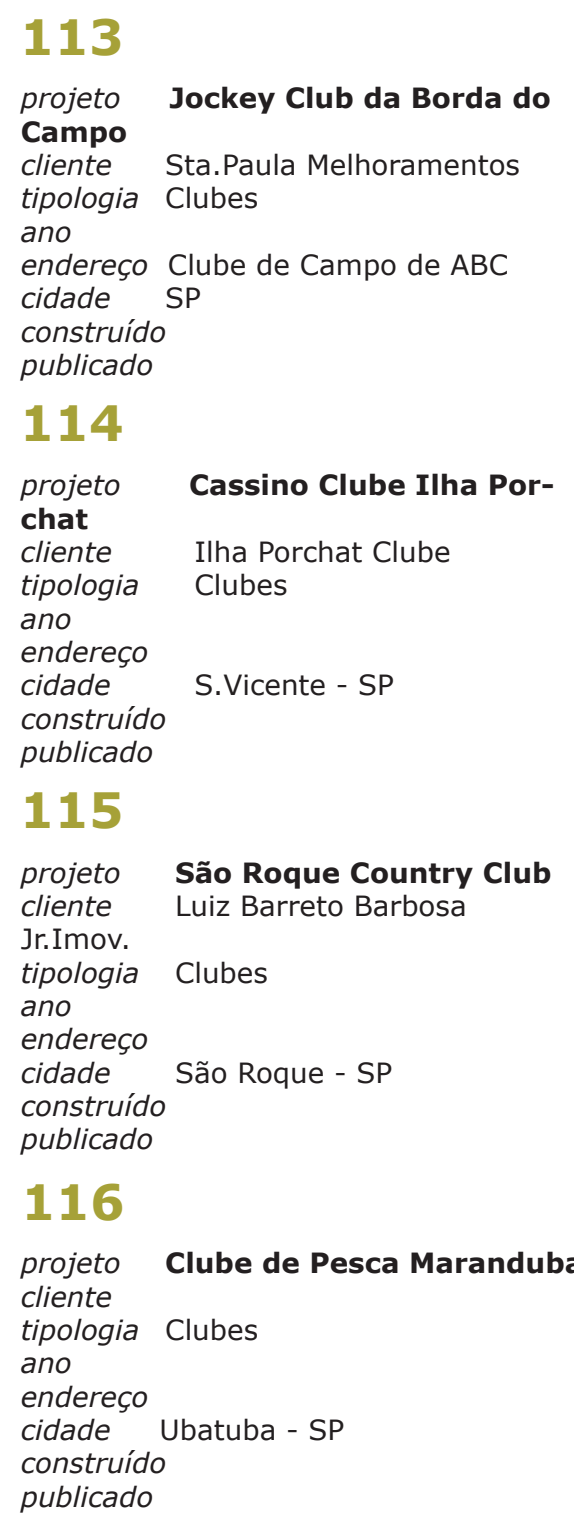

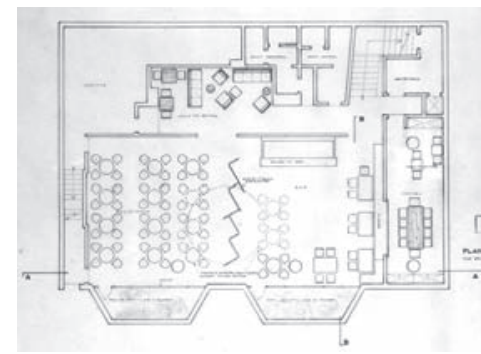

\section{7}

projeto Reforma clube dos Artistas cliente

tipologia Clubes

ano

endereço R.Bento Freitas 306

cidade São Paulo - SP

construído

\section{8}

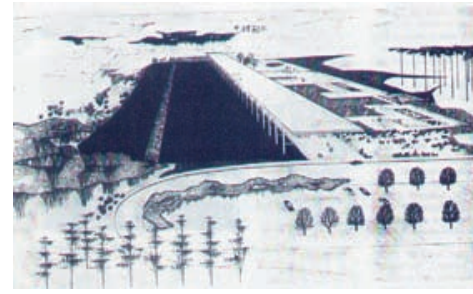

\section{projeto Lynce Estância Clube}

(associado a Miranda Magnoli)

cliente Lynce Estância Clube

tipologia Clubes

ano

endereço

cidade Atibaia -SP

construído não

publicado Habitat 76 p.18-23 (1964)

\section{9}

projeto Clube Atlético Ourinhense cliente Clube Atlético Ourinhense

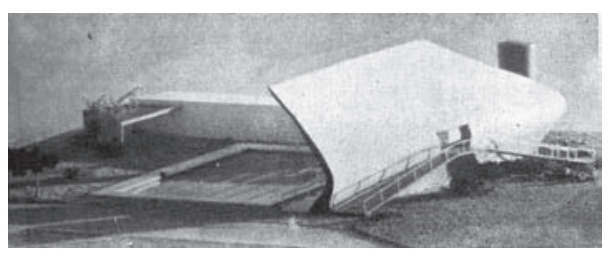

tipologia Clubes

ano

$\mathbf{1 9 4 5}$

endereço

cidade Ourinhos - SP

construído sim

publicado Habitat 2 (1951), Habitat

39 p7 (1957), Acrópole 184. Part. da $1^{\circ}$ exp. Int. de Arq. ( 1951)

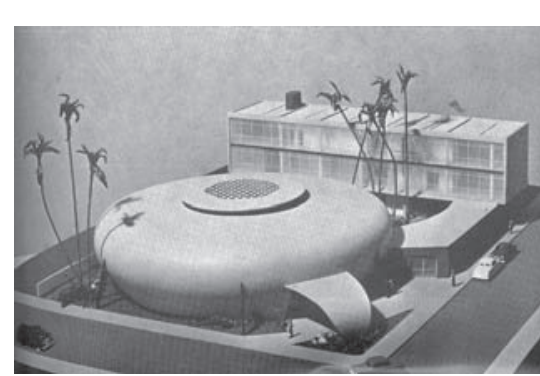

120

projeto Cruzeiro F.C

cliente Cruzeiro F.C.

tipologia Clubes

ano 1953

endereço R.Cap. Avelino Bastos/R.M.

Hermogenes

cidade Cruzeiro - SP

construído sim

publicado Arq. e Eng.32 (1954); Acrópole 184; Habitat 39 (1957); Habitat 12 (1953) 


\section{1 \\ projeto Clube At. Monte Libano cliente Clube At. Monte Libano tipologia Clube \\ ano \\ endereço Av. Rep.do Libano 2267 \\ cidade \\ São Paulo - SP \\ construído \\ publicado}

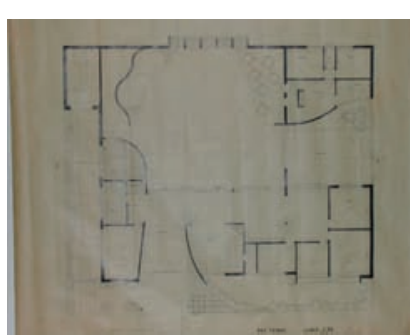

122

projeto

nina

cliente

tipologia

ano

endere

cidade

publicado sim

123

projeto

tipologia

ano

\section{Ocian Praia Clube}

1962

cidade

construído

publicado

\section{4}

projeto Reforma do Clube Nacional

( Associado a Miranda M.M.)

cliente Clube Nacional

tipologia Clubes

ano 1963

endereço R.Angatuba

cidade São Paulo - SP

construído sim

publicado Artigo de jornal de 1963

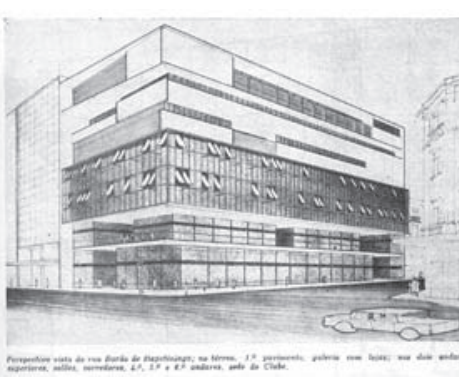

\section{5}

projeto Clube da Cidade de SP

(Associado a Miranda M.M.)

cliente Severo e Vilares

tipologia Clubes

ano 1963

endereço

cidade

construído sim

publicado Habitat 73 p.13-17 (1963)

\section{6}

projeto

cliente

tipologia Clubes

ano

endereço Av.Washington Luis

cidade

Santos - SP

uído

publicado sim

\section{7}

projeto

Imekhol

cliente

tipologia

ano
endereço Av.Sto.Andre/R.Abilio So-

ares

cidade,

construído

publicado

projeto

cliente

Almeida

tipolo
ano

endereço R.Domingos Leme

cidade
São Paulo - SP

publicado

\section{Edifíco de aptos.}

Maria Aparecida Munford 


\section{9}

projeto Predio de aptos c/Agencia cliente Caixa Economica Federal SP tipologia Edifícios

ano

endereço Pça.9de julho

cidade Jaboticabal - SP

construído

publicado

\section{0}

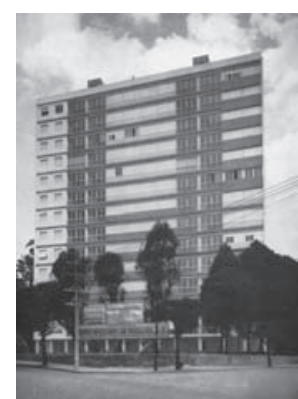

projeto

Perdizes

cliente Banco Hipotecário Lar Brasi-

eiro

tipologia Edifícios

\section{4}

endereço Rua Fco.da Rocha-Perdizes

cidade São Paulo - SP

construído sim

publicado Acrópole 184 e 200; Habitat

39; Arq. e Eng. 31; Arq. e Dec. 4

\section{1}

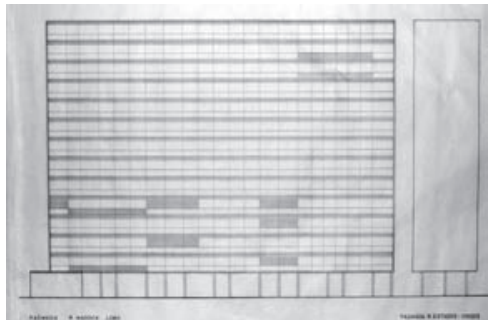

projeto Centro Comercial

cliente Rafael e Raul Franco de Mello

tipologia edifícios

ano 1953

endereço R.Estados Unidos/Haddock

Lobo

cidade São Paulo - SP

construído

publicado

\section{2}

\section{projeto Edifício Comercia}

cliente BNI

tipologia Edifícios

ano

endereço R.Boa Vista

cidade São Paulo - SP

construído

publicado

\section{3}

projeto

cliente

tipologia Edifícios

ano

endereço R.Marques de Itu/R.Bento

Freitas

cidade

construído

publicado

\section{4}

\section{projeto Prédio de Aptos}

cliente Casas Eduardo - Calç.e Cha-

péus

tipologia Edifícios

ano

endereço Av.Brigadeiro Luis Antonio/

Rui Barbosa

cidade São Paulo - SP

construído

publicado

\section{5}

projeto

rios

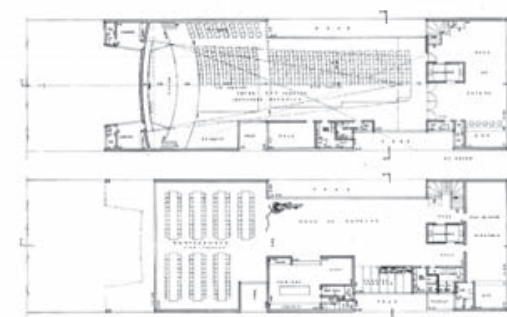

client

péus

tipologia

ano

Av.Brigadeiro Luis Antonio

São Paulo - SP

construido

\section{6}

projeto Prédio de Aptos

cliente Benjamin Batista Ferraz

tipologia Edifícios

ano

endereço Pça Osvaldo Cruz

cidade

São Paulo - SP

publicado 


\section{7}

projeto

cliente

tipologi

ano

endereco
cidade

construído

publicado

\section{8}

projeto Ed.Comercial cond.Copan

cliente BNI

tipologia Edifícios

ano

endereço Av.Ipiranga

cidade

São Paulo - SP

construído

publicado

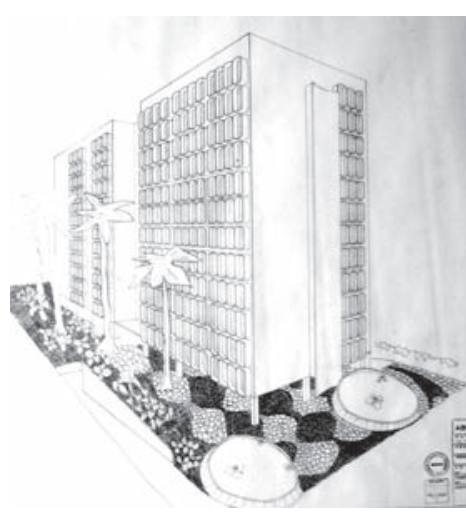

\section{9}

projeto Prédio de Aptos

cliente Moacyr Amorosino

tipologia Edifícios

ano $\mathbf{1 9 7 4}$

endereço Al itu 33/43

cidade São Paulo - SP

construído

publicado

140

projeto

cliente

tipologia Edifícios

ano

endereço

São Vicente - SP

publicado

\section{1}

projeto Prédio de Aptos c/lojas cliente CNI

tipologia Edifícios

ano

endereço R.Consolação

cidade São Paulo - SP

construído

publicado

\section{2}

projeto Prédio de Aptos c/lojas

cliente CNI

tipologia Edifícios

ano

endereço Av.Campos Eliseos/

Av.Ipiranga/Timbiras

cidade São Paulo - SP

construído

publicado

\section{3}

\section{projeto Predio de escritórios}

cliente BNI

tipologia Edifícios

endereço R.Direita/XV de Novembro

cidade São Paulo - SP

construído

publicado

\section{4}

projeto Predio de escritórios

cliente Wilson Russo S/A

tipologia Edifícios

ano

endereço R.da Consolação

cidade

R.da Consolação

construído

publicado 


\section{5 \\ projeto Prédio de Aptos c/lojas cliente Tufy Calfat \\ tipologia Edifícios \\ ano $\quad 1958$ \\ endereço Av.Brigadeiro Luis Antonio cidade São Paulo - SP \\ construído \\ publicado}

\section{6}

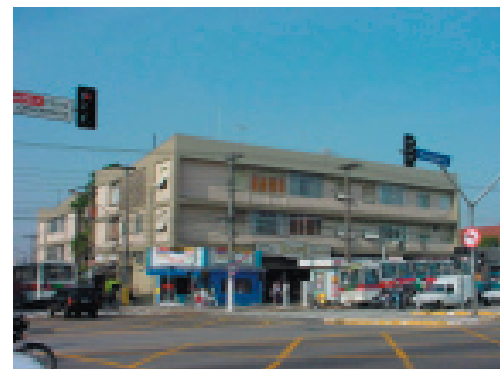

projeto
Rosa

cliente

sileiro

tipologia

ano

endereco

cidade

publicado Acrópole 158 p.56 (1951)

\section{7 \\ projeto Prédio de Aptos \\ tipologia Edifícios \\ ano \\ endereço Av.São João \\ cidade São Paulo - SP \\ construído \\ publicado}

\section{8}

projeto Prédio de Escritórios

c/lojas

cliente Imobiliária Deville

tipologia Edifícios

ano

endereço Centro

cidade São Paulo - SP

publicado

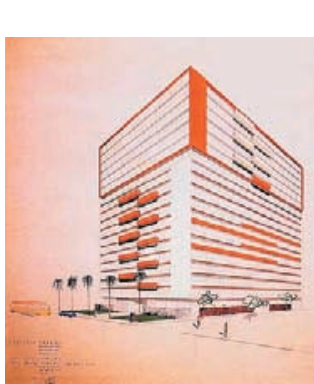

\section{9}

projeto Ed.Três Marias

cliente CNI

tipologia Edifícios

tipologia Edificios

endereço Av.Paulista/Haddock Lobo

cidade São Paulo - SP

construído sim

publicado Habitat 17,30 e 39; Acrópole 184 e Arq. e Dec. 4

\section{0}

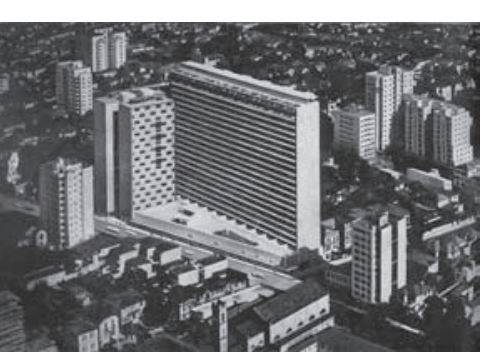

projeto Ed.Nações Unidas

cliente CNI

tipologia Edifícios

ano $\quad 1957$

endereço Av.Paulista/Brigadeiro

L.Antonio

cidade São Paulo - SP

construído sim

publicado Acrópole 184 e 262; Habitat

12, 39,57 e 60; ARq. e DEc. 1; Arq.

Moderna Paulistana

\section{1}

projeto Reforma Ed. Aptos

cliente Vicente de Noce

tipologia Edifícios

ano

endereço R.Carneiro Leão/Rangel

Pestana

cidade

São Paulo - SP

construído

publicado

\section{2}

projeto Prédio de Aptos

cliente Vicente de Noce

tipologia Edifícios

ano

endereço R.Campos Salles no44, Bras

cidade

São Paulo - SP

construído

publicado 


\section{3}

projeto Prédio de Aptos

cliente Vicente de Noce

tipologia Edifícios

ano

endereço R. Prof. Batista de Andrade,

Bras

cidade São Paulo - SP

construído

publicado

\section{4}

projeto Prédio de Aptos

cliente Elias Adas e Mussa Adas

tipologia Edifícios

ano

endereço Al.Casabranca 1194

cidade São Paulo - SP

construído

publicado

\section{5}

projeto Prédio de Aptos

cliente Nelson Russo

tipologia Edifícios

ano

endereço R.Diogo faria 215,231

cidade

São Paulo - SP

construído

publicado

\section{6}

projeto Escritórios de E.E.S.P.

cliente Sind.Trab.Ind.En.El.de SP

tipologia Edifícios

ano

endereço R.Tomás Gonzaga 44

cidade

construído

publicado

\section{7}

projeto

tipologia Edifícios

ano

endereço

cidade

construído

publicado

\section{8}

\section{projeto Ed.Trianon}

cliente Banco Hipotecário Lar Brasi-

leiro

tipologia Edifícios

ano

endereço Av. 9 de julho

cidade São Paulo SP

construído sim

publicado Anúncio do BHLB

\section{9}

projeto Prédio de Aptos

cliente Felicio Leonetti

tipologia Edifícios

ano

endereço R.Visconde Aguiar Toledo/

R.Unapitinga

cidade São Paulo - SP

construído

publicado

\section{0}

projeto

cliente

tipologia

ano

Av.Walter Ingrácia Oliveira

cidade

construído

publicado

\section{1}

projeto

cliente

tipologia

ano

endereço R. Nestor Pestana 121

cidade

construíd

publicado

\section{2}

projeto

cliente

tipologia

ano

endereço Av.Ipiranga/R.Vila Normanda

cidade

publicado

\section{3}

projeto

cliente

tipolog

ano

endereço

cidade

construído

publicado

\section{Prédio de Aptos}

irmãos Fracarolli

irmãos F

Santos - SP

\section{4}

\section{projeto Ed.Riomar}

cliente Comp.Amazonas

tipologia Edifícios

ano

endereço

cidade

construído

publicado 


\section{5}

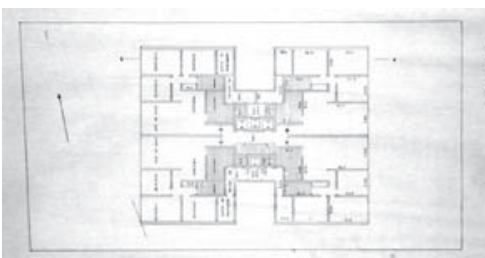

projeto

cliente

tipologia

ano

endereço R.Baia

cidade

construído

publicado

\section{6}

projeto

cliente

tipologia

ano

endereço Av.Duque de Caxias/R.Rio

de Janeiro

cidade

construído

publicado

167

projeto

cliente

tipologia

ano

endereço Av.Mal.Deodoro/Av.Pugliesi

cidade

construído

\section{Prédio de Aptos \\ Edifícios \\ Guarujá - SP}

\section{8}

projeto

cliente

tipologia

ano

endereço R.Fernão Dias/R.Goitacazes

cidade

construído

publicado

\section{Prédio de Aptos}

Irmãos Fracarolli

\section{9}

projeto

cliente

tipologia

ano

endereço

cidade

construído

publicado

\section{0}

projeto

cliente

tipologia

ano

endereço R.Tabatinguera 388

cidade

publicado

\section{1}

\section{projeto Prédio de Aptos}

cliente Said Murad

tipologia Edifícios

ano

endereço Estrada do Oratório-Mooca

cidade

São Paulo - SP

construído

publicado

\section{2}

\section{projeto Ed. Hecilda}

assoc. a Hélio Duarte e Zenon Lotufo

cliente Thimoteo Campos e Arman-

do Bittencourt

tipologia Edifícios

ano $\mathbf{1 9 4 8}$

endereço R.Major Sertório / Cezário

Mota

cidade São Paulo - SP

construído sim

publicadoAcrópole 120 p.321-3 (1948) 


\section{3}

projeto Sede APCB

cliente Ass.Paul.de Criad.de Bov.

tipologia Edifícios

ano 1966

endereço Av.Angélica

cidade São Paulo - SP

construído

publicado

\section{4 \\ projeto Obra Satélite \\ cliente \\ tipologia Edifícios \\ ano \\ endereço \\ cidade Bertioga - SP \\ construído \\ publicado}

\section{5}

\begin{tabular}{|c|c|}
\hline $\begin{array}{l}\text { projeto } \\
\text { lojas } \\
\text { cliente CNI } \\
\text { tipologia Edifícios } \\
\text { ano } \\
\text { endereço } \\
\text { cidade São Paulo } \\
\text { construído } \\
\text { publicado }\end{array}$ & $\begin{array}{l}\text { Av. Nove de Julho } \\
0 \text { - SP }\end{array}$ \\
\hline
\end{tabular}

\section{6}

projeto Prédio de aptos. c/ lojas cliente $\mathrm{CNI}$

tipologia Edifícios

ano

endereço $R$. Alvaro de Carva-

Iho/R. João Adolfo

cidade São Paulo - SP

construído

publicado

\section{7}

projeto Prédio de aptos.

cliente Nagib Jacob

tipologia Edifícios

ano

endereço Rua 13 de Maio

cidade São Paulo - SP

construído

publicado

\section{8}

projeto

cliente

tipologia Edifícios

ano

endereço

cidade - SP

construído

publicado

\section{9}

projeto Prédio de aptos

cliente S.I

tipologia Edifícios

ano

endereço

Ladeira do Castro

cidade

construído

publicado

\section{0}

projeto Ed. Infante

cliente Sr. Infante

tipologia Edifícios

ano

endereço Rua Bernardino de

Campos

cidade Campinas - SP

construído

publicado

\section{1}

projeto Prédio de Aptos. c/ lojas

cliente Comendador José Forte

tipologia Edifícios

ano

endereço

vão

cidade São Paulo - SP

construído

publicado

\section{2}

projeto

Prédio de Aptos. c/

lojas

tipologia Edifícios

ano

endereço Rua Paracatu

cidade São Paulo - SP

construído

publicado

\section{3}

projeto Prédio de Aptos. c/ lojas cliente CNI

tipologia Edifícios

ano

endereço

R. Cons. Crispiniano/

Pça. Ramos

cidade São Paulo - SP

construído

publicado

\section{4}

projeto Prédio de aptos.

cliente Sérgio e Eduardo Viana

tipologia Edifícios

ano

endereço Rua Salvador Cardoso

cidade São Paulo - SP

construído

publicado 


\section{5}

projeto

cliente

tipologia

ano

endereço Rua Iguatemi/Rua Iraci

cidade

construído

publicado

\section{6}

projeto

aptos

Cliente José Duarte de Oliveira

tipologia Edifícios

ano

endereço Av. Eusébio Matoso/Av.

Jóquei Clube

cidade São Paulo - S

construído

publicado

\section{7}

$\begin{array}{ll}\text { projeto } & \text { Prédio de aptos } \\ \text { cliente } & \text { Haroldo e Nelson Russo }\end{array}$

tipologia Edifícios

ano

endereço Av Rebouças 1332/1340

cidade São Paulo - SP

publicado

\section{8}

projeto Prédio de aptos $\mathrm{c} /$ térreo

comercial

cliente Max Schwartz

tipologia Edifícios

ano

endereço Rua Cubatão/Rua José Anto-

nio Coelho

cidade

São Paulo - SP

publicado

\section{9}

projeto Prédio de aptos

cliente Timóteo C. Campos

tipologia Edifícios

ano 1956

endereço Rua Augusta 1001/1015

cidade São Paulo - SP

construído

publicado

\section{0}

\section{projeto \\ loja}

tipologia Edifícios

ano

endereço Rua Conselheiro Crispiniano/

Rua 24 de Maio

cidade São Paulo - SP

construído

publicado

\section{1}

projeto Prédio de escrit./garagem

cliente Bonfiglioli C.C.

tipologia Edifícios

ano

endereço Rua Aurora/Arouche

cidade

São Paulo - SP

construído

publicado

\section{2}

projeto

cliente

tipologia

endereço

cidade

construído

publicado

\section{3}

projeto Prédio de aptos

cliente Rosa Bonfiglioli Trussardi

tipologia Edifícios

ano

ndereço Av. Brig. Luiz Antonio

cidade São Paulo - SP

construido

publicado

\section{4}

\section{projeto Prédio de escritórios}

cliente CNI

tipologia Edifícios

ano

endereço Rua C. de Toledo

cidade Santos -SP

construído

publicado

\section{5}

projeto Prédio de aptos

cliente BNI

tipologia Edifícios

ano

endereço R.Br.de Campinas/Av. São

João/R. Rego Freitas

cidade São Paulo - SP

construído

publicado

\section{6}

projeto Prédio de aptos

cliente BNI

tipologia Edifícios

ano

endereço Av. São João

cidade São Paulo - SP

construído

publicado 


\section{7}

projeto Prédio de escrit. e drogaria cliente CNI

tipologia Edifícios

ano

endereço Pça Ramos/24 de Maio

cidade São Paulo - SP

construído

publicado

\section{8}

\section{projeto Edifício Ícaro}

cliente Cap. Seyd Pereira Leduque/

Ten. Olney Araujo Dutra

tipologia Edifícios

ano

endereço Rua Pinheiros 431/441

cidade

Rua Pinheiros
São Paulo -SP

construído

publicado

\section{9}

projeto Edifício Amazonas

cliente M. Cobucci

tipologia Edifícios

ano

endereço Av. Júlio de Mesquita

cidade Campinas - SP

construído

publicado

\section{0}

projeto

tipologia Edifícios

ano

endereço R. Jorge Tibiriçá/R. Mario

Carpente

cidade Santos - SP

construído

publicado

\section{1}

projeto

cliente

tipologia Edifícios

ano

endereço Rua Galvão Bueno

cidade São Paulo - S

construído

publicado

\section{2}

projeto

cliente

tipologia

ano

endereço Largo do Arouche 193

cidade

construído

publicado

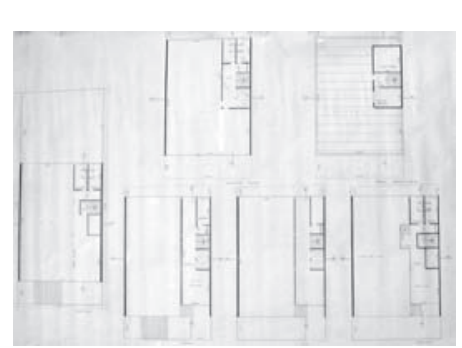

\section{3}

\section{projeto Prédio de escritórios}

cliente Fouad Aziz Nader

tipologia Edifícios

Rua Cons, Crispiniano 72,74

cidade

construíd

publicado

São Paulo - SP

\section{4}

projeto

cliente

\section{Prédio de aptos c/ lojas}

tipologia Edifícios

ano

endereço Rua João Adolfo/Rua Alvaro

de Souza

cidade

construído

\section{5}

projeto

cliente

tipologia Edifícios

ano

endereço Rua Líbero Badaró

cidade São Paulo - SP

publicado

\section{6}

projeto Prédio de aptos c/ lojas cliente BNI

tipologia Edifícios

ano

endereço Rua São Vicente de Paula

cidade

São Paulo - SP

construido

publicado

\section{7}

projeto

cliente

tipologia Edifícios

ano 1960

endereço Rua Santo Antonio

cidade

São Paulo - SP

publicado

\section{8}

projeto Edifício Monte Carlo

cliente

tipologia Edifícios

ano

endereço Ilha de Santo Amaro

cidade

Guarujá - SP

publicado 


\section{9}

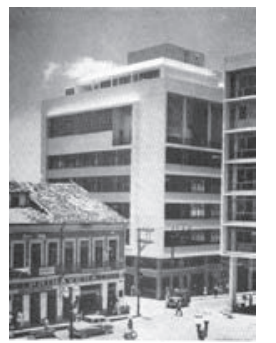

projeto Sede da Assoc. Baiana

de Imprensa (assoc. a Hélio Duarte

Zenon Lotufo)

cliente $\mathrm{ABI}$

tipologia Edifícios

ano proj. 1946/48 - obra 1960

endereço Rua Guedes de Brito $\mathrm{n}^{\circ} 1$

- Pça da Sé

cidade Salvador - BA

publicado Acrópole 98(1946); Acrópo-

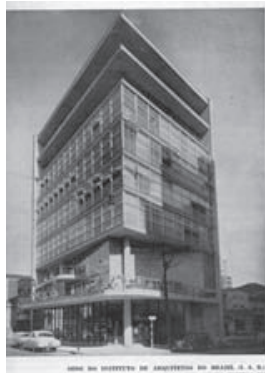

e117(1948); Acrópole259 (1960)

\section{0}

projeto Edifício sede do IAB

cliente IAB

tipologia Edifícios

ano 1947

endereço Rua Bento Freitas 306

cidade São Paulo - SP

construído

211

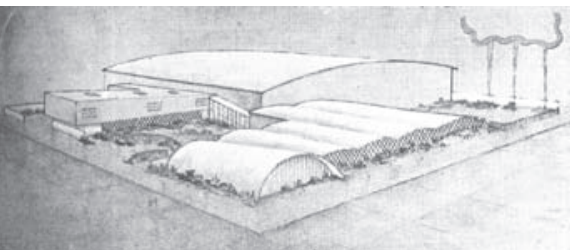

\section{projeto}

cliente

tipologia Gerais

ano

1948

endereço

cidade

construído não

publicado Habitat 39 p.9 (1957)

\section{2}

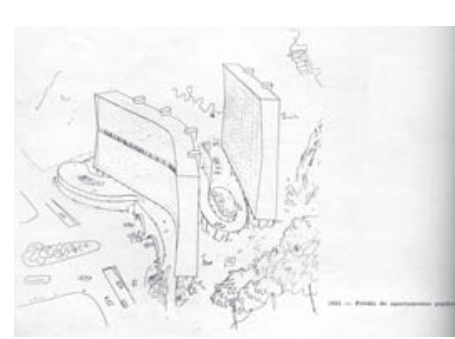

projeto

cliente

tipologia Edifícios

ano 1952

endereço Praça dos Andradas

cidade Santos - SP

construído não

publicado Acrópole 184 p.172

(1953);Habitat 39 p.10 (1957)

\section{3}

projeto

cliente

tipologia Edifícios

ano $\quad 1955$

endereço Rua da Consolação

Rua Martins Fontes

cidade São Paulo - SP

construíd

publicado Habitat 39 p.19 (1957)

214

projeto Edifício Myatã

cliente

tipologia Edifícios

ano

endereço Al. Joaquim Eugênio de Lima

cidade São Paulo - SP

publicado

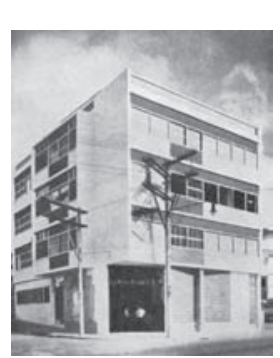

215

projeto Edifício biena

cliente Sérgio Pape

tipologia Edifícios

1955

endereço Rua João Lourenço 797

cidade São Paulo - SP

construído sim

publicado Habitat 39 p19 (1957); Arq. e Dec. 11(1955)

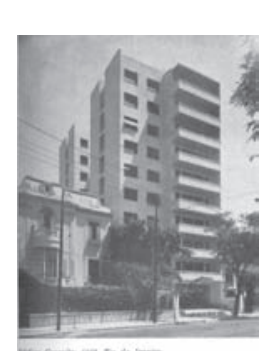

\section{6}

\section{projeto Edifício Cananéia} tipologia Edifícios ano 1938

endereço Av. N. Sra de Copacabana

cidade Rio de Janeiro - RJ

construído sim

publicado Acrópole 184(1953), Habitat 39 (1957) 


\section{7}

\section{projeto}

cliente

ano

Edifícios

1938

endereço

cidade

construído

Rio de Janeiro

publicado

\section{8}

projeto

cliente

tipolog

ano

endereço

cidade São Paulo

construído sim

publicado Habitat 39 p.3 ( 1957)

\section{9}

\section{projeto}

Edifício Pedra Azul

associado a Hélio duarte e Zenon Lotufo

cliente Soc. Imobiliária América

tipologia Edifícios

ano

endereço Alameda Jaú 1708

cidade

São Paulo - SP

construído sim

publicado Acrópole 114 p. 165 (1947)

\section{0}

\section{projeto Residência}

cliente Hermes Barreto Barbosa

tipologia Residências

ano

endereço Castelo

cidade Vila Bela?
construído

publicado

\section{1}

projeto Residência

cliente BHLB

tipologia Residências

ano $\mathbf{1 9 4 5}$

endereço Av. Itororó casa6/R. Curi-

tiba

cidade

construído

publicado

\section{2}

projeto Residência Benny Dionísio cliente Benny Dioníso

tipologia Residências

ano 1962

endereço Estrada de Itapecerica

cidade São Paulo - SP

construído

publicado

\section{3}

projeto

des

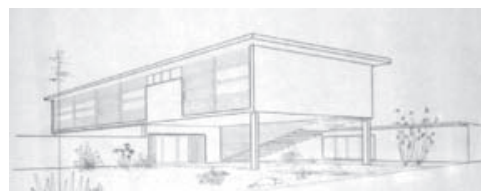

cliente

tipologia

ano

endereç

cidade

construído

publicado

\section{Res. Eduardo N. S. Men-}

Eduardo N.S. Mendes

$\mathbf{1 9 6 0}$

Av. Invernada

Congonhas do Campo - MG

\section{4}

projeto Residência José Forte

cliente José Forte

tipologia Residências

ano

cidade Guarujá - SP

construído sim

construído
publicado 


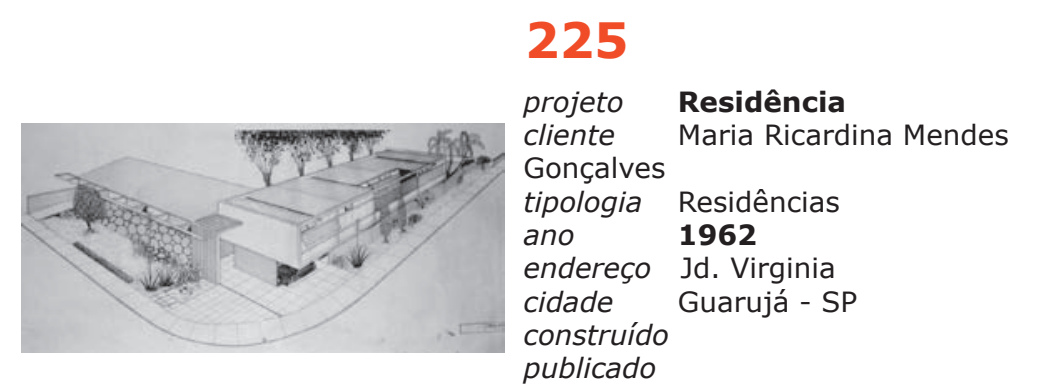

\section{6}

projeto Reforma de residência

cliente Renato R. de Araujo Cintra

tipologia Residências

ano

endereço Rua Manuel Maria Tourinho

860

cidade São Paulo - SP

construíd

publicado

\section{7}

\section{projeto Residência}

cliente Nesrala Rubez

tipologia Residências

ano

endereço Av Major Novais

cidade Cruzeiro - SP

construído sim

publicado

\section{8}

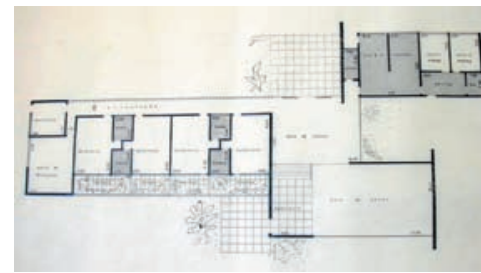

\section{projeto Residência}

cliente Carlos Raffael

tipologia Residências

ano $\mathbf{1 9 5 5}$

endereço Paineiras do Morumbi

cidade São Paulo - SP

construído

publicado

\section{9}

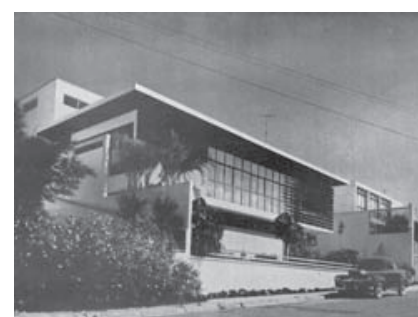

Residência

cliente José Ribeiro Sobrinho

tipologia Residências

ano

ereço R. Adalivia de Toledo Leite,

Paineiras do Morumbi

cidade São Paulo - SP

construído sim

publicado Habitat 54, p23-7. 1959.

\section{0}

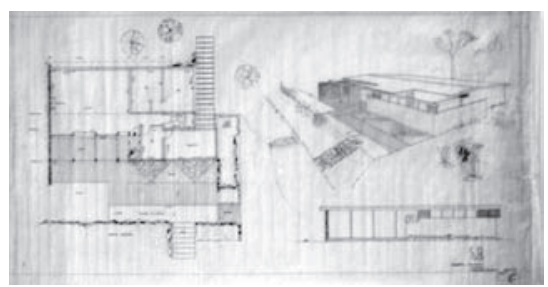

projeto Residência

cliente S.R.

tipologia Residências

ano 1957

endereço

cidade

construído

publicado

\section{1}

projeto

cliente

tipologia

ano

endereço Rua dos Italianos

cidade

construído

publicado

\section{2}

projeto Residência

cliente Fco. Emigdio Pereira Neto

tipologia Residências

ano

cidade Valinhos - SP

construído

publicado 


\section{3}

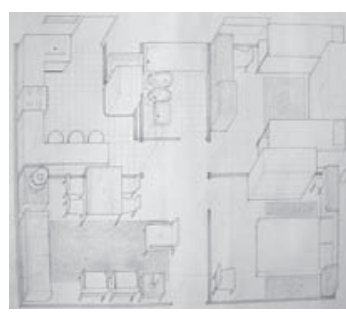

projeto Residência Pré-Fabricada

associado a Miranda Magnoli

cliente Jotace Ind. Com. Casas Pré

- Fabricadas

tipologia Residências

ano

1963

endereço

cidade

construído

publicado nota na folha $29 / 04 / 63$

234

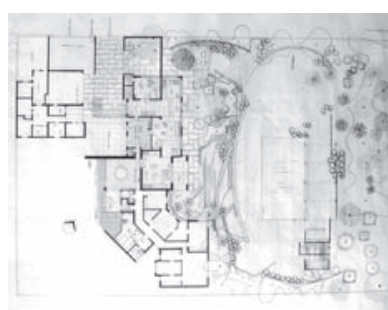

projeto

iação e reforma

cliente João de Lorenzo

tipologia Residências

ano 1962

endereço Rua Joaquim Nabuco 1050

cidade

São Paulo - SP

publicado

\section{5}

\section{projeto Reforma de residência}

cliente Cecília Alves de Almeida

tipologia Residências

ano

endereço Rua dos Bombeiros 74

cidade

São Paulo - SP

publicado

236

projeto

cliente

tipologia

ano

endereço

cidade

construído

publicado

\section{7}

projeto Residência

cliente José V. Cauduro

tipologia Residências

ano $\mathbf{1 9 5 9}$

endereço Rua Itacema 145/189

cidade São Paulo - SP

construído sim

publicado

\section{8}

projeto

tipologia

ano

anoreco Morumbi

cidade

São Paulo - SP

publicado

\section{9}

projeto

cliente

tipologia

ano

endereço R.E.Escobar Ortiz 138

cidade

construído

publicado

\section{0}

projeto

cliente

tipologia

ano

endereço Parque Ribeirão Preto

cidade

construído

publicado

\section{Residências Geminadas}




\section{1 \\ projeto Residência \\ cliente BHLB \\ tipologia Residências \\ ano \\ endereço Rua Curitiba \\ cidade \\ publicado}

\section{2}

projeto Residência

cliente BHLB

tipologia Residências

ano 1944

endereço Rua Nova c.5

cidade

construído

publicado

\section{3}

projeto

cliente

tipologia

ano

BHLB

cidade

construído

publicado

\section{4}

projeto

cliente

tipologia

ano

Residências

cidade

São Paulo - SP

construido

publicado

\section{5}

projeto Residência

cliente Waldomiro Delboni

tipologia Residências

ano 1948

endereço Estr. das Boiadas 28 - Alto

de Pinheiros

cidade São Paulo - SP

construído sim

publicado

\section{6}

\section{projeto Residência}

cliente Waldomiro Delboni

tipologia Residências

ano

endereço Rua Suzano 116

cidade

construído sim

publicado

obs: descaracterizada / reforma-

da por Isay Wenfeld $\mathrm{p} /$ Millenium Art

Gallery

247

projeto Residência

cliente Raphael Renato Vellega

tipologia Residências

ano$$
1975
$$

cidade

construído

publicado

\section{8}

projeto Residência Nelzina Fan-

tauzzi

cliente Nelzina Fantauzzi

tipologia Residências

ano

1958

cidade Itanhaem - SP

construído sim

publicado 


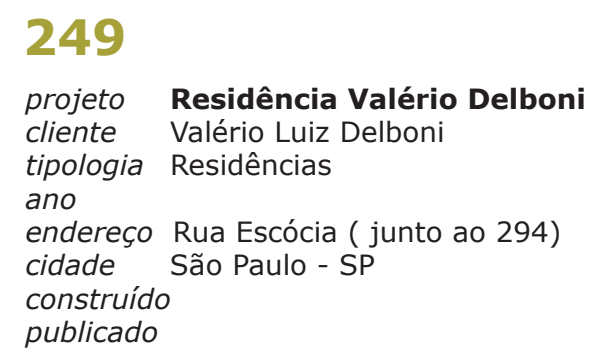

\section{0}

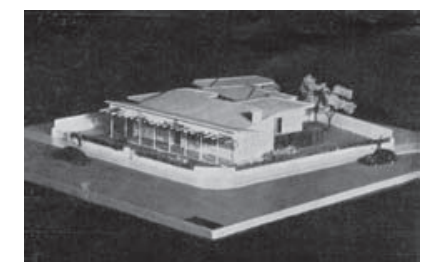

Residência Z. L.

cliente Zoroastro Leme

tipologia Residências

ano 1947

endereço Av.Sagres x Rua D. Henrique

cidade sim

construído sim

publicado Acrópole 105 p244-5 (1947)

\section{1}

projeto Residência

cliente Carlos Bianco

tipologia Residências

ano

endereço Rua Valinhos 67 - Jd. Paulista

cidade São Paulo - SP

construído

publicado

\section{2}

projeto Reforma de Residência

cliente Augusto Pirani

tipologia Residências

ano

Residências

lista

cidade São Paulo - SP

construído

construído

publicado

\section{3}

projeto Residência

cliente Narciso

tipologia Residências

ano

endereço Pacaembú

cidade São Paulo - SP

construído

publicado

\section{4}

projeto Residências diversas

cliente BHLB

tipologia Residências

ano

endereço Av. Rebouças

cidade São Paulo - SP

construído

publicado

\section{5}

\section{projeto Residência}

cliente Ruth Aguilar

tipologia Residências

ano

endereço R. das Crisálidas - V. Da-

masco

cidade

construído

São Paulo - SP

publicado

\section{6}

projeto

cliente

Lilian Panin Sander

tipologia Residências

ano

endereço Jd. Leonor - Mo-

rumbi

cidade São Paulo - SP

construído

publicado

\section{7}

projeto Residência

cliente Norma Birolli

tipologia Residências

ano

endereço

cidade

construído

publicado

\section{8}

projeto Reforma de Residência

cliente Felix Raci / Alexandre Walco

tipologia Residências

ano

endereço Planalto Paulista

cidade São Paulo - SP

construído sim

publicado

\section{9}

\section{projeto Residência}

cliente Jorge Hajnal

tipologia Residências

ano

endereço Rua Crisálidas

cidade São Paulo - SP

construído sim

publicado

\section{0}

projeto

cliente

Residências

tipologic

ano

endereço Rua Petrópolis

cidade São Paulo - SP

publicado 


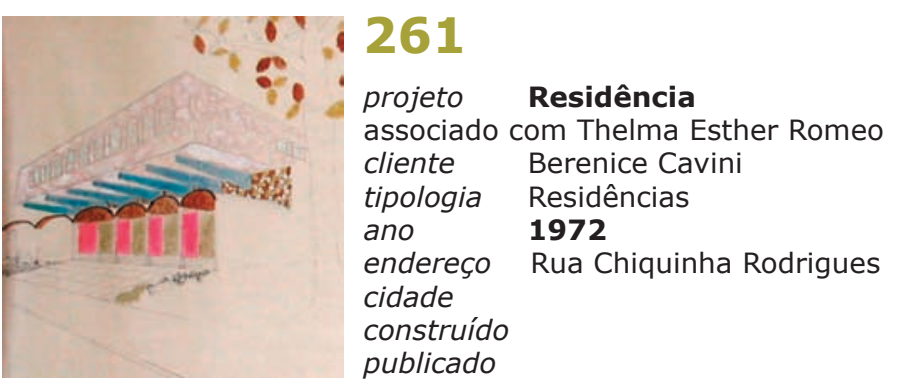

262

$\begin{array}{ll}\begin{array}{l}\text { projeto } \\ \text { cliente }\end{array} & \text { Residência } \\ \text { tipologia } & \text { Arthur Meira Lins } \\ \text { ano } & \text { Residências } \\ \text { endereço } & \text { Av. Pacaembú } \\ \text { cidade } & \text { São Paulo - SP } \\ \begin{array}{l}\text { construído } \\ \text { publicado }\end{array} & \end{array}$

\section{3}

\section{projeto Residência}

cliente

tipologia Residências

ano

endereço Rua Santana

cidade

construído

publicado

\section{4}

\section{projeto Residência}

cliente Timotheo Cezario Campos

tipologia Residências

ano

endereço Chác. Bela Veneza- Jd.

Europa

cidade

São Paulo - SP

construído

publicado

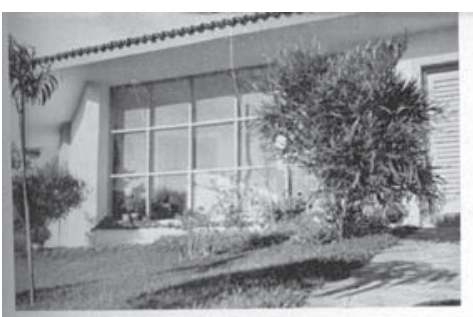

265

projeto Residência

cliente Abelardo de Souza

tipologia Residências

ano

endereço Av. Anhangabaú

cidade

São Paulo - SP

publicado Acrópole 184( 1953); Habi-

tat 39 (1957); Arq. e Dec 1 (1953)

\section{6}

projeto Residência

cliente Suzana Rodrigues

tipologia Residências

ano

1957

endereço

cidade

construído

publicado

\section{7}

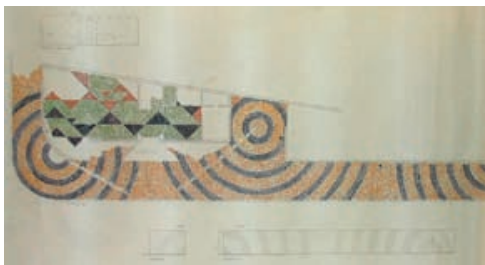

projeto

cliente

tipologia Residências

ano

1973

endereço Rua Curitiba 13

cidade

São Paulo - SP

publicado

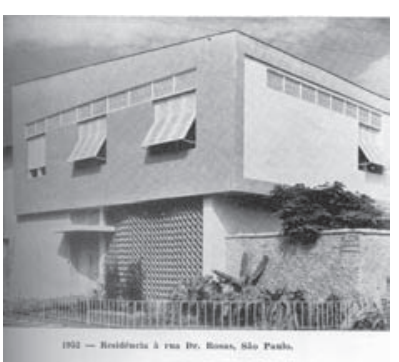

268

projeto Residência

cliente Aldo Bove / Carmem Arruda

tipologia Residências

ano $\mathbf{1 9 5 2}$

endereço R. Dr. Oliv. Pinto x R. dr.

Rosa - Jd Paulistano

cidade São Paulo - SP

construído sim

publicado Acrópole 184 (1953); Habi-

tat 39 (1957) 


\section{9}

projeto

Angelo Sallata

tipologia Residências

ano

endereço

cidade Araraquara - SP

construído sim

publicado

\section{0}

\section{projeto Residência}

cliente Isaac Rechulsky

tipologia Residências

ano

endereço Rua Jabaquara

cidade

construído

publicado

\section{1}

projeto Residência

cliente Jure Martins

tipologia Residências

ano

endereço Rua 14 - lote 310-90

cidade

construído

publicado

\section{2}

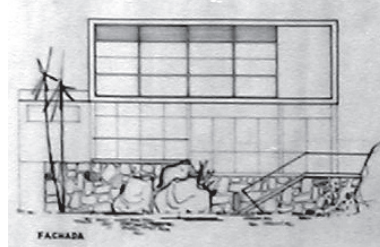

Alzira de Godoy

tipologia Residências

ano

Rua Circular, lote 393 - Pr.

do Sonho

cidade Itanhaém - SP

construído sim

publicado

\section{3}

projeto Residência

cliente Lamartine Cione

tipologia Residências

ano 1969

endereco R. das Tuias 33-C. Jd. S.

Paulo

cidade São Paulo - SP

construído sim

publicado

\section{4}

projeto Residência

cliente Antônio Girondi

tipologia Residências

ano

- Jote $15 \mathrm{C}$

- Jd. São Paulo

cidade São Paulo - SP

construído sim

publicado

\section{5}

projeto Residência

cliente Alcina Carvalho

tipologia Residências

ano

endereço Av. Ceci x Rua Guaianazes

cidade

construído

publicado

\section{6}

projeto Residência

cliente Armando Sander

tipologia Residências

ano

endereço Rua Recanto - Chácara Flora

cidade São Paulo - SP

construído

publicado 


\section{7}

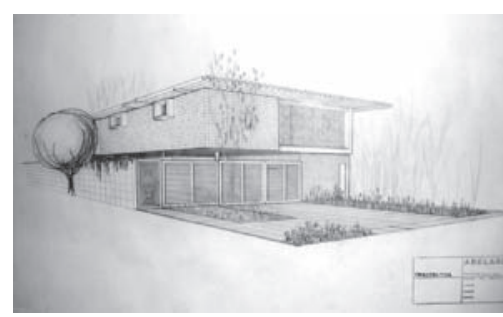

\section{projeto}

cliente

elson A. P. Russo

1965

Rua Alberto Faria, lote 10

q. 86

cidade

construído sim

publicado

\section{8}

\section{projeto Residência}

cliente Geraldo Luiz Romeu

tipologia Residências

ano

endereço

cidade Guarulhos - SP

construído

publicado

\section{9}

projeto

cliente

tipologia Residências

ano

$$
\mathbf{1 9 5 5}
$$

endereço Rua Luis Góes 431 - V.

Mariana

cidade São Paulo - SP

construído sim

publicado Habitat 39 p.21 (1957)

\section{0}

projeto Residência cliente Spartaco Vizotto

tipologia Residências

ano 1968

endereço Rua Argentina x rua Hon-

duras

cidade São Paulo - SP

construído

publicado

\section{1}

projeto Residência

cliente Evangelina Silveira

tipologia Residências

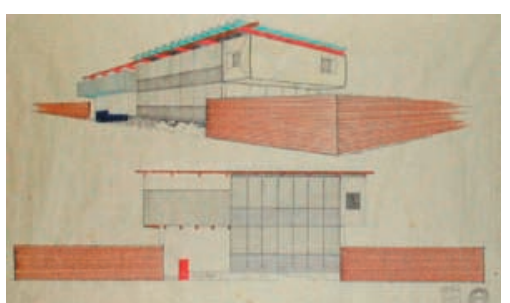

ano $\mathbf{1 9 6 9}$

endereço Rua Manoel Guedes x Dr.

Jerônimo da Veiga

cidade São Paulo - SP

construído

publicado

\section{2}

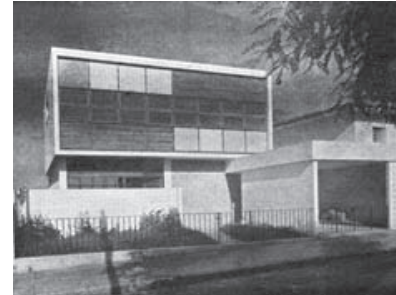

projeto Residência

cliente Bernardo Blay

tipologia Residências

ano 1956

endereço Rua Plínio de Moraes - Su-

maré

cidade São Paulo - SP

construído sim

publicado

\section{3}

projeto Residência

cliente João di Pietro

tipologia Residências

ano 1958

endereço Rua Dr. Flaquer x Rua Par-

ticular

cidade

construído

publicado

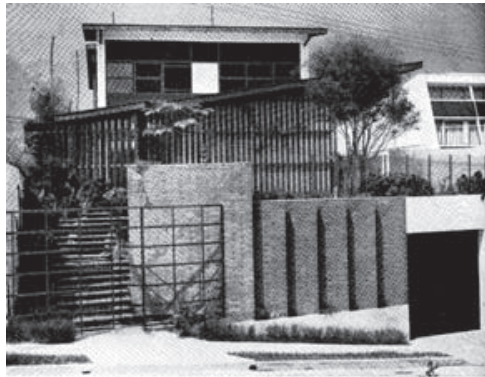

284

Residência

cliente Chaim Goldenstein

tipologia Residências

ano 1954

endereco Rua Wanderlei $\times \mathrm{R}$. Heitor de

Morais - Pacaembú

cidade São Paulo - SP

construído sim

publicado Acrópole 209 (1956) 


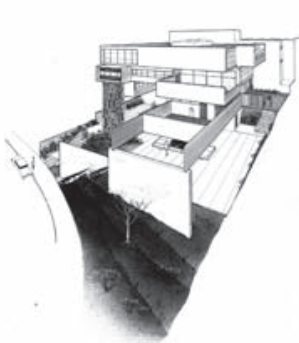

285

projeto Residência (Assoc. a Miran-

da M. M.)

cliente João de Scantimburgo

tipologia Residências

ano 1963 / 4

endereço Lote 13, Q17 - Paineiras do

Morumbi

cidade São Paulo - SP

construído não

publicado não

\section{6}

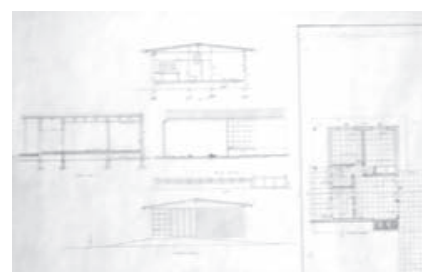

\section{projeto Residência}

cliente Evangelina Silveira

tipologia Residências

ano

1965

- Pr. Lagoinha

cidade Ubatuba - SP

construído

publicado

\section{7}

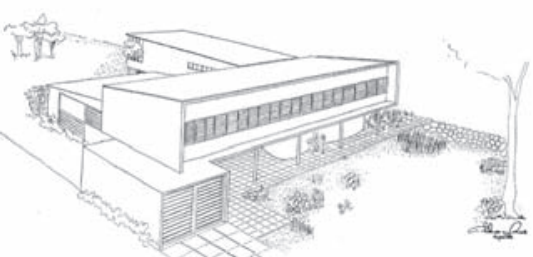

projeto

cliente

ano

1947

endereço Portugal Pequeno

cidade

publicado Acrópole 110(1947)

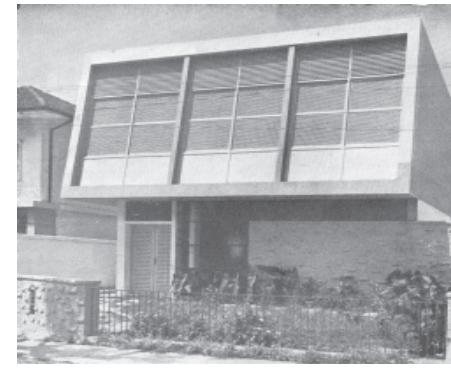

\section{8}

projeto

cliente

tipologia Residências

ano

endereço

cidade

construído

São Paulo - SP

publicado Habitat 39 (1957)

\section{9}

projeto

cliente

tipologia Residências

ano

endereço Rua Nebrasca ( junto ao

489)

cidade São Paulo - SP

construído

publicado

\section{0}

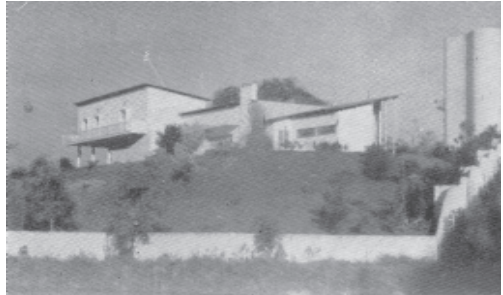

\section{projeto Res. Osvaldo Young}

cliente Osvaldo Young

tipologia Residências

ano

\section{4}

Santo Amaro

cidade São Paulo - SP

construído sim

publicado Acrópole 184(1953); Habitat 39 (1857)

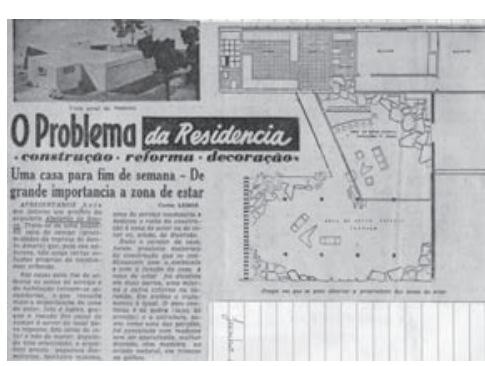

291

projeto Casa Sta Cruz do Rio Par-

do

cliente

tipologia Residências

ano $\mathbf{1 9 4 5}$

endereço

cidade

construído

publicado Acrópole 184(1953); Habitat 39 (1957)

projeto Estudo $\mathbf{p}$ / residência em SP

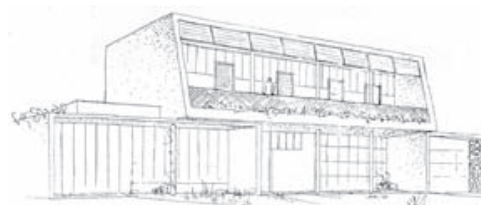

ssoc. c/ Zenon Lotufo e Hélio duarte cliente

tipologia Residências

ano

1948

endereço

cidade São Paulo - SP

construído

publicado Acrópole 118(1948) 


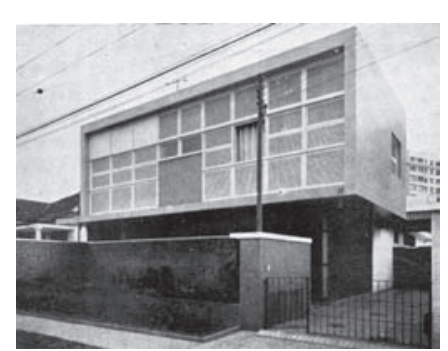

293

projeto Res. em São Paulo

cliente

tipologia Residências

ano 1959

endereço

cidade São Paulo - SP

construído

publicado Habitat 51 (1959)

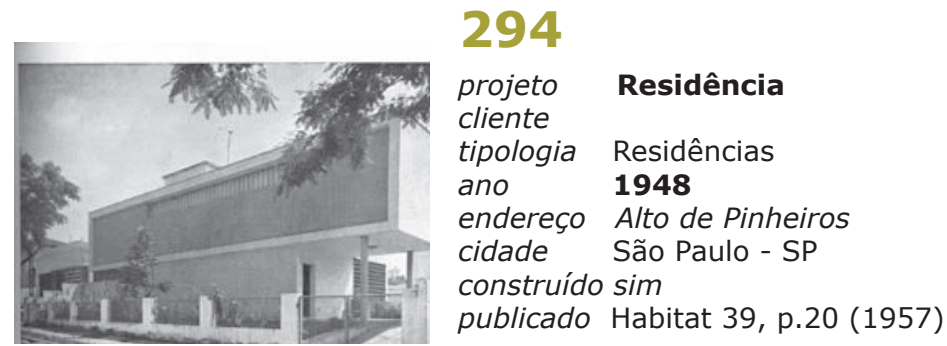

